Historic, archived document

Do not assume content reflects current scientific knowledge, policies, or practices. 



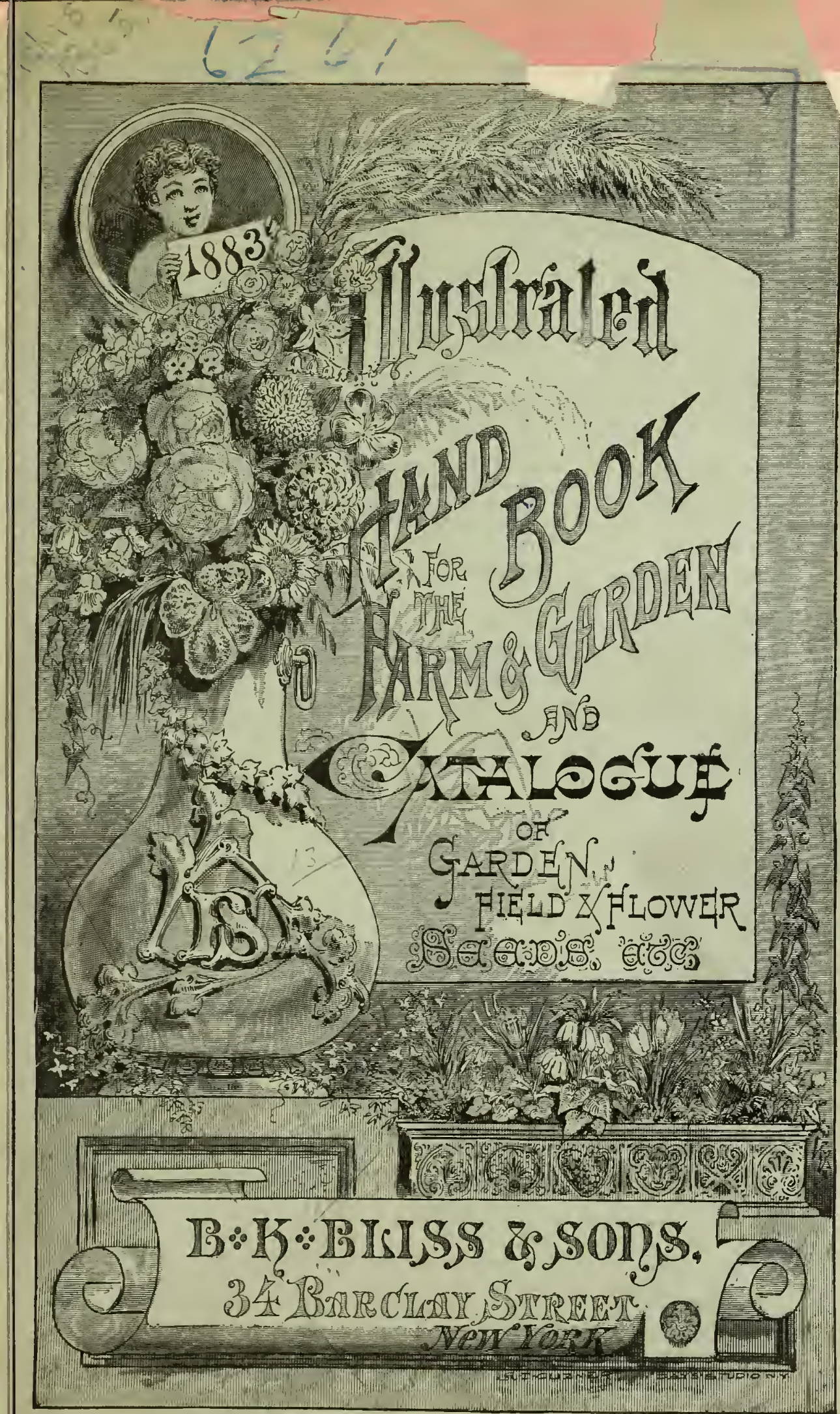


Should you not require this Catalogue, we shall feel much obliged if you will place it in the hands of your friends who are likely to require Seeds, Bulbs, Plants, etc., at the same time kindly recommending our Firm to their notice.

\section{WHAT WE GUARANTEE.}

That all seeds sold by us shall prove to be as represented, to this extent, that should they prove ot herwise, we will replace them, or send other seeds to the sanne value. But we cannot guarantce the crop any farther than the above offcr, as there are so many causes which operate nnfavorably in the germination of scels and maturity of the crop, over which we have no control. Among the causes of failure may be mentioneil unfavorable weather, which is one of the most important. The soil may be in proper courlition when the seed is planted, but the weather which follows may be cold and wet, which will cause the sced to rot, or it may be hot and dry, which destroys the germ, before it shows itself. The soil may also bo unfarorable for the variety of seed planted. Tho seeds may bo and are frequently destroyed by vermin of various kinds. And lastly, changes not unfrequently occur, especially among new hybridized varictios, by which frequent sports are produced which give the planter the idea that his secds are barly mixed. Such occurrences are beyond the powcr of man to prevent and for which we cannot be responsible.

That ail money sball reach us if sent by either Bank Draft, Money Order, Express or Registered Letter. If unablo to procure money orlers or currency, remittances may we made in postage stanips (of the lighest denominations convenient, not exceeding $30 \mathrm{c}$. stamps), caro being taken to prevent their sticking to each other, or to the order. Stamps are preferable to coin, as the latter is apt to break through the envelope.

That all seeds sent ont by us shall reach their destination, agreeing to replace any that may be lost in the mails.

We respectfilly solicit jour orders on the above very favorable conditions. Every possible care and precaution will be usel by us to prevent any mistake from occurring, but should such occur, we wish to be adrised at once, and they will bo chcorfnlly rectified, as it is our aim and desire that every trans. action with us shall be perfectly satisfactory.

We would also request that tho above instructions may be fnlly complied with; also that with each and every order you will give your COMPLETE ADDREsS DISTINCTLY WRITTEx, and givo slipping instructions if tho oriter is to go otherwise than by mail.

Do not ask to have small oriers sent C. O. D., as the charges for collecting tho money, added to the expressage on the gooils, of ten amounts to more than the expense of sending thou by mail or express prepait, and, to some points, more than the value of the sceds ordered. We would therefore request that each order be accompaniert by a remittanee, as much more satisfactory to all parties.

Thanking our uany correspondents for their past favors, both in orders received and for speaking so kindly of us to their friends, and awaiting your further favors, which shall receive our best care and prompt attentiou.

\section{B. K* BLISS \& SONS}

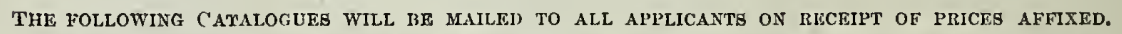

Regular customers, whose names aro recorded on our books, will be supplied witb a copy of each edltlon, when published, without application.

Bliss's Illustrated Hand-book for the Farm and Garden.-A completo descriptive list of all the most desirablo varietics of Garien, Fieli, and Flower Sceds, Plants, Summer Flowering Bulbs, Implements, and Hortienitural Reqnisites of every descrlption; illustrated by a beautiful colored plate and about 300 engravines; 150 pares; publisherl annually. 10 conts.

Bliss's Illustrated Potato Catalogne.-Contains a list of 500 rarietics of Potatoes, embracing sereral new and very promising rarieties, with explieit directions for enlture, and much other valuable information respecting this indispensablo csculent. 10 cents.

Bliss's Bubb Cafalogue (Illustrated).-Published September 1st, containing a choiee Collection of DOUBLE AND SIYGLE HYACINTHS, arranger in their soveral colors; TULIPS in many varictics, both donble and gingle; POLYANTHUS NARCISgus, CROWN IMPERIALS, JONQUils, SNOW-DRors, LILIES, etc. 10 cents.

\section{VALUABLE HORTICULTURAL WORKS. By EDWARD S. RAND, Ji.}

Any one of the following books will be mailed, post-paid, at the price quoted, or the six volumes for $\$ 9.00$.

Flowers for the Parlor and Garden,-Beautifully illustrated. \$1.75.

Popular Flowers, and How to Cul tivate Them.-Thoroughly rovised and enlarged. Illustrated. \$1.50. Garden Flowers? How to Cultivate Them.-New edition, thoroughly revised. Illustrated. $\$ 1.75$.

A Treatise on Hardy and Tender Bulbs and Tubers. - With full directions for cultivation. Beau. tifully illustrated, with two appendixes. 370 pages, 8 ro. $\$ 1.75$.

Orchids.-A complete mannal of Orchid Cultnre, with hints on construction of Orchid Honses. $\$ 2.00$.

Rhododendrons.-Third thousand, nowly revised. 8vo. \$1.25.

For Agricultural and other works, see third page of cover. 


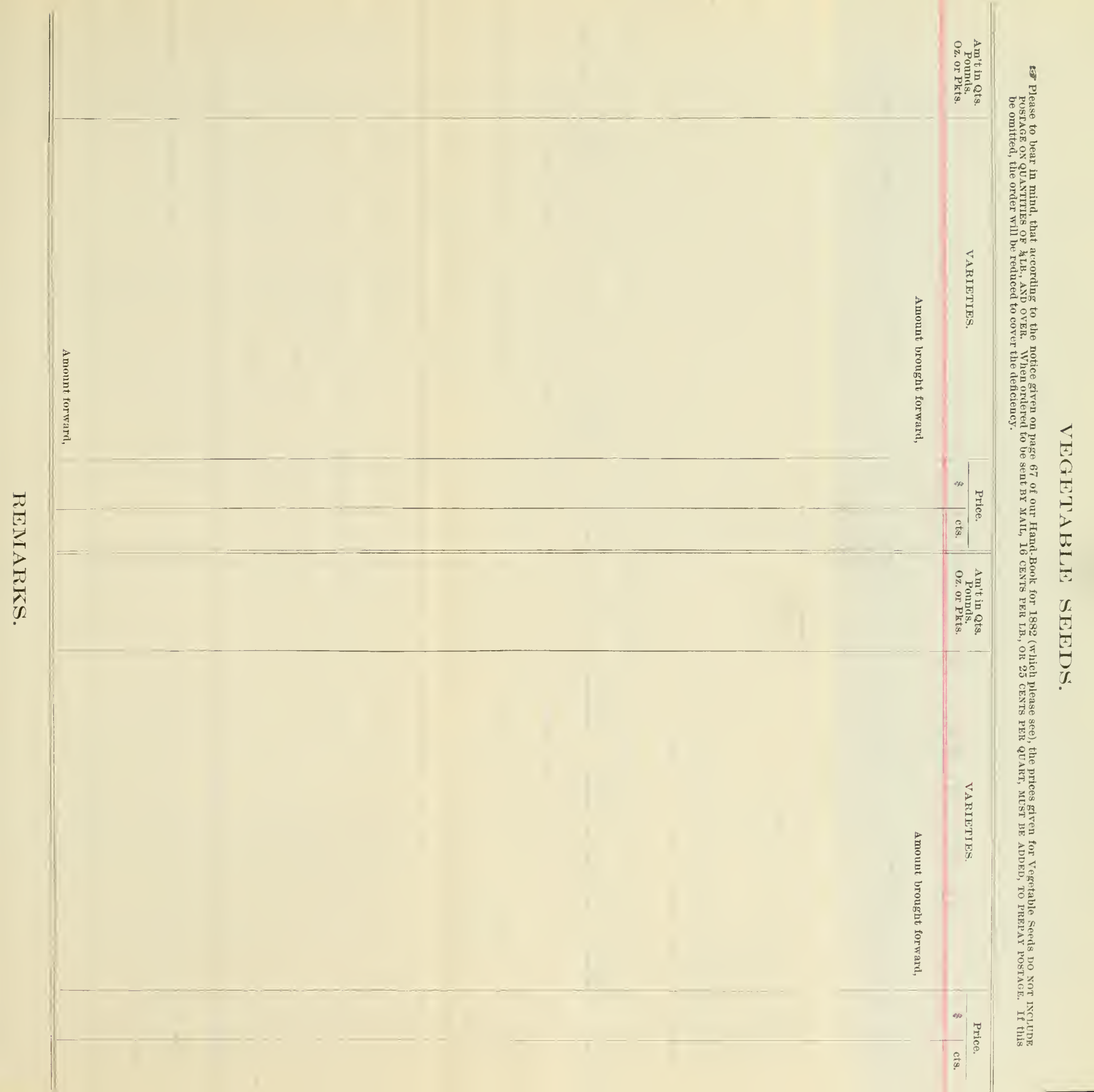



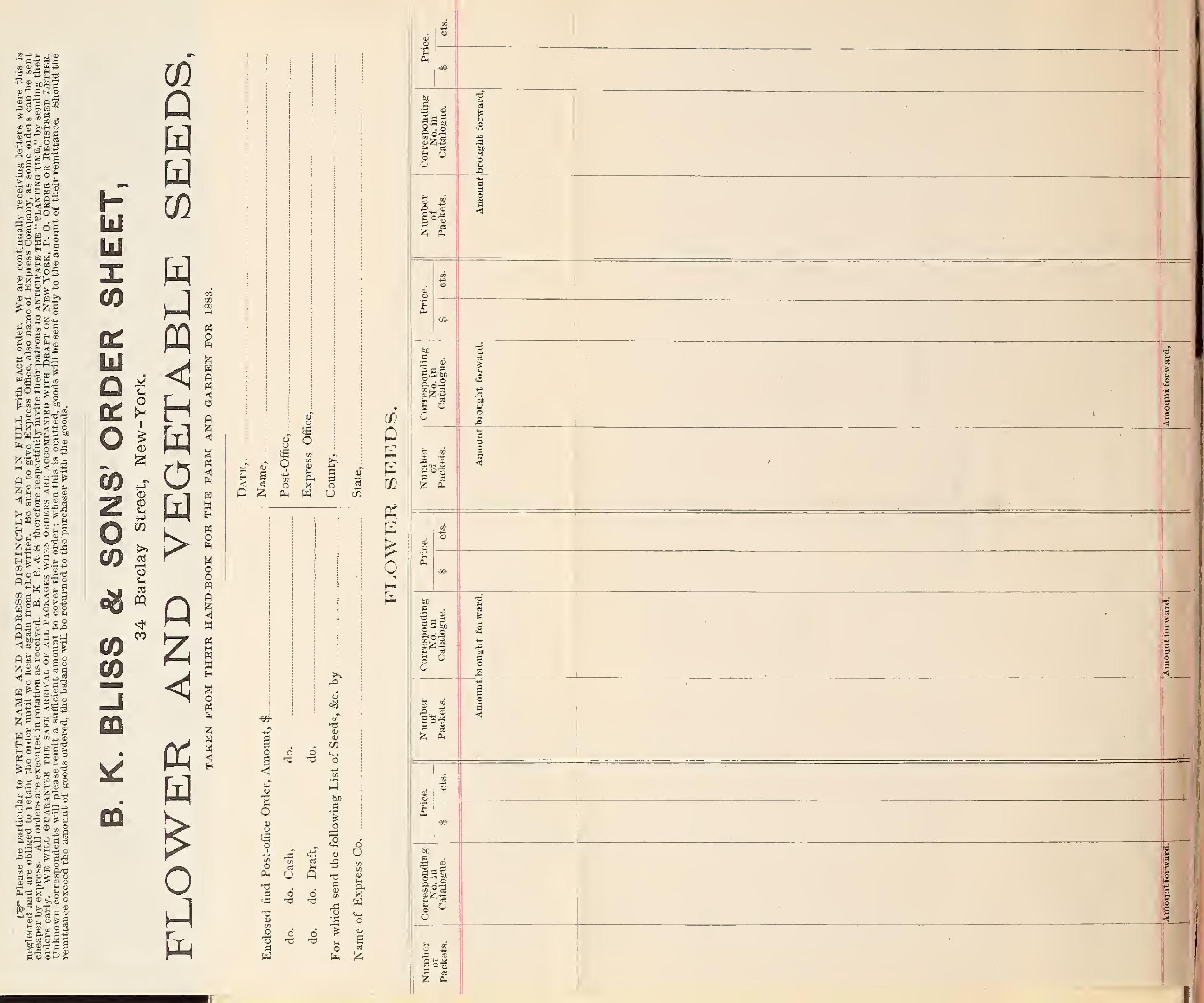


\section{SUPPLEMENT.}

NOVELTIES, AND OTHER SEEDS OF SPECIAL MERIT, OF RECENT INTRODUCTION,

MANY OF WHICI ARE NOW OFFEIRED FOIR TIE FIRNT TIME JN THIS COUNTIY.

tF Novelles for 1883 art designatol by *, and the duscriptions given are an funished wy thrir respretivo growers.

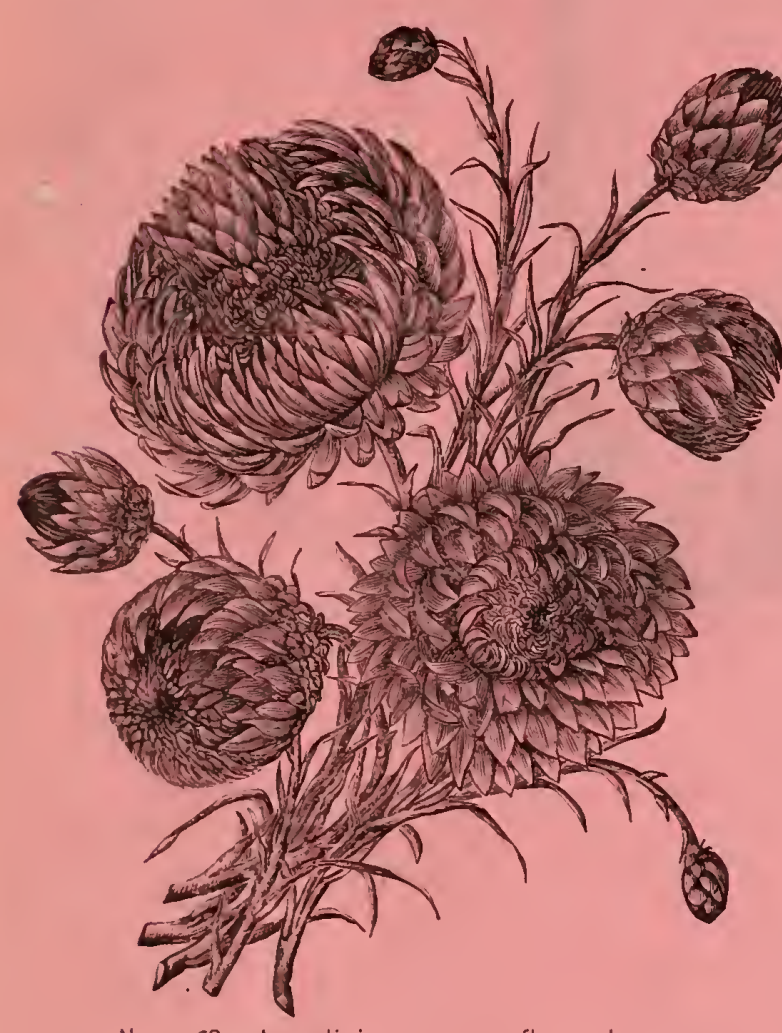

* No. 268. Acroelinium roseum flore pleno. - A distiuct double variety of this pretty everlasting annual, pos. sessing all the delicate tints and shades of color peculiar to tho single variety. For the ornamentation of the flower. garlen, for culture in pots, or for the composition of bot. funets aur, wreatlis, whetlier fresh or dried, nothing nore beatiful in the way of inumor. telles has yet been introrluces. It cannot fail to become a gen. mal favorite, and to be extcr. sively grown, especially for winter indoor flecoration, while (o) florists' work it is des. tined to play an important palt. The flower's are some. what linger than the single sort, and the plint is a little taller aud bore branchecl. Abont seventy.tive per ext. of iloutble flowerg will be ols. fahner from the seed offererl. Per pkt. 25 (\%)ls.

No, 323. A mumobium ala tumu grandiflorum. - In this unvelty we have a great inprovement over the old trope if this well-known evorlasting. 'Thr blooms are of a pure white, and about lonlle the size of tlanse of the Ammobium ala. tIIm. P'er pkt., 15 cents.

No. 359. Aquilegia Verveneaua atroviolacen pleuinsima. -All lestres of Arguilegias will hat this strrling novrlty with delight. Tha flow. (r)'s are very douldes, aud of a drep violet, which contrasts clearmingly witl the varieratten foliage of the plint. Per pkt., 15 cents.

" No. 497. Brownllia elata mun fl. curulea. All lovers of Browillia will hail the introtuction of this urvelty with more thau ordinary pleasure. It grows of au uniform lieight, only abont lialf as

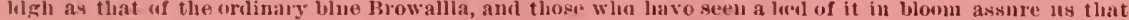
It luas all the appearane of an elegantly shateml blue conrpet. Prer pkt., 25 centy.

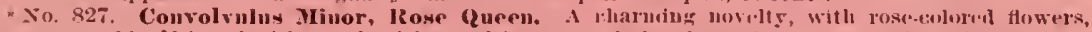

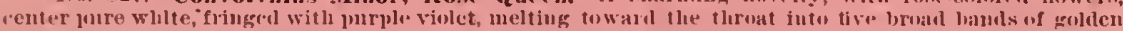
vellow. Perpkit., 15 cerrts.

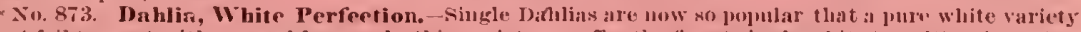

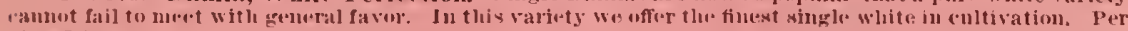
pkt., 25 cents.

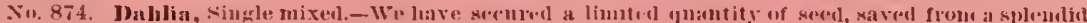

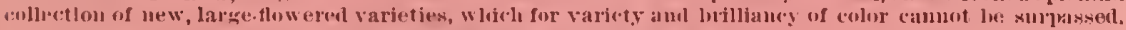

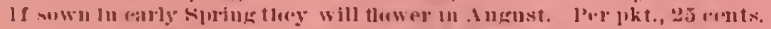

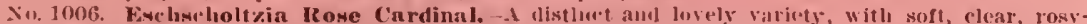

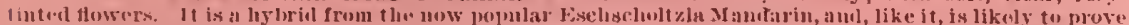

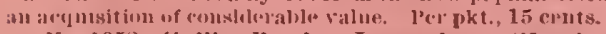

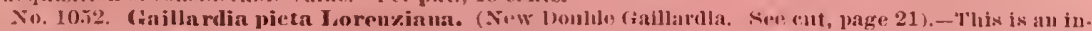

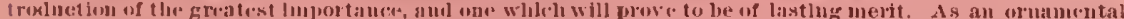

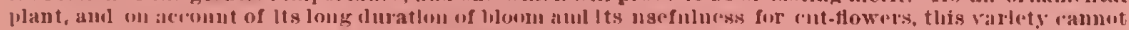

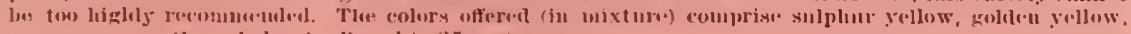

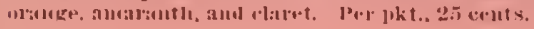


No. 1121. Godetia, Duchcss of Albany.-A superb new variety, produeing a profusion of large, haudsomo satiny-whito flowels, the inlivilual blooms freqneutly measuring four inches across; and ufiroubtedly the finest Whito Godetia ever seut out. The plants when iu full bloon resemlsle miniature Azalcas profusely covered with trusses of flowers which entirely hide the foliage. It is perfectly hardy, anıl sown in antumn and transplanted in early spring, will give a fino early display. Per pkt., 25 cents.

No. 1213. Helichrysum Fireball.-A new and beautiful overlasting, of the ricliest crimson-maroon color; a bright and pleasing contrast to the ordinary dull chocolate-1 ed everlasting flowers. For ehurch recoratious, etc., it will be invaluable. Per plit, 25 cents.

Ňo. 1329. Larkspur, Double-Stock flowered, "I Iustrous Carmine."-The new ant constant color of this novelty is not approached iu any Larkspur hitherto offered, and surpasses in beauty nost of

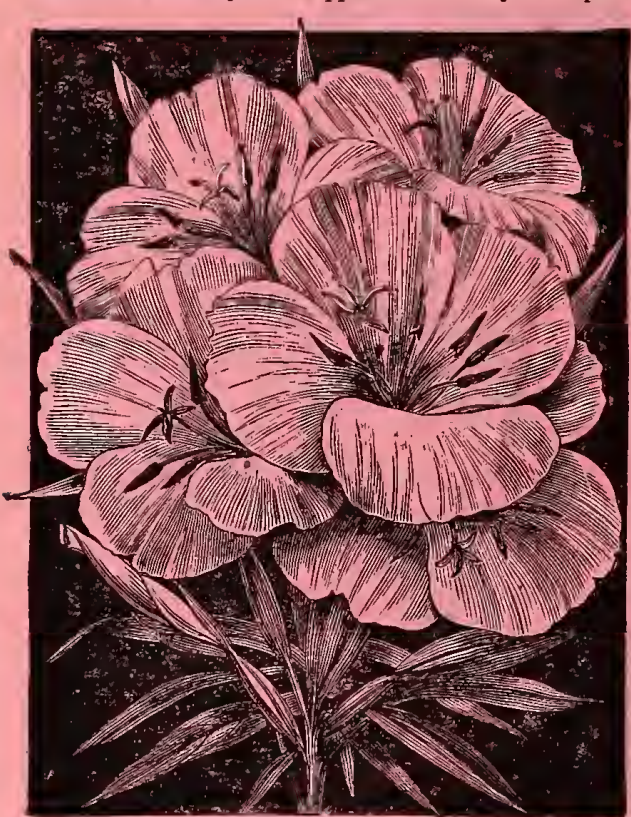

No. 1121,-Godetia, Duchess of Albany. the color's which have been obtained up to the present. It is of a fiery or lustrous carmine, and by its judicious employment brilliant effects may be produced. Per pkt., 25 cents.

No. 1344. Lathyrus latifolius delicrtr.-A distinet and bealtiful form of the Everlasting Sweet Pea, witl pale pink flowers; pleasing and effective. Per pkt., 25 cents.

No. 1488. Marigold, Compact French, Gold Striped.-For compact liabit, uniformity, and constancy of bloom, this is unequaled. It seldom exceecls six inclies in height, and is completcly covcred with large flowers, regularly striperl with chestnut biown, on a bright yellow ground. Per pkt., 25 cents.

No. 1503. Mrarvel of Peru, dwarf, pure white.- when fully dereloper theplants of this novelty do not exceed nine or ten inclies in height, aud form a charniug, compact little bush, studded witl snow-white flowers, and clothed witl flne yellowish foli. age. Per pkt., 50 cents.

No. 1547. Mignonctte, Jefieries's Snow-white. -A sterling novelty is offered in this Miguonetto, it being entirely distinct from any other we know of. The spikes are pure white, delicately fragraut, and freely produccd around a central stem of great size. For sowing in pots or beds, and for bouquets, it will be found invaluable as a sweet-scenter, pure whit o flower. Per pkt., 25 cents.

* No. 1553. Mrinulus nobilis (M. hybrid. us tigrinus nanus compactus duplex).-This is nndoubtedly one of the very best novelties of the season, and is distinguishable abore all other hybrids of "monkey flower" by its dwarf habit. Abovo its compact, bright green foliage it bcar's a perfect cushiou of double

flowers of brilliant colol's and striking design. Per pkt., 50 cents.

No. 1555. Mimulus, "Queen's Prize."-A most magnificent strail of this casily cultivated and brilliantly colored flower. Many of the flowors measure from two to threo inclies in diameter, the color comprising exquisite mottled shades of rich puple, crimson, yellow, ruby, ctc. Whcrever exlibited they have been pronounced superior to auytling of tho sort soen before. Per jkt., 50 cents.

No. 1582. Myosotis Alpestris robusta grandiflom.-The flowers of this new rariety are of a sky. bluo color, witl a clearly defined ycllow cye, aud of great size. The plant resembles in habit the form of a candelabrum, on whicl account it is quite distinct from all the older sorts. Per pkt., 25 conts.

No. 1602 . Nasturtium, Tom Thumb-Empress of Indin.-This plant is of a dwarf, compact luabit, with iark-tiuted foliage, and flowers of a deep, brilliant climson, many degrees dceper and richer than in King of Tom 'Thumbs, from which variety it lias probably originated. Its merits as a bedding plant can. not be too highly spoken of. Per pkt., 15 cents.

* No. 1636. Nicotiaua Afinis.-A very fine and lighly remarkable species, attaining about twenty inches in height, and prolucing freely, at the extremities of very long tubes, large, pure white flowers. They are iu full beanty nornings and evenings, and emit a delicious fragrance; in this respcet, indeed, few flowers can vio with thcm. This novelty is worthy of a place in every collcction. Per pkt., 25 cents.

No. 1696. Pnnsy, "Lord Bcaconsfield."-The ground color of the flower is purple violet, sliading off, iu the top petals only, to a wllitisl hue, a peculiarity which imparts to the whole flower an unusually bright appearance. This highly effective and singularly beantiful Pansy cannot fail to speedily become one of the niost pounlar, botli for bedding and boiquet-making. Per pkt., 50 cents.

No. 1791. Phlox Drummondi hortensix flora alba.-This is without doubt the finest white Phlox obtained up to the present time. It is of vigorous habit, and produces in wonderful profusion fiowers of unusually largo size. Per pkt, 15 cents.

No. 1792. Phlox Heynholdi globosa alba-rosea.-This is a perfect gem for pot culture, their particularly free and long flowering nature renclering them specially desirable. It is of a lolicate pink color, aud is reproilnced true from seed. Per pkt., 25 cents.

* No. 1836. Papaver Daneborg.-A new single Poppy, with billiant scarlet flowers, haviug a largo silvery white spot on each petal, forming a white Maltese cross on red ground. Very showy and striking. ler pkt., 25 cients.

\section{NEW GERMAN PANSY.}

No. 1681. The splendid colored plate of this celebrated strain of Pansies which appeared in our catalogue of 1882 , was by some considered overilrawn, but last season we learned of many instances in which those illustrated were far celipsci in both size and color. The seed we now offer has been imported direct from the glower of the best collection in Germany, and has been saved from his choicest named varieties. We are justitied in expecting even better results from it than have alrealy been olstained. Per packet of 50 seids, mixed colors, 50 cients. 


\section{BLISS'S AMERICAN RACER PEA.}

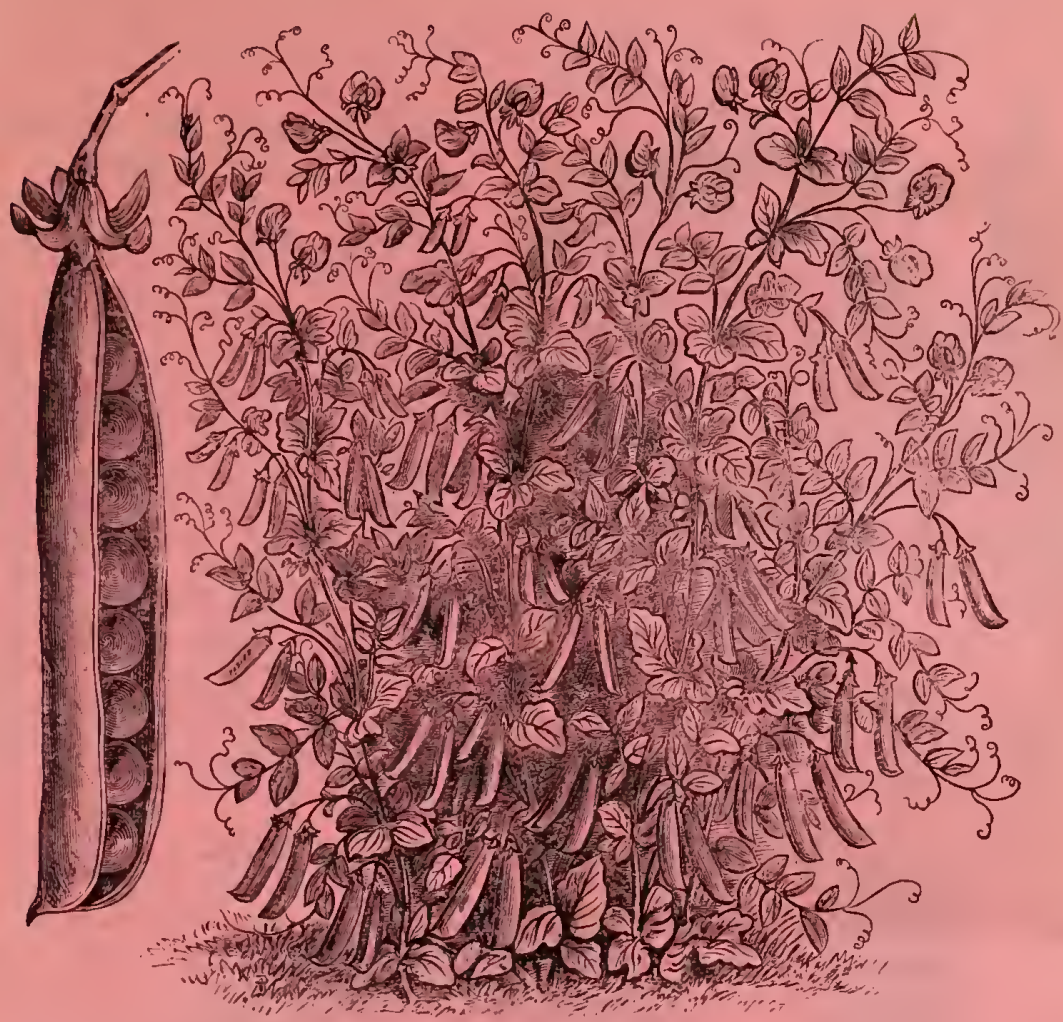

This r'markable Pea, which is now for the first time offerer for sale, was proineud several years aince by Dr. 'T. H. Hoskins, of Newport, Vt., by crossing Daniel O'Rourke witli Carter's First Crop. It was selected ont of a large mumber of gectlings raised at tho same tiuc, as the one which coulined the large rielil of the former with the moderate rowth of vine of the latter, and also becauso it was lutter in quality than either. Ever since that time we liave watehed this variety with inuch interest, butl, in our own experimental srounds and in many other localities, where we had them grown for trial, desirons not to offer it for sale lofore we hal positive uroof of its pernanency and arlaptability to viuions soils anu climates. Onr expectations have been fully realized, and all those who have grown this vartety during the last seasons praino its excellence in ligh terms.

In quality it is in alvance of all otlıer round varicties. The ripo Pea, thongl a yellow nne, is some. what wrinkled, thus inllicating the shrinkage in drying, due to the presence of sugar in the plice of stareh in the green Pia.

It lats bern grown in competition with all othur carly and "extra" early sorts ever aince its origi. uation, ind uot once with any competitor lias it failed to come ont alseal.

In vine, it is letween its two parents, from thres to fire feet, difierlng in wet and dry seasons aud in strong and weak soils, as all variteties do. Whin raised for market, on an early soil, it aftorils about three or four lickings at intervals of two or thres days - more in wet than in dry seasons, of conrse. It cau be growil withont brushing by sowing in rows one foot apart, and training togetler, which aftords ample silpjwrt.

In prodnctiveness it is not inferior to any early sort, and certainly is superior to Phlladelphia Extra Farly in this respect. After all the experienco we haul with the American Racer Pea, and, judgring fron the many conmendatory testimonials receivil fiom otliers, we confidently recommend it as the best and most desirable rariety of its claws for lowe nse as well as for market.

Prires-Onefourth pint package, 20 cents; pint, 65 cents: quart, 1.25 ; by mail, post-paid. Wlien delirered at our store or sent by express at the expense of the prrcluser: One pint, 55 reuts; one quart, $\$ 1.00$.

GEXESFE, N. Y., Ang, 22,1882 .

The Racer ladi peas large pnougl to eat at the saue time as First and Best and Lamireth and Buist's Extra Earlies. The Racer grew three amt one-half to tive feet, Laudreth's the same, the otliers two and one-half to threo and one.half feet.

The great value of this new Pea is its proluctiveness. I connted on one vine fifty.eight pods, all well

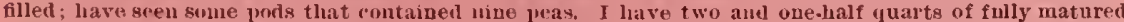
peas from that very small trial packet. 


\section{THE RURAL PREMIUM CORN.}

Most readers of agricultural journals are aware of the valuable experiments carried on at the Farm of The Rural New Yorker, with the diflerent farm crops. Corn has received special attention, and of the two varieties described below the Flint bas been raised through forty-one successire years, while the Dent was found so much superior to other similar varieties that it was at once selected as the best in cultivation. It is with pleasure that we announce that we lave been fortunate enough to secure the entire original stock, which we now offer tirst for sale.

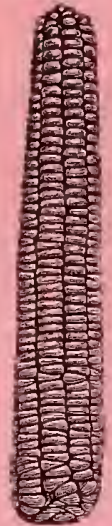

One-seventh

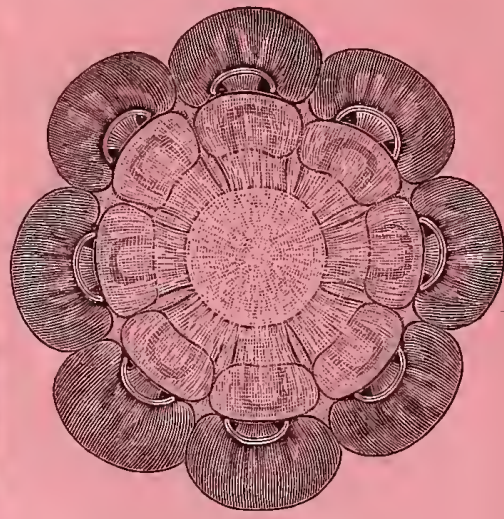

Section of Ear.

\section{RURAL THOROUGHBRED FLINT CORN.}

A remarkably distinct and wouderfnl va. riety. It is a Flint Corn, and has been raised, as stated, over forty years in the Rural's family, isolated from all other varieties, the longest anu most perfect ears only being selected for seed from year to year, It pro. duces the longest ears of any known variety. Ears of fifteen inches iu length are not un. common, and some have even reached the enormous length of seventeen inches, specimens of which may be shown. It is eightrowed, of a peculiar buff color, cob very small, and keruels large and very broad. The stalks are slender, eight to nine feet in height, and closely set with large, remarkably broad, leaves. Each seed produces upward of twelve strong suckers, - many of which mature perfect ears,--forming a regular bush, so that they cannot be distinguished from the main stalk. Owing to this spread. ing habit, ouly one kerncl - should be planted or allowed to orow in a hill, aul the lills themselves should never be closer than four feet each way. Its large yield, length of ear, and excellent quality make it a most desizable field variety throughout the Northern and Middle States while its great suckering habit, breadth of blade, and smalness of stalk will render it, as a fodder plant or for ensilage purposes, the most valuable variety of Indian Corn at present known. Price 25 ceuts per packet; 60 cents per pint ; $\$ 1.00$ per quart, post-paid, by mail.

THE RURAL HEAVY DENT CORN.

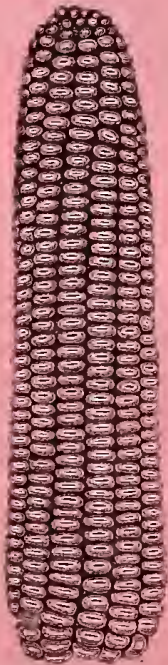

One-fourth Natural Size.

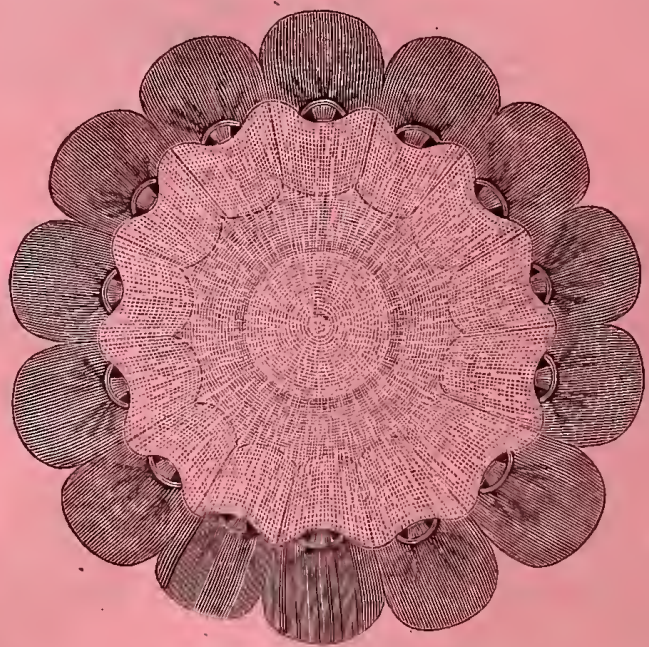

Section of Ear. Natural Size.

This variety is the result of careful selection continued ituring a ruarter of a century. The originator says: "About twenty-five years ago I picked out a few of the best ear's, the seed of which was plauted the next year by itself, and produced a better crop than the other portion of the field. The ears now are double the size they were theu." All those who grew it last year are unakimous in their praises, and declare it

\footnotetext{
"rTHE BFST DENT CORN GROWN."
}

The kernels are white, large, broad, and heavy, and inclined to shrink less than those of other kinds of Dent Corn, while the shape of the ears and of the kernels is very constant. It is generally a singleeared Corn, though often two good ears grow ou a stalk, and on the suckers also, one sced having produced ten ears which weighed five pounds, shelled four pounds, and contained 3670 grains. The yield of this variety is enormous, one hundred bushels of shelled Corn being an average field under good cultivation, while one hundred and fifty bushels per acre, and over, lave becn produced in favorable seasons. We are confident that no variety more desirable for the Southern and South-western States has ever veen introduced. Price 25 cents per packet; 60 cents per pint; $\$ 1.00$ per quart, post-paicl, by mail. 


\section{QUEEN OF THE PRAIRIE CORN.}

A mong the several new kinds of corn introduced within the last few years, none have gained as general and deserved popmlarity as the Qnecn of the Prairie. Being a Yellow Dent variety, its early maturity. combined with very lare yiedd, is something astonishlng. No other Dent Corn has ever been grown suc. cessfully as far north as this; planted on the th of July, it has fully matmret its crop before frost, and it has cven been planted as a second crop, after' the Whent harvest, and yielded a full and well-ripened crop.

We cannot give a better description than to quote what one of onr correspondeuts says: "I planted alsout five acres of this Corn, near the midlle of June. The ground was too low, wet, and miry to be acces. sible by horse and admit of plowing; so I dugr, with a hoe, holes varying froul three to five feet apiart, dropped hu rach three graius of Corn, and covered them ulv. Nothing more was done, no cultivation what. ever given, and the yich was 750 bushels of Corn. I also planted six rows on itpland alongside of ont Fichl Corn, and under tho same conditions and cultivation it Fielded two binshels nore. I do not liesitate to state that this corn has no equal, and has these adrantages, not possessed by any gther: First. It will grow on poorer soil. second. It nakes no suckers. Third. It grows quicker and matmres sooner.
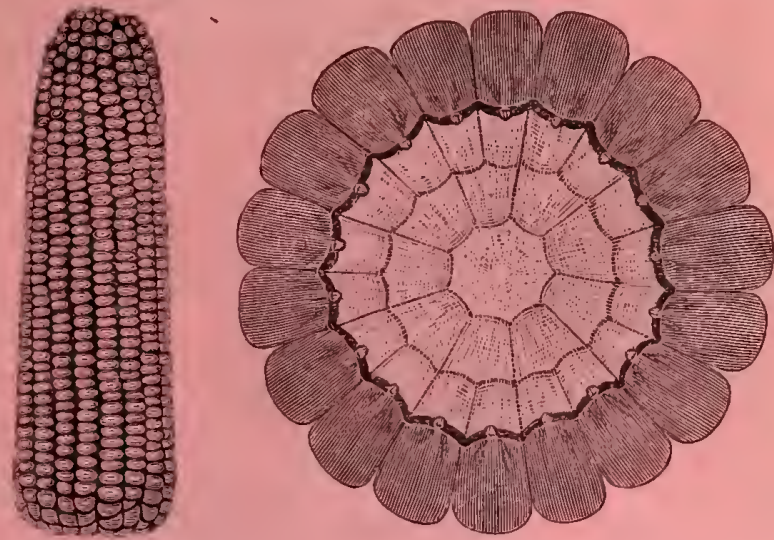

Section of Ear-Natural Size.

Fourth. It sliells two bnshels of grain from thee bushels of ears." Selectel rars, 25 cents; 3 lbs., slicller, \$1.00, by mail, post-paid; per peck, $\$ 1.25$; busl., $\$ 3.50$

\section{A NHW VHGITABIF:}

(Raised by Mr. Richard Gilbert, Gardener to the Marquisc of Exeter, Burghley, Stamford, England.)

Chou DeBurghley.-This remarkable 1 ew vegetable was awaricd a first-class certificate by the Royal Horticultural Society of Eugland, and it is safo to say no otler vegetable was ever intiouced with so many exccllent testimonials, from so many emincnt hodticulturists and others well qualificd to judge what a good regetable shonld be. Evidently it is the result of a lyluridization between a Cabbage and Broccoli, and, properly described, may be called a Cabbago Broccoli of a superior and distinct $t y$ pe. The heads are w ell form id, of mediun size, solid, and of a decidedly liglite color than most Cabbares, and contain a dimintive Broccoli as a solt of kernel in eacl. Every one who lias had the opportunity of tasting it cooked pronounces it of a distinct, delicate, and delicions flaror. In England it lias witlustood several severe: winter's, and is ronsidered a raluable acquisition to the list of winter vegetalsles. Pcr pkt., 25 cents.

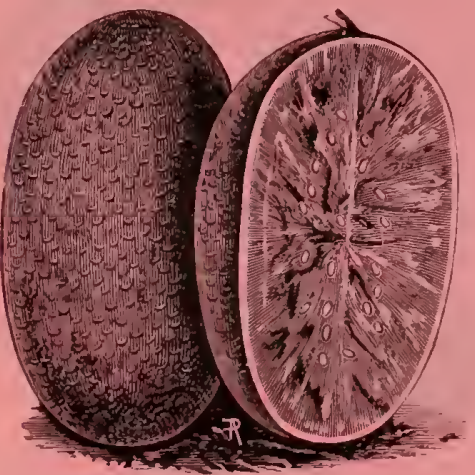

Scaly-Bark Watermelon.

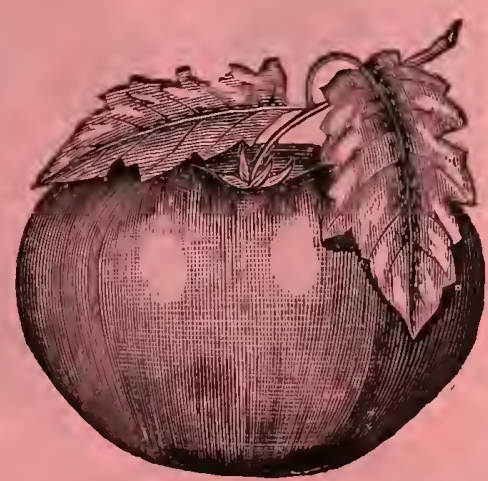

Livingston's Favorite Tomato.

A very large, oblong variety, with a lark, tough rind, which lias a peculial scaly appearanco; crim. son flesh, vely solit, remarkably sweet and free

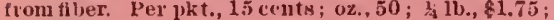
11). 85.00 .

This 1s said to be the largest perfect-8haped To. mato in cultivation ; ripens ('ve'uly aud early, holding its size to the end of the season. Very prolitic, good Havor, few sockls, flesl solid; bears slipping long distances. Per pkt., 25 cents; 5 packets for $\$ 1.00$.

Maxixe. - Tlis new regutable is from Brazil, where it is extcnsively usen, elther raw, as a salact,

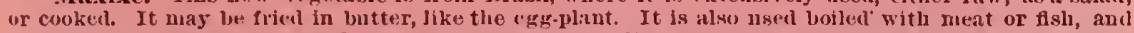
in somps. It may also bo sliced and eaten with vinegar, like the cncumber. For vickles, when abont lalf or two-thirls grown, it will be found palticularly desirable. It slonld be planted on light, warm soil, and treated precisely like uelons or cucnmbers. Per jkt., 25 conts; 5 jkts., $\$ 1.00$. 
For cultural directions and a more complete list of Potatoes, with full description of each variety, see our Illustraten Potato Catalogue, which also contains much valuable information upon their culture. Price, 10 cents. See also pages 91 and 92 of this catalogue for fuller description of the new varieties.

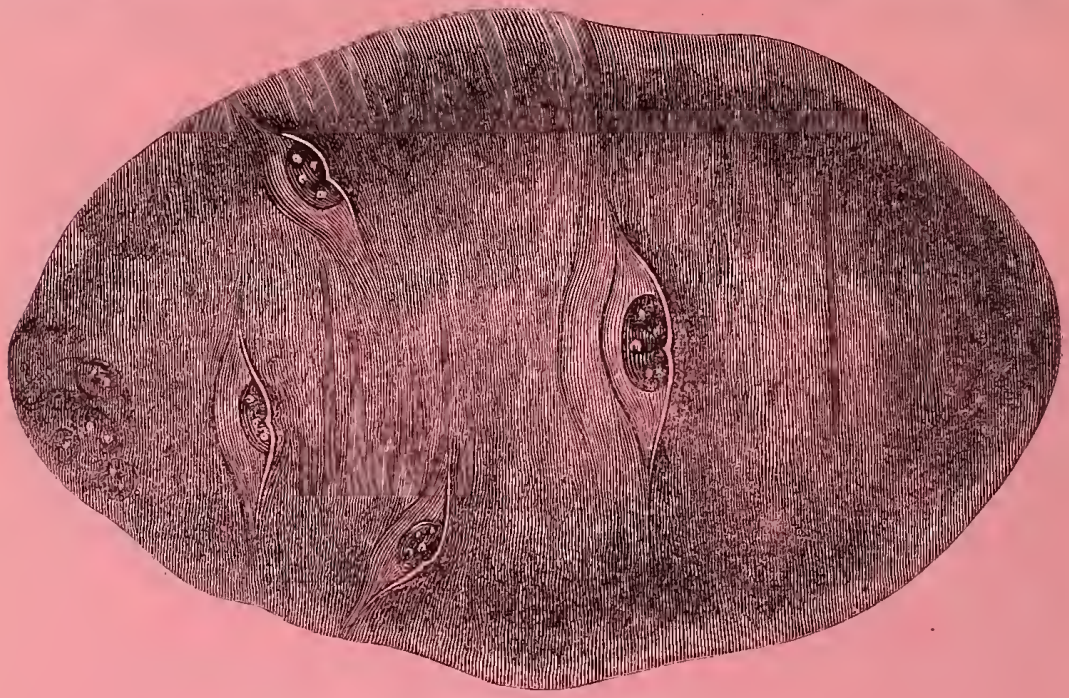

ROSY MORN.

In appearance this variety closely resembles Early Rose, lut in quality is deciderly superior, while it yielis ncariy double as much as Early Rose, planted side by sido, and under the same conditions.

Price, $\$ 1.00$ per pound; threo pounds, $\$ 2.50$, by mail, post-paid. By express or freight, at the cxpense of the purchaser, half peck, $\$ 3.00$; one peck, $\$ 5.00$; half busliel, $\$ 7.00$; oue bushel, $\$ 12.00 ; b 31$, $\$ 25.00$.

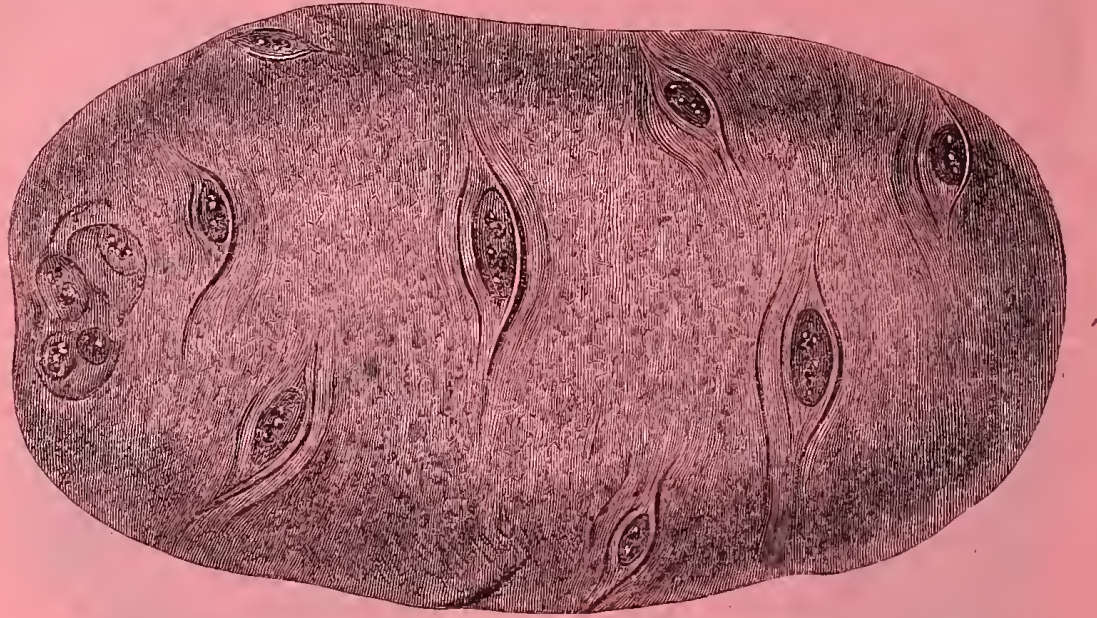

RUTBICUND.

This is a splendil, modium late variety, and iu quality ranks with the best, while in hardiness and vig. orous growtl of vines as well as in productiveness it hus fow if any eqnals. As a reliable wiuter keeping Pota to it is not exceller by any other kinds.

Price, \$1.00 per pound; three poutds, $\$ 2.50$, by mail, post-paid. By express or freight, at the expense of the purchaser, half peck, $\$ 3.00$; one peck, $\$ 5.00$; half bushel, $\$ 7.00$; one bushel, $\$ 12.00 ;$ bul., $\$ 25.00$.

Tyrian Purple.-The skiu is a dark purplish red; flesh white and firm, and, when conked, floury aud of good flavor it is an excellent keeper, and, ou account of its many merits, we believe every potato enltivator wonld do well to give it a trial. Price, 50 cents per pound; three pounds, \$1.25, by mail, post-paid. By express or freight, at expense of purchaser; one peck, \$1.50; me bushel, \$5.00.

Hammond's Slug Shot. A Guaranteed Exterminator of the Potato.Beetle. - It is an impalpable powder, lestructive to the Potato-Bugs in the varions stages of growth; at the same time the ill effects of Paris Green, or danger from having it aronnd in quautities, are obviated. It las been used with success in dcstroying Caterpillars, etc., on Pear and Apple Trees, Egg-Plants, etc.

Bbl. of $200 \mathrm{lbs}$, \$7.50. Packages of $5 \mathrm{lbs}, 30 \mathrm{cts.}$; $10 \mathrm{lbs}, 50 ; 15 \mathrm{lbs} ., 75$. Seud for descriptive circular. 


\title{
$\$ 250$ IN PREMIUMS.
}

\section{FOR PRINGLE'S AMERICAN TRIUMPH OATS, PRINGLE'S ADAMANT WHEAT, \\ PRINGLE'S GREEN MOUNTAIN WHEAT.}

\author{
For full description of thene Cereals mee page 107 of this Catalogue.
}

In orler to incluce farmers and others interested in the cuitivation of grain to give these rarieties a thorough and unirersal trlal, wo offer $\$ 210$ in premiums to those who produce the largest quantity of seed frou one packet of the seet, and for the twenty best and heaviest heads of both the varieties of Wheat and Onts purchased of us. Those ordering wirl please state, with their order, that they desire to com. pete for the Preminms.

For the largest quantity of Ameritan 'Trimnph Oaty grown fiom oue paeket of the seed............\$20.00 For the second largest quantity ................................................................... 15.00

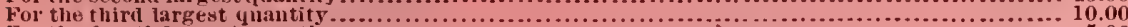

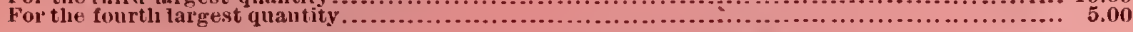
For the largest quantity of Adamant Wheat grown frou 1 packet of seed....................... 20.00 For the second hargest quantity ................................................................... 15.00

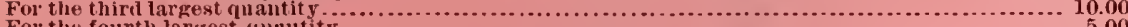

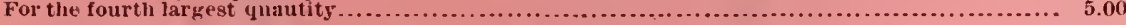
For the largest quantity of $G$ reen Mountain Wheat grown from 1 paeket of seed ................... 20.00

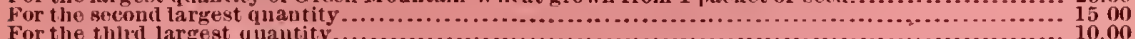

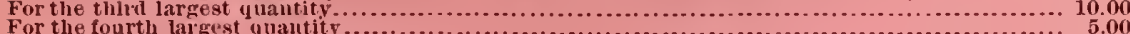

We also offer adlitional preminus of $\$ 60.00, \$ 20.00$ each, for the best 20 heads of wach of the above varieties, as follows:

For the best and heaviest 20 leads of American Trimnplu Oats ................................ $\$ 8.00$

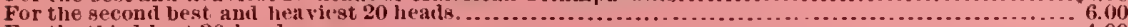

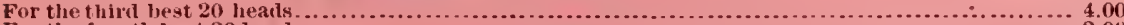

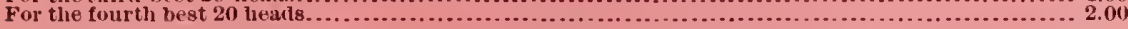

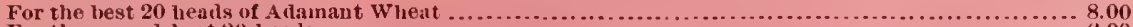
For the serond best 20 hearls....................................................................... 6.00

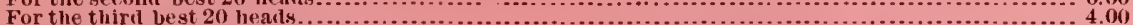

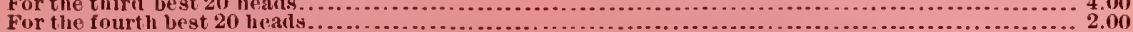

For the hest 20 heads of Green Mountain Wheat......................................... 8.00 For the seeond best 20 hearls.............................................................................

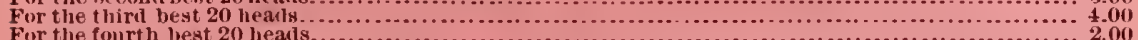

Competltors for the prizes will be reunired to give the date on whleh they gave their order, with a statement of the weight of their crops, which must be witnessed and sworn to before a Justice of the Peace, Notary, or any one comprtent to administer the oath, and sent to our address before the First of November, 1883 . The prizes will be pald in Decenber, 1883.

Competitors for the premiums for the best. heals of oats and wheat must deliver thein at onr offlce, 34 Barclay st reet, New.York (all charges prepaid), previons to the 10 th of September, 1883. The straw must be cut not less than eight inehes in length, exclusire of the heats, and carefnlly packed to prevent injury in the transportation. They can be sent by mail or express, prepaid, at the option of the grower. If sent by mail, they should be boxed in a light wooden or a stiff pasteboard box, the cover of which must be seeured by strong twine, and uot nailed or fastened in any way to prevent the examination of the parcels at the New. York post-oftice. Nowriting of any kind must be inclosed in the packages, as in that case letter postage would be eharged on the whole package, and would not he taken from the office. The name of the sender must be written on the outgide of the packase, with our address. Notify us by letter when the wheat is sent.

\section{NEW MAMMOTH PUMPKIN-JUMBO.}

This is undoubtedly the largest variety grown, often attainiug the weight of two hundred ponnds. Per pht., 10 cents: $\% \%, 20$; $231 \mathrm{~b} ., 60$; th., $\$ 2,00$. Every purehaser is entitled to compete for

\section{JOIRTY IOLLARE IN PREMITMIS,}

to be awarded as follows: $\$ 25.00$ to the grower of the largest Jumbo Pumpkin; $\$ 10.00$ to the grower of the second largest; and $\$ 5.00$ to the grower of the third largest. Specimens for competition to be delivered at. our store, free of expense to 118 , previous to October $15,18 \times 3$, and un November 1 st the casll will be forwarted to those entitlerl to it.

IRadish, Scarlet Turulp, White Tipped.-A very early variety; color, bright scarlet, tipped wlth white, presenting a beantiful appearance upon the table; an excellent market variety ; fine for forciug. Per pkt., 10 cents; ounce, $20 ; 1,1 \mathrm{l}, 40 ; 11 \mathrm{~b} ., \$ 1.00$

Endive, superb New Friuged.-Thls is said to be the most beantiful and perfect Endive yet int roduced, and, hesides being particularly valuable for culinary purposes, is of distinct color and highly crnameutal. It is superior in tinentess of fimbriation to the best Curled Futlives in cultivation, and must speetlily replaee the older and coarser kinds. Per pkt., 25 cents.

Turnip, Jerwey Lily.-Cuynestionably the must perfert in outline, and the earliest White Turnlp gown: of exenisite Huver ; in slape as perfect as an Orange; with a single tap-leut and very distinet, small top. Per balf-ounce parket, 15 ceuts. 


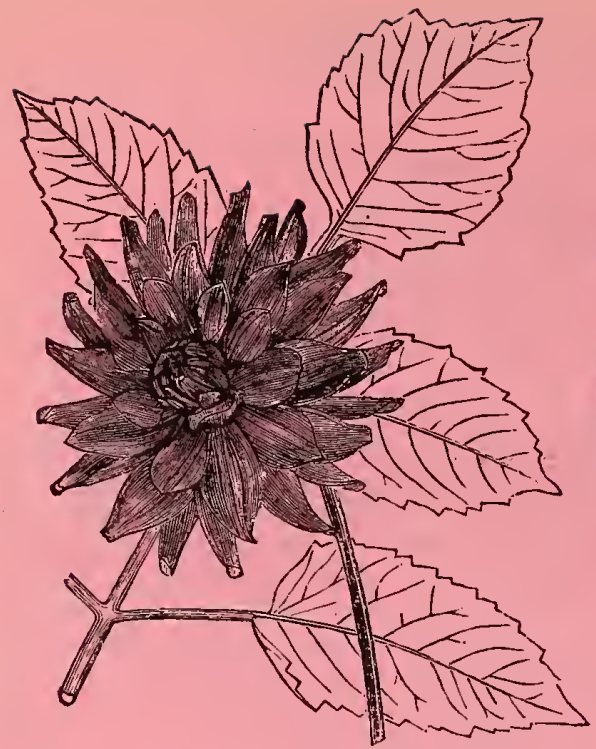

New Cactus Dahlıa - Juarezii.

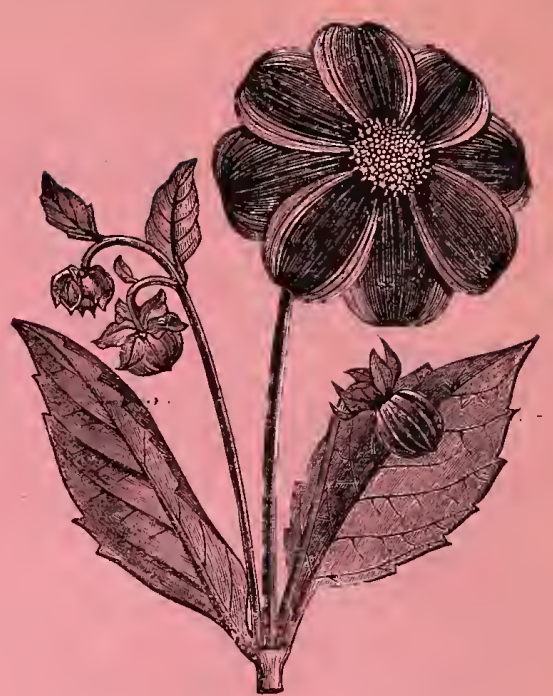

Single Dahlia - Paragon.

(These cuts represent the fiowers half the natural size.)

\section{NEW SINGLE DAHLIAS.}

Coccinea Ardens.-Deepest brilliant scarlet. 30 cents each.

Imperial Prince.-Flowers large; petals flat and plaited; eolor rich, deep purple, shated crimson. An early flowering variety. 75 cents each.

Juarezii.-A beantiful variety, distinct in form, and of a most exquisitely shaded purple-scarlet-crimson color; the flowers are on long foot-stalks, freely produced, and lasting well after being cut; a really fine novelty. 35 cents each.

Lord Lyndhurst.-Flowers large and flat; colır brilliant pure scarlet; habit d warf. An early flowering variety. 50 cents each.

Lut en.-Pure yellow, with dark orange center; very prolitic in hloom. 30 cents each.

Paragon.-Quite distinet, and must be seen to be admired; darkest velvety maroon, with sladings of bright scarlet around each petal; small yellow disk. 25 cents each.

Queen of Whites.--This is the great sensational flower of last year in Eng!ish fetes and entertainments : the flowers are of the purest white, from 3 to 4 inches in diameter. $\$ 1.00$ each.

The sut of seven varietics will be sent for $\$ 3.00$.

\section{NEW GERANIUMS FOR 1883.}

The favor in which our new Geraniums have been received the past two years warrants onr introduction of another new set. These will be found of superior merit, and are valuable additions to this already popular class of plants.

Hamlet.-Very rich, deep crimson, with very large, finely formed flowers and trusses.

Ingo.-Flowers very delicate flesh-pink, with markings of white in upper petals back of flowers; silvery white; habit neat and compact.

King Lear.-A maguificent flower; rich, pure scarlet; of the finest form; trusses and flowers very large.

Mercutio.-Very large trusses; fine, boli habit; with rich, bronzy flesh, salmon flowers.

Othello.-Flowers rich plum erimson, with deup purple shades a fine, bold, distinct variety.

Romeo.-Fabit neat and compact; flowers and trusses of good size; of the purest white.

Shyloek.-A rich, deep, fill purple, with large flowers and trusses; habit of plant compact and very free in growth.

Price, each 50 cents; or tle entire set of seren varieties, $\$ 3.00$.

\section{NEW CHRYSANTHEMUMS.}

Crimson King. -A new, large-flowering c'linese vartety; beantiful and distinct; of the richest deep crimson; flowers large; neat and compact habit. Feceived a first-elass certificato from the Royal Hor. ticultural Society of London, in November, 1882. \$1.00 each.

Nimbriata.-An early-flowering Pompon variety, with flowers unch fringed; eolor, rose, shading to pure white. 35 cents each.

Golden Indame Marthe. $-\Lambda$ rery beautiful golden yellow Pompon varidty ; Howering early in large lieals. 35 ccits each.

La Petite Marie.-The dwarfest and earliest puro white Pompou rariety ; rrowing only a few inches in height. 35 cents each.

Madame Marthe.-Flowers of good size; of the purest white, resembling the sull white Dahlia " Guiding Star." A valuable aequisition. 35 ecuts each 


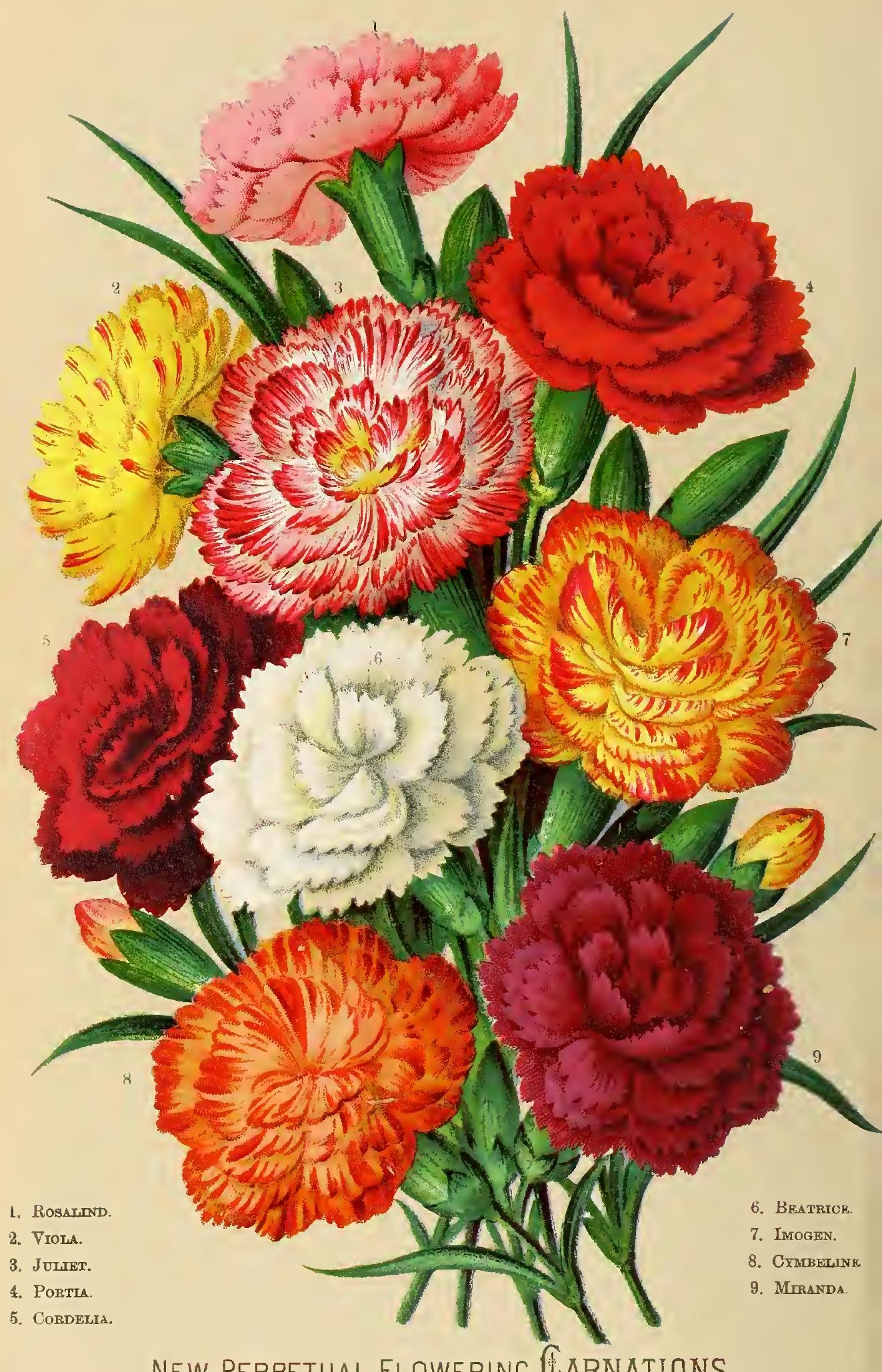

NEW PERPETUAL FLOWERING CARNATIONS

FROM B.K.BLISS \& SON'S GARDENERS HAND BOOK. 


\title{
OUR COLORED PIATE.
}

\author{
THE SHAKESPEAREAN COLLECTION OF
}

\section{NEW EVER-BLOOMING CARNATIONS。}

We have great pleasure in offering this entirely new and distinct collection of this popular flower, and wish to draw particular attention to their brilliant colors, distinct forms, and their constant and ever-blooming habits. The illustration does not in the least exaggerate or flatter them.

ROSAIIND.-A lovely shade of pure rose-pinls; Howers very large; deliciously scented.

VIOL.A.-Flowers of medium size, ground color rich lemon-yellow, faintly spotted and striped with brilliant cammine, some flowers conxing nearly pure yellow.

JULIET.-Flowers large, ground color white, heavily lined with narrow stripes, some of which are of a delicate pink, others of the deepest crimson.

PORTIA.-Color the most intense pure scarlet; flowers very large, of good substance, and finely formed; the most brilliant color seen in the Carnation.
CORDELIA.-Flowers large, much serrated, of a rioh, deep, velvety crimson; one of the most brilliant.

BEATRICE.-Neat and compact in habit; flowers of the purest white, deliciously scented.

IMOGEN.-Ground color buff-yellow, lined with deeper vellow, striped with lines of darls and light red; a compact, neat flower.

CYMBELINE. - Ground color of flowers rich orange-yellow, flaked with brilliant red; of good size, and very free flowering.

MIRANDA. - Flowors very large, much serrated, of a rich, deep maroon, with royal purple shadings; a most distingt variety.

Price, 75 cents each; the set of 9 varieties. for $\$ 5.00$. Orders will be booked in strict rotation for plants to be supplied on first of March. Orders will be bookcd only to the amount of stock on hand, which is limited.

Not the least important feature of this splendid strain of Camations is, that if sown early in Spring they will flowe freely the first season. We have been able to save a limited quantity of seed from our own unrivalled collection, which, if treated according to directions, cannot fail to give penfect satisfaction. It has all been carefully lyybridized by hand, and, judging by results obtained by us, will produce not less than seventy-five per cent. of double flowers. Paclzots (oontaining 20 seeds, mixed colors), with complete directions for culture, 50 cents. 



\section{ESTABL!SHED 1845. \\ B. K. BLISS \& SONS,}

\section{Illustrated Hand-Book}

FOR

\section{THE FARM AND GARDEN} FOR

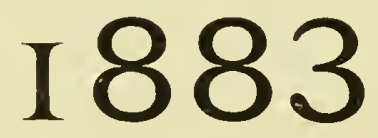

CONTAINING A COMPLETE LIST OF THE BEST KNOWN AND MOST POPULAR VARIETIES OF

GARDEN, FIELD \& FLOWER SEEDS, WITH DIRECTIONS FOR THEIR CULTURE.

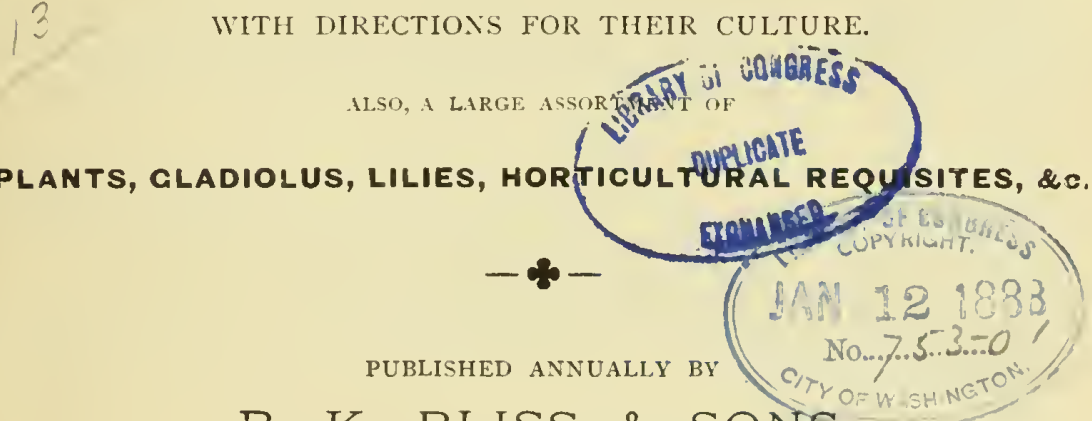

B. K. BLISS \& SONS,

IMPORTERS AND GROWERS OF

Garden, Field and Flower Seeds, Dutch Bulbous Roots, SUMMER FLOWERING BULBS,

And Dealers in Agricultural and Horticultural Books, Implements, Fertilizers, and General Garden Requisites,

34 BARCLAX STREET, NEW-YORK. 
DERHAPS the most pleasing duty that the annuat re-issue of our Hand-book cuables us to perform is that of thanking our many friends for the eontinued confidenee whieh we have for so many years enjoyed. To establish a relationship such as now exists between us and many thousands of our fellow-eitizens, and to have maintained the sume for over a quarter of a eentury, is a labor the consummation of which may well give eanse for satisfaetion.

The lavdatory remarls that reaeh us with pleusing frequeney tell us with no uncertain sound that the arrival of orr annual is looked forward to in many homes with a genuine pleasure. Cognizant of this wide-spread appreciation we have endeavored to have each saeeeding issue surpass its predeessor, - in points of merit,--and the edition that ne now have the pleasure of submitting for your approval is the best evidene that our efforts in this direction have not been relaxed.

Our HAND-BOOK FOR THE FARM AND GARDEN FOR 1883 will be formd unsurpassed as a guide to those interested in anything pertaining to Hortieulture or kindred pursuits, white in other respects it is as perfect as the best artistue and meehanieal skill can make it.

The greater part of this edition has becn entirely re-nritten, and serupulous eare has been exereisch to offer only such varieties as are really distinet and worthy of eultivation. IIany painstaking experiments have been made to enable us to to this, and we feel confident that only such sorts as will with proper treatment give satisfactory results are now offered.

Novelties in Hortieulture, as in everything else, are abundant, but those of real merit are rare. Every season it has been our good fortune to secure one or more raluable and distinet specialties, und this year we are happy to say will be found no exeeption to the rule. Bliss's Americun Racer Per witl prove a worthy sucessor to the famous Bliss's American Wonder Pea, which has everywhere been pronounced the best and earliest wrinkled Pea cxtant. In no sense do these two Peas rival each other-as the Raeer among smooth Pras will take the same runk as the Wonder does chong wriniled. Americren Triumph Orts aud Pringle's Neet Spring Wheat will prove far in advance of many, if not all, of the varieties now grown, and we feel sure an improvement in these will give pleasure to our many farming friends. Te have been fortunate in sceuring the entire stoek of the already famous new varieties of Corn,-The Rurat Thoroughbred Flint and The Rural Heavy Deut,-and feel eonfident they are so much superior to other similar varieties generally eultivated that they will both speedily take rant: us standard sorts. In new potaioes we offer Rosy Mom, Rubieund, and others, for which see page 91. For description of all novelties we would refer to our eolored supplement, in this Catalogue, and to our supptementary list of novelties, which is generally issued in February, and sent out with all goods ordered after that date, and free to all applieants who apply for it.

We wish to direet the speeial attention of our reaters to our splendid Nen Seenling Perpetuat Flowering Carnations, of which the beantiful colored frontispicce gives a life-tile represcntation. It speals for itsetf, and we must admit that the artist has done his duty truthfully and wett, but doubt not that those who try will, as was the ease with the popular German Pansy, produee in nature speeimen flowers that far exeel in size aind beauty the blooms whieh have been so faithfully reprodueed in the plate.

We must not omit a word of thanks for the many unsolicited testimonials as to the satisfaetory quality of our seds, reeeived from exery seetion of the country during the past season. Our thanks are also specially the and cordially offered to those who have kindly recommended us to their.

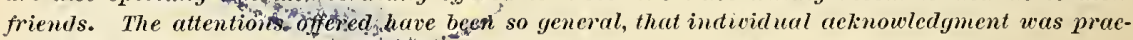
tieally impossible, but we ean assure yon that gratitude for the attention was none the less.

A earefal perusal of this Hand-book eannot fail to be of great benefit to the planter, the farmer, the market gardener, and every person who plants and loves flowers, as it will suggest the most desirable varicties for enltivation, give quentity of seed requiren, instruetions for grouing and earing for erops, etc.

To those espeeially interested in Potatoes, we would say that we publish in Febrary a special Catalogue on Potatoes, forty pages, profusely ithustrated, seut free on application to former patrons or intending putrehasers, and to others on receipt of 10 eents.

With thanks for post favor's, and trusting that the agrceable relations with our old friends and patrons may eontinue for many years to eome, and hoping that those who now entrust us with their fowors for the first time will never find eause for regret,

We remain, very respeetfully yours,

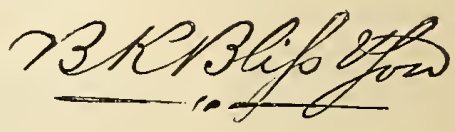




\section{A FEW REMARKS TO PURCHASERS.}

A S the soed season continuos only for a few months in the year, there is, of eourso, a great pressure of business just at the sowing season. Except 1 cases of extremo urgency, all oriers will be executed in strict rotation as received. We woull, therefore, foel greatly obliged if our customers will kindly forwarl their orders as soou as possible after the receipt of this Catalogue. This would greatly facilitate operations, and ensure groater attention. We use evory possible precaution to prevent any error being committed in tho excention and transmission of oriers, aud in the weights and measures. Should any deficlency occur, either by press of business or acciclent, wo earnestly desiru our enstomors to inforn ns of the fact. Such irregularities rarely occur, but it is almost impossible to escape a few, iu the hurry and haste of a busy seed season. We crave iudugence should thore be a brief dclay, and at the same time will do our utmost to prevent it.

\section{SEEDS, BUlBS, ROOTS, PLANTS, Etc., BY MAIL.}

Post-paid to all parts of the United sitates. The freight on all parcels by Express to be paid by the purchaser, unless by special agreement. The cost of collection aud return charges will be ndded to bills scnt $C$. O. I).

1 HE postage law autlorizes the seuding of BULBs, FLOWER Roots, CuTTINGs, ant SELDs, and various ArTICLES OF MERCHANDIsk, at the rate of one cent per ounce, package not to exceed four pounds weight. Under this law wo are enablod to forwaril many other articles besides Seeds and BuIbs that are enumerated in our Catalogue by wail insteal of express, by which a great saving can be effected to those of our patrons who resike at a distance. Articles esceeding four pouuds in weight must be sent by express as liere tofore.

WE WOULD PARTICULARLY IEQUEST OUR PATRONS TO STATE WHETHER IT IVILL, BE CONVENIENT FOR THEM TO RECEIVE THEIR ORDERS by express, and to give theip nearest express oflice. Upon either of the followiug lines, by a special agrement with the Alams, American, National, and the United States Express Companies, we aro onabled, BY PlREP YING cIARGEs, to senil packages to all points on their routes at reduced rates. It is often more convenient for us to send by express, prepayiug charges, than to send by mail in sercral packages. Customers will please not uuilerstand by this that wo agree to pay ALL express charges on any articles they may orier, only that we reserve the right to send by express (pre paying charges) gools offerod free by mail, provided, of course, it is couvenient for them to receive them by this method.

In giving orders please stato oxplicitly by what couveyance they are to be for warded, and if by express or railroal, the names of the parties to whose care they wish them cousigned at the various places of traushipment. When no particular routo is desiguates. we forward according to the best of our judgment Orders from unknown correspoulcnts, to insure attention, mnst invariably be accompanied with cash or a satisfactory reference.

\section{ALL ORDERS MUST BE ACCOMPANIED BY A REMITTANCE.}

T making a remittance, purchasers will please bo particular and send a suffieieut amonnt to eover their order. IVhen only a part of the amount is remitted, roods will be sent only to the amount of the remittance. Should the remittance exceed the amonnt of the goods sent, ahe balance will be returned to the purchaser with the goods. We have beeu compelled to adopt this rule ou account of the inconveuience and expeuse of collectiug small balances due from many of ou patrons at the close of onr business season. Remittances can be made in current Bauk.bills, Post-Office Orders, Registered Letters, or by drafts on New York, Bostoll, or Philadelplia. Post-Office Orders are preferable to all others, as thero is no possibility of Ioss, but when these cannot be obtaincd, Registered Letters are surest to rcach their destination. We will gunmentee the safe amival of all packages when orders are accompanied with n Draft on New York, Registered Letter, or Post-Oflice Order. The cost of the I'ost-Ofice Oriler, Draft, or of Registering tho Letter inay be doducted from the remittance on orders amountiug to $\$ 2.00$ and $u p$ wards.

N. B.-We earuestly request olar colrespondents to be particular and give their NAMES, POST-OFFICE ADDIESS, COUNTY AND STATE IN FULL, DISTINCTLY WRITTEN. We are in daily receipt of orilers defteient in some one of theso important requisites, and very frequently from prominent men of business, who not only forget to sign their namcs, but onit their place of resilteuce, often causing a delay of weeks in the execution of their orders, greatly to their incouvenience, as well as our own. Wo are in possession of many letters, the accumulation of former years, with moncy enclosed, without signature or place of resi ilence, the writers of which probibly cousidercd themselves bally swindled by not receiving their goods. Orders may bo addressed to B. K. Bliss A Sons, Box 3.j311, Post-Onice, New York. Please be particular, and give the address in full, as lotters are often miscarriel by not being jroperiy directed. For the convenience of our patrons, and to prevent errors, we have prepared an order-sheet, all ready for filling out, also an envelope upon which our address is printed, which will be seut with each copy of the Cata. logne. Purchasers will please use the orler.sheet according to the directions, and enclose the same with remittance in the envelope, and return to us.

\section{GREAT INDUCEMENTS FOR THE FORMATION OF CLUBS.}

Purchasers remitting $\$ 1.00$ may select Seeds, in phts., at Catalogue prices, amounting to $\$ 1.20$

Purchasers remitting 2.00 may selcet Seels, in plts., at Catalogue prices, annonnting to 2.50

Purchasers romitting 3.00 may select Scels, in phts., at Catalogue prices, amounting to 3.75

Purchasers remitting 4.00 may select Seeds, in phts., at Catalogue prices, amonnting to 5.00

Purchasers remitting 5.00 may select seeds, in phts., at Catalogue juices, amounting to 6.50

Purchasers remitting 10.00 may selert Seeds, in plits., at Catalogne prices, amounting to 13.00

Purchasers remitting 20.00 may select Seerls, in plits., at Catalogue prices, amounting to 27.00

Purchasers remitting 30.00 may select Seeds, in plcts., at Catalogue prices, amounting to 40.00

No variation whatever will be made from the above rates. Prices to Dealers, whose orders exceed the above amounts, will be given upon application.

We wish it distinctly understool by our correspondents that the above disconnt will be allowed only

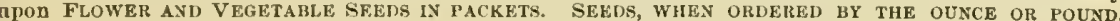
PLANTS, ROOTS, OR BULBS, WILI, NOT IBE INCLULED. 


\section{DIRECTIONS FOR SOWING AND RAISING SEEDS.}

$\mathrm{A}$

MELLOW loam, which is a medium earth between the extremes of clay and sand, enriched with a compost of rotten manure and leaf mould, is adapted to the generality of flowering plants. Previous to digging flower beds or horders, care must be taken that they are so arranged that the ground may be a little elevatod in the middle, that the water may run off, and that the plants may show to a better advantage.

All kinds of annual flower seeds may be sown in the months of April and May; the beds should he leveled and the seeds sown either in small patches, each kind hy itself, or in drills. It is particularly re. quisite that seeds should not be sown too deep, from whence arise most of the failures of inexperienced gardeners. Some of the larger seeds, such as Lupins, Sweet Peas, \&c., should be planted abont three. quarters of an inch deep; other varieties from a quarter to half an iuch deep, according to the size or nature of the seed. In about a montl, more or less, many of them will be fit to transplant. Take advantage of cloudy and rainy woather; move the plants carefully with a trowel; the smaller kinds set in front, the larger in the rear; if the wcather be dry and sky cloudless, givo a little water, and cover for a few days.

The best method to obtain an earlier hloom of the more tender Annuals, such as Schizanthus, Cockscomb, Iee Plant, Sensitive Plant, Cypress Vine, Thunbergia, Globe Amaranthus, Verbena, etc., and insure strength to the plants, is to sow the seeds in pots early in March, placing them in a warm greenhonse window, or plunging them into a moderate hotbed, carefully protecting them from the cold, shading them from the midday sun, and watering them very carefully with a finely-pierced watering can. The seed should be sown in very light, sandy compost, and the pots well drained by placing broken earthenware and rongh sods in the hottom; the finer seeds must not be planted more than a quarter of an inch deep, and the soil pressed down very closely over them. Water frequently, as above recommended, particularly if the house or frame is very warm. As soon as the seed leaf is fully developed, transplant into small pots, three or four in each, and when they have acquired sufficient strength, transplant into the flowor beds, not, however, be. fore the middle of May.

The less delicate, such as Ten Week Stoek, Pansy, Nemophila, Phlox, Double Balsaim, Caealia, Dahlia, Centaurea, ete, may he sown and transplantel as above, lut must be kept rather cooler. The finer varieties of German Asters should be sown in pots towards the end of April, pricked off into smaller pots in June, aud transplanted.

Hardy Annuals, such as China Asters (not the finer German sorts), Purple Sweet Sultan, Sweet Alyssum, Mignonette, Marigold, Gilia, Ipomea, Larkspur, Sweet Pea, Clarkia, etc., will succeed well in a border of natural earth, if sown the first week in May, but they will flower a month earlier if assisted by glass. If some of the Hardy Annuals be sown in September, they will become strong enough to survive the Winter, if protected with a slight covering of straw, or litter; and when transplanted in Spring will tower earlier and stronger.

Hardy Biemials and Perennials may he sown at the same time with the Annuals. As they do not blossom the first year, they may be thinned out, or removed firom the seed beds as soon as they are well rooted, and planted eitler into different parts of tho garden or into a nursery hed, in rows, a foot or more apart; keep them clear of weeds hy hoeing and stirring the earth occasionally, which will greatly promote their growtl, and prepare them for transplanting into the permanent blossom beds, either in the $A u t u m n$ or the following Spring. Biennials are raised principally from seed sown every year. Some Perennials and Biennials may bo sown in Septemher, or as soon as ripe; and if the plants get strong before the setting in of Winter, most of them will flower the next Summer. In transplanting, take care to preserve some earth to their roots, and tie the tall growing kinds to neat poles or rods. Remove decayed plants, and replace them with vigorous ones from the nursery bed. Keep all the beds free from weeds, and the walks clean and neat.

Seeds of Greenhouse Plants, especially Caleeolaria, requirc extra care in sowing, as the seeds are very fine and delieate. 'T'ho pans must be well drained, say half filled with crocks, and on this a layer of rough fibrous peat or turf, and fill up with compost of the following propor tions :-two-thirds light rich loam, one third peat, silver sand, and thoroughly decayed cow manure, the whole wcll mixed together. Make the snrface as smooth as possible, and sprinkle a littlo silver sand over it, water with a fine rose: after the pans have thoroughly drained, the seed must be very evenly and carefully sown-it will require no covering. After sowing, place the pans under a glass in a close frame (it will require no artificial heat), keep shaled, as cxposurc for a short time to the sun's rays is often enough to scorch the delicate leaves and rootlets of tho seedlings. Directly the plants are large enough to handle, thoy must bo prieked into other pans, which have been prepared in the same manner as for seed sowing, and allowed to grow till they touch each other, then shifted into small pots, and replaced in close frame; as soon as the roots fill these pots it will be necessary to re-pot in larger sizes. They will now do, if replaced in frames or put on shelves in the greenhouse nefr the glass; water regularly, re-pot and stake when required. If troubled with green fly, select a quiet evening and fumigate with tobaceo paper.

These remarks will apply also to the cultivation of the Cineraria, Chinese Primrose, Carnations, and many other raro seeds, cxcept that they aro more hardy, and will thrive with less care. 'The seeds being larger will require a light covering of finely pulverized soil.

Seeds of Trees and Shrubs requiro careful treatment. Most failures arise from not sowing them in PARTIAL SHADE. If hot hursts of sun come on the seed beds while the seeds are swelling, and cold follows, many seeds are liable to rot before they appear above tho surface. For raising seeds on an extensive scale, many now use artificial arbors, tall enough to work nnder. For smaller lots, brushwood, or a thin shade of corn-stalks, on a skeleton frame, is an excellent plan. Where birds aro destructive, lattice frames are made to cover tho beds with. There are many kinds of seeds which, in the hands of experienced cultivators, need no shade, but to all persons of limited knowledge we would recommend to sliade every seed.

Seeds take some time to swell their coats after going in the ground, hence all should be put in as early as possilile-even though tho frost be not out of the ground; if any dry soil can be liad to cover, many find advantage in sowing even on frozen soil. In some climates where tho Springs are early, some seeds will remain in tho gronnd till tho following Spring. If they fail to appear hy the time the Spring is over, examino, and, if found with fresh kernels, keep the beds weeded and shaded till the next season.

These simplo directions are all that any one necls, to liave tolerable success in raising tree seeds; the greater the experience, of course, the greatcr the success. 


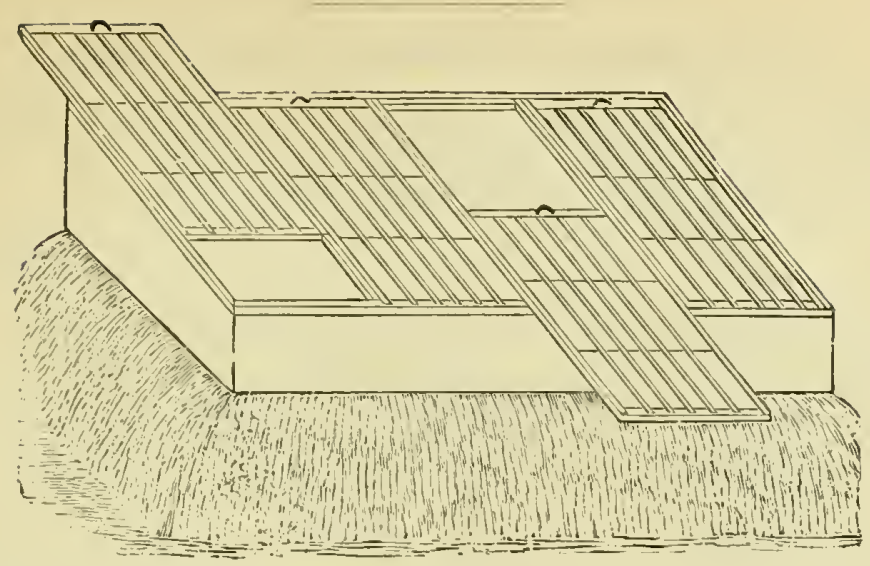

\section{PREPARATION AND MANAGEMENT OF A HOTBED FOR RAISING SEEDLINGS.}

66 Cow in heat-Sow in a hothed," are directions so commonly to be found in the notices of half.hardy annuals, that we feel we shall be materially aiding those who are their ow gardeners if we give a few simplo directions on the suhject of a hotbed, composed of stahle manure, the most frequent and aseful form in which it is to be found.

The Preparation of the Dung is a natter of great importance, and if the bed be expected to retain its usefulness for any length of time it should be well worked previous to being nsed. If obtaincd fresl from the stahle-yard, and found to be too dry, it should be well watered and thrown lightly together to ferment; this will take place in the course of a few days, and three or four days afterwards it should be completely turned, well shaken and mixed, keeping the more littery portion to the interior of the heap; a second turning and watering may be necessary, although one will be generally found to be sufficient; when thus cleaned of its rankness the bed nay he made.

The sitnation for this should be dry underneath, sheltered from tbe north as mnch as possible, and fully exposed to the sun; it should be built up from two feet six inches to four feet high, and wider by six inches every way than tho frame to be placed upon it. The dung should be well shaken and mixed while heing put together, and firmly pressed hy the feet. The frame should be kept close until the lieat rises, and three or four inches of sifted sand or ashes slould he placel on the surface of the bed; in a few days it will ho ready for use; but air sliould be given night and day while there is any danger from the rank steam, and if the sand or ashes are drawn away from the side of the bed they should bo replaced.

When the botbed is used for seeds only, nothing further is necessary; they are to be sown in pots or pans, placed or plunged in the bed, the heat of which will soou cause them to germinate. As this will, after some time, decline, what are called linings should be added, that is, fresh, hot, fermenting (but not rank) dung applied about a foot in widtl all round the bed; this renews its strength, aud will greatly aid its successful management.

A Cold Frame is formed hy placing the ordinary hotbed frame upon a hed of light, rich soil in some place in the garden where it will be protected from cold winds. They should both be shaded from the sum hy mats during the middle of the day.

All of the leading varieties of FLOWER SEEDS sent out from our establishment are put up in packets. upon which are also printed the COMMON and BOTANICAL NAMEs, the LINNEAN CLASSIFICATION and NATURAL ORDERs, with the adaptation and mode of culture of the variety which it contains, of which the fol. lowing is a sample:

\section{CARNATION PINK,-Fine German.}

Diathus Caryophylus-Fl. Pl.

Nat. Ord., Caryophyllacex. Linn., Decandria Digynia. Half-hardy Perennial. I ft. Fl., various colors. June to September. Native of England.

Sow in April or May, in pots of light soil mixed with leaf mould, scattering the seeds thinly, and covering very lightly with finely sifted ing made a few leaver, either into small pots or in nursery beds. the plants in frames through the winter, and transplant to the border in plants They may be increased by layers. Light, rich garden soil.

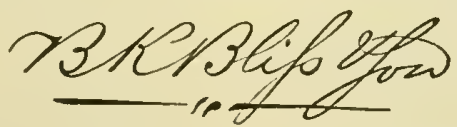

No. 34 Barclay Street, NEW-YORK. 


\section{COLLECTIONS OF FLOWER SEEDS BY MAIL.}

1

HE following collections contain the most showy varieties in our largo assortment, with fun directions for culture. Each packet contains a mixture of the differcnt color's and rar'ieties of its species, so that a greater display can bo made at less cost than when ordered iu separate paekets. Collection $\mathbf{A}$-Contains twenty choico varieties of Annuals . . . . . . . Colleetion $\mathbf{B}$-Contains twcuty choice valieties of Biennials and Perennials ....................... 1.00 Collection C-Contains ten extra varieties of Annuals and Perennials, embracing many of the new

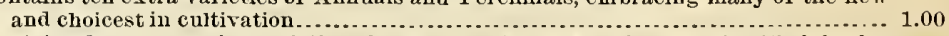

Collection D-Contains five very choico varieties of German Asters, Carnations, Double Hollylocks,

Pansics, and Verbenas . . . . . .

Any one renitting $\$ 3.00$ will receive the four collections postage free.

Tho following additional collections will also be sent at tho prices annexed, free of postage.

Collection $\mathbf{E}$-Contains fiftcen very select valietics of Grcenhouse Seeds ....................... 2.00

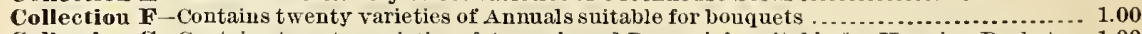

Collection G-Contains twenty varicties of Aunuals and Perenuials suitable for Iranging Baskets.. 1.00

Collection H-Contains fiftccu rarieties of Annuai and Peremial Climbing or Running Plants...... 1.00

Collection I-Contains ten choice varieties of Oruamental Foliage Plants ....................... 1.00

The sceds contained in the above collections are of our own selection. Purchasers who prefer to make their sclectiou from the Catalogue will be entitled to discounts, for which sce page 3.

\section{COLLECTIONS OF KITCHEN GARDEN SEEDS BY MAIL.}

Containing Vegetable seeds for One Year's Supply, for a Large or Small Gardeu.

THE following collections are made up ill the most liberal mauner, care being taken to give a sufficieut quantity of all the fincst varieties and most useful sorts of Vegetables required in the

Kitelien Garieu :

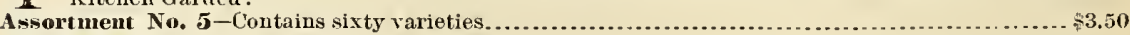

Assortment No. (j-Contains forty varicties.

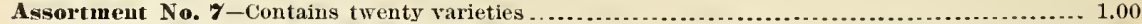

Larger collections, which can be safely sent by express (freight paid by pulenaser) to any part of the country, as follows: No. $1, \$ 20.00 ;$ No. $2, \$ 15.00 ;$ No. $3, \$ 10.00 ;$ To. 4, $\$ 5.00$. For list of the contents of each eollection, see page 105 .

\section{PLANTS IN SPECIAL SELECTIONS.}

These Selections ean be sent only by express, at the expense of purchasers.

Many of our customers being unable to determine what plants are best suited for a continuous display of flowers and foliage during the summer montls, we submit the following, which we are satisfied will prove satisfactory, being our own selectiou, and of such plants as we grow iu large quantities. A saving of 30 per cent. is made in ordering from these selections.

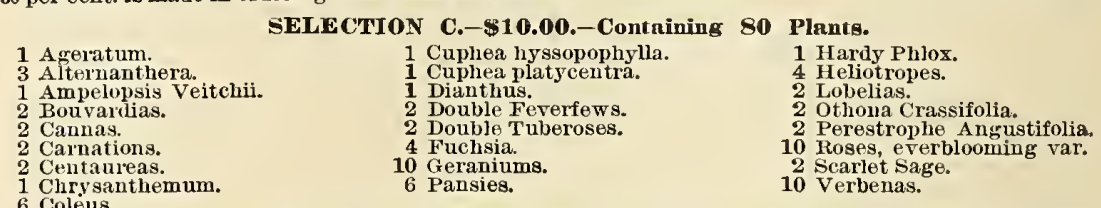

To which we will add, without extra charge, a plant of one of the New Double Ivy-leaved Geraniums.

2 Alternauthera.

1 Bourardia.

1 Canna.

1 Carnation.

1 Centaurea.

2 Colens.

1 Cuphea platycentra.

SELECTION D. $\$$ \$5.00.-Containing 35 Plants.

To which we will add, without extra charge, a plant of one of the beautiful New Double Ivy-leaved Geraniums.

\section{ONE DOLLAR COLLECTIONS.-PLANTS AND BULBS BY MAIL.}

DHE following collections of plants and bulbs, all distinctly labeled, will be forwarded, post-free to any post-office in the United States, on receipt of $\$ 1.00$ for each, or tbe twenty collections will be sent for $\$ 17.50$.

We will send only liealthy plants, securely packed, and mailed according to dircetions. We may state that plants can be sent, with very little fear of failure, at all seasons of the year; in fact, there is less risk ifuring the Winter months than in Summer, when the heat is excessive.

No. 1. 20 Verbenas, 20 ilfferent sorts.

2. 15 basket or bedding plants, 15 different sorts.

3. 10 Geraniums, 10 different sorts.

4. 10 Tuberoses, all floweriug bulbs.

5. 12 Gladioli, fine mixel sorts, all blooming bulbs.

6. 3 Roses, 2 Goraviums, 2 Fuclisias, 2 Carnations, all difierent sorts.

7. 6 Gladioli and 5 Tuberoses.

8. 8 Verbcnas and 5 Geraniums.

9. 6 Hybrid Perpetual Roses, 6 differcnt sorts.

10. 10 'Tea Roses, 10 different solts.
No. 11. 3 Moss Roses, 3 different sorts.

12. 2 Camellia Japonicas and 2 Azaleas.

13. 8 Doublo Gelaniums, 8 differcnt sorts.

14. 6 Varicgated Geraniums, 6 different sorts.

15. 5 Carnations and 5 Roses, all different solts.

16. 10 spleudid Carnations, 10 different sorts.

17. 6 fladioli, 6 different sorts, all named.

18. 8 Fuchsias, 8 different sorts.

19. 5 Colons and 5 Achyranthus, all different sorts.

20. 8 Verbenas and 5 Roses, ail different sorts. 


\section{A SELECT DESCRIPTIVE LIST}

\section{OF

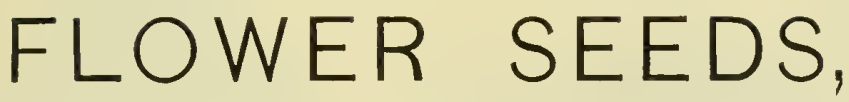

ISCLEDIXG

All the leading varieties of Annuals, Biennials, and Perennials adapted for cultivation in Conservatory, Greenhouse, or Flower-Garden.

In order to facilitate pureliasers in making their selections, wlo are unacrnainted with the botanical names, or different varieties of plants, we have, as far as possible, given the popular name of each variety, and have encleavored so to simplify the description, that any person, bowever unacquainted, may be able to make a fuclicions selcction.

In ordering Flower Seeds it is sufficient to give the numbers only, but it is absolutely necessary to state the edition of the Catalogue from which they are taken, as new editions are annually published and the numbers are frequently changed.

FULL CULTURAL DIRECTIONS ARE GIVEN ON FACH PACKET.

No.

ABOBRA.

Price.

n elegant climber, allied to the gonro family, with inconspicuous flowers, but the finely cut lark-green foliage and the small, glossy, searlet fruit render it lighly otnamental; lialf-liardy pereunial.

250) A bobia viriditlom, very graceful; $6 \mathrm{ft} .80 .10$

\section{ABRONIA.}

('harmlng trailer, with beautiful verbentike clus. tors of sweet-seented flowers; continucs in bloom a loug time; rery effective in beds, rock-work, or hanging baskets; half-liarty aunuals.

252 Abronia umbellata, rosy lilae ; fragrant 10 253 - fragazs, yellow; very fragrant.... .10

\section{ABUTITON.}

Desirable plants for the conservatory, freely pro. ducing a profusion of lovely bell-shaped flowers: many of the rarieties succeen well lf plunged in the border during sinmmer; half-harly shrubs.

255 Abutilou, choice varietics, mxed...... .25

\section{ACACIA.}

firaceful, elegant, and highly ornamental plants, that may be employed for ontdoor decoration, during the Sumner, with most satisfactory re. silts; greenhouse shrubs.

258 Acrcin, choice varieties, uixed

\section{ACHIMIENES.}

C'harming plants, combining great beauty with richuess and brillianry of color; succeeds well in a warm greenhouse; seed scarce; grecnhouse bulb.

262 Achimenes, choice varietites, mixerl.... . .50

\section{ACONITUM.}

A well.known showy favorite, popularly termed Yonkshood; grows ln xuriantly uuler trees or in other much shated situatious; harly perennial. 264 Aconit um napellus, blue and wbite; $3 \mathrm{ft}$. .0.

\section{ACROCIINIUTI.}

A beantiful class of everlasting flowers; graceful border plants and valuable for Winter bouquets and decorations; half-hardy anuual.

266 Acrocliuimm rosenm, light rose; $1 \mathrm{ft}$. . .05 267 - album, wire white; $1 \mathrm{ft} . \ldots \ldots \ldots \ldots .05$
No.

ADI,UNIA.

Price

A beantiful climbing plant of graceful habit, with delicate pale-green pinute foliage; Howers freely all Summer; also called Mountain Fringe and Alleghany Vine; larly biennial.

270 Adlumia cirrhos

\section{AGIRATUM}

Splendid plants for large clumps or masses, as wel as for in-door blooming during Wiuter; rery useful for cut flowers; lialf-hardy anuuals.

276 Ageratum iuperial dwn $f$, blue; $1 \mathrm{ft}, .10$

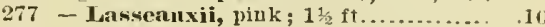

278 - Mexicanum, lavender bluc; $2 \mathrm{ft} . . .$.

279 - - albmu, white : 2 ft..............

280 - Wvendlaud's dwarf, white; $1 / 2$ ft....

\section{AGIROSTEMMA.}

Handsome, free-flowering, attractive borler plants, at lome in any garden; excellent for cut flowers; liatdy perenuial.

286 Agrostemua coli rosen, rose ; $1 \mathrm{ft} \ldots . .05$

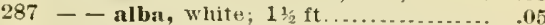
288 - hybrida fl. pl. donble; very showy.. . .10

\section{ATONSOA.}

Haudsome bedding plants, succeding well in ans good gatden soil, freely producing tlowers of great brilliancy from carly Summer nntil frosts; valn able for in-door dceoration; lialf.liardy annual.

294 Alonsoat graudiflorn, scarlet, 2 ft.... . 05 295 - incisifolia, orange scarlet, $2 \mathrm{ft}$....... .05

\section{ATOYSIA.}

This is the well-known Lemon Ferbena, and is ebiefly cultirated for its pleasiug fragrant foliage, easily grown, it is in consequeuce a popular favor ite; half-hardy shrub.

298 Aloysin citriodora, lemon-scented..... 25

\section{AT, YSSUM.}

Free flow ering, pretty little plants for beds, edg. ings, or rock-work. The annual varieties bloom the whole sunner, and the perennials are among our carliest and most attractive spring flowers. 300 Alyssuu, sweet, fragrant ; white

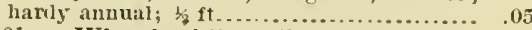
301 - Wierzbeckii, fellow and white

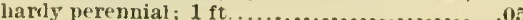




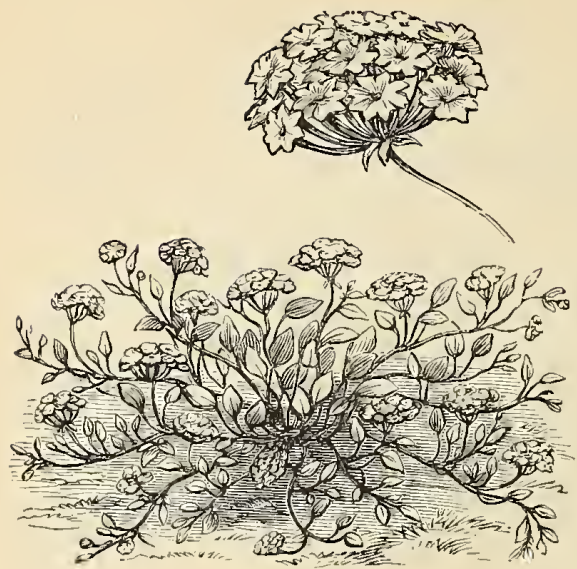

No. 252.-Abronia umbellata.

No.

AMARANTIIUS.

Price.

Oruamental foliaged plauts, extremely graceful and interesting, produeing a striking effeet, whether grown for the deeoration of the conservatory or outiloor flower garden; half-hardy annuals. 304 Amar'anthus Abyssinicns, very effeetive when grown as isolated speeimeus; $3 \mathrm{ft} . \$ 0.10$ 305 - bieolor ruber, foliage green, sharled with red and sometines pointed yellow; $3 \mathrm{ft}$ 306 - eandatus (Love Lies Bleeding), red drooping panicles of flower's; handsome; $3 \mathrm{ft}$ 307 - cruentus (Prince's Feather), erimson; highly ormamental ; $3 \mathrm{ft} . \ldots \ldots \ldots . . . \ldots \ldots . .$. 308 - Henderi, varied colors; very brill. iant; one of the best; $3 \mathrm{ft} \ldots \ldots \ldots \ldots \ldots \ldots . . .15$ 309 - melaucholicus inber, rieh resplendeut earmine foliage; $1 \mathrm{ft}$.............

310 - Prineess of Wales, foliage earmine, orange green, and bright yellow, beautifully blended; very handsome; $3 \mathrm{ft} . . . . . . . . . . . .$. .

311 - salicifolins, seariet, bronzy green foliage; graeefnl drooping habit; $3 \mathrm{tt} . . . .$. . 312 - tricolor (Joseph's Coat), foliage sear. let, yellow, and green ; beantiful ; 11/2 ft....

318 - Collection of 12 distinet varieties ...

AMMOBIUM.

Useful for dried bonquets and Wiuter deeorations; a show y border plant; half-hardy perennial.

322 Ammobium alatum, white; 2 ft.......

\section{VAGALIS.}

Valuable for small beds, edgings, rustie baskets, vases, or roek-work; half-hardy annuals.

326 Anagallis, fine mixed................ .10

\section{ANCHUSA.}

Remarkably effective border plauts; growing freely in shader situations; exeellent for shrubberies or the wild garden; hardy perennial.

330 Anchusa Italica, intense blue; $4 \mathrm{ft} \ldots . .05$ ANEMONE.

These rank among the earliest and brightest of our Spring flowers, and sneceed well in auy sumny situation, with rieh light loam; hardy perennial.

334 Ancmone coronaria, mixed ; $1 / 2 \mathrm{ft}$..... .10

\section{ANTIRRIINUMr.}

The Antirrhinum, populatly ealled Snap-dragon, is one of our most showy and useful border plants : half-hardy perennials.

340 Antirrhinum majus album, white

341 - - brilliant, erimson, wlite throat... .05

342 - caryoplyylloides, splendid striped .05

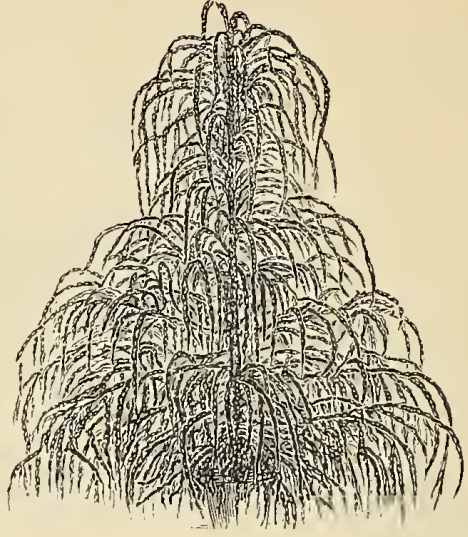

No. 311.-Amaranthus salicifolius.

No. ANTIIRTHINUMI.-Cont'd. Price 343 Antirrhinmm majus firefly, orange,

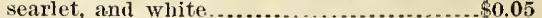

344 - nigrcscens, deep erimson; $2 \mathrm{ft} . .$. .05

345 - naumu album, white; $1 \mathrm{ft} \ldots \ldots . . . . .05$

346 - - lutem, bright yellow; $1 \mathrm{ft} \ldots . . . . .05$

347 - - kermesinasplendeus, erimson; $1 \mathrm{ft} \quad .05$

348 - - picturatum, shaded, marbled and striped flowers of surprising beanty ........ .25

349 - - striatmu, striped; $1 \mathrm{ft} \ldots \ldots \ldots \ldots . . .05$

353 - dwarf, many varieties mixed......... .11

354 - tall, many varieties mixed ............. .10

355 - Collection of 8 distinet enlors ........ 60

AQUILFGIA (Columbine).

A elass of highly ornamental plants; its varieties eombining at onee, flowers the most curions in form with colors the most striking and beautiful ; hardy perennials.

360 Aquilegia alba plena, white; 2 ft..... .10

361 - Califormica lybirida, a new variety;

eenter petals goldeu yellow, sepals and spur's deep orange red; 2 ft ........................

362 - chrysantha, golden yellow; 2 ft......

363 - caryophylloides, donble, splendid

striped varieties; 2 ft......................... .0. 364 - corulea hybrida, violet, blue, and yellow; fine; 2 ft -

365 - Durandii, double, variegated; $1 \frac{11 / 2 \mathrm{ft} . .}{.10}$ 366 - glandnlosa, blue, tipped white; $1 \frac{1 / 2}{\mathrm{ft}} \quad .10$ 367 - Skimnerii, searlet and yellow; $1 \frac{13 \mathrm{ft} . ~ .10}{}$ 368 - finest mixed ......................... .10 372 - Collection of 6 distinet varieties..... 50

\section{ARABIS.}

An early Spring-flowering plant, indispensable and exceedingly effeetive for roek-work, edgings, etc.; hardy perennial.

375 A rabis alpina, pme white; 3/, ft.... 10

\section{AlRCTOTIS.}

Handsome, fres-tlowerhig plants of elose compaet dwarf habit, with large, beantiful flowers that continne the whole snmmer. Some of the varieties hare the nuder surface of their leaves eovered with a elose white wool, whiell with the form of the leaves gives them a peculiar appear. anee. Will bloom first season, although they are half-hardy perennials.

378 Arctotis breviscapa, deep orange, with dark erimsou eenter; $1 / 2 \mathrm{ft}$. 379 - grandiflora argenten, silvery foliage, with large yellow, crimson-eentered flowers,

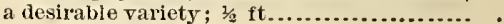




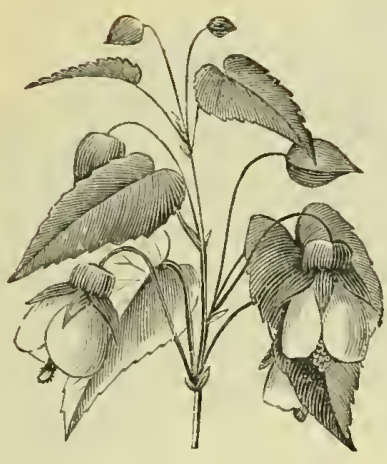

No. 255.-Abutilon.
No.

ARGFMIONF.

Remarkably distinct plants, loth in flower and foliage; their large poppy-like flowers are very effective in the border; hardy annuals.

384 Irgewone grandiflora, white; $2 \mathrm{ft} . \ldots \$ 0.05$ 385 - Iexicana, yellow; $2 \mathrm{ft} . \ldots \ldots \ldots \ldots . . .65$

\section{ARISTOTOOCIIIA.}

Highly ornamental and attractive climber, with curious horusshaped thowers, on account of which it is frequently called "Dutchman's Pipe"; trained against the louse or piazza, the effect of its massive foliage is matehless; liardy percnnial. 388 Aristolochia sipho, rich purple; $30 \mathrm{ft} . \quad .10$

ASPARAGUUS (Climbirg).

The finest of all the hardy climbers; it has the bcau. tiful feathery foliage of the orlinary asparagus in the form of a graceful running vine; invaluable for decorative purposes : lardy perennial.

390 Asparagus climbiug, bright red berries; very desirable; $10 \mathrm{ft} . . . . . . . . . . . . . .$.

ASPEIRUIAA.

A charming, profuse-blooming little plant, bearing clusters of fragrant fowers, admirably adapted for bonquet-luaking; lardy anmual.

398 Asperula azurea setosa, blie; $1 \mathrm{ft} . . . .10$

\section{A.MTTFiR.}

"Tlis is not only ons of the most popnlar", but also one of the most "ffective of our garden favorites, producing, in profusion, flow tis in which richne'ss and varicty of rolor are eombincd with the most perfect and beantiful form; Ialf-liarly annuals.

399 Astcrs, quilled. For beanty and qual ity of ffower; and varicty and brilliancy of rolor, notling finer in the way of a quilled aster can be had than this strain.

100 - Coeardean or Crown, large white centered Howers; attractive and beantiful. nised colors; $1 \frac{13 / 2}{\mathrm{ft}}$.

401 - Colleetion of 6 distinct colors 402 - Dwarf Chrssanthemum, immense flowers; free bloomer; mixed colors; 3 ft.. 403 - Colleetion of 12 distinct colors

404 - Dwa rf Pyranidal Bonquet, so pro. fuse in bloom that the follage is completely hiclden with Howcrs; mixed colors; $1 \mathrm{ft} . . .$. . 405 - Collection of 8 distinct colors... 406 - Giant Eumperor, immense brilliant Howers, very donble; mixed colors; $2 \mathrm{ft}$... 407 - Collection of 8 distinct colors....

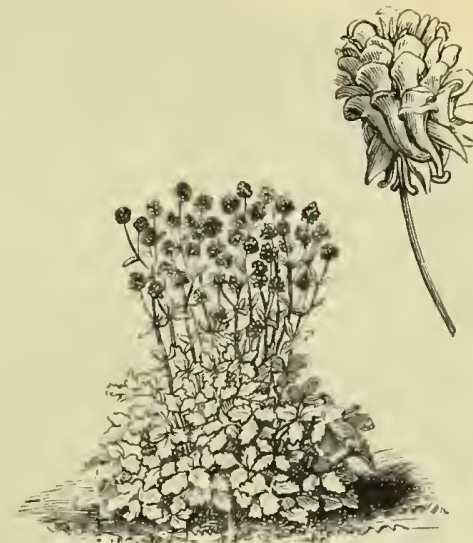

No. 368.-Aquilegia.

ASTI'IR.-Cont"d.

Price.

408 Aster, Half Dwarf white, one of the most useful varieties, where white flowers are desircol: $1 \mathrm{ft}$

109 - Iledgelog, Porcupine, or Needle, a grand variety, with lare massive flowers, the petals of which are long, quilled and slarply pointed ; mixed colors; $2 \mathrm{ft} . . . . . . .$.

110 - Imbrique Ponpon, exquisitcly formed smill towers; mixcl colors; $13 / 2 \mathrm{ft}$

411 - Collection of 12 distinct color's ...

412 - Paeny-flowered Alobe, very early variety, vigorous liabit, and large flowers, very double: mixed colors; $2 \mathrm{ft} \ldots . . . . .$.

413 - Qnilled Gevman Inproved, a branching large-floweled variety; au old favorite; mixed colors; 2 ft .................

$41 t$ - Collection of 12 distinct colors...

415 - rose-flowered, a beautiful variety, flower's regularly inbricated, brilliant and very double; mixed colors; $2 \mathrm{ft} . . . . . . . . . .$.

416 - - Colleerion of 10 distinct eolors. 417 - vichiller, a late dwarf bouquet Aster. very double, and a profnse bloomer; $11 \frac{1}{4 t}$. 418 - Truffant's French Paony-flowered Perfection. This is the most perfect type of the Pa-ony-Howered Asters; the liabit of the plant is excellent, the Howers are perfect in quality and form, while in size and colors they are beautiful; choicest mixed; 1 1 1 t.

419 - - pure white, very desiralue for bridal or funeral decorations, or for culture in cemeteries. 420 - German Prony-floweled, extra

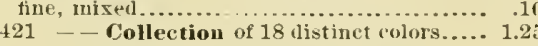
422 - - Collection of 12 distinct colors .... .90 423 - Collectiou of 8 distinct color's..... .65

424 - Victorin, of vigorous labit, py ram. idal form; Howers vers large, beautifully imbricated, and freely produeed; mixed eolors; 11 ft........................... 425 - white, tinted with rose, a new delicately colored rariety, the young flowers of whicli are particularly ehaming and well axlapted for bouquet-making........... 426 - Collection of 12 distinct colors 427 - Washington, witlout exception the largest Aster in cultivation, the flowers being fropuently 4 to 5 inches in diameter. and of perfeet form ; mixed colors; $2 \mathrm{ft} \ldots . .2 .25$ 428 - Collcction of 4 distinct colors.... . .60 429 - choice mixed, all sorts............. .10 430 - fine mixed, il sorts................ 


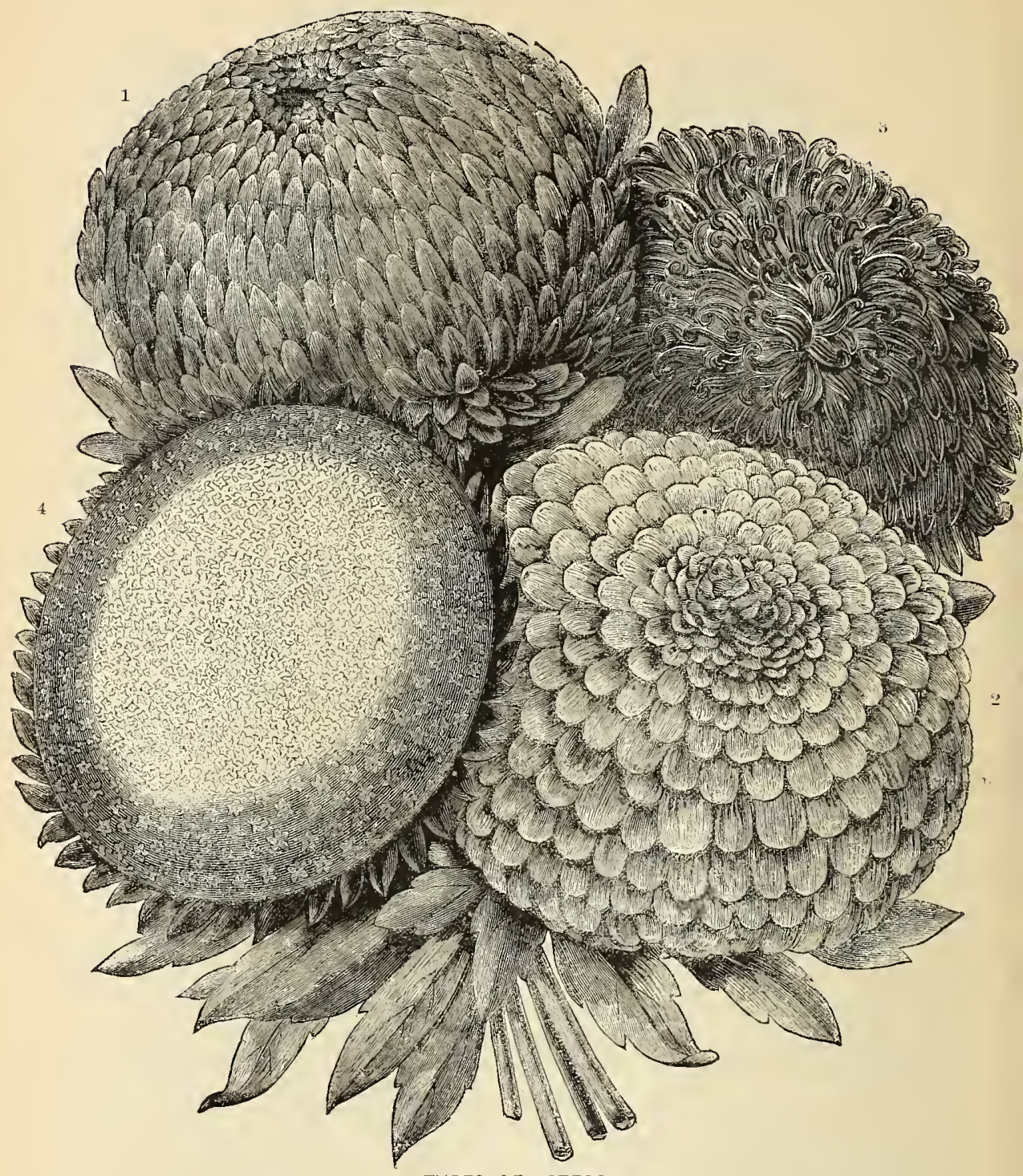

TYPES OF ASTERS.

1. Improved Parony. Flowered (No. 418) 2 Victoria $($ No. 424$)$.

3. Chysantlirmum-Flowered (Xo. 402). 4. Prize Quilled (No, 349).

HOW TO GROW ASTERS.

For carly flowering, sow rather thinly in the midtle of March or in April, in rooul rich compost, under a frame, or in pans iu a greenhonse; shade from strong smn, and keep close till the plants come inder a frame, or in pans iu a greenhouse, shade trom strong smn, anl keep close till the plants come up, afterward expose gradualy to the air, prick out when seedlings have two leaves, sharle and wa ter, plant ont in the midar or end of May. For later flow cring, sow the seed thinly in a cold trame under glass, on a soil nicely prepared in drils six mehes apart, the first week in May. The plants come np in a fow thas, when they must have plenty of air, and as soon as they are about an inclingh, take the crlass quite off for two or three clays, and then prick them out on a woll-prepared bed, three or four inches apart; shade them from the sun until well rootet, which will be in three or four days. Before the plants begin to run up in the stem, plant them out where they are to stand for blooming, in deeply trenched, wellmanured soil, being careful to remove them with as much moll attachel to the roots as possible; let the rows be one foot apart, and the plants ten inches or a foot apart in the rows. If the weather is dry they must be watered until tlrey take root, afterward keep clean fron weeds, stir between the plants, and about the first week in August top-tress with rotten manure from an old hot-bed, or water frequently with liquid manure. Give them plenty of water, and tie them to neat stakes as they advance in growth. If intended tor exhibition, leave but tiree or four of the most promising buils to bloom, and shade from the sun as they begin to expanil. Experience has proved that the later-planted rarieties give better and larger flowers, besides continuing much longer in bloom. 


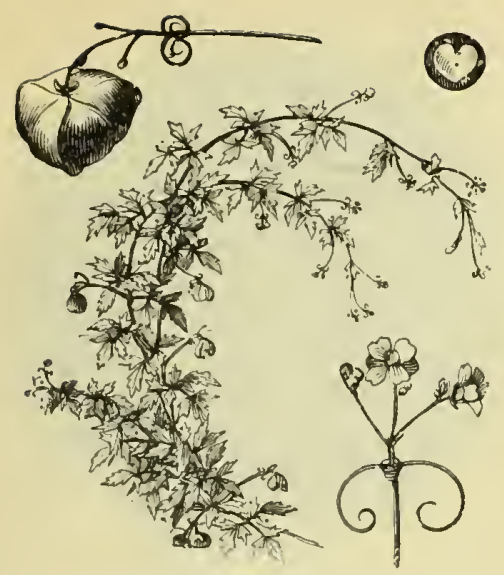

No. 452.-Balloon Vine.

No.

AUIBRIFTIA.

Price.

A eluaming carly free-flowering plant, sometime. called Blue Alyssum; indispensable for edgings, lock-work, or small beds; liardy peremial.

440) Anbrietia deltoidea, rosyllac; $\lambda_{4} \mathrm{ft} . . .80 .10$

\section{A UTRICUTA.}

A well.known garlen favorite of great beaut $\mathrm{F}$, suceeeding best in a northcrn aspect; half-hardy jerennials.

444 Anricula alpina, varions eolors; $1 / \mathrm{ft}$. . 15 445 - Luglish Hybrids, greenetged, ett.;

saved from luize flowers; $1 . \mathrm{ft} . . . . . . . . .$.

\section{AZATEA.}

Amongst the most beautiful and ornamental of om sreenhouse and lardy slirubs; requires carefu management until well established.

448 Azalen indica, saved from timest green. louse varipties: $1 \mathrm{ft}$.

449 - pontica, hardy varicties; $4 \mathrm{ft} \ldots \ldots . .2$.

BAILOON VINH: (Car cliospermum). A rapid.growiug, handsone climber, with an in. flated membranous capsule, from which it derives its name; loalf-hardy annual.

452 Balloon vine, white; $5 \mathrm{ft} . .$.

\section{BAIAAMT.}

Magnifieent conservatory or outuluor plants, pro. ducing their gorgeons masscs of beautiful brill iaut-colored flowers in the greatest profusion. The soil in which they are grown should be of the richest possible character; the plants shonli b set fifteen inches apart, securely staked, and ye. ceive frequent $w$ ateriugs of uanure. water; tender annuls.

455 Bal sam alba plena, floulle white; $2 \mathrm{ft} . \quad .10$

4.56 - atrosanguinea plena, donble red ; $2 \mathrm{ft} .10$

The above two varieties are insurpassed for florists' nse.

457 - Camellia-flowered, mixed ; $2 \mathrm{ft}$

458 - Collection of 12 distiuct colors.

459 - dwarf donble, mixed colors; 1 it $\mathrm{ft}$.

460 - rome-flowered, wixed colors; $2 \mathrm{ft}$..

461 - Ninith's Prize, from a celebrated English eollection: large and double ; $2 \mathrm{ft}$. $462-$ - Collection of 9 distinct colors....
463 - solferino, rery beautifully striped and streaked with lilac and scarlet; $2 \mathrm{ft}$...

464 - white Perfection, new double Camellia-flowered variety: iumense pure white flowers of the most perfect folm ............. 468 - fine mixed

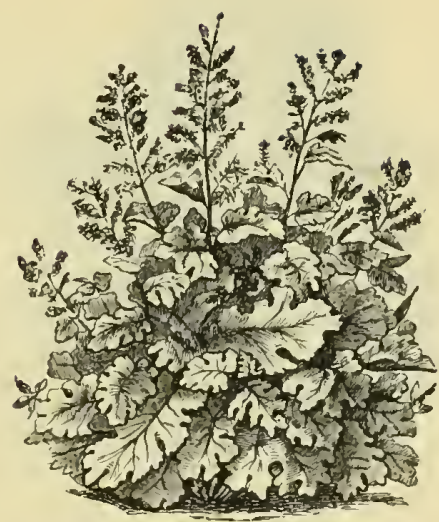

No. $481,-B o c c o n i a ~ J a p o n i c a$.

No. BARTONIA.

Price.

Au effective plant for borders and beds, produclug a profuslon of metallic yellow flowers showing well above the dowuy thistle-like foliage, and appear. ing exceedingly brilliaut in the sunshiue; hardy annual.

470 Bnironin nurea, golden yellow; $1 \frac{1}{2} \mathrm{ft} . .50 .05$

\section{I3FG:ONIA.}

A beautiful tribe of plants, resplendent during the Summer months, with their flowers of various sliades of scarlet, crimson, rose, etc, aurcl coutinuing in bloom uutil frost. Beiug as hardy as most of the bodling plants, aud of very easy culture, they are simply indispeusable where brilliancy of effect is desired. Mrasses ou a lawn prescnt a gorgeous aspect. They are also very desirable for jot culture.

472 Begonia, tuberous-loot ed, siver from the uewest Eurlish hybrids; cliose mixed. .50 Flowering bulbs, 50 ceu ts each.

473 - Froebelli, dazzliug scarlet; $1 \frac{1}{1 / 2} \mathrm{ft} . . . \quad .50$ 474 - Ne plus nltra, flowers bell-sliaped; gracefully peuclulons; blooms profusely.... . .50 475 - Rex lybrida, beantiful, variegated foliage, for pot culture...................... .25

HEI, VIDFIRH: Summer Cypress) A rapid-growing, highly oruameutal and extrenely graceful Cypress-like plaut, admirably adapted for the llecoratiou of celueteries; hardy auuual.

478 Belvidere (Kochia scoparia); $4 \mathrm{ft}$...... .0. 05

BIGNONIA. (Trumpet Vise).

Magnificent hardy deciduous climber, with brilliaut Howers; deserving tirst place as the most orna mental and effective corering for walls, houses. etc.; lardy verennial.

480 Bignonia radicnus, scarlet; $30 \mathrm{ft} \ldots . .15$

\section{IBOCCONIA.}

Ornamental follage plants, exceedingly effective as siugle spceimens onl lawns or in borders; hardy perennials.

481 Bocconia Japonica, produces racemes of bloom from 2 to 3 feet long.............. .

BRACHYCOME (Swan RiverDaisy). Beautiful free-flowering dwarf-growing plants, cov. ered duriug the greater portion of the Summer with a profusion of pretty Cineraria-like flowers very cffective as cdgings, in small beds, rustic baskets, or for pot-e'nl ture; lialf-hardy annuals.

494 Bracliycome iberidifolia, blue; 店 ft. . .10 495 - - albiflora, white; 1 ft.......... 10 


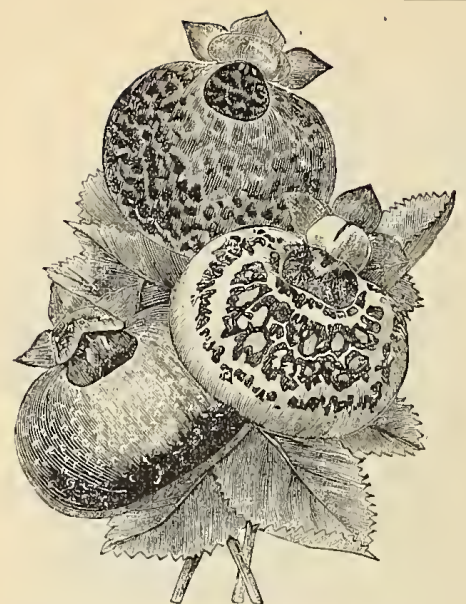

No. 517.-Calceolaria grandif́lora

No. BROW AIIIA.

Price.

Very handsome profuse-blooming plants, covered with rich, strikingly beautiful Howers; half-liarly annuals.

498 13rowallia Cerviakowskii, blue with white center, beautiful; $11 / 2 \pm t . . . . . . . . . . \$ 0.05$ 499 - elata alba, white; $11 / \mathrm{ft}$ - 05 500 - Roezli, azure blue or white; Howers

clouble the size of the other species........

CACAIIA (Tassel Flower).

A beautiful and profuse-flowering genus of plants With tassel-shaped flowers, fine for mixch borders; they are of remarkably casy culture, but suceed best in rather rich soil; half-hardy annuals.

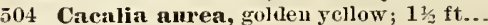

505 - coccinea, orange scarlet, flowering

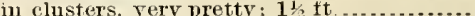

\section{CACTUS.}

Extremely curious and interesting plants, many of the varietics producing maguificent flowers of the most brilliant and striking colors. They succeed best in a mixtmre of sandy loam, briek or lime rubbish, and a little peat or well rot ted manure; greenhouse perennial.

508 Cactus, choice rauleties, mixed --2-2-25

\section{CAIANTDIRINA.}

Very beautiful irec-flowering plants, invaluable for elgings, rock-work anil dry, hot banks, or similar situations; they have fleshy leaves and succulent stems, like the Portulacea, and produce an abundance of blossoms, which, when fully expanded, have a charming effect; they all suceed in a liglit rich soil; harty annuals.

512 Calandrinia speciosa, rosy purple, a most protuse bloomer; $13 \mathrm{ft}$.

513 - - alba, a white-flowering rariety of the precerling, distinct and beautiful.........

\section{CAI,CEOIARIA.}

Plants of a highly decorative charactel, inclispensable for the greenhouse or the flower garden. Tlye finer strains of $C$. $h y b$ ricla are remarkable tor their large, magnificently marked flowers, ant are chiefly cultivated for in-toor decoration; rreenhouse perennials.

516 Calceolaria hybrida, choice mixed.

517 - sllperba grandiflora, bcautifully spotted, lalge-flowered, extra select; the finest, in cultivation ........................ 518 - rugosa, splendicl shrubby varieties for bedding saved from a very tine selection, embraciug a great variety of colors..........

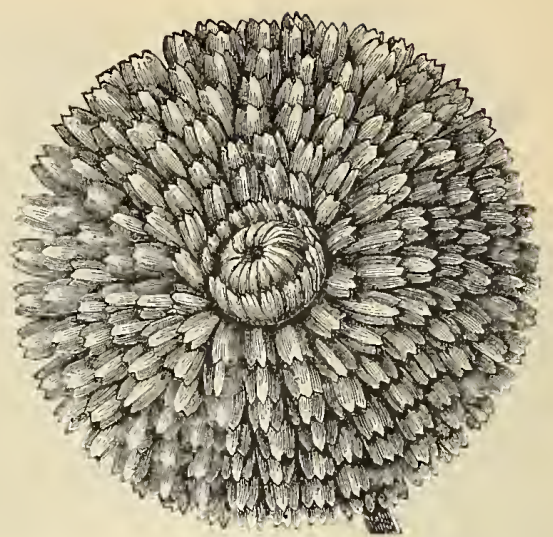

No. 526.-Calendula officinalis Meteor.

No. CAIENDUIA (Marigold.) Price. A very showy, free-flowering genus of plants, producing a very pretty cffect in mixed borders, and yrowing ireely in almost any soil; harty annuals. 521 Calcndula officinalis (Garden Mari. yold ), tine orange ; $1 \mathrm{ft} \ldots \ldots \ldots \ldots \ldots \ldots \ldots \ldots . . \$ 0.05$

525 - Le l'ponst, nankeen edged with

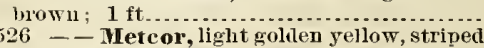
26 - Netcor, light golden yellow, striped late in Autumn 527 - Pongei f. pl., a white hybric Marigoid, with double flowers; 1 ft...............

CAILA (Richardia).

A very handsome plant, either as an aquatic or for the ornamentation of the drawing-room and conservatory; half-harly perennial.

532 Calla Ailiopica, white Ethiopian lily: $2 \mathrm{ft.} \quad($ Roots 50 cents each) .............

CAIIIOPSIS ON CORHOPSIS.

Few, if any, anuuals are morc useful than these; the colors are rich and striking, flowers numer ous and beautiful; prodnce a fine effect in mixed borders; hardy annuals.

535 Callopsis Atkinsoniann, yellow and erimson ; $2 \frac{1}{2} \mathrm{ft} \ldots \ldots \ldots \ldots \ldots \ldots \ldots \ldots \ldots \ldots \ldots \ldots . . .05$ 536 - bicolor ( Tinctoria), yellow and brown;

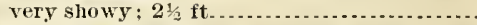

537 - IBurridgii, deep crimson copper, with a broad margin of gold; $2 \mathrm{ft} . . . . . . . . . . . .$. 538 - corouata, yellow, with crimson spots. 539 - Drummondii, yellow, twarf; $1 \frac{1}{2} \mathrm{ft}$. . 540 - marmorati, rich crimson, brown, and yellow, singularly marbled; $2 \mathrm{ft} . . . . . .$. 541 - nigra speciosa, rich crimson; $2 \mathrm{ft} . . \quad .05$ 545 - fine mixed varieties. .............. .05

\section{CAIIIRHOF.}

An clegant genus of plants, strongly resembling the Searlet Linum; commences to bloom wlien abont six inclies ligll, and presents a mass of flowers thung the entire Summer; harty annuals.

548 Callirhoe involncrata, a trailing variety, with large rich crimson-purple flowers. $\cdot 10$ 549 -pedata, purple crimson; $2 \mathrm{ft} . \ldots . \ldots . .05$

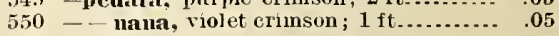

\section{CAMEIIIA.}

Favorite Winter and Spring Howering plants of great beauty. The seed we offer being saved from a splendid collection, many valuable varieties are likely to result from it; greenhouse slr rubs.

.50555 Camellia Japouica, various colors; $5 \mathrm{ft} . \quad .50$ 


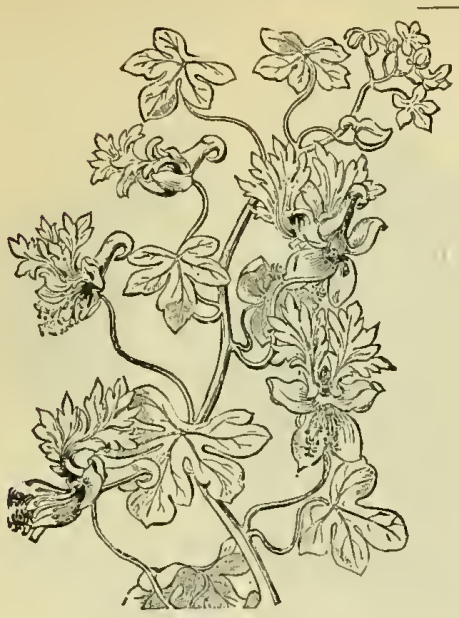

No. $5^{80}$ - Canary Bird Flower.

No. CAMIPANUIAA. Price,

A genus of exceedingly beautiful aumuls and perennials, all of which are cluaracterized by the ricli ness of their colors and the profusion of their bloom.

IIARDY PERENMIALS.

558 Campanula carpatiea, maure; $1 \mathrm{ft} \ldots . .50 .05$

- alba, white; $1 \mathrm{ft} . . . . . . . .250 .05$

- orandiflora, deell pmiple; $2 \mathrm{ft} . . . . . .0 .05$

- inedia (See Canterbury Bells).

562 - pyrnmidalis, blne, handsome; $3 \mathrm{ft} \ldots . .0$.

563 - 5 lba, pure white; $3 \mathrm{ft} \ldots \ldots \ldots \ldots . . .6 .5$

568 - perenuial varieties, mixed........... .10

IIARDY ANSUALS.

569 Campaunla Lorei, purple lilac; $1 \mathrm{ft}$.

$570-$ alba, silvery gray; $1 \mathrm{ft} . . . . . . .$.

571 - pentagouin, liclı purple; $1 / 3 \mathrm{ft} \ldots . .$.

572 - - alba, pure wlite.

575 - nunual varieties, mixed...

\section{CANAIR HIRU FIOUVH:TR.}

(Tropacolum peregrinum.)

A well-known, desirable climbing plant, of rapid growtli; highly ornanental foliage and a profnsion of curiously shaped flowers: the habit of the plant is of a luxnriant and lambling character, aud trained on even the most unsiglitly objects, it imparts to them a most jleasing aspect; lialfliardy anumal.

580 Cauri'g Bird Flower, yellow: $10 \mathrm{ft} \ldots$. .15

\section{CANIXTUT'}

One of the most useful border aumals, rely efficotive to berls, groups, ribuous, etc.: also very usptid for pot culture, for conservatory decoration dill. ing Vinter; seed sown in Antumn will flow' early in Spring, and if sown in . 1 pril or May will continue in bloom until frost; intispensable for bonquets ; liardy annuals.

582 Candytuft, Carter's New C'nrmiue, distinct aud beautiful, presenting one mass of vivil carmine bloom.

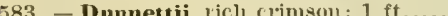

58t - fraprant, mure white ; 1 ft............

585 - hybrid Dwarf, very floriferona; elioice colors, mised.

586 - purple, $1 \mathrm{ft}$

587 - rocket, white, large trusses; $1 \mathrm{ft}$

588 - Tou Thumb, New White; forms a dwalf compact cluster aluut 16 inclses hil diameter, with large clear wlite flower.

589 - white, very desiralle; 1 ft...........

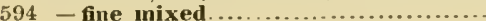

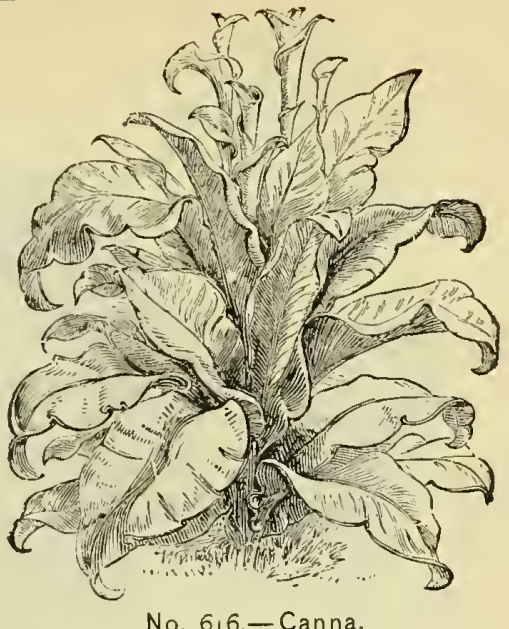

No. 6,6.-Canna. Ti. CANNA (Indian Shot). Price. for their large and handsome foliage, majestic labit, and billiant flowers. When planted in groups or masses, they impart quite a tropieal aspect to the garden. Cannas are casily raised by sosring the seed early in Spring, in a strong, moist lieat, when the plants are higlily decorative the first season; may also bo planted in the flower border in the latter part of May and June, but will not flower so early; half.hardy perennials.

600 Cunua Anneii, rich crimson; $3 \mathrm{ft} \ldots \ldots . \$ 0.10$ 601 - Biliorelli, brown violet foliage; $i_{4} \mathrm{ft} .10$ 602 - Bounetti, red and yellow; $7 \mathrm{ft}$....... .10 603 - Depure Hernon, leaves deep green, flowers sulpluur and orange; $5 \mathrm{ft} \ldots . . . . . . .10$ 604 - indien, rel, from Iudia ; $2 \mathrm{ft} \ldots . . . . .05$

605 - Krelagi discolor, dark stem, large leares, violet streaked witl purplish red ; $5 \mathrm{ft} .15$ 606 - limbata, intense scarlet edged witl yellow, very striking; $4 \mathrm{tt} . . . . . . . . . . . . .$.

607 - Neprleusis, foliage green, flower clear yellow, very beautiful; $3 \mathrm{ft} . . . . . . . . . . . . . .10$ 608 - Warscewiczii, brilliant red, foliage stripel, from Central America; $3 \mathrm{ft}$.

609 -zebrinn, beautiful zebra-striped folialge; $5 \mathrm{ft}$

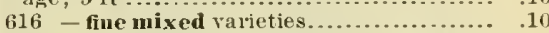

617 - Collection of 12 distinct varieties.... .75

Those desiring to nake more effective display than can be liad witl plants the first seasou from seed, can olutain extra strong roots of all the best varie. ties at 25 cents each, 22.50 yer dozen.

\section{CANTHIRBUTE THI,IS} (Campanula Mredia).

When well grown, Canterbury Bells are amongst the most attractive of border plants : they succeed in light, ricll soll, and slionld be transplanted two feet apart; larty biennials.

618 Cauterbury Bells, double blue, 2 1 ft. .10

619 - - double rose, $2 \frac{1}{2} \mathrm{tt}$. . . . . . . . . . .

620 - white, $2{ }^{2} \mathrm{ft} \ldots \ldots \ldots \ldots \ldots \ldots \ldots \ldots . . .11$

621 - mixed, 2 th $\mathrm{ft} \ldots \ldots \ldots \ldots \ldots \ldots . .10$

622 - single blue, $2^{1} \mathrm{ft} \ldots \ldots \ldots \ldots \ldots \ldots . .6 \ldots . .6$.

$623--$ white, $21 / \mathrm{ft} \ldots \ldots \ldots \ldots \ldots \ldots \ldots . . .6 . . .6$

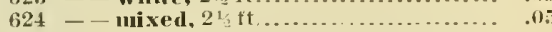

625 - Denu's lybrids, il splentid strain,

remarkable for the size of the flowers anc

their aliversity of color; $2 \frac{1}{2} \mathrm{ft}$............... . . $626-$ colyeanthema, 1 icl blue; $2 \frac{1}{2} \mathrm{ft} \ldots . .15$ 627 - - alba, pure white; $2 \frac{1}{2} \mathrm{ft} . \ldots \ldots \ldots . .15$ The two preceding varietles are remarkable in has ing the caly $x$ the same color as the corolla, and are libelly decorative, either as garden or pot plants. 


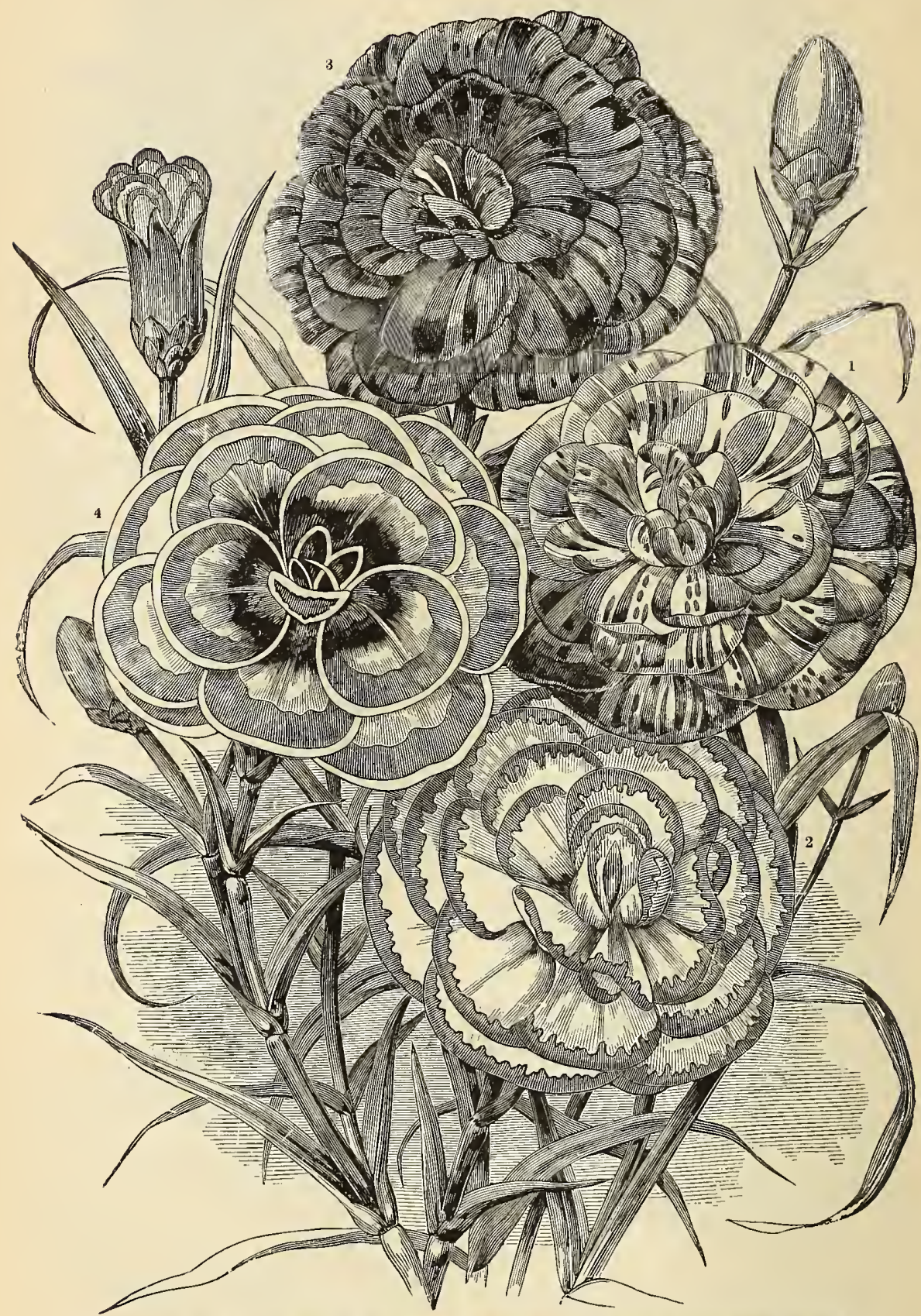

grodp of carnation, PICOTEe, PERPETUAL AND Florists' PINKS.

1. Carnation, No.640.

2.-Picotee, No. 1810.
3.-Perpetual or Tree Carnation, No. 643. 4.-Floristss Pink, No. 1 \&15. 


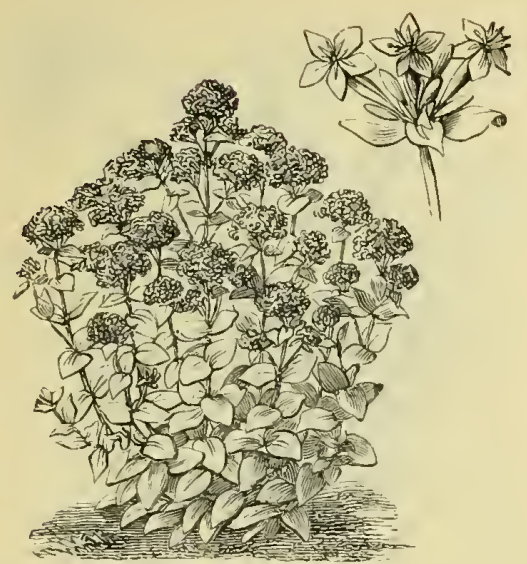

No. 655 -Catchfly.

Ni.

CARNATION

Price.

A maguiticent class of popular farorites, most of wlich are deliciously fragrant, and with color: extremely ricls and beautiful. The secd wo offer is from the finest collection in Europe, and will produce many domble flowers, and auongst them many choice novelties; lialt.hardy perennials,

$6 \pm 0$ Caruation, saved from clorcest double. flowers, viry select; $1 \frac{1}{1} \mathrm{ft} \ldots \ldots \ldots \ldots \ldots \ldots . . \$ 0.50$ 641 - fine German, from namcil flowers.... $\quad .25$ 642 - good mixed, for border culture....... .15 (543 - perpetual or tree, saved from choicest double flowers.................... $6+4$ - - fine Geruan, from named flowers 645 - dwarf donble early flowering, a dis. timet rariety, of compact bushy labit; $1 \mathrm{ft}$. $646^{3}$ - Greuadiu, a new early rariety of great promise, furuishing a trofusion of scarlet double flowers of great brilliancy, nusur. passed for florists' 11 se....................... 650 - Colleetion of 12 listinct rarleties... 1.00

CATCHFI, (Silene)

A showy free-flowering plant, for beds, borders or ribbons: succeeds in any soil; hardy annuals.

655 Catchfly, mired colors: 1 t/ ft ft.......... 05

- in variety (see silene)

CEIOSIA (Cockscomb).

Magnificent, free flowering, graceful growing plants, producing in the greatest profusion spikes of the most beantiful feathery flowers. Plants of tho Celosia flower freely if planted out in Jnne in light soil, not too rich; grown in pots, they are the most elegant of greenliouse and conservatory plants; half-harkly annuals.

660 Celosia argent ea, silvery mhite, sladed with rose; elegant; $3 \mathrm{ft} . . . . . . . . . . . . . . . . .$.

661 - Huttonii, a heantiful, dark foliage bedding or greenhouso plant ................. 662 - Japonica (Japanere Cockscomb). Tlie combs are almost as delicately cut as ruffled lace, while the eolors are the brightest twuaginable

663 - eristata nana, choice mixture of the newest dwarf rrested varieties, embracins the most brilliant colors....

i65 - C Crlasgow Prize, a splendid dis tinct dwarf variety, with dark foliage and crimson combs.

170 - pyramidalis, choice nixture of all the plumed or featlieren sorts............... (775 - Collection of 8 splendid varieties....

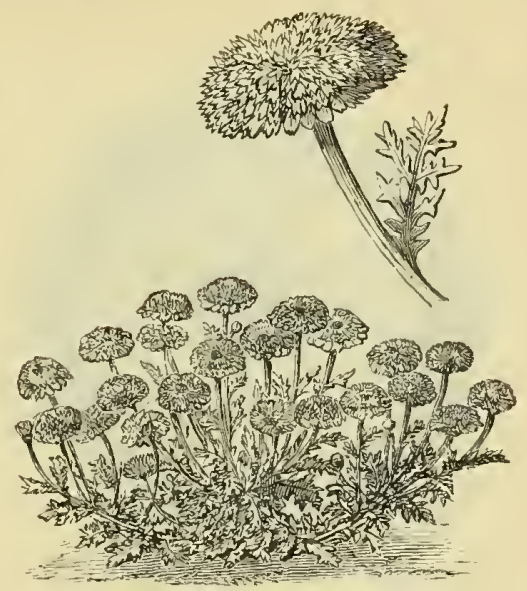

No. 757.-Chrysanthemum, double white.

No.

CENTAUREA.

Price

Showy, hardy plants; many of the varieties have beautiful silvery foliage, and are imdispensable for ribbon bortering or carpet belding.

686 Centamea Americnna, lilac purple showy; hardy annual; $2 \mathrm{ft}$...................\$0.0.5 688 - depressa, blue, red center, large flow. ers; liardy anunal ; $1 \mathrm{ft}$...

689 - candidissima, silvery-leaver plant for beds, ribbons, vases, baskets and pots; half. lar.ly perennial; $1 \mathrm{ft}$.

690 - Clementei, elegant, deeply cnt foliage, corcred with a slowy white dowu; hand. some; hardy werenuial...................... 691 - gyuuocarpa, a graceful silvery. leaved vin'iety; for bedling or pot culture; balf-Lardy perenuial; $1 \mathrm{ft} . . . \ldots \ldots \ldots \ldots \ldots . . . . .$.

- Moschata (see Śweet Sultan).

\section{CENTRANTHUS.}

Very pretty, free flowering, compact growing plants, very effective in beds, ribbons, or as an edging; their transparent stem, delicate branches and light glaucons leaves render them very bean. tiful; grow freely in any common garden soil; natises of tirenada; hardy annuals.

696 Ceutranthus, wixed colors; $2 \mathrm{ft} . \ldots . . . .05$

\section{CERASTIUM.}

Silvers-foliaged plants, admirably adapted for edg ings, lock-work, ttc.; so profuse and pure while are the flowers that the plant is frequently termed "Snow in Summer"; hardy perennials.

700 Cerastimm Biebersteinii, silvery foli.

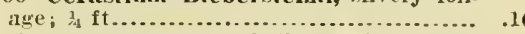
701 - tomentosum, similar to the preceto. ing, but smaller foliage; $t_{4} \mathrm{ft} . \ldots . . . . . . . .$.

\section{.10}

CHAENOSTOMA.

These are charming little compact-growing plants, acluirably adapted for the summer decoration of the flower garlen; may be snccessfully nsed as cd giugs or in rustic baskets; half-iardy pereunial. 703 Chrenostoma, many colors mixed...... .05

\section{CILAMAPEUCE.}

Sincnlarly beautiful, thistle-like plant s; for borkers are highly picturesque, while for centers of beds they are simply unique; lialf-hardy biennials.

705 Cham Thistle), glossy dark green foliage, covered witl. curious hairy splines; $1 \frac{11}{\mathrm{ft}}$.. 


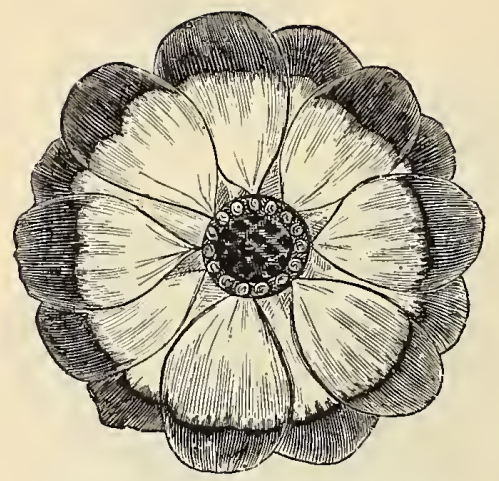

No. 731.-Cineraria, Extra Choice.

No. CHFILONE.

Price.

Beautiful hardy, herbaceous plants, with showy Penstemon-like flowers, very effective in centers of bels, or groups in mixed borters ; thrive in any rich soil; luardy perennial.

710 Chelone barbata, scarlet; $3 \mathrm{ft}$ .$\$ 0.05$

\section{CHINESE: PRIMROSE. (See Primula.)}

CHOROZEMA.

Desirable plants for the arcenhouse, combining flow. ers of the most beautiful descriptiou witl glaceful ness of habit and great profusion of bloom. Soak tlie seeds in warm water a few hours before sow. ing; greentorse shrubs.

712 Chorozema, finest mixed. 25

\section{CHRYSANTHEMUM.}

The tall, double-flowered, annual Clirysanthemums, when wcll grown, are amongst the most showy and effective of Summer-flowering border plants; to allow for iudividual development, they should be thinned out from twelve to eighteen inches apart. The dwarf kinds make slowy bedding plants; liardy annuals.

715 Chrysantheumin tricolor, white with yellow band; very showy ; $1 \mathrm{ft} . . . . . . . . . .$.

716 - Burridgeanum, white with crimson

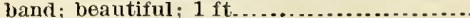

717 - Dumetii album fi. pl., immense double snow-white tlowers; 1 ft..............

718 - - aureum fl. pl., large domble golt-

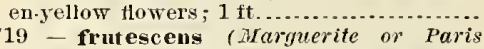
Daisy). The white, star-like Howers of this variety, so popular for decorative purposes, are freely produced under the most ordinary

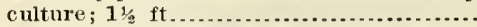

720 - Tord Beacousfield, crimson maroon edged and striped with a golden rim surromuling a rich brown eye................

721 - The Sultan, rich velvety crimson maroon, with golden rim surrounding a dark

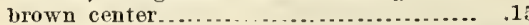

The following are the well.kuown half-hardy pereunial varieties so extensively grown in pots for late Autumn and early Winter Howering; no one should be without them :

725 Chrysant hennu Indic um, mixed; $3 \mathrm{ft}$. 726 - - Manuu (Dwarf Pompone), mixed..

727 - Japonicum, guite distinet from the old varieties in the style of the flowers, whieh are of a peculiar form, in a sreat vati. ety of colors..............................

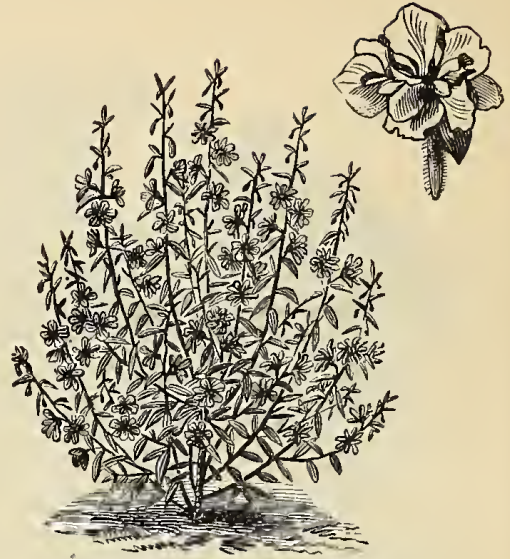

No. 745 - Clarkia elegans.

CINFRARIA.

Price.

No.

Well-known favolite, free-flowering plants for the greenhouse, whieh luay be had in splendid bloom througli the greater portion of the year; and from the richness and diversity of the colors, are among tbe most raluable of our early Spring flowers; succeed best in ligbt, rich, free, and open soil; greenhouse perennials.

730 Cinern ria dwarf, a new German strain bf compact grow th, liighly recommended....\$0.25 731 - extrit choice, from prize flowers; this strain is nusurpassed iu quality........ . .50

732 - fue nixed, good colors .............. .25 733 - new double, representing every shade of color, nnquestionably one of the best of recent introductions . ............ 1.00

734 - pure white, for purity of color and size of flower it is unequaled ................ $\quad .75$

The following half-liardy porennial varieties of Cin. eraria are desirable for betding and other purposes for which Centanrea is recommended.

740 Cinemria nenuthifolia, silvery leaves,

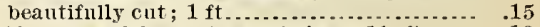
741 - maritima, silvery foliage; $1 \frac{11}{\mathrm{ft} . . . . .} \quad .10$

CIJARIIIA.

A beautiful tribe of farorite plants, with pretty, clieerful-looking Howers, growing freely and blooming profusely under almost any circum. stances; harily anuuals.

745 Clarkia elegans, rosy purple; $2 \frac{1}{3}$ ft.- .05 746 - alba, wlite; $2 \mathrm{ft} \ldots \ldots \ldots \ldots \ldots \ldots . . . . . . .5$

747 - - alba plena, donble, pure white... 10 750 - intcgripetela Tonu Thumb, rose crimson; 1 ft.......................... 751 - $\ldots$ alba, white ; $1 \mathrm{ft} \ldots . . . . . .05$ 752 - - luargiuatn, magenta, edgei white ; 1 ft.............................. .05 756 - pulcliella, deep rose ; $1 \frac{1}{1 / 4} \mathrm{ft} \ldots \ldots \ldots . . .05$ 757 - - fl. pl.., double, rich magenta....... .10 758 - fine uixed, double and single....... .05

\section{CIFIM A'TIS.}

Well-known rapicl-gluwing, free-flowering, ornamental elimbing shrubs, some of wlich are fragrant; admirably adapted for eovering arbors, verandas, ete. ; they sueeed well in any good gar. den soil ; hardy climbers.

765 Clematis cirrlosa, literally covers itself with white fragrant flowers.......... . .10 766 - fammula, white, fragrant ; $20 \mathrm{ft} \ldots . . .10$ 767 - hybrida, from Jackuan's lybrids, the best of all (llewatis ........................ . .20

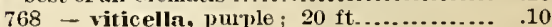




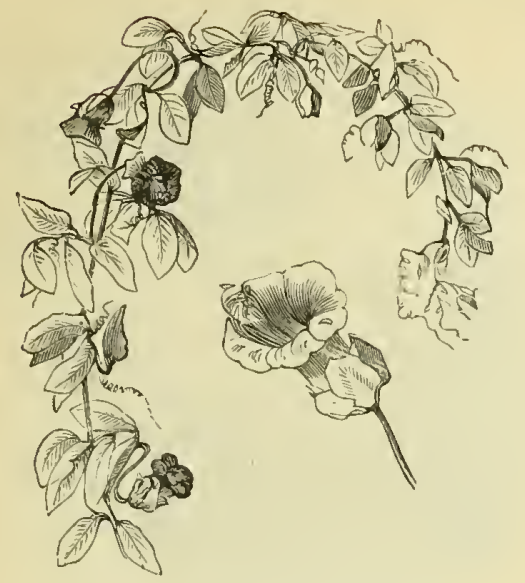

No. 785 - - Cobæa scandens.

No,

CLIANTIIUS.

Price.

One of the most beautiful plants in cultivation, with neat compound leaves, and drooping clustcrs of large, rich scarlet, pea-slaped flowers, each flower being pícturesquely marked with a large, black, clout-like blotele in front; half-hardy slirub.

775 Cliant hus Dampierii, magnificent; $3 \mathrm{ft} . \$ 0.25$

\section{CIINTONIA.}

Charming neat lit tle Lobelia-like plants, producing a fine effect as elgings or on rock.work, in rinstic baskets, viases, etc-; lalf-hardy anmuals.

778 Clintonia, mixed colors; $\frac{1}{4} \mathrm{ft} \ldots \ldots \ldots \ldots . . .10$

\section{COBAEA.}

1 A magnifieent rapill-growing climber, with beauti. fuI foliage and large bell-shaped flowers; trained on piazzas, arbors, etc., the effect is grand; lialflardy perennial.

785 Cobrea seandens, purple lilac; 20 ft... .10

$$
\text { COLAUS. }
$$

For the alornment of the greenlonse and sitting. room this plant is in great demand, and is also among the most popular plants for the flower. garden, eitler for groups, ribbon borders, or as single specinens.

790 Coleus, saved from the newest and most showy varieties; $2 \mathrm{ft} . . . . . . . . . . . . . . . . . .$.

\section{COLIINSIA.}

An excectingly pretty, free-flowering, popular genus, remarkably attiactive in beds, mixed borders, or ribbons; lardy anmuals.

795 Collinsia bicolor, purple and white; $1 \mathrm{ft}$. .05 796 - - alba, pure wlite: $1 \mathrm{ft} \ldots \ldots \ldots . . .05$

798 - Inulticolor marmorata, white and rose; $1 \mathrm{ft}$

800 - fine mixed........................

\section{CONTOLTITTES MIATOR}

MIomine Glory.

A well-known aml leautiful free-flowering class of clinbers, witll brilliant and varied colored flowers, growing freely in almost any situation, and pro. ducing a splendid effect when grown on rockwork, stumps of trees, or banks, and when trined over trellis, rnstic work, or asainst rougl fences; hardy" annnals.

810 Convolvulns inajor, 1,1 ue ............. .05

811 - crimson ......................... .05

812 _ - striped ...............................

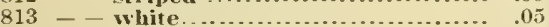

818 - mixed .......................... .05

819 - Collection of 10 distinct colors.... 50

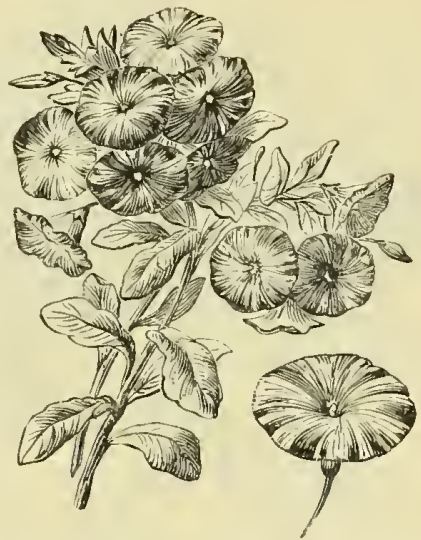

No. $820 .-$ Convolvulus tricolor.

No.

CONVOLVUIUSS TRICOIOR

(Dwarf Convolvulus).

Remarkably slıows plants, witlt exceedingly land some, ricli-colored flowers, producjug in beds and mixed borders an unusually brilliant effoct, eitler tn distinct colors, ribuoned, or mixed; lardy annizals.

820 Convolvulus trieolor, erinson violet. Flowers liave a brilliant yellow tye encil. cled witl a band of snowy white, margined with rich crimson violet . ................. $\$ 0.10$ 821 - - monstrosus, deep violet purple... .05 822 - - splendcus, rich violet, witlı white center

823 - - striped, blue, beautifully striped witl wlite, trailer.

824 - Mnuritanicus, beautiful for hanging baskets and rases, flowers blue, v'ry florifer. ous; liardy pereunial

825 - mnicaulis, npright growth, with a compact head of flower hurls, llossoms of rich purplislı blue....................... 826 - white

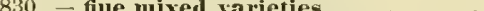

\section{COWSIIP}

Favorite, early, free-flowering plants, which should be extensively grown for filling the beds and lowders of the Spring Hower-garden; succeed best in ricli soil; liardy perennials.

840 Cowslip, tine utixed variettes; $3 / 4 \mathrm{ft} \ldots . . .10$

CUCUMISS ANI) CTTCTRIBITA. (Sce under Ornamental Gourds).

\section{CUPIIEA.}

A lighly decorative plant, equally well arlapted for the ornamentation of the conservatory or the flower border.

845 Cuphea platyeentra, scarlet, white, and purple; half-liarly perennial; $1 \mathrm{ft} \ldots \ldots . .10$

846 - purpurea, rosy scirlet, purple calyx, elegant; lialf-hardy annual; $1 \mathrm{ft}$........... .10

817 - choice mixed ..................... .10

CYANUS, Centaurea).

Befter known as Bachelors' Buttons and Corn Flower. Ornamental jlants for slirulbleries and mixed borders, aud exceediugly useful wlete cut flowers are in demand; growing in any conmon soil: harily annual.

850 Cyanus, mixcl colors, viz., bute, pink, rich purple and striped ; $11 / 2 \mathrm{ft} . . . . . . . . . .$. . 


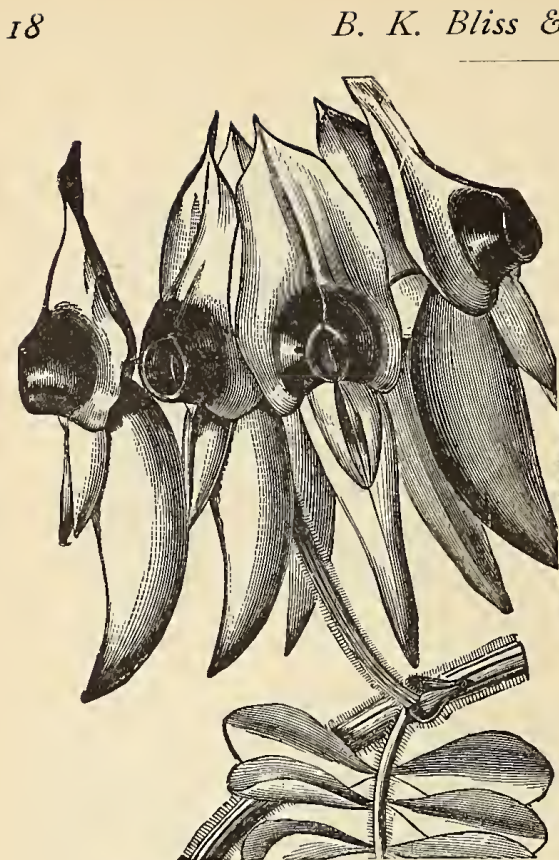

No. 775-Clianthus Dampieri.

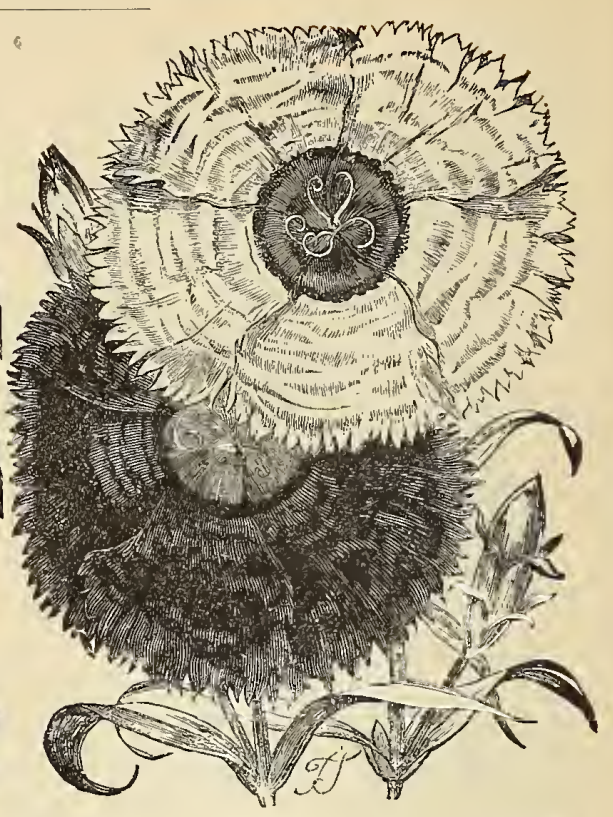

Nos. 929 and 930.-Dianthus, Crimson Belle and Eastern Queen.

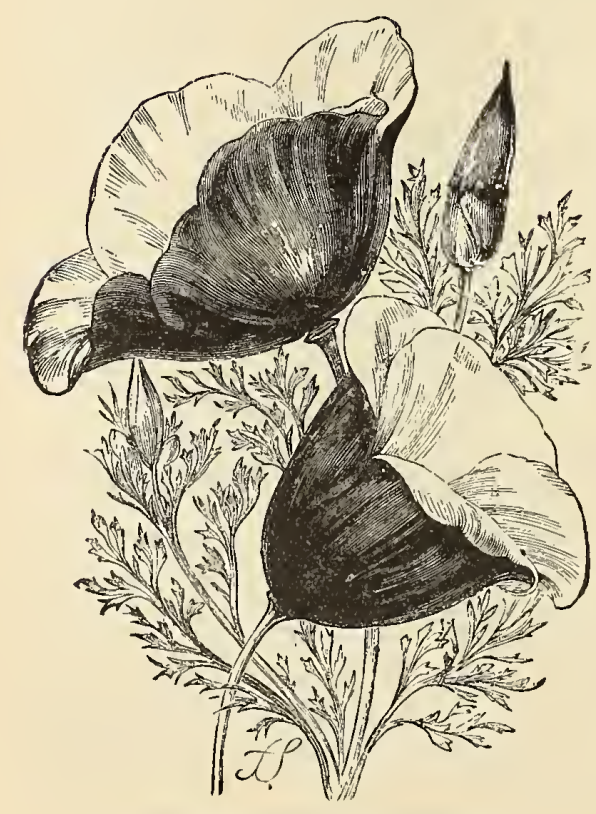

No. $1005,-E s c h s c h o l t z i a$ Mandarin.

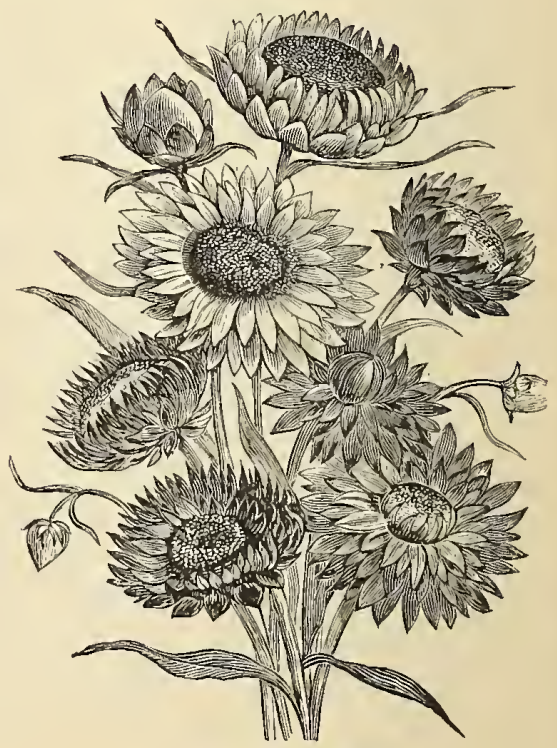

No. 12,6.-Helichrysum. 


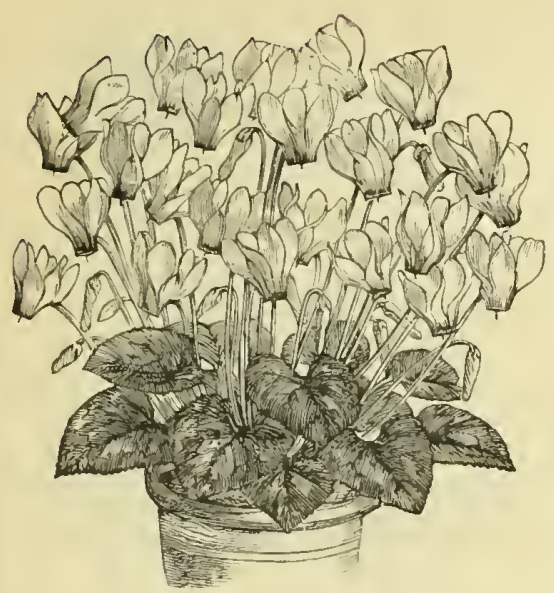

No. 856.-Cyclamen Persicum. Wiggins Prize.

No.

CYCILANIEN.

Price.

A genus of the most beautiful and clegant winter and spring blooming plints, for pot culture in parlor or conservatory, miversally admired. If sown early in spring under glass, and well grown, will nake tlowering bulls in one year.

855 Cyelamen l'ersicum, fine nixixed........\$0.25 856 - Wiggins prize, very robust in Habit, rich in color 857 - - giganteum. An improved typc, with broad, beantifully mottled leares, in. nuense flowers of great substance, pure wlite with riolet-purple eye

858 - choice mixed, including those varieties that are hardier than Persicm, many of which are charming both in flower and foliage, and delightfully fragrant

\section{CYCI ANTHERA.}

A free-growing elimber with handsome foliage and pretty oral-shaper fruit, explorling when ripe: Lalf.liardy annual.

865 Cyelanulera explodens, $10 \mathrm{ft}$

$$
\begin{gathered}
\text { CYPRFSS VINF Ipomea } \\
\text { Quamoclit:. }
\end{gathered}
$$

One of the most popular of all Summer elimbers flowers small, thickly set in a most beautifn dark-green foliage, forming a striking eontrast; lialf-hardy anunals.

868 Cypress Vine, crimson, brilliant; $10 \mathrm{ft} . \quad .05$ 869 - rose, rery delicate $\ldots \ldots \ldots . . . . . . . .05$ 870 - white, for cometerics................... .05 871 - - scarlet ivy-leaved, graceful climb. er of rapid growth; the tlowers, which are of fiery scarlet, are produced in great profusiou during the whole summer.

\section{DAHLIA.}

Admirers of this moble plant may confidently denenu upon the quality of this seed, it having been sared from the best varicties in enltivation; of various heights and colors: half-hardy perenuial bulbs.

875 Dithlia, tine mixerl ..................... .10

876 - extra fine, from prize flowers......... $\quad .25$

877 - new Lilliput, dwarf, very beautiful. 25

DAISY (Bellis Peremis).

A well-known and farorite plant for the border or not enlture; half-hardy peremuial.

880 Daisy, double white, pure white flowers, valuable for floristy: 881 - mixed, sared from double tlowers; 2 ft .25

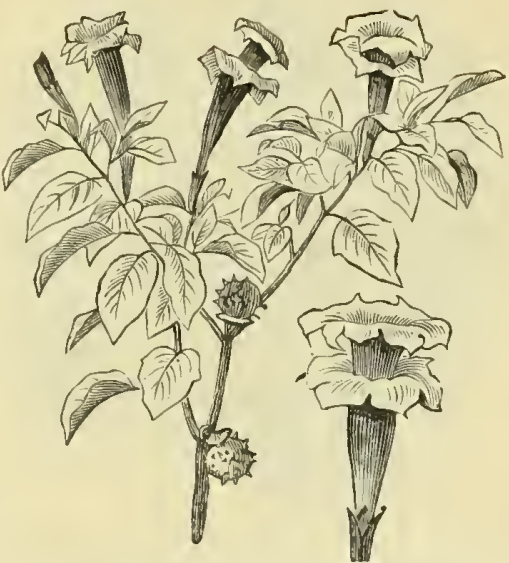

No. 888.-Datura fastuosa Huberiana varietates.

No. DATURA ('Trumpet Flower). Price An oruanental genus of plants, many of whieh pos. sess attractions of the highest orier. Iu large clumpe or bolders of shrubbery, they prolues an excellent effect. The roots nay be preservch in sand through the Winter in a dry cellar; half. harily perennials.

881 Dntura ntroviolacea plenissima, al. most black, inside hea ut ifnl light purple..... 0.10 885 - ceratocaulon, satin white, striped purple, 8 weet-scented; $2 \mathrm{ft}$... 886 - ellorantha 1l. pl., golden yellow, fragrant: $2 \mathrm{ft}$ osa alba, pure wlite, double; $2 \mathrm{ft} .10$ - Inbeviama varietntes, splendir. mixed, from new vartetics................. .15 889 - meteloides (Wrightii), white bor. dered lilac, liumbonre; $2 \mathrm{ft} \ldots . . . . . . . . . . . .10$

\section{DFI.THINIUNI}

(Peremial I tarlispur).

Plants remarkable for their great beanty, dirersity of sliades, and highly decorative qualities. They differ greatly in liabit of growth, some protheing magnifieent s]ikes of tlowers, while others are dwarf and completely eovered with bloom. The principal color is blue, shading from the softest cclestial to the darkest purple, while all are more or less shated or marked witl some other color. (For annual varieties, see Larkspur.)

900 Delphinimu eclestinum, blue; $2 \frac{1}{2} \mathrm{ft} . . \quad .10$

901 - eln 1 um (Bee Larlspur), blut: $5 \mathrm{ft} \ldots$... .05

902 - formosum, rich dark bhe, with white center: $2 \frac{1}{3}$ ft.........

903 - hybidum fl. pl. lonble, mixel ....... .10 904 - nudieanle, varying in color from liglit searlet to a shade rerging on crimson; very brilliant ; $1 \frac{1}{2} \mathrm{ft} \ldots . . . . . . . . . . . . . . . . . . . . . .25$

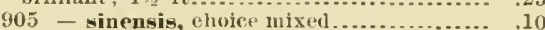

\section{DIANTIIUS.}

A ruagnificent geuus, which erubraces some of the most popmlar flowers in cnltivatron. D. Chinen sis and it s rarieties may ho considered the most veantiful and effective of onr hardy annuals; the donble and single varicties, with their rich and varied colors in beds or masses, are remarkably attractive; while the recently introduced rarieties, with their large, richly eolored Howers, close, compact liabit, and profusion of bloom, are unsurpassed for effctiveness iu beds or mixed borders. 


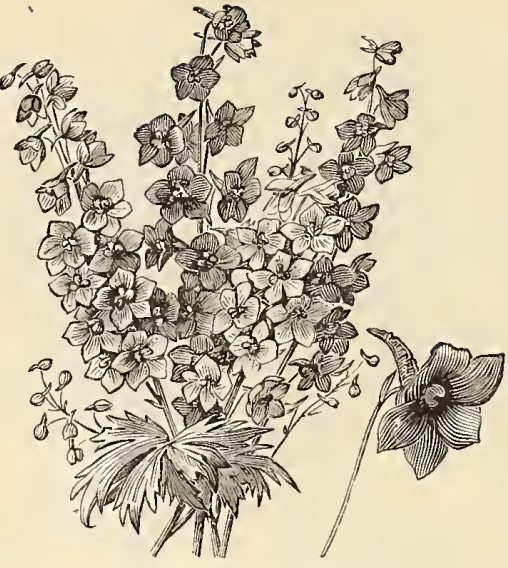

No. 902.-Delphinium formosum.

ANNUAL AND HENNIAL VARIETIES.

915 Dianthus Chimensig (China or Indian Pink), single, mauy colors mixed; show y ...\$0.05 916 - - fl. pl., a splendid mixture; produciug a large proportiou of doulle flowers...

917 - Heddewigii, color varies from the richest velvety climson to the most delicate rose; a maguifieent variety ; $1 \mathrm{ft} . \ldots . . . . .$.
$918-\mathrm{fl}$. pl., double variety of the preced-

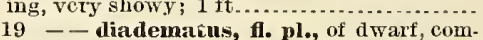
pact hahit, of various tints of rose, maroon, aud purple, oue of the hest of its species : $1 \mathrm{ft}$. 920 - laciniatus, beautifully fringed, fiucst color's mixed; $1 \mathrm{ft}$.

921 - - f. pl., a douhle variety of the preceding, in spleudid colors ; $1 \mathrm{ft} . . . . . . . . . . .$.

922 - imperialis, H. pl. (Double Imperial Pink), nauy colors mixed. . . ................ 928 - choice dwarf varieties, mixed.... 929 - Crimson IBelle, vivid erimson-lake flowers, large aud heautifully laccd; $1 \mathrm{ft}$... 930 - Eastem (queen, heautifully marbled, unique and attractive; $1 \mathrm{ft} . . . \ldots . . . . . . . .$.

PERENNLAL VARIETIES,

931 Dianthus atrorubeus, dark red; $1 \mathrm{ft}$.

- barbatus (sce Sweet William).

932 - deltoides, jiuk and white mixed,

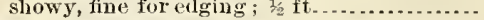
933 - dentosus, a mass of pretty rosy-lilac flowers, a perfect gem ; $1 \mathrm{ft} . . . . . . . . . . . .$. 934 - Gatrdneriauns, various colored, fincly fringed, donble flowers, fragrant

935 - Moschatus, f. pl. (Double Garden Pink), saved from clioice double varietics. 940 - choice mixed perenuial varieties.

942 - Collection of 12 distinct varieties

\section{DIDISCUS}

A pretty plant, from Australia; half-liardy annual. 950 Didiscns coruleus, blue; $1 \frac{1}{2} \mathrm{ft} . . . . . .05$

DIGITALIS (Foxglove).

Very ornamental aud cxeeedingly slowy plants for slirubberifs aud other half-shady places; liardy porennials.

954 Digitalis alba, pure wlitte; $3 \mathrm{ft} \ldots \ldots \ldots . .05$

955 - lutea, goldeu yellow; $3 \mathrm{ft} \ldots \ldots . . . . \quad .05$

956 - purpurca, purple, spotted; $3 \mathrm{ft} \ldots \ldots . .05$

957 - gloxinoides, splendid large-flowered

variety; brilliant colors, mixed; $4 \mathrm{ft} . . . . .$. .

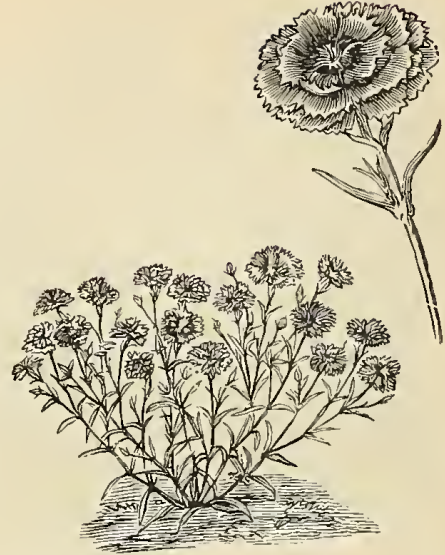

No. g16.-Dianthus Chinensis fl. pl.

No. DOLICHOS (Hyaciuth Bean). Price A beantiful class of quick-growing ornamental climbers, often growing fifteen to twenty feet in a seasoll; producing au abundance of clustered spikes of purple and white flowers, which are followcd by exceediugly oruameutal seed-pods; tender annuals.

968 Dolichos lablab, purple............. \$0.05 969 - - alba, white.....................

FCCREMOCARPUS (Calampelis).

A rapid-growing plant, with compact and pretty foliage, from which issue numerous clusters of haudsome tube-shaped flowers; invaluable for covering the stumps of old trees, unsightly walls, etc.; half-hardy perennial.

975 Eccremocarpus scabcr, orange; $10 \mathrm{ft} . \quad .10$

\section{ECIIEVERIA.}

Very popular plauts for beddiug or pot culture, their large, massive, sueculent, peculiarly colored leaves never failing to cngage attention. A group eomposed of the different varieties can be made one of the most attraetive spots in the flower garden. 977 Echeveria metallica, hroad, large, succu. leut lcaves, beantifully sliaded with a purplish glaucous hue. ............................ .50 978 - secunda slauca, silvery-gray foli. age; haudsome...........................

HPACRIS AND FRICA.

Well-known, beautiful and interesting greenlouse sliruhs, their profusion of bloow rendering them very effective.

985 Epacris, mixed, saved from fiuest va.

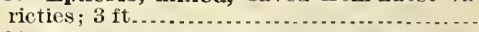

986 Erica (Cape Heaths), saved from choicest greenhouse varieties ; $2 \mathrm{ft} . . . . . . . . . . . . . . .$. .25

\section{ERYSIMUTM}

Very slowy, free-flowering, hanisome, hardy annu. als, very effeetive in bcds, mixed horders, or ribbons; succeed in light ricl soil.

990 Erysimum Arkansanum, sulphur yel-

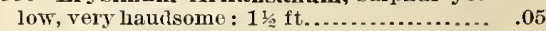
991 - Peroffskianmm, orange; $1 \frac{1}{2} \mathrm{ft} \ldots \ldots . .05$

FRTTIRINA.

A spleudid genus of half-hardy shruhs, with fine leares and beautiful brilliant scarlet flowers; they grow frccly out-of-doors if planted in a warm situation.

995 Ery thrima corallodendron (Coral Tree), scarlet; from West Indies ; $6 \mathrm{tt} \ldots \ldots \ldots \ldots . . .25$ 10996 - crista-galli, scarlet; from Brazil..... .25 


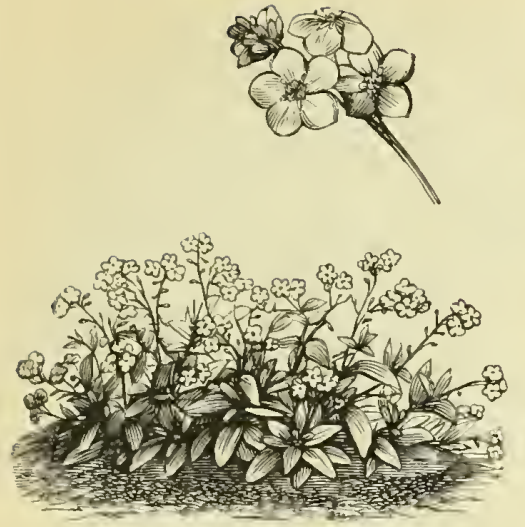

No. 1034-Forget-me-not.

No.

ESCH:CHOLTZIA.

Price.

An exeeedingly slowy, profuse-flowering genus of plants, with extrenely riel and beantiful colors attraetive for bedding, inassiug, or ribboning: light rieli soil: hardy annuals.

1000 Eschscholtzia Californica, bright yel

low, with rieh orange center: $1 \mathrm{ft} \ldots . . . . .$. . $\$ 0.05$

1001 - alba fl. plo, a new donble white variety of remarkable heauty.

1002 - carminen (grandiflora rosca), a eharming variety, with large flowers of intense carnine: bloous until late in the Fall. 1003 - erocen, rich orange: $1 \mathrm{ft}$

1004 - - nlba, ereany white ; $3 \mathrm{ft}$

1005 - Mandarin. The inner side of the petals is of a rieh orange color; the on ter side being the brilliant scarlet known as the mandarin scarlet.

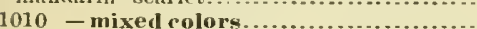

\section{FUPHORBIA.}

A showy border plant, with foltage veined and marginel with white; rery attractive; larly annual 1015 Euphorbia variegata, white......... .05

\section{EUTOCA.}

Showy and free-flowering plants, from California, suitable for beds or mixed horders; hardy annuals. 1018 Entoca multiftora, pink, a profuse

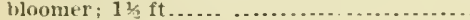

1019 - viscida, hriglit bhe; $1 \mathrm{ft} \ldots \ldots \ldots \ldots . . . . . . .05$

FTERNAT, OR FVFTI,ASTINC: FIOTWFRS.

Ornamental border plants, the blossoms of whicl are extensively used for "winter bonunets; hardy annuals. (See Helichrysum, etc.)

1020 Eternal flowers, many varieties and species mixed

1021 - Collection, twel ve distinct varieties.

$$
\text { FFNZIIA. }
$$

A splendid profuse-blooming neat little plant, graeefully beantiful for pot enlture, and very effective in beds; resinires considerable moisture; hardy annuals.

1024 Fenzlia dianthiflora, rosy lilat; ${ }_{\mathrm{i}} \mathrm{ft} . \quad 25$

$$
\text { IFIRNS. }
$$

This oraceful and magnificent order is too well known and bighly appreciated to need descrip. tion; from the seed we offer the amatenr has the certainty of raising many graceful varieties.

1028 Ferns, nixed, from choicest varieties.

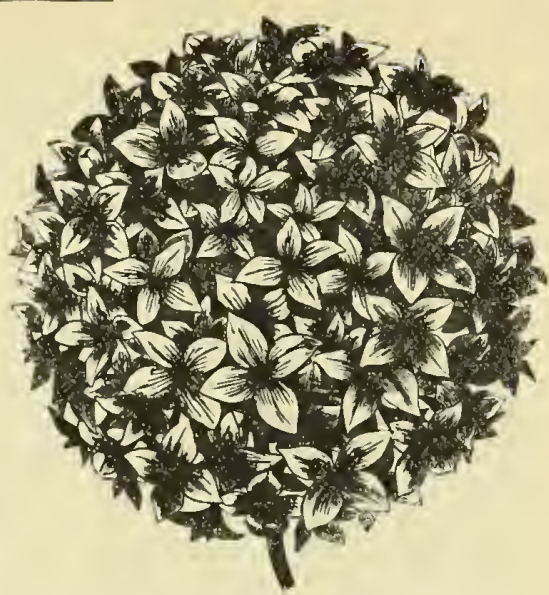

No. 1052.-Gaillardia Picta Lorenziana. No.

FORGFT-MF-NOT (Myosotis.)

A farorite and well-known border plant, flowers early, bloous freely, and is iudispensable for spring gardening; lablf-liarly perenual.

1034 Forget-1ne-not, fine mixerl varioties. 80.10 - in variety (see Myosotis).

\section{FIRAXINEILA.}

I andsone, very fragrant, free-flowering, lerbaceons plants, suitable for mixed borlers; snceed in any common soil ; lardy perennial

1040 Fraxinella, white; $2 \mathrm{ft} \ldots . . \ldots \ldots . . . .05$

1041 - red; $2 \mathrm{ft}$. ........................

\section{FRENCII HONFTSUCIXIE} (Hedysarum Coronariun).

A free-growing, exceeding showy border plant, of easy colture; bears racemes of attractive peaformed Howers; hardy biennial.

1044 French Honeysuckle, red and white. .05

$$
\text { FUCIISIA. }
$$

Well-known plants, of easy culture in pots, for conservatory or parlor decoration, or the opeu borler; thry are as easily grown from seed as from enttings, while raising from ehoice seed has the advantage of olbtaining many jmoroved varieties; greenhouse perennial.

1046 Fuchsia, from choice named varieties. .50

$$
\text { CAII,IA RIDIA. }
$$

spleudid belling plunts, remarkable for tho pro fusion, size, and brilliancy of their thowers, eon tinuing in beanty during simmer and Autumn barly annuals.

1050 Gailnudia, eloice mised, annual vari eties, rich colors; $13 / 2 \mathrm{ft} \ldots \ldots . . . \ldots . . . . .$. 1051 - Richardson, orange with brown

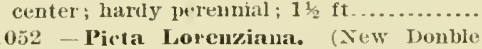

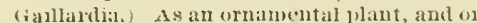
accont of its long duration of loloom and its usefulness for cut-flowers, this variety cannot bo too biglily reeommenicd. The eolors oftererl (in mixture) colnprise sulphor sellow, golden yellow, orange, andaranth, and claret.

$$
\text { GINTIANA. }
$$

These rank foremost amongat on arliest and loveliest Spring-flowering plants, very useful as edging or roek plants; thes should be grown in good rieh soil, to which lias been add'd a eonsiderable portion of peat earth ; handy ierenuials. 1058 Geutiana, fine mixel ................. .15 


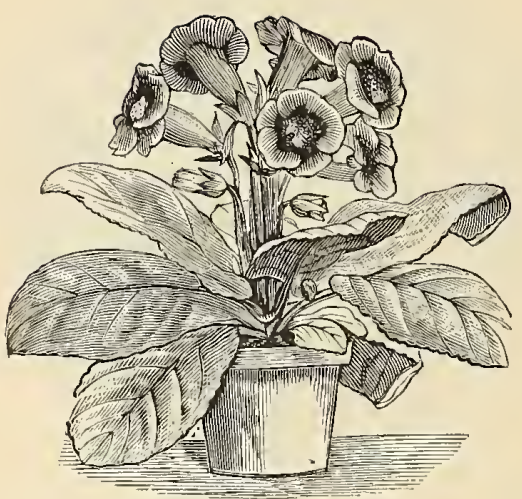

No. 1112.-Gloxinia.

No. GERANIUMI (Pelargoniuma). Price.

These well-known farorites are as indispensable for in-door as for out-of-door decoration, and should be extensively cultivated; the secd we offer having been saved from first-class varieties, the amateur las a fair chance of raising many charnung novelties; greenhouse perennial.

1060 Geranium, apple-scented, a well-

known favorite variety...........................25

1061 - famcy, choice greenhouse varieties. . .50

1062 - ivy-leaved, the graeeful beauty of

foliage renders these household pets........

1063 - large-flowered, from prize varieties .50

1064 - scarlet, fino mixed . . . . . . . . . . . . . . . .

1065 - zollalc, choicest hybridized rarie-

gated rarieties, embraeing all the gold and

silver, tricolor, and bronze sorts............ . .50

We have succedted in saving a limited quantity of seed from our owu superior eollection of American Seedling Gelaniums, and we confidently offer it as being of a quality that cannot be surpasser. Only such plants as wero perfect in every feature were selected for seod, and all were artificially fertilized with the gxeatest care. We believe the double will produce from 75 to 90 per cent. of double-flowering varieties, while the single will retain all tho excellence of tho parent plants.

1068 Geranium, double.-Packet of 20 seeds .50

1069 - single.-Packet of 25 seerts......... .50 GHSNHRA.

Beautiful hot-house plants, produeing their brill iant flowers in handsome spikes; tender perennial. 1074 Gesnera, ehoicest varieties mixed; 1ft. .25

\section{GIIIA.}

Very pretty dwarf annuals; bloom in alnost any situation, grow well in pots, and may be placed in a rockery; bardy annuals.

1080 Gilia achillcaefolia, hilac; $11 / 3 \mathrm{ft} \ldots . .05$

1081 - capitata, celestial blue ; $34 \mathrm{ft} . . . . .05$

1082 - nivalis, snow whito; $3 \mathrm{ft} . . . . . . . .05$

1083 - tricolor, white, lilac, and purple-- 05

1088 - mixed, all colors................... 05

GIADIOIUUS.

The seed offered has been carofully saved from the finest named hybrids of Gandavensis ; half-hardy bulbs.

1090 Gladiolus, ehoice mixer.

1091 - New Hybrid, very select, saved from

G. Lemoine, Froebelli, etc -

1092 - small bulbs, from named varieties..

For list of named varieties, see Summer Flowering Bulbs, on 49 and following pages.

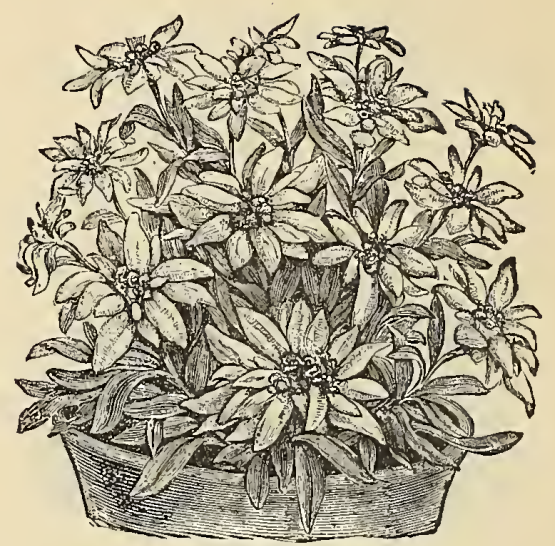

No. $11,8 .-$ Edelweiss.

No.

GIAUCIUMr.

Price.

Effective border plants, popularly ealled Horn-poppies, and among the prettiest of our white-foliaged plants; their elegantly indented glaucous green leaves make them attractive at all seasons; hardy perennials.

1094 Glaucium, fiue mixed. $\$ 0.10$

\section{GIOHF: AMATANTHUS} (Gomphrena).

Handsome everlastings, with showy flowers, whtch may be cut and preserved for. Winter decorations; thcy are exceeãingly beautiful plants for conservatory decoration, and when well grown in small pots are a pleasing feature in the sitting. room ; half-hardy annuals.

1098 Globe Amaranthus, flesh color ; 3 ft. . .05 1099 - - golden ycllow; $2 \mathrm{tt} \ldots \ldots . \ldots . . . .05$

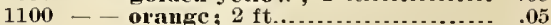

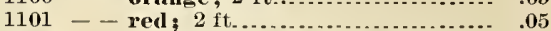

1102 - variegatcd, striped roseand white .05

1103 - - white; $2 \mathrm{ft}$ -

1104 - globosa nana compacta, a distinct new variety of dense bushy habit; flowers a rich deep violet red; excellent for

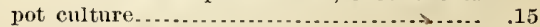

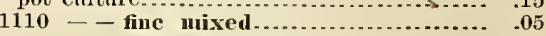

GIOXINIA.

A superb genus of greenhouse plants, producing in great profuston beautiful flowers, of the richest and most brilliant colors; thrive best in sandy peat and loam; stove perennial bulbs.

1112 Gloximia, choicest mixed, from the finest erect and drooping varieties.......... .

GNAPHAIIUM.

Everlastings of great beauty and easily grown; indispensablo for Winter bouquets and decoraticns, for which purpose the blossoms should be gathcred wben on tho point of opening, and dried in the shade; half-hardy perennial.

1116 Gnaphalinu fetidum, citron yellow,

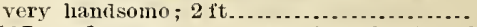

1117 - decurrens, a recent introduction of branching growth, 8 to 10 inches high, with a main flower-stalk 24 to 30 inches in height. Flowers white, and produced in thick clusters. I t is a charming Immortelle, and grows freely in any garden soil................... flowers are pure white, star-shaped, and of a downy texture. This is the true Edelweiss of the Alps, well-known and so much prized by tourists in switzerland...................
.10 

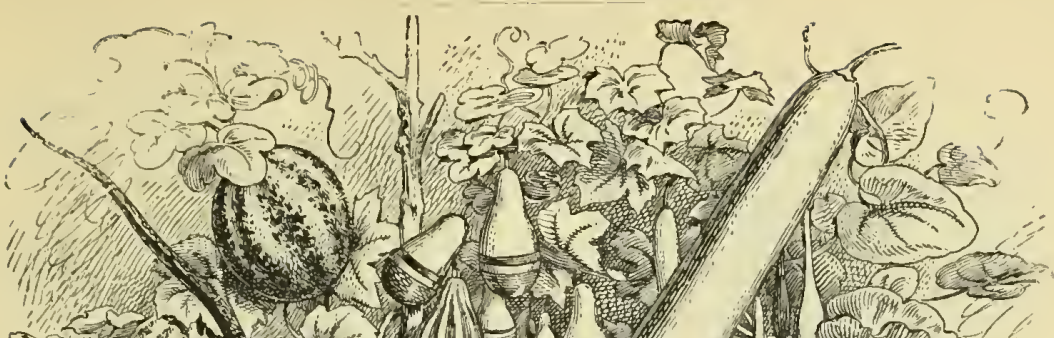

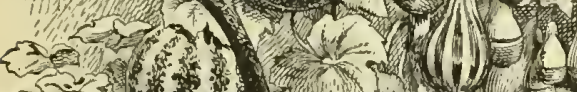

2. (1)

3. W

n 10020

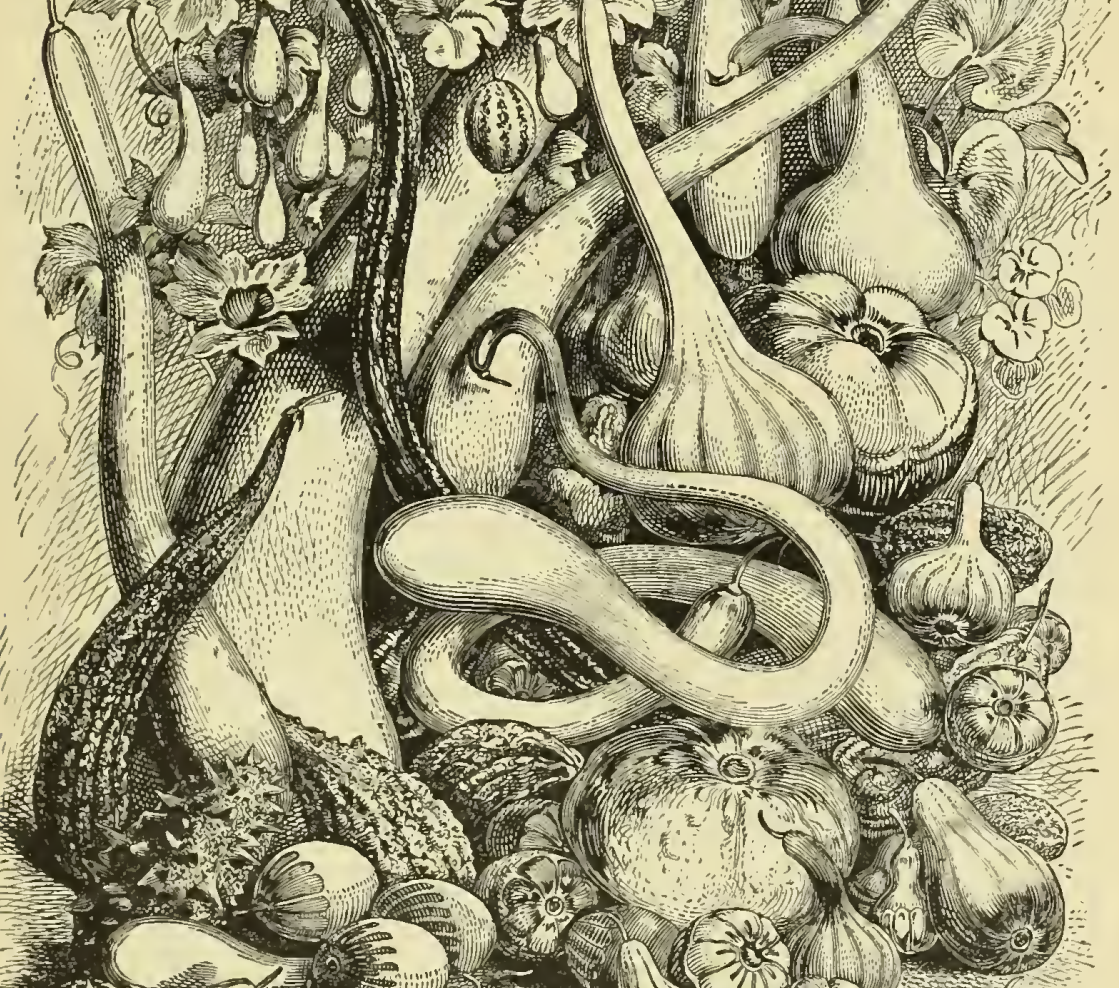

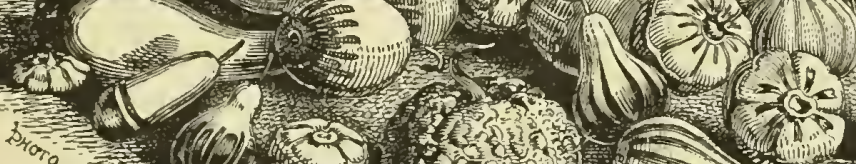

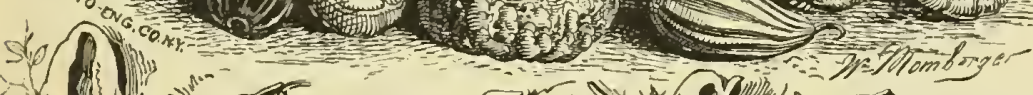

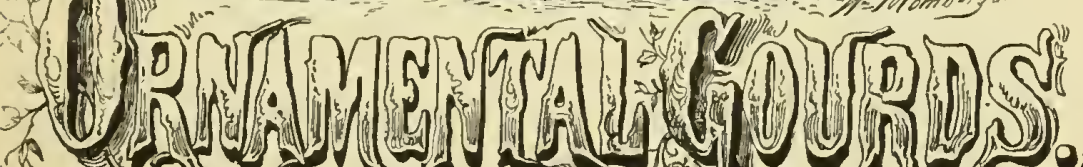
310304) 


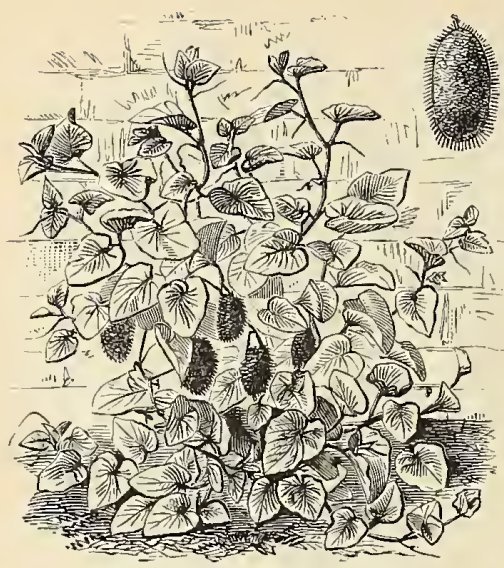

No. 1141 - Cucumis Dipsaceus.

No. GODFTIA.

Price

A very desirable, free-flowering genus, attractive in beds, mixed borders, and ribbons; hardy annuals. 1122 Godetia alba, puro white; $1 \frac{1}{2} \mathrm{ft} \ldots . . . \$ 0.05$

1123 - Lady Albeunarle, intense carmine crimson, compact habit, very beautiful; $1 \mathrm{ft}$. 1124 - Ciud leyana fi. pl., purplo; $1 \frac{1}{2} \mathrm{ft} .$.

1125 - The Bride, wlite, with a ricl varmine eenter; $1 \frac{1}{2}$ tt. ......................

1126 - Whitneyii, pearly satiu white; $1 \frac{1}{2} \mathrm{ft}$

1130 - fue inixed ......................

GOURIS (Ornamental).

(Including Cucumis and Cucurbita.)

The varieties in this collection have beeu selected either for the ornamental character of their foliage, the singularity or symmetry of their fruit, or the variety and peculiarity of their coloring; some are of very large size and of curious form, wlible others areminiatures of various forms. The growth is as diversified as the fruit; some arevigorous growers, others slender and delicate. Wher ever grown they never fail to excito admiration. Cultivation the same as for squashes or melons.

1140 Cueumis Auguria, small yellow fruit, growing in pairs............................

1141 - dipsaeeus, yellow, teasel-like......

1142 - flexiosus, snake eueumber.......

1143 - medulliferus, scarlet, thorny ......

1144 - Melo Chito, variegated, brown and ycllow, small oval fruit, very pretty ........

1145 - percmnis, foliage highly ornamental

1150 Cucurbita argyrosperma, fruits large and finely striped or nottled.

1151 - digitata, foliage marbled with white, fruits dark green, striped white.............

1152 - leneantha, long curious fruit......

1158 Gourd, apple-striped, very ornamental

1159 - bottle, well-known and very usefu!

1160 - - miniature, ornamental..........

1161 - dipper, a favorite variety...........

1162 - exg-shiped, resembles an egg......

1163 - mooseberry, very pretty

1164 - Iereules' club, large club-shaped.

1165 - lemou, showy..................

1166 - miniature, orange and green striped,

very urnamental, one of tho best.

1167 - orange, well-known sort............

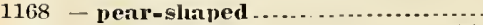

1169 - surar trough, immenso size, holds

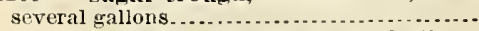

1175 - fue mixed, from a large eollcction..

1176 - Collection of 12 distinct varieties ..

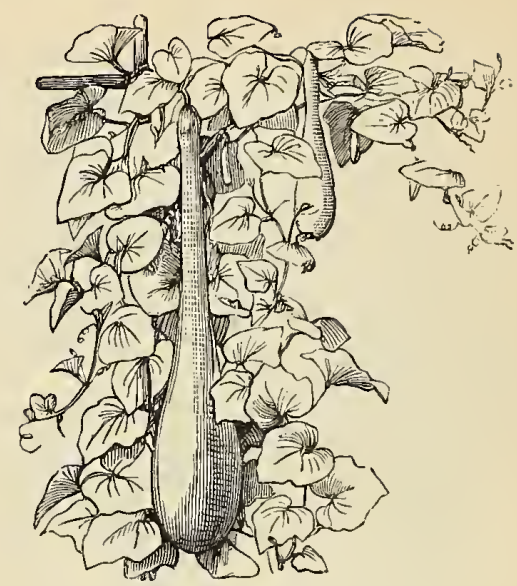

No. $1164 .-$ Gourd, Hercules' Club.

No.

GIRAMMANTHES. Price

Beantiful miniature plants for rock-work or rustie baskets, yielding a profusion of star-shaped flower's; half-hardy annual.

1180 Grammanthes gentinnoides, ricl

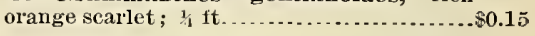

GIRASSFS (Omamental).

For full list of all the most desirable varieties, see speeial list at page 45 .

1182 Collection of 12 distinct varieties......

\section{GUNNFRA.}

A very showy, olnamental-foliaged plant, with leaves of an immense size, presentins a striking appearance; succceds best in rielı loamy soil, and requires protection in Winter; from the cape of Good Hope; half-hardy perennial.

1184 Gumera scabra, flowers greenish

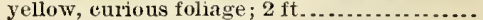

\section{GYPSOPHIEA}

A pretty, free-flowcring, elegant little plant, best adapted for rustic rock-work, baskets, and edgings, succeeding in any gardeu soil; hardy annuals.

1185 Gypsophila elegaus, white and pink;

fine for table bouquets; $1 \frac{1}{2} \mathrm{ft} . . . . . . . . . . .$.

1186 - muxalis, a cliarming little plant, coyered with red flowers, which contrast beantifully with its graeeful foliage; $\frac{1}{4} \mathrm{ft} . . . . . .$.

\section{HAWIZWEED.}

Remarkably showy and effective on rock-work, in beds or masses in mixed borders; hardy annuals.

1190 Hawkweed, mixed colors............ .05

IIEIIANTHUS (Sun-flower).

A well-known genus of the most showy plants, remarkable for their stately growth and the brilliancy and size of their flowcrs; liardy annuals.

1195 Helianthus argophyllus, yellow, double, leaves silky white; $5 \mathrm{ft}$............

1196 - Califorvicus, orange, extra large, and double; from California; $5 \mathrm{ft} . . . . . . . . .05$ 1197 - grcen centered, yellow, very double, with a eouspicuous wreen eentcr; $4 \mathrm{ft} . . . . . \quad .10$ 1198 - Russian mammoth, very large.... .05 1199 - Itwus foliis variegatis, a dwarf variety; with variogated foliage........... 1200 - Oscar Vilde, a small black-centered variety of great utility as a bedder and most attraetive as a corsage flower............. .15 1204 - fue nixed . . . 


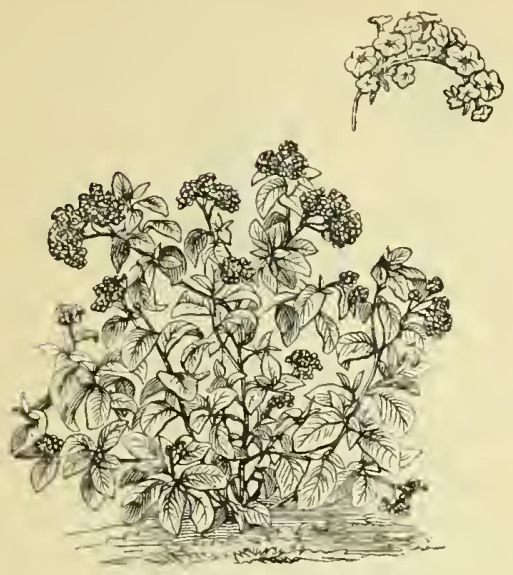

No. 1225.-Heliotropium.

No.

HFIICHRYSUM.

Price.

Exceedingly handsome and ornamental plants for mixed borders, and peculiarly desirable as dried specimens; liandsome bounuets and festoons may be formed of them for in-floor deeorations during Winter: hardy anmuals.

1205 Helichrysum bractcatum album,

white $2 \mathrm{ft} . \ldots \ldots \ldots \ldots \ldots \ldots \ldots \ldots \ldots \ldots . . . .10$

1206 - - aureum, golden jellow; $2 \mathrm{ft} . \ldots . . . .10$

1207 - nannm atrococcineum, dwarf, rose .10

1208 - ntrosanguineum, $\mathrm{k}$ warf, red ; $1 \mathrm{ft} . \quad .10$

1209 - monstrosum album, fl, pl., dontble

white; 2 ft

1210 - - Intcrm, fl. pl., double yellow...... $\quad .10$

1211 - - purpmrcmu, fl. pl., purple; $2 \mathrm{ft}$.. .10

1212 - - rosenm, fl. pl., double rose: $2 \mathrm{ft} . \quad .10$

1215 - minimum, very dwarf, nixed...... .10

1216 - fine mixed varieties............... 10

1217 - Collection of 10 splendid vartieties.. .60

The following three varieties have elegant silvery. gray foliage, and ball-like tufts of flowers, resem. bling the yellow Immortelles; they do well in pots, and are very decorative ont of doors in sunny situations.

1218 Felichrysum brachyrhynchum, lemon yellow; $1 / 2 \mathrm{ft} . . . \ldots \ldots \ldots \ldots \ldots \ldots \ldots \ldots . . . .10$ 1219 - elegans, yellow; $1 \mathrm{ft} \ldots \ldots \ldots \ldots \ldots . . . . . . . .10$ 1220 - strictum, yellow; $1 \mathrm{ft} \ldots \ldots \ldots \ldots \ldots . . . . . . . . . .10$

HEITOTROPE.

A well-known gemus of profuse-flowering and de liciolel y fragrant plants, splendiol for bediling or ribloning, and for baskcts or pot culture; seeds sown in Spring nake fine plants for Summer ani Autumu decoration; half-liarly perennial.

1225 Heliotrope, fincut mi

1230 - Collection of 6 clioice varieties...... 50

HELIPTERUM.

For summer blooming, or for W'inter boucuets, a valuable border plant; tender annuals.

1235 Helipterum anthemoides, white,

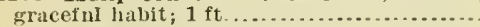
1236 - Sanfordii, of dwarf, tuftel habit, ronnd chnster's of yellow flower's; ${ }^{2} 4 \mathrm{ft} \ldots . .$. .

\section{IHIBISCUS.}

Ono of the most ornancutal, beantiful, and sliow genera of plants cultivated; characterized by the sizc, and varied and beantifnl colors of their flowers; ladely annmal.

1240 Hibiscus Africanus, cream color, rich brown center ; $11 / 2 \mathrm{ft}$

1241 - choicc mixed, saved hy an eminent grower from splendil varieties; all perfectly hardy.

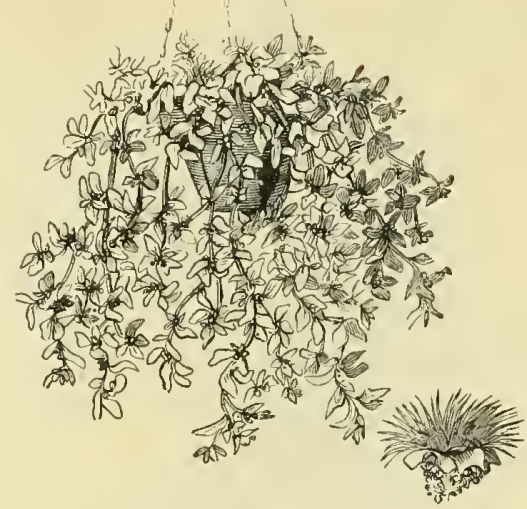

No. 1265.-Ice Plant.

No.

\section{HOI, Y HOCIS.}

Price

This splendid plant now ranks with tho Dahlia for Autumn dccoration, and from its stately growth and tho varied colors of its manificent snikes of flowers, may justly demand a place in every large garden or pleasure gromnd. If sown early in licat the plants may be in bloom the first year; hardy perenuials.

1245 Hollyhock, choice mixed, saved from

Chater's prizo varioties................ \$0.25

1246 - finc mixed

1247 - white, double, valuable for florists. .25

1248 - Chincse scarlet, an annual variety;

very sliowy ................................

1250 - Collection of 12 dist inct colors, saved

from Chater's prize varieties.............. 1.50

IIONFSTY (IUnaria).

Early summer frec-flowering plants, with silvery seed-pods, much admired for Winter decoration witl ornamental grasses, ete. ; lardy biennials.

1252 Honesty, purple, very showy; $2 \mathrm{ft} . .$. .0

MUMTHA

A remarkably handsome plant, invaluable for deco rative purnoses, whether in the conserratory or dispersed in pots about the lawn, planted in the cente's of beds or mixal bordery, its majestic and graceful appcarance renders it a nost effuctive and striking object; half-hardy bienuial.

1256 Humea clegans, red; $3 \mathrm{ft} \ldots \ldots \ldots \ldots . . .15$

1257 - albida, the panicles of this ra-

riety are of a whitish slade; very effective,

and useful for bouruets.....................

ITFIrIs (Pexennial Candytuft.

Profuse-blvowing pretty littlo plants, especially adajted for rockeries, old stmmps, or rustic bas kets; they come into flower amougst tho carliest Spring plants, and for at long tinc continno a dense wass of beauty ; liardy peremials.

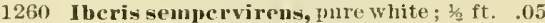

\section{ICF I'IAN'T}

(Mesembryantluenum crystallinum). A pretty little trailing plant, mueh used for garnishing, the leaves of which aro covered with crystal line globules, thus giving it the appearances of buing couted with ice; hilf-hardy anumal.

1265 Ice Plaut, white, very effective...... 05

\section{IONOPSIDIUTI.}

A charming early flowering plant, growing best if moist, sharly situations; excellent for edging and rock-work, also a ucat pot plant; liarily annual.

1268 Ionopsidium acaule, sky binc; $\frac{1 / 4 \mathrm{ft} . .}{.10}$ 


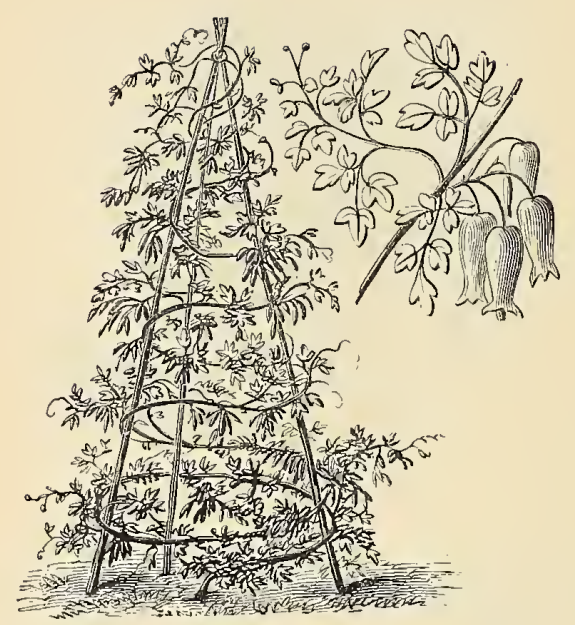

No. 270.-Adlumia cirrhosa.

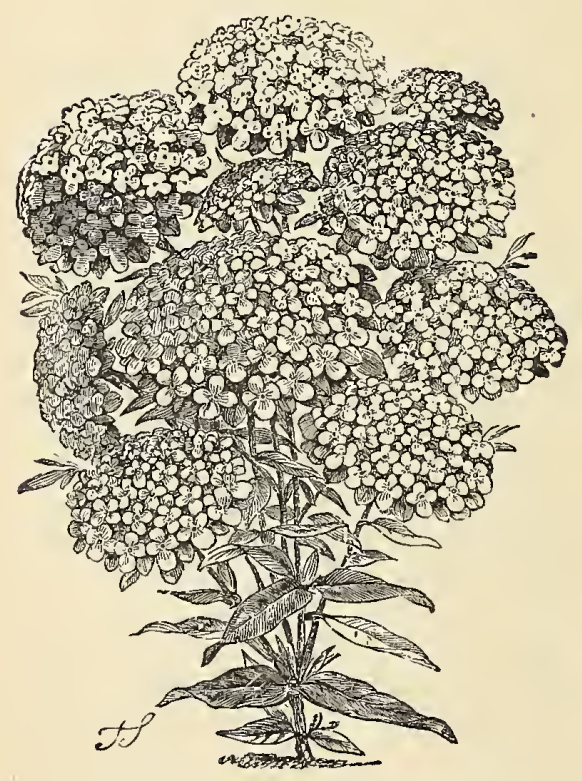

No. $5^{82}$ - Candytuft, New Carmine.

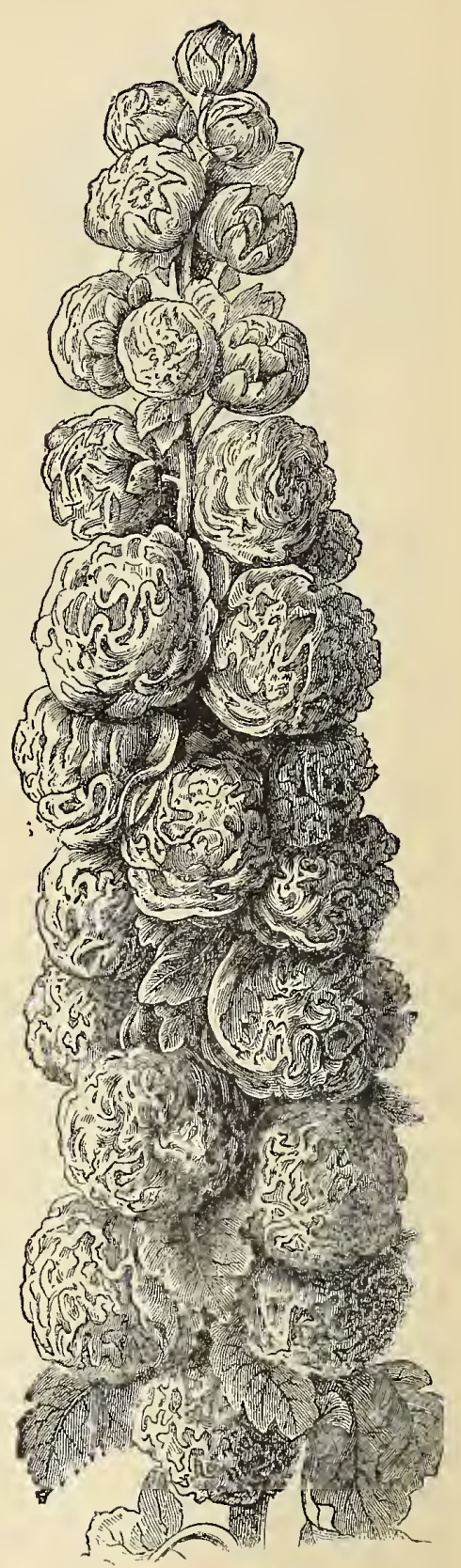

No. 1245.-Double Hollyhock. 


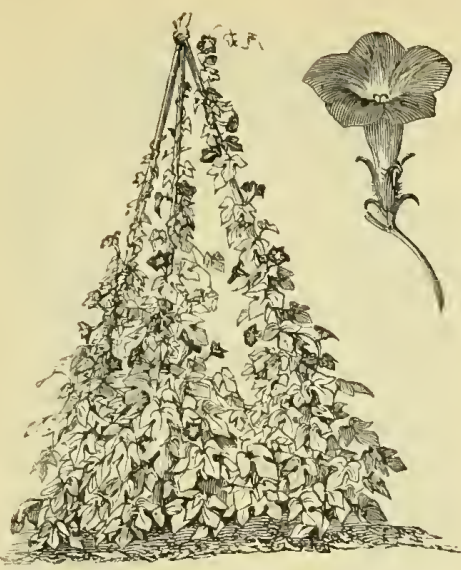

No. 1273.-Ipomea hederacea superba.

No. IPOMTCFA Convolvulus) Price

of all flowers in general cultivation, this rauks preeminent for delieato and intrinsie beanty; the brilliant and vasied hues of its many speeies and varieties are exeeedingly beautiful, and its tine foliage and graceful form render it an indispensa ble ornament for greenlonse, conservatory, or garden decoration.

$$
\text { ANIUAL VARIETIES. }
$$

1270 Ipomoa Bona Nox (Evening Glory), satin rose, large, fragrant blossoms, whieh expand in the evening; $10 \mathrm{ft} \ldots \ldots . . . \ldots . . .80 .10$ 1271 - coecinen (Star Ipomoea), searlet, small flowers, in great profusion; $8 \mathrm{ft} . . . . .$. 1272 - fol. marmoratis, Japanese varietiex, foliage beautifully mottled ; mixerl eolors...

1273 - hederacer superba, ivy-like foliage, rery sliowy, mixid colors: $8 \mathrm{ft}$.

1274 - limbata elegantissina, ricl bluisl purple center in the forn of a star, with broac pure white margin......................... 1277 - rubro crerulea, sky blue, large, handsome flowers: $10 \mathrm{ft} \ldots \ldots \ldots \ldots . . . . . .$. 1278 - - alba, pure white; $10 \mathrm{ft}$. ..........

1280 -Collection of 10 distimet varieties... DERENTAL VARIETLE.

1282 I pomon I,earii, rich blue, elanging to rect. niagrificent ; from Ceylon; $20 \mathrm{ft}$

1283 - leptophylla, a native rariety; from Colorado, forming a bushy mass abont three feet in height : rosy purple.

1284 - Mexicana sraudifiora alba, in mense white flowers, delieionsly fragrant...

\section{IPOMIOPAIS:}

Handsomo free-tlowering plants, with long spike of dazzling fiowers, very effective for eonscrvatory and ont loor deeoration: half-hardy biennials.

1290 Ipowopsis aurant iaca, orange; $3 \mathrm{ft}$.

1291 - pictn, wrauge, scarlet and gold; 3 ft

1292 - sangninen, scarlet. very brilliant..

1295

- sangninen, scarlet, very brilliant...

\section{IRIS IIAWNI'HFIRI.}

Amongst thoroughly harly plants the finc varieties of this species are unsurpassed; thoflowers, which are of immense sizo and lieary textnre, embraee a marvellons range of color; harty percunials.

1300 Iris F aemuferi, all colors mixet. ....

$$
\text { JACOBALA Senecio. }
$$

A nseful and exceedingly showy class of gay.col ored, profuse-blooming plants; lardy annuals. 1305 Jacobren, fine mixed double varieties.

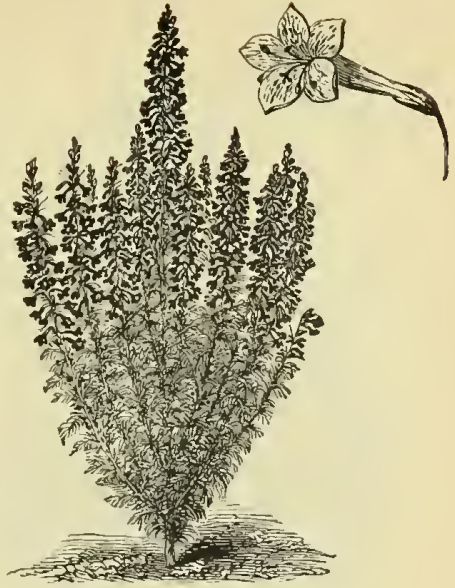

No. 1295.-1pomopsis.

No.

IX A UITUSEIA.

Price.

Pretty little free-flowering plints of a neat, compaet growth, execedingly effective in beds or mixed borders; hariv annuals.

1310 Ḱaulfussia nmelliodes atroviolncen.

intense violet, very attractive; $1 / 2 \mathrm{ft} . . . . . . \$ 0.05$ 1311 - - alba, whrte; $1 / 3$ ft............... 05

1312 - - kemesinn, crimsoll; $\frac{1}{2} \mathrm{ft} \ldots . . . .05$

1313 - - roser, rose; $1 / 2 \mathrm{ft} \ldots \ldots \ldots \ldots \ldots . .05$

\section{KK FII,WORTH IVY}

(Iinaria eymballaria).

Admirably adapted for culture iu baskets, pots, or rases, and for the ornamentation of rock-work it is unsiryassed; hardy perennial.

1320 Keuilvortlı Ivy, lilac; $1 / 4 \mathrm{ft} \ldots . . . \ldots . .15$

\section{I.ANTA NA.}

A remarkably handsome, freo-flowering genus of plants with brilliantly colored flowers, constantly eluanging in line; very effeetive, eitler for pot culture or for bedding.

1325 Lantann, finest varieties mixol....... . .15

\section{IARISSPUIR (Delphininum)}

Extremely ornaniental plants of great beaty, eom bining the riclest possible variety of brilliant and effective eolors, witl great duration and profusion of bloom. For laroc beds on liwns, or masses and mixed flower burlers, also for ent flowers, the taller growiug varieties are the most desirable; harty anmuls.

(For perennial varieties, see Delphinium.)

1330 Iarkspur. Bismarlk, a beautiful red.

striped raliety of great merit.; $1 \mathrm{ft} . . . . . . . .10$

1331 - candclabrum, doml, le, mixed; $1 \frac{1}{2} \mathrm{ft} .05$

1332 - - Collection of 6 distinet colors ... 50

1333 - double dwarf locket, fiue mixed.. .05

1334 - Collection of 10 tistinct colors... .50

1335 - tall rocket, fino mixed ............... .05

1336 - Collection of 8 distinet rarieties. .50

1337 - Emperor, a pofuse blouner, very donble, mixed iolols; $1 \mathrm{ft}$. 10

1338 - raunculus-flowered, very double, extra fine; $1 \mathrm{ft}$

- Trock-flowered, tall, mixed; $2 \frac{1}{\mathrm{ft}} .05$

1340 - - Collection of 8 distinct varieties .50

1341 - tricolor elegans, rose, white, and blne, very handsonte; $2 \frac{1}{2} \mathrm{ft} . . . \ldots . . . . . . .$.

IATHYRUS (Fverlasting Pea). Showy, free-flowering plants, growing in any com. mon soil; very ornamental on trellis-work, old stumps, fences, or walls; harty perennials.

1345 Lathyrus, mixed eolors, $5 \mathrm{ft} \ldots . . . . . . .15$ 


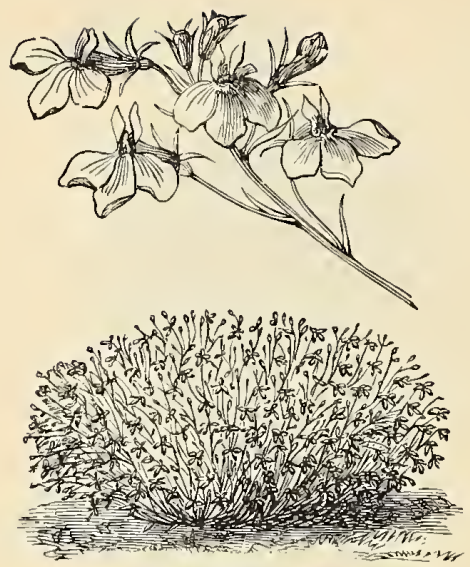

No. 1400.-Lobelia erinus.

Free-flowering handsome plants, exceedingly effect ive when used as a background to other plants hardy annuals.

1350 Lavatera, rose and white, mixed, $3 \mathrm{ft}-\$ 0.05$

I,AVENDUTA (Tavender).

A genus of plants chiefly cultivated on account of the delicions fragrance of their flowers; they succeed in any common soil; hardy perennial.

1355 Tavendula spica, lilac; $2 \mathrm{ft} . . . . . . . . .05$

\section{LEITOSIPHON.}

of rare beauty both in flower ant foliage, exceed. ingly attractive in beds or ribbons, while the dwarf sorts are well adapted for rock-work or cdgings; harly anuuals.

1358 Leptosiphon aureus, yellow; 1/3 ft... .05 1359 - densiflorus, rosy lilac; $1 \mathrm{ft}$......... .0. 05

1360 - - albus, white; $1 \mathrm{ft} \ldots \ldots \ldots \ldots . . . . .05$

1361 - hybridus, mixed colors............. . .10

\section{IU M.}

Too well known to need description. As the sceds often lie dormant for months, it is best to sow in boxes or pots, where they will not be disturbed. Altliou gh a slow process, tho raising of this class from seed is highly interesting to amatears. For Bulls, refer to our complete collection in another part of this catalogue, which embraces every desirable variety, including all recent introductions.

1367 Lilium teunifolium. This splendid searlet lily docs better from seed than either of the other varieties

1368 - choice mixed from best varieties

\section{IIMNANTHES.}

Easily glown, free-flowering, slightly fragrant plants, excellent for beds or chgings in camp shady places; hardy anumals.

1372 Limnanthus, mixed colors; $1 / 2 \mathrm{ft} . . . . . \quad .05$

\section{IINUM.}

One of the most effective and show $y$ beding plants we have; labit of growth is slender and delicate.

1378 Limm graudiforum coccineum, rich scarlet-crinusoll, with dark black center; hardy annual ; 1 ft. . . . . . . . . . . . ..............

1379 - I itteum corymbiflorum, straw color,

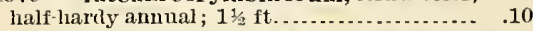
The three following varieties are charming harly perennials, rraceful and effective.

1380 Linum Lewisii, blue, white striped... . .10 1381 - perenue album, pure white...... . .10

1382 - - roseum, delicate roso........... .10

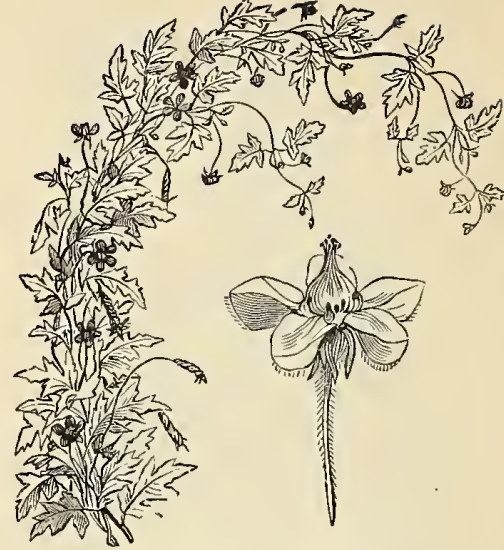

No. 1392.-Loasa aurantiaca.

No. IJOASA (Caiophora). Price A handsome genus of rapid-growing, free-flowering climbers, witlr curious and beautiful flowers, which must not be handled, nor any part of the plant, without gloves, as the hairs sting.

HARDY ANNUAL VARIETIES.

1390 Loasa tricolor, yellow ; $3 \mathrm{ft} \ldots . . . . . . \$ 0.10$ 1391 - vulcauica, elegant white star-like flowers of peculiar shape; $4 \mathrm{ft}$............. .25 HALF-HARDY PERENNIAL VARIETIES.

1392 Lonsa nurantiaca, orange ; $4 \mathrm{ft} \ldots \ldots . .10$

1393 - Herbertii, scarlet ; $4 \mathrm{ft} . . . . . . . . . . .10$ I,OIBI,I,IA.

Exceedingly pretty, profuse-blooming plants, of great value and importance to the flower garden. The low growing kinds make the most beantifn edsings. All the varieties of $L$. erinus are valuable for hanging-baskets, rustic-work, or vases, over the edges of which they droop in the most graceful and elegant manner. The perennial vari. eties are exceedingly ornamental, and are valuable from their blooming in Autumn.

ANNUAL VARIETIES.

1400 Lobclia crinus, deep blue; $1 / 2 \mathrm{ft} . . . . . .10$

1401 - - alba, pure white; $1 / 2 \mathrm{ft} . . . \ldots \ldots \ldots . .10$

1402 - - erecta bicolor, compact, bnshy

habit, with erect branches, giving the plant almost the shape of a ball; flowers white and blue.......................................

1403 - Paxtoniaua, pure white, with sky

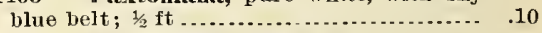
1404 - gracilis, celestial blue; $1 / 2 \mathrm{ft} . \ldots . . . .10$ 1405 - - alba, pure white; $1 / 2$ ft.......... .10 1406 - - rosea, delicate rose; $1 / 2 \mathrm{ft} \ldots \ldots \ldots . .10$ 1407 - ramosa (heterophylla), deep blue... .10

1408 - alba, white; 3 ft ft 1409 - speciosa (Crystal Palace variety), deep blue, extremely beautiful; $1 / 2 \mathrm{ft} \ldots . . . . \quad .10$ 1410 - - kermesina, rosy crimson; $1 / 2 \mathrm{ft} . . .10$ 1414 - mixed varieties of uniform height. .10 1415 - Collection of 10 distinct varieties... .75 PERENTIAL VARIETIES.

These are conspicuously beantiful border plants, the richness of color rendering them remarkably striking.

1416 Lobelia cardimalis, brilliant scarlet.. . .10

1418 - hybrids of Fulgens and Cardinalis, splendid shades of color, both in foliage and flower; blooms from July to

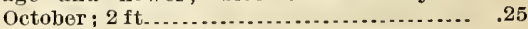
1419 - Queen Victoria, dark mulberry foliage, deep scarlet Howers; 2 ft...............

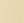




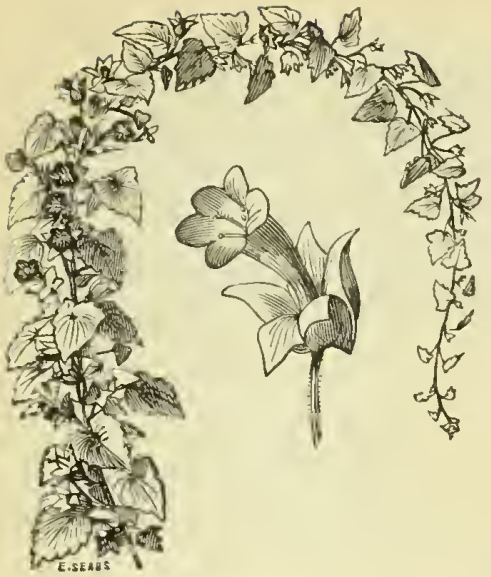

No. 1425.-Lophospermum scandens.

LOPHOSPEIRNTUMI.

Price

An exceedingly beautiful and highly ornamental genus of climbers, witl hamlsone, slıowy, fox. glove-like flowers: may be nsed with advantage for hanging-baskets: half-liardy perennial.

2425 Lophosperumu scanlens, rosy pur. ple, very tine trellis-plant; $6 \mathrm{ft}$.

\section{ITTINUSS.}

A splendid genns of ornamental, beantiful, ano free-flowering garten plants, with long, graceful spikes of pea-shaped blossoms; colors rich and varted: liardy anmmals.

1439 Lupinus aflinis, blue, wlite, and pur. ple; $1 / 2 \mathrm{ft}$.

1431 - albo-coccineus, rich rosy red half way of the spike, from thence to the apex pure white; $1 \mathrm{ft}$.

1432 - Cruikshankii, blue, while, and yel low ; $3 \mathrm{ft}$.

1433 - mutabilis, changeablo colors; $2 \mathrm{ft}$.

1434 - pubescens elegans, purple, violet, aud wlite; $1 \frac{1}{2} \mathrm{ft}$

1438 - Inixed annun! rarieties

1439 - - perennial varieties

1440 - Collection of 12 choice varieties...

\section{IYCIINIS.}

A genns of liandsome and lighly ornamental plants, of easy culture; strikingly effective in mixed thower and shrnbbery borlers; good rich soil; harty perenuials.

1445 Hycluris Chalcedovica, scarlet: $2 \mathrm{ft}$. .05

1446 - alba, white; $2 \mathrm{ft} \ldots . . . . . . .05$

1447 - Laaseaua, bright searlet, splcodil. .10

1448 - - hylovida, varions sliades......... .10

1449 - viscaria splendens, rose jink, $1 \mathrm{ft} . \quad 10$

\section{I.TGODIUMI $\triangle$ IC: NDENS}

Japanese Clinbing Fern).

A graceful climber, growing to an indefinite length; easy of cultnre, and alajted for dowra tion in the same manner as smilax, which plant it rivals in lurability after being cut; tender perennial.

1455 Lygodimn weandens

\section{ITITIRUMI}

Very showy plant. with long spikes of beantiful flowers; very effective in mixed borlers; this is an attractive aud stately plant, and deserves a place in every collection; haruy per'nnial.

1458 Lythum roweuu superbum, pink,

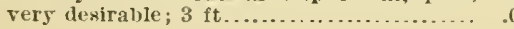

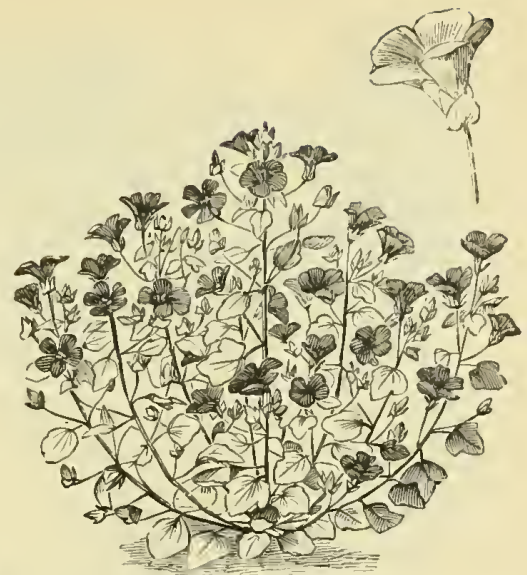

No. $1466 .-$ Malope trifida.

No.

MI A IOI'F.

Price

Handsome plants, of a brancling habit, prolucing their large flowers in great profusion; very effect. ive in mixed borders; suceed in common garden soil; larily ammals.

1465 Malope graudiflora, crinson; $2 \mathrm{ft} . . .05$

1466 - trifida albn, white; $2 \mathrm{ft} \ldots . . . . . . . .05$

MAITA OR MAIIOW.

Showy and free-flowering border plants, suceeding in any common garden soil : harily annmals.

1469 Malva zebrina, white and purple, striped ; very showy ; $2 \frac{1}{2} \mathrm{ft} . . . . . . . . . . .$. 1470 - moschata, rose, foliage fragrant.... .05

\section{MARTGOTD.}

Well-known, free-flow cring plants, with handsome donble flowers, of rich and beantiful color's. Thu African is the most striking in large veds, or mixed borders, The dwarf Fronch is nsed as a foregromud to taller plants, and makes splendio compact elgings; lialf-liarly anntals.

(See Calendula and Tagetes for other varieties.)

1475 Marizold, African, lemon ; $2 \mathrm{ft} . . . . . .05$

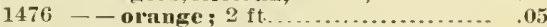

1478 - - fine mixed, all colors............. .05

1479 - Collection of 6 distinct varieties..

1480 - French, swarf, brown; $1 \mathrm{ft} \ldots . . . . .05$

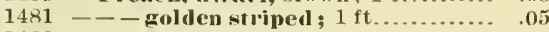

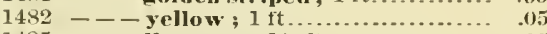

$148.5-$ tnil, olange; $11 / 2 \mathrm{ft} \ldots \ldots \ldots \ldots \ldots . . .6 . .05$

1486 - . - striped : $1 \frac{1}{\mathrm{ft}} \ldots \ldots . . . . .65$

1487 - Clotl of fold, a cliarming variety, covered with flowers having bright trold hars on dark velvety petals; 1 1/ $\mathrm{ft}$..... . .15 1489 - - fine mixed, all colors ............ $1490--$ Collection of 10 distinet varieties. MARTYNTA.

Handsome, free-flowering plants, prodncing a fine effect when planted in the open bonder; flowers as large and handsome as Gloxinias, snceeded by curions double-loomed fruit; half-hardy aumals.

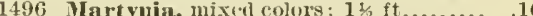

MA IRVIII OF PHIRU (Mirabilis) Few plants combine so much beauty, loth of foliage and flowers, as this handsome gems; the roots may be preserval throngl the Winter; sometimes called four-n'elocks; lialf-harily peremials.

1500 Marvel of Peru, golu stripud ; $2 \mathrm{ft} \ldots . .05$

1501 - wlite, sweet-sccuted : $2 \mathrm{ft} \ldots . . . . .05$

1502 - viriegnted foliage ; $2 \mathrm{ft} \ldots \ldots \ldots . .05$

1507 - fine mixed ....................... 05

1508 - Collection of 8 clioicr varieties... .50 


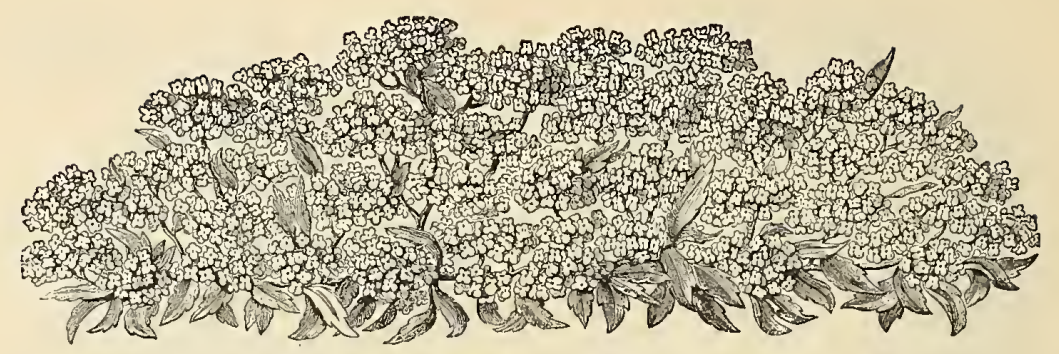

No. 588.-Candytuft, Tom Thumb new white.

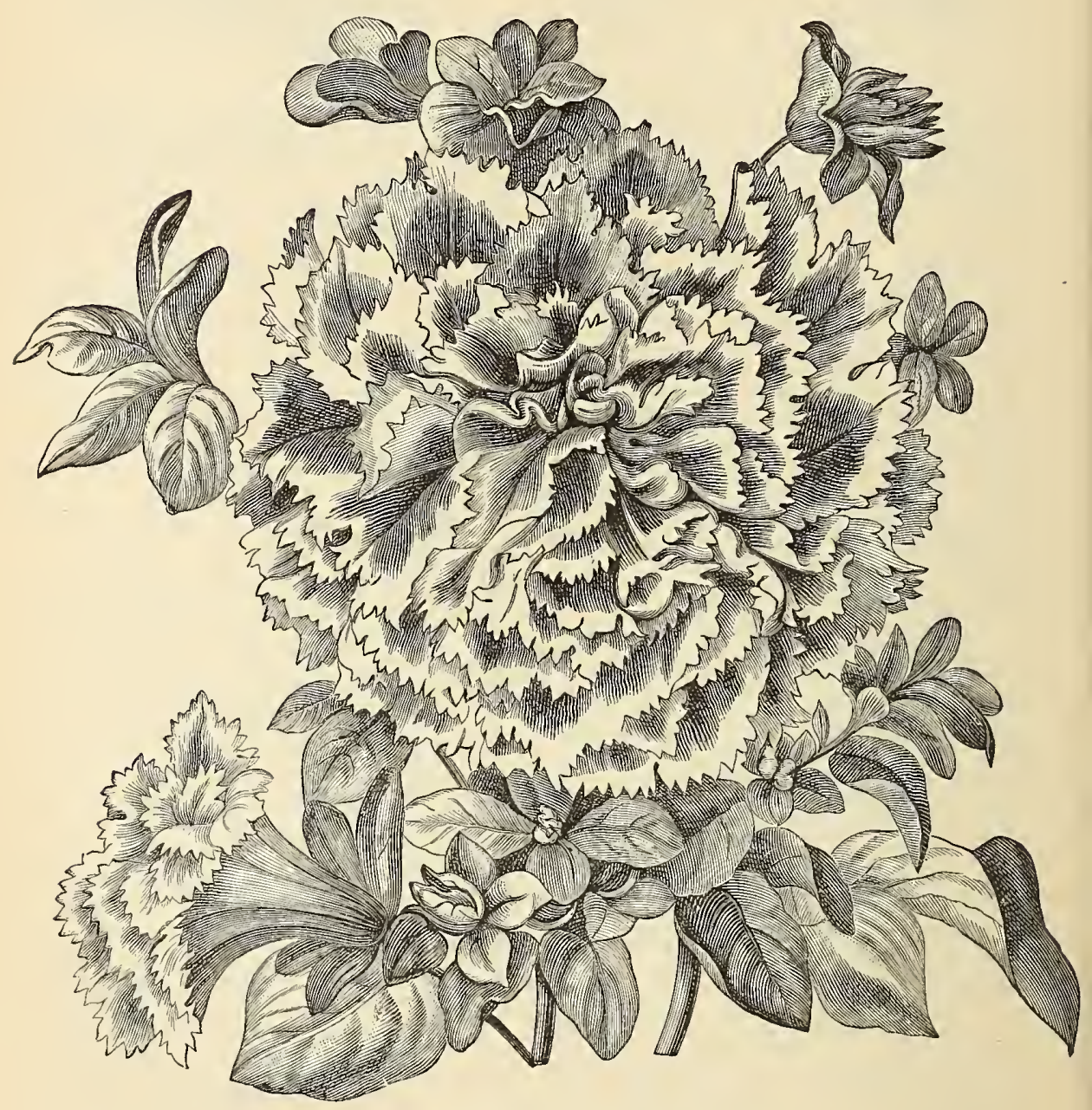

No. ${ }_{1760}$-Petunia, New Double Fringed. 


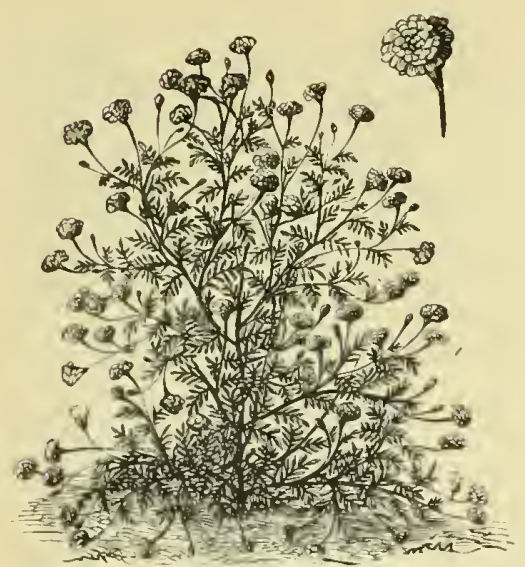

No. ${ }^{4} 4^{8}$. - Marigold, French.

No.

MIATIIOIAA

Price.

Night-scented Stock).

The delicious rich p'rfume emitted by the flowers of this plant, in the afternoon, evening, and after a shower, is truly deliogliful, and perceptible some distunce off; hardy annual.

1510 Iatliola bicornis, pink and lilac ; $1 \mathrm{ft}$ \$ $\$ 0.10$

MATIRICARIA Feverfew?

Handsome, free-flowering, oruamental plants, finc for bodding or pot culture; laalt-larky perenuials.

1512 Intricaria eapensis, dwarf, donble, white, very tine; $3_{4} \mathrm{ft}$.

1513 - eximia grandiflorn, an improved pure white variety, very donble.........

1514 - - nan, f. pl, a dwarf variety, with double white tlowers; usefnt for bouquets.

\section{MAUIRANIYY.}

These superb climbers can not be too strongly recommended; they are particnlarly adapted for greenlionse or conservatory decoration, or for training on trellises in the flower garden; they will be loaded all the season with rich purple, white and rose forglove-shaped blossoms; the seed shonld be started in a lot-bed or greenhonsc, as without artiticial heat they will scarely thower the first season; half-liarly pereanials.

1520 Ia urandya Rarclayana, $v$ iolet; $10 \mathrm{ft} . \quad .10$

1521 - - alba, a protty white varicty; $10 \mathrm{tt} . \quad .10$

1522 - luceyana, rose, very showy; $10 \mathrm{ft} . \quad .10$

1525 - fine nixcd, from above varieties... . .10

MFSFIMIBIRYANTHFIMUAI.

A brilliant and profuse-flowering tribe of dwarfgrowing plants, (ffective in beds, edgings, rock. work, rustic baskets, or vases in warm, snnny situations; finc for pot culture.

1530 Mesembryantheuun capitatum, pale yellow; 3 f $\mathrm{ft}$.

- crystallinum (Ice Plant), spe No. 1265.

1532 - tricolor, rusc, purple center; li ft.

1533 - albur, white, purple center; $3_{4} \mathrm{ft}$. .05

1536 - fue nixed, all color's.............. .10

MOIJUFiI, I MIolueca I3alm).

A singular plint, with sinuare stems spreading and curling upwart like the arms of a candelalurnm, which culin tufts of bright leaves and tiny enps of pea.green color, reined with whitish green; with. in the calyx a button-sliaped bud appears, which unfolis into a flower formcal like a shell, of a white and purple color, very curious; hardy annual.

1538 Iolucella lavis (Shell Flower); $1 \mathrm{ft} .15$

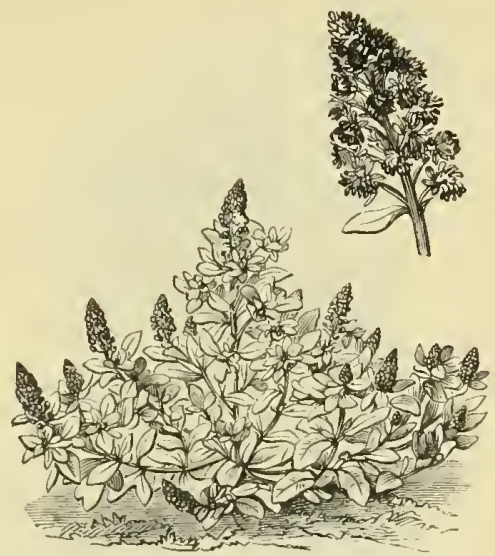

No. 1545.-Sweet Mignonette. No. MIGNONFTTE. Price. No. MIGNONHTTE. Price.

A well-known fragraut favorite, which produces a pleasing contrast to tho more sluwy occupants of the parterre; if well thimned out immediately the plants are largo enoltgh, they will grow sitronger, and prodnce larger spikes of blom ; hardy annual.

1540 Mignomette, Golden Queen, a tistinct and attractive variety, with large spikes of golden-yellow blossoms.

1541 - Miles's IIybrid spiral, a robust, profuse-bloming variety, and very fragrant; splenclid for pot culture.

1542 - Parsons's White, a distinct, telight. fully fragrant variety; lighly Iecommender 1543 - New (Niant, a recent introuluction of marked improvement, a rapid compact grower, yielding a profinsion of immense spikes of fragrant flowers; the best rariety for bee-keepers and floristis' nse

15.44 - pyramidal large-flowered, a rolust variety, of an oranre red color.........

1545 - - iweet, the old favorite.

1546 - The Prize, hirhly recommended ou afcomt of beauty of color, size of llower, and delicions tragrance .................... We will send one packet of eaell of the abore rarieties for

\section{IMUT,UES.}

A genus of cxtrentely handsome, profuse-flowering plants, witl singnlarly sliaped and brilliantly colorel flowers: splendid conservatory or sitting. room plants; half-lıardy perennial.

1550 Mimulus cardimalis, scarlet; $1 \mathrm{ft} \ldots . .10$ 1551 - naculosus, beantifully spotted; $1 \mathrm{ft}$. .10

1552 - duplex, domble, tigrer spotted..... 25

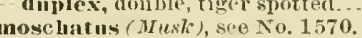

1554 - Roczlii, bright yellww, spotter with crimson, finc for lertaling; $1 \mathrm{ft} \ldots \ldots \ldots \ldots \ldots . .25$

1558 - choice mixed ..................... .25

NI ) MOIRI)ICA.

Trailing plants, witl curious and very ornamental foliage; the fruit is of a golden-yellow color, wartech, and when ripe, opens, disclosing its seerls and brilliant carmine interior. Planted on rockwork, stumms of trees, etc., and allowed to ramble, the effuet is very striking; half liarty anutuals. 1565 Momordica balsamina (Balsam

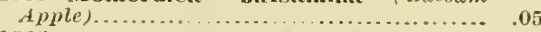
$1566^{\circ}$ - charuntia (Balsain Pear)........... 05

MOIRNING: GIORY.

(See Convolvulus Major, No8. 810 to 819.) 


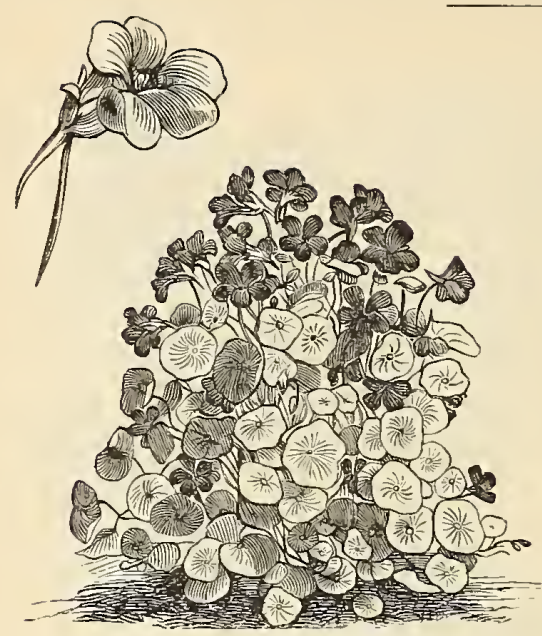

No. 1605.-Nasturtium, Dwarf.

No. MIUEIS PIANT.

Price.

This fragrant and universally favorite little plant is so well known, we need only remark that it is equally at homo in the sitting-room, greenhouse, or thower-garden; half-hards perennial.

1570 MIusk (Nimulus moschatus); $3_{4}^{3} \mathrm{ft} . . . . \$ 0.10$

MIYOSOTIS (Forget-me-not).

Charming little plants, vers popular, produeing their bcautiful star-like flowers in great profusion; invaluable for Spring garden deeoration; halflariy perennials.

1575 Myosotis alpestris nana alba, very dwarf, white; $1 / 4$ ft........................ 1576 - - cuerulea, bright blue; $1 / \mathrm{ft} \ldots .$. . 1577 - - rosea, thelieate rose; $\frac{1}{4} \mathrm{ft} . . . .$. 1578 - Azorica, blue, shaded purple; $1 \mathrm{ft} .$. . 1579 - - alba, pure white; $1 \mathrm{ft}$. ............ 1580 - dissitiflor, elear blue, Howers vely early, and continues long in bloom; $1 / 2 \mathrm{ft} .$. 1581 - palustris semperflorens, a heautiful azure blue, continues in hloom until frost; does well in moist and shady sitnations...... fine mixed, see No. 1034

\section{NASTUIRTIUM, DWARF} (Tropacolum manurn).

The dwarf improved varieties of Nasturtium are among the wost useful and beautiful of garden favorites, for bedding, massing, or rihboning; their elose, eompaet growth, rich colored flowcrs, and the freedom with whiel they bloom, all eombine to plaee them in the eategory of first-elass bedding plants; should be grown in rather poor soil; hard $y$ anuuals.

1590 Natsturtim, Tom Thumb Beanty, yellow, Huslied with vermilion.............

1591 - - corulea rosea, beautiful peaeh.

1592 - - - erimson......................... spotted mauve 1594 - - Golden Ii ing, goldeu vellow... 1595 - - King of Tow Thumbs, iutense searlet, bluish-green foliage

1596 - King Theodore, new rariety, dark green foliage, flowers almost blaek.......... 1597 - - pearl, creamy white.......... 1598 - - rose, very desirahle...........

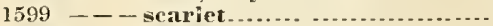

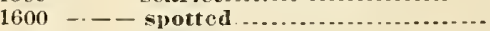

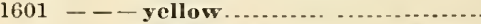

1605 - - - fine mixed, from ahove varieties 1606 - - Collection of 12 distinet colors.

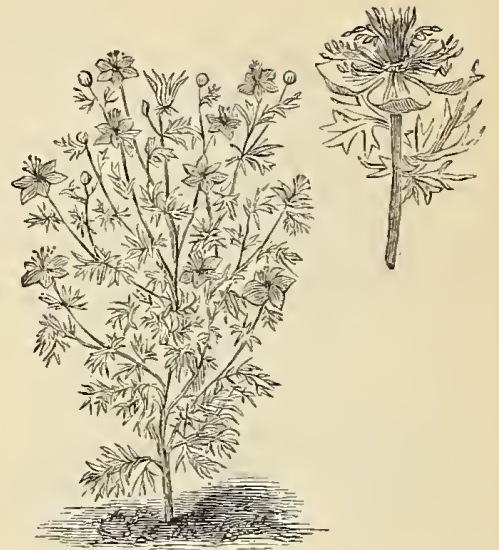

No. $1645 .-N i g e l l a$.

No.

\section{NASTURTIUA, TAII}

Price.

(Tropxolum MIajus).

Well-known, profuse-Howering plants, admirably adapted for roek-work, banks, eorering trellises, or rustie work; the seeds, if piekled foung, arean exeellent suustituto for capers; hardy annuals.

(See Tropoeolum for choicer varieties of Tall Nasturtiums.)

1610 Nasturtium, tall, erimson ; $6 \mathrm{ft} \ldots . . . \$ 0.05$

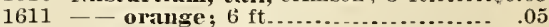

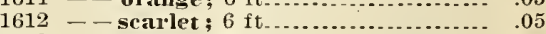

1613 - - spotted; $6 \mathrm{ft}-05$

1614 - - striped; $6 \mathrm{ft}-05$

1615 - yellow; $6 \mathrm{ft} \ldots \ldots \ldots \ldots . . .65$

1620 - - fine uixed, from above rarieties. .05

1621 - Collecrion of 12 distinet colors... $\quad .50$

\section{NFMIFSIA.}

One of the prettiest, freest blooming, and most in. teresting of anwual plants; adapted for heits, eig. ings, rock-work, or pot eulture; the growth is compaet, and the blossoms so mumerous as to entirely hide the foliage; half-hardy annual.

1625 Nemesia, tiuest mixed varieties; ${ }_{3 / 4}^{3} \mathrm{ft}_{-.} .05$

\section{NFMTOPHIA.}

This is perhaps the most eharming and useful genus of twarf-growing harily annuals ; all the varieties hare a neat, compaet, and nniform labit of growth, with shades and colors the most strikingly heautiful; to seenre the greatest perfeetion the plants should be thimner to four inches apart, and the plants will then present a dense mass of flow. ers; if the soil is too rieh, the flowers will be less ahundant; hardy annuals.

1630 Nemophila, best varieties mixed...... .05 1635 - Collection of 10 distinet varieties... .50

NIFREMIBFRGIA.

\section{Charming little plants, whieh flower profusely dur-} ing tho whole Summer; well adapted for hanginghaskets and edgings; iu fact, for this purpose it cannot be reeommended too highly; half-hardy perenuial.

1640 Nierembergia frutescens, white..... . .10 1641 - gracilis, slender, lilac, yellow eje... $\quad .10$

NIGFII.A (Love in a Mist, or Devil in the Bush).

Compact.growing, free-flowering plants, with eurious-looking flowers and sech-pods. From the exhas received its singular names; hardy annuals.

1645 Nigella, dwarf, mixed; $3 / 4 \mathrm{ft} . . . . . . . . .0 .05$

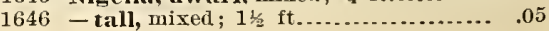
traordinary appearanee of the stamens this genus 


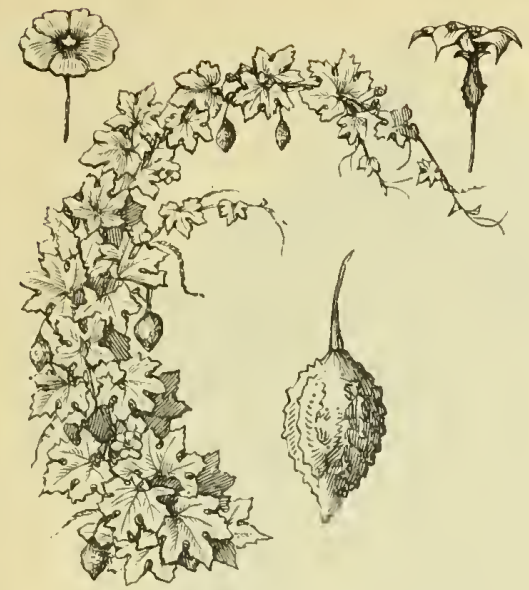

No. 1565.-Momordica balsamina.

No.

NOIANA.

Price.

An extrcmcly beantiful, tree-flowering genus of trailing plants, the flowers resembliug the Convolvulus Triculor, bnt softer in color, while some are beautifully penciled; fine for rock.work, lang. ing-baskets, oli stmmps, etc.; hardy annnals.

1652 Nolana atriplicifolin, blue, violet.

white and yellow; $1 / 2 \mathrm{ft} . \ldots . . . . . . . . . . . . . . \$ 0.05$ 1653 - alba, white, yellow center; $2 / 2 \mathrm{ft.} .05$

\section{NYCTERINIA.}

Teat, compact littlc plants, covered with pretty, sweet-scented, star-shaped flowers, valnable for edgings, rockeries, stum js, or small beds; they blossom very early in Spring, and lemain in bloom the whole season; half-hardy perennials.

1658 Nycterinia capelsis, white, with bright yellow center; $1 / 3 \mathrm{ft} . . . . . . . . . . . . .$.

\section{OBBELISCARIA.}

This is a family of rather coarse-luoking plants, but at a distance are showy and effective. It is allied to and rery nunch resembles the well.known wild flower of our meadows, Rudbickic lirta or Cone Flower. The blossoms are rich-colored, and have curious acorn-like centers; half-hardy pereunial.

1659 Obeliscaria pnleherrima, rich crim. son, tipued with yellow ; $2 \mathrm{ft}$................

.05

\section{OENOTHERA.}

Bcantiful, frce-blooming plants of majestic labit, witl large, silvery wlijte, goldcu-yellow, and crimson spotted flowers; sow tho anmul varteties in tho open ground in May, where tliey are intended to flower, and thin ont when they como np; the perennial varieties are best sown in boxes, and afterward transplanted; annuals and perennials. 1660 Enothera, annual varieties, mixed. .10 1661 - perenuial varieties, mixed ........ .10

$$
\text { OXATIS. }
$$

A splendid class of plants, with brilliantly colored Howers and dark foliage, suitable eitler for greenlouse decoration, rock-work, or rustic baskets ont-of doors; half-laardy peremnials.

1670 Oxalis rosen, rosc-colosed, blooms abmulantly; 桨 $\mathrm{ft}$.

1671 - wopeoloides, deep yellow, brow leaves; a very interesting variety ; $1 / 2 \mathrm{ft} . . .$.

OXYUIRA.

A showy plant, with beantifully fringed flowcrs : prodnced in great abundance; liardy annual. 1675 Oxyura ehrysanthemoides, golden yellow, edged with white.

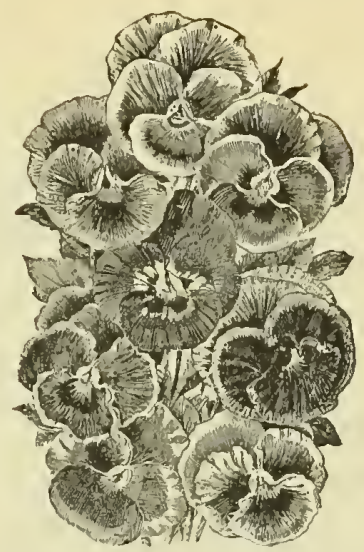

No. 1681.-New German Pansy.

No. PANEI (I Ieart's-ease). Price. This lovely flower, a favolite with every one, is too well known to necd any description. Nothing can be more effective, whether. grown in beds, ribbons, groups, of interspersed among other plants in the border. It is also admirably adapted for pot. culture, for tho dicoration of the cunservatory during the Winter aud spring montlss. The fol. lowing collcction cubraces some of the finest varieties ever oftered; lialy perenuials.

1679 Pansy, Belgian $01^{*}$ fancy, large flow. ers, beantifnlly bloteled; very attractive... \$0.50 1680 - English show. The flowers of this class are one-colosed, and embracemany rich

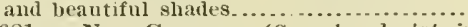
1681 - New Geimau. (See colored plate in
Catclogue for 1882.) Fo strain of this favorite flower erer cujoyed sucl populatity. or gave such general satisfuction, as this lias done. It embraces eiglit of the most strikingly leautiful colors; mixed......... .50

1682 - Collection of the 8 varieties...... 3.00

1683 - azure blue, very finc ............. 15

1681 - bronze, revilish-biown flowers...... .15

1685 - Cliveden, yellow, purple, magpie, and white, mixed; best for bedding........ .15

1686 - Emperor Willian, brilliant blue, witl well.detimed purple cye; splendid...

1687 - Faust $01^{\circ}$ Kiug of the Blacks, lensest black Pansy known ............... 15

1688 - gold margiued, very showy ........ .15

1689 - goldeu yellow, beautiful ............... .15

1690 - malogauy-color, peculiar shade... .15

1691 - maxima quadricolor, a new and beautiful variety, the remarkable blending of tho peculiar color's of which cannot be de. srifbed; milst bo seen to be appreciated....

1692 - Odier, or five spotted, a distinctly blotches varicty of great bcanty. . .........

1693 - Snow Qneen, a charming, delicate satiny wlite, slightly tinged witl yellow to. ward the center; splendid bouquet variety.. 1694 - striped or variegated, very sliowy. 1695 -.. white, appropriate for cemeteries.. 1700 - choice mixed, from above varieties. 1702 - good mixed . Collection of 12 distinet varietics ... $\quad .75$

\section{PASAIFIORA OR PASSION} IIOWH:R.

A genus of magniticelut ornamental twiners, whose flowers are at once interestiug and beantiful.

1710 Passiflora cerulea, sky blue........

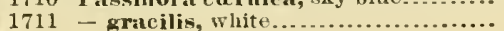

.50 


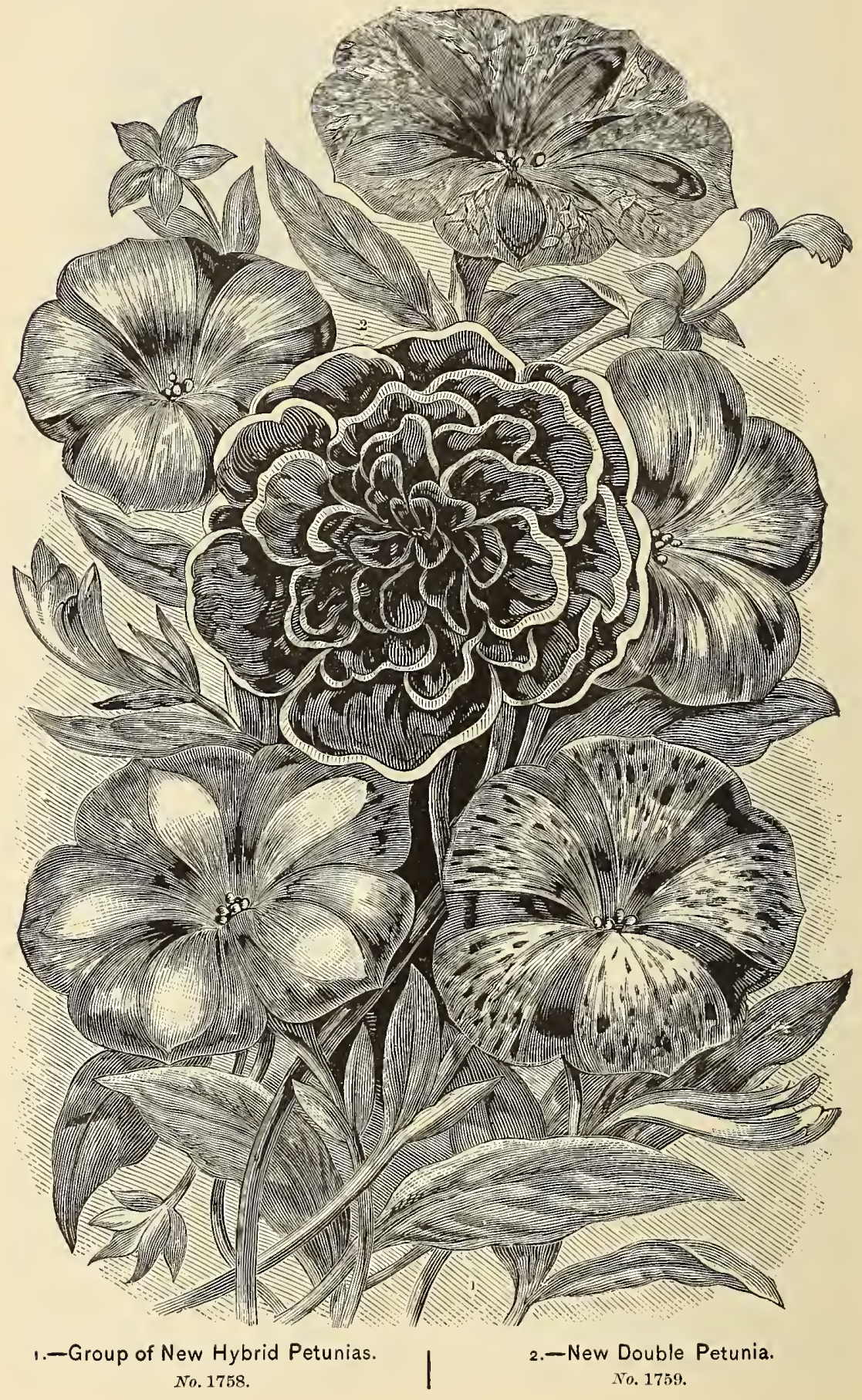




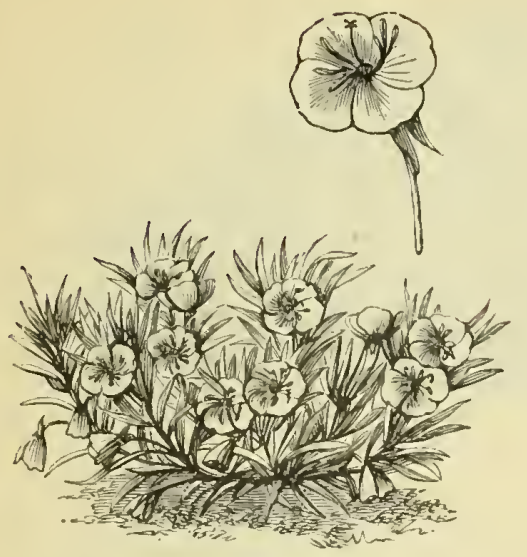

No. $1660 .-$ Enothera.

No.

$$
\text { PFAN, NTWFE' }
$$

Price.

Exceedingly na:ful, well-known, freo-flowering, lighly ormamental plants, flowrishing in any open situation, and when sown on rich soil, and mulehed during dry, lot weather, will attain a consil erable height; if not allowerl to ripen seed they will continue blooming till destroyal ly frost liardy annuals.

1715 Peas, swect, black invincible, the darkest varicty grown

1716 - Butrerfly, whito gromnd, rlelieate ly laced witl lavender bluc; vey fragrant and valuable for bouguets

1717 - Crown Prineess of Prussia, a delicate bluslı: very fine.

1718 - painted lady, rose amd white....

1719 - - purple

1720 - - searlet inviucible, rich searlet.

1721 - striped

1722 - - Violet Queen, a charming variety

ranging from de(e) mauve to light violet.

1723 - white

1724 - mixed, from above varieties.

1730 - Collection of 10 distinet varieties.

- everlasting (see No. 1345.)

PFINATEHMON.

Plants of a liglily ormameutal cliaracter, graceful in luabit, and remarkable for the abundance and beauty of their individnal blossoms; in bloom from July to Octoler; lialf-luarly perennials. 1740 Peustemon, ehoice mixed.............

\section{I'Fis I I, I, A.}

Amongst ornamental-foliaged plants for flower-grarden decoration the Perilla clains attention; its foliago is of a deep nulberry or blackisl purple, and forms a fine contrast to the silvery foliage of Cineraria Haritima, (r the lively green of other plants; half-lıarly anmul.

1750 Perilla Naukiurusis, leares deep mul. berry or purplish blatck: $11 \% \mathrm{ft}$

1751 - - atropurpurea foliis lacinintis, the foliage recularly fringed and toothesl. whicls gives the plant anexcedingly attract ive appearanee

\section{I'I I C:IEI,I A.}

Pretty annuals, of the easiest culture in the open ground. They have branched tufted stemis, in. cised leaves, and slikikes of blue flowers, which, when in bud, are cireinate, like those ot tho lieliotrope. Tho rariety we offer is cultivated for loces, and is excellent for that purpose.

1753 Plancelia tanactifolia, lilac; $2 \mathrm{ft} \ldots . .10$

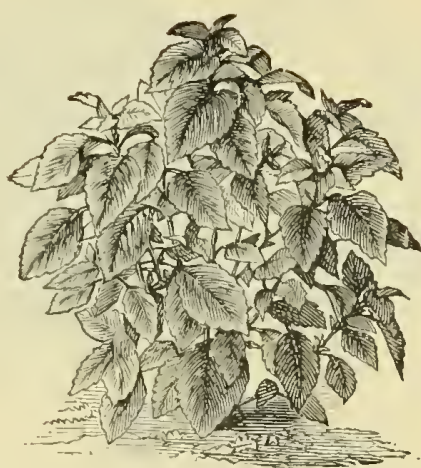

No. 1750.-Perilla Nankinensis.

Nio I'ISTUNIA. Price.

A highly ormamentil and pofnse-1lowering, caslly cultivated garden favorite: effeetive and beauti. ful for the decoration of the greenhouso and sitting-room window, whilo for planting out in beds or mixed borlers they are unsurpissed. The brilliancy and variety of its colors, combined witl the (Anration of its blonming period, reuler it invalu. alole; loth-lanty peredulals.

1755 Petunia, Comutesin of Ellesmere, rose, witls white throat, very petty ..............\$0.10

1756 - finged, licli colors, finely fringed.. .25

1757 - greell-edged, various sliales; bor. dicred with a distinct belt of green...........

1758 - lyybrida grandiflora, froul a celebrated Gorman eollection, flower's beautifully blotelied, narbled, fringed, and rariegated, quality unsurpassed.

1759 - new double, this strain, personally selceted in Enrope, continues to maintain its reputation, and is olstained from the same source, It is savid from carefully fortilized tlowels, and will produce a large pereentage of donbles, whilo snel plants as are single are marvels of beauty in colors nuld markings..

1760 - new double finged, for rielmess and delicary of tint this variety is uasur. passed, and yiclds at least 25 per eent. of plants that never fail to elicit themost un. yualitied praise

1761 - new dwarf inimitable, too much cannot be said in favor of this splendial owarf variety, sclibom excecting six inehes either in leiglit or diameter; plants lecome literally coverel with regularly strijed flowers, and are exceclingly effeetive................. 1762 - nyctaginiflora, white, fragrant. 1763 - robusta flore pleno, of compact, symuetricinl growth, and ('mbraeing a wide range of 1 ich colors; so freely are the flow. "r's produced, tlist a fully developed plant has all the apluearance of a narle bouguet ... 1764 - striped, large flowers, beautifully

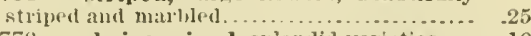
1770 - eloice nixed, splendid rarieties... . .10 1771 . Colleetion of 12 single varieties.... I.0n 1772 - -6 double varicties .......... .75

I'I I AKI: ( I, ITS.

1 beat iful conservatory elimly. flowering in mag. nificent clusters, modnciner a fine eflect.

1775 Plaseolus earacalla, lilac and white, very handsome. .............................. 


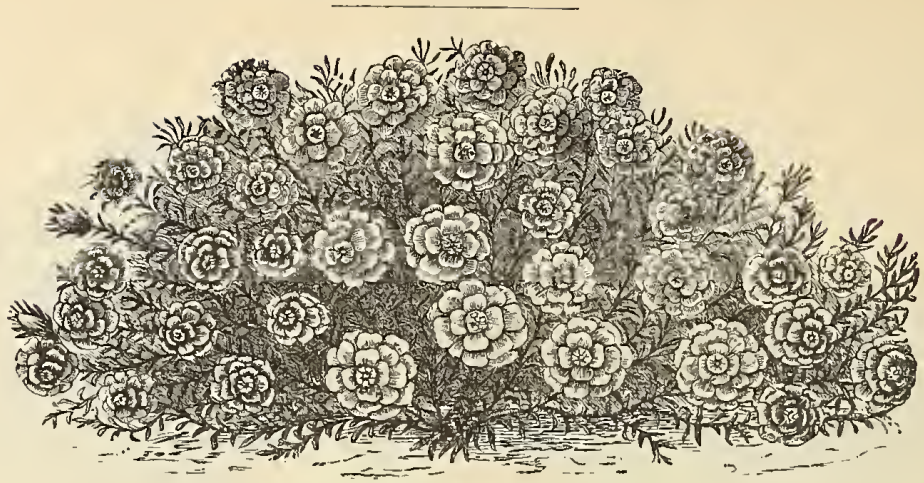

No, 1860.--Portulaca grandifiora, fl. pl.

No: PIIJX DIRUMMONDY Price.

These flowers are of extreme beauty, and are greatly admired by all; their long duration in bloom, combined with their almost mnequaled richness of color, renders them of invaluable servico iu the general flower gardon, and a finer sight tlian a bed of Phlox Drummondii is rarely to bo seen. Halt hardy annuals.

1778 Plılox Drummondii alba, wlito; $1 \mathrm{ft} . \$ 0.10$ 1779 - _ - oculata, white, with crimson eye; $1 \mathrm{ft}$

1780 - - coccinea, deep scarlet ift

1781 - Heynholdi, vermilion scarlet; 1 ft. .25

1782 - - cardiualis, intenso scarlet; very beautiful; $1 \mathrm{ft}$

1783 - Isabellina, primiose yellow; $1 \mathrm{ft} . \quad .10$

1784 - - marmorata violacea, violet mar-

bled; very desirable; $1 \mathrm{ft} . . . . . . . . . . . . . . . . .$.

1785 - - purpurea, deep purplo; $1 \mathrm{ft}$..... .10

1786 - Queen Victoria, violet, with a

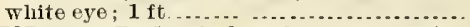

1787 - Redowitsliy, deep rose, striped with white; $1 \mathrm{ft} .$.

1788 - rosea, bright rose; $1 \mathrm{ft} \ldots . . . . .$.

1789 - - variabilis, slate blue, marbled; $1 \mathrm{ft}$

1790 - - grandiflora, an improved variety,

with unusually large flowers of great substance; mixed colors. .......................

1799 - - fine mixed....................

1800 - Collection of 12 distinct varieties.

PII,OX, PFRFNNIAI.

One of the finest of lierbaceons plants, for berls or mixed borters. The seed offered is saved from the newest and best varieties; hardy perennials.

1801 Phlox, peremial, finest lybrid...... .25

1802 - fine mixed

.10

PICOTFE PINIS.

Favorito and well-kuown plants of great beanty, combining with the most perfect form the richest colors. They havo a delieate perfume, and are easily cultivated ; lalt'-harly perennial.

1810 Picotee Piuk, savel from the most desirablo varieties; 1 1/ ft.................

1811 - German unixed, double ............ .25

1812 - good inixed, fine borter varieties.. . .10

PINIX (Diantluus Plumarius, fl. pl.). A well-kuown and highly valned plant, remarkable for its great beauty, easy culture, and accommo dating labit, growing freely, and flowering profusely, eitlier in pots, in the greenhouse, or in the open boriler; hardy peronnial.

1815 Pink (Florists' or Paisley), from the finest named varieties. Flowers with white grouud, beautifully blotched and edged with different shades of purple.

1816 - Brown's mule, a very free-flowering

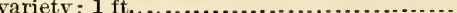

No. POT,YANTIYUS.

Price. Splendid spring-flowering plants, either for pot. culture or the open border; hardy percnnials. 1825 Polyanthus mixed (Primula elatior),

fine boriler varieties ; $3 / \mathrm{ft} \ldots \ldots \ldots . . . . .10$ 1826 - splendid mixed, extra clioice; $3 / 5 \mathrm{ft}$. $\quad .25$ POPPY

A genus of slowy, free-flowering plants, producing a rich and effectivedisplay in large mixed borters, or select plantations.

$$
\text { ANNUAL VARIETIES. }
$$

1830 Poppy, camation, double mixed; $2 \mathrm{ft}$. $\quad .05$ 1831 - French, or Lamunculus, double; $2 \mathrm{ft}$. $\quad .05$

1832 - preony-flowered, (louble; $2 \mathrm{ft} \ldots . . .05$

1833 - scarlet, singlo; $2 \mathrm{ft} \ldots \ldots . . . . . . . .05$

1834 - sommiferum (opium), white....... .05

1835 - umbrosmm, immensc flowers of a bril. liant crimson, witl a large black blotell at the base of each petal; very showy; $1 \frac{1 / 2}{\mathrm{ft}}$. $\quad .15$ 1839 - Collection of 12 double varieties .... $\quad .50$ PERENNIAL VARIETIES.

1840 Poppy, bracteatum, orange crimson; very large and handsome ............... .10

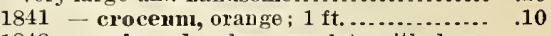
1842 - orieutale, leep scarlet, with large

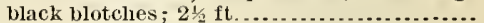

\section{PORTUI,ACA}

For brilliant, beautiful, and delicate colors, this charming genus stands unrivaled, and whether in baskets, small beds, edgings, or rock-work, its large, spleudit flowers, produced in the greatest profusion, are extremely effective; succeeds best iu light, gravelly soils, or mixed with lime rub. bish; half-hardy annnals.

1845 Portulaca alba, pure white; $1 / 2 \mathrm{ft} \ldots . . \quad .05$

1846 - aurea, gollen yellow; $1 / 2 \mathrm{ft} . \ldots . \ldots . .05$

1847 - caryoplyylloides, finely striped; $1 / 2 \mathrm{ft}$. .05

1848 - purpurea, purple; 1/2 ft.......... .05

1849 - rosea, delicate 10 se; $1 / 2 \mathrm{ft}_{\ldots} \ldots \ldots . . . . .05$

1850 — scarlet, very brilliant ; $1 / 2 \mathrm{ft} \ldots . . . . . .05$

1851 - splendens, rich crimson; $1 / 2 \mathrm{ft} \ldots \ldots \ldots . .05$

1859 - mixed, from abovo............... .05

1860 - grandiflora, fl. pl. These seeds have

been selected from largo double flowers of the most beautiful and brilliant colors, and will produce a large proportion of double flowers ot uusurpassed beauty ; mixod............... 1864 - Collection of 8 ilouljle varieties...... POTFNTIIIAA.

Handsome flowering lierluaceous plants, exceedingly useful and ornameutal in mixed flower borders, lasting a long time in bloom; hardy perenuials.

.251865 Potentilla, double, choice varieties,

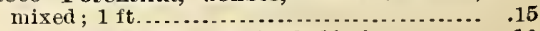
1866 -single, finest mixed; $1 \frac{1 / 2 \mathrm{ft} \ldots \ldots . . . .}{10}$ 


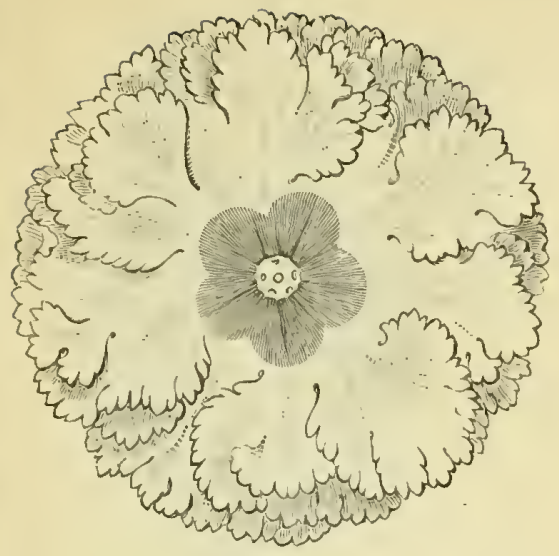

No. $1879 .-$ Primula alba magnifica.

No.

DIRIMIRONF.

One of the most useful aul earliest sipring flowt wo have; the well-known yellow variety being unexcelled for brilliant effect, whetler ('mployed to brigliten the flower gardeu, decorate rockeries, or otleer semi-wild lieations; latriy perennial.

1870 Primrose, choice mixed ; ${ }_{4}^{3} \mathrm{ft} \ldots . . . . .50 .25$

\section{PRIMIUIAA.}

A cliarming, profuse-flowering plant, indispensable for WWinter and spring decoration in the conservatory or sittiug.room; the seed we offer has been saved from flowers remarkable for their size, color, and perfect form, and is of mosurpassed quality ; greenhonse pereunials.

1874 Primuln cortusoides, roso lilac; a liardy variety; ${ }_{4}$ ft

1875 - Japonicn, a havily Jajanese variety, of a splendicl magenta colo1 ; 1 ts ft.

1878 - siueusis fimbriata alba, pure white, fringed flowers.

$1879-\ldots$ alba magnifica, a novelty of real merit ; foliage deeply budeuted; the flow. ers, which are of immensi size and great substance, are m we white, with a citron eye, aud mot beautifully fringed.

1880 - - marginata, lilic, bordered with white, one of the best

1881 - - rosea, beautiful rose

1884 - - mixed, from fringed rarieties.

1885 - f flicitolia alba, beantiful fern leaved foliage, white...

1886 _- rosen, fern-leaved, crimson lake, very showy

1887 - _ - sfiain, foru-leaved, striped. 1890 _ _ mixed, from ferm-leaved varieties of brightest colors................. .50

1891 - - alba fl. pl., clouble, white ..... 1.00

1892 - - rosen f. pl., double, rose ...... 1.00 1893 - _ scarlet, duuble, very brilliaut.. 1.00 1896 - Collection of 12 choice varicties.... 1.50

\section{TXIRETHAUMT.}

Handsome, freeflowering, lighly ormameutal plants, producing a fine effect in the mixed thower and shrubbery burlers; hardy jerennials.

1900 Pyrethrum atrosanguinemm, tark red, shows; 2 tt...

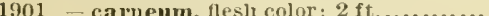

1902 - loubleg, white. 10

1903 - Golden Fentuer (l'arthenifolium. aureum), gollen foliage; $1 \mathrm{ft}$.

1904 - hybrid fl. pl., domble varietses,mixed

1905 - roseum, jight rerl ; $2 \mathrm{ft}$............ .10

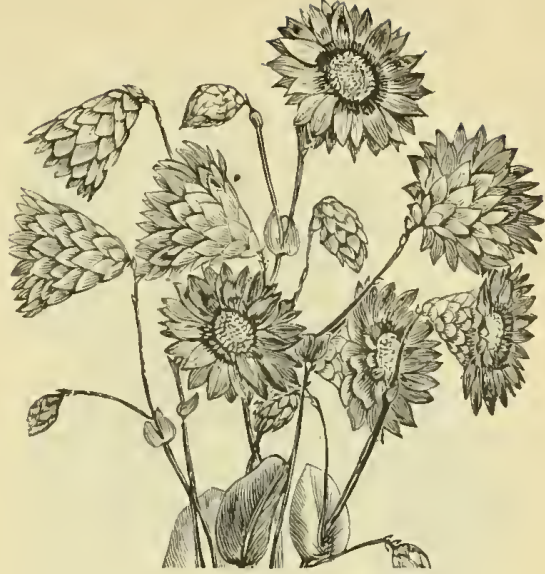

No. Ig16.-Rhodanthe maculata.

V.. IR1IOIJANTHI: Price.

A well-known everlasting; valualule for the decoration of the conscrvatury and flower garlen; fine for bodding or ribboning; lualf-hardy annuals.

1915 Rhodanthe atrosauguimen, purplo

crimson; $1 \mathrm{ft} \ldots \ldots \ldots \ldots \ldots \ldots . \ldots \ldots . . \ldots . . \$ 0.15$

1916 - maculata, rosy purple, with crimson

center : $1 \frac{1}{3} \mathrm{ft} . . . . . . .15$

1917 - nlbn, white, rery slowy $; 1 \mathrm{ft} \ldots . .15$

1918 - manglesii, briglt rose ; 1 ft. . ....... .10

1919 - - fl. pl., double, bright rose........ 25

1920 - nimor compactn, plants globular,

blossoms freely, fine for pot-culture........ .25

1925 - nixed, from abov' $\ldots \ldots \ldots \ldots \ldots \ldots \ldots . .10$

TRIODODENDIRON.

Well-known and magnificent flee-flowering ever. sreen slumbs, which should occupy a prominent place in every garden.

1930) IR hododendron ponticum, mixed......

.25

IRICINUS-

I magnificent and highly ornamental genus; the picturcsine foliage and stately growth, combined with brilliant-colorer fruit of the giant varieties, impart to select plantations, slirnbbery, and mixed flower borders quite an oriental aspect. Growu as single specimens on lawus and pleasmre-grounds, they form a striking foature; lalf-liarly annuals. 1935 Ricinus Africanuw albidus, new, white

fruited, stem and leaves silvery ; $8 \mathrm{ft} \ldots . . . . \quad .10$

1936 - Borboniensis arboreus, very large and showy foliage; $15 \mathrm{tt} \ldots \ldots . . . \ldots \ldots \ldots . .10$ 1937 - Brnziliensis, dark green fruit; $10 \mathrm{ft} .10$ 1938 - conmumis (Castor Oil Plant); $6 \mathrm{ft} . . \quad 05$ 1939 - gigantens, large and slowy; $10 \mathrm{ft}$. .10 1940 - macrocurpus, light green ; $8 \mathrm{ft} \ldots . .10$

1941 - nams, dwarf, for gromping; 3 ft. .10

1912 sangnisens (Obermanii), splendil

red fruit in clusters, very ornamental, proincing a grand effect; $10 \mathrm{ft}$.

1943 - species from Philippiues, gigantic foliage: $10 \mathrm{ft}$.

1950 fine uly

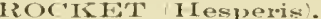

Vory pleasing early spring flowering, profuse-bloom ing plants, with clelicionsly fragrant flowers, nrowing frcely in any liglt rich soil ; nnlike most plants, they do better if transplanted every second season; larily peremials.

1955 Rocket, wweet, murple; $1 \frac{1}{2} \mathrm{ft} \ldots . . . . .05$

1956 - - whice; 1 h $\mathrm{ft} \ldots \ldots \ldots \ldots \ldots \ldots . .05$

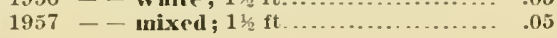




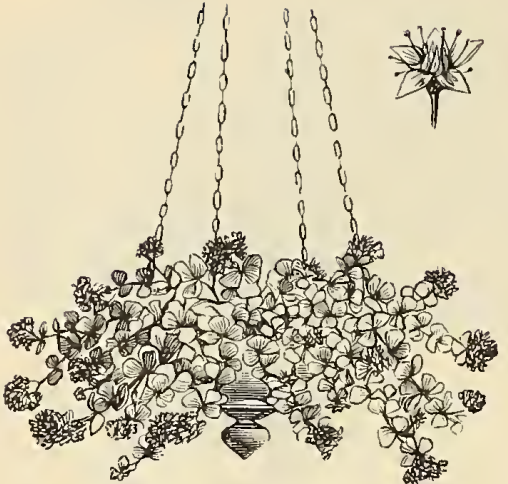

No. $1138 .-$ Sedum.

No.

TOSE.

Price.

Too wcll known to require any description ; the culture of the rose from seed is very simple, gener ally rewarding the amateur with flowers tho second year.

1960 Rose, saved from choice varicties. . . . \$ \$ 0.25

$$
\text { SATPIGTOSSIS. }
$$

Ornamental and useful plants for autumn decora tion; their euriously penciled and marbled fun nel-shaped flowers produce a fino effect in berls, borklers, edgings, and ribbons; half-hardy annuals.

1965 :ăalpiglossis, choice mixed; tall; 2 ft. .10 1966 _ _ _ dwarf varieties; $1 \mathrm{ft} . . . . . .6 .10$

\section{SATVIA.}

Magnificent bedding-plants, loaded with spikes of scarket flowers, from July till Oetober. HALF-ILARDY ANNUAL VARIETIES.

1970 Salvia coccinea, scarlet : $2 \mathrm{ft}$

1971 - - mang e oimpacta searlet; 3 ft -.10

1972 - - punicea, new dwarf, scarlet; $1 \mathrm{fi} . \quad .10$

1973 - Romeriana, crimson, dwarf; 1 ft.. .10 HALF-HALDY IEREXXIAL VARIETIES.

1974 Salvia amabilis, lavender blue; $2 \mathrm{ft}$

1975 - argentea, silvery foliage; $3 \mathrm{ft} \ldots . .$.

1976 - paters, splendid deep blue; $3 \mathrm{ft}$.... .15

1977 - splendens, bright scarlet; $2 \mathrm{ft} \ldots . . . .15$

\section{SANVITAIIA}

Pretty, thwarf-growing, free-flowering plauts, lblooming all the season; hardy annuals.

1985 Sanvitalia procumbens, rich brown and yellow; i, $\mathrm{ft}$

1986 - - fl. pl., a doublo variety of abovo, a profuse bloomer. ..............................

\section{SAPONARIA.}

Charming littlo plauts, flowering all tho season splendid for beds or ribbon borters; half-hardy annuals.

1990 Saponaria Calabrica, deep piuk; 1/2 ft. .05

1991 - - alba, very pretty; to ft.......... .05

1292 - ocymoides, pink; hardy perenuial.. .10

SCABIOSA OIR MOUIRNING IBIRIIF:

Handsome showy plants for mixed borter's ; flowers beantifully varjegated; haldy perennials.

1995 Scabiosn candidissima plena, double, whito ; usefnl for 1lorists; $1 \mathrm{ft}$.

1996 - najor atropurpurea, velvety dark priple; 2 it

1997 - uana, fl. pl. doublo; brilliant color's ;

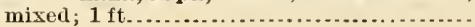

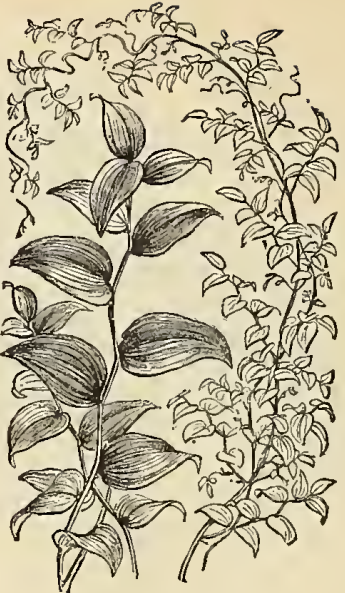

No. 2040.-Smilax.

No. SCHIZANTTIUS. Price.

No. SCHIZANTITUS. Price.

Few plants aro more attractivo than these when well grown, whether in pots or in the border ; they are of a wranching, elegant havit, well covered with peculiar-shaped flowers; half-hardy annuals. 2000 Schizanthns, mixed, best varieties....\$0.10

SHDUAX (Stonecrop).

Pretty little plants, growing freely on rock or rustic work, also on ornamental mounds, cte., where they flower in great profusion; hardy annuals.

2010 Sedum coruleum, blue; if $\mathrm{ft} . \ldots . \ldots . .10$ 2011 - fine mixed....................... .20

STNSITIVF TIANT (Mimosa).

Very curious and iutercsting plants, their leares closing if toucherl or shaken; half-hardy annuals. 2025 Sensitive Plant, pinkish white; $1 \frac{1}{1 / 2} \mathrm{ft} . \quad 05$

\section{SIIANE: OR CATCHTII.}

Ornawental, free-flowcling plants, with bright and beautifully colored flowers; hatiy annuals.

2030 Silene penilula, rosy purple........ . 05

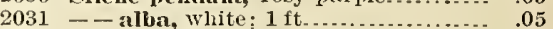

2032 - - ruberrima, rosy lilac, dark foliago .05

2033 - pseuda arocion, rosy pink; $1 \mathrm{ft} \ldots . . \quad .05$

2034 - Schafta, hilac ; harly perennial; $1 / 2 \mathrm{ft} . \quad .05$

- fine mixed varieties (see $N o, 655)$.

\section{SMIIIAK.}

A beautiful Winter climbing plant, adapted to the conservatory. Nothing can excel this jlant in beanty of foliage aud orange frastanco of tho flower. It is extensively used for bouinets and floral itecorations of every description.

2040 Smilax (strong roots, 25c, each) ....... . 20

\section{SOIANUMA.}

A very elegant, higlly ornamental, and interesting renus of fruit-bearing plants; some of the varie. ties being singularly grotesquo in fruit and foliage, whilo others aro exceedingly handsome and attractive; lualf-harly aunuals.

2044 Solanum capsicastrum (Jerusalem cherry), covered all Winter with a profusion

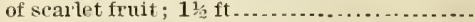

2015 - ciliatum, spiny, ornamental leaves, and scarlet berries, Tho fruit resembles a plum in shapo and size: color bright scarlet 2016 - Warscewiczioides, fine foliage plant, with a rolust growth, ormanueutal fruit....

\section{SPIIENOG YNE.}

05 A free-flowering plant, from South Aluerica; useful for beds, borters, or eflgings; hardy annual.

2055 Spheuoryne speciosa, yellow; $1 \mathrm{ft} \ldots . .05$ 


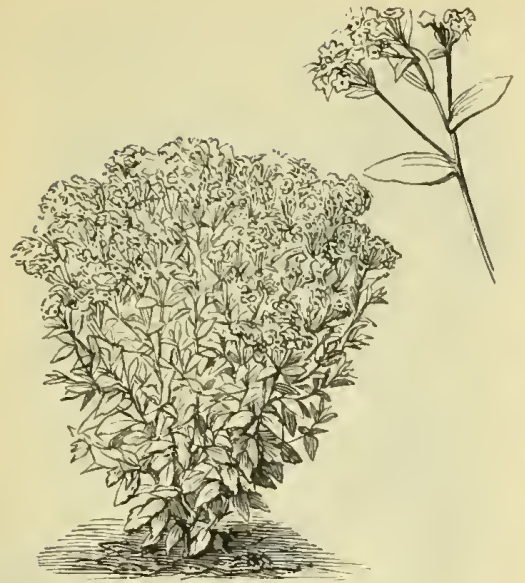

No. $2076 .-$ Stevia purpurea.

No.

SIPIRAC: ITAA.

Price.

A elarming plant, with Amaranthus-like flowers: extremely graceful and beantiful; very effeetive as an edging, or for rock-work; hardy is rennial. 2060 Sipracuea umbellata, wlite, sliaded

and spotted purple; $3_{4} \mathrm{ft} \ldots . . . . . . . . . . . . .80 .25$

\section{STATICF.}

Exeedingly interesting plints, of easy enlture Tlsey are all very frec-flowering, and remain a long time in bloom : the flowers are valuable for winter bonquets; half-hardy and hardy perennials. 2065 -itatiec Bonduebli,golden-yellow; $1 \frac{1}{1} \mathrm{ft}$.10) 2066 -ineana hybrida, mixed eolors; $1 \mathrm{ft}, .10$

2067 - sinuata, purple and white; $1 \mathrm{ft} . . . . .10$ 2068 - spieatn, emerald-green foliage, rosy. pink flowers ; $1 \mathrm{ft}$...........................

$$
\text { STITIA. }
$$

A nseful plant, eitler for potenlture or the border lialf-hardy perennial.

$207 \overline{5}$ Stevia Liudleyana, white............. 10

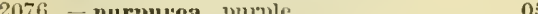

$$
\text { STOCOES. }
$$

The Stoek Gillyflower is one of the most popular, beautiful, and important of our garden farorites. aud whether for beldine, massing, edcring, vilyboning, or pot culture, it is unsurpassed ritlier for brillianey and diversity of color, or profusion and duration of bloom.

$$
\text { ANNUAT VARIETIES. }
$$

2085 Stock, Geruan dwaif, ten week, briglitest color's mixed : $1 \frac{1}{4} \mathrm{ft}$............. 2086 - - large-flowering, bright erim. son: 1 \& $\mathrm{ft}$.

2087 - - ealnat.

2088 - - pure white; 1 is ft...........

2092 - - large-flowerius, mally varie ties mixed, extra fin.

2093 - - Collection of 12 distinet eolors 2094 - - pyramidal, splendid colors mixed

2095 - - tree, or giant, many eolor: mixcrl.

$209 i 3$ - - wall - flower - leaved pure white, patral tine, very alesirable for bon-

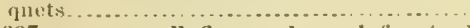
2097 - - wall-flower-lenved, fint:st eolor's mixed .......

2038 - - Collection of 6 distinct colors, wall-flower-leaved...

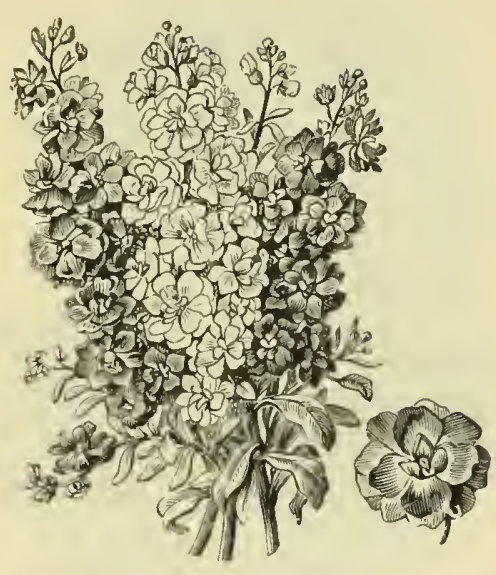

No. 2092.-German Ten Week Stock, Large-Flowering.

No.

STOOILE--Cont'd. Price

IBIENTIAT AND PEREXIAL VARIETIES.

Intermediate stoeks are prized on aceount of their flowering late in Antumn; also as pot plants for early spring blooming, for which purpose sow the secrl in July or Aurust.

2099 Fitock, internediate, purple; $1 \mathrm{ft} \ldots \$ 0.15$

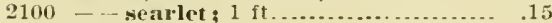

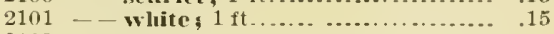

2102 - wall-flower-leaved, snow.white,

a great improtement in this class, bearing

immense pure white flowers............. .25

2103 - Collection of 8 ilistinet eolors..... . 60

This section may be treated in the same manner as

the Intermediate; and wili last screral years, if proteeter from the frost. The Brompton is a biennial of branching liabit, producing a grantl dis. play when in bloom.

2104 Stock, Brompton, mirple; $2 \mathrm{ft} . . . . . .15$

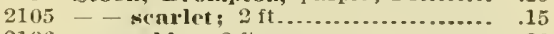

2106 - - wlite; $2 \mathrm{ft} . \ldots \ldots \ldots \ldots \ldots \ldots \ldots . .20$

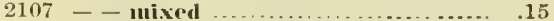

2108 - Emperor, or perpetual, new large.

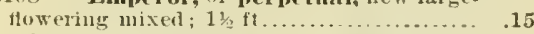

2109 - Collection of 6 distinct colors... . .50

2110 - French Wiuter, wr Cocardeau, a beantiful variety for pot-culture, fino mixed

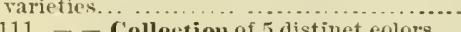

2111 - Hatdy's All the Year Round. 2112 - Hatdy All the Year Round. wlite flowers from Jamnary to Docember. The plants frow abont 12 inches higll, and if plenty of room is given, 3 foet thromgh, and will produce lumble'ds of bloous, fully 75 per cent. of whith will be double.

SITISTAN ('entaruea MIoschata). swert-sented, profuse-flow rering plants, veryeffeet. ive in mixed or slivblory borlers: prodice a very show and striking effect; the flowers cmit a diclicate homey prime, and are nmeh prized for bouquets; srow frecty in rich soil: ilarkly nituluals

2115 fultan, wweet, purple; $1 \frac{1}{2} \mathrm{ft} \ldots \ldots \ldots . .05$

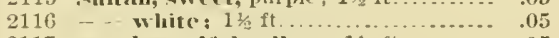

2117 beautiful yellow; 1 1\% ft........ .05

$$
\text { SUNTIOVITIR. }
$$

(sice Irelianthus, Nos. 119 s to 1204.) 


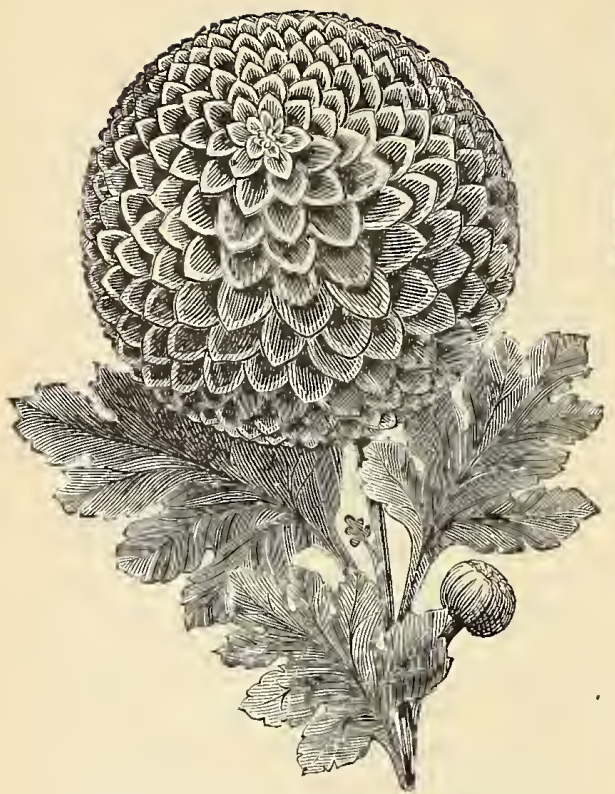

No. 725 -Chrysanthemum Indicum.

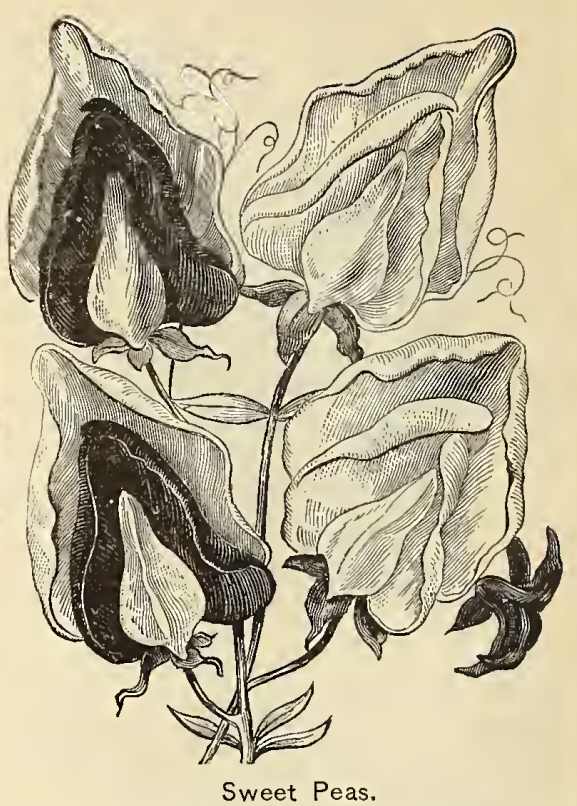

No. 1716-Butterfly. No. 1722. - Violet Queen.

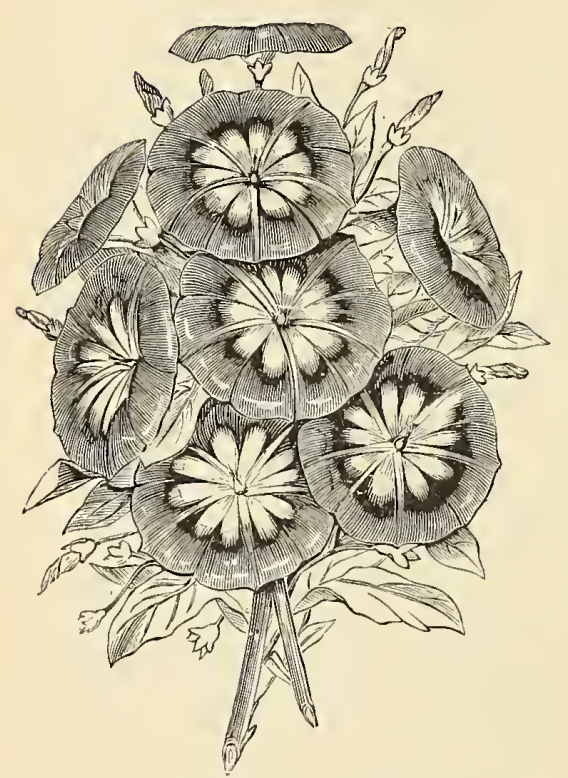

No. 820.--Convolvulus tricolor, New Crimson Violet.

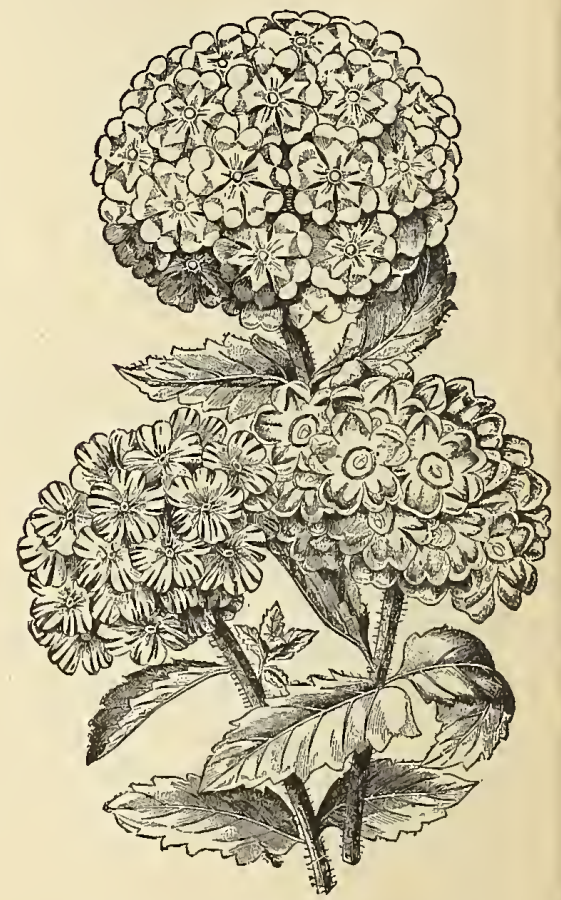

No. 2220.-Verbena, choice mixed. 


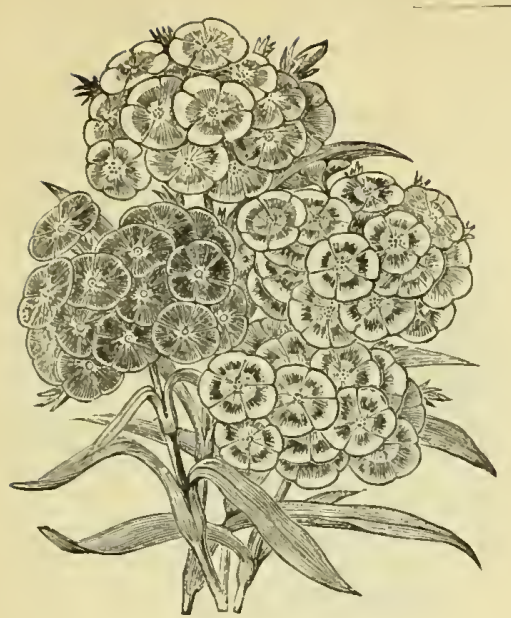

No.21 25.-Sweet William, auricula.flowered.

No. SWFiET WIIIIANI. Price.

A well-known, frec-flowering, pophlar favorite; tho great improvements upon the old varieties manlo within tho last few ycars have rendered it still more desirable; hardy pereunials.

2125 sweet Willinu, auricula-flowered, a very liandsome variety, prorlucing immense

trusses of bloom; $13 / 2 \mathrm{ft} \ldots . . . . . . . . . . . \$ 0.20$ 2126 - double-flowering, mixed; $1 \frac{1}{2} \mathrm{ft} . \quad .10$ 2127 - nigricaus, lark crimson; $1 \frac{1}{2} \mathrm{ft} . . \quad .10$

2128 - - white, useftl for bonguets; $11 / \mathrm{ft}$. .10

2135 _. fine mixed................... 05

TACSONIA.

Magnificent climbers, wbich, for dazzling brilliancy and boanty of Hower are unsurpassed. The flowers are suspended on thread-liko filaments, and givo the roof of tho conservatory the appearance of be. ing studded with star-lights; grecnhonse climber.

2140 Tacsonia Van Volxemi, intenso scar. let flowers, followed by fruit of a plcasant

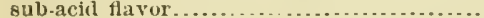

\section{TAGITES.}

Beautiful and delicato fern-leaved plants, forming compact bushes coverel with neat bright-colored blossoms; lialf-hatry annuals.

2145 Tagetes pumila, bright jellow with a redulish-brown stripe; $1 \mathrm{ft} . . . . . . . . . . . .$.

2146 - tenuifolia, a wetty niniaturo varicty, orange flowers, delicate foliage.........

THUNBHEGIA.

A genns of slenter ant rapith-growing climbers, with extrcmely pretty and mucl almired fiowcrs, which are frecly produced; half-liardy annuals.

2155 Thuubergia alata, orange, ricb brown eye ; $4 \mathrm{ft} . . . . . . . . . .$.

$2156-$ alba, white, with dark cyo; 4 ft.

2157 - aurantiaca, orangc, dark eyo; $3 \mathrm{ft}$. .10

2158 - Bakevii, pure whito; 4 ft $\ldots$;

161 - mixed, from above

2162 - Collection of 5 choice rarieties..... .50

\section{TOIRINI}

On account of its comparatively recent introduc tion. this charming plant is but littlo known. For langing-baskets or culture in pots, it is unsur. passed, and during the warmer months of the year its builliaut florescenco adls a pleasing vari ety to ontdoor decoration; tenile $r$ annuals.

2165 Torenia Bailloni, gollen yellow, with

dark thloat ; distinct and beautiful.

2166 - Fournieri, azure blue, spotted.....

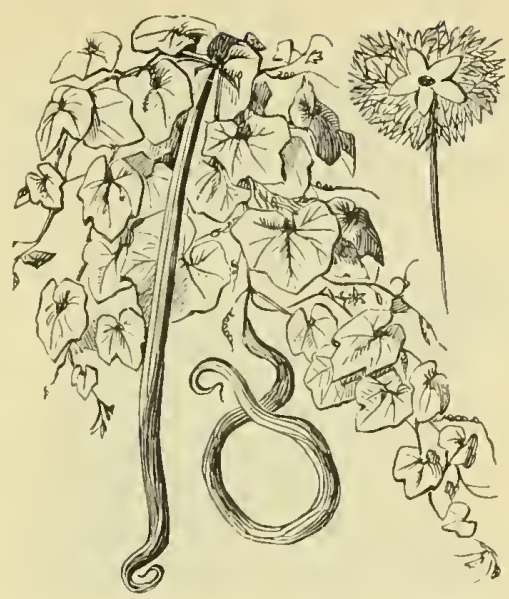

No. 2172.-Tricosanthes colubrina.

No. TRICOSANTIIES. Price Beautiful plants, with long, elegant, serpcnt-like fivit; half-harly anmals.

2172 Tricosauthes colubrina, serpent $\mathrm{cu}$. cumber; from 5 to 6 feet in leugth; when ripe, is of a brilliant carmine... $\$ 0.10$

\section{TRITOMIA.}

Interesting and sliowy plants, popularly known as Red-hot Poker, on acconut of the color of the flower-spikes, which are produced in great profusion, and remain a long timo in bloom; haldy pereunial.

2175 Tritoma uvaria grandiflora, bright

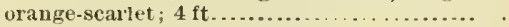

TROPAFOI,UNT.

Elegant growing, profusc.fiow (eling, and easily cul tivated climb +18 , combining with these important qualities great richness and brilliancy of color; with finely formed and beantifully marked flowers, for corering trellises, velaulas, and bowers; for beching purproses they are nnsurpassed; half havdy aumuals.

\section{Tropaeolum lobbianuu Caroline}

Selnuidt, deel'searlct....................

2182 - - Dnc de Luynes, tark crimson.... .15

2183 - Geant des Batailles, brilliant

cal'mino; fillo......................... .15

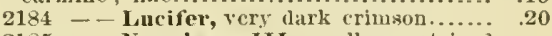

2185 - Nimpoleou III., yellow, striped

with rosy scarlet

2186 - Q Qucen Victoria, vermilion and scarlet: very show $\ldots \ldots \ldots \ldots \ldots \ldots \ldots \ldots \ldots . .15$

2187 - - Trionulue le Gand, orange. scarlet; dlistinct anıl beautif ut .................. 15

2188 - IRoi des Noirs, almost blick ..... . .15

2189 - - spitfire, lidliant scarlet; slowy. .15

2190 - - brown, bcantiful lark brown

vigorous and abumlant bluoner............ 15

2195 - fuest mixed vurieties............ .15

peregrimum (Canary Bircl Flower),

fellow, higlily omanental, and deservedy a general favorite (see No, 580).

TUBEIZOUS-ROOTED VARIETIES FOR IX-DOOR CLLTURE ONLY

2196 Tropaeolum azureum, sky blne, very delicate ind beautifinl. ..................... 2197 - pentaphyllum, scarict, tipped witl green; graceful foliage ................... 2198 - tricoloruu, scarlet, yellow, and black; very bandsome.................... 


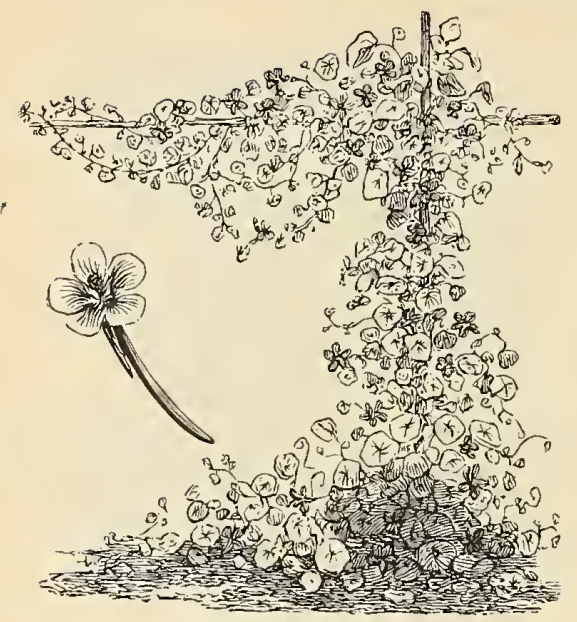

No. 2195-Tropæolum lobbianum.

No.

VALERIAN.

Price.

Showy plants for mixed borders or slurubberies, bearing large corymbs of briglut flowers; bears shade aud moisture well; hardy perennial.

2200 Valerian, all colors, mixed.............\$0.05

VENUS, IOOKING-GIJASS.

A free-flowering pretty little plant adapted for beds or rock-work, ribbons or edgings. The plants form a small sprcading mass of about nino inches ligh, and may be hat in bloom for the whole sum. mer by successive sowing; hardy annuals.

2205 Venus' Looking-glass, mixed colors. .05

\section{VFRBENA.}

Unrivalcd in the spleudor of its tazzling brilliancy, tho Verbeua is the most effective bedding plant in cultivation: it blooms from seet the first sca. son; half-hardy percnnials.

2210 Verbena hybrida aurieula flora; choicc mixed varieties, with white eenter... 2211 - - eandidissima, immense trusses of pure white flowers.

2212 - - eorulea, beautiful blue, constant

2213 - - Defince, bcautiful rich scarlet.

2214 - - Italian striped, mixed............

2220 - - ehoice mixed ....................

2221 - - fine mixed....

2222 - aubletia, retdish pnrple..........

- lemon seented (see No. 298).

2223 - montana, a perfect gem; the plaut litcrally covers itself thing the Summer with its briglit rose-colored flowers; perfectly hardy

2224 - teucroides odorata, fine white, fragrant .....

2225 - venosa, violet purple, good bcdding-

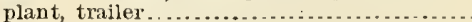

VERONICA.

Showy plants for pot-culturo or the open borier; they requirc but litile attention, as they grow with the greatest facility, and are readily increased by partition of the roots; half-hardy aunnals.

2230 Veronica Syriaea, briglit blue and

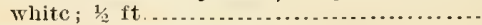
2231 - alba, white; $1 / 2 \mathrm{ft} \ldots \ldots . . . \ldots \ldots \ldots . .15$

\section{VINCA.}

Highly ornamental, frcc-flowcring, compaet, grceuhouse, cyergrech shrubs, with shining greeu foliage and liaudsomc eirenlar flowers.

2235 Viner rosea, rose; $1 \frac{1}{2} \mathrm{ft} . . . \ldots . . . . . . . \quad .10$

$2236--$ alba, white with crimson cye; $2 \mathrm{ft} .10$

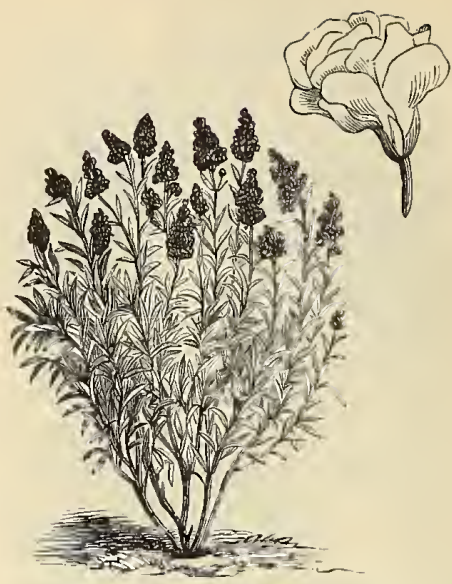

No. 2272.-Wallflower, double.

No.

VIOLA (Violet).

Price.

Well-known plants, suitable for edgings, groups, or mixed borders, and suuch in demand ou account of their pleasing fragrance and profusion of bloom, which lasts from early spring throughout the Summer months; hardy perennials.

2245 Viola cornuta alba, white.......... \$0.25 2246 - - manve queen, deep manve blue.. . 10 2247 - Intea grandiflora, golden yellow. $\quad .25$ 2250 - odorata semperflorens, sweet-

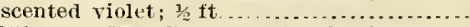
2251 - The Czar, light violet, large and fragrant

2252 - - The White Czax, a white variety of the preceding, protucing an abundance of tmmense fragrant flowers.....................

VIRGINIAN STOCIR.

Extremely pretty, profuse-flowering little plants, effective in suall bcds, baskets, or as edgings; they grow freely anywhere, and if sown early in February, they generally bloom in April or May; harly annuals.

2260 Virginiau stock, red and white, mixed .05 VISCARIA.

Pretty, profuse-flow cring plants, for beds, ribbons, or mixed borders; they do best in an extremely light soil, libcrally mixed with old mortar, powderet brieks, or sımilar substanee; hardy annuals. 2265 Visearia, mixed colors; $1 \frac{1 / 2}{2} \mathrm{ft} . . . . . . . . .10$

\section{WAITZIA.}

A charming section of crerlastings, equally valua. blo for potculture and tho flower.border. For Winter bouquets, pick the flowers before they fully expand; half-hardy annuals.

2266 Waitzia aurea, billiant yellow; 1 23/2 ft. .15 2267 - corymbosa, bright red ; 11/2 ft.... .15

\section{WALI-FI,OWER.}

The flowers of the Wall-fiower aro deliciously fragrant, and greatly prizcd; the large, massive, eonspicuous spikes of the double German varietics havo a eharming effeet, wlile the morebushy, compact growth and protusc-blooming of the single ones rcuder them exceedingly attractive; half-harily perenuials.

2270 Wall-flower, canary yellow; $2 \mathrm{ft} \ldots . .25$ 2271 - dwari, mixed; $1 \mathrm{ft} . . . . . . . . . . . . . .25$ 2272 - finest double, German mixed; $2 \mathrm{ft} . \quad .25$

2273 - IIarbinger, rich blootl-1ed; $1 \mathrm{ft} \ldots . . .25$ 2274 - single, mixed...................... .05 2278 - Collection of 8 distinct colors....... .75 


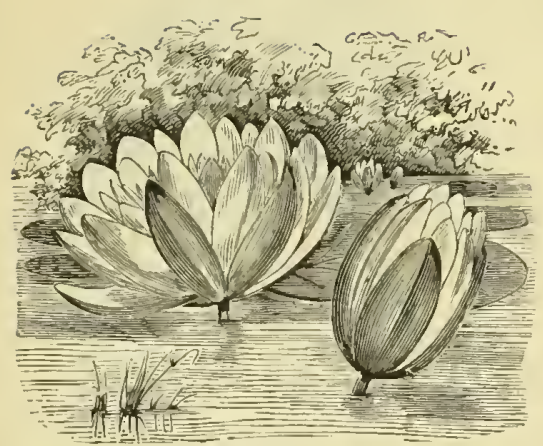

No. $2280 .-W a t e r$ Lily.

No. WATIil-LILY Nymphaea). Price.

The variety we offir is tlie true fragrant white Water-Lily, and ean be enltivated with far less trouble than most people imagine. I1s liome, of eourse, is in ponds and streams, but it can be sueeessfully grown in tuls ant apuariums; in faet, some of the loveliest Lily Gardens are freguently met with in some such artificial tleviee.

2280 Water-Lily ( $N$ ymphece orlorat $(\ell)$, white.\$0.25

- Root s, 40 cents each, st.00 per dozen.

\section{WIIITIAXIA.}

One of the most charming Calitornia introluetions; very effective for bedding, ribboning, or nixed borders; hardy annuals.

2282 Whit lavia graudiflora, violet blue; $1 \mathrm{ft} .05$ 2283 - - alba, pure wlite; $1 \mathrm{ft} \ldots \ldots \ldots \ldots . . .25$ 2284 - gloxinoides, tube of eorolla pure white, lines of a delicate light blue. .

\section{WIGANDIA.}

Grand and mavuifeent plant, with stupendous leaves richly veined, aud stoms covered with erimson hair. Of rapid growtl and splendid lobit, it formus one of the finest objects amongst orna mental-foliaged plants, to iupart a tropieal aspect to a garien, or for conservitory deeoration; halflarily perenuials.

2286 Wigandia Caracasaua, lilac; $7 \mathrm{ft} \ldots . .25$

2287 -Vigieri, superl), glaturus foliage; $8 \mathrm{ft} .25$

\section{WVINTER CII IATR IR Y}

Physalis Allzelienoil.

There are several species of this plant, but the lardy variety which we offer is the best-known one. It bears scarlet, cherry-like fruit, inclosed witlin an evlarged ealyx, whiclı also assumes a bright res color, and thus renters the plant very ormanental in the beginning of the Winter season.

2290) Winter cherry, very showy.

$$
\text { WVISTAIRIA. }
$$

One of the most elegant aul rapicl-growing of all climbing plints; attains an imneuse size; fre "juchtly grows at the rato of 15 or 20 feet in a sea. son ; produees long pendulous elusters of flowers carly in spring; larrly slurub.

2202 Wistaria simensis, pall: blue.

$$
\text { YUC'CA Adam's Needle: }
$$

Splemlit, slıowy, lardy plants, with al loe like foliage, bearing a close paniclo of creani-colored, clrouping, tulip-like blossoms; plint the seed where it will remain undisturbed. as tho plant takes some timo t'arrivo at perfeetion.

2294 Yucca, mixel varieties.

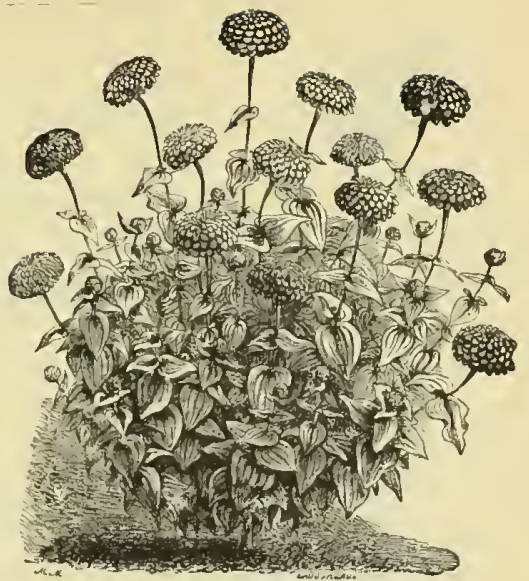

No. 23:4.-Double Zinnia.

No. XEIRAN'THEMIUAI. Price A showy class of Everlastings; the flowers, when gathered young, aro useful for Winter bonquets; they are among tho most easily enltivated of an. muals, recuiring only to be sown, about May, in the open border, and thinmed out for Howering: for sneeession, sow at intervals of a month; latrly annuals.

2295 Xeranthemum album fo. pl., donble

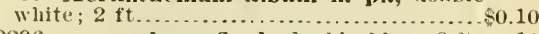
2296 - ecruleum ff. pl., double blue; $2 \mathrm{ft}$. 10 2297 - superbissiumm fi. pl., new, dis tinet, and very double; moloubtedly the best form of this tlower ever offered; blue; $1 \frac{1 / 2}{2}$ t. 2298 - - albium fi. pl., a white rariety of the pleceding, eveli more desirable for bour quets on aecount of the color; $11 \frac{1}{2} \mathrm{ft}$.........

\section{ZINNIA IELGANS.}

The double Zinnia is one of the sterliug novelties of reeent years. The flowers aro large, beautifully formed, and excecdingly landsome. Few plants in the flower borilep are more effective: and searecly any tower, when cut, is more suitable for talle bouquets; being of ratler robust labit, it recuires but moderately riels soil; the seed may be sown in the open ground or in lieat, aecord. ing to the time it is desired to flower; haif hardy anuuals.

2305 Zimia Elegans fi. pl. alba, pure white. .10 2306 - - - aurea, goldrn yellow....... .10

2307 - - - eocinca, searlet............ 10

2308 - - - - keruesiua, crimson .......... 10

2309 - - - - lilacina, lilac................. .10

2310 - - - purpmea, purple............... . 10

2311 _ _ striata, magnificent eolors, shadedand striped.

2314 - - f fuest double varieties, mixed 10 $2315---$ Collection of 8 dlistinct va. rietio's.

- Haageama fl. pl., a new domble variety, of nice labit, and luriglit, soft, oraugrecolored flowers.

2318 - - puuila fi. plo, dwarf, ilowers very brilliant and doulfle....................... 2319 - - tagetiflora fi. plo, new double, petals quilled like Globe Aster...

2320 - Elegaus uaua alba fl, pl. This splenulicl novelty supplies a long telt waut in the sliale of at thoroughly goot ininiatureflowered dwarf white Zinnia, which, for flor ists' usc, must he invalualole, it is eompact in habit, wluls in color, form, and size of flower it is simply perfection ................ 


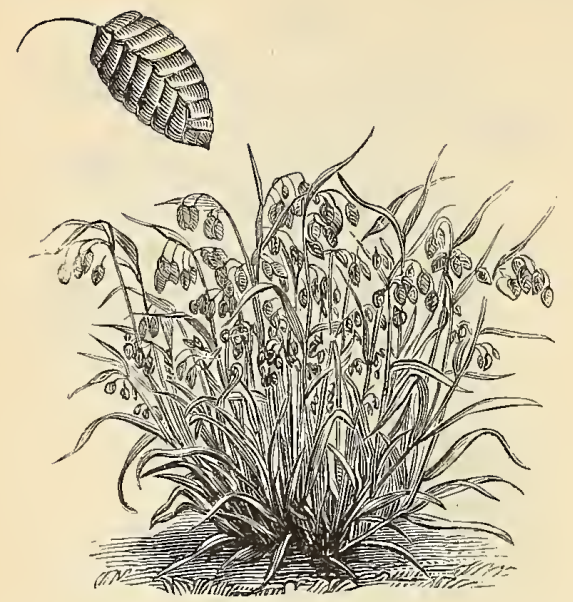

No. 2348.-Briza maxima.

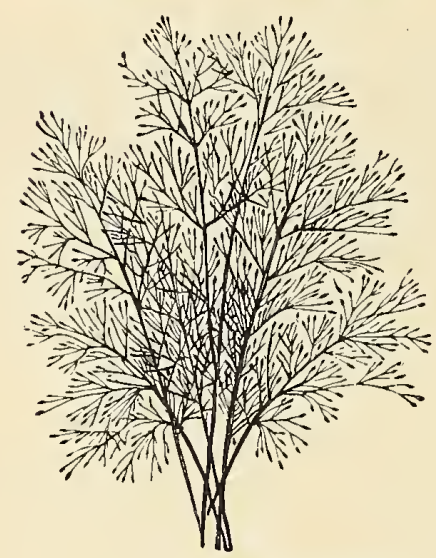

No. 2332.-Agrostis nebulosa.

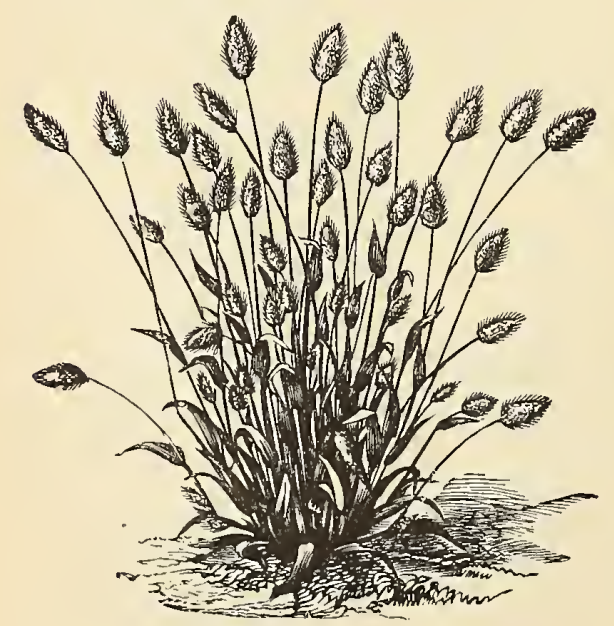

No. 2385.-Lagurus ovatus.

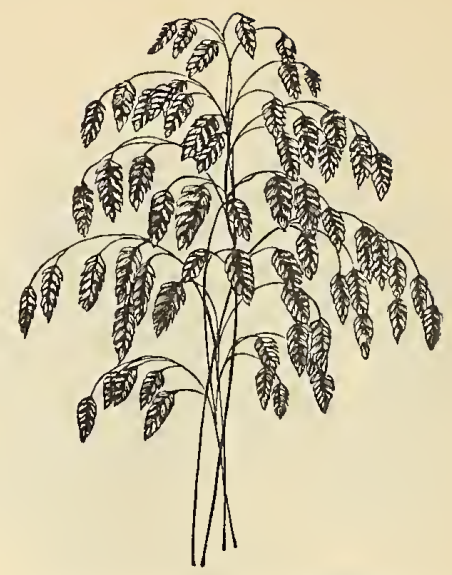

No. 2442.-Bromus brizæformis.

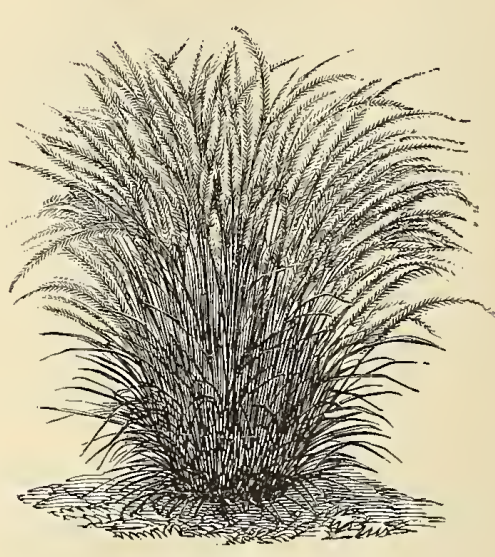

No. 2482 .-Stipa pinnata.

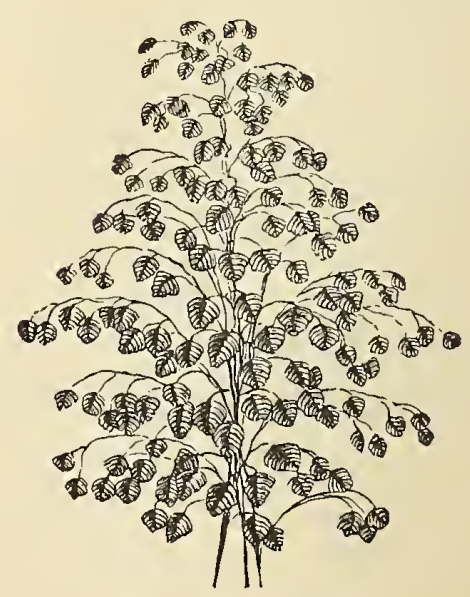

No. $2347 .-$ Briza gracilis. 


\section{ORNAMENTAL GRASSES.}

For Winter Bouquets, Diuner-Table Decolntions, Edpings, Izibbous, Centers of Beds, Mixed Borders, and Sinubberies.

Most of the varieties may be dried for Winter bouquets, or used for filling vases, citluer in a dried or grecu state.

That the plants may develop their true claracter, transplant or thin out sufficiently to afford space for the growtl of cach, and this should be done as soon as the plants can be lianded.

\section{ANAIAI, VATRIJTIFS.} Price. No.

2330 Truilons cylindrica, knotted, enrious and pretty; $2 \mathrm{ft}$

Agrostis. All tue rraceful bouruet grasses.

2331 - laxiflorn, rery graeefinl; $1 \frac{1}{\mathrm{ft}}$

2332 - nebulosi, the profertion of erace, indispensable for bond pur to: 1 1 s ft. .

2340 Aut hoxanthum sracile, elegant : $3 / 2 \mathrm{ft}$

2342 Aveua stevilio (1nimater oats), $2 \frac{1}{2} \mathrm{ft}$

Briza. Charmins rarieties of the well linown d juaking grass.

2345 - compacta, very cliaming; $1 \mathrm{ft}$

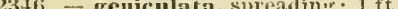

2347 - gracilio, smill ruaking grass; $1 \mathrm{ft}$

23.18 - maxima, large quaking grass; $1 \mathrm{ft}$.

2352 Brizonvrum siculuu, splentil for

elgings and bouguets: $3_{\text {i f }}$.

2355 Ceratochloa peuclula, graceful; $1 \mathrm{ft}$.

Chloris. Singularly radiated, aud very cffective in lononuets and borders.

2360 - elegaus, slender and elegant ; $x_{2} \mathrm{ft}$.

2362 - trumcata, clegant for bonquets and other decorations: $13 / \mathrm{ft}$ rery lesirable sort; th $\mathrm{ft}$

2366 Coix Jacliryna (Jod's Tears); $1 \frac{1}{2} \mathrm{ft}$

2370 Echinocliloa colona, spotted brown, peculiarly attractive; $1 \frac{1}{2} \mathrm{ft}$

Eleusine. Pretty. All enrionsly lom. cd grasses, equally effective in bon. qucts and growing in the borders.

2372 - Indica, spreading and graceful : $1 \mathrm{ft}$
2365 Chrysurus aureus, golden-s]ikerl; a

0.10

10

2375 - cylindriflor m, most graceful; $2 \mathrm{ft} . . \$ 0.0$

2376 clegans (Love Grass), fine; $1 \mathrm{ft}$..... .05

2380 Hordenu jubat um, squirrel-tail grass,

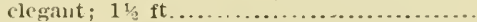

2385 Lagurus ovatus (Hare's-tail), elegant; a well-known sort; $1 \mathrm{ft}$

2390 Lasiamostis argenca, beautiful and very distinct: $3 / 4 \mathrm{ft}$

2430 Agroatis Stevenii, glaceful ; $1 \mathrm{ft}$... Andropogou. 'Tliose enumerated ate of large growth and tine sub-tropical plants, imparting to shrubberics or lawns quite a picturesque appearance. grgeutcus; $5 \mathrm{ft}$

2434 - bombycinus, silvery spikes ; $6 \mathrm{ft}$

2435 - Sicliuperi, very statcly; $6 \mathrm{ft}$.

2438 Arundo conspicua (New Zealand

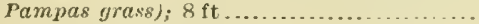

2439 - douax versicolor, striped foliage; a well-known sort; $7 \mathrm{ft}$

2442 Bromus briza formis, fine Briza-like excellent for bounuets; $1 \mathrm{ft}$.

2443 - macrostadiys, fine grass for unixed borders; 11\% ft

2448 Cliloris barbntal, locardel; ift

2450 Chloropsis Blanelateliaua, bottle. brush-like flowers of a brisht rose-color; a variety of treat merit; $4 \mathrm{ft}$.

2455 Erianthus ravemna, a noble grass, resemuling the Pampas; $7 \mathrm{ft}$

2456 - violasceus, violet tinted; $7 \mathrm{ft}$

2460 Eulalia Janonica. Marnificent new Japaneso ornamental grass of robust growth, attaining a height of 6 to 7 feet, and a cir. cumfercnce of about 17 to 18 feet. A single plant throws 11 ) from 30 to 40 elegantly re. curved flower-spikes of a light violet color.

Panicuul. Sutitale for bouquets and elegant in borlers.

2400 - eapillare, most elegant; $2 \mathrm{ft} \ldots \ldots . .05$

2401 - sulcatuu, very decoritive; $4 \mathrm{ft} \ldots \ldots . .10$

2405 Paspaluu elecans, wretty for borders or shrubberies: $2 \mathrm{ft}$

Pennisetuu. The most distinct and beautiful of ornamental grasses.

2406 - fimbriatum; $1 \mathrm{ft} \ldots \ldots \ldots \ldots \ldots \ldots . .05$

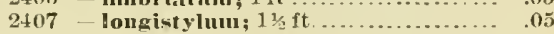

2408 - setosuu, covered witl silky lairs, brilliunt as rubies: $11 \% \mathrm{ft}$

2115 loa aumbilis ( 1 bysinian gr

2418 fetaria nacjocheta, elegant; $1 \frac{1}{3} \mathrm{ft}$. 10

2420 Uniola latifolia, beautiful in bouguets or otluer decorations ; $3 \mathrm{ft}$

Lea (ornamental Maize). Valnable sub-tropieal plants. Japonica is much prizcol for its bcautifully variegated foliage.

2424 - gracilliua (Miniature Maize); $2 \mathrm{ft} . \quad 10$

2425 - Japouica vaticgatn (Stripel maize);

a well.known plant ; $3 \mathrm{ft} \ldots . . . . . . . . . . .$.

2461 Eulatia Japonica zebrina. This beautiful grass grows from 3 to 4 feet high, and is said to be quite liarly. It has a grand appearance when in bloom, and is very valu. able for growing as a single specimen or gronping witl other plants on the lawn...

Festuca. Dwarf, well.known conplact. growing grasses.

2464 - pectinclla, for bonquets aud edg.

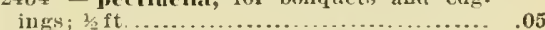
2465 - viridlis, fine cltring plant; $3 / 2 \mathrm{ft} \ldots \ldots . .05$ 2470 (:yncrim argenteuu (Pampas Grass); a well.known variety ; $7 \mathrm{ft} . . . . . . . .10$

2471 - roseun, rosc-tinted; $7 \mathrm{ft} \ldots \ldots \ldots . .10$ 2472 - . varic satuu, foliago varicgated; a magnificent sort; $7 \mathrm{ft} . . . . . . . . . . . . . . .$.

2478 Isolenis gracilis, tine forjarlinets; $1 / 2 \mathrm{ft}$ Stipa. Of all grasses tlio most elegant in the flower bordrer, and bouquets.

2480 - elegantissima, extremely elcgant; the best of its class; $2 \mathrm{ft}$

peutuata (Feather Grass); $2 \mathrm{ft}$........ .10

485 Fricholiena rosea, very petty; $1 \mathrm{ft} . . .10$

2486 - violncen; $1 \mathrm{ft} \ldots \ldots \ldots \ldots \ldots \ldots \ldots \ldots . .10$

2490 Tripancum dactyloides, pretty for ellgings ; $3 ; \mathrm{ft}$

2491 - inonostrchyum, drooping leaves and cylindrical spikes of inflorescence; $5 \mathrm{ft}$. 


\title{
CHOICE FLOWER SEEDS IN QUANTITY.
}

\author{
(For description of which, see preceding pages.)
}

As many of our customers requile larger quantities of Flower Seels than are usually sold in packets, We offer a few of tho leading solts by weight. They havo been selected as the most effective and ornamental for bediing, edgings, or similar situations, and will bo fonud most economical whero extensive sowings are required.

The numbers prefixed refer to their position in the body of the Catalogne. We will mail free, at prices quoted, but no discount or preminm can be allowed; and unless the prico exeecds fifty cents per ounce, not less thau one ounce packets will be solk.

\begin{tabular}{|c|c|c|c|}
\hline $\begin{array}{l}\text { No. } \\
266\end{array}$ & Acroclinium roseum & $\begin{array}{l}\text { No. } \\
1333\end{array}$ & Iuakspur, lwarf rocket, mixed.... Per oz. \\
\hline 267 & - albmi & 1335 & - tall, branchiug \\
\hline 278 & Agerutum Mexicaumn. & 1355 & Laveuder ... \\
\hline 300 & Alyssum, sweet . . . . . . . & 1378 & Linum graudiforam coecineun. \\
\hline 309 & Amarantlus nielancholicus ruber. - & 1409 & 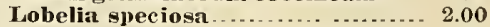 \\
\hline 312 & - tricolor. & 1438 & Iupinus, anusal, mixed...... \\
\hline 353 & Autirihinum, dwarf, fine uixed . . . 1.00 & 1478 & Marigold, Afican, mixed. . . . . . \\
\hline 354 & 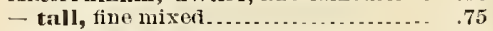 & 1489 & - Freuch, nixed. \\
\hline 368 & Aquilegia (Columbine), mixed........ & 1507 & MIarvel of Peru, mixed........ \\
\hline 413 & Aster, German, quilled.... 1.00 & 1544 & BIignonette, large-flowered py- \\
\hline 418 & - Truffaut"s Perfection & & s' 11 se... . \\
\hline 429 & - clnoice nixed & 1545 & - sweet . . . . . . . . . \\
\hline 452 & Balloon viue... & 1546 & _" The Prize"" . . . . . \\
\hline 455 & Balsam, double white $\ldots \ldots \ldots \ldots \ldots$ & 1605 & Nasturtinu, Tom Tlummb, mixed.... \\
\hline 456 & 1.50 & 1620 & tall, mixed. \\
\hline 457 & - camellia-flowercd, mixed . ....... 2.00 & 1630 & 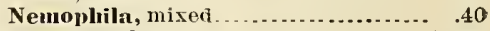 \\
\hline 459 & five domble mixed. & 1679 & Pansy, Belgian or Fancy ........... 10.00 \\
\hline 470 & Bartonia anrea & 1680 & C English Slıow 10.00 \\
\hline 505 & n eoceiven.............. & 1700 & - cloice mixed ........ \\
\hline 545 & mixed . . . . . . . . . & 1701 & - good mixed ......... \\
\hline 580 & r. & 1716 & Peas, sweet-Butterfly \\
\hline 583 & son $\ldots . . . \ldots \ldots$ & 1718 & _- Painted Lady . . . . . \\
\hline 584 & (n) & 1720 & - - searlet.... \\
\hline 587 & .............. & 1721 & - - striped. \\
\hline 595 & ed & 1722 & - Violet Queen \\
\hline 616 & (1. . . & 1723 & - white \\
\hline 621 & Cauterbury Bells, double, mixcd.... 1.00 & 1724 & - - mixed ... \\
\hline 624 & - - single, mixed... & 1770 & Pctunia, choice \\
\hline 655 & . . . . & 1799 & mixed.... \\
\hline 670 & 1.00 & 1830 & Pol \\
\hline 741 & ria maritima (Dusty Siller).. 1.00 & 1859 & Por \\
\hline 758 & 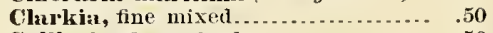 & 1860 & 5.00 \\
\hline 800 & 1.................... & 1903 & (Golden Feather). \\
\hline 818 & Convolvulus major (Morning Glory). & 1950 & mixed... \\
\hline 830 & xed................. & 1965 & mixed. \\
\hline 868 & 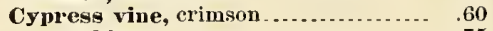 & 1977 & 5.00 \\
\hline 870 & — white. & 1997 & ing Bride)............. \\
\hline 915 & (China Pink) ... 1,00 & 00 & ilie mixed........... \\
\hline 957 & unixerl . . . . . . . . . & 25 & ve Plant \\
\hline 10 & cer1. & 2040 & Smilax - 3.50 \\
\hline 1 & Euphorbia variegata & 2092 & Stocks, Gepman ten-week, large. \\
\hline 20 & Everlasting Flowers, mixed ..... . 100 & & ixed.................. \\
\hline 88 & 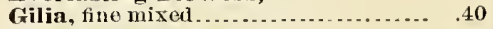 & 2085 & -2.00 \\
\hline 10 & mixed...... & 2125 & Sweet William, auricula-flowered.... \\
\hline 1130 & .50 & 2135 & - fine nixed $\ldots \ldots \ldots \ldots \ldots \ldots$ \\
\hline & .50 & 2161 & Thumbergia, fino mixed. $\ldots . . . . . . . .$. \\
\hline & cerl. . . . ... & 2221 & a, fine mixed. \\
\hline & (2.......... & 2260 & a Stock, mixed .......... \\
\hline & tar Ipoinoea) & 2314 & , finest double, mixed.... \\
\hline & bides. . . . . . . . . & 316 & ale mixed \\
\hline
\end{tabular}

2314 Zinnia, finest double, mixed......... $\quad .75$

\section{WILD GARDEN SEEDS.}

The introduction of these has proved a most marked suceess, and we are daily in receipt of the most satisfactory eridence of the estimation in which the wild rarden is held, wherever this modest phase of flodiculture has found a homo. Any ono who has planted and cultivated flowers in neatly laid out beds or carefully planncd ribbon borders is aware of the auount of labol and constant attention necossary to produce the desirel effect. To those who cannot give this care, the "Wild Garden" presents a substitute which, for its unusual and varied effects, for cheapness and the small amount of labor necessary for its construction, has no rival. "With Garden Seeds" are a mixture of over ono hundred varioties of harty Flowerseeds, and being mixed together can be offered at a meh less price than when sold in separate packets. No ono who has uot seen such a bed can form an idea of its possibilities, tho different seasons of bloom insuring something new almostevery day. Half-ounce packets, with full cultural airections, 25 cents. 


\section{DRIED NATURAL FLOWERS.}

IMMORTELLES, MOSSES, GRASSES, Ete.

In Great Demand for making into Wreatls, Crosses, Winter Bouquets, Christmas Decorations, ete.

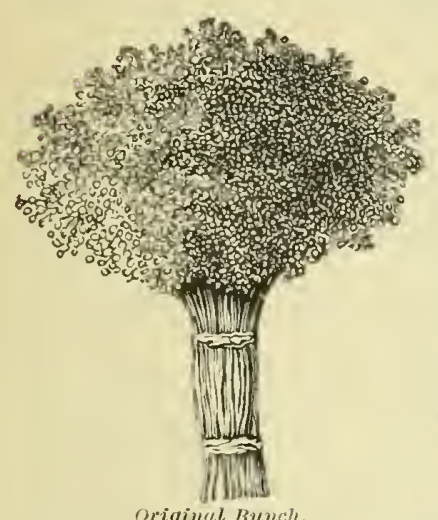

Original Bunch.

DIRIFIO NATU12AI FICNTHIR-

Acrocliniunı.-Rose or white; per rloz., 10 cts.; per humbled, $50 \mathrm{cts}$.

Autnmu Leaves. - Per doz., 25 ets.

Cape Flowers.-Natural colors; per doz., $15 \mathrm{ets.;}$ per lumbrer, $\$ 1.00$; dyed in brilliant colors, per (loz., 20 cts.; per hundrol, $\$ 1.50$.

Edelweiss.-A pretty, velvety white, Alpine flower, each, $10 \mathrm{cts.} ;$ lor" doz., $\$ 1.00$.

Ferns.-Hartford, pressed; per doz., $50 \mathrm{cts}$. - Mailen Hair, " " " 50 cts.

Telichrysnu. Tatural colors, per oz., 15 ets. ; pel 娄 1b., 50 ets. ; dyert in brilliant colors, oz., 25 cts.; $\frac{1}{4} 1 \mathrm{lb}, 75 \mathrm{cts}$.

Helichysum.--Native, natural colors in buncles (of about 25), 25 cents eacl.

Moss.-Dyed grecn, punle, red, etc., small bunchu's, each, 10 cts.; per doz., 75 ets.

Moss-Frencli, dyol green; large bunches; each, 20 ets.: per doz., \$2.25.

Moss, Florida.-Selectorl, per 11)., 40c.

Moss, Sea.-Preparod, per bunch, 50c.

Statice iucana liybrida. - Natural colors, 07., $15 \mathrm{c}$, $1 / 41 \mathrm{~b} ., 50 \mathrm{c}$

\section{HVFIRI, ASTING IBOUQUIATR-}

Being beantifully and tastefully arranged, in bright and pleasing colors, thesc permanent ornat. monts are greatly arturiretl.

Round Bouquets. -Composed of colored grasses, irumortelles, etc. $25 \%$ to $\$ 1.50$ cach, accoriling to size.

Feather Grass Bonquets.- Very graceful, $75 \mathrm{c}$. to $\$ 1.50$ each.

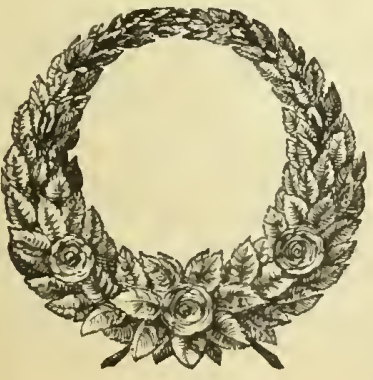

Pampas plunes cannot be sent ly mail, on account of their length. If a morc completo list than the abore is desired, onr Catalogue of Iried Flowers and Grasses will be mailed, free, on application.

\section{METALLIC \& PORCELAIN WREATHS AND CROSSES}

of leares and thowers for tombs and rarious decorative purposes unaffected by tho weather, heat or clust. Mfuch admired every where. Thiy cau be had in thrco styles, viz.: entirely of metal, of metal leaves and porcelain flowers, eutirely of porcelain in various patterns racli. Prices from \$3.00 to $\$ 10.00$ each. 


\title{
SUMMER FLOWERING BULBS.
}

\author{
GIJADIOI,US.
}

Rare and Beantiful French and Belgian Hybrids of Glatiolus Gandavensis sent by mail, post-paid, upon receipt of price aflixed.

Our collection of this magnificent tribe of plants is one of tho most extensive in this country, and embraces many new and rare varieties not before offeret.

The eolors comprise the most brilliant of orange, scarlet, and vermilion tints upon jellow and orange grounds, including a gradıated scale of intermediate sliales - from white, with rosy blush and salnou rose tints, to salmon red and wankeen; from biusl white, witl purple crimson throat aud marginal streaks of pink, to liglit rosy salmon gromds witl tlakes of deep carmine. Thns, from white np to rose, and rose to the brightest and deepest crimson, and from crimson to tho brightest orange, flame, and scarlet, this rery splentid selection affords a combination of the richest conceivable colors, which no other genus cau offer.

To keep up a constant flowering from July to September, it is only necessary to Iaut at the end of March, or early ir April, a portion of tho bulbs (choosing the smallest), a second portion about the end of April, a third about the 15th of May, and the last at the end of May-preserving the largest bulbs for the last planting.

The cuiture of these is attended with no difficulty. It is only uecessary to plant them in ortinary garden mold; they object to no soil bnt a stiff clay, and succeed best in good earth, manured well with well-rotted lorse-itung. If planted in rows, the rows ought to be from eleven to thirteen ineles apart, and the bulbs iu each row from six to ten inclies apart, according to the size of the bulbs. Deptli of planting, two to two and a half inches. While growing they must be copiously watered, if the seasou is dry. In the Autnmn, when the stalks are quite dry, the bulbs aro to bo taken up anil placed in a dry place-better on shelres-protected from the frost, where they will keop well till deeded for planting again. The stalks cut from the Gladiolus flourislı well in water; the bulbs, slightly developect, expand rearlily, and continue te flower for some time. Pretty bouquets fur rooms can be marte by mingling them with light branches like the Tamarisk, the A sparagus, or leavos of the smaller reeds.

\section{NH:W VARIFTIFS FOR $1882-1883$.}

Abricote.- Large rounded petals of a very fresh apricot-rose, slightly tinged with Jilac. Late flowering variety, robust and vigorous. \$7.00 each.

Arabi Pacha. - Scarlet towers of a very bright shade, with a large ivory white bloteh, golden at the edges; very original color. $\$ 5.00$ each.

Bayard.- Fine spike of large carmine-red flowers, sliglitly tinged with lilac, delicately banded with wlite in the center of the petals. Vigorous and very liardy. $\$ 4.00$ each.

Bicolore.-Vely distinct and striking variety, with large flowers of bright rosy salmon, with the excep. tion of the lower petals, wlich are ivory-white, suffusel witl rose at the edges, $\$ 5.00$ each.

Bloudiue.-Tall, compact spike of large straw-colored Howers, slightly streaked at the edges with rosy lilac. Very delicato shade; vigorous. Heiglit, three and a Lalf feet. $\$ 4.00$ each.

Cor'saire. - Very fine aud compact spike, with large flowers of a very intensive dark and velvety scarlet, tinter with brown at the eriges of the sepals. Height, four feet. $\$ 3.50$ each.

Fatma.- Very large flowers of ivory-white ground, profusely striped and suffused with bright rosy salmon; violet bloteh on creamy ground. $\$ 3.50$ eael.

Feu Follet.- Well opened flowers, witl ivory-wlite throat, richly tinted and striped with carmine at the ediges of the sepals. $\$ 3.50$ each.

Gloire de Fontaineblenu. - Tall spike of well-opened large flowers of bright rosy carmine, striped red at the edges; white band in the nidille of the sepals. $\$ 3.50 \mathrm{each}$.

Grand Ronge.- Splendid spike of large flowers of bright scarlet, with small violet bloteI. Splendid variety of grand effeet. $\$ 5.00$ eacll.

Nereide.-Long and compact spike of large flowers of mother-of-pearl rose, suffusch witl lilac blotched bright violet. Very lelicate color. \$6.00 each.

Pepita.-Middling compact spike of briglit golden yellow flowers, slightly striped carmine at tlie edges of the petals towari tho end of the flowering season. The most free flowering yellow variety of all grown till now. $\$ 3.00$ each.

\section{NHW VAIZIFTIFS INTRODUTED IN 1882.}

Cervantes.-Flowers very large, of bright rose-color, slightly tinged lilae, and profusely streaked and suffused with carmino and pure white bani on each jetal, $\$ 2.00$ each.

Dr. Fontan.- Close spike of well-opened flowers, rosy-lilac. blotehed with bright carmine, specially on the edges; fine plaut, very distinct. $\$ 3.00$ each.

Flauboyant. - Beautiful spike of large flowers, fiery scarlet; very cffective variety. \$3.75 eaeh.

Jeauuette.-Large, bright rose flowers, richly striped and blotched with rosy caruine at tho edges; close spike, very fine. $\$ 2.50$ each.

Mabel. - Splendid spiko of large, perfent flowers, pure white in the center, and blotched with brillant car. mine at the eilges; cxtra tine. \$3.00 each.

Mile. Mavic Verdalle.-Very fine and large flowers of rosy-salmon grotund, flamed and striped vermilion an.l dark carmine; large creany -white blotched streaked violet. $\$ 4.50$ each.

Mount Etna. - Long spike of large, well-arranger florvers of the most brilliant velvety scarlet, slightly streaked with deeper scarlet at the edges; wihte band iu the center of the upper petals; very effective variety. \$3.50 each.

Opale. - Fine spike of large flowors of extremely delicate rose; a charming variety of the freshest color. $\$ 3.00$ eacli.

Teresita.- Lovely and very distinct flower, upper petals of pure white, suffused with rose and striped carmino at the eiges; Iower petals pale rose, largely blotched and striped with bright violet, stamens white. $\$ 3.00$ each. 
CIADIOLUR゙ーGFNERAI, COLI,WCTION.

Purchasers selecting one lozen varieties frou tho following list will be entitled to a discount of tive per cent. from Catalogue pric's; twenty-five Firieties, lisconnt of ten per cent.; fifty varieties, fifteen prer cent.; the entine collection, twenty per cent.

As our stochs of some of the varieties bcome cxhauster as the season advances, purchasers will please state whether they wish any other substituted in the veent of our being out of the variety ordereu.

Wheu siugle price is $10 \mathrm{c}$, we supply at $\$ 1.00$ per dozen; when $200 ., \$ 2.00$ per dozen; when $30 \mathrm{c} ., 53.00$ 1'r tozen.

Achille.-Beantiful currant-red, white stripe in thi mildle of each peral

Airaiu.-Entirely distinct variety of quito a novel color, slaty. brown on scinlet groun, streaker with scarlet and pure white, with comspiouous white blotch; a dark colored variety of remarkable effect; ; lense spike.

Azatla.-liose, suffused with lake, flamed with carmine amiranth, char yellow spots

Alexauder.-Interse crimson.searlet

Aualthée.-Pure white, large violet-red blotch, gromul of the corolla velvety.violet, the lower petils slightly tinged with lilac.

tuaranthe.-Fine, well-shaped thewer of pale violet-rose gromul, richly flaked and specklerl with bright earmine.

Aubroise Versoluffelt. - Rosy-carmine tlimed with garnet, large rose blotch.

Audromede.-Very tall spike of well-shapei thowers, of a fine rose color, sliglitly tinted with carmino and profuscly streaked with white, lare, yellow blotch

Angele.-White; showy and effective.

Amm.-Cherty, tinged briglit orange, lowe petals striped dark earmine on white gromel.

Autigone.-Delieate rose, Hamed witl car unine .

Amonius.-Scarlet-cherry, slightly tinget with orange, tlamed carmine, pure white bloteh.

Apollon.-Rosy-lilac, with a lare, light rose blotch, finels strijuel white in center.

Arcthuse.- VWhite, slightly tinter with rose, suffused aui strijul with light carmine

Arsinoe.-Fine satin-1\%se, flumed with wiglt cirmine

A smodce.-Brilliant cherry-purple, ellgerl ani flamed garuet, with white stains and stripes

Astree--Pure wlite, with distinct violet ear mine bloteh, throat siffiused witl pale lilac, luvel shale of color.

Arbalin.-Violet, slightly tinteil with rose

flamed with purple; novel eolor.

Atlas.-Well furnisled spike, with numerons large Howers, transparent white, slightly tinger with libc and conspienously stripul with bright violet

Aurone-Bright salmon-rose, striped orange carmine, aud lilac, blotehed cherry-rose strakel piolet: very boight, lovely shale.

Buroness lBurdeti Contts.-Delicate lilac, tingel with rose, flamed rosy-purple, spike very long, Howers numsually large; a ieciled acquisition

Beatrix.-Pure white ground, relicately tlusherl witl carmine-lilac

Belladonua.- White, tinted with licrlit lilac, lower petals with bright carmine stripes...

Bernard de Jussieu.-Violet, slated cherry and pumple, purpho blotch on white gromnd

Bijou.-Bright orange-cherry, flinuel with searlet ; brilliant

Brimoutier.-l3right rose, profusely tinter carmine, blotel and bands pure white, streakul violet, fint effective spike........

Breuchleyensis.-Brisht vermilion scarlet. Cameliou.-Fine compact truss of large slity-lilae flowers, flamed orango, white banils flown the mithlo of cacl petal, large creany.white blotch, streaked riolet...
Each.

0.20

Camille,-Extra large flowers of a beautiful nilgenta.litac ('ulor, shated towarl the rentter, flamed aud featherell with dow lilar; a splendirt variety, with robnst, tall spike. S1.25

Canari.-Light yellow, streated with rose on tho lower petals.

Caruation.-Large, well expantled flowers of a Heshy-white color, profusely tinged at the rlges with the richest suminr, the lower petals blotelud purplish-carmine, tine, long. well furnished spike....................... 1.00

Ceres.-Purow wite spotted with purplish-10st .20

C'laries Dickens.-Delieate rose, tinted with buff, tlaned antl strijed carmine-rose........

C'lerubini.-White, Hamed carmine-violet. .

Chloris.-White ground, pofusely mottlet with carmine, Hamed with purplish-carmine. lower petals blotchol listinctly with car. mine-purple

Cluristopler Columbus. - Rosy - carmine, thaned red, large violet red, bloteh on lower petals marbled ant spottol erimson.

Cicerou.-Fino dark rose, tingeul with violet. crimson earmine, tlanted with bright car mine, throat white, novel sharle.

Citrinus. - The mperr petals light ycllow, the lower petals darker........................

Clcopatra.-Sift lilac, the lower petals of a larker liue, suffisen with violet; purple featheren blotel

10 Colbert.-Clieriy-red, slightly tinged orange, a white stripe down the midule of each petal.

Conde.-Iight orange-red, whito bloteh, featheret carnine

Conquete-Bright cheriy ren, with a con. spicuons pure white bloteb, upper petals striped witl delicate rose.

Corime.-Rosy-carmine flowers, shating oft to eherry, streakid pure white, and pencilet carmine at the elges; blotch creany-whe

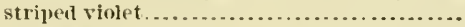

Croesus. - Yellow, shated darker towant the center, Haned carmins at the edges, anil featherecl anaranth-red on salmon monucl.

Dalila.-Bright roso fluwers, streaked and Hamul witl carmine: pure white hloteh... 3.0

De Inuboldt.-Magenta, borilerel ant flamed with bright crimson, carmine feath. ered white bloteh

Delicatissima. - White, suffised with soft carmine-like, the pure white, hower petals ederot lilac

De llirbel.-Fine rose, slightly tinted with lilac-viohet, striped and flamed with dark carmino

benost hemes.-Bright rose, profusely tlameri with intenso carmine, streaked pure white, bright enter, blotehed violet-carmine......

Dinuant.-Flowers extra large, fleshy-white, of a remarkable frcsliness, throat ivory white, blotehel, and streaked carmine..... 1.25

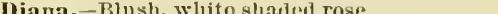

Didon.-White, suffused with pale lilac, lower petals pure white.

Diomede. - White, Hamed with crimson, dark carmine-viulet bloteh ...........

Duc de Malakoff:- White gromil, feathered blotile of ilersp orango.

Dumont d'Crville.-Brieht cherry, flakid aud stripel rich earmine, listinct pure white blotell, white stribe in center of each petal. 1,50 


\section{GILADIOIUUS-GENARAI, COIAFCTION.-Cont'd.}

Each.

Eclair.-Bright scarlet, flamed tiexy rcal blotch pure white, with broad, white bands in the center of cach petal

Exlantine.-Pure white, tinged with dehicate jose, and profuscly flamed and edged with carmine-red.

Esmeralda.-Ground ivory-white, striped and Haked with carmine-red, lemon-colored blotch, tall and tinc spike.

Et endaud.-White, slightly suffused carmine

Engrene Sicribe.-Flower very large and wide, perfect, tender rose, with blazed carminate red.

Felicien David.-Iight carmine, feathered whit.o bloteh

Flamboyant.-Beantiful spike, fiery scarlet.

Flamingo.-Fiery red, bloteh of rich purple

Flavia.-Bright led

Floriau.-Cherry-lose, violet blotch, center of the petals streaked white.

Fulton.-Velvety-vermilion, bloteh briglit. purplo

(Aalut hea.-Blusl-white, with carmineblotel.

Frenze.-Intense cherry, Hawed witl lake, hitte blotch

(Aulliver.-Tall spike, of large, bright carmine Howcrs, conspicilous wlite bands in the mid. the of each petal, pale yellow blotch slightly strcaked, violet.

Hecla.-Fiery orange-searlet, ceuter pure white feathered carmine, niddie-sized flower.

Heruione.- - White ground, entirely covered with mincrous and delicate lilac and carmine stripes, large, pure white bloteh, slightly streaked violet.......................

Hesperide.-Profusely blotelied and flaked, bright rosy-salmon, ou a pure white ground.

Torace.-Ricl scarlet, harge, pure white

blotch, featlered red
Horace Vernet.-Bright purple-red, large, pwe white blotch, feathered red .............

Hortense.-Beautiful rose-color on wlite rround, flamed carmine.

Isane Buchanan.-The best yellow variety growu.

Iala. - White ground, sliglitly tinted witlı rose, Hamed with carmine roso, lower petals light yellow

Isabella-Puro white, with large, dark carmime-violet blotell

Isis. - Vel'miliou-searlet, wlite bloteh ........

James Carter.--Light orange-red, white

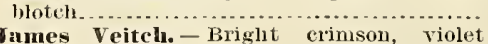

James Veitch. - Briglit crimson, violet

Jeane d'Arc. - White, slishtly tinter with rose, streaked and blotched carmine-purple feammette. - Large, bright, rose Howers, lielly striped and bloteled with rosy-earmine at tlie edges; close spike, vely fine.

foln Bull.-White, slightly tinged witl sul. plunt

Jupiter.-Light red, shating off to dark crimsou

La Candenr. - White, lightly striped earmine-violet

Lacepede.- Rose, tinged cherry and violet.

Lady Frauklin.-White, slightly tinged with rose, fucly streaked witl carmine, ant Hamed with carmine-rose .................

La Favorite.-Rose, Hamed with carmine, lower petals light yellow . .................. slighty Lamarck (de).-Cherry-colored, slightly very well ligliter, very large, pure white

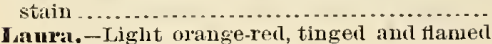
with carmine; jure white blot.ch ...........
Leander.-Lilac, beautifully shading off to carmine, a distinct whits band in tle middle of each petal, and conspicuous white bloteh on lower petals

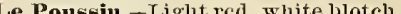

.75 Lesseps (de).-Pure white ground, profusely striped and bordered with bright carmine ... 2.50

Le Titien.-Very brilliant rosy.scarlet....... . .25

Lord Byron. - Brilliant scalet, bloteled and Haked purc wlite..............

Ine. Lesèble.-Pure wlite, rose blotch....

Mue. Momneret.-Delicate rose, with white stripe in the ccuter of each petal, carmine blotcli on salmon ground.

Mme. de Vatry.-Frcnch white, purplishcarmine blotch.

Iarie Berger--Rosy-lilac, blotched and striped with red, shading in to yellowisll-roso toward the center; dense spike of well. opened flowers.

Iarie Dumortier.-White streaked rose violet-purple blotcl......................

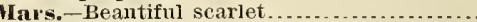

Mardha.-White, Hamed with carmiue-rose.

HIatador,-Brilliant carminc-red, striped and blotched pure white.

Iathile de Landevoisin- Twhite, slightly tinterl with flesh-colored rose, streaked witl

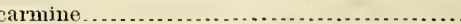

Iazeppa.-Orange-lose, largo yellow blotcl feathered with red.

Meyerbeer.-Brilliant scarlet, flamed with vermilion, amaranth-red blotch...........

Milton.-Cherry-rose, flamed with red.......

Mirabilis,-Light red
Mr. A. Brongniart.-Rose ground, slightly tinted with orange flamed with red, large, white bloteh ..

Mr. Lebi’un d'Albauc.-Brilliant red, pure white blotch

40 Mr. Legonve.-Fiery-red, wlîte line flown the midlue of the upper pctals, pure white blotelr...

Napoleou III.-Bright scarlet, white striped in the center of the petals .................. Nelly.-White, flamed with carmine-rose, large blotcl of dark earminc .................

10 Niuon de Lenclos.-Plush, Haked with rose.

Niobe.-Flowers extra large, of good shape, pale glossy rose, flamerl profusely with rosy carmine

Norma, - Pure white, occasionally very sligh tly suffused with pale lilac ............

Opbir.-Dark yellow, purple blotell ..........

Oracle.-Fery brilliant, cherry-rose ...........

Orphens.-Rose-cherry, Hamcd witlr carnine, carmine-purple blotch

Ossian.-Bright rose, tinged with violet and Hamed witl carmine, light ground..........

Ovide-Carminc-red flowers, witl a lilac sheen, Hamed toward the exlges witl. garnet-red, and pure white bloteh

Pactole.-Beautifinl yellow, slightly tinger with rose at the ciges, bloteh of a darker sliado

30 Panoraua. - Lilac, shaded, and mottled witl to brilliant carmine, throat crcany white, center of eacli petal banded wlite. ...............

Paruentier.-Clcar anlaranth, Hamed car.75 mine, aul tinged with lilac, pure white bands, carmine, feathcred on white ground.

25 Prsquiu. - Brilliant scarlet, shaded fiery red and striped with libac, white edges of petals slightly suffused with slate-color..............

Penelope.-Blush wlite, lower petals tiuted witl yellow, streakci carmine.............. Phebus.-Brilliant red, with large, pure white and very conspicuous blotell ................. 
GI, DIOI,US- ( FFN

Each.

Primatice.-Rose, slierlitly tinged with lilac, flatuel with blight carmine, carnuime blotch un wlito groniul.

Princesw of Wales.-White, Hamed witll 'all uine rose, deep carmine bloteh..

Psyche.-Delicato rose, borlered and thamel with dark earmine, well lighted ienter.

lygualiou.-Cherry-red, slishlity flamell with liel of a darker shate, pure white bloteli featlered violet, each petal lias a whitr bills down tlin mirlile.

Rebecoa. - White, slightly mottled and veined

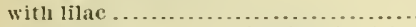

Redoute.-Rose, slichlly tinted witli violet, Hamed with loright camuine, large, white blotelı. .

Regina.-White, very slightly snffused with

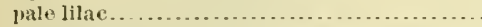

Reine IBlanehe.-l'ure wlite, dark curmine blotel.

Reine Victoria. J'ure white, carmine-violet bloticl.

Ric hard C'our-de-Lion.-Fine spike ot large Howers, of a bright crimson-red color, flumed and eled with simet, lower [w-tals spotted ind blotched goldin yellow

Robert Fortune-Orange-lake shatinte of tis burpla-criuson, veined white

Roi Leopold.-Blusli-rose, sliwhtly suftused with oratere and shaded deep chirrant-red, " lipto blotel.

Romulus. - Very brilliant lark red, linge pure white blotch, large white lines on the lower petals....

Rosea Perfecta.-Fine rose, tingerl riolet, center very light, white veins on all jutals.

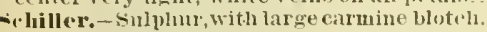

-ilakewpeare.-White, very slightly suffust: with rarmine-rose, large fusy blotelı...... \$ 0.50

-iella.-White, slightly tinted witli yellow mud rose, Hamed with earmine............. 10.

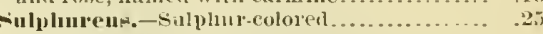

-illubide.-ivhite, thued witl camine, rery

large purple-carmine bloteh................

Sylvie.-White, slierlity elseri with delicate elopry-lose, throat very clear, perfectly sliaped, well opened flower's.

1.25) Talimnan. - Fine violet, witl a large majeri of bright carmine-cherry, veneal pure whito.

Talua. Fine spike ol rosy-cimmine flow'rs, Haned witl briglt carnine and stripel sear. let and pale violet: bloteh amaranth-red specklod with sulplur.yellow.

Thalia.-White, tlankel and streaked witl

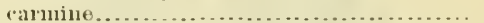

Theuim.-Fine spike of delieate satin-rose col ored flowers, conspicuonsly flushed with car nine, cream.colored bloteh

Thomas Methven. - Violet, tinged witl rose, center light transparent, sliaking oft to earuine-violet

Thunberg. - Light olange, sliadial cliriry,

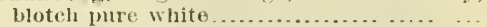
Van Dyek.-Crinson-amarantl, striped with white.

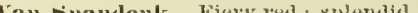

Virgil.-I3right, glowing crinsm .......... . to

.25 Virginalis.-Pure white, borklered and Haurd witl carmine; tlelicate.................. .50

Vulcan. - Velvety searlet-pnrple, shaded vio. let-purple in the ennter.

Zenobia.-Rose, slightly tintel witl violet, tlamed with dark carmine, white bloteld featlered with carmine.................

special enllection not broken at price quoted.

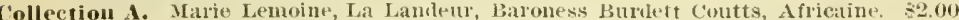

- B. Shakespearo, Meyerberr, Engesseli, Isiac Buchanan. \$1.00.

C. Engene siribe, ingele, Froebeli, Midi Jonnoret, ('Pe's, sylphile. \$1.00.

D. Ten gooul naned sorts. $\$ 1,00$.

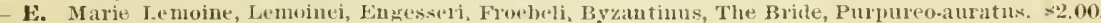

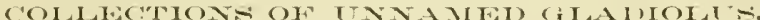

The following collections are nuale nj, from nany of the naned varietics whose names hare ixen lost

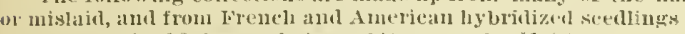

Collection I. 12 tine varieties, white grounc. s1.00.

- J. 12 fine varieties, rosy and reel ground, $75 c^{\circ}$.

İ. 12 tine varieties, yillow antlight ground. \$1.00).

1. 12 fine varieties, fine mixel lyybits. 75

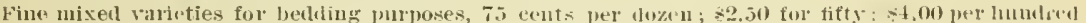
$\$ 30.00$ per thousanil.

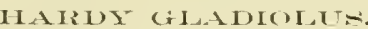

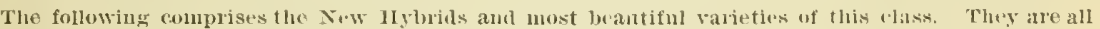
gowl growers, and very desirable:

Purpureo-nuratus. - This is a ue suecies from Vatil quite distinct from the conmon species of

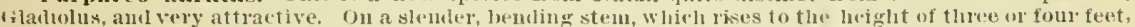
sre borne from eight to twelve nodkling flowers, somewhat bell-shiped in form ant yellow in color, with broad pmple stripes on the lower livisions within. Its bulbs are small, ind at the cull of lumg rumuers

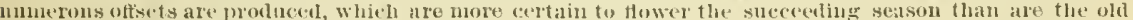
bullos. 20 . (2ach; ; $\$ 2.00)$ per dozen.

Tlue four following rarietiesare hyluribs betwen Gauda veusis and (Hatioluw purpureo-aulatus, having much larger and finer flower's than the list. ter, and of most intense coloring. They are ex. tremely landsone, and the prite at which they are now offered places them wthin the reach of all.

Engenneri.-Very deop pink, low wetals blotchesl brierlit maroon Each.

Froebeli. Flesh-colored, streaket with pink carmmoblotel, bortered witl yellow ...... Lemoinei.-Pukish cream, spotted ileep puxplish erimson, bordered with brierht vellow and salmony real.. 80.50 50$$
-
$$

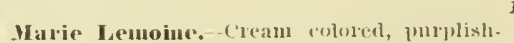

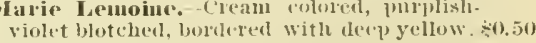

The following are the brst and most distinct of the remainder of the hardy varieties:

Byzantiuns.-(riuson purple (per doz., 50e. so. so.) Cardinalis. - 3right ficry scalet, flaked with wlite (per doz., 1.25$) \ldots \ldots \ldots \ldots \ldots \ldots \ldots \ldots$

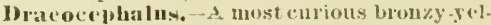
low Hower (per doz. $\$ 4.00$ ).

The Bride.-(Colvilli alba). - 1 most beanti. ful pure white variety (jer loz, s1.50)....

\section{2}

40 


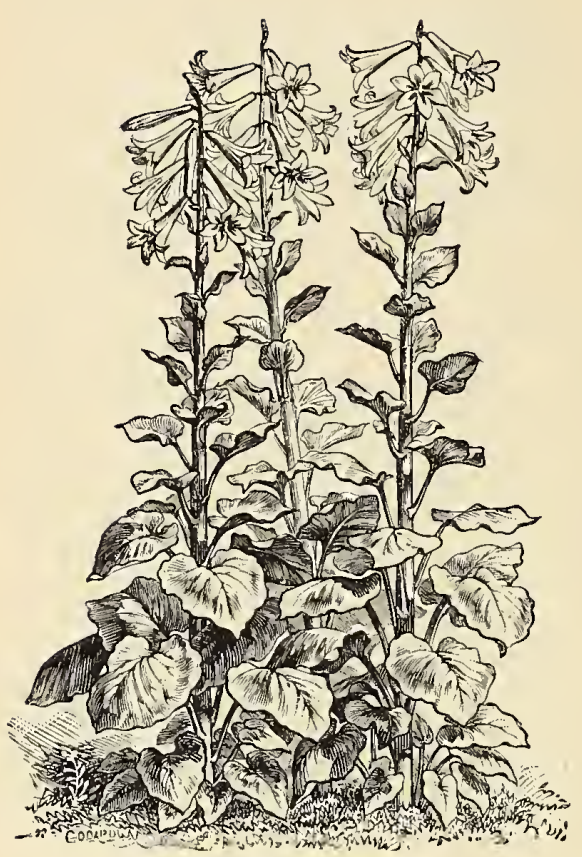

Lilium Giganteum.

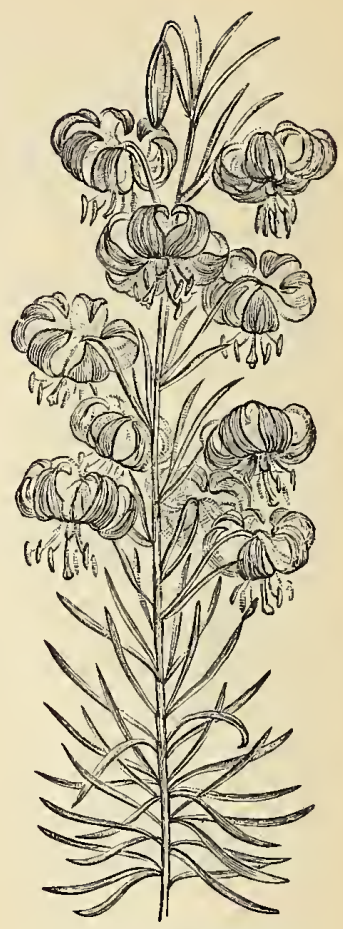

Lilium Tenuifolium.

\section{NEW AND CHOICE LILIES.}

Our collection of Lilies is one of the largest in the world, and contains all the new and rare varieties of recent introduction. See our Autumn Catalogue for directions for cultivation.

Lilium Longiflorum var. Harrisii. This is supposed to be a sectling of Lilium Eximium, the liabit ani flower being almost identical with that well known variety. It bids fair to eclipse all otlıer forms of Lilium Longiflorum, in size of flower, freedom of bloom, and, above all, its enntinnous flowering, and the ease with which it can be forced into bloom, even in milwinter. The flowers are trumpetsliaped, measuring from seren to nine inelies across, of good sulustance, and very fragrant. Habit of growtl, free but dwarf, height beiug from fifteen to twenty inches. Perlaps the most commendable feature in this remarkable variety is its distinctive characteristic of blooming two or three times in succession, without lest, one grower reporting that it flowered last year no less than threo times from a bulb no larger than a pea. We believe that, for a louse plant, it will be unsurpassed, while the ease with which it can be forced, and the durability of the cut flowers, render it indispensable for Horists. 1st size, 75 cents each, 7.50 per Doz.; $2 d$ size, 50 cents each, 4.50 per Doz.

Lilimu Longiflormm var. floribunda. This desirablo new variety is also of the Longiflorum elass, and was offered for the first time last season. It is a remarkably robust grower, and blooms about the samo time as $L$. Longiflorum. The bulbs grow to an enormous size, and protuco from ten to forty flowers eacll. A bulb of this variety was exlibited in New-York the past Spring, bearing one hundleil and forty flowers. It is a native of Bermula, and the bulbs we offer were imported from thero. 1 st size, 50 cents each ; 21 size, 35 eents each.

Liliun Gigantenm. With proper culture, this variety will grow from eiglit to twelve feet higlı, witlı large spikes of from fifteen to twenty flowers, of a fine white, striped reddish violct at the base, and of the most powerful fragranee; is uoarly hardy, requiring only slight protection for the young growth, against frosts and winds in spring. The large and beatiful foliage of this superb Lily cutitles it to a first place as an ornamental plant, and amply repays the delay that sometimes oeeurs in getting it into a Howering state. 3.00 eacll.

Lilium Tenuifolimm. Althougl not a new variety, this dazaling little gem is wortly of all praise. $\mathrm{Evel}$. one who loves a Lily slould secure several of these, as we now offer them at a price even lower than any previous wholesale figure. It blooms ont of doors about the third week of May, and its graceful, wax-like flowers, of a lovely vermillion-scarlet, cannot fail to impart mualloyed pleasuro to all lovers of the heantiful in naturc. It is easily grown, and, being a native of Siberia, is, of eourse, perfectly liarily. Extra selected Bulbs, 50 eents eaelı; 2d size, 25 cents eacl. 


\section{LILIES.}

For years past the name of our firm has been intimately associated witl the introduction of many of the lealing varieties of this matelless flower. Couvincing evilence of our efforts to main tain this reputation will be found in the following list, containing as it docs screral noveltics now offered fol tle first tiule in this country. It is satisfactory to be able to call attention to a substantial reductiou in price of many of the chuicest Lilies, and better bulbs of all tho standard sorts are oflered at lower prices than ever before. Tlo past season, having becu extremely favorable for the bulb crops, enables us to make this reduetion.

We cheerfully place onr cxperience at the disposal of all not practically acquinted with the varieties best alapted for decorativo purposes. Those desiring to experiment with a limitel collection will find the following assortments at once conomical and eflectife. They have been selected with great care, and will give a pleasing diver'sity of color and form, as well as a profusion and succession of bloom.

\section{SPECHA COLLECTIONA OF IILIEX OF OLR FELECTION.}

Collecion IR For (onservatory or Parlordecolation, 10 beantiful varieties (including $L$. Harrisii). S3 50

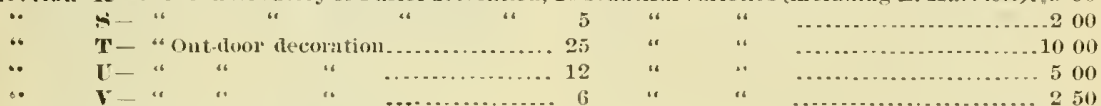

A BEAUTIFUL COLORED PLATE OF LILIES is now in course of preparation, and will bc mresented free to cvery subscribcr to the "American Gardcn," for 1883 , and (on application) to all ordcring Lilies to amount of two clollars.

\section{GENERAL LIST OF LILTES,}

\section{EUHRACING ALL THE MONT DEAIRABLE STANDARD VARIETIES.}

Lilimm Auratum (Golden-rayed Qneen of Lilies). This magnificent varicty has become on of the staudart favorites of the flower garden, and is cousidered by many the finest of all Lilies. Their immense blooms-measuring nearly a foot in widt when fmly expande-l -are procluced in great jornsion, ant are delicionsly fragtant. Choice lome-frown bulbs, 40 and $60 \mathrm{cts}$. each, according to size.

Batemana. A Jipaneso Lily, glowing from 3 to 4 feet high, ant griving richly colored unspottel Howers of a liright Apricot tint ; most lesirable,

- Browuii. A magniticent variety, with fine, largo foliago; flowers very large, fine white insille, purple outside. 'Ilhe stannens are a rich chocolate color, aul form a very distinct feature in this species,

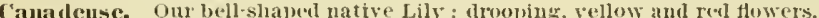

- fiagrans. A fragraut variety from Virginia,

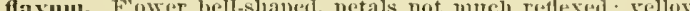

- - voruu. Vigorms grower; flower, rich dark red, . . . . . . . . . 20 200

- Caudidum. The well-knowu hardy garden-Lily; suow-white fragrant blossoms; one of the Irest varieties for forcing,

- - flore pleno. A double variety of the precelling, very showy,

- - st riat ulu. Flowers striped with purplo.

- Carniolicau. A fine early growing variety, deep orango red flower

- CHalc clonicum. Intensely searlet recurred blossoms, resembling 'Tur'k's 'als,

Colmubianmu. A variety from tho Columbia river; flowers bright reddish orange; densely spot terl with purple dots; a miniatnre form of $L$. Humboldtii,

- Comedor. Graceful, slender foliage, with numerons flowers of a brilliant crimson color,

Coridion. Similar to preceding, except in color, the flowers being yellow, with black dots,

- Elegans (Thunbcrgianum). Erect grower; deep maroon flowers

atrosanguine $\ldots u$. Rich blond crimson, spotted with black,

Alice Wilson. IBright straw.colored flowers, sparsely spot ted with black; yuitedwarf; a raro and desirable varicty,

- citrium. Dwarf, with beautiful light-yellow flowers,

robusta. Of robust liabit : Howers orange, changing to yellow, . . . . . . . 35

sancuiueuu. Elowers very large; crimson, shading to tawny yellow, slightly spotterl,

stauinosum. Blool crimsou; perfectly abuble,

Van IFouttii. Verg rich, decp scarlet, blotched with goh,

Veuustum. Lat 'st of all varieties, clear bnff withont spots,

Fxcelsm (Irabellinum). The stately form, beanty of color, ant lelightful fraqrance of this variety, has male it a great favorite wherever grown. It grow from five to six feet higl, and proluces from six to twelve nodling lilies, of a dolicate light lufft color.

- Fansoni. The flowers are borne in clusters, petals remarkably thick, giring the appear. ance of having been prolnced in wax. The outsile is yellow, streaked with white. and the inside bright yellow, spottel with purple. It is one of the most interesting and valuable species int rodnced in some time,

Each. Doz. 


\section{LILIES. - Cont'd.}

Eiltum Humboldtii (Bloomeranium). A remarkably fine variety, attaining the lueiglit of about five feet, and freely producing file, large thowers of a golden-yellow color, spotted with purple; a native of California,

Each. Hoz:

Baponicum Colchesterii. One of the most beantiful Lilies in cnltivation; a vigolons grower, produeing large flowers, the interior of whielt is pure white, and the exterior of a pinkish brown,

Krauneri. Since the introthction of the beantiful $L$. A uratum, nothing luas been offerer that will compare with this variety : the flowers range from a flelieate blush to rieh rose, and are deliglifully fiagrant. An aequisition of no little merit, owing to its beantiful shates of color.

- Lompillormu (Easter Lily). 'The well-known besutiful, suow-wlite, fragrant. I.ily; fine for foreing,

- - eximium. An exceedingly landsome, pure white variety, that slonll be in erery eollection,

folis albo marginatis, A ristinct varioy, with foliage molered with pure white; very searce,

Takesina: A late rariety, with fine foliago and large whito flowers, _. . . . . 30

Wilsoni. Similar to $L$. Longiflorum, but tle flower is larger and tube longer, . . . 40

Leichtinii. A beantiful Japauese speeies of neat and elegant labit; the flowers are pre canary-yellow witl erimson spots; a real aconisitiol,

- Martagon (Turk's Cap). Various colors mixel,

alba. Pure white, very searee,

Dalmaticum. Rieh, glossy crinson-puple. A magnifieent species,

Maritimul. A new California rariety of a teep rentlisl orange color,

Maximowiczii (Fortunii). Like a tiger flower, but nole delicate ant no bulblets out the stellu,

Monadelplunu. Rich citron color, spotter witl black; one of the best of Lilies,

I'ardaliumu. Searlet, slialing to rieh yellow; freely spotted purple brown,

Parryii. Al exquisite California variety ; clear, vellow, trumpet-sliaped flower,

- Paxvin. Cnrionsly slaped canary-yellow flowers, sliglitly spotted witl purple,

- Eomponium Vermi. Bright crinison searlet, somewhat resembling L. tenuifolium, but more robust. An elegant variety,

Pulchellum. Brilliant crimson uprixlt flowers of star-like appearance, spotted witl blaek ; new and lishly desirable,

beciosnu Albun. Pure wlite aut rery fragraut, Monstrosum. An interesting aud distinct variety, witl a broad, flat stem; jum white thowers; very floriferons,

- Kraetzeri. Pure, clear wlite; very beautiful, . . . . . . . . . . Delpomone. A magnificent variety, deep crimson, with blood-colored spots and borklered witl wlite; very desirable, .

pracex. Color pure white, witl a aliglit rose tint on the ends of the petals; form lerfect; petals nore reflexed than in the other valieties of the species. The fringe in the eenter of the flower is very long and finc, giving it an exquisite appearance; it is perfectly haxty,

roseum. White, spotter with rose,

rubruu. Rose, spotted with zimson,

- - Loustrosum rosemu and pubrum. Distinet varieties, with biond, flat stems, aud in color sinilar to the two meeding : free blooming and effective. Eitler variety, .

- Superbmur. Beantiful and riel as many of our native lilies are, this far excels them all, bearing, as it rloes, a pyramid of yellowisll-red thower's, from twenty to fifty in number : bloous early in July ; il good soil it will irenuently leaell the lieight of eight feet,

- 'Niginum (Tiger Lily). Orange-salmon, spotted slack,

flore pleno (Double Tiger Lily). This is a plaut of stately habit, rrowing from 4 to 6 feet high ; foliage dark gleen, very long, bearing an immense number of double, bright orange-red flowers, spotted with blaek,

- mubellatmu. Of vigorous growtl, free blooners, and in eolor vary from yellow flaked witlı red, without spots, to yellow or red eovererl with tots; very showy, . . .

- Wa!lacei. A magnifieut Japanese variety, with beautiful, elea buff thowers, spotter with black; very listimet,

- Washingronianum. One of the most beautiful Lilies yet introducril flowers ereet, pure white, with bright scarlet spots. l'hey are produeed in great mumbers, and are very ilagrant, plant one foot deep in well-drained soil,

\section{NEW GIANT FRENCH ANEMONES.}

Preferrea by many to the Dutel varieties, being of stronger habit, and produeing a greater abuudanee ant larger flowers of the most brilliant eolors. Tho tazzling line of the "Fulgens," and immense size and beautiful tints of the donble-flowered varieties, cannot be exeelled by any spring-blooming plant. Aneunone fulgens (Scarlct Windflowcr).-Flowers large, of the richest vermilion or seirlet

Auemone, single, French.-Splendid rarieties mixed. 20e. eaeli, \$2.00 per doz. "6 dowble, French.-Splendid varieties mixed

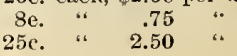




\section{MISCELLANEOUS BULBS FOR SUMMER CULTURE.}

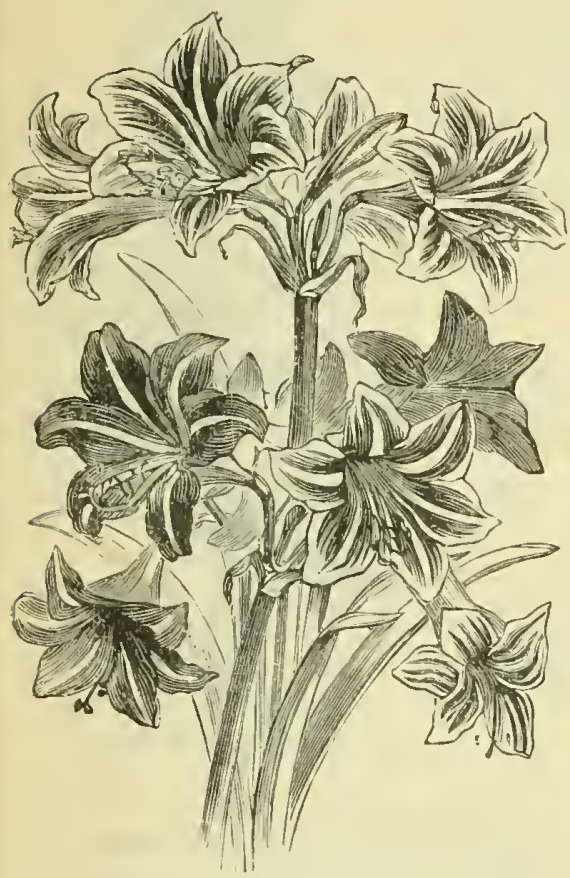

Amaryllis Vittata.

\section{AMIATYILISS.}

Bulbs of rare beanty, with large drooping, bell. shaped, libs-like tower's, varying in color from the richest crimson to pure white, striped $x$ ith erimsom or scarlet. They are of the casient possible culture, and a very little management wonlu secure a sue cession of blom throughout the yein, thins moliting an inportant feat ure in collections of plants, whelher

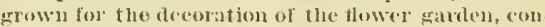
servatery, or drawing-room.

Aunaryllis atamasco, pink aml white,

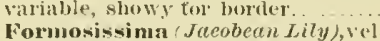

Formosissima Jaeobean Lity), rel.
vety crimson, at desirable borter rety crimson, a desirable borter

Bella Dorna (Bella Donna Lizy),

white, flushed with rosy pmiple...

- Iongiflora, alla and rosea, fiue.

Intea (sternbergia), a handsome,

showy, yellow antum tlowering

bults.

Each, $\quad l n z$.

252.30

60 6i.01

.75

5t) $5 .(0)$

$25 \quad 2.50$

Vitrata.-Tlese mannificent varieties are vig orons in their growth, and protace a free supply of fluwers, are tlaked aut striped with the most striking tints, and justly esterenel the most beantifitl of the Auaryllis family.

Wo offer red or white gromm hishrids, all batt. titully' striped and faked, $51.25 \mathrm{eceh}$.

\section{VAIIATA I'UIRI'UTREA.}

(me of the nost beantiful and desirable plants grown, prodneing harge crimsun searlet lily-like, Howers, in heats of tive or six blomms each, which renain a long timo in perfeetion. Large bulbs. if kept growing, will tlower several times dhring the year, As easily cultivated as the Calla Lily. Priee, io cents each; $\$ 4.00$ per dozen.

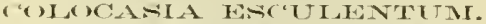

(hnozon relso as C'aladium Eiseulentum.)

One of the most beantiful and striking of the orna mental foliaged plants in enltivalion, either fon cult nore in large pots or tulbs, or for planting ont on the lawn. It will grow in any garden soil, and is of the pasiest culture. When of full size it stauds about five fect high, with immense leaves, oft en measmring four teet in length by two and a laif in breatth. vry smooth, of a light green color, beantifully veined and variegated witl dark grren. The roots shonld be preserved in dry sand in the cellar during Winter oat of danger from frost. A plant shonld lo. in every collection, how ever suall. 25 to 50 cents each; $\$ 2.00$ to $\$ 4.00$ per dozen, according to size.

C1IAIIITMIS Fancy Foliaged.

It is no surprise that within the last few years these elegint plants lave become popular favorites. for a bed of them is a sight nusurpissed for beanty aul brilliancy of variegation. Most of the varieties do werl, planted in the open $\mathrm{ng}$ romnt, in a partially shaty and moist loeation, about the first of June. They grow rapidly and spreat their leaves, glowing will the rich rolors of the tropies, mutil fader by the.Autumu frosts. Majegined and delicately traced with a net. work of shater green on a snow.white gronuct, bronze tipperl with like, slowing a metillic. luster in the sun; rose, violet, carmine, gohten green. crunson, and, in a wort, almost all colors can be. fonnd in this plant. As exhibilion plants, for tairs in Smmer and Fall, when pot-grown, they are nn. equalet. Eightecn distinct sorts. I'rice, $30 \mathrm{c} n / \mathrm{s}$ eneh ; 83.00 per dozen. Never and seareer varieties. 50 eents eaeh ; $\$ 5.00$ per dozen. 


\section{DOUBLE TUBEROSE}

\section{(Polianthes Tuberosa).}

The tubers of this delightfully fragrant flower may be plant. eil from January until March. Whero a succession is reqnired, and can be accommodated with a warm grecnlouso or conservatory temperature, planting may begin with tho former period: but wliere conrenience is limited to a hot-bed and rreenhouse, tho latter period is suitcd. In pianting, remove the nseless small offsets around the main loot, place a single tuber in a pot six iuclies wirle, or a group of two or three in a proportionately larger one. Use good rich-bodied loam.

Each. Per Aoz. Fer 100. Flowering roots . .......................\$0.08 $\$ 0.75 \$ 4.00$ Large flowering roots............... $.10 \quad 1.00 \quad 5.00$ Extra large flowering roots........... $.15 \quad 1.50 \quad 8.00$

\section{NEW DOURLE TUBEROSE.} ("The Pearl.")

This is a new and cutirely distinct form of the old rouble tuberose. 1ts chief characteristies are its slout robust stem and great size of flower's, the latter being as freely prodnced as in tho common sort, while they are quite donble the size and of pnrer white tlian tho old variety.

Each. Per doz. Per 100. Flowering roots..................... \$0.10 \$1.00 $\$ 5.00$ Extra large flowering roots.......... $.15 \quad 1.50$

\section{NEW TUBEROSE IVITUI VARIEGATED FOLIAGE.}

A beantiful plant, either for vases, borders, or planting ill groups or beds. The leaves are finely striped witl bright yellow lines. It flowers earlier thau any other tuberose. Tho Hower's are large, single, and deliciously secnted. 25 cents each; sez.50 per dozen.

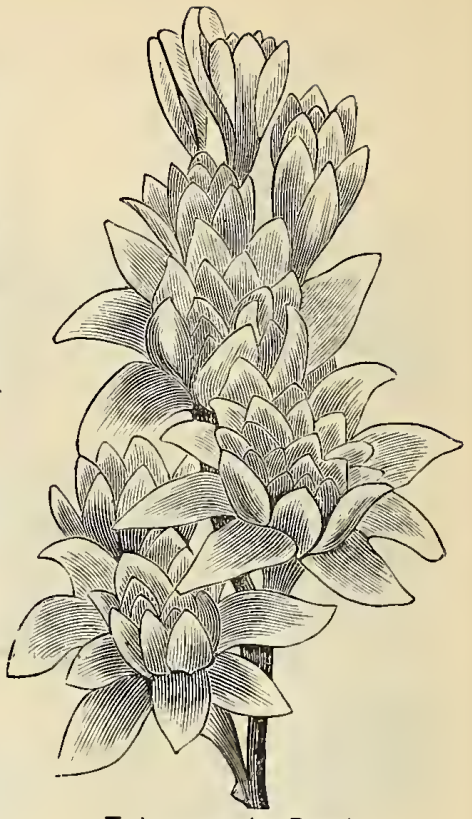

Tuberose, the Pearl.

(One-half the average size.)

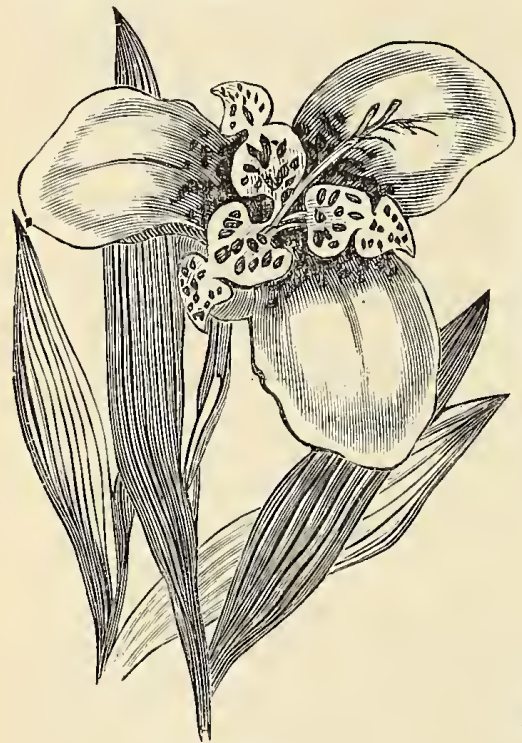

Tigridias.

\section{TIGRIDIAS (Tiger Flower).}

A genus of Mexican bulbs, growing about one and a lialf feet bigll, and protucing flowers of tho most exquisite beauty; flower's large, about fonr inches across, of singularly curious shape, and the color of each variety gorgeons and purcly contrasted. No flower can snrpass it in beauty. In bloom from J uly to the first of October. The bnlbs may be planted any time in May, or tho first of J mue, about two. inches decp, in any garden soil, and require no particular care. In Antumu, after the tops are killed by frost, take up the bulbs and leep them in a dry place a way from the frost until the timo of planting an the spring.

Conchiflora.-Ricliest orange, variegated Each. Doz. with golieu yellow, and spotted with black.\$0.15 $\$ 1.50$ Pavonia.-Richest scarlet, tinged and spot. ted with pure yellow......................... $.15 \quad 1.50$

\section{MADEIRA VINE.}

A half-hardy tuberous-rooted climber, of rapia growtl. with thiek, glossy, light green leaves. It bears a profnsion of graceful racemes of delicionsly fragrant white flowers, and for screens or trellis work, in a shcltercil or smnny situation, no better plant can bo used. Eacl, 10 cents; per doz., $\$ 1.00$; per liund., $\$ 5.00$.

\section{DOUBLE DAHLIAS.}

When well-grown, we know of no Antmmn flowering bulb more stately in appcarance, or more varied and beantiful in color than tho Dahlia. They requiro a well-trenched, deep, and very rich soil. Plant out in May or Jume, and during growtl apply eopions waterings of liquid manure at lcast onco a week. Oux stock of these embraces cvery desirable variety in cultivation. Dry roots of Dahlias grown in small pots ibongl the Summer, which will bear transportation to any part of the world, can be supplied after the first of October. They are more compact and will flower equally well with the gronnd roots. 30 cents each ; $\$ 3.00$ per doz.; $\$ 20.00$ per hundred. 


\section{General List of Plants.}

Eubraciug all the uow desirable

\section{NEW, RARE, AND STANDARD VARIETIES.}

We can either send by mail or by express, as desired, only when schdiner by mail a smaller size of plant is seut; but whenever it is practicable, we strougly alvise that plants be sent by express: for, thengh the purchase is recuirerl to pay express charges (which are nsually urolerato, frour our liwht system of packing;, fet he always buys chenper-gnality of plants considered - than when plants are seut by urail, free.

\section{ABUTII,ONE.}

Arthul Belshan,- beep erimson-orange. Blaudii.-Orauge yellow, veinetl crimson,

Blnod-Red.-Color blood-red, with very dirk vins; flowers large and very freely produced; a crand varioty. $50 c^{\circ}$. *ach.

Darwiui Major.,-Buft.orange; fine,

Emblem.-Drooping varicty, witl crimson aud brouze tlowers.

Josepli IIill.-Orange, erimson reins,

Johu'lborpe. Bright grollow ; tinest of its color.

Roscefloruu. - Rose-colored Howers; tine.

-nossitorul.-White, compact, and tive.

Thompsoni. - Folinge finely markerd. $25 \mathrm{c}$, each; 10 varieties, $\$ 2.00$.

Agerntum, New White Blauche.-A pure white, A rerutum, very desirable for eut thowers, both u winter and in summer, 25e. eacli; $\$ 2.00$ per doz.

-John Douglas.-Deep nazarino blue, compact liabit, profuse bloomer: 25c. eacli; 82.00 jer loz.

Alyssum, Double White.-Similar in erery way to the sweet Alyssum; valuable for cut flowers at all seasons. 30c. tach; $\$ 3.00$ per dozen.

Anthericun repens vitatum var.-Beantifully variegated with white and green stripes; one u the best plints for lianging baskets. 35e. each.

Aloysia Citriodola (Lemon Verbena). A well known shrnb, indispensible tor the flelightful fragrance of its leaves in the construction of bournets, etc. 15 conts to 25 cents rarch.

Aralea Indica. -12 finest and most distinet varietirs. 50c. ench; $\$ 5.00$ per doz.

\section{I3FGONIAS}

Begonia metallica.-An entirely new and dis timet spacies, intermediate between tlue Rex viliety and tho stronger growing sroen forms, The plaut is of slurublus erect, free growtl. br:meling into numerous tower scapes, which are pale bink, covered with bright coral hairs. The laves and strms are bright silvery bronze, ant like the flowers, costued with deep coral-red liairs. 50c. (each.

- schmidtii. - I beautifnl free-flowering variety with pure white flowers, slightly reined with pink: the foliage is thick green, with a metallfo lustrir. 35e. rach.

- Rubra. - (New), bearing in profusion beatiful coral-colored flowers. $30 \mathrm{c}$ each.

- rcx.-Large ornamental leaves, 10 varieties. 30c. eircll.

\section{BOUTAIRDIAİ.}

Bouvardia Alfed Neunce.-A charming novelty, with bealutiful double pure white rosette-like Howers, which are prodnced very freely. 50c, each.

- Davidsonii. - White, fine form.

- Elegans. - Bright carmine, large+ Howers.

IIumboldtii.-Lare pure white.

- Leiantla.-Briglit searlet.

- Lady IIyslop.-Bright flesh color.

- Sanquincu.-(New), tinest deep crimson. $25 \mathrm{c}$ eachl, ver doz., $\$ 2.00$.

Calla Ethiopica (Lily of the Vile).-Fine plants. 30c. ench : s:3.00 pri dozen.

Camellia Janouica.-Double white, $\$ 1.00$ to $\$ 5.00$ each.

- - in rariety, colored, $\$ 1.00$ to $\$ 3.00$ each.
Campsidium filicifolium.-An elegant ("limber, of so delicate and gratcetul form as often to be mis taken for a tlimbing fern. Tlue fuliare is bright green; it is one of the choicest plants tor latmoring baskets. $3 \tilde{u}$ c. eacll.

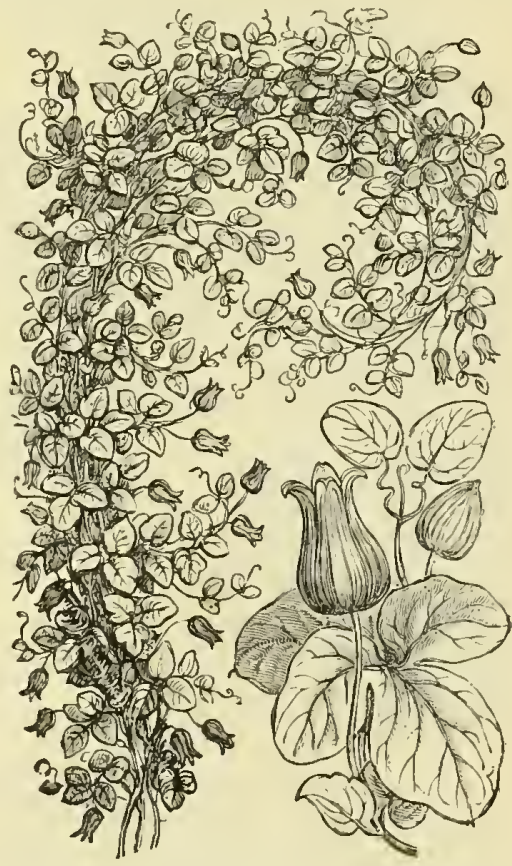

NFW SCARIAT CIAMTATIS. (hee leseription, lage 58.)

$$
\text { CANNAS. }
$$

The following are a superb collection of these noble plants.)

Atropurpurea.-Fine bronze-purple leaves; tall. August Ferricr.-Rerldish-green leaves, searlet tlower; fine.

Barilletrii.-A fine aistinet tall-growing vartety.

Biborelli. - Sten and leaves green, with real ribs and vins; fine.

Bremingsi.-Beantiful variety, light greon leaves, variegated witl whito and yellow; very lwarf. Gigantea. - Very tirll growtl, dark bronze foliage. IIouletti.-Broney-grecen aud brown foliatre; tall. Insignis.-Flowers scarlet and sellow; rery dis timct and effective.

Metallica.-Bronzy leaves compact, stiff growth. Nigricaus. - Leaves uearly blark; fine tluwrots.

Premices de Nice.-Liglit green leaves, very large yellow tlow ris.

Fan Honttci.-Brown foliage, broal and massive.

Warsceviczi. - Dwarf-grower, bronze-leaves; tine. $25 \mathrm{c}$ euch; $\$ 2.00$ per dozen. 
CARNATIONS.

Bridesmaid.-Very large white flowers, some of which have salmou-rose, shell-like blotches in center of thowers; delicions elove perfume.

Crimson King.-Flower's crimson; a fine variety. 4traee Wilder.-Color, a beautiful delicate pink; flowers large, finely fringed, clove-seented.

Inalequin.-Color yellow, erimson, and maroon.

Minsdale.-Rosy pink, cdged white, sweet-scented.

Mrs. C. Chessons.-Blusli, striped and spotted roxe, very desirable.

Perer Henderson.-Very large pure whlte flowers: a crand valiety.

Princess Iconise.-Color pink; Hower's large, well formed, beantifully fringed, and stoong clove. scented.

25c. each ; $\$ 2.00$ per do\%.

\section{CIIRYSANTIIEMTUMS.}

These are beeming more and more popular ;our collection is one of the very best.)

Those marker * ake small-flowered.

Alba Perfecta. - Pure white.

Alex. Pele.-Rose and crimson.

Bolb.-Crimson.

Bonquet Blane.-Puie white.

Cirele.-Pink on lemon.

C. H. Glover-Lovely yellow.

Dr. Sliarp.-Magenta erimson.

Fremy. I free-flowelung variety, with peculiar shaped orauge-red flowers.

fien. Camiobert.-Lemon-y ellow.

George Glemiy.-Golden-y ellow.

Aloria Hindi.- Yellow.

Le Grand.-Peach color.

Hue. IRoux.-Flowers very large, paeny.formed, imarantl-red, reverse of petals white.

Mue. Crinue.-White.

Mrs. G. Rumdle.-White.

Vontgolfier.-Crimson.

Vodel of Perfection.- Rose and white.

Pink Perfeerion.-Pink.

Pride.-l'ure white; fine.

prine ess Lonise.-Rose.

Sans sonei.-Deep violet and white.

Sanoninemm.-Deep blood-red. Very effective.

Tremple of Solomon.-Golden yellow.

Veuns.-Rose.

Virsin Rneen. - White.

White Prineess, - White.

$$
\text { 25c. each; } \$ 2.00 \text { per dozen. }
$$

$$
\text { JAPANESE VARIETHS. }
$$

The peculiar twisted and thread-like petals of this section are unlike auy other flowers growu.

Bras IRouge.-Rich velvety red, with bronze tips, a showy variety, early towering, large and fime. Cite des Fleurs. - Velvery amarauth.

Bavly IRed Dragon.-Deep erimson and gold.

Ela ine.-White and lavender; early flowering.

Frulton.-Bright golden yellow.

Golden Dragon. - A truly beautifnl variety, witl long threar-like petals, often fonr inches long, twisted and curved, Hower's in cluster's of a rich golden-yellow, luabit dwarf.

Her of Hagdala.-Blood-red, very larare.

La Chimoise-Matoon and gold, large thowers, much Huted and friller.

Magnmm 130nmu.-l'ink; a rery pleasing and distiuet sliade.

Mme. Chapon.-Orange aud sellow; a novel and slowy variety.

M. Castel.-Flowers large, with long, twisted petals, fiery crimson aud gokd.

M. Maney,-Flowers deep violet and white.

Y. R.onx.-Very large, deej red-erimson flowers.

M. Plancheuau. - Liglit blush, rose striped

Mons. William Bull.-Crimson, tipped with gold.

Parasol (1380).--Flowers very large, of a peculiar shade of deepest bright chamois color: 25 c. each; $\$ 2,00$ per dozen.

\section{CIFMATIS COCOINEA. (New Scarlet Clematis.)}

This is a plant of reeent introduetion and of great merit, being perfeetly liardy, growing, wlien weli establislied, from 8 to 12 feet ligh each season. The Howers are from 1 to $1 \frac{1}{2}$ inclies long, bell-shaped, and of the most intense coral searlet, shining as if polished. They are produeed from the axle of each leat, ou strong, wiry footstalks, 3 or 4 inches long, standing out boldly from the foliage. The leaves are of a rieh, decp, shining greeu, deeply lobed and of thick texture. The plant is herbaceous, dying down to the grouml-line each year. It begins to floweriu July, and eontinues until cut down by the frost. Plants established 2 year's liave had on one single vine 25 Howers and buds in view at one time. Priee, 50 eents each; 3 plants for $\$ 1.00$.

Clematis Jaekmanii.-Intense deep violet-purple Howers of large size, glowing rapialy and cover ing over a large space very quickly. Price, for strong 2 years old plants, grown in 5 -incli pots, 75 eents each.

We have a limited stoik of 25 of the very best varieties of Clematis, embraeing all sliades of light and dark purple, laveuter, and pnre white of the same quality as Jackmanii; $75 \mathrm{c}$. each.

Clerodendron Balfouri.-Magniticent elimbing plant, bearing pnre white bracts and bright searlet thowers, lasting iu perfectiou for two months. 35e. eaeh.

Cobea Scandens,-Handsome free-flowering climbing plants, growing rapidly, with large, bellshaped, purple flower's. One of the best summer elimbers, and an excellent house plant for Winter. 30 cents each ; $\$ 3.00$ per dozen.

\section{COI AEUS.}

Alleglıeny. - A charming variety, with bright greeu leaves aud lemon eenter.

Buming Bush.-Chocolate gronud, striped and Haked with purple and crimson.

Midnisht.-Deep violet purple leaves, shaded real. much serrated; a grand bedder.

Nompareil.-Fine, large lcares, maroon, edged with crimson, mid-rib creamy white.

Old Gold.-A distinet and beautiful variety, with much laciniated heaves of bright deep gold, spotted with crimson aud błack.

Rosedalc. - Large leaves, lemon ground, bright carmine center.

Unique.-A varicty with the leaves very deeply lobed and cut, rich deep yellow and dark erimson purple.

25 eents eaeh; the sercu varieties for $\$ 1.50$.

We grow ail the most popular aud ristinct old kinds, including Verschaffeltii, and other good bed. hing kinds, 15e. each; 1.50 per do. Special prices given for large quautities.

Crotons.-Eight distinet varieties of this very elegant greenhouse plant. The rieh, glossy leaves are striped, spotted, and marbled with various sliades of pink, yellow, and red. 50c. eacli.

Dahlias.-Iu many choice varieties, including all shatles of eolor to be found in the Dithlia. 300. caeh ; $\$ 3.00$ per dozen.

Daplme Blorata.-A well known greenlouse plant, bearing elusters of small, pinkish-white Howers, exquisitely fragrant. 75 cents each.

Dracena Teruinalis.- Scarlet for center of baskets, rases, ete. 50e. to $\$ 1.00$ each.

Guebaris Amazonien.-An exquisite white, star. shaped flower, for greenhouse enlture; deliciously fragraut. $\$ 1.00$ eaeh; $\$ 9.00$ per dozcn.

Eraponien green, longitudinally. Next to the Zebrina, the most ornamental of all liardy grasses. Large plants, $\$ 1.00$ each ; $\$ 9.00$ per dozen. Sinaller, $50 c$. eaeli; $\$ 4.50$ per dozen. 


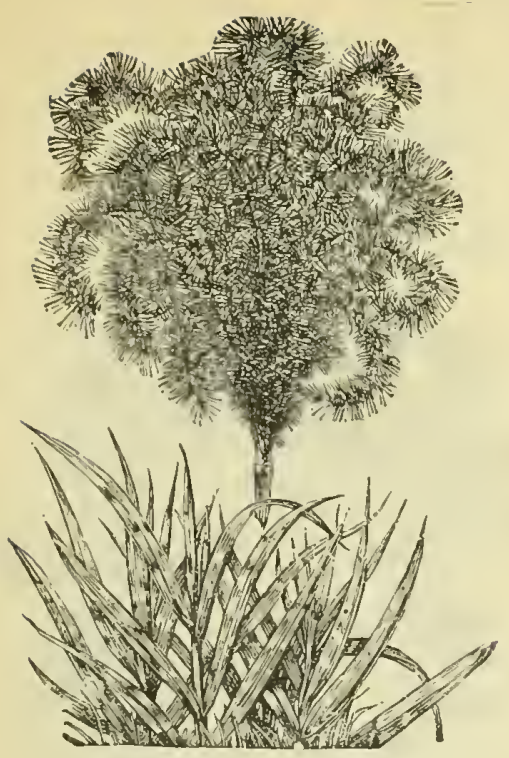

Eulalia Japonica Zebrina.

Fulatia Japonica Zebrinn-Onlike everythiug (') so, the siripius or marking is across the leat instead of longitulinally. It grows from four to six fert in heiglı, forming a most striking and grateful plant, res('ml)ling nothing else tlat we know of in cultivation. Tlese (-spanted flower remembles the astrich plume, and when dlricel, tlu? kecufor years. Plant entirely hardy. First siz" $\$ 1.00$ eacll. Serwud size, 75e, earell.

Echeveria.-Usefnl eitliej as pot plants for the orative pulposes, or for lecdeling out in summe pliey thrive best if plantul in a dry situation, crowiug vher. most ot her plants would fait. 250 cam

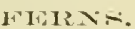

No colloction of plants, however small, is com plete without a few rarieties of these clegant plants. 'lle'y arc now rely generally cultivated; their grobt tiversity and gracofulness of folinge router them invaluable as plants for Warelian cas's, former ic's, ant rock. work, or similar shaty aml moist sitnations. 30c. a.ach; ; 3.00 per lozen.

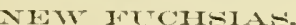

Depute Berlet.-Flowers lawere and rery domble, enolla violet. with wetallic sllatings: tube anc sepalk briglit rect.

Ciracienx. - Flow's's large sincle, tmbes and scpats lisht. re(l, ('orolla laventler-blue, lablit. dwart ant eoupsct; carly and fice-flowering; will make a (ime narket plaut.

Josepli Konnin. - Domble, very large searlot tub ancl sepals, corolla violet-blus, siripeol clo"ps-searlet Jules Ferry. - I rery fiue toulle flower, suon habit, freetlowering, mnnems: tlowers after the style of Itenterson's "Avalanehe."

New Mastodonte.-Flowers globular, devp crim soll tube aul sepals, with rich, derlu violet-colored corolla, of huntuse size; a crant varicty

Pascal. - A grant atlition to the basket Fuchsia with strong, spreading haluit; color light red ant rosy purple; tine, froe grower; groot.

$$
\text { Price } 35 \text { cents eacli. }
$$

of the older varietius of Fuchsias we grow a very large stotk, embracing all the most desirable in cul tivation. Wr believe that for quality of plauts aur excelleuce of varieties, no better collection can be fomul. 20 cents eroll : $\$ 2.00$ per dozen.
DCITHI,F: SHIHIOI,ING ( IHISANITMI OF 188?.

Barbara.-ritliant decen mangescallet; trnsses rery large, A liroge, finely formut tlower.

Bernice.-Deep rich scarlot, with a distimet white "ye ; very pleasing variety.

C'onquest.-Large tlusses of well.formed tiow els; color, fawn, witl disinet purple-bronze sluding.

Dione.-Immense deep crimson flowers; very frecly produced on long foot-stalks.

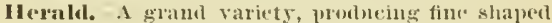
tlowers, of a there brouze elamois color.

Inspertion, - Vtry larero trusses, colol seft reti, shinded starlet pimrple.

President.-Deep pink, unper petals milked white. trusses lasere and frecely produerd.

rocisnl.-Large trusses of tinely formed flowers

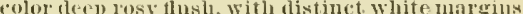
Price, 250 , wach; of 8 varieties for $\$ 2.00$.

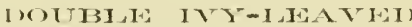 CI:R I NITMIS-}

Indre Theuriet (Lemoine),-Delicate rose, (')oulcel with salnuts, slıtlcel darker, a ntw e:olor.

Inna Plitzu (Pfitzu).-Flowers very lange, semi. cloubla: : color cle's rose.

Iucy Lemoine (Boucharlat). Flowers singlu. show white, delicate lose at the ceuter. Vury loautiful and distunt

HIle. ('. Soupert (Lemoine).-Flowers rery rouru

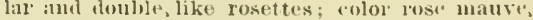
tinted with lilile.

I. Dubus (Dubus).-Flowers simele, very linge:

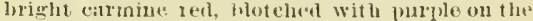
nivel potals.

Robert Fortume.-A grand rariety, witl fim lare carmine, shated pink flowers: trussug linge and ireely probluced: labit compart.

The alowe are all ritremely firs and valuable acepuisitions.

25 ceuts cach : 6 varioties for $\$ 1.25$.

GIEIRANITMT TRICOOAR.

Th enurey in works any inlea of the beantifnl mark. ings of these is simply impossible. Every color ind shade to be seen in Antum leaves art fond ill the foliage of this class, Best varietics, $40 \mathrm{c}$. each ; \$4.01) 1).1 dozen.

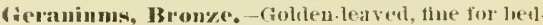
sling. 30\%. eatuls; 83.00 perr dozent.

Cieraniums, silver.-White-latvel, Mount of

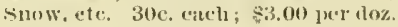

ficraninus ficented.-Six sorts, reilly desinablo. 250 . cach ; $82 ; 25$ jer lomen.

(1eraniums Prolargonimus (Lady Washington (ieraniums).-5oc. arch ; 4.50 per dozeds.

\section{I'I; I IIRC;CNIIJAI-}

(1.arly U'ashington. Type of Geranium.)

Fred. Dorner. - An entirely distinct and beantiful varuty, pussessing nearly all the everbloming Ifralities of the ordinary bechling Geraniums. "Tlu" Howers are of good siz", of al lovily sliaten ear. mincerinson, with maroon.(riuson markings.

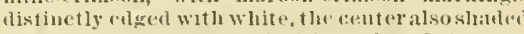

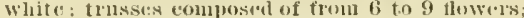
the habit of growth is vigorolls, l lwate abl t:om pact : valuablo either for cut flowers or gentral decoration. 750 ciall.

we can also ofler a full ("ollection of all the most tesirable and standart varicties of this elass, the markings and slmules of whicll are so varicel that description enveys no alequate idea of thair leauty. We will formirt a set of twelve of the vely best, including all the colors foumt in the cliss, for $\$ 4.50$; single plants, 5uc. each. 
GERANIUMS, ZONALE.

(A selection of the very finest and well tested varieties.)

DOUBLE VARIETIES.

Amelia Baltet.-Pure white, large trusses.

Dr. .5. P. Kirt land.-Carmine-red, slraded purple. Dr. Phinney. - Intense scarlet, shaded with decp. est chestuut-crimson; a variety of great merit.

Hazel Kirke.-Immense trusses of rich purple crinusou towers; distinct and beautiful.

Henry Cammell.-Largest Howers, bright scarlet; onc of the most beautiful.

J. H. Klippert. - Immense trusses of deep scarlet. Le Niagada. - Large trusses of the purest white Lemoine's Camell.-A grand, deep purple, snf fused with crimson and scarlet; new. 35c. each.

Mary Geering.-Pure rose pink, white markings; distiuct and desirable varicty.

ICLeod.-Immensc scarlet trusses.

Mrs. E. G. Hill. - Entirely distinct, ground color fale blush, overlaid with a lavender shade.

Mons. Dibos. - Blush, shaded rosy salmon, tistinct.

Peter Henderson.-Exceedingly bright orange. scarlet, with base of petals pure white.

Remarkable. - A much improved Ernest Lanth; trusses very large.

Richard Brett.-Immense trusses of flowers; an entirely new shade.

Robert George. $-A$ deep crimson scartet; a remarkably free flowerer.

The Blonde.-A distinct and beautiful varicty, ground color salmon, deeply shaded orange; base of petals white, with a distinct margin of wlite.

Ville de Namey (Lemoine).-Enormous trusses of large flowers; delicate rose; rery leantifnl.

Victor Hugo.-Rich color, often marked white; ground color orange salmon, Price, except where noted, $25 \mathrm{c}$. each; por twelve varieties, $\$ 2.50$.

\section{SIXGLE VARIETIES.}

Baun ford's Glory,-Bright cerise red.

Beacon.-Flowers of deep crimson-scarlet, of fine shape, small whitc eye.

Cardiua lis.-Very deep crimson, distinct.

Clement Bontard.- White, shaded blush.

Corsair.-Deep, prire scarlet; very tiue.

Dr. Denny.-Purple, shaded blue, top petals orange color. 30c. each.

Happy Thonght. - A novel style of leaf variegation; flowers rich magenta rose ; a good bedder.

Jealonsy.-Deep orauge; new color

Jean Sisley.-Scarlet, pure white cye.

Mary Hallock Foote.-Briglit pale salmon, with a pure wlite eye; ilumense trusses of splcudid shape ; a graud variety.

Master Christiue.-Pink ; best bedder of the color.

Iazeppa.-Flowers deep pure scarlet, of fine shape and substance, and of free habit.

Mrs. Whitely,-Large flowers, white eye; fino.

New Life.-By far the finest striped variety. Gronud color deep scarlet, striped and blotched with white; we have found it to run back to plain scarlet, salmon color, ete., all ou the same plaut, but the arerage are constaut in character.

Panline Lucea.-Largo trusses ; fine variety ; flower's pure white.

Orange Boven.-Center of flowers bright orauge, eacl distinctly margined with white.

Snowden.-Large trusses of pure white flowers.

Price, except where noted, 25c. each; per twelve varieties, $\$ 2.50$.

\section{GIOXINIAS.}

Twelve distinct new varicties, drooping and upright flowers; truly wontlerful in their richness of color. ing-blne, scarlet, rose, crimson, and white, ist size, 50c, each; $\$ 5.00$ per set. 2 d size, $30 \mathrm{c}$, each ; $\$ 3.00$ per set.

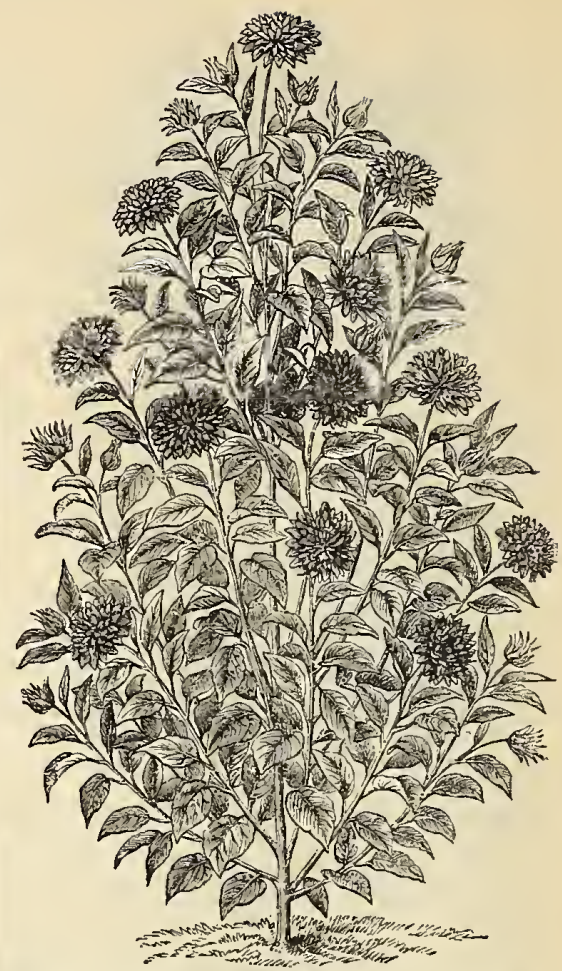

\section{HEIIANTHUS MITTIFLORUS: PIENTS.}

(The Perennial Golden, Double-flowering Sunfiower)

We offered this grand plant in onr Spring Catalogue of last year, and have again pleasure in call. ing attcntiou to it. The illustration gives a fair representation of a single plant; we had hundreds of plants even larger and with many more flower's. These plants were ont of 2 .inch pots and not planted until the 10th of June, and by the 1st of August wany were in flower and continued to flower until octo. ber. The plant is perfectly Lardy ; the flowers are of the richest golden-yellow, as large as the largest Chrysanthemum, anṫ lasting for many days after being cut. Price 35c, each.

\section{HEIIOTROPES.}

President Garfield.-A new variety, imported fron Europe, and said to be one of the most beantiful yet raised; Howers in very largo trusses, deep violet purple, and jemarkably swect-scented.

Price, 50 ccuts each ; 3 plants for \$1.00.

Juliette.-One of the darkest; fine compact habit, exquisite fragrance. $25 \mathrm{c}$. each ; $\$ 2.00$ per dozen.

Mme. Blonay,-The nearest approach to pure white we have yet had in the Heliotrope; truss very large, growth compact; a decided acquisttion. 25c. each ; $\$ 2.00$ per dozen.

Heliotrope. - Best light and dark kinds ; older varieties. $25 \mathrm{c}$. each ; $\$ 2.00$ per dozen.

Hibiscus.-A genns of greenlouse plants, exceedingly valnable for bedang purposes. The largo scarlet and ycllow flowers are uuusually showy. Five kinds, $50 \mathrm{c}$. each; or $\$ 2.00$ for the entire set.

Hoya Camosa (Tax-plant). - A splendid climber, admirably adapted to house cnltnre; bears beantiful flesh-colored flowcrs, resembling wax; makes. a fine trellis plant, and continues a long time in bloom. 30 cents eael. 


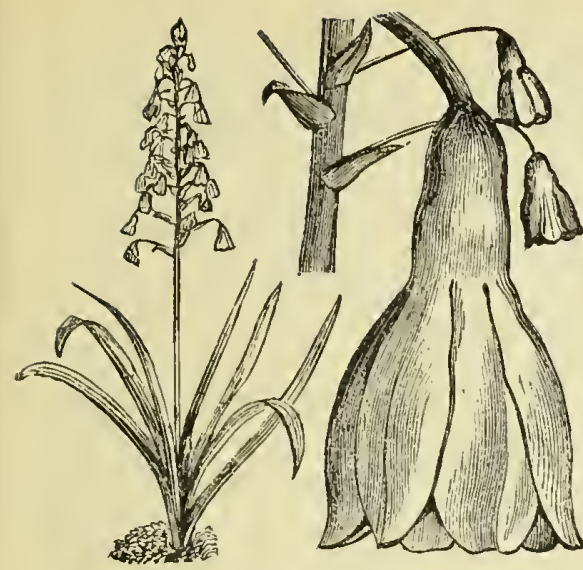

Hyacinthus Candicans.

IIYACINTIITE CANTIOAN-.

A magnificent Yucea-like plant, protueing in July :mal Allgust a flower-st'm 3 to 4 feet lingh, cor. ered witlo from twenty to thirty pure white, pen. dent, bellsshaper flowers. This plant shonlel finl a plaes in every collection. It is believer that it will prove perfectly havly, having stood thes reeent severe winters withont injury. Priw, 30c. each.

\section{HYDRANGHA.}

Thos. II gg. - This beantifnl new Japanese variety lias large heads of pure white flowels, and is a very freoand abundant bloomer. It grows very thrift ily, and soon forms a largi speeimen plant; one of the finest norelties ever introilued into this country. 25c. vacls.

Otaksa. A new variety from Japan, witl very large flowers. 25e. eacli.

Hortensis. - The old tarden rariety", with lare eorymbs of rose-colored flowers. 35c. eaeh.

Panienlata Graudiforn.-Seo larty plants.

\section{IRIS.}

Among the many forms of floral beanty which atorn the flower borlers in Jnne, the Iris haselains which entitle it to a more than ordinarily promt nent position; the flowers are large and handsome, the colors extremely rich and varied; the height of the plant is from eigliteen to twenty fonr inehes, while its cultiration is unnsually simple, succed. ing in any ordinary garden soil; when planted in elumps of three or more, and allowed to remain un. distmrbet, they improve in bemity cach sncessive rear.

English.-Twenty.five finest unmer varietiex. Eaeh, 10e,; per ilozen, $\$ 1.00$.

Euglish.-Finest mixed withont names, Each, je; per thenen, 50c.

Ferman or Fleur de his.-A spleudin herbaceons perennial. Each, 1 5e,; per dlozen, $\$ 1.50$.

Sinsiana. - Blush tinted, netted with tark lines: an excerlingly lianlsome flower; succeetls allmirably in pots. Each, 35e, ; per clozen, 83.50 .

$$
\text { TRIS IHIEIRIOA. }
$$

One of the most remarkable and interesting plants in cultivation. Its d warf habit, grigantic flowers, great snow-white, ereet sepals, its equilly large, strangely enlorel petals, and its stigmas with shining lolack.purple, lumperl bases, mako up a flower of singular oldity and of remarkable beanty. Snch a curious conbination of color is rarely seen in the same plant. Price, 35 c. each : $\$ 3.50$ per dozen.
ITIS IECENIPINEIR.

Amongst thououghly liarif plants of later into. anction, the fine varieties of this species are unsur. passert. They are liardy in every sense of the work; let the weather be ever so serere, they are notin the least affecterl. They aro truly magnifieent, aul a perfectly distiuct race, bearing a profinsion of large Clematis.like flowers. The prevailing colors are from decpest black, purple, tlroholl various shades of blue, to the purest white. The individual flow. ers are of great size and heary texture, flowering from the middle of June to the end of Jnly. The plants, when ont of flower, aroeflectire, erraceful, ant pleasing, retaining a bright amb show y miss of amplo folia ee until quite lato in flue year.

Calypso.-Lglit. veined purple, deep purple center. Clio.-Rich deep purple, shaded red.

Exqnisite. - White, reined and sladed with blue.

Fairy Qneen.-Lairender, shaded rich purple.

IInmlet.-Deep sky-blue, large, fine.

Iagro.-Deep purple blire, fine sliade.

Inliette.-White, veined purple, purple center.

Maebetl.-Deep red, striperl white.

Miranda.-Fine liglit blue, larore white center.

Othello.-Ricl phun purple, yellow eenter.

Portin.-Red, shaded mirple, white center.

Prinec Hal. -Laventer, mottlol with deep pnrple. Vemis.Large, mure, white, fine.

Eaeh, 25e.; per tozen, \$2,00.

Hixed Varieties, suitable for larre masses,

in all colors. Per $100 \ldots \ldots \ldots \ldots \ldots \ldots \ldots \ldots$

\section{IYY, GETRMAN OY I'ARI,OR.}

(Senecio Seandens.)

A rapill.growing, climbing plant, with yellow flowers; well adapted for covering trellis.work quickly, or as a housenlant in winter: leares glossy green. 15e. eacl ; $\$ 1,50$ per doz.

\section{IJATANAS}

There are few becling plants that bloom more contimnomsly or afford grwater varjety than this, ind they aro justly considered one of the best summer flowerins plants for ont elimate.

\section{NEW V.IRIETIEN.}

Giselle.-Very large flowers, rich purple rose, aut light yellow eenter, tino bedider. $35 \mathrm{c}$. ench.

Reveil.-Pure white, golden gellow center, very large trusses and flowers. 35ं., each.

Goleouda. - Butf, ellanging to deep golden yellow; extral fine, 25̄ce eacli.

Marechal Mac.Valrou.-Tho rery finest Lantana crer raisel : trusses as large as verownas, flowers bright as crimson and gold. $25 \mathrm{c}$. ear.h.

WFe will forwarl six distinet varieties of Lan. tants, incluting puro white and deep yellow, for $\$ 1.00$.

Myrlle, Crape.-One of the most beautiful of lialfharly slirubs, growing aul blooning fins.ly in the Summer, and only requiring the shelt er of a cellar in winter.

Indien.-The olt and popular crape Myrtle, pink flowers, 50c. eatel.

- Indiea A lba. - A white crape Myrtle, 60c. each.

\section{TEGODIUUN SCANDIENS. (Japanese Climbing Fern.)}

A climbing Ferm from the Fast Inties, and a most graceful plant, as easy of culture as the sullax. Although elimbing when supported by strings or wires, it ean bo usen with equal aulvintage as a drooping plant, for baskets or vases, and as a lowse plant for the parlor; nothing is more easy of enlture. It is now preferred by mauy florists to smilax, for fine cut flower work, being much more houtiful and norly as chrable, if the ohler sprays are ased. 50e. racli. 
PANDANUE UTIUAS (Screw Pine).

So called from the arrangement of the leaves on the stem. It is a beautiful plant, exccllently arlapted for the centers of vases or baskets, or grown as a single specimen. No plant is better suited for room culture. 1st size, $\$ 1.00$ cach ; $\$ 9.00$ per dozen. 2 a size, 50c, each ; $\$ 4.50$ per dozen

Pandams Veitchii.-One of the handsomest foliaged plants over introduced, growing as freely as Utilis. The leavos are of a rich dark shining green, striped with pure white, some being nearly all white. $\$ 1.00$ each.

\section{PAPYRUS ANTIQUORUM.}

This is tho Eryptian paper plant, and is said to be the plant from which the paper was made whereon tho Seriptures were written. $I t$ is a rery landsome sub-aquatic plant, growing to the heiglit of seven or ciglit feet, and is of great beauty. Strong plants, by express only, $\$ 1.00$

\section{PASSITIORA. \\ (Passion rlower.)}

Very handsone climbing plants, growing rapitly and blooming frcely, with blue, purple, or scarlet blossoms. P. Corulea and Incarnata are hardy; the other sorts roquiro in-door culture. Strong plants 50c. each.

\section{PARIS DAISIFS.}

Etoile d'or. $\rightarrow$ A very distinct and beautiful variety witl clear golden yellow flowers, 30c, each.

Madame l'an'feullion.-Large flowers, with pure whito rays and yellow disk. $30 \mathrm{c}$ each; the two varieties, one of eacli, $50 \mathrm{c}$.

NHWW GERMAN PANSIFS.

ransics are now being largely used for bedting pulposes, vases, etc, and this new and fine type lias wroatly increased their popularity. Seedling plants, 25c, each ; per dozen, $\$ 2.25$.

We also offer common varicties of pansies at 15 cent.s caeh ; $\$ 1.50$ per dozen.

\section{PEONIFES.}

Tliese have become iudispensable to every garden some of them begin to bloom with the T'ulip, while other's finish with the Summer Rose. They aro all lidrdy and admirably adapted to the climate of onr most northern states; growing in almost all situations, and even flourishing under tho slade of trces.

Our stock consists of over 100 varieties (all lierbaccons), of every shade and color, double and single, mostly rose scenter. Price 25 to 50 eents each; $\$ 2.50$ to $\$ 5.00$ per dozen.

\section{PETUNIAS (Double).}

Amongst the following varieties will be found nome of the most beautiful and distinct free flowering kinds.

Gigantea.-Richest deep crimson, the largest Pe tuuia we have seen.

Hebe.-Pure white, dwarf, compact habit

Ivanhoe.-Decp maroon-crimson, margined white. Verriuac.-Fine light rose, deeply fuinged.

Orhello.-Deep velvety purple; a grand fringed flower.

Pandora.-Light lavender, margined white; fine shape.

30c. each ; the 6 varieties, $\$ 1.50$.

SINGIF PETUNIAS.

For out-door decolation or house culture few plants cxcel this class. They are casily cultivated, eommenco flowering early, and contiuuo a mass of bloom the whole season. In color, the strain now offered is uearly perfect-comprising, as it does, all the most delicate tints and shades,

We lave propagater 10 distinct aud beautiful kinds of the Grandiflora type, with very large and tinely marked flowers.

25c. each; per 10 plants, \$2.00.
PFIRENNIAI PHI,OXFIS.

These are perhaps the most beautitul and sliow $y$ hardy plants for Summer and Fall flowering. For cut flowers they are valuable and ornamental, and if grown iu pots, they are excellent for conservatory decoration. The collection we offer embraces ail colors found in the section, and are most distinct.

SUFITITOCOSA (Faxy Flowering). (These flower from June uutil September.)

Clonded Gem.-A bright, rosy lavender flower, mottled and sliated witl white

Forward.-Rosy-crimson, with darker eye, a fine spike, and very free.

Iohn Bailie.-Light rose, often marked with white; awarf grower.

Keno.-Dclicate lavendex, mottled with white, deep rosy-erimson eye.

Lady Musgrave. - A beantiful variety : pnre white, with delicate pink eye.

Miss Robertson.-Very large spikes of the purest white flowers: fine.

Rosy Gem.-Deep bright rose color, very larwe spikes : a distinet variety. $30 \mathrm{c}$, each ; the 7 varieties 1.75.

DHCUSSATA ( Late Flowering.

(These flower from July until Oetober).

Arago.-Bright rose, deep crimson ceuter.

Bijon.-Very large pure white flowers dwarf.

Bridesmaid.-White, witı very small pink eye.

Charlenague.-Rich violet-purple; quite distinct.

Cross of I Ionor.-Lavender, distilictly variegated witl white.

D1. Gilkinet.-Dcepest red, rich violet center.

Heloise.-Fosy-pink, whito center ; fine.

La Tour du Monde.-Soft rosy-pink.

Lothair.-Fiery rerl, with deep erimson eyc.

Ime. IR endat ler.-White, criuson eye.

Hine. de Caen.-White, purple-red eye.

Ionsienx Delannay,-Striped stmon, purple center

Premier Minister.- Pure white, deep red eye,

Richard Wallace.-Very lar.ge, white, lose eye.

White Queen.-Puro white.

Each, 25e. ; per dozen, $\$ 2.00$.

POINSETTIA (New Double).

The siugle variety of Poinsettia is known to be one of the most gorgeous of plants, - the bracts, or flowcr leaves, being often over a foot in diameter. aud of the most brilliant rermilion color. The kind above offered is the double variety of this beantiful plant. The donble variety, $\$ 2.00, \$ 3.00$, anc $\$ 5.00$ each; the single variety at frou $25 \mathrm{c}$. to $\$ 1.00 \mathrm{each}$, according to size.

Pepperomia.-Curious, succulent, stripert Inaves. 20c. eacli.

Plumbago capensis.-Light blite, blooning very abundantly, 30c. eacli ; $\$ 3.00$ per dozen.

Physiantlus albus. $-A$ climbing plant, with clus. ters of white flowers growing very rapialy; it is known as the "Cruel" plant. 35c. each.

Richardia alba maculata. - A spotterleaved Calla. 50c. each ; $\$ 4.50$ per ilozen.

Salvia splendens ( Scarlet Sage). -Intense nearlet. 25c, each: $\$ 2.25$ jer dozell.

Sedums (Stone Crop).-Twelve distinct sorts. $25 \mathrm{c}$. etch ; $\$ 2.25$ per dozen.

Sempervivum (House Leelss). - Three specien, $25 \mathrm{c}$. each; ; $\$ 2.50$ per dozen.

Smilax.-The well-known cliuber. 25c. eacli.

Vase Plants aud Basket Plants. - Of these we grow large quautities, snitablo for urns, baskets, anil vases; a fine collectiou. From $\$ 2.50$ to $\$ 4.00$ per dozen.

Violets: Marie Lonise, Neapolitan, etc. $-25 \mathrm{c}$, each : $\$ 2,25$ per dozen.

Verbenas. - A splentid colleetion. 10e, each; $\$ 1.00$ per dozen. Unmamed varieties, $75 \mathrm{c}$. per dozen. 


\section{ROSES.}

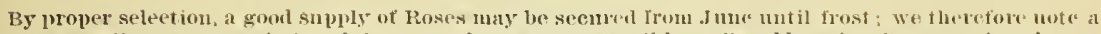

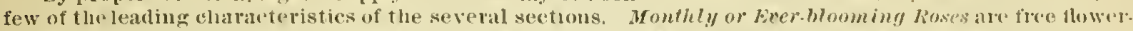

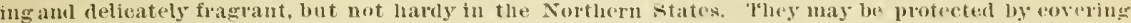

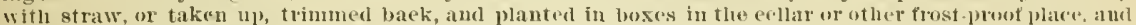

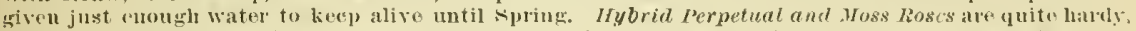

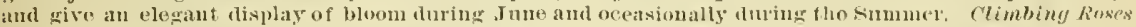
are, witl one or two "xceptions, perfectly hardy, and are indispensable for arber and trellis work.

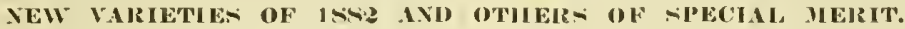

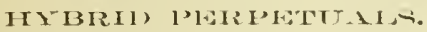

1. I. Ampere.-Decp red purple, with back ot jotals slraded lavendar; very full, of good size. stroug. and rignolous.

Contesse H. Coombs. lirithlt rose, willt silviry lellex; large, full, and very vigorous; in the way of M(a)ic Banman.

Id. Marie IRoederer.-Bright elarry rose, shaded carmine: lareo and full showtls: verv vion orous; a seedling from Jules Marguttin.

Md. Martha d'Halloy.-Clerey red; very larere and full ; growtl very stroug; a fine varint! ; serel ling from Vietor Verdicr.

Sonvenir de Mad. Berthier. Fius dere briglit (trusun; Fery lalgo and full; grow th vigorous ; finc and distinet variety.

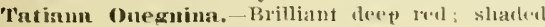
earrine; a truly pelpotual Howcel.

\section{TH. 1:-}

I3eraty de l'Enrope. Of the (iloire de i ijon type of '7eas. lolowers vely larege, full, and verg well makc, with form of centifolia. Color dark yellow: reverse of petals copperyellow. Vury florif. erous. The most remarkible jellow rose yet obtained from Gluine do Dijon seedlings.

Etoile de Lyon.--Tery vigorous, with a fine ha bit. plowers fragrant, very latere and very full, of a line brilliant sulplur-yellow, res.rese liglit yellow, of full and hamdsome form, the outer petals bean fully imbricated. This masnificent variety is, beyoul dispute, one of the ruost beatiful yollow roses obtained up to this diy.

Sules Finger.-Full and finely formed; wo brichlit rosy scarlet, sliaded witli intense crimsou; very tragrant and freo bloomer.

Indume Cusin (fruillot). - Flowers nedium sim. to burese, well formed anis of zoot texture. Color, rosy-punple, Bast of petals and cent(') of the flowers almost white. Very distinct, frere, and vigrorons.

Flag of the Union.-The advent of striped lioses is lot oftell, and in this varioty we hate ont that is a strong growar, al flee blowner, and of groou size, It is a sport trom the well.known " 130 silene." Tis" flowrss are rilual in size; rich, flet carmine rose, mottled witl pure white. The glowtli is equal to "13on silene," and quite alis finct from "Anerican Banner."

Price, 50 cents each, or the above 1 I varieties 101 $\div 4.501$

IIT BIRID 136,1 IR136) .

Indame Isane Pereire.-Beantiful vivil tar mine; full and of immense size; perfect imbri. cated form; blowns thiongliout tle season; grow th very vigorous. 500

HIIJIRII) NUISHTTE.

Madaue Alfred Cariere.-Flesh white, with salmon-yellow at the biso of the petals, large, full aud well formed; growth very vigorous; a $a m b$ climber. $35 \mathrm{c}$

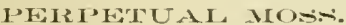

Bhanche Moreau.-Pure white, large, and full opens well, perfoctly formel, blooms in clustris: growth very vigotons, 750

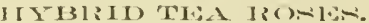

lieanty of stapleford. Outer petals very pal linkislt juse, wraklually shaded to a dexpe ros fonter; a fincexhibition rose. 33. .

Camoens,-7lis is a very beatiful and distinct new variety frowing and floweriug ax frecly as $t$ lu "Hermosil." Tho tlowers are large, of a brimbt silvery pink, sharled with yellow, and olten strijed white. 'The petals are quite pointerl, giving tlie flower a very distinct appearance. Vory different from any lose we are acplainted with. l'rice, so ("ints welt.

Doke of Commoght.-This is a must brilliantly colored deap eriusons fower, slladed with liglit carmine, ol the tinest. sliape, aud perlispes the most persistent blooning rose ret raiscl ; after hecoming establisled, it grows as firely as the orimay 'Tea IRose. $75 \mathrm{c}$

Dncliess of Westminster. Exteedingly litro. without coarseness, tinely" torumbl, brightert cerise: a crinul rose. 3.5e.

Hichael finuders,-Large, of the tinest form, very firll of petals, which are beatifilly reflexal, bonzy pink, very sweet-scented. 35e.

Tlue ahove 5 varietios for $\$ 2.00$.

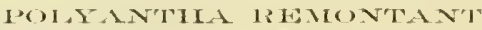 IROKES-}

This is an entirely new class of roses, the pancent. of which lraverecently beenintroched frou Japan. "lley mierlit be enlled "Fairy Roses," witl their miniatue and beatiful-shaped flowers, which are erown in inumense elusters, IVe have seen as many as 150 flowers on tho viriety Mignonette all one fime. 'liey will no doubt prove to be perfectly litriy in nearly arery section of the country.

Ame Marie de Iontravel. - A lowatiful pot or horderplint : the rose is very dwint, lout branches freely, and proulues in the groatest abuudance clustris of viry small but very perleet whit blossoms; a continuous bloomer. 50e. racli.

Ille, Cecile I3rumer. - Bright rose, Jellowish in: tho ecuter, flowers in clnsters, very sweet; of

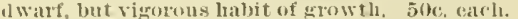

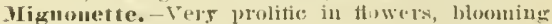
incessantly in immense flit (:orymlom the color is blusll. White, sllating to rosy pink. joce, each. The 3 varicties, $\$ 1.00$

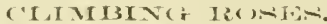

Willan Alen irichardson.- New" and tius" very distinct: eolot deen olauge yellow, rlatuging to

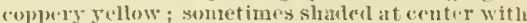
rost blish ; flower is large, quite full, and donble, and very fragrant. $500^{\circ}$. eacli.

Keine Marie Ifenriette. - $t$ nost distinct and rapul growiug elimber, with flow ors vary larere. louble, and of briglit rerise real; a counterpat to that gramd liose, "(Iloirede Dijon," and, we have no doubt, cyualiy as harly; a rreat aryuisition. 350 , each.

We ean supply first-class well-pooted plants of ali tlue best varieties of this rlass, $30 \mathrm{c}$. eachl set we r.ielat listinct and beantiful varietixw for $\$ 2.00$.

$$
\text { Mrasi IROALE- }
$$

Of these popular favorites we grow large stocks of all the stamald sorts. 35c. eachi set of cisht dis tiuct aul beantifnl varieties for $\div 2$.00 


\title{
HYBRID PERPETUAL ROSES.
}

\author{
(Quite Hardy.)
}

Price, 20e. each ; the 20 varieties for $\$ 3.00$; for well-rooted plants, in $2 \frac{1}{9}$-incli pots.

Wo have a large quantity of good plants in 4 and 5 inch pots, which can be sent by express only. Purchasers' selection, 50c. each; $\$ 5.50$ per dozen. Our selection, $40 \mathrm{c}$. each ; $\$ 4.50$ per duzen.

Alfied Colomb. - A splendi九 rose; large globular form, full and very sweet, bright clear rei.

Antoine Monton. - A fine, free bloomer, hariy, flower of large size, full and sweet, color brilliant carmine, reverse of potals silver rose.

General Jaequeninot.-Rich volvety scarlet, changing to searlet crimson : magnifieent bui.

Jeall Liaband. - Large, full, bold flower, elegantly sconted; color dark rich velvety erimson.

Jolm Hopper.-Brilliant rose, elonging to bright crimson, reverse of petals iilac purple ; a fine large sllowy sort, very fragrant.

Jules Margotten.-Bright eherry rei, large, well formed; a splendid old variety.

Ia Franee.-Lovely peach-blossom color, delicious tea fragrance, extra large size, very full and beautiful ; a constant and profuso bloomer.

Louis Carrique.-Rieh relvety crimson, large size, very double, iull, and sweet.

Lonis Odier.-Bright silvery rose, imbricated, sweet-scentca.

La Reine-Beautiful clear white rose, fine full form, ver'y fragraut.

Ingua Charta.-A splendid new English Rose; extra large, full form, very double and sweet color clear rosy pink, beantifully flushed and edged witi violet crimson.
Mue. Chirard.-Fine globnlar form, large, very rouble and fragrant, deep rosy pink; beautiful.

Ime. Boutou.-Very largo and full, rich erimson; a free flowerer; and fine variety.

IIme. Franeois Pittet.-Lovely pure white Rose, very full, clouble, perfect in form and flower; one of the best new whites; blooms in beautiful clusters.

Mrs. I ating.-A charming Rosc, boune in clusters. soft carmino color, reverse of petals light; very full aud sweet.

Paul Neron. - Extra large, full fine form, tecp earmine eolor, very fragrant, free bloomer ; an exee lent Rose.

Perfeetion des Blanehes.-One of the finest White Hybrid Perpetuals; a morlerately freo bloomer, flowers large, pure snow-white, very donble and fragrant.

Perle des Rlanelres.-Pure white, medium size; full, good form.

Souvenir de Dreher.-Medium-sized, compract Howers, very double: beantiful brilliaut scallet, deepening at center to dark maroon; very tra grant, larily, and cesirable.

Whomas Mills.-Extra large, fine cup-shaped flow. ers; color bright rosy carmine, sometimes witl fine whitestripes; fragrant and gook.

\section{ROSES, EVER BLOOMING.}

NoTe,-The following Roses are not hardy in the Northern States, and should be protected in a cold frame or a cool cellar on the approach of liard frost. In tho Southeru States they will be perfectly liarly, and ilo not require covering.

Price, 20c. each, or any 20 varieties for $\$ 3.00$; for well-rooter plants in $2 \frac{1}{2}$-inch pots.

Adala. - A superb rose, with large, fine, pink shated flowers, frasrant and very free.

Aline Sisley.-A lovely shade of rosy pink, some. times very bright; sweet-scented, fine.

Anna Ollivier.-Large, full, and very fragrant; creamy white, shailed light red.

Agrippiua.-Splendid deep crimson; one of the unost beautiful garden roses.

Alba Kosea.-Creamy white, shated flesli and rose; large, donble, and sweet.

Bon Sileme-Rosy carmine, sluated pale roso; lovely budts, freo blooming and fragrant.

Catharine Mermet.-This is an exceedingly beantiful rariety, color clear silver-rose, with delicately shaded amber and fawn center'; the flowers ar'o large, full and globular, very double and sweet; an elegant rose.

Cornelia Cook.-Large, pure white; one of the very finest rarieties grown.

Duchesse de Brabant.-Silvery rose, edged witl calmine; one of the most fracrant; very fine.

Hermosa.-Silvery rose, pink, very double; flowering ineessantly; extra.

Isabella siprunt.-Lichl canary yellow ; fino buts ; tiagrant.

Lasmarque.-White, with lemon eenter; very (L)uble; fragrant, chimbing.

Lady Warreuder. - Pure white, very free flowerins; an exquisite variety.

Matie Gnillot.-Splendid large whito flowers, s'lobe-shaped; tine grower; one of the best.

Marie Vau Houtte.-White and rose, deep yellow eenter; delicionsly scented; tree bloomer.

Ime. Canaille.-Blusl, shaded salmon pink; a very large tine Hower.
Mme. Devaeout.-Canary yellow; large and double; a beantifnl variety.

Mue. de Vatry.-Spleutid deep rose, sliaded erimson; fine grower.

Mue. Bravy.-Exquisite shape, large, full ; nearly pure whito, blusll center.

Ime. Pauline Laboute.-Salmon, shaded eoppercolor : large, full, and free.

Matechal Niel.-Golden yellow; a grant variety ; climbing luabit.

Iarie Dneher.-Salmon, shated rose and pink; large towers; swect.

Nipletos.-Pure white: an exquisite variety.

Perle des Jardins. - One of the very finest sort introdnced ; the Hower is extra largo ; full globular form, very double, and highly perfumed; color clear golden-yellow; very bcautiful.

Rovelli.-A lovely shate of bright carmine; large, double, and very sweet.

LRubeus.-Palo creamy yellow, shaded white anil tinted rose ; a superb variety.

Souvenir de la Malmaison.-Creamy white and pink; a grand rose.

Souvenir d'ua Ami.-A lovely losy pink, sharted decper; splential flowers.

Sonvenir din David.-Very bright light red ; a free bloomer; fine grower.

Safranot Buff-Apricot and yellow; fine, large buds; one of the very best.

Sombrieul. - N early pure white ; large, free-flowerins, sweet, splentid.

vir Walter Scott.-Frce-Howering; very bright redi sweet-scented; free.

Washington.-Pure white; very free tlowering; larre clusters; a tine climber. 


\section{COLLECTION OF ROSES.}

For the conrenionce of those who desire a finc collection of roses, lunt who are unacquainted with the best varicties, we make the following offers, and, being at reduced rates, the varieties must be exclnsiyely our selection. The best varieties of roses will be sent-all gool, healthy plants, correctly labcled.

These Roses are especially giown'for mailing, and are stout and thrifty.

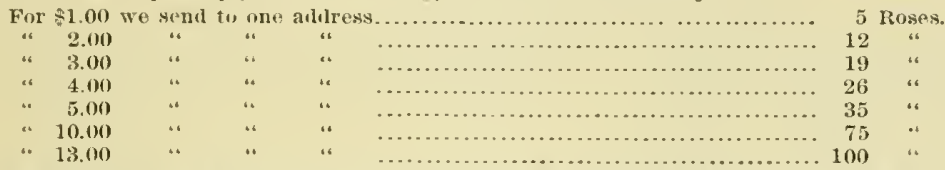

50 Roses, purcluaser's selection, not to excend 25 varieties, by cxpress, \$6.50. By mail, $\$ 7.00$.

100 Roses, purchaser's selection, not to exceel 50 rarieties, by cxpress, \$12,00. By mail, \$13.00.

When ordered sent by express, the purchaser must pay express charges.

Planters requiring several hunded Roses or other plants, will ou application receive special quotations.

Large plants from 5 -iuch pots by express at donble the prices.

\section{HARDY SHRIIBS, HARDY PLANTS, AND HARDY CLIMBERS.}

II adlition to onr list of shrubs and chimbers on page sixty.six, we offer below a choice assoltnent - that are either new or scarer. possessing distinctuve teatures of merit, (1) have not been in general eultiva. tion - at prices that render them obtainable by anatenrs generally.

\section{SHRUBS.}

Altiea Maryiuara IRubra fl. pl. - A distinct double varioty; renl, margincl white. 35 cents eacli.

Althea Coevulea tl. pl.- Rich jurple, shaded light bluc; novel and effectivecoloring. 25 cruts each.

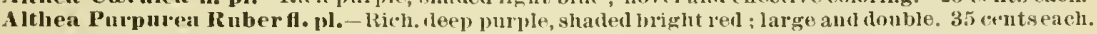

Altien Violnecus Atropmpurens 11. pl.-Vinlet, striped aml spotted white; shaded with deeplpurple. 3.) erents each.

Corehorus Japonieus FIore Albo.-An ahust perpetual Howering shrub, with purt: white daisy. like Howers. 35 cent each.

Cydonia Japonica Candiva.-A new and beatifnl variety of the Japan Quince, with very large purc white Howers, blooming as early as end of March. 50 cents each.

Cydonia Japonien. Mallavdii. - Flowers variegated, rieh, deep pink and palest blush. $35 \mathrm{ccuts}$ each.

Desmodium Peuduliflorum. - A very distinct shrubby, herbaceous plant, covered in september and October with rich purplish-led Howers, growing foun two to thee feet liogh. 35 cents eacls.

Deutzia Creuata Candidissima fl, pl.-A new and distiuct variety, with rery large, pure white Hower's, in spikes four to six inches loug. 35 cents each.

Forsytlia suspensa. - An elegant shrub, Howering before the appearance of leaves; Howers deepest yellow, in long, weeping wieaths; a vely charining plant. 25 cents each.

Forsytlia Viridissina. - The earliest of its class to tlower; rich, dcep golden yellow. 25 cents each.

Iyperienm Patulum.-Largo, bright yellow flowers: plant of very compact growth. 35 rentseach.

Philadelplus Ketelecti fl. pl.-Flowers double and very large, and of the purest white; a beautiful shrub. 35 cents each.

Philadelphus Nepalensis Variegatus,-Flowers large, pure white; foliage distinetly margineul with pure white. 35 cents each.

Rlus Glabra Laciuiatn.-This is one of the nrost elegunt and gracefnl plants for decoration. The foliage is much divided, and in general appearan' l'sembling sonut of the vesy choicest ferns. 35 c'nts each.

Spirea IRevegiana f. pl.-Lovely pure wbite Howers, coveriug the whole plant and lasting long in perfection. 35 cents wach.

Spirea Tlunbergii.-A distinct, drooping plant, covered in May with niyriads of pure wlite Howers; one of the most beantiful. 35 cents each.

-iyringr (Lilac) Euodi.-Has bright, leathery leaves, and rich colorud Howers. 35 reuts each.

viyriugr (Lilae) Josikea.- U pright in shape, deop green leaves, and rich lilac.pink Howers; bloomingr In Junt: the lat ost variety, and very desirable. 35 centseach.

Syringr (Lilne) Rothomagensis.-Distiuct, deep red Howers, in rery large trusses or pauicles; thu deepest rell variety. 35 cents each.

The complete set of 20 shrubs for $\$ 6.00$.

\section{CLIMBERS.}

Arimtoloebia Sypho (This is known as the Dutchman's Pipe).-Very large, heart-shaped leaves, coveriur a large space very yuickly. The Howers are on long sten s of a pecullar pipe-shapel formation, color brownish purple, spotted green and whitc. This is a raluable and desirable plant. 50 cents each.

Louicern Flava (Honeysuclile).-Flowers rich, (leep yellow and very fragrant. 35 ('ents each.

Lonicern Fuchsoides.-Rich, deep, coral scarlet; of the brightest color, tlowering in $J$ ume; a masnifi. cent valiety; of fine, frestow th. 35 cents each.

Wistaria sineusis Albn. - A beantiful valiety of the Chinese Wistaria, with delicate white and very pale lareuder Howers, growing and Howering as freely as the well.known purply kind. 75 cents each.

Wistaria Frutescens.-The Howers are of a more decided sliade of culor than the Chinese varinty. The bunches not quite as large, but of the most graceful form. 30 cents each.

Wistaria purpurea f. pl.-Flowers quite doublc, of a rich, deep violet-purple, shated in the center with pure white; perfectly hardy and distinct. \$1.00 each. Tlie 6 Climbers for $\$ 3.00$. 


\section{HARDY SHRUBS.}

Althea, or Rose of Sharon.- These are among the most effective and continuous flowering shrubs; iu varions colors, such as double purple, double white, donble rose, and double violet. 25 cents each.

Althea, Variegated Leaved. $-A$ most beautiful and compact growing shrub; leaves margined with golden yellow; flowers donble bright pink. 25 cents each.

- Calycanthus Floridus (Strawberry Trec),-Dolicionsly swcet-scented donblo purjlo flowers, often tlowering at intcrvals during the summer. 25 cents each.

Dentzea Gracilis. - A charming shrub, with very bright green foliage growing two or three feet high. Flowcrs pure white in large racemes. 25 ccnts each.

Deutzea Crenata.-Growing three to four feet high, with spikes of very double pure white flowers of the hardicst constitution. 25 cents cach.

Hydraugea Paniculata Grandiflora.-This is perhaps the finest lato summer flowcring slurnb known, giving large quantities of white flowers in immense heads or panicles; per fectly hardy. Prices of extra large plants, $\$ 1.00 ; 2 d$ sizc, 50 ccuts; $3 d$ size, 25 cents, each.

Jasminum Nudiflorum. $\rightarrow$ Golden yellow Jcssamine, hardy. 25 cents oach.

Kerria Japonica.-A slender-branched shrul), with bright groen leaves and donble, yellow, globluar. shapeci flowers. 25 cents each.

Lilacs, Persian.-Persian White, Large W7ite, New Purple, aud Charles $X .25$ conts each.

Mock Orange.-Syringas, three varieties, bearing exquisito pnre white flowers in grcat profusion, 25 cents cach.

Pyrus Japoniea (Japan Quince).-Fine bright crimsou scarlet; flowers in early spring. A fine liedge plant. 25 cents each.

Spirens.-These are mostly beantiful early flowering shrnbs, of various shaped flowers, either rose colored or whitc. The following are very fine: Aurea, Callossa, Alba, Prunifolia, Billandierii and Recvesii. 25 cents each.

Weigela Rosea.-Flowers opening light pink, passing to deep rose. One of the liardiest and most prolific flowuring plants in cultivatiou, 25 cents cach.

Weigela Aurea Variegata.-Deep green leaves, marginch creamy white and yellow; flowers deep rose color. 25 cents each.

Viburnum Opulus (Snowball).-Large, pure white balls of flowers, eud of May and Juue. One of the most bcantiful shrubs. 25 cents each.

The above twenty.five very desirable varieties, one of each, for $\$ 5.00$.

\section{HARDY CLIMBERS.}

Akebia Quinata.-A veantifnl slender climbiug plaut, with haudsome aud distinct foliage; flower: sweet.sccntch, decp chocolate. 35 ceuts each.

Ampelopsis Quiuquefolin (Virginiau Creeper).-A handsome native, rapid-growiug riue, with theeply' Iobed leaves, and which change iu autumu to dcepest crimson. 25 ceuts cach.

Ampelopsis Veitchii. - A gem amongst tho "I Ivies," with most gracefnl-shapcd and richly deep-colored foliage clinging to the merest support. One of the most beautitul. 25 cents each.

Clematis Viticella. - A free-growing kind, with deop parple bell-shapet flowers, hardy. 25 ceuts each.

Honeysuckle, Chinese sweet-scented.-Fine fragrant yellow and white flowers. Constant flowering. 25 cents each.

Honeysuckle, Everyreen sweet-scented.-Flowers buff, yellow and white, nearly al ways in flower. Vig. orons grower; fiue for veranda. 25 cents each.

Honeysuckle, Sweet-scented European.-Flowers large and rery sweet. Fine large trusses, pink, vellow and white. This is tho old English Woodbine. 25 cents cach.

Honeysuckle, Japan or Golden.-Beautifnlly mottled golden yellow leaves. Flowers yellow and very fragrant. 25 cents cach.

Honeysuclkle, Halliniana. - I fine white variety, changing to yellow. A free grower; one of the best. 25 cents cach.

Honeysuckle, Red Coral._A superl, variety, rapicl grower, tmmpet-shaped flower's, lrightest scarlet. 25 cents cach.

English Ivy. - Strong piants. 25 cents each.

Vista ria.-Fino strong piants of the true Chinese variety: one of the handsomest climbers grown. Large plants, $\$ 1.00$; second sizc, 50 cents; third sizo, 25 cents, each.

The twelve beantiful varieties, one of each, for $\$ 2.25$.

\section{VARIOUS HARDY PLANTS.}

The following list of plants are among the most showy and thoronghly hardy plants, and should be planted early.

Anthericun liliago (St. Bernard's Lily),-Spikes of pure whitc flowers.

Cbeloue barbata.-Scarlet tube-shaped flowers.

Delpliniu m formosum. - Brilliant blue.

Dielytra spectabilis. - Very fine clumps.

Funkia va riegata.-Fine in early Spring. subcordata.-Large pure white flowers.

Hemerocallis flava. - Yellow, lily.like flowers.

- Kwauso, fl. pl.-Showy, double, oránge.

Ifibiscus Califoruicus.-Large, pure white; fine.

- moschentus.-Very showy; hardy; hcrbaceous; pink flowers.

Iberis Gibraltariea. A perfectly larily candytuft; pure white.

Lyclunis visca ria, fi. pl. - Spikes of double stocklike piuk flowers.

Spirea painuata. - Beautiful rose.colored flowers.

- Japonica.-Beautiful pure white flowers. Each, 30 c.; 12 rarieties for $\$ 2.50$. 
Dor Novelties and Varieties of Special Merit, see Colored Supplement, and for Collections of Vegetable Seeds, see page 105.

\section{A SELECT DESCRIPTIVE LIST}

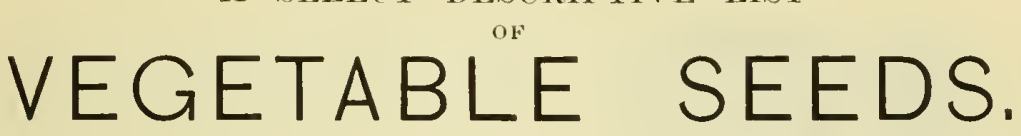

Embracing all the leading and most popular varieties, with brief directions for their culture, which will be found under their

respective headings.

T $T$ is our aim to offer in this department only such varicties as are really distinct and worthy of cultiva

tion. Many painstaking experiments have been male to enable us to do this, and wo foel conficlent

that only such sorts as will, witl proper treatment, give satisfactory results, are now offered. Our customers may rely on the good growing qualities of all our seeds, as, besicles being new anl of the best quality, they are thoronghly testeu, so that wo know they will vegetate; and while it would be manifestly wrong to warrant what is to souse extent beyond our personal control, still we are quite conficht that every bling will be found true to namo and description.

\section{IMPORTANT TO PURCHASERS.}

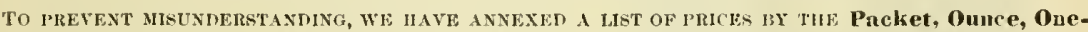
quarter Pound, Pound, (quart, Peck, and Bushel. PURCHAsens ORDERING i HALF-POLNH OR ILALF BUSIIEL WILL, IEE SUPILIED AT I'OUND OR BUSHEL RATES; QUANTITIES LESS TH.AN OXE-II.ILI POUXI OH

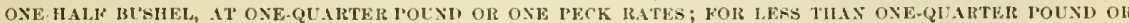
PECK, OUNCE AND QUART RATES WILL BE C"HARGED; FOR LESS THAN ONE OUNCE, AT PACKET IRATES. (SEO Remarks to Purchasers, Page 3.)

Please to bear in miul that the prices given for Vegutable Seeds no XoT INCLUDE I'OST,MF ON QUAX-

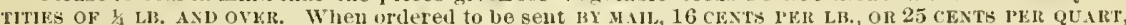
MIST BIS ADDED, TO JREIP JOSTIGE. In cases where the postage is not allowed, we shall ve ohliged to deduct from the orler a sufficient quantity to cover the deficiency, to avoid the necessity of opening accounts for small balances.

In consequence of possible flnctuations in the inarket, we cannot be bounl by these prices for any length of time. Our customers may rest assured, however, that their ordirs shall at all times be executed upon as favorable tel'us as the state of the market will allow.

\section{ARTICHOKE.}

[Cynara Scolymus, LIN. Artichaut, Fr. Artischoke, (iER. Alcachofa, SP. $]^{\circ}$

CULTURE.-The Artichoke may be propagated by seed or offset suckers, separateil in the spring. When raised from seell, let them be sown early in th" sipling, say at the time of the flowering of the peach, in drills a foot a part, and four inches apart in the drills. The next spring transplant to permanent beds in

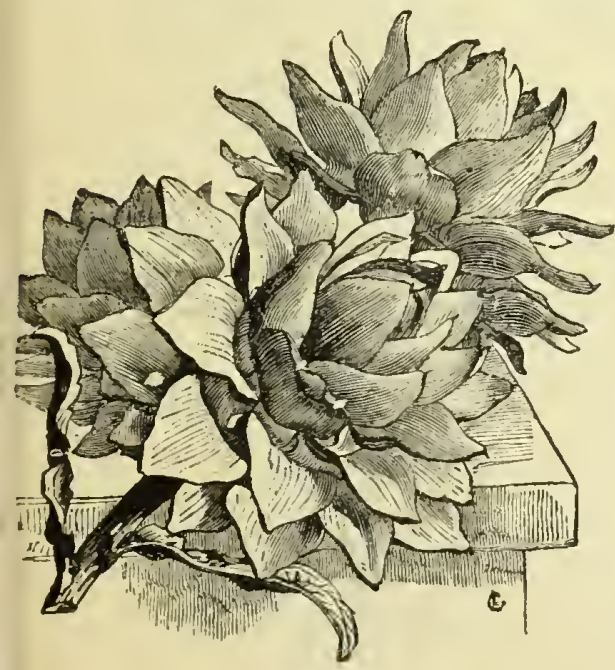

Artichoke-Green Globe. hills, three feet apart each way, with three plants (1) a hill. It reguiles a deep, rich loam, abounding ill moisture, and may be protected in Winter by coveriug with litter' or earth.

If by mail in quantities of 1 ounces and upwards, postage must be added at the rate of 16c. per pound.

Giant Green Globe.-The best for general cul ture. Prouluces large, globular heads, with thick. succulent seales, the lottom of which is the bible part. Bullel till tender, and sfrrol eithe lot or cold, with butter aud salt, it makes a deli. cious dish. Per pkt, 10 t:ents; $0 \%, 35 ; 14 \mathrm{lb}$., $\$ 1.25 ; 11 ., 54.00$

JEIRUSAIAMM AITICIIOISF. Helianthus tuberosus, LIS. Topinambour, Fh, Erdartischoke, GER. Pataca, sr.

II no way resemble's the above, except that its tubers when cookirl have the same taste and flavor. The plant viclis an inmense crop of tubers, winch 1.e the richest in fat-produciug elements of any o unr cultivated roots. Cultivate the same as notil toes, and take cate to lemove all the small roots, for, if left in the ground, they will come ul the next sprimg, and nay becone a troublesome wect.

Jerumalen Artivhoke. Not produced frou seed tubers much estereucel for vickling; also make excellent food for stock. Three 1 b. packages, by

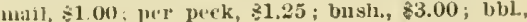
$\div 8,111$ 


\section{ASPARAGUS.}

\section{[Asparagus officinalis, Lix. Asperge, FR. Spargel, Ger. Esparragos, SP.]}

One ounce will sow abont fifty feet of drill.

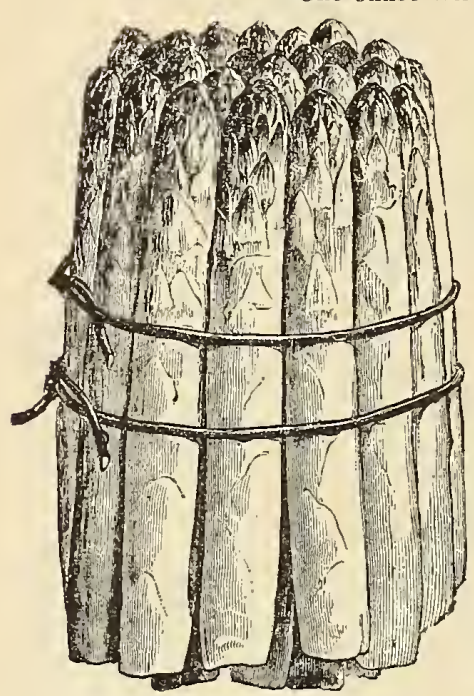

Asparagus-Conover's Colossal.

CULTURE. - Soak the seed twenty. four hours in tepid water and sow early in Sprin $x$ in drills two inches deep and lows a. foot apart, and keep thoroughly clean by frequent weed. ing and hoeing. When grown an inch or so, thin to twelve inches apart. In the following spriug the plants will be ready to remore to permanent beds. This should be prepared with more than usnal care, as, when once established, the plants will yield abundantly for many years. Where it can be done, the roots onght to be set mot less than two feet and a half apart each way. This is a greater distance than is generally allowch; lout, when the bed becomes thoroughly established, it will be found none too great. In cases where limited space renders this distance impracticalole, give as much room as possible, but nerer have less than eighteen inches each way bet ween the plants. Place the roots in their natural position, and cover four inches deep. A light, sandr loam, two feet deep and perfectly drained, is the most snitalble. Rich, well-rotted manure sufficient to cover the ber six inches shonld be trenched into the soil to the deptl of two feet, as the roots will reach that deptl in a few years. During summer water liberally with liquid mannre. It should not be cut for tlio table during the first year, and very sparingly during tlie second year. The next season the bed will give a full crop, but should be annually manured after the last entting, and well cultivated through the remainder. of the summer. On the approach of Winter unt down the stems and clear off all weeds, and cover with a dressing of mamre; this slould be forked in with abont one quart of salt to the square rod early in the spring. Planting roots in. stead of seed will save a year in time.

If by mail in quantities of 1 ounces and upwards, postage must be added at the rate of $16 \mathrm{c}$. per pound.

Hoore's New Cross-bred.-This new Asparagns is the resmit of careful cross-breeding between the Giant. Improred and another excellent variety. It retains the head close until the stalks are quite long, is of uniform color, while for teuderness and quality it is unparalleled. The size is large and remarkably uniforu ; a specumen bunch of twelve stalks weighed over three pounds, while the general appearance is so fime that it finds a ready sale in the market. Per pkt., 15 cents; $0 z ., 40 ; 16$., \$1.25; lb., $\$ 4.00$. One-year old roots, $\$ 2.50$ per 100 . Two-year old roots, $\$ 3.50$ per 100 .

Conover's Colossal. - A well.known variety of large size; tender, and of goorl quality. Per pkt, 5 cents; $13 ., 10 ; 1$, 1).. 20; 1 b., 60 .

Simalley's Defince.-Of a rich green color, very early, goot size, tender, and of delicious tlavor. Per 1)kt., 15 cents; oz, 50 cellts ; 1 1 11 ., \$1.50; 11 ., \$6.00.

(Conover's Colossal Roots.-One year old, $\$ 0.75$ per 100 $\$ 6.00$ per 1000 ; by mail, $\$ 1.00$ per 100 . Two year old $\$ 1.25$ jer $100 ; \$ 10.00$ per 1000 .

Smalley's Defiance Roots.-One year old, 30 cents per doz.; $\$ 2.00$ per 100 ; two years old, 40 cents per doz.; $\$ 3.00$ per 100 .

In conseqnence of the bulk of two years old Asparagus, we ean only seud one year old roots by mail.

\section{BEANS (English).}

[Faba vulgaris, Lix. Fève de marais, Fr. Gartenbohne, Ger. Haba comun, SP.]

One quart will plant one hundred feet ot drill.

CULTURE.-Plant as early in the Spring as the grüund can be worked, from two to four inches apart, in drills from twenty-four to thirty iuches apart. As soon as the plants are in full blossom and the lower poits begin to set, pinch off the tops; tbis will insure the filling of tho pods and hasten the maturity of the seeds. A strong, heavy soil, with a con siderable portion of clay, is indispensable for a good crop of this class of Beaus.

If by mail, postage must be added at the rate of 15 cents per pint, or 25 cents per quart.

Broad Windsor,-Particularly valuable from its luabit of ripening unequally, some pols being quite full, wlile others are in varions stages of filling. Per qt., 40 cents; peck, $\$ 2.50$; bush., $\$ 8.00$.

Early Mazagan.-This variety is suitable botl for field and garden cultule. Per qt., 30 cents; peck, $\$ 1.75$; bush., $\$ 6.00$.

Long-pod Sword.-This sort is also adapted either for the garden or the fielt. Per qut., 40 cents; peck, $\$ 2.00$; bush., 87.50 .

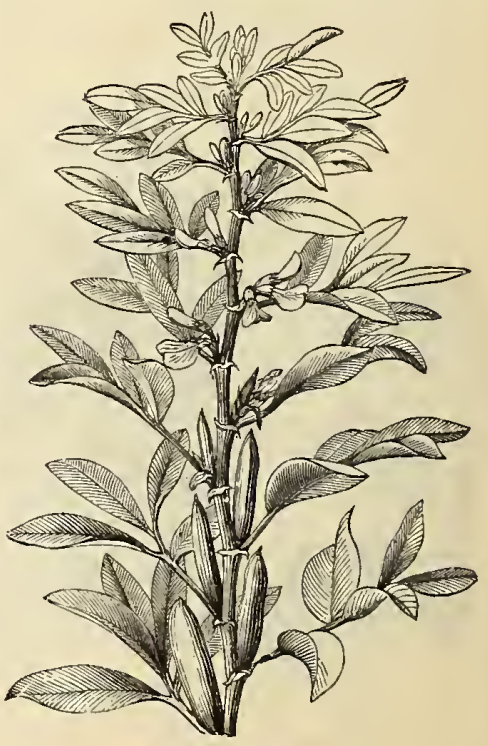

English Bean. 


\section{BEANS (Dwarf, Snap, or Bush).}

[Phaseolus vulgaris, Is. Haricot, H'k. Bohne, (HER. Frijol enano, Sp.]

Under the name of Dwarts aro elassified all the low growing sorts, called jn difforent Catalogur's Bush, Band, sinap, string, or F'rench Beans.

\section{Oue quar will plant from 100 to 150 feet ot arill, accordins ro size of Bean.}

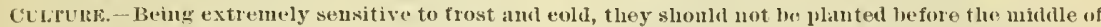
ipring, when the ground has become light and warm. In a favorable season the first of $\mathrm{May}$ will genc' ally be found about right. Select a dry, slueltered spot, which las bech previously slightly mamred and well dug; make drills two ducles derv and two feet apart, aud plunt the Beans threo inches apart in tho (lill, aud cover not noro than two inclus drep. Iloo of ten, but only when dry, as ('antl seattered on tho leares when wet with dew or rain will cause thom to rust, and greatly iujure the crop. l'laut at intervals throughout the season, for a shccession, finishing about the ent of July.

$$
\text { If by mail, postaye must be alded at the rate of } 15 \mathrm{c} \text {. per pint, or } 25 \mathrm{~s} \text {. per quert. }
$$

Black Wax.-Highly recomminded as a string leau; pods almost transpatrent; waxy, yellow, thick, aud tender. Per pkt., 10 ceuts; yt., 30 leck, $\$ 2.00$ : busli., 87.00 .

Crystul White IVax. - distiuct variety, with waxy, translurent pots; stringless, snceulent, crisp, tender, and of the richest flavor. The pods are slow to harlen, and retain their delicions tenleruess on the busl louger tban ang otler sort Per jkt., 10 cents; qt., 35 ; jrek. 2.25 ; busl. 5800 .

Dwarf Hout d'Or Bealus. A new variety of wux bean, from Germany. A profuse beares, and a decided acepistion. Per pkt., 15 cents; pint, 75.

Wwarf White Wax.-Similar in every lespect to Black Wax, except in color. Per pkt., 10 cents qt., 30; leck, s3.00; busli., 87.00.

Early China, - Viry early and of time guality reeds white, spotted witl purplisli red. Peropt. 10 cents: qt., 30 ; peck, $\$ 1.75$; buslı., \$6.00.

Eurly Feejee.-Thw earliest and most hardy vari. ety srown, of good size, very prodnctive, alli of extellent quality. I'2x pkt., 10 cents; qt., 30 ; peck, 31.75 ; busl., \$6.00.

Early Jong Fellow -ix Weeks.-Hardy and prolific; excellent for general crop. P\&r pkt., 10 cents; it , 30; peck, $\$ 1.50$; buslu., 85.00 .

Early Mohawk.-One of the lardiest amol nost productive of the dwarf varieties. Per pkt., 10 uents ; at. 30 ; peck, $\$ 1.50$; buslı, $\$ 5.00$

Early Rachel.-One of the enlliest, hardy" aur. pro luctive; porls crisp and tender when young. Pei pkt., 10 cents: "It, 30 ; peck, $\$ 1.50$; busl., $\$ 5.00$.

Garly Kound Fellow six Weeks.-Very hardy, 'arly and prolitic; pxcellent for general crop. Fer pkt., 10 cents; qut., 30 ; 1eck, \$1.50; busl., \$5.00.

Early Valemine.- Early and problustive: pods tonler and sicculent. Per pkt., 10 ceuts; 1 t., 30 ; prek., \$1.50; busl., \$5.00.

tallega or Large kefingee.-An improved form of the well-known Refugre Bean, being uot ouly fac more prolific, but pols and beans are much larger in size tlan in that well-known variety. p'er phit., 10 cents; 4t, 30 ; prek, \$1.75; busl., $\$ 6.00$.

Golden Wax Dwart--Earliur than tho Dwart Black IVax; pods large, long, and brittle, and eu tirely stringless. As a snily 13tan it excels al otler sorts in tenderuess aud rieluess of Havor, and has the further merit of being one of the best shell Beans arrown for Winter use. Por pkt., 10 conts; qt., 30 ; jeck, \$2.00; busl., s7.00.

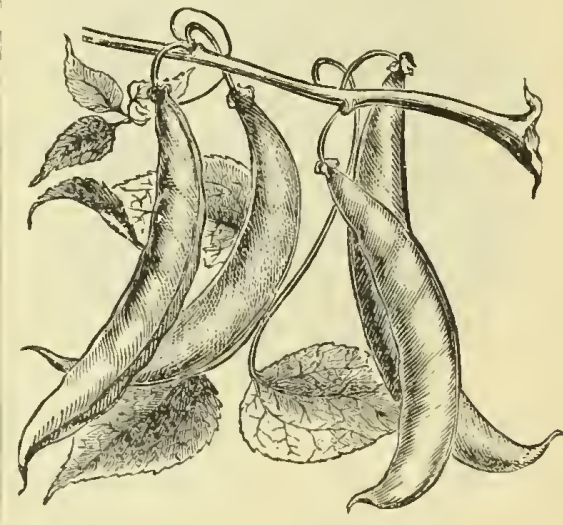

Ivory Pod Wax.

Irory Pod IVax - This variety cannot be tor lighly praised, as a suiju-sliort, or for a Winter shelled Bean, and ean not bo sn rpassed for canning purposes. It is fully a week earlier than the Black Wax, enormonsly prodnctive, long, stringless, temler, succuleut, with transparent ivory white pods, and of ricli ereatmy flavor. It is, witl out doubt, the most productive Wax Bean now grown, the vines being a perfect mat of pods the eutire season. Per pkt., 10 cents; qt., 50 ; peck $\$ 2.50 ;$ lusb., $\$ 9.00$.

Large White Kidney, or Koyal Dwarf- As a

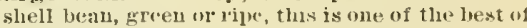
the Dwarfs. I'er pkt., 10 eents; qt., 30; perk, $\$ 1.50$; busll., $\$ 5.00$.

IRefugee, or Thousand to Oue.-llardy, yields abundantly, aud of fine quality; as a string be:al or for pichling, it is considered tlie best. Per pkt. 10 cents; qt., 30; peck, s1.50; busl., \$5.00.

Turte soup l3lack. - The young pots of this varioty are tender and of excellent quality; the ripe seed is used in the preparation of Turtlo soup. l'er pkt., 10 cents: yt., 80 ; wek, 1.25; busl., \$4.50.

White Marrow.-An excellent variety for cooking when ripe, for which it is a tensively grown. l'er pkt.. 10 (:ents; qt., 25; peck, $\$ 1.50$; bush., $\$ 5.50$.

\section{BEANS (Pole or Running).}

[Haricots a Rame's, Fr. Slangen Bohm, Gre. Frijol vastago, SP.]

One antrt will plaut about 1.50 hills.

These are more tender, aud require rather more core in culture that the lusli bous, and, as a rule, loonl be sown two weeks later. They snccenl best in sandy loam, which should bo liberally enriehed with short manne in the lills, whieh are formed, according te the varicty, fion three to four foct aluart; from tive to six seeds are planted in cacli hill, with the eye downward; cover about two inches. Wharil the plants are well established, thin out, leaving four to each hill. They transplant easily if grown in frames so as to fill up around the poles, whele they miss or fail to come 11, wing to unfarorable weatler. 


\section{POLE BEANS.- - cont'd.}

If by mail, postage must be added at the rate of $15 \mathrm{c}$. per pint, or 25e. per quart.

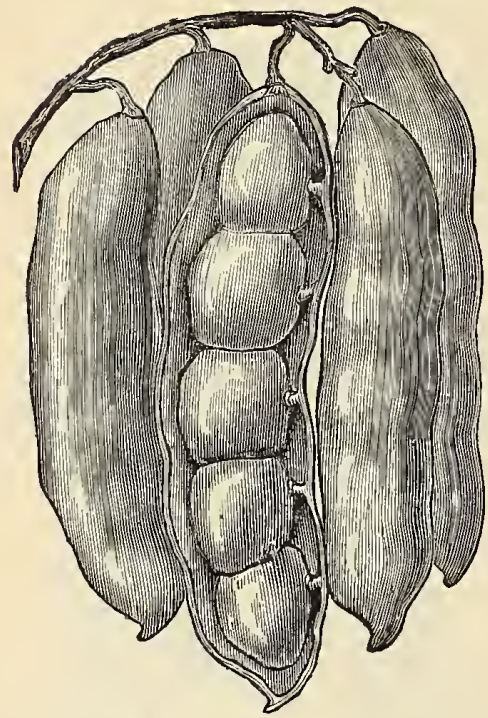

Dreer's Improved Lima Beans.

Dreer's Improved Lima.-The distinctivo improvements are its carliness, remarkable productiveness, delicious flavor, and the forming of the beans so closely in tho pod. Per pkt., 10 cents; qt., 50 ; peek, $\$ 3.25$; bush., $\$ 11.00$.

Large White Lima. $-\Lambda$ large, lato bean, with broad, rough pods; and, although late, is surpassed in quality by no other variety. It is a general favorite wherever cultivated. Per pkt., 10 cents ; qt., 50; peck, $\$ 3.00$; bush., $\$ 10.00$.
Extra Early Lima.-A new and distinct variety, fully ten days earlier than any otlicr. Recommended market sort; very productive and of ox tra fine quality. Per pkt., 15 ; pint, 50.

Early Dutch Case Knife.- Early and productive, and excellent, whother used green or dry. Per pkt., 10 ccnts ; qt., 40 ; peck, $\$ 2.25$; bush., $\$ 8.00$.

Giaut Wax.-Pols six to nine inches long, thick and fleshy, of a palo ycllow color and waxy appearance; the seeds are tender, and shelled green or as a snap Bean, it lias no superior. Per plit., 15 cents ; qt., 50 ; pcck, $\$ 3.50$; bush., $\$ 12.00$.

Horticultural Cranherry, or Wren's Egg. - An old and popular variety; green beans, large, eggshaped, and of the higliest quality ; the dry beans are very superior for baking or stewing. Per pkt., 10 cents; qt., 35 ; peck, $\$ 2.00$; bush., $\$ 7.00$.

Indian Chief, or Algerian Wax.-Produces in great abundance; flno, tcnder, succulent, and richly coloreil pods, that continuo fit for uso longer than any other variety. Per pkt., 10 cents; qt., 50 ; peck, $\$ 3.00$ : busl.., $\$ 10.00$.

Mout D'Or, or Golden Batter.-A splendid variety with golden yellow pods, very prolific, and of excollent quality. Per plkt., 10 cents: qt., 50; peck, $\$ 3.50$; busk., $\$ 12.00$.

Scarlet Runner. - A favorite sort, cultivated for the boauty of its flowers, as well as for culinary uses. Per pkt., 10 cents; qt., 50 ; peck, $\$ 2.50$; busl., $\$ 9.00$.

Southern Prolific. An excellent bean for cooking in the pod. The pods aro produced in clusters, and as it matures in sorenty days, the grewth is rapid and tho pods brittle and tender. It is ono of the most popular beans in the Southoru States, where it is better lnown than in the North. Per pkt., 10 cents; qt., 50; peck, \$3.50; bush., \$12.00.

White IR unner, or Dutch.-Similar to scarlet Runner, except in color of secd and tlower. Per pkt., 10 cents; qt., 40 ; peck, $\$ 2.25$; bush., $\$ 8.00$. Small Lima, Carolina, Sewee, Sieva, or Saba. Resembles the Largo Lima, but is interior in flaror, is earlier, more hardy, and surer to produce a good crop. Per pkt., 10 cents; qt., 50 ; peck, $\$ 3.00$; bush., $\$ 10.00$.

\section{BEET.}

\section{[Beta vulgaris, Lis. Betterave, Fr. Runiklereube, GEr. Remolacha, SP.]}

\section{One ounce will sow one hundred feet of drill.}

Cucrule.-Select for this crop deep and rich, yet rather light and loany soil which has been well manured during the previous soason.

For an carly supply, sow as soon as the ground cau bo worked in spring, and the main crop tho first week in May; but for Winter use sow as late as June. Sow in drills abont ono inch deep, and from fifteen to eighteen inches apart, and, if possible, select a dry day when the ground is in good working orter for putting in the seed. By seaking the seed in tepid water for twenty-four hours it will vegetate much sooner.

If by mail in quantities of 4 ounces and upvards, postage must be added at the rate of $16 e$. per pound.

Bastian's Early Blood Turnip.-This valuable variety is larger thau Egyptian Blood Turnip; teuder and sugary, and retains its bloot-red color after cooking. Per pkt., 5 cents; oz., $10 ; 1 / 31 b$. 25 ; lo., 80 .

Dark Red Egyptian.-Early and distinct, very deep red, tender and delicious; ten days earlier than any other; a valuable inarket variety. Per pkt., 10 cents; oz., $15 ; 1,1 \mathrm{l} ., 35 ; 1 \mathrm{l} . \$ 1.00$.

Dewing's Improved Blood Turnip. - Of fine form and flavor, and deep blood.red; a desirable variety. Per pkt., 5 cents; oz., 10; $1 / 41 \mathrm{lb} ., 25 ; 1 b ., 80$.

Early Blood Turnip.-A standard round variety, with small top; very tentler; flesh of good color. Per pkt., 5 cents; oz., 10 ; 1 1 lb., 25 ; 1b., 80 .

Early Yellow Turnip, or Orange.-Flesli yellow, very tender and juicy. Per pḱt., 5 cents; oz., 10 ; 1/41b., $25 ; 10 ., 80$.
Early Flat Bassano. - A flat, turnip-shaped variety, flesl whito, circled with rose color; grows to a good size; is tender and juicy. Per pkt., 5 cents; oz., $10 ; 3 / 1$ b., $25 ; 1$ b., 80.

IIalf-Long Blood. - A favorito varioty; smooth skin and very dark flesh ; keeps well. Per pkt., 5 cents; $0 \% ., 10 ; 1 / 1$ b., 25 ; 1b., 80.

Pine-Apple.-An Euglisil raricty, foliage small, but very dark rcd ; roots dark crimson. Per pkt., 10 cents; oz., $15 ; 1 / 11$. $40 ; 1$ b. $\$ 1.25$.

Smooth, Long, Dark Blood. - This grows to a good size, half out of the ground, with few or no side roots; thesh dark blood-red; keeps well. Per pkt., 5 cents; oz., 10 ; $1 / 1$ lb., $20 ; 1 b ., 60$.

Swiss Chard, or Silver. -This is sometimes called "Sea IKalo Bect," and is cultivated for its leafstalks, which are serred uy llke Asparagus or Spinach. Per pkt., 5 cents ; oz., $10 ; 1 / 413 ., 25 ; 11$., 80. 
For the Farm and Garden.

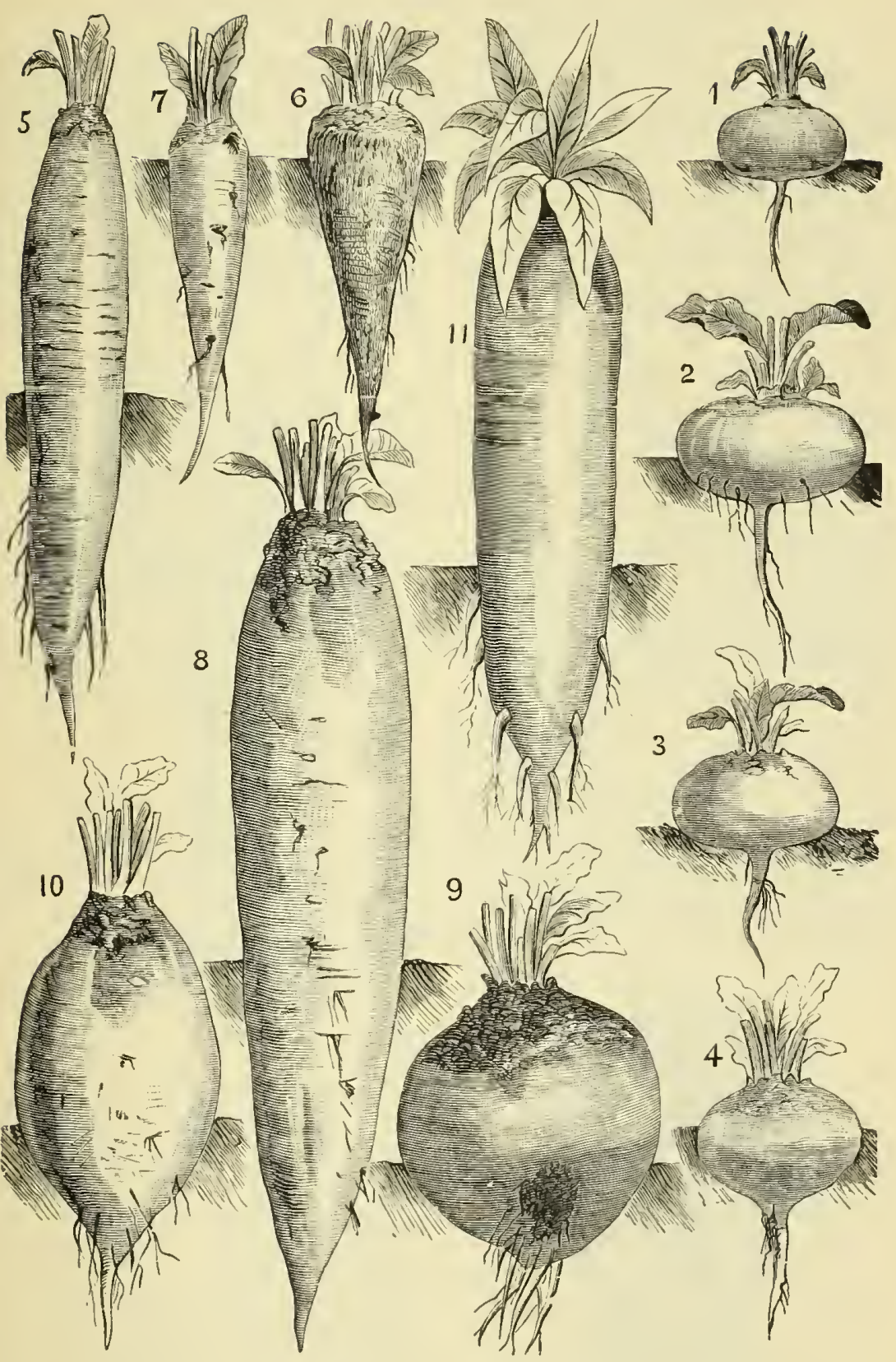

GARDEN AND FIELD BEETS.

1.-Early Dark Red Egyptian.

2.-Bassano.

3.-Blood Turnip.

4-Dewing's Blood Turnip.
5.-Long Smooth Dark Blood.

6.-Rough Skinned.

7.-Deep Red Castelnandary. 8.- Mammoth Long Red Mangel Wurzel.
9.- Yellow Globe Mrngel Wurzel.

10.-Olive Shaped Mangel Wurzel.

11.-Lane's Improved Sugar. 


\title{
BEET.-Cont'd.
}

\section{MANGEL WURZEL AND SUGAR BEETS.}

From fomr to six pounds of seed will sow one acre.

CuLTURE.-The following varieties are extensively grown for feeding stock, and are excellent food to increase the flow of milk. As they grow much larger than the varieties cultivatec for table use, they require more room, and should be sown in drils about two fcet apart. Tho sceds slionli be iropped about two inclics apart in the drils, and, when strong enough, thinned out to twelro or fiftcen incles in the row. The long rarieties are best suited to a deep soil, and the globe sorts succecd better than the long sorts on sandy soil.

If by mail in quantities of 4 ounces and upwards, postage must be added at the rate of $16 e$. per pound.

Golden Tankard. - One of the most nutritious varietres in eultivation; Hesl deep yellow, very productire. Per oz., 10 cents: $1 / 1 \mathrm{lb}, 25 ; 1 \mathrm{~b}, 80$.

Kinver Yellow Globe. $-A$ new and very produc. tivo variety; one of tho best. Per oz., 10 cents; $3_{1} 11,, 25$ 16., 75.

Long Red Maugel Wurzel. - This is more gencrally grown for agrieultural purposes than any other, producing roots of large size and fine quality. Per pkt, 5 cents; oz., 10; 1. 1b., 15; 11). 50 .

Mammotl Iong Red.--This varicty produees roots of uammoth size, very regnlar and with a sinall top. Per oz, 10 cents; $1410 ., 25 ; 1 b ., 75$.

Obendorf IRed and Obendorf Yellow,-Two new German varieties, of file sliape, which grow to a large size, and are very productive. Per pkt., 5 cents; $0 z ., 10 ; 1$; 1b., 25 ; 1b., 75 .

Prize lellow Clobe- of beantiful sliape, fiue, clear skin, productive, and of excelleut nutritive qualitics. Per oz, 10 cents; $/ 41 \mathrm{~b}, 25 ; 1 \mathrm{~b} ., 80$.

IRed Globe.-Differing from Yellow Globe only in color. Per 1 kt, 5 cents; $02 ., 10$; $1 / 41 \mathrm{~b}, 20 ; 1 \mathrm{~b} ., 60$. Warden Orange Globe.-A yellow Globe, mnoqualcd for excellence of quality and protuctiveness; twelve well-shaped roots weighed 192 ponuds. Per oz., 10 cents; $1,16 ., 20 ; 1 b ., 60$.
Yellow Globe.-A large, round, orange-colorcd variety, exccllent quality, keeps better than the long red, and is better adapted for growing on sluallow soil. Per plkt., 5 cents ; $0 z, 10 ; 1,11,15 ; 11,40$. Yellow Ovoid.-Bulb ovoid, internediate bet ween the Long ant Globo varieties; flesh solid; usually white, zoned with yellow; hardy and prodnctive; very uutritious. Per oz., 10; i lb., 25; 1b., 75.

\section{SUGAT BFF'T.}

Frencb Sugar.-This grows to large size, much above glound; roots medium length, and white fleshed; leaves green; considerably grown in this conntry for feeding. Cultivated extensively for the mauufacture of sugar. Per pkt., 5 cents ; oz., 10 ; 1 / 1b., $15 ; 1 \mathrm{~b} ., 50$.

Lane's Improved Imperial Sugar.-An im. proved varicty of the French Sugar Beet, obtained by careful sclection in this conntry, and recommended as being hardier, more productive, and contaiuing a greater porcentage ot sugar than the ordinary variety. Per pkt., 5 cents; oz., $10 ; 1 / 1$ b. $25 ; 116 ., 80$.

Vilnoriu's Improved Imperial Sugar.-An improved variety from France, said to afford the largest percentage of sugar of any known variety. Per plit., 5 cents; oz., $10 ; 111$., $25 ; 11$., 80.

\section{BORECOLE, or KALE.}

\author{
[Brassica oleracea acephalo, Liv. Chou-rest, Fr. Griener Kohl, GER. Breton, Sir.]
}

One ounee will sow a bed of forty square feet, and prodnce about 3,000 plants.

CuLrure,-Borecole, or Kale, may bo grown in aluost any soil, but the riclier it is the more abundant the product. Sow from the midd o of Apil to tho beginning of $\mathrm{Mar}$, in prepared beds, covering the seeds thinly and evenly; transplant in $J$ une, and trcat in the same manner as for cabbare. Of all tho cabbage tribe this is the most delicious, and would bo much more extcnsively growu than it is, if its excellent qual. ities wero generally known. The varieties are all extremely hardy, and are best when touched by frost.

If by mail in quantities of 4 ounees and upwards, postage must be added at the rate of $16 \mathrm{c}$. per pound.

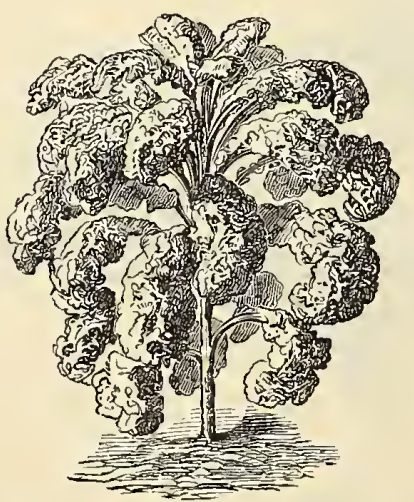

Green Curled Scotch Borecole, or Kale.

Dwarf Cnrled Kale, or German Greens.Dwarf ; leaves yellowish green, very tinely frimgert. Per pkt., 5 cents; $0 z ., 10 ; 1 / 11$., $25 ; 1 b ., 90$.
Dwart Purple or Brown Kale.-A beautifnl curled variety, with reddish tinted leaves. Per pkt., 5 cents; oz., 15; 1 1b., $30 ; 1 \mathrm{~b} ., \$ 1.00$.

Green Curled Scoteb.-Very liardy, and, like the Saroys, is improved by a moderatefiost. Per pkt., 5 cents; $0 z ., 10 ; 1416 ., 30 ; 1 b ., \$ 1.00$.

Improved Camishiug.-- Very ornamental as a bor. der plant, as well as useful for culinary jurposes. Per plkt., 10 cents.; 0\%, 30; 1/ lb., \$1.00; 11., \$3.00. Improved siberian.-A new and very hardy variety, much ill faror with the market gardeners around New-York. Per jkt., 5 rents; oz., 10; $\frac{1}{4} 1 \mathrm{~b}, 25 ; 1 \mathrm{~b} ., 80$.

New Russian Hardy.-A beautifully laciuiated, extreuely liardy variety, with thick foliage of a peculiar sea-green color. It las remained uninjured during very severe Winters, while other varietics, growing alongside, were completely do. stroyed. Per plit., 25 cents.

Thonsand-ITeaded.-Yiclis abundantly on any soil, and greatly relishcd by eattle or slioep; grows from threc to four fect higl, the stem being cov. ered with leaves, which form small heads. It is not aftected by slight frost, and by successive sow. ing may be had all the year round in the Sonthern States or on the Pacific coast. P'er pkt., 10 cents; oz., 20; 1/4 lb., 60; 1b., \$2.00. 


\section{BROCCOLI.}

[Brassica oleracea botrytis, LA. Chou lroeoli, Fu. Brocoli. spurgel-Kohl, isk. Broculi, SP.]

One ounce will sow u bed of forty sumare feet, and produce ubout 3,000 plants.

C'rLTURE.-The seed should be sown in hotheds, for early crops, in April; for matu crops, in May. When the plants are suficiently strong, and before they are drawn by growing too closely togetler, trans. plant them into nursery beds or lint's, allowing about four ineltes between the plants.

Plant out as soon as the plants are sufficiently established, in rows from two feet to two feet six inehes apart, leaving about the same distance between the phats. Kfep them well supplied with water until they get fairly established.

If by mail in quantitics of 1 ounces and upvards, postage must be added at the rate of $16 \mathrm{ic}$ per pound.

Early Purple Cupe.-This is the most valuable kind for the North, produeing large, close lieads, of a brownislı parple, and lias an "xcelleut tlavor: Per pkt., 10 cents ; $0 \%, 50$; 1 ; $1 \mathrm{~b}$., \$1.50.

Baleheren.-One of the harliest and bist, with very large, firm licals. Per pkt., 10 ecnts; $0 \%, 60$; is $11 \mathrm{~b}, 52.00$.

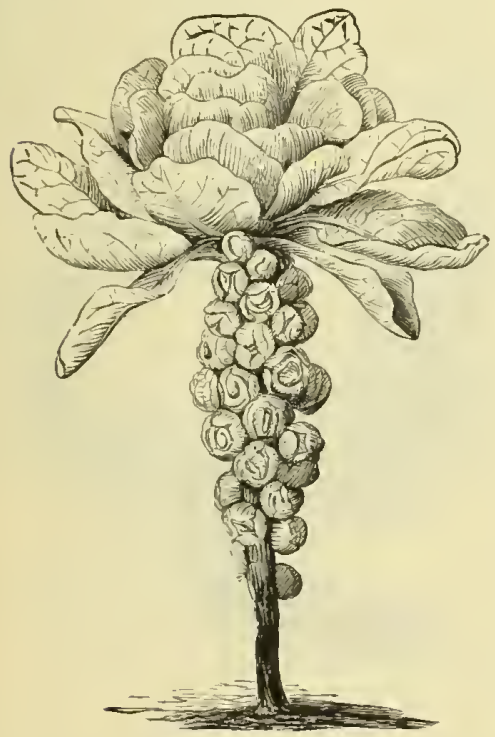

Brussels Sprouts.
White Cape. $-A$ later sort, and should be sown at the North very carly in the Spring. The heals, when perfected, are large, white, and compact, so nearly lesembling the Cauliflower that it is sometimes called the "Caulitower Broccoli." Per pkt., 10 etents; oz. $75 ;$ is $1 \mathrm{~b}$., 32.00 .

\section{BRUSSELS SPROUTS.}

[Brassica oleracee bullata, Is]. Chou de Brurelles, Fin. Gruener Sprossen. Geu. Breton de. Bruselas, si.]

Ouf onuce will row a bed of forty aquare fect, and produce about 3.000 plants.

(:thives, - Althongh sot in general use in this country, this is a most defieious veretable. The plant grows two or three fiet ligh, aud produces from the axils of the leaves an abundance of sprouts, one or two inches in dianeter, resembling small eabloates, and of excellent thavor. The culture is unch tho same as for ('abbage. If eurly plants are raised in a loot-bed, they will be fit for use in Sor). tember, and a later wowing in the open gromnd will be in perfection abont the time Winter commences. These shomld be taken up) and stored in a coot cellar, with the roots in earth, where they will remin fit for use during the Wiuter. Where the winters are not very severe, they may remain in the ground, to b. ('ut as neeled : in fact the sprouts arc inneh im. proved by a moderate, frost.

If by mail in quantities of 4 ounces and upwards, postage must be added at the rate of $16 \mathrm{e}$. per pound.

Improved Dwari-A new variets of excellent quality. P'r pkt., 10 ('ent.s; $0 \%, 25 ; \frac{1}{4} 1 \mathrm{~b} ., 80 ; 1 \mathrm{~b}$., $\$ 2.00$.

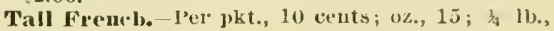
$50 ; 11 ., \$ 1.75$

\section{CABBAGE.}

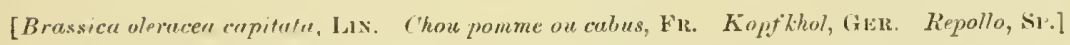

(bne ounce will sow $n$ bed of forty square feet, and produce about $\mathbf{3 . 0 0 0}$ plants.

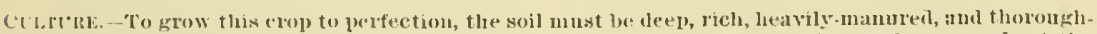
1y worked. For early use, sow the seed in hot.beds in February or Mfarch, or it mag be sow about the midale of septeulber, ant the plauts wintered over in cold frumes. Transplant in spring, as soon as the ground can be worked, un rows two fert apart, and the plauterightern ineles apart in the rows, and set the plants in the gronmil ny to the first leaf, no matter low long the stem may be. For late or Winter use. the seed should be surn in May or Jume, and the plants set out in . Iugust, two and a half by three feet.

If by mail in quantities of 1 ounces and upwards, postaye must be added at the rate of $16 \mathrm{c}, \mathrm{per}^{\circ} \mathrm{pound}$

Early Bleichield Giant. - In early, short-stem

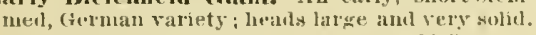
Per jukt., 10 rents: $04 ., 50$ teents; ? 11\%., \$1.50.

Enrly Blood Red Erfirt. - A bout ton days earlier than tle Red Dutch, anl ("rually gook for pickling. Per pkt., 10 cents; $0 \% .40 ; 1_{4} 11$ )., $\$ 1.25 ; 1 \mathrm{~b}$., \$4.50.

Early Drumbead or Battersea.-A second early varicty, romml, flat-licaded, of excellent quality, and not liable to exack. Per pht., 10 ("nents; $0 \%$, $20 ; 1,11, .75 ; 1 \mathrm{~b} ., 22.50$
Early Flat Dutch. - A vahable early varicty, of goot size; solil aud of good flavor. I'el pkt., in teuts; $0 \%, 50 ; 1,11), \$ 175 ; 11$., \$6.00.

Eauly cumuer, IIenderson's.-A time early sort, commo in just after Wakefirlel; larese firm lucals.

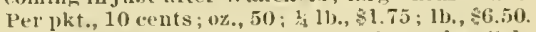
Early Wyaru. - one of the best early market ('ab. batges glown; it heals carly in the season, is of large size and first quality. P'er pkt., 10 cents: $0 \%, 50 ; 111 ., \$ 1.75 ; 11 ., \$ 6.50$. 


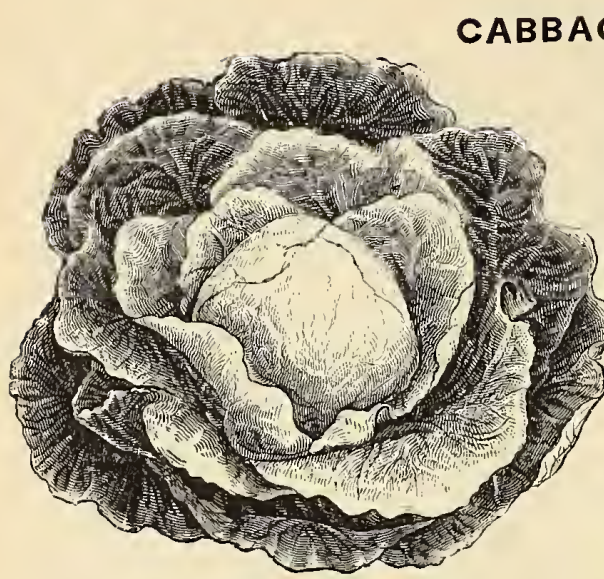

Early Jersey Wakefield.

Early Wakefield (True Jersey variety).,-This is a favorite varicty with market gardeners in all parts of the country; it is very early, of medium size, good quality, and suro to head. Per pkt., 10 cents: oz., $75 ;$; $1 \mathrm{lb} ., \$ 2.00 ; 1 \mathrm{~b} ., \$ 7.50$.

Early Wakefield (Importer).-Grown from Amer. ican stock. Per pkt., 10 cents; $0 z ., 40$; $\frac{1}{4} 1 \mathrm{lb}$., $\$ 1.50 ; 1 \mathrm{~b} ., \$ 5.00$.

Early York. -A well known variety, with small, heart-shaped heads, firu, tender, and of excellent Hlavor. Per pkt., 5 cents; oz., $20 ; 1 / 1 \mathrm{lb} ., 60 ; 1 \mathrm{~b}$., $\$ 2.00$.

Filderlkrant. - A desirable German variety, introduced some years ago; heads np very solid, and does equally well as an early or late varicty. Per pkt., 10 cents ; oz., $30 ; 1 / 1 \mathrm{~b} ., \$ 1.00 ; 1 \mathrm{~b} ., \$ 3.00$.

Fottler's Improved Brunswick. - This is tho best Larly Drumhead variety, producing a good firm and solich hearl, of splenitid quality. Per pkt., 10 cents; $0 z ., 50 ; 1 / 1 \mathrm{~b} ., \$ 1.75 ; 1 \mathrm{~b} ., \$ 6.00$.

Large Bergen or Great Americau. $-A$ large, late sort, of a light green color, with a short stem; the heads are firm, teuder, and of goot Havor. Per pkt., 10 cents; oz., $40 ; 1 / 1 b ., \$ 1.50 ; 1 b ., \$ 5.00$.

Lau'ge Early Schweinfurt. $-A$ German variety, with very large heads of tine quality, adapted for Summer and Fall use: it is the largest early variety in cultivation. Per pkt., 10 cents; oz., 30; $1 / 4 \mathrm{lb}$., $\$ 1.00 ; 1 \mathrm{~b}$., $\$ 3.50$

Large Carly York,-Larger and lator than the Early York; it eudures the heat well; aud is much estcemed at the South. Per pkt., 5 cents ; oz., 20 $\frac{1}{4} 1 \mathrm{~b} ., 60 ; 1 \mathrm{~b} ., \$ 2.00$.

Large French Ox-heart, - An excellent variety, in nso after Early York; lieads closo and firm, with but few lonse leaves. Per pkt., 10 cents; oz., 20 ; $1 / 1 \mathrm{~b}, 75 ; 1 \mathrm{~b} . \$ 3.50$.

Large Late Drumhead, Americau. $-A$ very large varicty, witli solid, flat, or round licads. Por pkt., 10 cents; oz., $40 ; \frac{1}{4} 11$., $\$ 1.50 ; 1 b ., \$ 5.00$.
Large Late Drumhead, English. - Resenubles the preceding. Por pkt., 5 cents ; 0z., 20; $1 / 41 \mathrm{~b}$., $60 ; 1 \mathrm{~b} ., \$ 1.50$.

Marblehead Mammoth Drumhead.-This is the largest variety of the Cabbage family, and suecceds admirably in the Southern States, where it is considerch one of the best for that latitude. Per pkt., 10 ceuts; oz., $50 ; \frac{1}{4}$ 1b., $\$ 1.75 ; 1$ b., $\$ 6.00$. Premium Flat Dutch.-As a variety for the Winter market this las no superior. Hcads large, round, solid, broad and Hat on the top; they open white and crisp, are tender and well-flavored; it is also one of the very best varietics to keep. Per pkt., 10 conts ; oz., $40 ; 1 / 41$. $\$ 1.50 ; 1 \mathrm{~b} ., \$ 5.00$.

TRed Dutch, or Pickling.-A bout medium size, with very liard, oblong lieads, of a dark red color. Per pkt., 10 cents ; oz., 20 ; 4 i 1b., 75 ; 1 b., $\$ 2.50$.

Silver-Leaf Drumhead.-An excelleut market varicty, firm, solid lucad, of lar ge size, good k eeper. Per plkt., 10 ccnts ; oz., $50 ; 1 / 4 \mathrm{~b} ., \$ 1.75 ; 1 \mathrm{~b} ., \$ 6.00$. Stone Mason (Imported).-An improved variety of the Drumhead; flat and solid; quality sweet, teuder, and rich; a profitable market variety. Por pkt., 10 cents; oz., 40 ; $\frac{1}{4}$ 1b., $\$ 1.25 ; 1$ b., $\$ 4.00$.

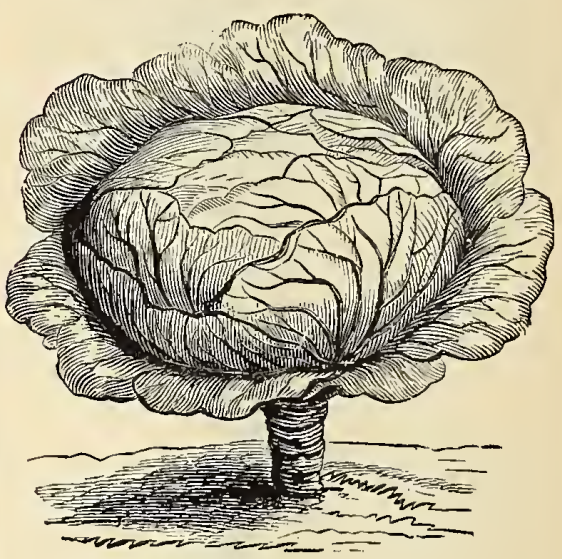

Premium Flat Dutch.

Winnigstadt,-One of the best for geueral use; comes both early and late; remarkably solid and hard; keeps well in hot and cold weather. Per pkt., 10 cents; oz., 25 ; 1/1 1b., 75 ; 1b., \$2.50.

\section{COLIAARDS}

A variety of Cabbago growu extensively at the South, whero it is cultivated for greens, aud will always givo a crop when Cabbage fails. Our seed is truo Creole, the only varicty worth growing. Per pkt., 5 cents ; oz., 20 : 1/ 1b., 60 ; 1b., \$2.00.

\section{SAVOY CABBAGE.}

The Savoy Cabbages have wrinkled leaves, and are of excellent Havor; they approach nearer to the delicious riclness of tho Caulitlower thau auy of the other Cabbages, especially after a slight frost has touched tlien in early winter.

If by mail, in quantities of 4 ounces and upward, postage must be added at the rate of $16 \mathrm{c}$. per pound.

Drumlıad.-Very tender and excellent for Wiuter. Per pkt., 5 cents; oz., $40 ; \frac{1}{4} 1 \mathrm{~b}$., $1.25 ; 1 \mathrm{~b}$., $\$ 2.50$.

Green Globe or Curled,--Leaves wrinkled and dark green; very liardy, and improved by frost. Per pkt., 5 ceuts; oz., 25; 1/4 1b., $75: 1 \mathrm{~b} . \$ 2.50$.
Improved American.-A most excelleut variety, with large, firm heads, of superior tlavor.। Por pkt., 10 cents ; oz., 40 ; 1 1b., $\$ 1.25 ; 1 \mathrm{~b}$., $\$ 4.00$.

vietoria.-Excellent in evory way; lreads large and firm. Per pkt, 10 cents; oz., 40; $1 / 4 \mathrm{lb}$., $\$ 1.25$; 1b., $\$ 4.00$. 

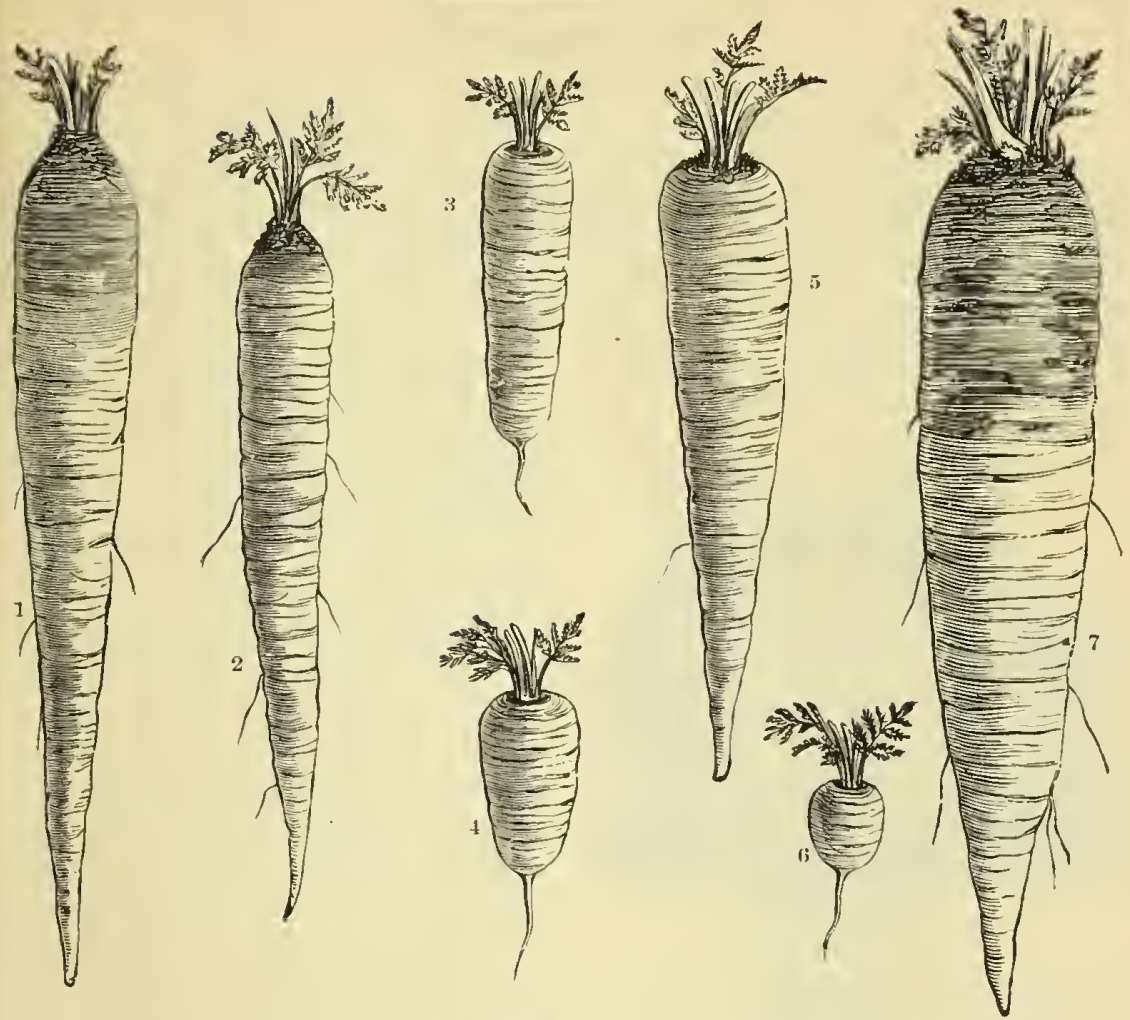

\section{2.-Alt ringham. \\ 3.- Early Half-long sicarlet.
4.-Early Horn.}

1.- Bliss's Improved Long Orauge.

\section{5.- long Orange. \\ 6.- Earliest Freneh Forcing. \\ 7.-Large White Belgian.}

\section{CARROT.}

[Daucus Carota, Lix. Carotle, Fr. Mahre, Ger. Zanahoria, Sr.]

One onuce will wow one hundred feet of drill.

Cultur.-A light, deep, sandy loam is the most snitable, and, as minure applied in a fresh state often induces forked and illshaped roots, the gronnd intended for carrots slould be heavily manured and well dug the previous seasou. If ahtitional mumre is consilered reguisite, let it be applied after the crop is up, using guano or some good artificial manure. Sow as early in spring as tlie ground is in fair working contition, in drils twelve to fifteen inches apart, covering the seeds ovenly to the deptli of abont half an incl. As soon as the plants are sufficiently strong, thin ont to from four to six inches, according to the variety, the larcer ones requiring the greater distance, and keep the surfuee open by a frequent use of the hoe. Carrot sepd being slow to germinate, if soaked in tejid water for alont twise lonrs, and afterwart mixed with dry sand to separate, it will germinate more fr'sly.

If by mail in quantities of 4 ounces and upwarls, postage in ust be addeal at the rate of lic. per pourul.

Altringlam. - An excellent variety, smaller than the Orange: inild and well flavoret. Per pkt., 5 cents; $0 z ., 10 ; x_{4} 16 ., 30 ; 1 b ., \$ 1.00$.

Bliss's Improved Long Orange.-A great in. provement on the common Long Orange, obtained by a eareful selection for successive years of the best formed and deepest colored roots; it is larger; better flavored, of a dceper orange color, and more certain to produce a crop. Per pkt., 10 cents; $\omega \%$, $15 ; \frac{2}{4} 11$.. $35 ; 1 \mathrm{~b} ., 81.00$.

Earliest French Forcing.-A favorite litte car. rot, prized on account of its extreme earliness and superior thavor; best for forcing. Per pkt., 5 cents; 0z., 15; 1/4 1b., $50 ; 1 b ., \$ 1.50$.

Early Half-long sicarlet.-A stnmp-rooted sort, in size between the Early Horn and Long Orange, good for suallow soils. Per pkt., 5 cents ; oz., 15 ; $141 \mathrm{~b}, 40 ; 1 \mathrm{~b} ., 81.25$.
Early Horn. - One of the earliest varieties : tinegrained and agreeably thavered; excellent table Carrot, and grows well on thin soil. Per pht., 5 cents; 0z., $15 ; 11 \mathrm{~b}, 40 ; 11 \mathrm{~b} ., 81.25$.

French Intermediate-An excellent variety, in size betwern the above and Long Orange; very smooth ant of beautiful form. Per likt., 5 cents; $02 ., 15 ; 1111 ., 35 ; 16 ., \$ 1.00$.

Improved Danvers.-Cylindrical shape, stump. rooted, briglit orange red. Per pkt., 10 cents; oz., $15 ; \frac{1}{4} 1 \mathrm{~b} ., 40 ; 11 ., \$ 1.25$.

Long Orange. $-\Lambda$ well-known varioty, suritable for cither garden or farm culture. Fer pkt., 5 cents; oz., 10 ; 有 $16 ., 25 ; 11$., 80.

Large White Belginn.-This variety grows gbout one-third ont of the gromul; roots white, green alyove grominl; grown bxtensively for feeding stock. Per pkt., 5 cents ; $0 \% . .10$; $2 / 11$., 25 ; 11 ., 75. 


\section{CAULIFLOWER.}

\section{[Brassica oleracea botrytis, Lin. Choufleur, Fr. Blumen-koll, GER. Coliflor, SP.]}

\section{One ounce will sow a bed of forty square feet and produee abont 3000 plants.}

CuLtukE.-When grown to perfection, this is a most delieious vegetable, and well repays generous treatment in enltivation. With a deep, rieh soil, and an abundanee of moisture, which in dry seasons must be applied artitieially, Cauliflowers can be grown well. Frequent and rigorous hoeing, and a liberal supply of riell liquid manure, to keep up a continuous and rapid grow th, will produee splendid heads of the most delicate flavor. It faeilitates blanehing if the leaves are gathered loosely together aud tied over the top of the heal. For sowing the seed, the same general directions as reeommended for Cabbage will answer for this erop.

If by mail in quantities of 4 ounces and upward, postage must be added at the rate of 1 be. per pound.

Algiers. - A very popular late variety, and one of the very best for the market. Per likt., 15 eents $0 \mathrm{z} ., \$ 1.00 ; \% 1 \mathrm{~b}, \$ 3.50 ; 1 \mathrm{~b}$., $\$ 12.00$.

Early Dutch. - An early sort, with large, eompaet hearls. Per pkt., 10 cents ; $0 z ., 60 ; \frac{1}{4} 1 \mathrm{lb} ., \$ 2.00$ $1 \mathrm{~b} ., \$ 7.00$.

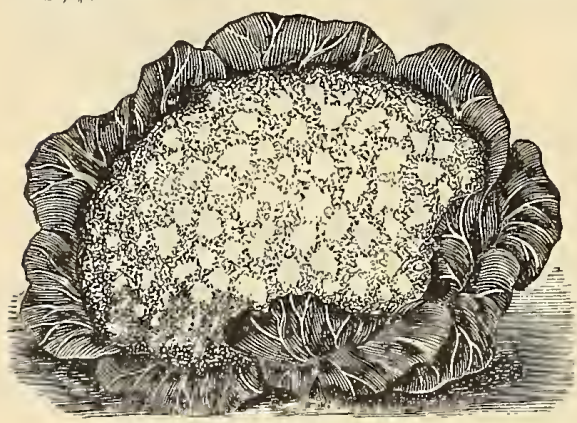

\section{Erfurt Earliest Dwarf.}

Erfinrt Earliest Dwart-Seed grown in Erfurt the earliest variety in cultivation, rery dwarf, with solid, pure white heads, and of superior qual. ity; one of the surest to head; seed rery suree. Per pkt., 50 eents; $0 z ., \$ 10.00$.

Erfurt Early Dwarf. - A favorite variety; very early; compaet heads of fine quality. Per pkt. 25 een $18 ; 0 \%, \$ 2.00 ; 1 / 1 \mathrm{~b}, \$ 7.00 ; 1 \mathrm{~b} ., \$ 24.00$.
Erfurt Large Early White.-An exeellent variety, produeing large, white, eompaet ledals, of tine quality. Per plit, 25 eents; $0 z ., \$ 1.50 ; z^{\prime} 1 b$. $\$ 5.00 ; 1 \mathrm{lb} ., \$ 18.00$.

Early Lomdon.-An exeellent early variety : heads large, very white and tender. Per pkt., 10 eents ; oz., $60 ; 11 \mathrm{~b} ., \$ 2.00 ; 1 \mathrm{~b} ., \$ 7.00$.

Early Paris. - The best known of all the early varieties; tender and delieious. Per pkt., 15 eents; oz., $\$ 1.00 ; 1 / 1 \mathrm{~b} ., \$ 3.50 ; 1 \mathrm{~b} ., \$ 12.00$.

Early Snowball.-An extremely early dwarf vari. ety, produeing magnificent white lieals of the finest quality. Per pkt., 25 eents; $0 z ., \$ 5.00$.

Half Early Paris. - One of the most popular varie. ties; heads very white and eompaet; good for an early or late variety. Por plit., 15 eents; 0z., $\$ 1.00$ : $1 \mathrm{~b} ., \$ 3.00: 1 \mathrm{~b}, \$ 10.00$.

Imperial. - A mediun early French variety, sure to head; grows to a large size, is of delicious tlavor, and will prove a valuable market varietr. Per pkt., 15 eents; oz., \$1.00; 1 b., \$3.00; $1 \mathrm{~b} ., \$ 10.00$. Lenormand Short Stemmed. - A superior variety, with fine, large, and well-formed hoads. Per pkt. 15 eents: $0 z, \$ 1.00 ; 1,1 \mathrm{l} ., \$ 3.00 ; 11 ., \$ 10.00$.

Nonpareil. -A well-known variety, highly es. teemed; sure to head. Per pkt., 15 cents; 12. $\$ 1.00 ; 1 \mathrm{~b} ., \$ 3.00 ; 1 \mathrm{~b}, \$ 10.00$.

Veitch's Antmmn Giant. $-A$ raluable distinet late variety, prolueing large, white, firm heads, well protected by the foliage. Per pkt., 15 cents; $0 \%$. $\$ 1.00 ; \frac{1}{4} \mathrm{lb}$., $\$ 3.00 ; 1 \mathrm{~b} ., \$ 10.00$.

Waleheren.-A favorite late rariety, rery hardy, and produnes large, white, firm heads, of uniform closeness. Per pkt., 10 eents; oz., $60 ; 1$ i 1 b., $\$ 2.00$; 1b., $\$ 7.00$.

\section{CELERIAC, or TURNIP-ROOTED CELERY.}

[Apium graveolens rapaceum, Lrx. Celeri-rave, Fr. Knot selleri, GEr. A pio raiz de Nabo, Sr.]

\section{One ounce will sow a bed of nine square yards.}

Sow early in the spring, in liglıt, riel soil, trans. plant in May into beds, and water freely in dry weather. When the plants are nearly full grown, it is eustomary to earth up the bullos to the height of four or five inehes. In about a month they will be found suffieiently blanched for use. The roots, whieh resemble Turnips, will be ready in October, and may be preserved in sand dnring winter. This vegetable is mueh esteemed in Europe, where its cultivation is very general. The roots are used in soups or, after being seraped and slieed, boil very teuder and stew for four or five minutesin just milk enough to cover, after whieh, season with salt and serve with bntter.

If by mail in quantities of 4 ounces and upward, postage must be added at the rate of $16 \mathrm{c}$. per pound.

Common.-Per pkt,, 10 ecnts; $0 z ., 25 ; .41 \mathrm{~b}$., 75 ; $1 \mathrm{~b} ., \$ 2.50$.

Apple-shaped.-Of a very regnlar, almost splierie. al, shape, with a fine neek and small leares; itmay be planted very thiekly, and will yield a heavy crop. A valuable variety for the market on aceount of its fine and regular form and exeellent quality. Paeket, 10 cents; $0 z ., 25 ; 21 \mathrm{lb}, 75 ; 1 \mathrm{~b} ., 22.50$.

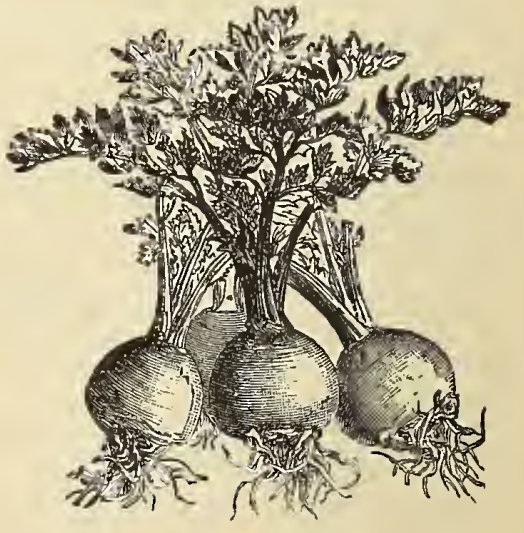

Apple-shaped Celeriac. 


\title{
CELERY.
}

\author{
[Apium grareolens, Lix, Celerie, w'r. Selleri, Gek, Apio, SP.]
}

One ounce will sow a bed of nine squa re yards, and prodnce abont 7,000 plants.

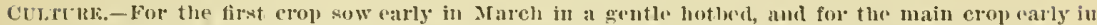
A pril on a warm sheltered horler, and water carefully. Tle plants nust be transplanted as soon as they will bear handline; plant out at intervals until the middle of .I uly. Planting upon the surface insteal of

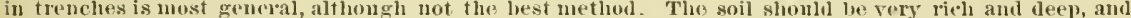
the plants placed in row thro fept apart, and from six to eight inclies apart in the mow. Earth up the plants as they adrane in growth, bnt leave the hearts nueovered until the final soiling.

If by mail in quantitics of 4 ounces and upwaris. postuge must be alded at the rate of $16 e$. per pound.

Goldeu I Ieart, or Golden Dwarf. The size and labit of gowtl reseubles Crawtord's Half Dwarf, but the heat is of a beantiful golden yellow. It is rery solicl, of pxcellent flavor, and one of the best

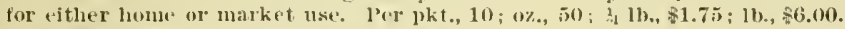

Boston Market. A favorito variety, remarkable for its teuder, crisp, and suceulent stems, and its peculiarly mill flavor: it is gown almost ex(rlu. wively by Bostou market gardeners. Per pkt., 10 cents: 0\%., 50 cents. 1, 1b., $\$ 1.50 ; 1 \mathrm{~b}, 55.50$.

Crawford's IIalf Iwarf. An extra tine variety, of fine flavor: a favorje anong narket gardener*.

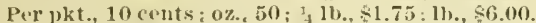

bwarf White Fremel, ox Incomparable Dwart. A superly lariety, of dwarf habit, very solid, crisp, and of tine tlavor: Per pkt., 10 ecuts: $0 \%, 30: 2,16 ., \$ 1.00 ; 1 b ., 33.00$.

(tiant White folid. A gool variety, clear whit, solid and crisp. Pex pkt., 5 cents; $0 \%, 25 ; 1 / 1 \mathrm{l}$. $75 ; 11 \% ., 2.50$.

Incomparable I)wart (riusou, of viry tharf habit; excereliugly solid and of tine tark trimson color. Per pkt., 10 cents: $0 \% ., 25 ; 111$., $75 ; 1$ )., 82.50 .

Yanmoth Red (1,aing's). This is tho largest growu, attaining, unler good cultivation, the ex. traordinary weiglit of $t e n$ or $t$ wel $v^{2}$ pomuls, and is perfectly solid. Per pkt., 10 cents ; $0 z ., 20 ; 1,11$. $75 ; 16 ., 82.00$.

fandriugham White. A much rstremed variety. very solid, erisp, and of tine flaror. Per pkt., 10 cents; 0z., $20 ; 411$.. $65 ; 11$., 22.25 .

- feymon's superb White. Esteened as onc of the best; it grows to a large si\%e; very (०risp aud perfectly solirl. Per pkt., 10 cents; oz., 30 ; 4011 ., $\$ 1.00 ; 1 \mathrm{~b} ., \$ 3.00$.

sutton's Fulhau Prize. Withont ixception the best pink Celery in cultivation ; it is remarkably solitl and crisp, and of a fine walnnt flavor. Per pkt., 15 cents; oz., 50.

noup Celery. Fxtellent for Havoring, 50 rents per 11 .

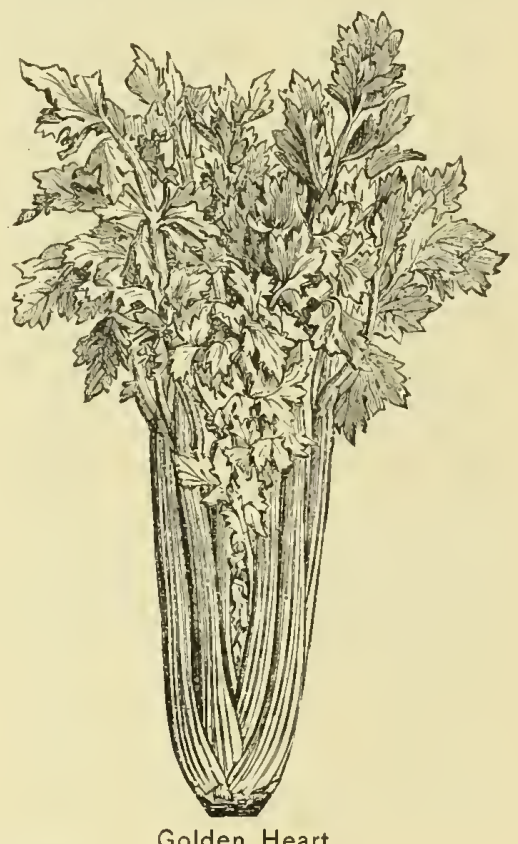

CHERVIL.

[Charophyllum satioum, Lis. Cerfenil, Fis. Gavlenkerbel, Grir. I'erifolio, Sp.]

One ounce will sow ubont one hundred feet of drill.

CtLTun.-Sow either in Autumu or spring, in drills lualf an incl dep and about one foot apart, cover. ing the seeds to the deptli of half an inch. When the llants are large enongh, thin out to about eight inches apart. Keep free from weeds, and in rery dry weather, water occasionally.

If by mail in quantities of 4 ounces and upward8, postage must be added at the rate of $16 \mathrm{c}$. per pound.

Curled. An uromatic, swert lierb; in appearanes. Tuberous rooted. When boiled, the flesh is like Parsley, largely ustu in somps and salads. white and of a pleasing nntty flaror. Per pkt.

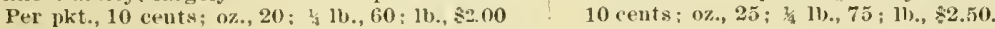

\section{CHICORY.}

[Cicharium Intylus, Lis. Chicorée, b'r. Chieorie, (HER, Achivoria de Cafe, SP.]

One ounce will wow a bed of four wquale yards.

CuLTukE.-Sow in Spring, in orills half an incl, leep, in goou mellow soil; and the after.culture is the sane as recomuended for Carrots. Chicory is cultivated chiefly for its roots, which are dried, and used as a substitute or flavoriug ingredient for coftie.

If by mail in quantities of 4 ounces and upwards, postage must be added at the rate of $16 \mathrm{c}$. per pound.

Large-rooted, or Coffee.-The l'aves, when blanched, are esteemed as an excollent salal. Per plit., 5 cents; oz., $10 ;$, 14 1h., $30 ; 1$ b., $\$ 1.00$.

Whithef.-Somew hat resembling chicory, iud excelleut nseul either as a salau of boiled. por pkt., 5 cents; oz., $15 ;$ z $110 ., 50 ; 1 \mathrm{~b} .$, s 1.50 . 


\section{CORN, SWEET.}

\section{[Zea Mays, LiN. Mais, Fr. Welschkorn, Ger. Maiz, Sr.]}

One quart will plant two hundred hills; one peck will plant one acre in hills. Three bushels will sow one acre broadcast for soiling, or half that quantity in drills.

Culture.-Plant for a succession of clops every three weeks, from April to July, in hills three feet apart each way, and six seeds in a hill; cover about half an inch; thin ont to three plants.

10 cents per pint, 20 cents per quart, extra, for postage on corn, of all kinds, when ordered by mail.

Black Sugar.-Sweet, tender, and delicious; the ripe grain is black, but the corn, when in condition for the table, cooks pure $w$ bite, and is by many considered one of the sweetest varieties grown. Per pkt., 10 cents; qt., 25 ; neck, $\$ 1.25$; bush., $\$ 4.50$.

Crosby's Extra Early Sugar, or Boston Market.-The ears are rather short, averaging from twelve to sixteen rows; rich, sugary flavor; very productive. Per pkt., 10 cents; qt., 25 ; peek, $\$ 1.25$; bush., $\$ 4.50$.

Darling's Extra Early Singar.-This is one of the earliest of the tall swect varieties, ears small, well formed, and very sweet. Per pkt., 10 cents; at. 25 ; peck, \$1.25; bush. \$4.50.

Dolly Dut ton.- The earliest sweet Corn ever introduced. A very dwarf-growing sort, stalks from three to four feet high. Ears small, averaging from tive to six incbes in length, kernels of good size, tender, very sweet and delicious. It ripens from seven to ten flays earlier than the early Min nesota, and is of much better quality. Per pkt., 10 cents; qt., 50 ; peck, $\$ 2.00$; bush., \$6.00; select ears, 75 cents per doz. ; by mail, $\$ 1.00$ per doz.

Early Eight-10wed Sweet.-A fine variety; ears very long; cob white; eight-rowed, kernels large, deep aud straight in the rows. It is highly recom mended. Per pkt., 10 cents; ‘t., 25 ; peck, \$1.25; bush., $\$ 4.50$.

Early Warblehead.-An extra early variety, producing large ears, well filled with plump kernels of good size and very sweet; of dwalf habit, and, except in earliness, bears a close resemblance to the well known Narragansctt. Per pkt., 10 cents; qt., 30 ; peck, \$2.00; bush., \$6.00; selected ears, 75 cents per doz. ; by mail, $\$ 1.00$.

Early Mimnesota.-An early sort, of dwarf habit, ears swall, vely productive, and of excellent quality. Per pkt., 10 cents; qt., 25 ; peck, $\$ 1.25$; bush., $\$ 4.50$.

Early Narragansett.- One of the earliest of the sweet varieties, small ears, of fine flavor. Per pkt., 10 cents; qt., 25 ; peck, $\$ 1.25 ;$ bush., $\$ 4.50$.
Evergreen Sweet.-The latest, and said to be the sweetest variety; will keep green till frost; medium size, white, kernels small, deep, and fre. quently irregnlar in the rows. Per pkt., 10 cents; qt., $25 ;$ peck, $\$ 1.25$; bush., $\$ 4.00$.

Extra Early Dwarf Sngar.-Of medium beight, eal's small, eight-rowed, and corn very sweet. Per pkt., 10 cents; qt., 25 ; peck, $\$ 1.25$; bush., $\$ 4.50$. Iammoth Sweet.-The largest late variety; twelve to sixteen-rowed; cob white, large and well filled; very productive, and fine fiavored. Per pkt., 10 cents; qt., 25 ; peck, $\$ 1.25$; bush., $\$ 4.50$.

ILoore's Early Concord.-A superior variety, eitber for the market or for family use, matures earlier than any otber variety of equal size. Per nkt , 10 ; qt., 25 ; peck, $\$ 1.25$; bnsh., $\$ 4.50$.

Red Cob Sweet.-Medium early, ears long and well filled; one of tbe best for main crop. Per pkt., 10 cents; qt., 25 ; peck, $\$ 1.25$; bush., \$4.50.

Triumph.-The earliest of all the large varieties, and uusurpassed for sweetness, delicacy of flavor, and productiveness. Per pkt., 10 cents; qt., 25; peck, $1.25 ;$ bush., $\$ 4.00$.

Washington Market, or Egyptian.-This is one of tbe best of the large varieties, of vigorous habit; ears large, having from twelve to fifteen rows of keruels of good size, and very productive; it is very sweet and tender, and of delicious flavor; invaluable for canning. Per pkt., 10 cents; qt., 30; peck, $\$ 2.00$; bush., $\$ 500$; select ear's, 20 cents.

Sweet Fodder.-For soiling or ensilage. $\$ 2.50$ per bush.

Early Burlington, or Adans.-A vers early vari. ety; cob and kernels white, and in the true variety slightly indented; the ear good size, but rather short. An excellent early table variety. Per pkt., 10 cents; qt., 25 ; peck, $\$ 1.50$; bush., $\$ 5.00$. Tusen rora.-This is a large variet 5 , with flourwhite kernels, a little indeuted; eight-rowed, cob red. It remains a long time fit for boiling, Per pkt., 10 cents; qt., 30 ; peck, $\$ 1.25$; bush., \$4.50.

\section{CORN, FIELD.}

10 cents per ear postage must be added for Field Corn ordered by mail.

Blunt's White Prolific. - An early eight-roweu white flint rariety, with short, uniform, wellshaped ears. Remarkably prolific, averaging six and eight good-sized ears on each stalk; has been used successfully for ensilage. Per ear, 8 cents: loz., 75; hundred, \$5.00; sbelled, per quart, 20 cents; peck, $\$ 1.00$; bush., $\$ 3.00$.

Comptou's Early Field. -A very early and prolific variety, eight to ten feet in beight, ears well filled to the cad; kernel medium, bright yellow, and of the flinty order. Per ear, 8 cents; doz., 75; hundred, \$5.00; shelled, per quart, 20 ceuts; peck, $\$ 1.00$; unsh., $\$ 3.00$.

Early Canada, or Cauada Yellow.-Ears small; very early; usually ripening in Augnst; admirably adapter for culture in the Northern States. Per ear, 5 cents; doz., 50 ; hundred, $\$ 2.50$; shelled, per quart, 20 cents; peck, $\$ 1.00$; busli., \$3.00.

Eight-rowed White Flint.-Ears about ten incbes long; kernel white, productive, and of good qual. ity. Per ear, 5 cents; doz., 50 cents; hundred, $\$ 2.50$; shelled, per quart, 20 ceuts; peck, \$1.00; bush., $\$ 3.00$.
Eight-rowed Yellow Flint,-Similar to the pre. ceding, except in color. Per ear, 5 cents; doz., 50 ; hundred, $\$ 2.50$; shelled, per quart, 20 cents; peck, $\$ 1.00$; bush., $\$ 3.00$.

Prewium Chester Comuty Tammoth.-This variety gives uuiversal satisfaction, both on account of its large yields, fine quality of grain, and smperior foddler, Per ear, 8 ceuts; doz., 75; bundred, 55.00 ; sbelled, per quart, 20 cents; peck, \$1.00; busb., \$3.00.

Queen of the Prairie.-A varicty of Yellow Dent Corn, ant certainly the most prolific and the ear. liest field corn in cultiration; planted as late as July $4 \mathrm{th}$, it has fully matured by 1 st of October. Selected ears, 15 cents; shelled, 3 lbs. by mail, post-paid, $\$ 1.00$; peck, $\$ 1.25$; bush., $\$ 3.50$.

Yellow Dutton.-Highly prized for mealing, both on account of its quality and bright, rich color. Per ear, 5 ceuts; doz., 50 ; hundred, 3.50 ; shelled, per quart, 20 cents ; peck, $\$ 1.00$; bush.. $\$ 3.00$.

Parching, ears, per lb., 8 cents; bundred $1 b 8 ., \$ 6.00$;

Southeru. for fodder, shelled, per peck, 50 cents. bush., 1.75 . See colored supplement for description of Kural Dent and Rnral Thoroughbred Flint Coru. 


\title{
CORN SALAD, or FETTICUS.
}

[Valeriana locusta, LiN. Mache, salade de ble, H'r. Ackersalat, Lammersalat, Ger. Macha, SP.]

One onuce will sow twenty feet square; wix pounds will sow one nere.

CULTURe.-The seeds are thickly sown in september, in shallow drills one.fonrth of an inch decp. If the weather be dry, the ground should be conpressed with the feret or the back of a spale. It requires no other culture, except to kecp the ground clear of weeds. In a high northern climate it requires protection during Winter with a slight covering of straw. If the soil is gool and rich, the Havor of this plant will be greatly improved.

If by mail in quantities of 4 ounces and upward, postage must be added at the rate of lfic. per pound.

Corn Salad (Lamb's Lettuce).-The Well-known common valuety. l'er pkt., 5 cents; oz., 15; th Ib., $30 ; 1 \mathrm{~b}, \$ 1.00$.
Lettuce-leaved.- Leaves large, light green, and of fine quality. Per pkt., 10 cents; oz., 20; r. 1b., $50 ; 11 ., 81.50$.

\section{CRESS, or PEPPERGRASS.}

\author{
[Lepidium sativum, Lix, Cresson, Fr. Kresse, Ger. Mastuerzo, Sp.]
}

One ounce will sow kixteen square feet.

Extensively used as a small salat. Sow early in Spring, very thickly, in shallow drills. The sowings sloukl be repeated at shoit intervals, as it soon rins to seel.

If by mail in quantities of 4 ounces and upwarl, postage must be anderl at the rate of 1 fic. per pound.

Broad-leaved, or Commou.-Per pkt., 5 ents ; oz., $10 ;$ i $16 ., 15 ; 16 ., 50$.

Extra Curled.-Fine flavos. Per pkt., 5 cents: $0 \%$, 10 : $\frac{1}{4}$ lb., $20 ; 1 b ., 65$.

Australiau.-This is a superior variety, with fine, delicate grecu loaves; of a pleasing, piruant

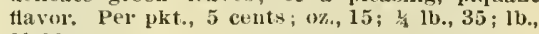
2.1.00.

\section{CRESS (Water).}

[Sisymbrium nasturtium, I.r. Cresson de fontaine, Fr. Brunnenkresse, Ger. Berro, SP.]

One onnce will sow one lundred square feet.

CULTURE. - The plant is cultivatel $1, y$ sowing the secds by the side of running water, near springs which are not severely frozen in Winter. Trumsplant ing. however, is al ways surer than sowing. and is, therefore. preferred. This may be done from March till A ugust. The distance between the plants should not generally be less than teu or tifteen inches. Stirring the parth about tlo roots from time to time is useful; but, having once taken root, no further care is necessary.

If by mail in quantities of 4 ounces and upwari, postage must be added at the rate of $16 c$. per pound.

Water Cress.-The leaves are miversally nsed and eaten as an early and wholesone salad in spring.

Per pkt., 10 cents; $0 z ., 50 ; 1,11 ., 51.50 ; 113 ., 5.5 .00$.

True Erfurt.-A new, sweet variety. Surpasses the tommon sort in vleasing delicacy of thavor. Pre pkt., 20 cents; oz., 75 .

\section{CUCUMBER.}

\author{
[Cucumis sativus, Is. Concombre, Fk. Gurke, Ger. Pepino, SP.]
}

\section{One ounce will plant fity hills; two ponnds will plaut one acre.}

Culture,-Cucumbers nucered best in wam, moist, rich, loany grouni. They shomlin not be planted in the open air until ther. is a prospect of settied, walu weather. Plant in hills about four fect apart each way. The hils should be previonsly prepared by mixing thoroughly with the soil in wach a shorelful of well-rotted manure. When all danger fron insects is past, thin ont the plants, leaving three or four of the strongert to each hill. The fruit shonld be plucked when large enough, whether levinited for nse or not. as, if left to ripen on the vines, it llestroys their prodnctiveness.

If by mail in quantities of 1 ounces and upward, postage must be arliled at the rate of $16 c$. per pound.

Boston Pickling,-One of the best for pickling; of superior quality, nniform size, and very proluc tive. Per pkt., 5 cents; $0 \% ., 15 ;$; $1 \mathrm{~b} ., 40$; lb., \$1 1.25 .

Early Frame. -The standard sort for the table and for pickling; of medium size, straight and handsome. Keeps well as a pickle. P('r pht., 5 cruts: oz., 10: 1. 11)., $25 ; 11$., 85 .

Early (Arecu Cluster, - it slort, prickly variety, bearing in clusters near the root: it is a great bearer, aud in earliness comes next to the Early Russian. Per jkt., 5 cents; $0 \%, 10$; $\frac{1}{4} 11$ )., 30 ; $1 \mathrm{~b}, \mathrm{~s} \$ 1.00$.

Early Russian.-The earliest in cultivation; it set s in pairs, and the first lolossous nsually produce fruit; flavor pleasant aut agreeahle, P(r j)kt., 5 cents; oz., 10 ; 1 ib., 30 ; 1b., 81.00 .
Exıra Long White sipine.-A marked improvoment ou the well-known White Spime varicty, being longer, far more prolific, superior for table ust, and equally as good for pickling. Per pkt., 10) cents: az., $15 ; x$ 1b., 30 ; 1b., $\$ 1.00$.

Enrly White sipine.-An txodlent old variety ; re. tains its fresh apearance for a long time; good for forcing, and a great bearer. Per lokt., 5 cents : (1) Z., 10: 1, 1b., 25; 1b., 85).

(Aducral Grant.-Ifiglily recommended : solid, and of a most asreeable tlavor. P'er pkt., 25 cents.

Greeu Prolific Pickling. - A splendirl varlety, selected with great care by one of the largest grow. ers of pickling cucmuluers in the country; with goml culture 200,000 can be grown on one acre. Pir pkt., lo cents; 0z.. 20) t 11 b., 40; lb., \$1.25. 


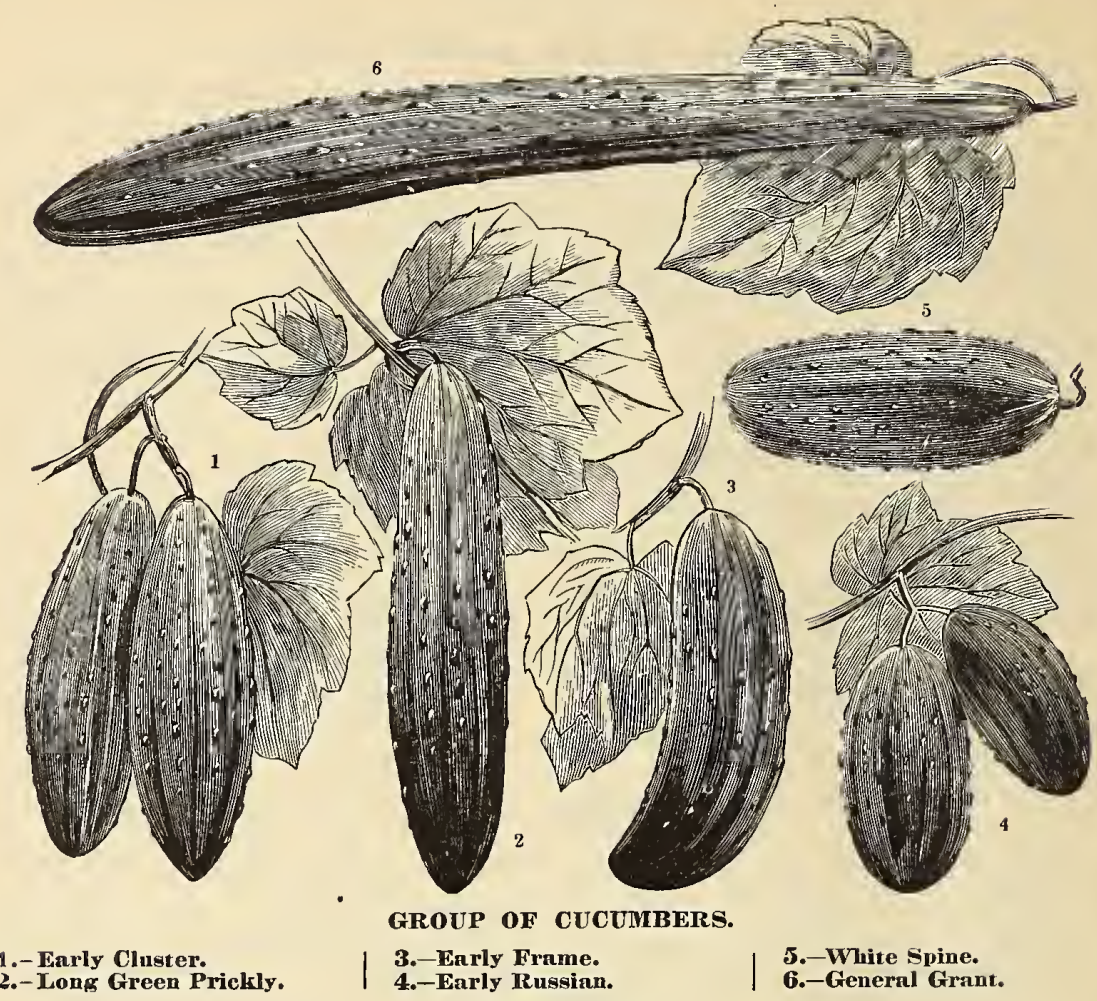

\section{CUCUMBER.-Cont' $d$.}

Improved Early White Spine, or Arlington,-An improved varioty of the White Spine, and a great favorite aruong marketmen, for forcing ou a large scale; of medium size, flesh, crisp and of superior Havor: extensively grown in the Sonthern States for shipping North in the early part of the season. Per pkt., 10 cents ; oz., 15 ; 1/ 1b., $30 ; \mathrm{bl} ., \$ 1.00$.

Loug Green Prickly.-A very excelleut variety, a good bearer, alout a foot in length, firm and crisp. Per pkt., 5 cents; oz., $15 ; 1 / 41$., $30 ; 1$ b., $\$ 1.00$.

Russian Netted.-Exceedingly prolitic, and hardiness surpasses all other varieties; of medium size, white flesh, skin covered witl a pretty, white net. work, which imparts to the fruit a peculiar and handsome appearance. Per pkt., 10 cents; oz. $25 ; 1 / 416 ., 75 ; 1 b ., \$ 2.50$.

Simall Glerkiu, or Burr.-Fine for pickles. Per pkt., 10 cents; oz., $25 ; 1 / 11$., $75 ; 11 ., \$ 2.50$.

Tailby's Hybrid. - A cross between the white Spine and English sort; grows to a large size, ani is well wortlyy the attention of amateurs and market garceners. Per packet, 10 cents; oz., 30.
White Japan.-A pure white variety, protuctive aud of fine quality, either for the table or for piekles. Per likt., 10 cents; oz., $30 ; \frac{1}{4} 1 \mathrm{~b} ., \$ 1.00$.

\section{ENGLISH AND GERMAN FRAME VA RIETIES.}

The following aro recommended for forcing, and shonld be sown in sinall pots early in February, and grown in hot-bed or lot-honse. Wheu the seedlings liave three leaves, plant ont in hills of loose, rich soil in the center of each sash, aud maintain a uniform temperature of from 65 to 75 degrees.

Iarquis of Lorne.-A uew and highly esteemed variety, of handsome form and of fine flavor. Pkt. of 10 seerts, 25 cents.

Rollisson's Telegr'aph.-Very prolific, early, crisp, and of superior quality. Pkt. of 5 seeds, 25 cents. Giant of Arnstadt.-Very long, of fine quality, 20 inclies. Per pkt., 25 cents.

Glory of Erfurt, New White.-Early, very long, pure snow white. Per ukt., 25 cents.

\section{DANDELION.}

[Leontodon Taraxacum, LiN. Pisse-en-lit, Fr. Lauenzahn, Ger. Amargon, SP.]

One ounce will sow one hundred feet of drill.

CuLTuRe.-The dandeliou resembles Endive, and affords one of the earliest, as well as ono of the best and most liealthful Spring greens. It is also sometimes blauched and used as a salad. The roots, when dried and roasted, are often employed as a substitnte for coffeo. The seerls may be sown in May, in drills ten inches apart; thin ont the young plants about three inches apart; cultivate during the season, and in the followiug spring the plau ts will be fit for the table.

If by mail in quantities of 4 ounces and upwards, postage must be adled at the rate of $16 \mathrm{c}$. per pound.

Common Variety.-Per pkt., 10 cents; 0z., 30 ; Improved Large Leaved.-Per pkt., 20 certs; $\frac{1}{4} 11$., $\$ 1.00$; 11)., \$3.50. 


\section{EGG-PLANT.}

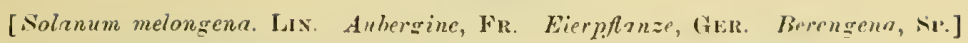

One ounce will produce ubout one thousand plantw.

CurTURE-Sow thickly on a hot.bed for early erops, or very early in the suring, in a warm, sheltered, dry sitnation in open grumin, where they can bo proteeted by liand-glasses. When the plants are theren or tonr inches high, and the warm weather has set in, transplant them into well-enriehed gromnd, about thirty inches apart, each way. Draw earth to the plants ins thes ad vauce.

If by mail in quantities of 4 ounces and upwards, postage must be added at the rate of $16 \mathrm{c}$, per pound.

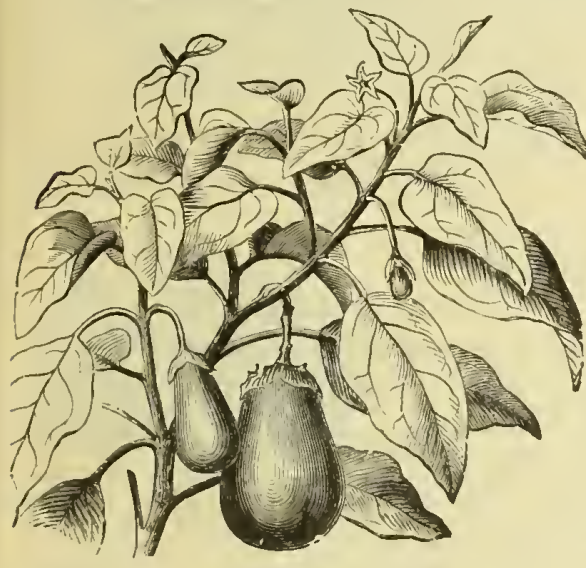

N. Y. Improved Purple Egg Plant.

Furly Ioug Purple.-Dors well in almost any section of the Northern states, and, if startiol rarly, will perfect its frut in the Canadas. Per pkt, 5 eents; $07 ., 30 ;, 111, \$ 1.00 ; 11$., $\$ 3.00$.

findaloupe -iripedo-Fruit nearly ovold, skin White and vartegater with pmrple; very ormamental. Per pkt., 10 eents: oz., 50.

New-Yorlc Improved Purple-An improved varicty of the Renmel Porple, of deeper color, and of larger size, ant of fine cunality ; a superior mar. ket variety. Per pkt., 10 eents: 0z., 60; 1, 1b., $\$ 2.00: 1 \mathrm{~b}, . \$ 7.00$.

Pekin New Blaek.-A distinet rarly variety from China; very prolific; frut globular and almost black; fine grained and delieately flaroret. P(r) pkt., 10 eents; oz., 60; 2, lb., \$2.00; 11)., \$7.00.

Serrlet Fruited. Highly ornamental; frutit abont the size of a hen's egg, of a whitish (a)lor, which chinges to al yellow, and afterward to a brilliant searlet: not edihle. Por pkt., 10 cents : oz., 50.

Touat o-shaped.-color hright red; rery orma-

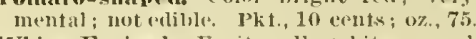

White Frnited.-Frnit malk white, egr-shapen; grow m prineipally for ornament. l'er pkt., 10 cents: oz., 50.

\section{ENDIVE.}

[Cichorium endivia, IIx. Chicoree-cndive, Fr. Endiren, Frr. Endivia, SP.]

Ouf oune will sow sixty square fert.

('ItTune.-Rather moist, woll pulverized, rich soil is best adapted for this erop. For early use, sew in May, seattering the soetl thinly ant covering it lightly, and for sncession every t wo or lhree wewk mitil midsmmer. When large enongh, thin ont the plants to eight or nime inches apart, and in diry seasons water frecly, to kepp the plants in il cutiek.errowing and consequently in acrisp and britnlos state.

If by mail in quantities of 4 ounces cend. upwarils, postage must be adled at the rate of $16 \mathrm{c}$. per pound.

Broad-leaved Batavian.-This is the rhicorce scarolle of the French, and is elhiefly used in somp.s.

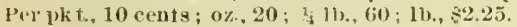

Freneh Iross, - Beautifnlly enrled, and when we!l developed appears like a tuft of moss. Per pkt. 10 cents; $0 z ., 30 ; 1$ 1 1 ., $\$ 1.00 ; 11$., \$3.50. (areen Curled.-The hardiest of all, with beantifully curled dark green leaves, teuder and rrisp

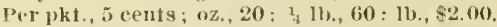

White Culled.-Resembles the Green, axcept in color and liardiness. P'er pkt., is ceuts; 0 ., 20 ;

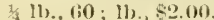

\section{GARLIC.}

\section{[Allium satieum, L.IN. Ail, Fr. Knoblanch, GER. Ajo, Sir.]}

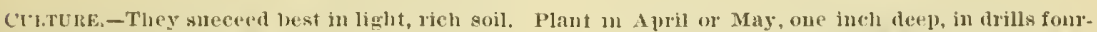
teen inehes apart, and fiv or six inches apart in the rows. Krep the soil leose ant fore from weeds, and when fully grown, whieh will be albout the end of July, the bulls may be harvested like the onion.

Garlic sets. Por lb., 40 cents. If $1, y$ mail, 56 eents.

\section{KOHL-RABI.}

\section{[Brassica caulo-rapa, Lis. ('hou-rave, Fr. Kohlrabi, ('ter. Colinabo, NP.]}

One oume will sow a drill of abour iwo humdred feer.

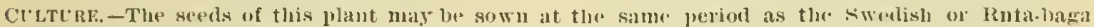
Turnip, and may be enltivated in the same way, remombering to leave the chief part of the stems uneoverel by the eartlı. The lubbs keep sond and nutritions nntil late in spring.

If by mail in quantitics of 4 ounces and upwards, postage must be added at the rute of $16 \mathrm{c}$, per pound.

Early Purple Vienna. A hove gromil f fine early sort, excellent talje viriety. Per pkt., 10 eents: $0 \%, 30 ; 311$., $\$ 1.00 ; 11$., 83.00 .

Early White Vienna. Ahore gromul; similar to preceding, except in eolor. P'er pkt., 10 ernts; $0 \% ., 30 ; 131) ., \$ 1.00 ; 1 b ., \$ 3.00)$.

Late Purple (xiaut, Gows to an (-nornons size ; very productive and of extra fine quality. Par pkt 10 cents; $0 \%, 05 ; 3,11,75 ; 11,82,00$.

larke, Whise, or (ireen. Fxcrlient for farm colture. P(r) likt., 5cents; $1 \%, 20 ; 1,1$ 1h., 60: 1b., $\$ 2.00$. Late White (riant. Similar to alore, exeept in color. Per plit., 10 er.nts; $0 \%, 25 ;$ \& $11 ., 75 ; 11 .$, 52.00. 


\section{LEEK.}

\section{[Allium porrum, Lis. Poircau, Fr. Lauch, GER. Puerro, SP.]}

\section{One ounce will sow a drill of abont oue lundred feet.}

CULTUnE.-Tho Leek is very harly, and easily cultivated; it succeds best in a light lout well-euricherl soil. Sow as early in Spring as practicable, in drills one inch deep and one foot apart. When six or eight inches high, thoy may be transplanted in rows ten inches apart each way, as deep as possible, that the neck being covered, mas be blanched. If fine Leeks are desired, the ground can liardly be too rich.

If by mail in quantities of 4 ounces and upwards, postage must be added at the rate of $16 \mathrm{c}$. per pound.

Broad London, or Flag.-A large and strong plant, with broad leaves growing only on two sides, like the Flag. Per pkt., 10 cents; oz. 15 ; $31 \mathrm{~b} ., 50 ; 1 \mathrm{~b} ., \$ 1.50$.

Extra Large Carentan.-Very hardy, of extraorilinary size, much larger than any other variety, and of fine quality. Per pkt., 10 cents ; oz., 30; z/ 1 b., $\$ 1.00$; 1b., $\$ 3.00$.
Large Americau Flag. - A favorite variety witl the market grardeners; of strong and vigorons

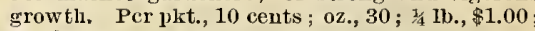
lb. $\$ 3.00$.

Large Ronell,-Leaves lark green, broad aul thick; largely grown in the vicinity of Paris; it is also the best for forcing. Per pkt., 10 eents; oz., $30 ; \frac{1}{4} ., \$ 1.00 ; 13 ., \$ 3.00$.

\section{LETTUCE.}

\section{[Lactuca sativa, LiN. Laitue, Fr. Lattich, GER. Lechuga, SP.]}

\section{One onnce will sow one hundred square feet, or oue hundred and twenty feet of drill.}

CuLTUize.-For an early crop sow under glass in Febrnary, and transplant on a well-prepared bed, in some sheltered corner, in April. For successional crops, sow in beds of well-pnlverizer soil in March, ani at intervals of about a fortnight until the end of May. When sown for cutting young, the seed may bo put in ratler thick, in rows or broadcast, but to lhave finer heads it should be sown thinly in rows, and transplanted a foot apart into the richest soll. The hardy varieties may be sown in September, in a dry, shelterch sitnation, and if slightly protected will stand the Winter woll, and give a good crop in spring. or they may be transplanted in cold frames, where they will head during the Winter and early spring.

If by mail in quantities of 4 ounces and upwards, postage must be added at the rate of $16 \mathrm{~b}$. per pound.

All the Year Roumc. - A valnable variety, liarily, crisp, and compact, with sinall, close heads. Per 1.kt, 10 cents: oz., 30 : 3/ 1b., $\$ 1.00 ; 1$ b., $\$ 3.00$.

American Gathering. - A ristinct variety, the tips of the leaves being marked with red; very solid, exceedingly erisp, and of excellent flavor. Per pkt., 10 cents; $0 z ., 25 ; 141 \mathrm{l} ., 75 ; 1 \mathrm{~b} ., 22.50$.

Bath Cos. - A superior variety, of enormons size. crisp and fine thavored; excellent for either Spring or Autuun sowing. Per pkt., 10 cents ; 0z., 25 ; 1. $1 \mathrm{~b} ., 75 ; 1 \mathrm{~b} ., \$ 2.50$.

Boston Curled.-Of great beauty ani smperior inality; the fine, elegant frilling of the lcaves render's it highly ornamental. Per pkt., 10 ccuts ; oz., $25 ; \frac{1}{4} 11 \mathrm{l} ., 75 ; 1 \mathrm{~b} ., \$ 2.50$

Black-Seeded Simpson.-Nearly double the size of the orlinary Curlet Simpson; stands the Snmmer well. Per pkt., 10 cents; oz., 25; z, 1b., 75 ; 11)., $\$ 2.75$.

Boston Market. An improved variety of the Ten. nis Ball; one of the best for forcing. Per pkt., 10 cents; 0 z., $30 ;$ i, 1 b., $\$ 1.00 ; 1$ b., $\$ 3.00$.

BHown Dutch.-Generally sown in Antumn, as it will endure the Winter with slight protection. Per pkt., 5 cents; $02 ., 25$; 1 1 1b., $75 ; 1$ b., $\$ 2.00$.

Brown Winter Cabbage. $A$ A hardy variety that stands Winter well. Per pkt., 10 cents; oz., 25; $\frac{1}{4} 1 \mathrm{l} ., 75 ; 1 \mathrm{~b} ., \$ 2.50$.

Druuluead, or Malta. - One of the best Summer Lettuces; large, crisp, compact. Per pkt., 5 cents; oz., $15 ; 111 \mathrm{~b} ., 40 ; 1 \mathrm{~b} ., \$ 1.30$.

Larly Butter Salad.-Tender and of delicate flavor. Per pkt., 10 cents ; 0z., 25; $141 \mathrm{l}$., 75 ; 11., $\$ 2.50$.

Early Curled Silesia. - An early variety of strong growth; leaves large, light yellow, wrinkled. Per pkt., 5 cents; oz., $15 ; 1$ 1 1 b., $50 ; 1$ b., $\$ 1.50$.

Farly Curled Simpson.-An improved variety of the preceding, very early, aml excellent for forcing; is largely grown by warket gardencrs. Per pkt., 10 cents; oz., $20 ; 2 / 1$ b., $75 ; 1$ b., $\$ 2.00$.

Early Prize Head. -An early variety of nammoth size; tender and crisp; superb flavor; very hardy. Per pkt., 10 cents; oz., $25 ; 1+11$. 15 ; ; 1b., $\$ 2.50$.

Green Fringed. $-A$ distinct variety, with the edges beantifully fringed; inner part of the leaves well blanched; remains fit for use nearly all snmmer: l'er njt., 10 gents: $\%$., 25; 1; 1b., $75 ; 1$ b., $\$ 2.50$.
Haumersmith IIarly Green.-The best for tu tumn sowing to stani Winter. Per pkt., 5 cents oz., $25 ; 1 / 41$ b., $75 ; 11$., $\$ 2.50$.

Hanson Lettuce.-Heads large, solid, tender, crisp, and of fine flavor; color beantiful green outside and white within; stands tho summer heat well; one of the very best in cultivation. Per pkt., 10 cents; $o z_{*}, 30 ; 1 / 1 \mathrm{~b} ., \$ 1.00 ; 1 b ., \$ 3.00$.

Large Iudia. - One of the largest varieties; forms large, lound lieads, which cut whitc, brittlo, aud almost transparent. Per pkt., 10 cents : oz., 25; $1 / 4$ $1 \mathrm{b.,} 75$; $1 \mathrm{~b} ., \$ 2.50$.

Large Wiuter Cabbage.--Larger than Hammersmitl, whiter in color, and healing more frcely; a valnablo Winter Lettnce. Per pkt., 15 cents; $0 z$. $50 ; \frac{1}{4} 1 \mathrm{~b} ., \$ 1.50 ; 1 \mathrm{~b} ., 54.00$.

Pruis Green Cos.-One of the best of the cos vari. ecies; lonw, narrow, dark green leaves; stands heat well. It shonld he tied np to blanch a wcek or ten days before cutting. Per pkt, 5 cents; oz. $20 ; 1 / 1 \mathrm{~b} ., 60 ; 1 \mathrm{~b} ., \$ 1.75$.

Paris White Cos.-Similar to the above, with leaves of lightor color. Per plit., õ cents; oz., 20 ; म 1 b., $60 ; 1 \mathrm{~b} ., \$ 1.75$.

Perpetual.-This is one of the most tender and best Havored lettnces grown; strictly speaking, it does uot head, but forms large, compact bushes, that remain in splendid condition for a long timo. Per jokt., 15 cents.

Perpignar. - A German variery, lighly recommended; stands the Summer lieat well; roes not I'nn to sced so readily as most other varieties. Per plkt., 10 cents; $0 \%, 30$; 1 1 Ib., $\$ 1.00 ; 1 \mathrm{~b}$., $\$ 3.00$.

Royal Summer Cabbage.-Woll formed, good size, close, and a little flattened; it stands the heat well. Per plit., 10 cents ; 0z., $25 ; 1$ 1b., $75 ; 1 b ., \$ 2.50$.

Salawauder.-An excellent summer variety, forming gool-sized heads that stand the drought and heat withont injury longer than any other sort. Per plit., 15 cents; iz., $40 ; 1 / 4 \mathrm{lb}$., $1.25 ; 1 \mathrm{~b} ., \$ 4.00$. satisfaetion. - An English variety, large, eompact, solid, and crisp; stands the lieat well. Per. pkt., 10 cents; oz., 30 ; 14 10., $\$ 1.00 ; 1 \mathrm{~b}, \$ 3.00$.

Tenuis Ball. - Well-formed lieads, hardy and crisp; of excellent quality; ono of the earliest of the hearling varicties. Per pkt. 10 cents; ož., 55 ; is 11 . $75 ; 110 ., 82.50$. 

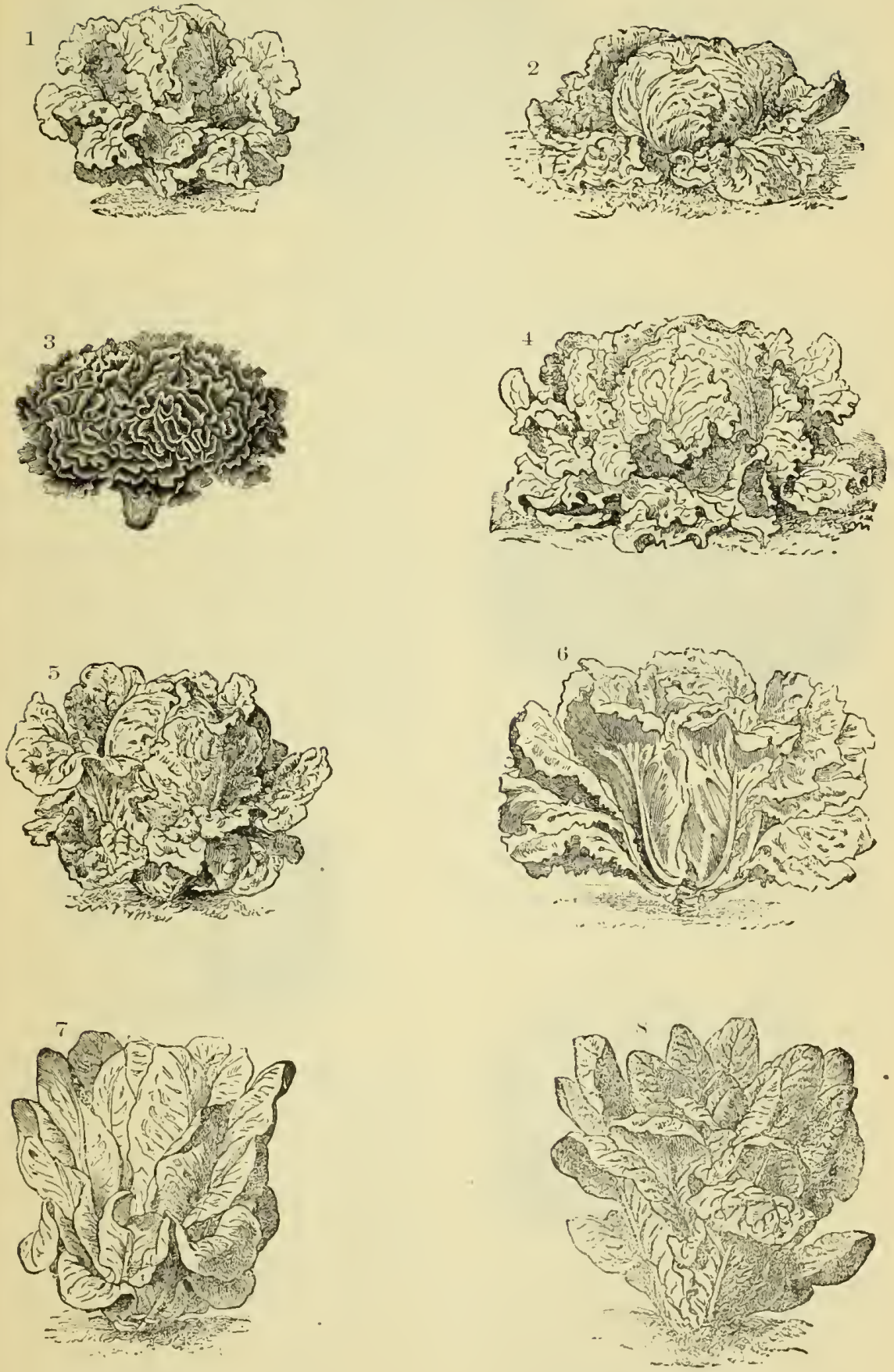
1.-Fillpsour
2.- Royal simmuer (abbage.
3.-Boston Cincled.

J. Drumhead, or Malta.

6.-- Lavge India.

7. White Pariv Cos.

s.- Bath cos. 


\section{MARTYNIA.}

\section{One ounce will plant about two hundred hills.}

CcLTURE, - The pods of this plant, if picked when greeu and tender, make excellent piekles. For very eal'ly plauts, sow iu March in a hot-bed, aud give necessary protection uutil the weather is sufficiently mild to allow transplantiug out of doors. Sow in May, in the open ground, in hills about three feet apart, allowing three or fonr seeds to each hill. When well started, thin out, leaving one plant to a hill.

If by mail in quantities of 4 ounces and upwards, postage must be added at the rate of $16 c$. per pound.

Mart yuia proboseidea. - Per pkt., 10 eents; $0 z ., 30 ; 1 \frac{1}{4} 1 \mathrm{~b} ., \$ 1.00 ; 1 b ., \$ 3.00$

\section{MELON, MUSK.}

\section{[Cucumis melo, LiN. Melon, Fr. Melone, Ger. Melon Muscatel, SP.]}

\section{Oue ounce will plant about eiglty hills.}

CULTURE--A rich, deep, sandy loam, well worked, and highly nanured with old rotten compost, is of the first importance. Plaut, when all danger of frost is over, in hills five or six feet apart each way; scatter a dozen seeds to a hill, and after they are out of danger from bugs, thin to three or four plants, When they have four or five rough leaves, pinch off the ent of the main sloot, which will cause the lateral branches to put forth soouer. This will strengthen the growtl of the vines, aud the fruit will come carlier to maturity.

If by mail in quantities of 4 ounees and upwards, postage must be added.at the rate of $16 \mathrm{c}$, per pound.

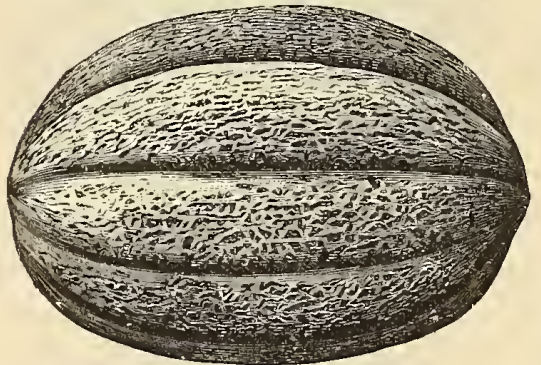

Bay View Melon.

Bay View Melou.-The largest, most prolific, best Havored, aud finest eantaloupe in eultiration; luseions and sweet and very hardy; picked greeu it will ripen up finely, and earry safely for a long ristance. Per pkt., 10 eents ; oz., $30 ; 2 / 4 \mathrm{~b}, \$ 1.00$; $11 \mathrm{l} ., \$ 3.00$

Cassaba.-of extraordinary size and delicious flavor. Per pkt., 5 eeuts; oz, $10 ; 1416 ., 25 ; 1 b .80$.

Christiana.-An excellent yelow-tleshed variety, teu days earlier than Nutmeg, of fine Havor and very early. Per pkt., 5 cents; $0 z ., 10 ; 1$ 1b., 50 11., $\$ 1.25$.

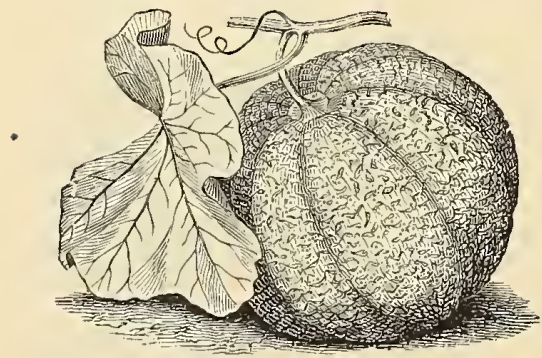

Green Citron Wielon.

Freeu Citron.- Handsouve fruit, roughly netted all over; flesh thick, green, melting, and very sweet. Per pkt., 5 eents; 0z, $10 ; 1,11, .25 ; 16 ., 80$.

freen Climbing Melon.-A netter variety that grows best trained upon a trellis or fence; produetire aull of exquisite flavor. Per pkt., 10 cents.

Hackensaek. - A variety of the Greeu Cition Mnskmelon: grows to a large size; verr produetive and of exquisite flaror. Per pkt., 10 cents ; oz., $20 ; \frac{1}{4} 11 ., 50 ; 16 ., \$ 1.50$.
Jeuny Liud.-Small size, delicious flavor; very

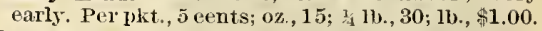
Large Musk.-This is the largest variety; long, oral shape, rleeply ribberl; fleslı thick, light salmon colored, early and productive. Per plkt., 5 (cents; oz. 10 ; $1 / 1$ b., $25 ; 11$., 80.

Large Yellow Cauralome, - of good size, netted and slightly ribbed; Heshl salmon-eolored, thick aud musk-flavored. Per pkt., 5 cents ; 0z., 10; 14 1b., $25 ; 1 \mathrm{lb}, 80$.

Montreal Green Nutmeg.-Nearly roum, flattenerd at the ents; deep, regular ribs; skiu deusely netted; Hesh thick, and of delicious flavor. Per pkt., 15 ceuts; $0 z ., 50 ; 1 / 1 \mathrm{l}$., $\$ 1.50 ; 1 \mathrm{~b} ., 6.00$.

Netted Grut. - In form a perfect globe, skim green, ribberl and uetted; flesh light green, melting, and of luscious flaror; early, prolific, and keeps well, the most profitable small musk-melon that cau be raiser. Pkt., 10 eents; oz., 30; $\frac{1}{4} 11 \mathrm{l} ., \$ 1.00 ; 1 b ., \$ 3.50$.

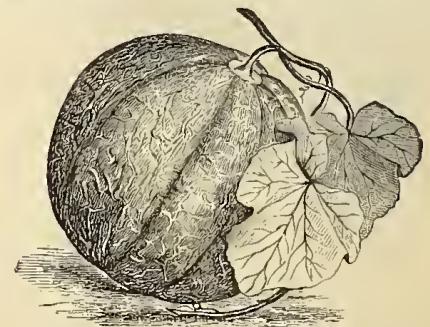

New Surprise Melon.

New Surprise Helon.-This ruelon las a thin, crean-colored skin, thiekly netted; thesh teep salmon-color, of exquisite fla vor aud very prolific. Per pkt, 10 cents ; oz., $30 ;{ }_{3,1}^{1 b}, \$ 1.00 ; 1 b . \$ 3.00$.

Nutmeg. -Of large size; fleslı green, rich and sugary. Per pkt., 5 eents; $0 \%$., 10 ; $\frac{1}{4} 1$ b., 25 ; 1b., 80 . Pine-Apple.-Dark gicen ; of medium size; rough netted; Hesh thick, firm, and sweet Per pkt, cents: oz., $15 ; \frac{1}{4} 1 \mathrm{~b} ., 30 ; 1 \mathrm{~b} ., \$ 1.00$.

sill's Hybrid.-Mertinm size ; salmon-colorerl Hesh; productive, sweet, and of delicious flavor. Per pikt., 5 cents; $02 ., 20 ; 1 / 41 b ., 50 ; 1 b ., \$ 1.25$.

Sliiluma's Fiue Netted.-A small, rely early, rough netted variety; thesl green, thick, firm, sugary, and of delicions flavor. Per pkt., 5 ceuts ; $02 ., 15 ; 14 \mathrm{lb}, 30 ; 1 \mathrm{~b} ., \$ 1.00$.

Ward's Nectar. $-A$ green-tleshed variety, of fine quality, sweet, rich, and delicions. I'er pkt., 10 ceuts; $0 \% ., 25 ; 1$ 1 $1 \mathrm{~b}, 50 ; 1 \mathrm{~b}$., 1.50 .

White Japau.-Very early, mediuu size; flesh thick aut remarkably sweet. Per pkt., 5 eents; $0 z, 20 ; 21 b ., 50 ; 11 ., \$ 1.25$. 


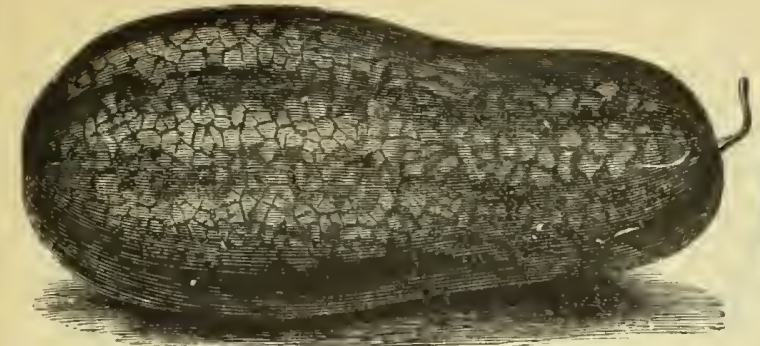

Mountain Sweet Water-melon.

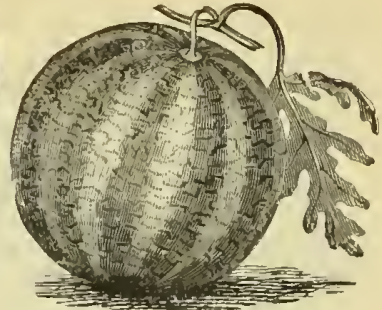

Citron Water-melon.

MELON, WATER.

[Cucurbita citrullus, Lin. Melon deau, Fr. Wassermelone, Ger. Zaudis, sp.]

One ounce will plnut about sixty hills.

Cubture. -The general diretions given moler the heal of Mask-Melon are suitahle for Water Mrelons. The plants will frut better by wceasionally pinching the leading shoots off the vines.

If by mail in quantities of 4 ounces and upuards, postnge must be aldeat at the rate of lice. per pound.

Apple Pis Melon.-When stewed and mals into lies, it is an excellent substilute for apyles: kereps till May. Directions for eooking areonimsny ench piteket. Per pkt., 10 cents ; 17., 20) is 11 ., 50; 11).; $\$ 1.50$.

IBlack Spanish. Ronnd, dark greell, searlet tlash, thin rime, lielt sllyary Havor. Per pkt., 5) ('ents: $07 ., 10 ; \frac{2}{4} 1 \mathrm{~b} .25 ; 1 \mathrm{~b} ., 80$.

Citron.-For preserving ; striped and malled with liglt green: Hesh white and solit. Per pkt., is cents ; $0 \% ., 10 ; 1,1 b ., 30 ; 1 b ., \$ 1.00$.

Cuban (queen.-Benutifully striped, dark and hight

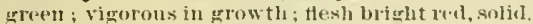
luscions, crisy, and sugary, and in delicions thatror unsmpassed; an excellent ketper, and, althourh the rind is munsully thin, bears transit well. Per

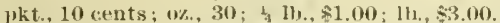

Excelsior.-Resenbles Mountain sprent, being betulifully marked with bright green stripus; flewh bripht red, delicate and sweet : in siz.' one of the largest. Per pkt., 5 cents; 112,15 ; 古 1b., 50) 11 .. $\$ 1.00$.

Gypsy.-A superior variety : oblong, light green, mottled and striped with whito; thesh starket, sol. id, ant of delicions thavor: Per pkt, 5 cents; oz., $10 ; 1 / 416 ., 25 ; 16 ., 80$.

Ice Crean.-M Dedium size, nearly round : color pale green; thin rind: Hesh solid, scariet, crins, and of gooul tharor. Pey ukt., 5 cents; $07 ., 15 ;$ it lb., $35 ; 1 \mathrm{l} ., 81.06$.

Iceing, or Ice-IRind.-Roumd ; rery solit; thiu rint, and of a ricl, luscions, sugary tharor. Par pkt., 5 cents; $0 \%, 15 ; \quad 1 \mathrm{lb}, 40 ; 1 \mathrm{~b}, \$ 1.25$.

Homtain sprout, or Loug Corolina.-A large, lone, stripell varuty, witl loright sianlet tlesh, tirn and swcet. Per pkt, 5 cents: oz., 10: 14 Ib., $25 ; 1 \mathrm{~b}, 80$.
Mountuin sweel.-Ono of the hest for genersil curl. ture: color dlark green; tind thin; Henh starlet, solid ; very swet anul dehcions. L'cr plet, 5 cents; oz., 10: 1 16., 25: 1b., 80.

Odella. Ronnl, of large size, light green skin, bricht real thesh of fine tharor; rarly and prolitic. I'el pkt., jcents; $0 \%, 10$;

Orange. - A n oval, rel-thesherl variety, of medium fuality; peculiar for the division of its Hesh from the lind, which nay be taken off like the rind of an orange, by a little scuaration with a kuife; Per pkt., 10 cents; 0z., 20: + 16., 40; 11., \$1.25. Persiatu.-Pake green, witl lark stripes: ertinsolt Hesh, of fime textme amb ilelicious flavor ; vall be taken off the rme to ripen and will keep till Wil. fer: Per pkt., 15 cents; $0 z, 50$.

Early Oval (Phimey"s).-Bright red thesh, wwert, temeler, and well-tlavored; tilne minket variety. I'er pkt, 10 cents; $02 ., 15 ; .4$ lb., 30; $1 \mathrm{~b} ., 81.00$.

IR ussian Auteriegn. Sulid erinsun thesh, of de. lieions crispnetss and sweetness of Havor. Per pkt., 15 cents; oz., 50 .

cicaly Bark. - A very large, blboug varlety, with il liak, tomgh rinu, which has a peculiar scaly anpearance, trinsor: thesh, rery solicl, renarkably sweet aml tiee from fiber. Perpkt, 15 conts; $1 \mathrm{z}$, $50 ; 1,1 h ., 51.75 ; 1 \mathrm{~h} ., 55.00$.

-onthern Rattlesmake. - A popular variety, on atecomet of its fime shipping qualities ; of obloms shape; light green color, beautifuly striped; re. markably thin riml; scarlet flesh, sulid, and de. licionsly swet. Per ukt., 10 cents; $0 z ., 15:$ \& 1b., $50 ; 1 \mathrm{~b}) . \$ 1.50$.

Vick's Early.-A long, smouth, rather small var. rty, highly prized for its earliness: sizenuedizm. t'eslı bright piuk, sweet, and solil. Per ykt., 5 cents; $0 z ., 10$; $1 / 11$. $30: 1 \mathrm{~b} ., \$ 1.00$.

\section{MUSHROOM SPAWN.}

\section{Ten pounds will spawn about ten feet sefuare.}

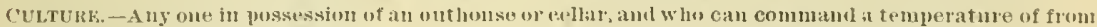

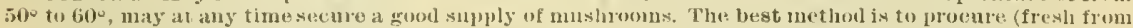
the stable) as much short mimure as is necessary to make a bed from fourteen to eighteen mohes derp, and any size the houso can convelliently hohl; throw the mamme into a heap for a few days, nntil it becomes heated, and the greater pirt of the musture is thrown off; then spread it out for a day ur twu until ury anl guite cool; atter which, put it again in a heap, and allow it to remain five or six lays; it will

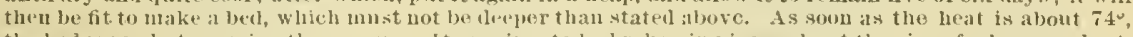
the berl is realy to receive the spawn. It requires to be broken in pieces about tles size of a large walnut, Hud placel in the manme' ibout two inches below the sulface, and six inches apart. Fhe bed should then be covered about two inclus deep with fine light swil, and pressed down evenly. If the temperature is right

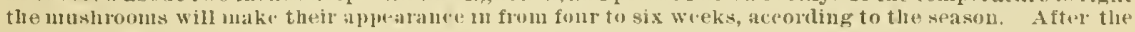
bed has ben spawued do not water nuless quite dry, aud, when neccssiry, use lukewarm water only.

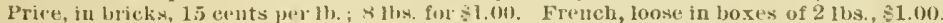




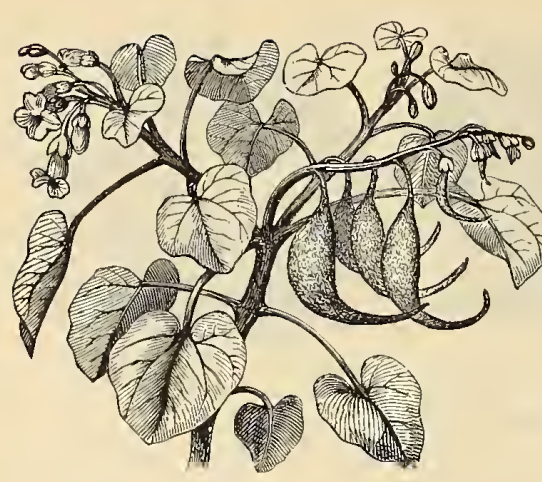

Martynia. (See page 84.)

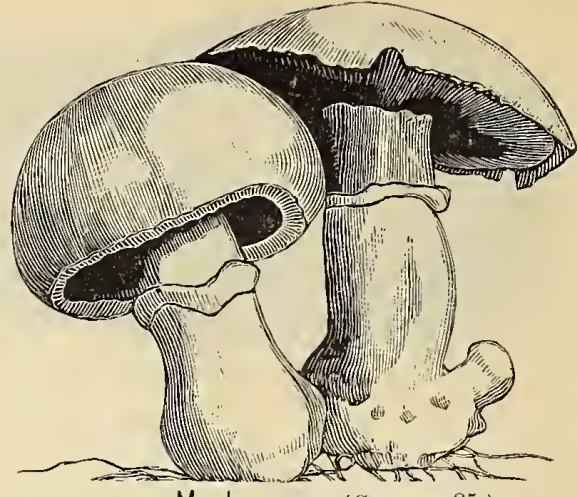

Mushrooms. (See page 85.)

\title{
MUSTARD.
}

[Sinupis, Lrv. Moutarde, Fr. Seuf, Ger. Mostaza, Sr.]

One onnce will sow about eighty feet of drill.

CULTURE.-For early salads, sow on a slight hot-bed in Mareh, and for a general cropat intervals through the Spring, in rows six inches apart, and rather thick in the lows; ent it when about an inch or two high.

If by mail in quantities of 4 ounees and upwards, postage must be added at the rate of $16 \mathrm{c}$. per pound.

Chinese.-Leaves twice the size of the ordinary White Mustard, of a decper green, Havor pleasantly sweet and pungent, and preferable as a salud. Per 0z., 10 cents; 1 1b., 20 ; 1b., 75.

Black or Brown.-For culinary use. Per oz., 10 cents ; $1 / 11$., $15 ; 11 ., 40$.

White or Yellow.-For salads or medicinal purposcs. Per oz., 10 cents; 411 ., $15 ; 11$., 40.

\section{NASTURTIUM, or INDIAN CRESS.}

[Tropaolum majus, IIN. Capucine grande, Fr. Kresse Indianische, GER Naranuelia, SP ]

\section{One onnce will sow about twenty feet of drill.}

CuLTuRE,-Sow early in the Spring in drilts one inch deep, the Tall variety by the side of a fence, trelliswork, or some other support, to climb upon, and the Dwarf to form border's or edgings. They will thrive In almost any situation, but are most prortuctive in a light soil. The seeds, while yonng and sncculent, are pickled and used as capers.

If by mail in quantities of 4 ounces and upwards, postage must be added at the rate of $16 e$. per pound.

Tall.-Per pkt., 5 cents; oz., $15 ;$ 1/4 11., 40 ; 11., $\$ 1.25$.

Dwarf.-Per pkt., 10 cents; $0 \%$., $30 ; 1,11$., $\$ 1.00 ; 11$., $\$ 3.00$.

\section{OKRA, or GOMBO.}

\section{[Hibiscus esculentus, Liv. Gombo. Fr. Fsbarre Hibiscus, GER. Quimbombo, SP.]}

\section{One onuce will plant one hundred hills.}

CuLture.-In uild chmates plant late in the spring, after the gronnd has become warm, in hills about two avd a half feet apart, and thin to three plants in a hill. Hoe often, aud carth up a little to support the stems. The pods should be gathered while quite young and tender. Okra is casily preserved for winter use by slicing the pods into uarrow rings, and dryiug them upon strings hung np and exposed to the air. The ripe secrls are sometimes used as a substitnte for coffee.

If by mait in quantities of 4 ounees and upwards, postage must be added at the rate of $16 e$. per pound.

New Improved Dwarf. - Long sleuder pods, very productive, and only fourteen inches high. Per pkt., 10 cents; oz., $30 ; 1$, $1 \mathrm{~b} ., \$ 1.00 ; 1 \mathrm{~h} ., \$ 3.00$.

Dwarf Greel.-Small, green, smooth pods. Per pkt., 5 cents; oz., $10 ;$ s 1 lb., $25 ; 1 \mathrm{~b} ., 75$.

Long Green.-Long ribbed pods. Per' pkt, 5 cents: oz., 10; 1 lb., $25 ; 1 \mathrm{~b} ., 75$.

\section{ORACHE, Or MOUNTAIN SPINACH.}

\author{
[Atriplex hortensis, Lin. Aroche, Fr. Garten melde, GEr. Espinaca, SP.]
}

One ounce will sow ore lundred feet of drill.

CutTunc.-The seed may be sown abont the end of September, and again in the spring, for succession, in drills, six inclies apart. Wheu the seedlings are about an inch high, thiu to six inches apart; and those removed may be planted out at the same distauce in a similar situation, and watered oceasionally, if needed, until established. The leaves must be gathered for use while young, otherwise they will be worthless and stringy. The leaves of the orache are cooked aud eaten in the same manner as spinach, to which it is preferred by many persons.

If by mail in quantities of 4 ounees and upwards, postage must be added at the rate of $16 e$. per pound.

White.-Per 1kt., 10 cents ; $0 \%, 15 ; \frac{1}{4} 11 \%, 50 ; 11 ., \$ 1.50$. 


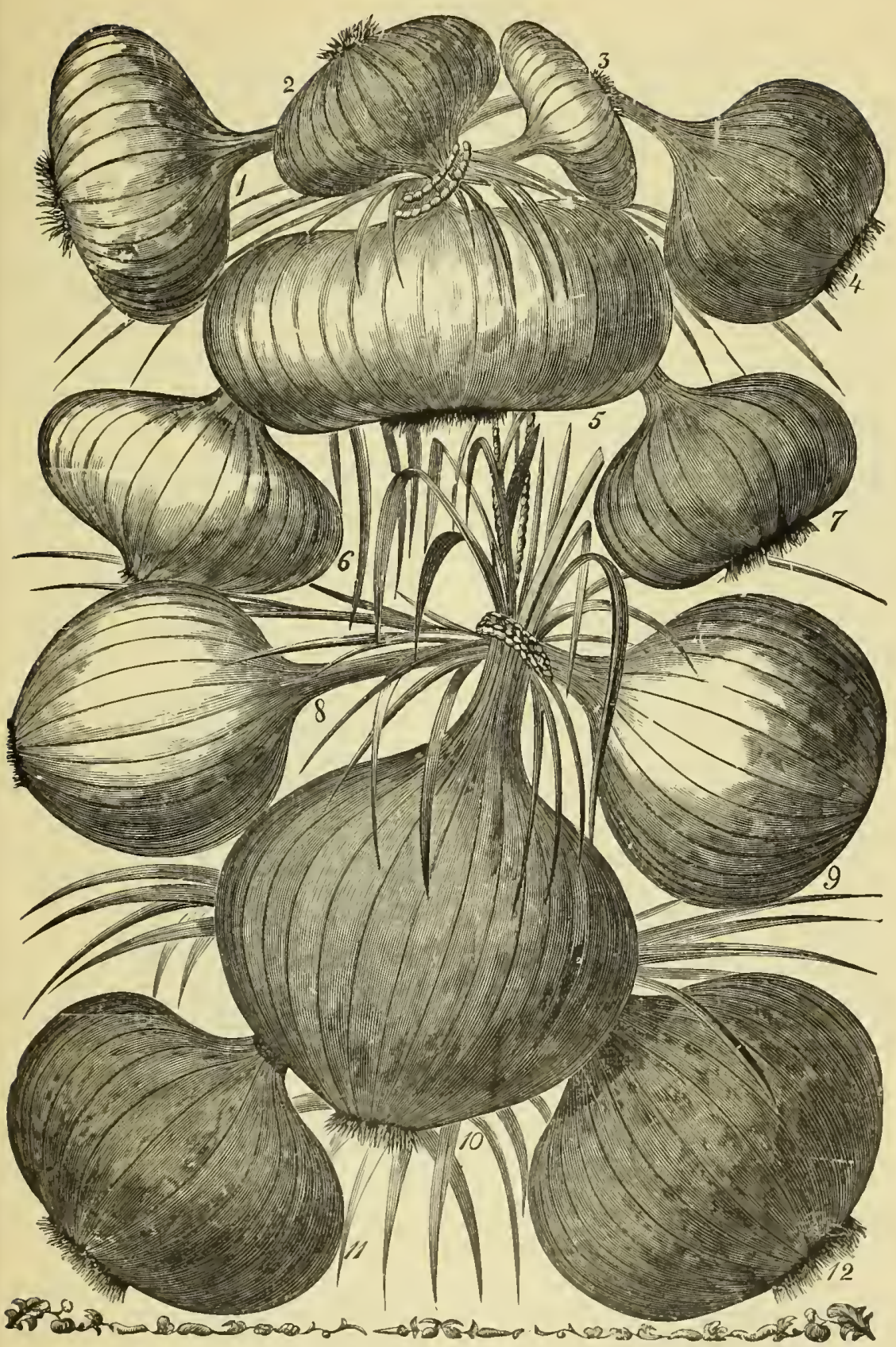

GROLP OF ONIONS, SHOWING THEIR PROPOITIONATE SIZE.

1.-White Portugal.

2.-Early Red Wethersfield.

3.-Early Cracker.

4.-Yellow Danvers.

5.-Giant White Tripoli.

6.-Yellow Dutch, or Strasburg.
7.--New Qucell.

8.- Yellow Globe.

9.-White Globe.

10.-New Giant IRocer.

11.-Larme Red Wethersfield.

12.-Red Globe. 


\section{ONIONS.}

\section{[Allium cepa, Lin. Ognon, Fr. Zwiebel, Ger. Cebolla. SP.]}

\section{One onnce will sow one hundred feet of drill.}

CULTLRE. - A lather strong, deep, aud rich loany soil is most suitable for this crop. The gronnd slionli be lieavily diessed with rieh, well-rotted mannre, trenched deeply, and ritged up early in Antumn, and if the soil is of a light, sandy nature, cow manure will be most suitable. Tle main crop slowd be sown as early as the ground may be in working condition, and a favorable opportunity for put ting in the seed shouli not be suffered to pass. Sow the seeds thinly and regularly, and cover with the soil displaced in making the drills, or whero this is toolumpy, with other fine soil. They snceed equally well any number of years on the same ground, if kept highly enriehed with fine yard manure, spread on every Spring and turned in with a liglit furrow. A top-dressing of mood ashes, applied after the second weeding, is very beneficial to this crop, as will soon bo observed by the dark and healthy change of color given to the plants.

Onion sets and tops aro placed on the surfare in sliallow twelve-iuch drills, about four inclies apart, slightly covered. Potato onions should be planterl in April. Select the large bulbs, place them ten inches apart, with the crown of the bnlbs jnst below the surfaee of the wround.

If by mail in quantities of 4 ounees and upwards, postage must be added at the rate of $16 \mathrm{e}$. per pound.

Extra Early Red.-Smaller, and more flat-shaped than Large Red; close.grained; keeps well. Per pkt., 10 cents; oz., $25 ; 1 / 1610 ., 75 ; 1 \mathrm{~b} ., \$ 2.50$.

Early Red. -Abont teil das s earlier than the large red; productive, of mild flavor, and i good keeper. Per pkt., 5 cents; oz., 20; 1/ 1b., 60 ; 1b. $\$ 2.00$

Wethersfield Large Red.-Large size, deep red, thick, aplu'oaching to ronnd shape, fine-grained, pleasant-flavored, and productive; keeps well. Per pkt., 5 cents; 0z., 15; 1; 1b., 50; 1b., \$1.75.

Red (Slobe.-Distinct in form, being nearly globu. lal; very productive. Per pkt., 5 cents; oz., 20 ; t/4 $1 \mathrm{~b} ., 60 ; 1 \mathrm{~b} ., \$ 2.00$.

Danvers Yellow.-A heavy, straw-colored onion, mild-tlavored, and yields abnndantly; ripens early and keeps well. Per pkt., 5 cents; oz., 15; 1/4b., $50 ; 1 b ., 1.50$.

Yellow Clobe Danvers. - Distinct in form, being nearly globular; of a beantiful silvery yellow color; mili flavor and good keeper. Per pkt., 5 eents; vz., $20 ; 1 / 1 \mathrm{~b}, 60 ; 1 \mathrm{~b} ., \$ 2.00$.

Southport Yellow Globe.-Forn nearly ovoia, regular aud symmetrieal; mild aud pleasant thavor keeps well. Per pkt., 10 cents; oz., 25; 14 $1 \mathrm{b.}, 75 ; 1 \mathrm{~b} ., \$ 2.50$.

Yellow Dutch.-The common yellow variety; is rather flat-shaped, and excellent flavored. Per pkt., 5 cents; $0 z ., 15 ; 131 \mathrm{~b} ., 50 ; 1 \mathrm{~b} ., \$ 1.50$.

White Portugal. - A nild, pleasant onion, which grows to fair size and handsome shape. Per pkt., 10 cents; oz., $25 ; 11$ b., $80 ; 1$ b., $\$ 3.00$.

White Globe.-Form nearly ovoid, regular and symmetrical, milh and pleasant flavor ; keeps well. Per pkt., 10 cents; $0 z ., 30 ; \frac{1}{4} 1 \mathrm{~b} ., \$ 1.00 ; 1 \mathrm{~b}$., $\$ 3.50$.

Bermuda. -This is the well-kliown large Onion of commerce, the demand for which is very great.
When well cultivated, bulbs grownin this countrs are equal in size to importon ones. The seed we otter is gelluine and is the probluct of large, se. lected bulbs. Per pkt., 10 cents: oz., 30; $1 / 41 \mathrm{~b}$., $\$ 1.00 ; 1 \mathrm{~b} ., \$ 3.25$.

\section{NEW ITALIAN ONIONS.}

Giant White Italian Tripoli.-Grows to an enormous size, and like all of this clas, is of a mild and pleasant flavor. Per pkt., 10 cents; 0z., 25; 1/ $1 \mathrm{b.}, 80$; $1 \mathrm{~b}$., $\$ 3.00$.

Large Italiau Red Tripoli.-Bubs of this variety were exlibited in England weigling two and one lialf pounds; flavor is exceedingly mild and pleasant. Pkt., 10 cents; 0z., $25 ; 1,1$ b., $80 ; 1$ b., $\$ 3.00$.

Marzagole.-Silcery white skin, and sait to be the earliest of all. If sown in Autumn in wamn cli. mates, they will be ready for use in March. Per pkt., 10 eents; $0 z ., 25,3 \frac{1}{4} 1$ b., $80 ; 11$., $\$ 3.00$.

New Giant fRocen of Naples.-Light brown skin; telicate thavor, aud of globnlar form. Per pkt. 10 cents; oz., 25; 4 1b., 80; 1b, $\$ 3.00$.

New Qneen.-A silver.skinned Onion, remarkable for its keeping qualities and rapidity of growtl. Very mild flavored, and excellent for pickling. Per pkt., 10 cents; 0\%., 35; 1/4b., $\$ 1.25 ; 1 b ., \$ 4.50$.

Nocera. - A very early, flat-shaped, silvery-skinned variets, similar to the New Qneen; of excellent. flavor; splendid for pickling, aud keeps well. Per pkt., 10 cents; oz., 30 ; $1 / 1 \mathrm{~b} ., \$ 1.00 ; 1 \mathrm{~b} ., \$ 3.25$.

When the following are orderea by mait, 20 eents per quart must be adaled for postage.

(Prices Variable.)

Top, or Button Onious. - Per qt., 35c.: peck, \$2.25. Potato Onions.-Per qt., 35c.; peck, \$2.25.

Onion Sets, Vellow or Red.-Qt., $40 \mathrm{c}$; peck, $\$ 2.50$.

(Dnion Sets, White.-Per qt., $45 \mathrm{c}$.; peck, $\$ 2.50$.

\section{PARSLEY.}

\section{[Apium petroselinum, Lin. Persil, F'r. Petersilie, Ger. Perejil, SP.]}

\section{One ounce will sow one hundred and fifty feet of drill.}

CULTURE. - A rieli and tolerably deep soil is best for this crop. Soak the seeds a few hours in tepid water, and sow early in the Spring, in drills a foot apart: thin out tho plants to three or four inches apart; a single row forms a very good edginm for beds or walks. The seed germinates very slowly, and sometimes two or three weeks will elapse before the plants make their appearance. It often fails entirely in dry weather. To havo Parsley green during Winter, remove some plants into a light eellar, and treat thon as in open culture in Autimin.

If by mail in quantities of 4 ounees and upwards, postage must be added at the rate of $16 c$. per pound.

Curled, or Double.-Dwarf and temter; leavos beantifully crimped and curled : used principally as a garnish for the table. Per pkt., 5 cents; oz., 10 ; $\pi / 1$ lb., $25 ; 1$ b., 80.

Exima Hoss Curled.-Leaves beantifully curled, extra tut for grarnishing. Per pkt., 5 cents; oz., 10. $1 / 410 ., 30$, 1b., 1.00 .

Hamburg, or lioozed.-The roots are user for flavoring soups, ete. Per pkt., 5 cents; oz., 10; 1 (1)., $30 ; i 1) ., \$ 1.00$.
New Fern-leaved.-Exquisite in form, and admirably suited for mixin w with dwaj'f ormamental foliage plants in the flower garden; also for table decoration. Pex pkt., 10 cents; oz., 25; ti lb. $75: 11$., $\$ 2.50$.

Plain Parsley.-Hardier, and the leavos are longer and of a clarker green than the curled; better flavored for seasoniug. Valnable for feer? ing sineep. Per pkt., 5 eents; oz., 10; $\frac{1}{4} 1 \mathrm{lb.}, 20$; $11, ., 60$. 


\section{PARSNIP.}

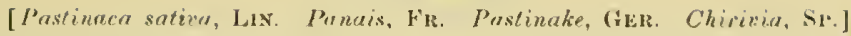

Gne ounce will sow too feet of drill; five ponuts rectured for one nere.

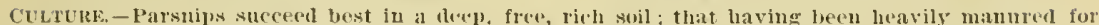
previous crop should be selectal, and if manure must be nsid for this crop let it be well ilecomposal, or

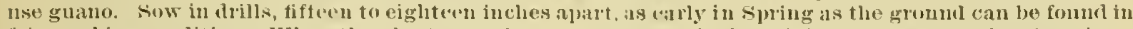
fitir working coudition. When the plants ale about two or three inches high, thin them ont, leaving six or

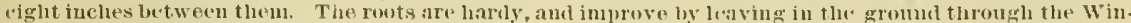
ter, taking only eumgh in the cellar to last durine cold wother. They arn very valuable for feeding cattle. as well as for the talole.

If by mail in quantities of 1 ounces and uparards, postage must be added at the rute of $16 \mathrm{c}$, per pound.

Long Sinooth, or Hollow - Crawned. - Ruts very long, whito, smooth, frets from sille roots, teuder, sugary, and most excellent thavonil the best variety for a generil erop. Pir jkt., 5 cents. $0 \%, 10 ; 131,25 ; 16 ., 75$.
Short Round Freneh. - The carlinst variety: Pet pkt. is cects: $0 \%, 10: 1,1 \mathrm{~b}, 20: 1 \mathrm{~b}, 60$

situdem. -A hilf long viriety, of delicions thaver

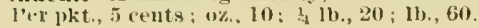

\section{PEAS.}

\section{[P'isum sativum, Lrs. Pois, Fr. Erbse, Ger. Chicaros, Sp.]}

One quart will plant about 12.5 fert of urill; frou one to two bushels per aere.

Colture, - For an early crop plant in the spring, as suon as the gromul can be worked, in a warm, dry xituation, and cover abont three inches. Tho grount must be mamred the year previous, or the Peds wil be apt to grow $t(x)$ much to straw. If this has not bren done, nse thoronghly deeomposen maunre just before planting. They are usnally plantecl in touble rows, from three to four feet apart, and, those requiring it, bushed whell about six inches hifgh. The large and later sorts do better at a greater distance apart, leaving a broat space for planting low-growing vegutables between. They slonlu bo kept clean, ant earthed two or three times luriug growth. In dry weither the Peas should be suaked tive or six liours before planting, and, if the gromul is very diry, shonld he watered in the drills.

15c. per pint; 25e. per quart, extra for postage on Peats if sent by mail.

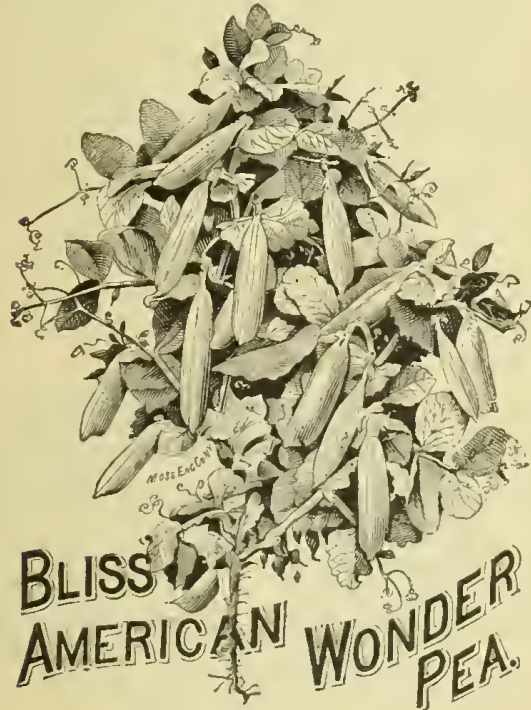

Bliss's American Wonder.

EXTRA EAlRLV.

Blisy's American Wonder. - This variety stants uwrivaled in point of productiveness, tla ror, alud quality, and is, without exception, the earlis:st wriuklel Pea in cultivation. It is of llwarf and robnst habit, growing from ten to fiftern inches litgh, and produces a jurof usion of goon -sizerl and well-fillet porls of the tinest. flavor. Per pkt., 10 cents; lalf-pint, 25 ; piut, 45 ; (1uart, 80 ; l,y mail, post-paitl. When delivered at onr stor't, or scut by express at purcliaser's expense, pint, 35) cents: quart, 60 ; lialf-peck, $\$ 2.50$, peck, st.50. l'riees for larger quantitis's un application.
Bliss's American Racer.--After trial, in almost "Very section of the conntry, this Pea lias provel very early, exceedingly prodnctive, ant in general good quality surpasses all other tall-gruwing. early varieties. For full description, see colorecl supplement. Per pkt. of 1 pt., 20 cents; pint. 65; qt., 81.25 , by mail, post-paitl.

Alpha.-One of the earliest wrinkled Peas ; of ex. quisite fla ror, very prolific: pois, well tilled antl of gooul size: $3 \mathrm{ft}$. l’er pkt., 10 cents ; q1t., 50) ; peek. $32,50: 131 \leqslant 1 . .89,00$

Carter's First Crop.-Very early, proluctive, goot Hilvor: the lianlm being liter:illy coveret with pots: $2 \frac{1 / 3}{3}$ ft. Per pkt., 10 cints: (1t., 25: peck, $\$ 1,75:$ linst., $\$ 6.00$.

Earty Dau O'kourke, humpeved,-finc of the earliest, : 1 ul a popular mitrket variet $y$; porls well

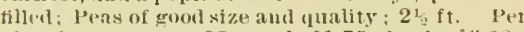
pkt . 10 cents: qt., 25: lwek, \$1.75; bush., \$6.00.

Early Keut. An early, populis market variets. moiluetive and well tilvoredl: $2 \frac{1}{2} \mathrm{ft}$. Per pkt., Io e'nts: qt., 25: peek, $\$ 1.50$; busl., $\$ 5.00$.

Extra Early Preminu (icem.-- Pods long ant of

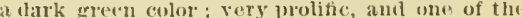
earliest; 11/2 ft. per pkt., 10 crents: at., jo) : peck. $82.00:$ binsli. 87.00

First and Best. Very early, of exeellent flavor: and rupens with great uniformity: $2 \frac{1}{2}$ ft. Pel

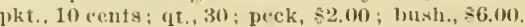
líentish Invictu. - A round blue variety, enrly. aul of superior thaver: $2 \mathrm{ft}$. P'er pkt., lo eents:

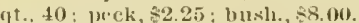

Philadeiphia Extra Early.-Favorite market varicty in the Simthern states: very parly : $2 t_{\mathrm{ft}}$ Par pkt, 10 cruts: 4t, 25; peck, s1.75; bush. (15. 0100

\section{EATRY P'E.A.}

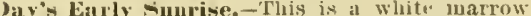
rery lares for an early l'ca, and of fine tlavol While in constitution and hobit it is hardy and robust. 3 ft. Per plit., 10 (nuts: itt., 30) : peek,

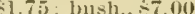

Mr Lean's Alvancer. A twarf green, wrinkled

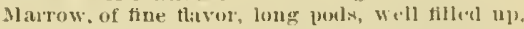
rery prolffic: nearly as early as Dall O'Rourke

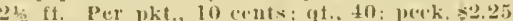
1)11sh.. : s.00. 


\section{PE AS.-Cont'd.}

McLean's Blue Peter.-It is well described as a "Blue Tom Thumb," but possessing a more robust habit; very prolific aud of fine flavor. Per pkt., 10 cents; qt., 40 ; peck, $\$ 2.00 ;$ bush., $\$ 7.00$.

VeLean's Little Geu. $-A$ dwarf prolific, green wrinkled Marrow; very early. 3/4 ft. Per pkt. 10 cents; qt., 30 ; jeek, \$2.00; bush., \$7.00.

Telegraph.-This is an extraordinary acquisition, the Pcas often being soclose together as to appear to be forming a double row in the pod; robnst in habit, bearing immense pods ; a great bear er and of fine flavor; $5 \mathrm{ft}$. Per pkt., 15 cents; pint, 35 . qt., 60 ; peck, $\$ 4.00$; busli., $\$ 12.00$.

Telephone.-Selected from Telegraph, from which it differs in the seeds being wrinkled, whilst the quality is superior. It is an extraordinary cropper, bearing immense semi-touble pods full of large peas of exquisite flavor; 5 ft. Per pkt., 15 cents; pint, 35; qt., 60: peck, \$4.00; bush., $\$ 12.00$.

Tow Thumb.-Dwarf, stout and branching ; early. of excellent quality, yields abundantly ; itrequires no sticks; $3 \frac{4}{4}$ ft. Per pkt., 10 cents ; qt., 30 ; peck, $\$ 2.00$; bnsh., $\$ 7.00$

William I.-Recently introduced; early, and one of the best green marrows; $3 \mathrm{ft}$. Per pkt., 10 cents ; qt., 40 ; peck, $\$ 3.00$; bush., $\$ 10.00$.

\section{GENERAL CROP.}

British Queen.-Strong and vigorous, superior quality; continues long in bearing; does not mil. dew in Summer; 5 ft. Per pkt., 10 cents ; qt., 50 ; peek, \$3.00; busli., \$10.00.

Challenger.-This is one of the liandsomest, most prolific, and best thavored in cultivation. It is a dwarf, dark gleeu inarrow, and isliterally covered with pods; 2 唐 ft. Per pkt., 10 cents; qt., 50 peck, $\$ 3.00$; bush., $\$ 10.00$.

Champion of England.-Universally admitted one of the best Peas grown; of delicious flavor and a profuse bearer ; 5 ft. Per pkt., 10 ceuts ; qt., 30 ; peck, $\$ 2.00$; bush., $\$ 7.00$.
Dwarf Blue Imperial.-A good bearer and tine flavored; a good Summer Pea: $3 \mathrm{ft}$. Per pkt., 10 cents; qt., 30 ; peck, $\$ 1.75$; bush., $\$ 6.00$.

Dwarf White IIarrowfat. - An old variet. dwarf liabit, aud on that account preferable for small gardens; 3 ft. Per pkt., 10 cents; qt., 25; peck, $\$ 1.50$; buslı., $\$ 5.00$.

Laxton's Prolific Early Long Pod.-Very productive; frequently averaging 11 to 12 Peas in a pod; rery hardy; $4 \mathrm{ft}$. Per pkt., 10 cents; qt., 25 ; peck, $\$ 1.75$; bush., $\$ 6.00$.

Caxton's Supreme. - A rariety of the green Marrows, with long, well.filled pods, nearly as early. as Dan O'Rourke; $3 \mathrm{ft}$. Per pkt., 10 cents; qt., 40 ; peek, $\$ 2.25$; busl.., $\$ 8.00$.

Marrowfat Black-Eyed.-Excellent either for sarden or field culture; has large and well-filled pods; a popnlar market variety; 4 ft. Per pkt., 10 cents; q t., 20 ; peek, $\$ 1.00$; bush., $\$ 3.00$.

Harrowfat Iarge WVhite. - A favorite late market sort, witlı large, broad pods, well filled, of excellent quality; $6 \mathrm{ft}$. Por pkt., 10 cents; qt., 20; peck, 80 ; bush., $\$ 3.00$.

Pride of the Market.- It is very productive, and the pods are well filled witl large and fine-flavored Peas. Its robust constitution, enormous productiveness, and supcrior appearance insure its acceptance as a farorite by the public. $2 \mathrm{ft}$. Per pkt., 20 cents; pint, 60 ; qt., $\$ 1.00$.

Stratigem.-This is one of the best, if not abso. lutely the best, of the many Fuglish Peas lately introducel. It is a dwarf wrinkled blue marrow, a leavy cropper, with large, remarkably well-filled pods. 2 ft. Per pkt., 20 cents; pint, $60 ; q t ., 1.00$.

Sugar Dwarf--Eable pods; can be used in a green state, like string Beans; 2 ft. Per pkt., 10 cents; qt., 50 ; peck, $\$ 3.50$; busll., $\$ 12.00$.

Sugar Tall.-Edible pods ; 5 ft. Per pkt., 10 cents; qt., 50 ; peck, $\$ 3.50$; bush., \$12.00.

Yorkshire Hero-One of the most desirable varieties in cultivation; is very prolific and of delicious flavor; $2 \frac{1}{2}$ ft. Per pkt., 10 cents; $q$ t. 40 ; peck, $\$ 2.50$; buslı., $\$ 9.00$.

\section{PEPPERS.}

\section{[Caspicum, LiN. Piment, Fr. Spanisher Pfeffer, Ger. Pimiento, SP.]}

\section{One ounce will produce two thousand plants.}

Cultunk. - Sow early in April in a hot-bed, in sliallow drills six incles apart, and transplant to the open grouml as soon as the weather is warm and settled. Set the plants in mellow soil, in rows sixteen inclies apart, and the same distance apart in the rows. The seed may also be sown in the open ground, but not until all danger of frost is past.

If by mail in quantities of 4 ounees and upwards, postage must be added at the rate of $16 e$. per pound.

Cayeune (true).-Pods small, cone-shaped, red, intensely acrid. This variety furnislies the Cayenne Pepper of commerce. Used for pickles, and for making pepper-sauce. Per pkt., 10 cents; $07,35$.

Cherry Red.-A small, smooth, ronuil variety, of iwar' growth. Fruit at luaturity of a deep, rich, glossy scarletcolor. Per pkt., 5 cents; oz., 25; 1 $75 ; 1 \mathrm{~b} ., \$ 3.00$.

Chili.-Pods pendent, slarply conical, abont two inches in lengtlı, lualf an inclı in aliancter, very piquant. Per pkt., 10 cents ; oz., 50 ; 1/4 1b. $\$ 1.50$; 1b. $\$ 5.00$

Large Bell, or Bull Nose.-Early, sweet and lleasant to the taste, less pungent thau most other sorts. Per pkt., 5 cents ; 02, $25 ;$ 年 Jb., 75 ; $1 \mathrm{b.}, \$ 3.00$.

Long Red.-Fruit brilliant coral red, from three to foul inclies in lengtl, aud an inel to one and a half inclies in diameter. Per plit., 5 cents; oz., $25 ; 1 / 1 b ., 75 ; 1 b ., \$ 300$.

Long Yellow. - Similar to the Long Red in sluapo and geueral appearance, excepting in color. Per pkt., 10 cents : oz, 30 : 14 1 b., $\$ 1.00$; 1 b.. $\$ 3.30$.

New Cramberry. - Small, piquant : and of fine flavor. Per pkt., 10 cents; oz., $50 ; \frac{1}{4} \mathrm{lb} ., \$ 1.25$; 11., $\$ 4.00$.

New Golden Dawn. - In color this is a bright golien yellow, aud in productiveness it is said to sur. pass any otlier variety. It is entilely free from fiery flavor, eveu the secis and pulp lave not the least smarty taste. Per pkt., 15 ceuts.

New Oxlneart.-Medium-sized, heart-sliaperl, productive, jiquant; excellent for pickles. Per pkt., 10 cents; 0z., $30 ; 1 / 161$., $\$ 1.00 ; 1 b ., \$ 3.50$.

Spanish Monstrous. - of cylindrical form. When ripe, the fruit is of beautiful coral red; sweet and thick thesh. Pel pkt., 10 cents; oz., 50.

Squash or Tomato-shaped.-Of a brilliant coral red; flesli thick; mild aud pleasant to the taste; an excellent sort for pickling, Per pkt., 10 cents; oz., 30 ; ti 1b., 1.00 ; $1 \mathrm{~b},, \$ 3.00$.

sweet Mountain, or Maminoth.-Similar in shape to the Large Bell, but of larger size; rind thick; Heshy and tender: much nsed for pickling. Per pkt, 10 cents : 0 .., 40 , 1/4 lb., $\$ 1.25$; $1 \mathrm{~b}$., $\$ 4.00$.

Sweet Spanish.-The earliest of all tlie varicties. The thesh is swret, mild, aur plcasant. Per pkt. 10 cellts; oz., 40 , y 11., $\$ 1.25$ lb., $\$ 4.00$. 


\section{GENERAL COLLECTION OF WELL-KNOWN STANDARD VARIETIES OF POTATOES.}

Except when otlerwise noted, the price of the following varieties, wlien scut by mail, is 50 cents pel ponnd; three pounds tor $\$ 1.25$, post-paid. When orderert in lots of three 1 bbls., 25 cents per bbl., or five bbls, 50 cents per bbl., may be dedncted.

Adirondack. - This favorite variety may be classer as medium or second early ; the tubers are rentskinned, almost a perfect ball, and grow in clus ters; oi excellcut table qualities, being pure white in Hesli, flomy, aud of faultess Havor. It is an abnndant cropuer, whileits keeping qualities have so far been perfectly satisfactory. Per peck, $\$ 1.00$; bnsl1., $\$ 2.25 ; \mathrm{bul} ., \$ 5.00$.

American Giant.-One of tlte largest and most productive second early varieties in cultivation; of splendid flavor and an excellent keeper; on account of its lar ge size it is a restrable exhibition variety. Per peck, \$1.25; bush., $83.50 ;$ blul., \$7.00. Americau Magnmm Boumn.-This variety pos. sesses many of the most essential qualities to render it a standard sort. It matures a few days after the Early Rose, while in prodnctiveness it surpasses that popnlar variety. Per peck, 75 cents; bush., $\$ 2.00$; bul., $\$ 5.00$.

Benuty of Hebron.-A fine eropper, of excellent quality ; ripens witl the Early Rose, and equally valuable as a inarket variety. Per peek, 75 cents bush., $\$ 2.00$; bbl., $\$ 5.00$.

Bliss's Trinmph.-This is one of the most attract ive in appearance of any that we have yet offered, and compares farorably with the best of them in quality. It is more productire thau Early Rose, aud matures its crop at least seven days in adrance of that favorite solt. It strongly resembles tlie early varieties from Bermucla; flesl tine grain and of excellent flavor. Per peck, $\$ 1.25$; busll., \$3.00: bul., $\$ 7.00$.

Brownell's Best.-This splendid second early vari ety belongs to that excelleut strain of Potatoes represented by the Snowflake, Pride of America, and a few others. Enormously productive; in color, white, shading to r'usset; shaje oblong, some what flattened; eyes few and entirely smooth; 1lesl white, fine-grained, floury, and of the purestflavor 'Takiner all in all, we do not liesi tate to assert tlia the higluest pertections, in shape, in size, in yield, and in qualits, are combined in this new variety. Per peck, $\$ 1.50$; bush., $\$ 4.00$; bbl., $\$ 8.00$.

Burbank's Seedling.-A white-skinned medimm early variety; flesll of fine grain and of excellent

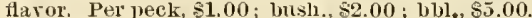

Early Ohio.-A seedling of the Early Rose, resem. bling it in color. The quality is cxcellent; earliex tlian Rose; a desirable market valiety. Per peck. 75 cents; busi., $82.00 ; 1$ bl., \$5.00.

Early Rose.-This was the first of Mr. Bresee's seedlings, offered by ns in Jantuary, 1868, and has now becone the standard variety for earliness, quality, and productivencss. Per peck, 75 cents; busl., $\$ 1.25 ;$ blul., 54.00 .

Early Suowflake.-This favorite variety possesses more good qualities than any variety heletofore introduced. It ripeus abont a week later than the Early Rose. Its mealiness, pme, delicate flavor, and the evenness with which it cooks through, have never been cxcelled by any Potato. Pei peck. 1.00 ; bush., $\$ 2.25$; bbl. $\$ 5.00$.

Extra Early Vermout.-Similar in color, form and general appearance to the Early Rose. It is, lowever, earlier, more lards, more prodnctive, and of better quality. Per peck, 75 cents; bnsh., $\$ 2.25 ;$ blul., $\$ 5.00$

Late Beanty of Ilebron.-This was first discor cred in a fielul of the Early Beauty of Hebron, and is very similar, if not ictentical, wtll the White Elephant. It is remarkably prodnctive; tubers oblong and of extra size; skin and flesh white table properties good, and keeps well. Per peck, 75 ceuts: per besh., $\$ 2.00$; per bul., $\$ 4.50$.
Late Kose.-This variety ripeus two or tluee weeks later than the Early Rose: liarty, produc tire, aud keeps well. Per peck, 75 cents; buslı, $\$ 1.75$; bbl., 84.00 .

Mammoth Pearl. - Of good table qualities, skin white, and flesh whitest of any variety. For tlie table it cooks like a ball of flour. It ripens in Augnst; very productive. Per peck, 75 cents: bush., 1.75 ; blbl, $\$ 4.50$.

Iatchless. - in excellcut variety for general crop; rery prolific; tnbers generally round, but occasionally oblong and flattened; skin slightly russeted, pale red, except the eyes and seed end, wlere it is much brighter; eyes slightly de. pressed. Flesh pure wlite, of excellent qnality. An excellent keeper, and has never yet shown any signs of disease. Per peck, 75 cents; busli, $\$ 2.00$; bul., $\$ 4.50$.

Peerless (Bresee's No. 6).-One of the rery best varieties for genelal culture. Per peck, 75 cents; busli., $\$ 1.75$; bbl., $\$ 4.00$.

Pride of America.-This superb variets closely resembles the well-known Snowflake, but ripens a few days later, and is adapted to a yreater variety of soils, more productive, grows to a larger size, and produces but a very few small tubers, and, so far, lias showu no signs of disease. Flesh fine-grained, and of snowy whiteness. It is an excellent keeper, aud retains all its good qualities throughout the entixe season. Per peck, $\$ 1.00$; brisl., $\$ 2.00$; blul., \$5.00.

Queen of the Valley.-One of the most prolitic varieties in cultivation. Season medium; tubers very large; sliape long, Hattened, somewliat square cnt at the ends; color, deep pink at the seed end, gradually clianging to almost white at the stem ena; cooks rnealy, without falling into pieces. Its only fault, as a table potato, might be found in its enormoussize, but its immense plodnctiveness will, no donbt, make it of great ralne to all whis appreciate the nutritive propertics of potatoes as food for live stock of all kinds. Per peck, \$1.00; bush., $\$ 2.50$; bul., $\$ 6.00$.

Vermont Champion.-This very acsirable variety is the result of selections from seedlings of Compton's Surprise and White Peachblow, and has proved to be one of the most valuable varieties ever cultirated. It is of large size, roundish oval form, has a sil rery white skin and wlite flesll; its Havor is pnre and delicate. The vines frow very strong aud upright, and have never shown bliglit. It is a good cropper, producing but few small tubers, and keeps well till the following Sumnier. Per peck, $\$ 1.50$; busl., $\$ 4.00$; bbl., $\$ 8.00$.

White Elephant.-This snperl late variety is justly popular on account of its great prodnctiveness, excellent thavor, power of resisting diseasc, and splended keeping qualities; it cooks well and is of goot flavor. Similar to, if not ictentical with, the Late Beauty of Hcloron. Pel peck, 75 cents; busl., $\$ 2.00 ;$ bbl., $\$ 4.50$.

White star.-This excellent medinm early potato las more than maintained the introdnetory leputation given it. The foliage is dense, dark green; vines strong, stocky, and rigorons, on which account it is well caleulated to resist the ravages of the Colorado bectle. Tlıe tubers are oblong, large. uniform, and hantsome; wlile in yield it las proved remarkably prolific, and so far lias effectually resisted bliglit. Whether bakel or boiled, its cooking qualities are faultless; its purity of color, fine tlowy textmre, anit delicious flavor being unexcelled by any other variety. Per peck, \$1.00; buslı., $\$ 2.50 ; \mathrm{bbl} ., \$ 6.00$. 
For the Farm and Garden.

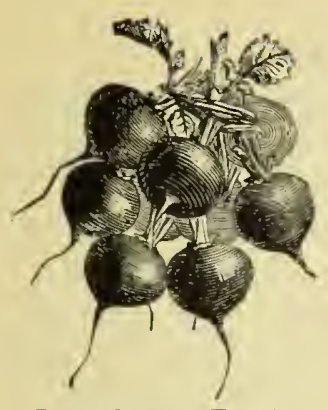

Early Scarlet Turnip.

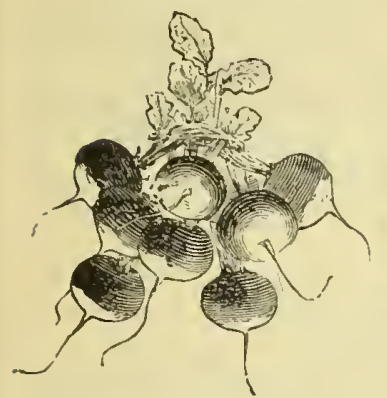

Scarlet Turnip White Tipped
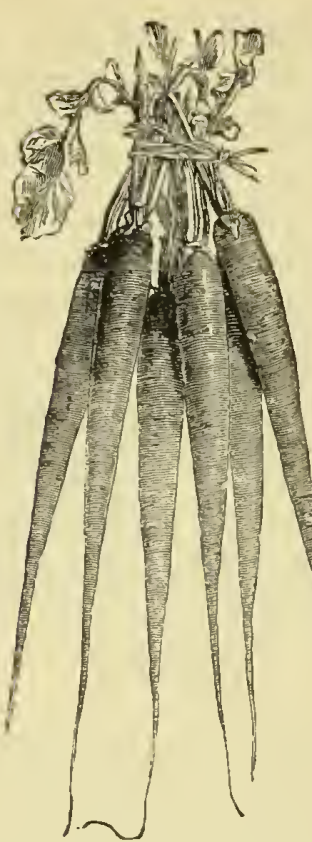

Long Scarlet Short Top.

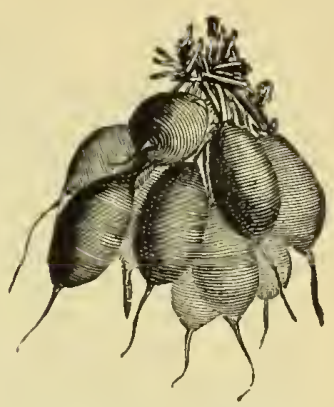

Scarlet Olive-Shaped.

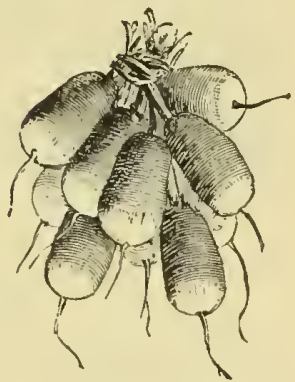

French Breakfast.

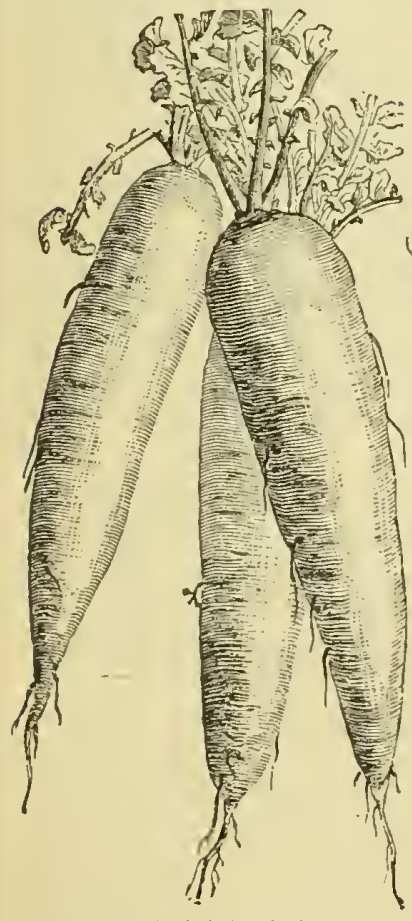

California White Winter.

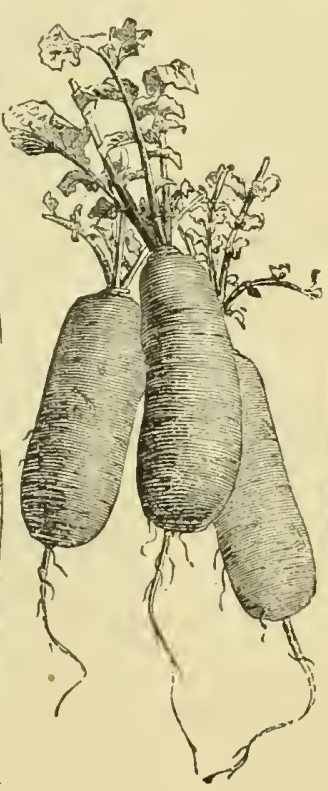

Scarlet China Winter.

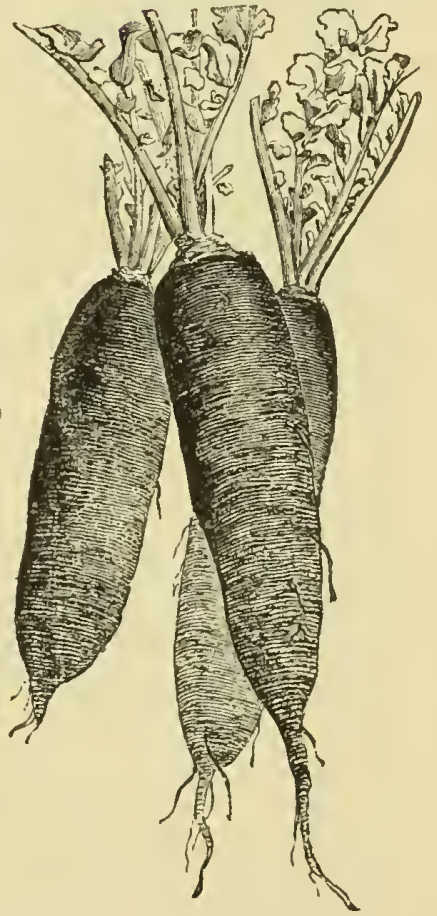

Black Long Spanish Winter. 


\title{
HYBRIDIZED POTATO SEED.
}

The success which has attended the attenupt to improve this valuable esculent has encouraged us to make still greater efforts in lybridization, and we have now the pleasure of offering a very choice strain of secd, the product of numerous hybridizations between many of the best new and old varieties in cultivation, both English and Americau. Full directions for swwing accompany each packet. Price, 25 cents per packet; 5 packets, $\$ 1.00$.

\section{PUMPKIN.}

\author{
[Cucurbita pepo, Lis. Potiron, FR. Kurbis, GER. Calabaza, SP.]
}

One pound will plant from 200 to 300 hills.

Culture.-The common practice is to drop two or three seeds in every secona or thirt hill, in the cornfield, but if cultivated on a large scale the seel may be sown in hills, eight feet apart each way, four plauts to each hill, and otherwise treated in the same manner as recommended for Melons or Cucumbers.

If by mail in quantities of 4 ounces and upwards, postage must be added at the rate of $16 c$. per pound.

Caslinw. - Similar to the common Crookneck Winter Squasli. Per pkt., 5 cents; $0 z, 10 ; 1,1 b ., 30 ; 1 b ., 85$.

Connecticnt Field. - A large yellow variety; the best for fiela culture. Per pkt., 5 cents; oz., 10; 1 . 1 b. 15 ; 1b., 35.

Jumbo. - The largest variety grown, ofter attaining the weiglit of two hundred pounds ; very produc. tive. Per pkt., 10 cents; oz., $20 ; x_{1} 11$., $60 ; 1 \mathrm{~b}$., $\$ 2.00$.
Iarge Cheese.-Hardy, productive, and superior in ail respects to most of the field-grown sorts; of fine grain and excellent flavor. Per pkt, 5 cents; oz., 10; $1 / 1$ 1b., $25 ; 1 b ., 50$.

Larae Tolls, or Mammoth.-Very productive, large size, often weighing one hundred to one hundred and fifty pounds. Per pkt., 10 cents; oz., $30 ; .41 \mathrm{~b}$., $\$ 1.00 ; 1 \mathrm{~b} ., \$ 3.00$.

\section{RADISH.}

[Rlaphanus sativus, Lrn. Radis, Rave, Petite Rave, Fr. Rettig Radies, Ger. Rabano, SP.] One onnce will sow one hundred feet of drill.

Culture. -The soin for radishes should be very rich, light and mellow, well broken by digging, as their tender and mild qualities depend mucl upon their rapid growth. For very early use sow on gentle hot-beds in February, and in the open air as soon as the ground can be worked, at intervals of ten or twelve days for a succession, as long as they may be wanted. The Tumip-rooted and the olive-shaped are the best for sowing in the Summer. The Winter varieties should be sown iu August, and lifted before severe frost, and stored in the cellar.

If by mail in quantities of 4 ounces and upwards, postage must be added at the rate of $16 c$. per pound.

California Mammoth White Winter.-Intro duced into California by the Chinese; it grows to a large size; Heslr wlite, firm, and of good flavor Per pkt., 5 cents ; oz., 10 ; $2 / 1$ lb., 35 ; 1b., \$1.25.

Early Short Toy Long Scarlet. - When pure and true it has a bright scarlet root, and very small top. Per pkt., 5 cents ; oz., $10 ; 1 / 1 \mathrm{~b} ., 20 ; 1 \mathrm{~b} ., 60$.

Early Purple Turnip.-Color deep purple, very early, and of fine flavor. Per pkt., 5 cents ; oz., $10 ; 1 / 1 b ., 30 ; 1 b ., \$ 1.00$.

Earliest Scarlet Erfin't.-The earliest variety sliort-leavcd; the finest for forcing. Per pkt, 10 cents; oz., 15 ; t Ib., $30 ; 1 b ., \$ 1.00$.

Early Scarlet Turnip.-Small top ; quick grow th ; mild and crisp. Per pkt., 5 cents ; oz., 10; 1 lb., $20 ; 1 \mathrm{~b} ., 60$.

French Breakfast. - A quick- growin\& varicty, and orre of the best for early foremg. It is of oval form, color scarlet, tipped with white. Per pkt., 5 cents; oz. $10 ; \frac{3}{4} 1 \mathrm{~b} ., 25 ; 1 \mathrm{~b} ., 65$.

Long Sahnom.-Longer aud lighter colored than tho above, with a larger top; a few days later. Per pkt., 5 cents ; oz., 10 ; 1/ 1b., 20 ; 1b., 60.

Long White Naples.-White, but when exposed to the light, tiuged with green; flesh white, crisl) and mild. Per pkt., 5 cents; oz., 10 ; t/ 1b., 30 ; 1b., 85 .

Olive-shaned Golden Yellow Summer.-Very early ; atapted both for forcing and the open ground. Per pkt., 10 cents; $0 z ., 15$; $1 / 4 \mathrm{lb} ., 30$; $1 \mathrm{b.}, \$ 1.00$.

Olive-shaped Scarlet.-A very early and hand some variety, of a lively rose color and oblons sliape. Per pkt., 5 cents ; oz., 10; 1, 1b., 20; 1b., 65.

Olive-shaped Violet White Tipped.-Equally as constant and as attractive for table decoration as the French Breakfast. Per pkt., 10 cents; $0 \% ., 15$; $1 / 1 \mathrm{~b}, 40 ; 1 \mathrm{~b} ., 81.50$.

Otive-mhaped White.-Same as preceding, except

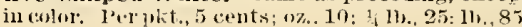

Raphanus Caudatus, or Rat-tail Radish. Produces pods fron two to three feet long, which may be used either boiled as a salad, or in pickles. Por pkt., 10 cents ; oz., 50.

Rose Colored China Winter.-Form rather conical and very smooth; of a lively rose color ; Hesli firm and pungent. Per pkt, 5 cents; oz., 10 ; 省 $1 \mathrm{b.}, 30 ; 1 \mathrm{~b} ., 85$.

Russian Frane.-Comes into use rapidy. The root exceeds ten inches in length, and is of an average thickncss throughout of about an inch. The flesh is white, delicate, and fine flavored. Per pkt., 10 cents ; oz., 25; 夜 1b., 75 ; 1b., 2.50 .

Rnssian Large White.-The largest of all Winter Radislics ; produces roots weighing three pounds; quality medium. Per pkt., 10 cents; $0 z ., 15 ; 1 / 4$ 1b., 50 .

Spanish Winter, Long Black.-Ot very large size and firm texture. Store in sand in the cellar for Wiuter use. Per lukt, 5 cents ; oz., $10 ; \frac{1}{4} / \mathrm{lb}$, $20 ; 1 \mathrm{~b}, 60$.

Spanish Winter, Round Black.-Similar to the above, except in form. P(r pkt., 5 cents; oz., 10; $i_{4} 1 \mathrm{~b} ., 20 ; 11$. 60.

Spanish Winter, White.-Similar to the foregoing, except in color. Per pkt., 5 cents ; oz., $15 ;{ }_{14}^{1}$ lb., $40 ; 1 \mathrm{~b} ., \$ 1.25$.

T'urnip-shaped Golden Yellow.-A new French variety of a beautiful golden color; very early. Per. pkt., 10 cents; 0z., 15; 年 $1 \mathrm{~b} ., 35 ; 1 \mathrm{~b} ., \$ 1.00$.

White China Winter.-Except in color, this vari. ety is similar to Rose Colored China. Per pkt., 10 cents; oz., 15 ; 南 1b., 40 ; 1b., \$1.25.

White Turnip.-Tike the searlet in sliape, but in color pure white. Per pkt., 5 eents; 0z., 10; $1 /$ 1b., $20 ; 1 \mathrm{~b} ., 60$.

Yellow Turuip. - The very best to stand the heat and drouglit of summer. Per pkt., 5 cents ; oz.,

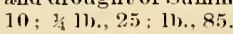




\title{
RHUBARB.
}

[Rheum hybrdum, Lis. Rleuburbe, Fu. Rhaburber, Gek. Ruburbubastardo, Nr.]

\section{One ounce will produce about onc thousand plants.}

Cultukb--Sow in April in trills eighteen inches apart, and cover the seed with fine soil, pressing it down firmly. When the plants are stronu enough, thin out to six inches. In the Full or following Spring, transplant the roots intorleep, rieh soil, blire teet apart each way. Do not cut until the thirel Spring after sowing. The most expeditions way to seeure a supply is to preserve roots alreacly grown, which will eome into 11 se in one season.

If by mail in quantities of 4 onnces and upwards, postage must be added at the rate of $16 c$. per pound.

Victoria.-Large, fine for cooking. Per pkt., 5 cents; $0 z_{.}, 25 ;$, 1 b., $75 ; 11$., 82.00 .

Limnaus. Large, temler, and ver'y tine. Per pkt., 5 cents: $0 \%, 25 ; 1,1 \mathrm{l}, 75 ; 1 \mathrm{~b}, \$ 2.00$.

Roots. -25 cents each; $\$ 2.00$ per ilozen. By mail, 40 cent s oach; $\$ 4.00$ per dozen.

\section{SALSIFY, or OYSTER PLANT. \\ [Tragopogon porrifolius, LIN. Salsifis, Fr. Bocksbart, CrER. Ostru l'egctal, Sp ]}

\section{One onnee will now fity feet of drill.}

CuLture.-Sow the seed in light, deep soil, early in spring, hir drills twelve inches apart and one inch deep, thinning out the young plants to six inches. The roots will bo ready for nse in Octolser, wlien : supply shomlit be taken np and stored like Carrots. Tlrose remaining will snffer no tnjury by being left in the gronnd till spring, bnt slould be ding up before commeneing their grow th.

If by mait in quantities of 4 ounces and upwards, postuge must be added at the rate of $16 c$. per pond

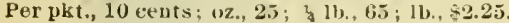

\section{SCOLYMUS (Spanish Oyster Plant).}

\author{
[Scolymus Hispanicus, Lis.]
}

\section{One ounce will sow fifty feet of drill.}

CULTURe.-Any good garien loam, thoroughly worket, is alapted to the grow th of the scolymns. Sow the seeds from the midlle of April to the first of May in drills one incls deep and one foot apart. Thin the young plants to five incles a part in the rows, and afterwart treat as Parsulps or Carrots.

If by mail in quantities of 4 ounces and umoards, postage must be alded at the rute of $16 \mathrm{c}$. per pound.

Per pkt., 10 ceuts; oz., $30 ; 411$., $\$ 1.001$ 11)., $\$ 3.00$.

\section{SCORZONERA.}

\section{[ S'corzonere, Fr. Skorzonere, (xkk. Escorzonera, Lip.]}

One ounce will sow fifty feet of brill.

CULTLk.-Sinulax in many lespects to Salsify, and callol by sunc Black Salsify. Culture the same as recommented for salsify. 'They may be boilen like the Parsnip and served plain at the talble, or they may be cooked like the Salsify. Before cooktng, the onter coarse rind slould be seripen off, and the roots soaked a few loors in cold water to extract their bitter flavor.

If by mail in quantities of 4 onnces and upuards, postaye must be added at the rate of $16 \mathrm{c}$. per pour.t.

Per pkt., 10 ceruts; $\left.\left.02 ., 25 ; \frac{1}{4} 11\right) ., 75 ; 11\right) .52 .00$.

\section{SEA-KALE.}

[Crambe Ifarilıma, Lin. Crambe Varitime, Fr. Selkohl meerkohl, Gik. Breton de mar, Sr.]

One ounce will produce about three hundred phants.

CoLTURE, Cultivated for hts blanched shouts, whelt are cooked as Asparagns. A supply uay be lial all Winter by planting roots clesely in a warm cellar before frost. sow one inch deep, in drills two feet alpart, thin out to six fuches, and the next spring plant hullis three foet apart.

If by mail in quantities of 4 ounces and umeards, postage inust be adiled at the rote of lbe. per ponnd.

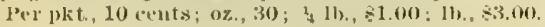

\section{SORREL.}

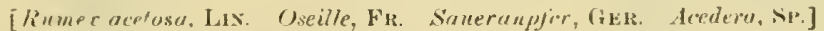

(One ounce will sow one hundred and fitiy feet of thill.

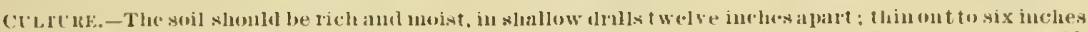

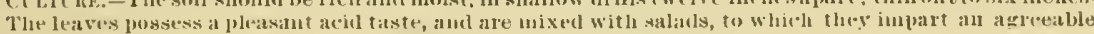
refreshing flavor.

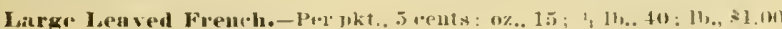


B. K. Bliss \& Sons' Catalogue

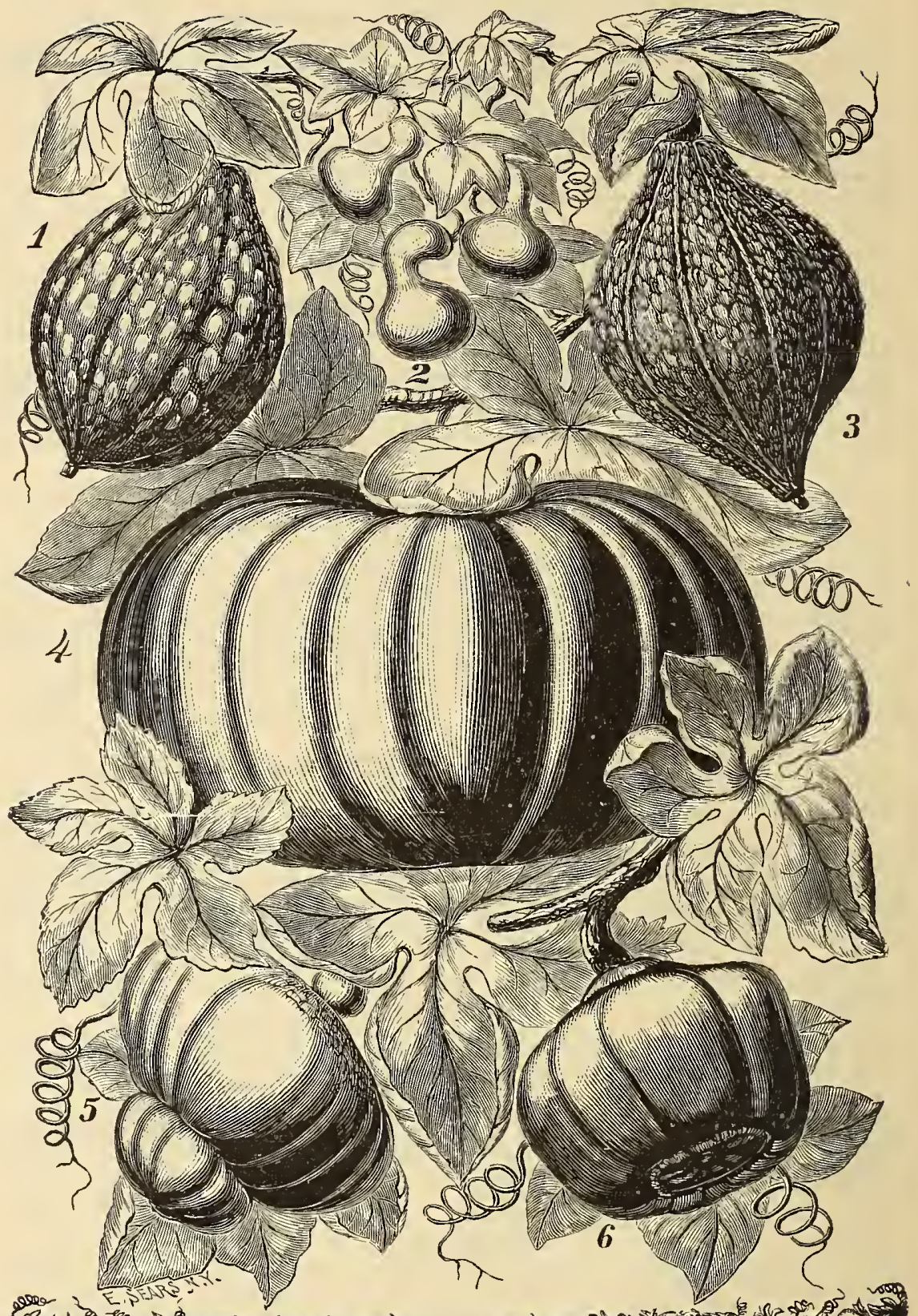

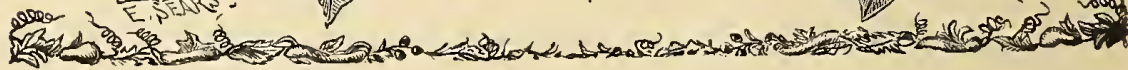

GROUP OF SQUASHES.

1.-Boston Marrow.

2.-Canada Crookneck.
3.- Hubbard.

4.-IIammoth.
5.-French Turban.

6.-Improved Turban. 


\title{
SPINACH.
}

\author{
[Spinacea oleracea, LiN, Fipinard, Fr. Spinat, GEr. Espinaca, Sr.]
}

One ounce will sow one lund red feet of drill; teu lbs. for one nere.

CULTURE.-For the summer erop sow oarly in March, and at intervals of threo weeks or a fortnight, until the mildio of Jnly, in inantities according to tho domand. Tho ronul seeded varietics are the best for Simmer crops. Tho Winter eropr should bo sown from tho middle of Angust to tho beginuing of September; the prickly seeded is the liarliest, and slould bo partly nsed for this crop. All tho crops should bo sown in drills from one to two inches deep, and from twelvo to ei whteen inches apart, scattering the seed thinly, and eovering with fino soil. Protect the Winter crups on approach of sevoro frost with a little st raw or evergrcen bonglis.

If by mail in quantities of 4 ounces and upwards, postaye must be alded at the rate of $16 c$. per pound.

Ext ra Large Roumd-Leaved Virofiny. - I splen. mer. The plants shomld staml two or three feet di.l variety of tho Lottice-leaved Spinach, but with leaves much longer and broaler, round, thick, and fleshy, lark green. Young plants transplanted into a rich soil will grow to an enormous size. Per plit., 5 cents: 0z,., 10; ? 1b., 20 ; 11), 50.

Lettuce-leaved. - A new sort of very superior quality; leaves liarge, thick, and deep green ; sind, round; best suited for spring sowing. P'er pkt. 5 cents; $02 ., 10$; 1 b., 20 ; 1b., 50.

New Zenlaud.-This plant grows very large and Iuxuriant in warm, ricl soil. It will endure severo drouglit, which is its mreatest aclvantage, and produces a large quantity of leaves duting sum apart. Per pkt, s cents; oz., 10; 3 i lb., $30 ; 1 \mathrm{~b}$. $\$ 1.00$

Prickly, or Fall.-This is tho hardiest varioty; prickly seceled, with triangular, oblong, or arrow. sliaped leaves. Mostly employed for Fall sowing. Per pkt., 5 cents ; $02 ., 10$; $\frac{1}{4} \mathrm{lb} . .15 ; 1 \mathrm{~b} ., 35$.

Roumd, or Snumer. - Has a smootl, rominl seed thick, fleshy leaves, a little crimped; generally prefierrecl for Spring sowing. Per pkt,, 5 cents;

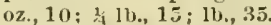

Snvoy-Leaved. - Ono of the best market rarieties prodinctive, hardy, tender, ancl well.flavored. Per pkt., 5 cents; oz., $10 ; \frac{1}{4} 1 \mathrm{l}$., $20 ; 11$., 50.

\section{SQUASH.}

\author{
[Cucurbita melo-pepo, LIN. Courge, Fr. Kurliss. GER. Calabaza tontanero, SP.]
}

\section{One onace Early will plant fifty hills; oue ounce Marrow tweuty hills.} Four to six pounds will be required for acre.

CULTURE.-Being very tender and so sensitive of cold, sinusl camot bo planted with sufet $y$ in the Mid. de and Northern States before tlo Middlo of May. Tho hills shonld be highly manred, and prepared in a similar inanuer to thoso for Cncumbers; all sorts thinned to not more than three plants to a hill.

If by mail in quantities of 4 ounces and upwards, postage must be added at the rate of $16 e$. per pound.

Boston Mnurow,-Form ovate, pointed; rind ex tremely thin; briglt orange or salmon colored flosli dcep orango, finely grained, and excellent Havoren. It keeps well in Winter, and will boil as dir as a potato. Per pkt., 5 cents ; $0 z ., 10$; 尓 $1 \mathrm{~b}$. $35 ; 11) ., \$ 1.25$

Bntinan. - In size and protueticeness it resembles the IIubbard; it has a thick shell and is thick. meated; dry, sweet, and delicins; in its prime from October to Jannary. Per pkt., 5 cents; oz., 10 ; 1 ; $11 ., 35 ; 11$., $\$ 1.25$.

Canada Crookneck (True), - I small, early vari ety of the Winter Crookin'ck. One of the best for keeping, and when hung up in a dry room, of even tenperature, will often keep good until tho crol is gatluered tho following year. Per pkt., 10 cents oz., 20 ; *1/ 1b., 50 : 1b., $\$ 1.50$

Coconnnt. - A handsome littlo siquash: very pro. lific and excellent for tablo use; culor a creamy yellow, except at tho bottom, where it is of a rich grecn lue; flesh fine grained and solis. Per pkt. 10 eents : oz.. $20 ; 2 / 1 b .50 ; 11$. 81.50 .

Custard Marrow.-An English variety of delicat flavor: high?y recommended. Per pkt..25 rents. Early Busli Sumner Crookneck.-Thebest sort for Summer; very early and prodinetive. Per pkt. 5 cents : 07,$10 ;$ i 1 b., $25 ; 1 b ., 80$.

Early White Bush Scalloped. Sinilar in sliape to the yollow lirlit eream.colored. Both varietius are called "Patty.Pan" in the Soutlern and Min.

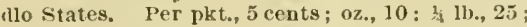
$1 \mathrm{~b} ., 80$.

Early Yellow Bush Ficalloped.-An early, fiat, scalloper-slraped sort, of a deep orange yellow. Per pkt., 5 cents : oz., 10 ; 4 , 1b., 25; 1b., 80.

Fall or Wincer Crookneek.-Extensively grown in tho Eastern States; neck long and solicl; color pale yellow, sometimes striped. Per pkt., 5 cents ; oz., 10 ; 为 1b., 30 ; lb., 80 .
II ubbard.-This variety is morc largely grow w than any otleer ; thas a haril slell, and will keep three months later than the Marrows. Perpkt., 5 cents oz., $10 ; 1 / 4 \mathrm{~b} ., 35 ; 1 \mathrm{~b} ., \$ 1.25$.

Lov's Preuium Turban.-This is one of the richest flavored, finest grained, sweetest, post productive, and best keeping siuashes wo know of. Being rery early, it may be planted as a second crop) after (early Peas, Potatoes, or Cab. baures, Per pkt., 10 cents ; 0 ., 25 ; 1 1b., 65; 1b. $\$ 2.00$

Narblelead. - Flesh lighter in color than the Hubbard, while its combination of sweetuess, lryucss, and delicions flavor is something really remarkable. Per pkt., 5 cents ; oz., $10 ; \frac{1}{4} 1 \mathrm{lb}$., 35 ; 11. $\$ 1.25$.

Mamuot h. - Very large, often attaining the weight of two huntreil pounds; excellent for pies or stock; rery prodnctive. Per pkt., 10 cents; oz. 20 ; 1 1b. $60 ; 1$,,$\$ 2.00$.

Perfect (iem.--Excellent botl as a sumuer ant Winter sinash ; of a creamy white color; thin skinged, witl fino grainerl, sweet, delicionsly fla vorel flesh ; a frce grower, productive, and of ox collent kecping qualities. Per plit., 15 cents ; oz. $30 ; 1,1 b .75 ; 11$., $\$ 2.50$.

Tuubau, or 'Turk's Cap.-A most excellent late tablo variety; tlesh orange-yellow, thick, fine graiued, sngary, and well flavored. Per pkt., 10 cents; 0\%., 15 ; z 4 Ib., 40 ; 1b., $\$ 1.20$.

Vegetable Inrrow.-A favorite English sort shin greenisl yellow; flesl white, soft, rich flavor. Per pkt., 10 ecnts; 0z., $25 ; 1 / 41$., 80 ; 1b., $\$ 3.00$

Fokolatua, - When fully ripe is of a uniform tul orange color" flesh of a de'ep orang cclor, tinely flavored, sweet and iry, very tino graincl, and withont any tiber; a gool keener. Per pkt., 10 cents; $0 \% ., 25$; $y$ lb., $75 ; 1 b$, 82.50 . 


\section{NEW TOMATO-MAYFLOWER.}

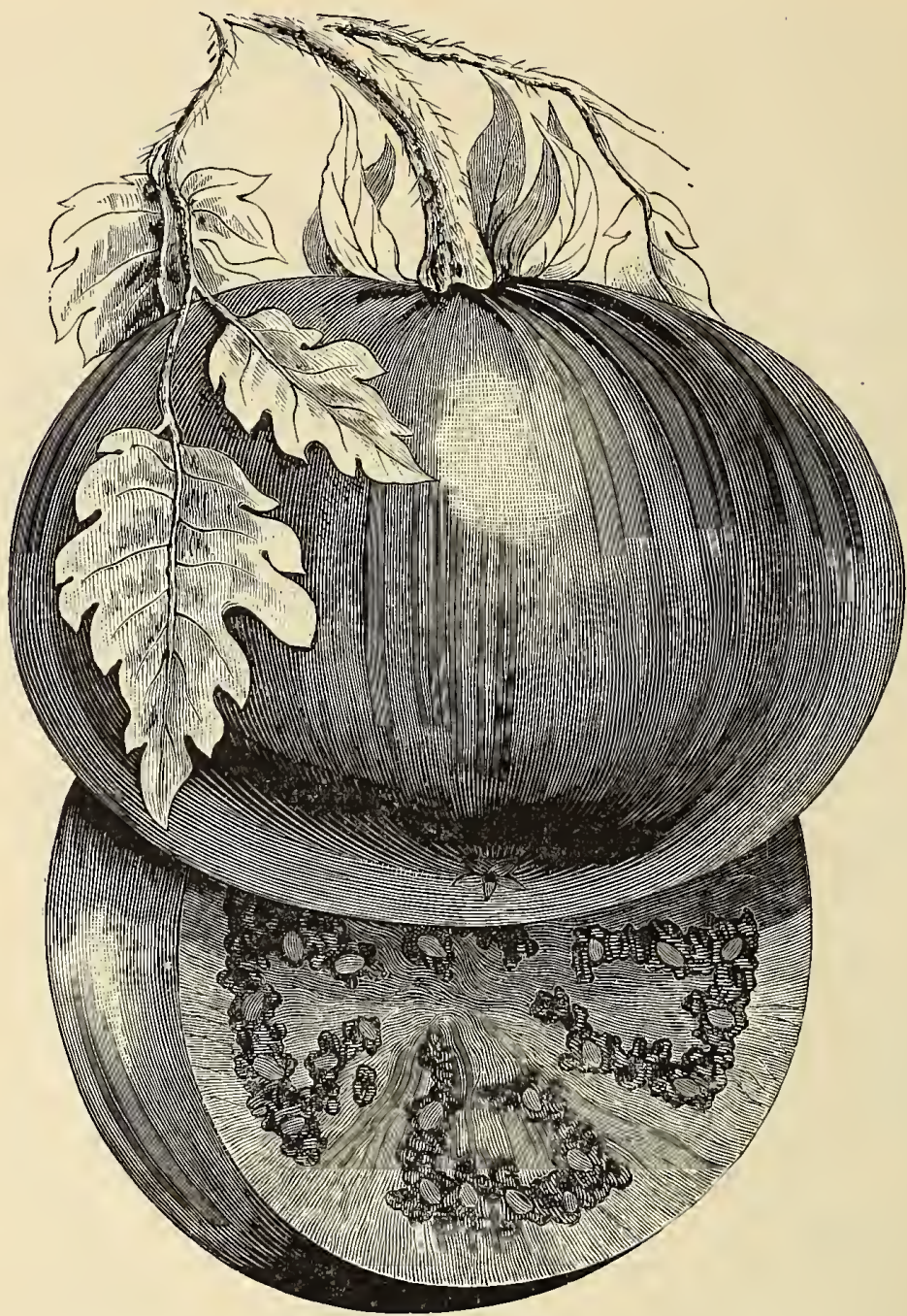

In this new seedling variety, whieh we had the pleasure of introdueing last season, all the qualities desirable in a Tomato are eoubined in a degree not heretofore attained. It is the earliest large Tomato enltivated, ripening but a few days later than "Little Gem," and averaging in size about one-third larger than " $\Delta$ eme." It is of a glossy, bright red eolor, so desirable in a market Tomato, and ripens so erenly and perfeetly up to the stem, that it presents a most beautiful appearanee. Its shape is perfeet, giobular, slightly flattened and perfeetly smooth; flesh solid, unusually free from seeds, and of a pure, rieh flavor. In produetiveness it is not exeelled by any other sort, bearing full crops until killed by frost. Its skin is firm and smooth, indicative of the best shipping qualities. From the many testimonials reeeived from numerous growers in every section of the country, we are lead to anticipate an unusual demand for this exeellent variety the coming season. In view of this, together with a short erop of seed, we would suggest that those desiring a supply would order early, to avoid disappointment. (Head-quarters seed.) Per pkt., 15 eents; oz., 75 eents. 


\section{TOBACCO SEED.}

One ounce will sow twenty-five feet square, und prodnce plaus for one acre.

Directions for cultivation, curing, and preparation for tho market will be furuishod with the seed. If by mail in quantities of 4 ounces and upwards, postage must be added at the rate of $16 \mathrm{c}$. per pound.

General Grant.-The earliest Tobacco in cultiva. tiou; produces inumense foliage, of fine texture, small rened aud rery elastic: ripens as far uolth as Minuesota. Per pkt., 25 cents.

Councetient seed Leaf--Saver from solected plants. Per pkt., 10 ceuts; oz., $35 ; 1 / 41$ b. $\$ 1.00$; Il)., $\$ 300$

Havana.-Imported seed. Per pkt.. 15 cents; oz. $50 ;$ मे $1 \mathrm{~b} ., \$ 2.00 ; 1 \mathrm{~b} ., \$ 6.00$.
Marylaud and Ohio, - Per pkt., 15 eents; $02 ., 40$; ${ }_{4} 1 \mathrm{~b} ., 81.25 ; 1 \mathrm{~b} ., \$ 4.00$.

Kentueky.-Per pkt., 15 cents; oz., $40 ; \mathrm{lb} ., 84.00$

Porto Rico.-Imported sccil. Per pkt., 20 cents; oz., $75 ; 1,11$. $\$ 2.50 ; 1 b ., \$ 8.00$.

salenichi.-Very large leaves. Per pkt., 25 cents $0 z ., 81.00 ; 1,1 \mathrm{~b} ., \$ 3.00 ; 1 \mathrm{~b} ., \$ 10.00$.

Virminia, Jaures River.- P'er 1kt., 15 cents; $u z .$, 40 ; $11 \mathrm{lb} ., \$ 1.25 ; 1 \mathrm{~b} ., \$ 4.00$.

\section{TOMATO.}

\section{[Solanum lycopersicum, Lin. Tomate, Fr. Liebasapfel, Ger. Tonates, SP.]}

\section{One ounce will produee about twelve hudred plants.}

CulTure.-For early use, sow in February or March, in boxes or pots, and place near a window or in a hot-bed. Wheu abont two iuches high prick thom out singly iu suall pots, and nurse carefully in fraues; and when tho danger of frost is past plaut them out in a sheltered situation, where they dnay liave tlie full influeuco of the suu. To hasten the uaturity of the first fint which sets, pincli off the extremities of the tops and all the secondary slioots which afterward appear above the flowers.

If by mail in quantities of $\$$ unces and upwards, postage must be adder at the rate of $16 c$. per pound.

Livingaton's Favorite.-This is sair to be the largest, perfect-shaped Touato in cultiratiou, snwother tlian the Paragon, dnes uot erack or rot like tho Acme, is a darker red than the Perfection; ripens ereuly aud as early as any good rariety, holding its size to the end of the season; very prolifie, good flaror, few secols, flesl solid; bears slipping loug tistances. Per packet, 25 ceuts : 5 packets for $\$ 1.00$

Acme.-Oue of thoearliest; produces an abundauce of liantsome, medinm-sized finut, of a datk led color, sliglitly tunged witl purple; bnt few secks, is free from core, and of delicious thivor. Per plit. 10 evuts; oz., $25 ; 1 / 1 \mathrm{~b} ., 75 ; 1 \mathrm{~b} . . \$ 2.50$.

Arlington.-Fruit large, perfsct in form, brishlit red, solid; productive, of tiue flavor, and excellent for canning. Per pkt., 5 ceuts; oz., 25 ; $/ 41 \mathrm{~b} ., 75$; lb.,$\leqslant 250$

Conad: Victor, $\rightarrow$ An early variety, originatiug in Cauada ; frut solid, and of rich flaror. per pkt. 5 cents; $02 ., 25 ; 1,11 ., 75 ; 11 ., 82.50$.

Conqueror. $\rightarrow$ of good size, uniforu in sluape, color leep red; thesh solir, of rich, mild flavor; it ripens well np to the stem, and is cxcmpt from cracking. Per pkt., 10 cents ; oz., 25 ; 1 i lb., 85; 1b.,\$3.00.

Early smooth IRed.-Very carly, smootli, round, of medium size, productive, of good quality. Per pkt., 5 cents; oz., 25 . 3 Ib., 75 ; 1b., $\$ 2.50$.

General Grant.-Rouud, slightly tlattened, rory symuctrical : color brilliant glossy crimsou, flesl solid, skiu smooth aud slining, coloring well up to the stem: rery productive, and of tine flaror: Per pkt., 5 cents; 0z.. 25; 3 Ib., 75 ; lb., $\$ 2.50$.

Golden Trophy.-A sport from the well-known Tropliy; of a beautiful light yellow, oceasionally faintly streaked with red; a desirable acquisitiou for preserving as well as for the table. Per pkt., 10 eents; oz., 30 ; 3 ib., $\$ 1.00 ; 1 \mathrm{~b} ., \$ 3.00$

freen (Fage Tomato.-Au Englisl variety, me dimm size, resentbling a bright yellow plum iu shape aud color, witli a distinct, piquaut, and highly agreeable flavor. Per pkt., 10 conts; oz. $30 ; \frac{1}{4} 1 \mathrm{~b} ., \$ 1.00 ; 11$., $\$ 3.00$

IIathavay's Excelsior. - A farorite variety, early of merium size, solid, of excellent quality, and very productive. Per pkt, 5 ceuts; oz., 25; $1 / 4 \mathrm{lb}$. $75 ; 16 ., \$ 2.50$

Large Smooth, or Round Red.-Smootli aud fair, color bright ral; an excellent market rariety, Per pkt., 5 cents; $0 z .425 ; 1 / 16 ., 75 ; 1 \mathrm{~b}$. $\$ 2.50$.
Large Vellow.-Abont tho size and shaje of the Smootl Red ; color bright yellow: Hesll firm and very solid. Per pkt., 5 cents; oz, 30 ; / $/ 4$ Ib., $\$ 1.00$; 11., 83.00 .

Lester's Perfected (Fejee Island),-Fruit of largo size, piukisll ded; of tine llavor. Perpkt., 5 cento; oz., $30,3_{4} 1 \mathrm{~b} ., \$ 1.00 ; 1 \mathrm{~b} ., \$ 3.00$.

Paragou. - A secoud early : fruit large; color bright crinson ; smooth, solit, of excellent flavor ; bears transportatiou well; very productive; au excellent market variety. Per pkt, 10 ceuts; 0z., 25; 2. $1 \mathrm{~b}, 75 ; 1 \mathrm{~b}, 52.50$

Iittle Geun.--Tho carliest variety kuowu : bight red color, uniform in size and sliape, and haudsome in appearanee. It uay be relich npon to yield several pickings a week or ten days earlier thau any other variets. Per pkt., 10 cents; oz., 40 ; $1 / \sqrt{s}$ ib., 81.25 .

Livingston's Perfectiou, - An early variety, of blood-red color: perfectly suooth, ripens uui. formly, and bears abundantly untıl frost; for can. uiug it surpasse's any sort lithel'to oftered. Per pkt. 10 cents; oz., $50 ; 1 / 1 \mathrm{~b} ., \$ 1.25 ; 1 \mathrm{~b} ., \$ 4.00$.

Mayflower.-This is the earliest largo Tomato we know of ; of splendid sliape, perfectly smooth, of a bright red color, and ripeus uniformly up to tho stem. The flesli is solid, free from seeds, and of a jure, rich flaror; in productiveness it is unexcelled. Per jukt., 15 cents; $0 z ., 75$.

New Erect Frenel, or Tree (Tomate de Laye).Distinct from all otlicrs, of upright growth, in the form of a buslı; fruit solid aud of fino quality. Per jokt., 10 cents; oz., $\$ 1.50$

Red Cherry - A small, rommi, red Tomato, of the sliapeaud size of a cherry; tine for pickling Per pkt. 5 cents; $07 . .30$; $\frac{1}{4} 11 ., 81.00 ; 16 ., \$ 3.00$.

Strawberry, or Ground Cherry (Physalis Eduiis).-A ristinct variety; the frut lias a juicy pulp, of a pleasant, strawberry-like flavor, witl a certain dregree of sweetuess and acidity iuter. mixerl; with the aldition of lemon jutice it is frequently preserved liko plimms. Per pkt., 10 ceuts; $07 ., 30 ;$ s lb., $\$ 1.00 ; \mathrm{Ib} ., \$ 3.00$

Trophy,- Fuit rery large, generally smooth. solid ; ripens early, aud is of fino quality ; our seed is all saved from selected specineus. Per pkt., 10 ceuts ; $07.50 ; 2,1 \mathrm{~b}, \$ 1.25 ; 1 \mathrm{~b} ., \leqslant 4.00$

Yellow Plnm,-Shilpo unlormly oral, and per. fectly smooth; color lemon yllow ; nsed for preserves. Per pkt., 5 ccuts; 0z., $30 ;$ z 1 1b., $\$ 1.00$; 1b., $\$ 3.00$. 
TURNIP.

[Brassica rapa, Lis. Navet, FR. Rube, GER. Nabo, SP.]

One ounce will sow one hundred and fifty feet of drill; two los. will sow an aere.

$\Gamma$ Cultule. - For early use, sow as soon as the ground can be worked in spring, in drills fifteen inches apart, and thin to eight inches apart as soon as plants are large enough to liandle. For succession, sow at intervals of a fortnight until the last week of July, from which time until the end of Augnst sowings may be made for main and late crops. The sowing shothl always be done just before rain, if possible, and the suceess of the crop in a great measure depends upon quiek germination, and a rapid and free growth at first. If by mail in quantities of 4 ounces and upwards, postage must be added at the rate of $16 e$. per pound.

WHITE FIJSEI VARIETIES.

Early Flat Dutch, or Spring Turuip.-Size medium; white, of quick growtl. For Spring or Fall. Per pkt., 5 ccnts; oz., 10 ; 1/4 1b., 25 ; 1b., 75.

Early White Ega.-A desirable variety, perfectly smooth and nearly egg-shaped; of rapid growth and of fine quality. Per pkt., 5 cents; oz, $10 ; x_{4}$ $1 \mathrm{b.,} 25 ; 1 \mathrm{~b}, \mathbf{7 5}$.

Extra Early Purple-top Mnnich.-A very dis. tinct and remarkably handsome early Tumip, with a bright purplish-red top and fine mouse-tail root. It lias proved to be quite three weeks earlier than any other variety sown on the same day side by side with it. Per pkt., 10 cents; 0z., $15 ; 1 / 1 b$. $30 ; 1 \mathrm{~b} ., \$ 1.00$.

Large White Norfolk,-Large size; skin white below the surface, but sometimes grcenisl above. Per pkt., 5 cents; oz., 10; 1 1b., 20; 1b., 60.

cong White, or Cow Horn.-Flesll white, fine graincd; and sweet; keeps well, and is one of the best of all for culinary purposes. Per pkt., 5 ceuts; oz., 10; 1 1b., $25 ; 1$ b., 75.

Purple Top White Globe.-Of globular shape, very landsome, aud of superior quality, either for the table or stock : an excellent keeper, and a fino market variety. Per pkt., 5 cents; oz., $10 ; \frac{1}{4} \mathrm{lb}$. $30 ; 1 \mathrm{~b} ., \$ 1.00$.

Red Fop Strap-leaved.-This variety has the form and character of the White-topped, except in color, which is red or purple above ground. Per pkt., 5 cents; oz., 10; 1/1b., 25 ; 1b., 75.

White Globe.-Root globnlar, skin smootl, perfectly white, flesh white. It grows to a largosize. Per pkt., 5 cents; oz., 10 ; $1 / 4$ 1b., 20 ; 1b. 60 .

White Top Strap-leaved.-Form roundish or flat, medinm size, small top; one of the best. Per pkt., 5 cents: oz., 10 ; 1 ib., $25 ; 1 \mathrm{~b},, 75$.
YEIILOW FIESII VARIETIES.

Early Yellow Finland.-A beautifnl medium-size variety ; flesh is tender, close-grained ; of a sweet, sugary flavor; an cxcellent garden variety. Per pkt., 5 cents; oz., 20 ; $1 / 4$ lb., $50 ; 1 b ., \$ 1.50$.

Large Yellow Globe.-Handsome, globular shape; color pale yellow with greenish top. One of the best for a general crop, either for talle use or stock; keeps hard and brittle until late in Spring. Per pkt., 5 cents; oz., 10; $1 / 4$ lb., 25; $1 \mathrm{~b} ., 75$.

Petrowski.-Flesl dark yellow, similar in form to Egyptian Beet. Per pkt., 10 cents ; 0z., 15 ; 1 lb., $30 ; 1$ b., 1.00 .

Robertson's Golden Ball. - The most delicate and sweetest yellow-fleshed Turnip we know of; not large, but firm, liard, and of excellent flavor; keeps well, and as a table variety has no superior. Per pkt., 5 cents ; oz., 10 ; $1 / 1 \mathrm{lb}, 25 ; 1 \mathrm{~b} ., 75$.

Seveu Top. - A variety largely grown in the Soutll. ern States, whero tho tops are nsed for greens. Per pkt., 5 ccnts; 0z., 10; 1 1b., 25 ; 1b., 75 .

Teltow, or small Berlin.-The smallest variety growa; very early ; tine grained and sugary. Per pkt., 5 cents ; oz., 10 ; $1 / 1 \mathrm{lb} ., 30 ; 1 \mathrm{~b} ., \$ 1.00$.

Yellow Aberdeen Purple Top.-Bulb globular, reddisli purple above, and deep yellow below, taproot small, flesh pale yellow, tenter, sugary, and solid. Perplet 5 cents ; oz, $10 ; 1,1 b, 25 ; 1 b ., 75$.

Yellow llalta. - A beautiful, symmetrical, small, early variety; skin smooth, bright oran ge yellow. Per pkt., 5 cents; oz., 10 ; $1 / 1$ b., 30 ; 1b., $\$ 1.00$.

Yellow Stone.-Similar in appearance to the Golden Ball; splendid for table, and highly recommended for feeding stock; exeellent for late sow. ing, and in its keeping qualities unsurpassed. Per pkt., 5 cents ; oz., $10 ; 1 / 1$ b., $25 ; 1$ b., 75.

\section{SWEDISH or RUSSIAN TURNIP (Ruta-Baga).}

[Brassica campestris, nabo-brassica, LrN. Chou Rutabaga, Fr. Kohlrab in der Erdegelber, GER. Nabo Rutabaga, SP.]

One onmee will sow one hundred and fifty feet of drill; two lbs. will sow an acre.

CuLTure.-Should be sown from the twentieth of June to tho middle of July, in drills two feet apart, and thinneil ont at the first working to ten inches between each plant. The flesh is closo grained, very hard, and will endure a considerable degree of cold without injury. The roots are best preserved in a pit or cellar during Winter, and are excellent for the table early in Spring.

If by mail in quantities of 4 ounees and upwards, postage must be added at the rate of 16e. per pound.

Carter's Imperial Hardy swede.-An English variety, ligly recommended as producing extraordinary crops. Per pkt., 5 cents ; oz., 10 ; $1 / 1 \mathrm{lb}$. $20 ; 1 \mathrm{~b} ., 70$.

Improved Amerieam.-This variety is largely grown, both for table and for stock; fiesh solid; of fine quality; keeps well until summer. Per pkt., 5 cents; oz., $10 ; 1 / 1 b ., 20 ; 1 b ., 70$.

Laing's Improved.-A handsome variety, of excellent quality; purpla above and yellow under gronnd; almost perfect globo-shaped when well grown. Per pkt., 5 cents; oz., $10 ; 1 / 1 b ., 20 ; 1 b ., 70$.

Loug White Fremeh.-Flesh white, solid, mild, and sweet; oxcellent for the table, also for stock. Per pkt., 5 cents; oz, 10 ; $1 / 4$ lb., 25; 1b., 75 .
Skirving's Purple Top (Imported seed).-A n improved pnrple-top variety, of stroug growth; large size; best suited to field culture and cattle feeding. Per pkt., 5 cents; $0 \%, 10 ; 1 / 11$ b., $20 ; 1$ b., 70.

Sutton's Imploved Champion Swede. -A favorite English variety. It is the liardiest, the lieaviest cropping, and the most nutritions variety grown. Per pkt., 5 cents; oz., 10 ; 141 b., 25 ; 1b., 75.

Sweet German. -Bnlb four or five inches in diam. eter and six or seven iu depth; ueck two or thrce inches long; skin greenish brown above ground, white beneath ; flesh pure white, of extraordinary solidity, very sweet, mild, well-flavored; retains its solidity and frcshness until spring. Per pkt., 5 cents; oz., 10 ; 1/ 1b., 25 ; 1b., 75. 


\section{POT, SWEET AND MEDICINAL HERBS.}

Herbs in general lore a mellow and free soil, and some pains shonld be taken in properly harvesting them in a dry state. The chief points are, fir'st, to cut them when not gnite iu full blosson, and on a dry day to dry them guickly in the slrale in a secure place, aud wheu dry to pack them close in dry boxes or ressels, and keep them entirely excluded from the air. Sow the seeds early in Spring in shallow drills, and when they are up thin them ont to a few inches apart.

If by mail in quantities of 4 ounees and upwards, postage must be added at the rate of 16e. per pound.

Angelica Garden (Archangelica officinalis). 1'er pkt., 10 cents; oz., 20.

Anise (Pimpinella anisum). Per pkt., 5 ecents;oz., $10 ;$ Ib., $\$ 1.00$.

Arnica (Arnica montana). Per pkt., 10 cents ; oz. $\$ 2.00$.

Balm (Melissa officinalis). Per j)kt., 10 cents; oz., 40.

Basil, Sweet (Ocymum basilicum). Per pkt., 10 cents; oz., $30 ; 11$., $\$ 3.00$.

Bene (Scsamum orientale). Per pkt., 5 cents oz., 20.

Bornge (Borago oncinalis). Per pkt., 5 eents; oz., 20.

Belladonn (Atropa bclladona). Pcr plit., 10 eents oz., 75 .

Bryonin (Bryonia dioica). Per pkt., 10 eents $0 z ., 81.00$.

Carnway (Carum earvi). Per plkt., 5 cents; oz. $15 ; 16 ., \$ 1.00$.

Castor Oil Plant (Ricinus communis). Per pkt., 10 eenty; oz., 20.

Corinuder (Coriandrum sativum). Per pkt., 5 cents; oz., 20.

Dill (Anethum gravcolens). Per pkt., 5 cents; oz., 15.

Fennel, Swcet (Anethum fonieulum). Per pkt. 5 cents; oz., $15 ;$ Ib., 81.00 .

Fenngreck (Trigonella foenum groeum). Per pkt., 5 cents; oz.. 15.

Hemlock (Conium maeulatum). Per pkt., 10 cents; oz., 50.
IIenbane (Iryoseiamus niger). Per pkt., 10 cents. Horehound (Marrubium vulgare). Per pkt., 10 cents; oz., 40.

Hyssop (1ryssopus offeinalis). Per pkt., 10 cents; oz., 40.

Lavender (Lavendula vera). Per pkt., 10 cents ; oz., 25.

Marjorum, Sweet (Origanum marjoram). Per pkt., 10 cents; $0 z ., 25 ; 1 b ., \$ 2.50$.

Opiun Poply (Papaver somnifcrum). Perpkt, 10 cents; oz., 30 : 1b., $\$ 2.00$.

Pot Marigold (Calendula oficinalis). Per pkt., 10 cents; oz. 40.

Rosemary (Rosemarinus offieinalis). Per pkt., 10 cents; oz., 50.

Rue (Ruta Grazeolens). Per pkt., 10 cents; oz., 25.

snflion (Carthamus tinctorius). Perpkt., 5 cents; oz., 15; 1b., s1.50.

Sage (Salvia oflleinalis). Per 1)kt., 5 cents; oz., $20 ; 16 ., 2.00$

Sage, Red (Salvia sclarea). Per pkt., 10 eents. Strnnoninu (Datura stramonium). Per pkt., 10 cents; oz., 30.

Sumner Savory (Satureja hortensis). Per pkt., 10 cents; oz., 20 ; $1 \mathrm{~b}$., 82.50 .

Tansy (Tanacctum vulgaris). Per pkt., 10 cents. Thyme (Thymaus vulgaris). Per pkt., 10 cents; az., $40 ; 1 \mathrm{~b}, 4.00$

Woodroof (Asperula odorata). Chief ingredient of the Maitrauk. Per pkt., 10 cents.

Wormwood (Artemisia absinthium). Per pkt., 10 cents; oz., 30 .

\section{KITCHEN GARDEN ROOTS, PLANTS, etc.}

Asparngus, Conover's Colossal.-Oue-sear-old roots. Per limired, 75c.; thousaud, $\$ 6.00$.

Asparngus, Conover's Colossal.-Two-year-old roots. Per limndred, $\$ 1.25$; thousand, $\$ 10.00$.

One-sear-old roots by mail, 25 cents per linnolred extra; two-year.old roots are too bulks for mailing.

Horse-Rndish Siets.-Per dozen, 20 cents; hundreal, 75 ; thousand, 86.00 .

Rhnbarb, Myatt's Victoria.-Each, 25 cts.; per doz., $\$ 2.00$; hund., $\$ 10.00$. By mail, 40 cts. each.

Rhnbarb, Iinnaus,-Each, 25 ceuts; per dozen, $\$ 2.00$; hundred, $\$ 10.00$. By mail, 40 cents each will be ready in May. Special list sent on application.

\section{EARLY GOLDEN SWEET POTATO.}

This variety originated in Virginia a few years since, by an oll cultivator of tle Sweet Potato. It is a sport of the old Early Ked, but said to be far superior to that variety in earliness, productiveness, color, and quality. Slips planted May 10 th produeed tubers large enough for the market July 25 th. On acconnt of its early maturity, it is believed to be better alaptel for cultivation in the Northern States than any otber variety. In shape they are somewhat sliorter than the uriluary varieties, of a golden yellow color, cook very dry, and are of superior Havor. Another valuableconsideration in favor of this variety is, that they will grow on quite ordinary soil with but a slight coat of manure, and yielded a large crop the past season upon lind that would not grow above fifteen busliels of corn to the acre. In good soil tbey will produee nany specimens weighing three tu five pounls each. 1t is also an excellent keeper.

We first offered this rariety in spring of 1880 , and liave received tnany favorable notices from those who liare test ed it. It maturel its crop as far north as Canada. Sperimens have been exhibited weigling 6 pounds. Slips realy abont May $15 \mathrm{tl}$; tubers, early in A pril.

Price of slips, with directions for planting, by mail, post-paid, 50 ceuts per dozen; $\$ 1.00$ for fifty; $\$ 1.75$ per limndred. By express, at purcliaser's expeuse, $\$ 1.00$ per luundred, $\$ 7.50$ per thousand.

Price of Tubers, 60 cents per pound; 3 lbs., $\$ 1.25$ by mail. By express, at purcliascr's expense, 5 los, $\$ 1.00 ; 20$ Ius., $\$ 2.50 ; 50$ Ius., \$5.00.

14 addition to the above, we offer the Nansemond and Southern Queen varicties.

Prices of swet Potato Plants delivercd in Mny or Jnne.

Nansemond. -25 cents per duzen; 75 cents per lundred, by uail: 50 ccuts per lunudred; \$4.00 jer thousand, packed, by express.

Southern Quecn. -25 cents per dozen; 75 ceuts per liundred, by mail : 50 ceuts per hundred; \$5.00 per tbousand, by express. 


\section{COLLECTIONS OF KITCHEN GARDEN SEEDS.}

\section{A COMPLETE ASSORTIENT OF VEGETABLE SEEDS FOR ONE YEAR'S SUPPLY, FOR A LARGE OR SHALT GARDEN.}

The following collections are made up in the most liberal manner, care being taken to give a sufficient quantity of all the finest varieties and most useful sorts of Vegetables required in the Kitchen Garden for successive crops, and are prepared for immediate shipment during the busy season; consequently no change can bo made in the quantities or varieties. For the different varieties, Peas, Beans, Beets, \&c., contained in each collection, see our Guide to the Flower and Kitchen Garden. Those who do not wish for the entire collection, are advised to make up their orders from the body of the Catalosue.

Collections Nos. 1, 2, 3, 4 will be sent by express at the expense of the purchaser; Nos. 5, 6 and 7 are prepared expressly for forwarding by mail, and will be mailed, post-paid to any address in the United States. upon receipt of the price affixed.

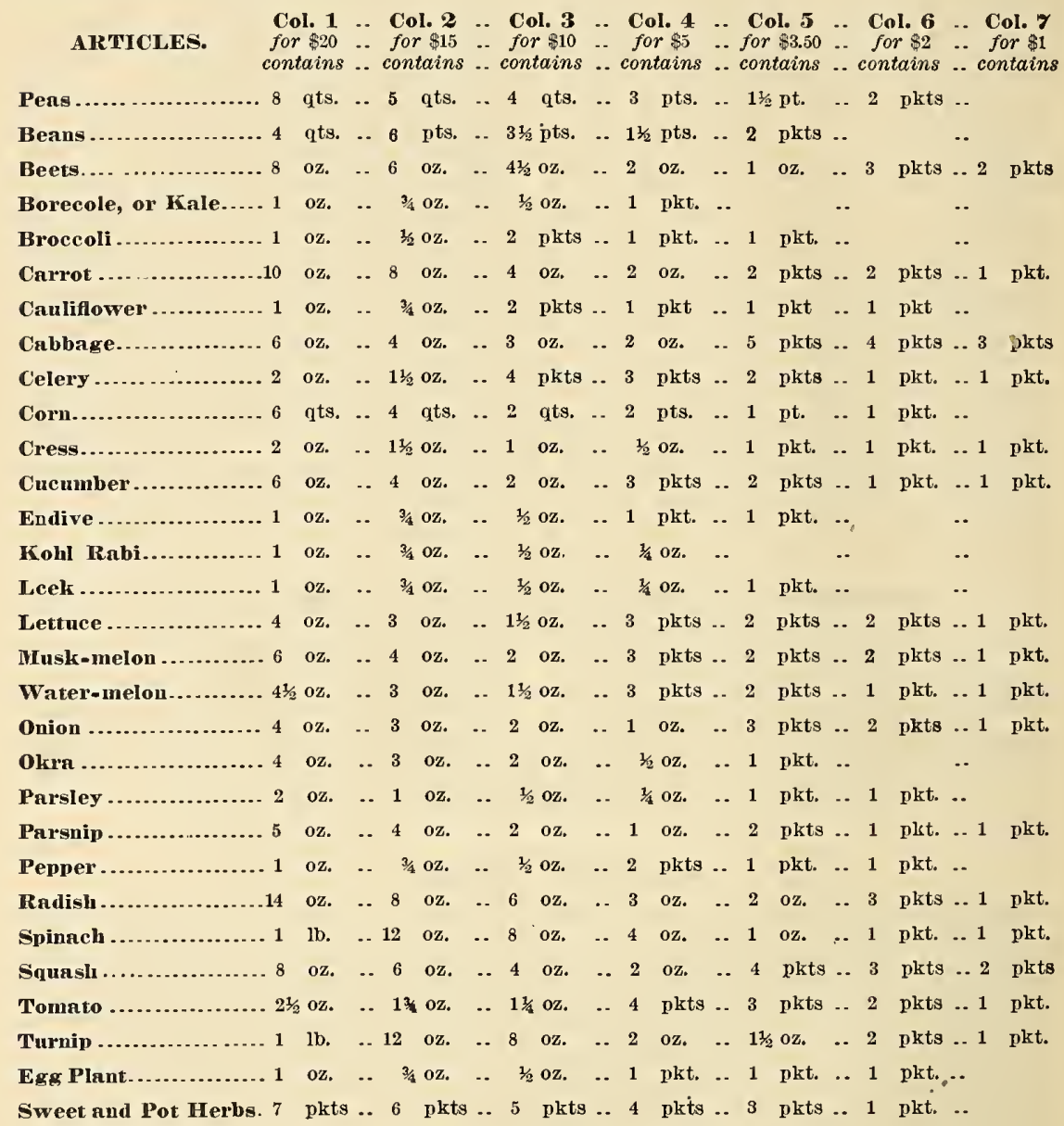

\section{SEEDS FOR HEDGES.}

If by mail in quantities of 4 ounces and upwards, postage must be added at the rate of $16 \mathrm{c}$. per pound.

Acacia, Three Thorned, or Honey Locust ( $Q$ te. ditschia triacanthos). - Very hardy and effectual for protection against man or beast; admirably adapted for the prairies. Per $1 b ., 60$ cents.

Buckthorn (Rhamnus Catharticus).-Clean seed. Per oz., 15 cents; $1 \mathrm{~b}, \$ 1.50$.

Yellow Locust (Robinia pseudo acacia),-Per oz., 10 cents ; lb., 60 .
Osage Orange (ILaclura Aurantiaca). 33 lbs. to the bush. Per oz., 10 cents; lb., 75; bush., $\$ 9.00$.

Barberry (Berberis vulgaris).-Very hardy, producing a fine compact hedge, affording ample security against intrusion; also valuable for its fruit, which is excellent for preserving. Per oz., 20 cents; lb., $\$ 2.00$. 


\title{
MISCELLANEOUS SEEDS, Etc.
}

\author{
By mait, 25c. per quart, 16c. per pound additional for postage.
}

Broom Com, Improved Evergreell,-This sect was carefully saved from brush, none of which wils less than 20 inches in lengtl, and stalks nut wพ* $\mathrm{r} 4$ feet in lieiglit. Pel (1t., 25 cents; busl., 84.00 .

Bronu Coru, Dwarf. - Frows from 3 to 5 feet lierli. Pel' q t., 25 cents; per bush., s4.00.

3 room Corn, California.-Per qt., 30 cents.

Cot ton, sira Is land. - l'er 1 b., 25 cents.

Cotton, Upland.-Per 11 ., 25 cents.

Flax fied.-Clean. Per it., 25 cents; buslı, 84.00 .

Jute seed. - Per oz., 25 cents; $1 \mathrm{~b} ., \$ 3.00$.

Lupins.-per qutat, 50 cents.

Madder.-The poots of this plant, when flriol and grouud, furuish a reel coloring matter, murlı used by dyers. Per lb., $\$ 1.00$.
IR:umic, or China (Arass (I'rtica Nivea).-A new fibous plant, much used by the Chinese for the manufacture of a tine silk summer clotl. Will grow wherveotton wall be raised. Per oz., $\$ 2.00$.

- iainfoin,-Donlulo cutting. Per $1 b, 40$ cents.

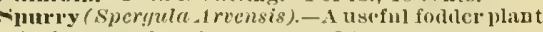
fur light sauly soils. P'er lb, 25 conts.

sinnflower. l'el qt, 30 cents; bush., $\$ 5.00$.

Tarragon.-The arontatic properties of this plant are ereatly estermed for cin!mary lurposes. Seeds, per j)kt., 25 cents; roots, $110 \%, \$ 3.00$.

Teasels. - For fullers' nse. P(r lin, $40^{\circ}$ ceuts.

Vetehes, spring.-Much llserl as a forge plant; alsu al sillestitute for peas. Per qt., 25 ceuts: busli., st.00.

\section{KENNEY'S EARLY AMBER SUGAR CANE.}

In this variety wo have a plant that is lestined to prove of iumense value to tho northern portion of our country. It has becul tested in Minursota for several years past. A large grower gives the following statement to the Statc C'ommissioner

Planter on the 27th of MIaF, on new laud, it was ripe before frost. Its saccharinc qualities are of the first orler, and its earliness bichly recommenuls it to the whole country. It is not easily blown flown, and nsmally grows eleven and twelve feet higl with w. When planted between tho 1 st and 10 th of May, the seed alnost in raviably rijens, thus giring the al rantage of a doublecrop in one year from oue planting. If shillfully handled it will yield some 20 or 25 bushels of seed ant 150 or more gallons of fino sy.up per acre. All kinds of falm stock are foml of the secd; when gromul and nixol with bran it makcs a good heary feed for lorses. We liave seen sugar prodneed frum this variety "untul to tho best coffeo sugars in the market.

By mail, 40c. per lb. When sent by express at purchaser's expense, 15̄c. per lb. ; per 100 lbs., s10.00.

\section{EUCALYPTUS GLOBULUS, or Australian Fever Gum Tree.}

This is now being extensiv'ly plantel in our sonthern sitates and in faliformia, where it luas become famous for draining damp soils and destroying malaria. It is beliered by unan that when this treo lias been extensively planter in the swampy and malarious disticts in the sonthern states, thcy will ho

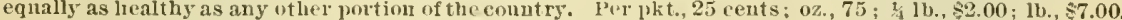
We can offer several other varieties of Fucalyptns, from Anstralia, at 25 cents per packet.

\section{DIOSCOREA BATATAS-NEW CHINESE YAM.}

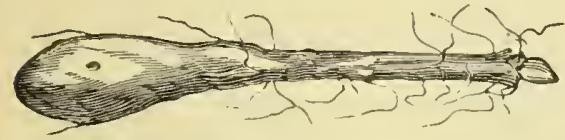

Root one year old-1-6 ordinary size.
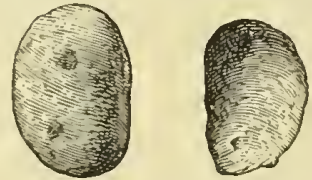

Bulblets-average size.

One of the most valnable esculents in cultivation, thongh but littlo known. Stem twelve to twcoty feot in length, of rapil growth, of creeping or climbing liabit, forming an excellent covering for a screen; flowers small, white, in clusters; leaves heart-shaper. The root is of a pale russet color, oblong. regrlarly rounded, elub-shaped, largest at the lower end. Plant in a deep, light soil, tolerably rich and thoroughly stirred two feet deep. A well mpown loot will measure 2 feet in lengtl aul $2 \frac{1}{2}$ inches in its broadest diameter, and are quite hardy, remaining in the ground over Winter without protection. The flesh is remarkably white, and very mucilaginous in its crule state. They may be boiled or roasted, and wlien eooked possess a rice-like taste; are quite farinaceous, nut ritive and valuable for food. It is also a very tesirable climb ing plant, suitable for covering sereens, arbors and unsightly places. A few tubers planted near a door or window, and the vines trained over and about it, make an urmament worthy the admiration of all. The flowers are numerous, and have a cinuamon fragrance; but the vines do not blosson until the roots are two years old. There is scarcely any difference, percentible to the tastr, betwcen a Chinese Yam, when properly cooked, and tho potito, tlough tho yam is nucli whiter and finer grainct. One-year-old roots, $\$ 1.25$ per dozen; $\$ 6.00$ per humdred. Bnlblets, 20 eents per dozen $\$ 1.50$ per hundred.

\section{REANA LUXURIANS (Teosinte).}

Much has been spoken lately in tho agricultural ani horticnltural papers of this gigantle graminæa, both as an ornamental as well as a forago plant. It is a native of Central Ameriea; perennial in hot climates, it will not stanil our winters; resembles Indian corn in aspect and regetatjon, but proluces a great number of shoots, growing threo to fout yarls high, thickly covered with leaves, aul yielding suel an abundance of forage that one plant is estimated to bo sufficient to feed a pair uf cattle for twenty-four hours. In our northern countries, it is doubtful whether it will bo aveilable for forage, but it will certainly find its place in largo gardens as a dccorative plant, for sowing in Spring in pots and plantet iu May, in the open ground, it will produce a mass of shoots, forming a large bunch of more than a yard in diameter by three yards in height. Per packet, 15 cents; 0z., 25; 11)., \$3.00. 


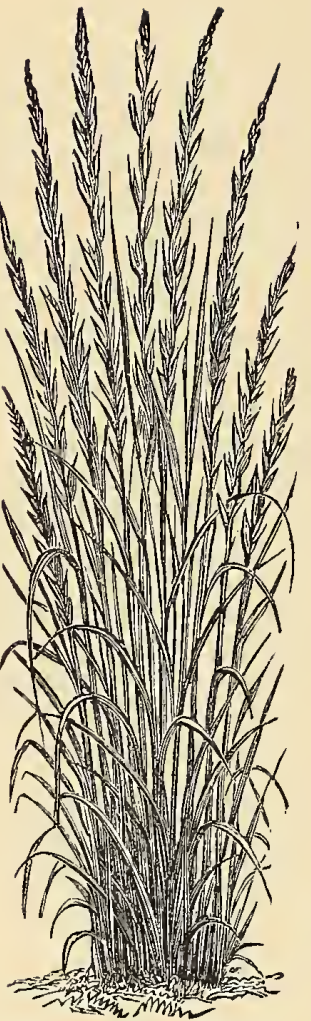

Perennial Rye Grass.

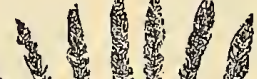

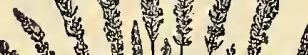

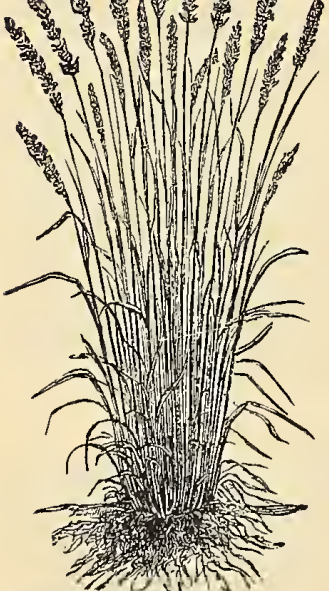

Crested Dog's Tail Grass.
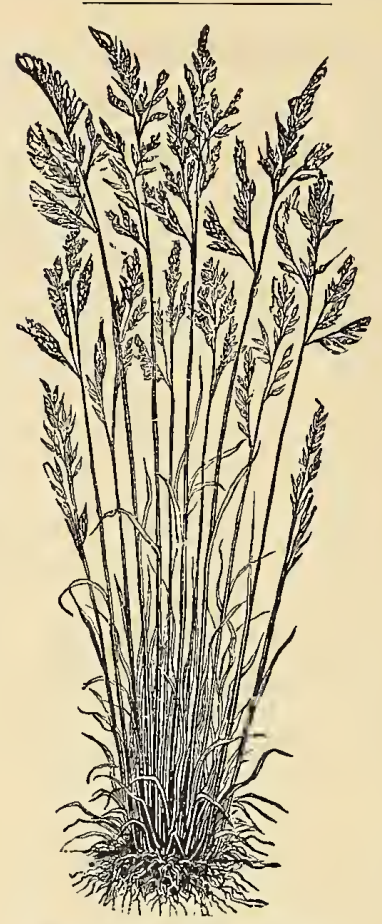

Meadow Fescue Grass.
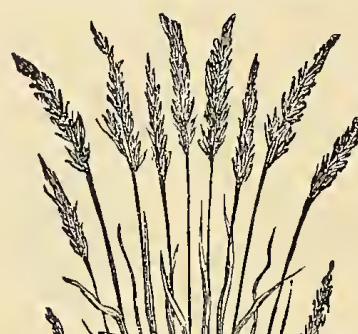

H N

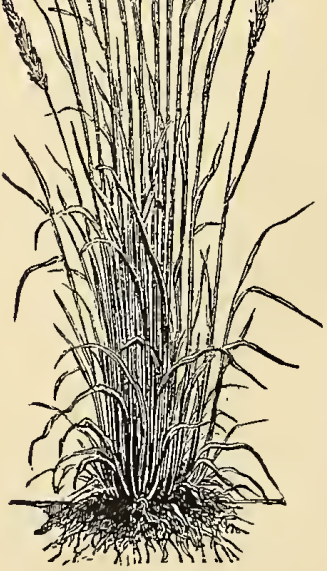

Sweet Vernal Grass.

GRASSES.
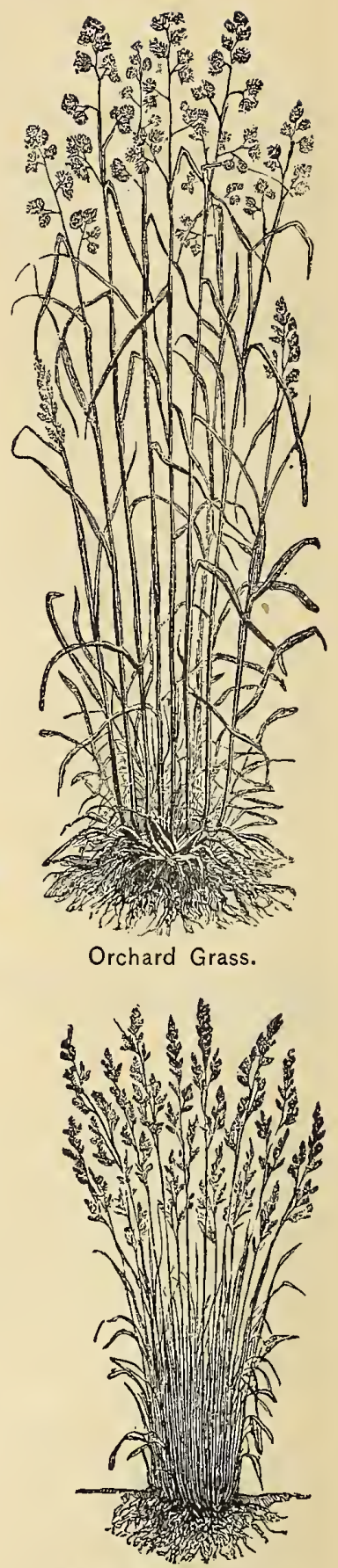

Sheep's Fescue Grass. 


\section{GRASS SEEDS.}

Subjeet to slight varintions in price to eorrespond with the mnrket.

If by mail in quantities of 4 ounces and upwards, postage must be addcd at the rate of $16 c$. per pound.

Red Top Grass (Agrostis Vulgaris).-Valuable for pasturage; is well known and cxtensively culti. vated; 14 lbs. to tho bush.; 2 to 3 bush. Will sow 1 acre. Per lb., 15 cents; bisls., $\$ 1.50$.

Creeping Bent Grass (Agrostis Stolonifera), $-\mathrm{A}$ valuable variety for lawns or croquet grounds, or for permanent pasture; 15 lbs. to the bush., 2 to 3 bush. to the acre, Per lb., 30 cts.; bush., \$3.50.

Mendow Foxtail (Alopccurus Pratcnsis), -This is one of the best and ealliest of pasture grasses; it thrjes best on meadow lands; 7 lbs. to the bush., $251 \mathrm{los}$, to the acre. Per lb., 50 rents.

Sweet Scented Vernal Grass (Anthoxanthum Odoratum).-Peimanent pasture slould not be without this variety, as it is of good quality and very early; also very fragrant; 10 lbs. to the buslı., 30 los. to the acre. Per 1 b., 40 cents.

Thode Island Bent (Agrostis Canina).-Ar excel. lent variety for lamus and pasturage; $11 \mathrm{lbs}$, to the bush., 2 to 3 bush, to the acre. Perbush. $\$ 3.50$.

Schracder's Brome Grass (Bromus Schracderi).A forago plant from Australia, particularly recommended for resistiug the drouth better than any other variety, aud will thrivo on any soil, ex. eept where there is superabundance of moisture; yields two good crops in a season; 16 lbs. the bush., 35 lbs. to tho acre. Per 1b., 50 cents.

Crested Dogstnil (Cynosurus Cristatus).-This grass, forming a closo turt, and having rather fine foliage, mas be adrantageously sown on lawns and other places to bo kept under ly the scythe; jt is also useful for very dry or gravelly soils; 28 los. to the bush., 25 lus. to the acre. Per lb., 50 cents.

Orehard Grass (Syn. Round Cocksfoot.) (Dactylis Glomerata).-A valuable grass on acconut of the quantity of nutritious feed which it yjelds, and tho rapidity with which it grows after being ent or grazed; if allowed to stand for hay it has rather a coarse appearance, but if grazed it alwars lias a fresh green line; 14 lus. to the bush., 3 bush, to tho acre. Per $1 b ., 25$ cents; bush., $\$ 2.75$.

Hard Fescue Grass (Festuca Duriuscula).-Will thrive in a great variety of soils, and resist tho effect of drontl in a remarkable degreo; from tho fineness of its foliage it is well adapted for lawns or a sheep pasture, and its liabit of reproduction after sowing is very great; 12 lbs, to the bush., 30 los. to the acre. Per lb., 30 cents.

Mendow Fescue (Festuca Pratensis).-This thrives in all soils, excellent for a permanent pasture, is well liked by all linkls of stock; 15 lbs. to the bush., 40 lbs. to the acre. Per lb., 40 cents.

Tall Fescue (Festuca Elatior). - A robnst variety; succeels admirably in moist soils or where tho mearlows are subject to floods; $15 \mathrm{ll} \mathrm{s}$. to the bush. 40 lbs. to tho acre. Per 1 b., 40 cents.

Sheep's Fescue (Festuca ovina).-This grass forms a greater part of the sheep pastures of the Finglish Sonthdowns; it should always enter into the conposition of pastnres in which sheep aro to be pastured, as they are very fond of it, and mutton from snch pasture is of the finest flavor: $12 \mathrm{lbs}$. to the bush., 25 lbs. to the acre. Per 1b., 25 ccnts.
Red Fescue (Fcstuca Rubra),-Especially suitable for dly, lonse soils; 12 lhs. to the bush., 25 lbs. to the acre. Per lb., 40 cents.

Dnrucl-spiked Fescue (Festuca Loliacea).-One of the most valuablo grassis iu cultivation, either for peruacent pasturo or lawn; it springs early, is rery productive, very nutritious, and improves by age; it thrives on all good soils, aud ucreasis in bulk if pastured for many years; 12 lbs. to tho bush., 40 llos. to the acre. Per 1b., 60c.

Tougl sitalked Mendow Grass (Poa Trivialis).P'roduces a constant supply of lifglily nutritious herbage, particularly on daup soils; oue of the most valuabl for laying down pastures and meadows on soils either mojst or motierately dry 14 lbs. to the busli., 25 lbs. to tho acre. Per 1b., $35 \mathrm{c}$. Wood Ifendow Grass ( $P 0 a$ Nemoralis).- There is no grass better adlapted for pleasur's gronuds, par. ticularly umler trees, as it will not only grow in such places, bnt forms a finc sward where few other grisses can exist; $141 \mathrm{bs}$. to the bush., $25 \mathrm{lbs}$. to the acre. Per lb., 40 cents.

Kentucky Blue Grass, or Smooth Meadow Grnss (Poa Iratcnsis).-This grass yielts, at a very enrly perjod of the season, herbage of the most nutritions properties; tlurives in morlerately dry soils; exteusively grown in many parts of the country: 1411 s. to the busll., $1 \frac{1}{2}$ bush. to the acre. Рer lh. 20 cents: buslı. $\$ 2.00$

Timothy, or IIerd's Grass (Phlcum Pratense).Very prodnctive, and thrives on almost any soil; for laying down strong, tenacious and moist soils it should form a considerable portion of the mix. turo required for huslondry or permanent pas. ture; it is also very profitable wheu grown alone; 45 los. to the bush., $1 / 2$ busb. to the acre; price ac. corting to matket.

Reed Canary Grass (Phalaris Arundinacea).Guows well by streams or marshes; $251 \mathrm{bs}$. to the acre. Per lb. 75 cents.

Hendow foft Grass (Holcus Lanatus).-Grows from $1 \frac{1}{2}$ to 2 feet high; thrives iu almost any soil; nseful for orcliarls or pastures overhung with trees; 3 busli. to the aero, 7 lbs, to the bush. Per lb., 40 cents; bush., $\$ 2.50$.

English Rye Grass (Lolium Pcrenne).-Very nutritious, and valuable for peruanent pastures; 24 lbs. to bush., 3 busl. to acre. Per bush., $\$ 2.50$.

Italian Rye Grass (LoliumItalicum).-For alternate husbaulry this is invaluable, especially for early shecp feed and soiling; 18 lbs, to the bush., 3 busli. to the acre. Per busli., \$2.75.

The two varieties of Rye Grass are very largely used in Europe, and enter largely into the composition of the many mixtures recommeuded for varj. ous anils.

Yellow Ont Grass (Avena F'lavescens).-Should be sown with other varieties, such as Crested Dogs. tail or Sweet Vermal; valuable for dry mearlow aud pastures; 8 los. to the bush., 35 lbs. to the acre. Per $1 \mathrm{~b}, 75$ cents.

NOTE. - When large shipments of the above are re quired, special quotations will be furnished.

\section{CLOVERS.}

By mail 16 cents per pound additionat.

Red Clover (Trifolium Pratense).-Large or Pea vine. Markel price.

Red Clover.-Mfedium. Ifarket price.

White Clover (Trifolium Repens).-Per Ib., 40c. Lueerne Clover (Afedicago Sativa).-Per lb., $45 \mathrm{c}$. Alfnlfa or Chilinn Clover.-Per lb., 35 cents.

Alsike or Hybrid Clover.-Per lb., 35 cents.
Italian Clover (Trifolium Incarnatum).-Scarlet. sow in July for solling or mowiug before Winter. $201 \mathrm{lbs}$, to the acre. Per lb., 40 cents.

Boklinra Clover (Meliletus Leucantha),-Affords excelleut feed for bees. Per 1b., 60 cents.

Trefoil Yellow (Medicago Lupulina)-Hop clover. 15 lus. to the acre. Per lb., 40 cents. 


\section{GRASS SEEDS.}

\section{FOR LAWNS, CROQUET GROUNDS, ETC.}

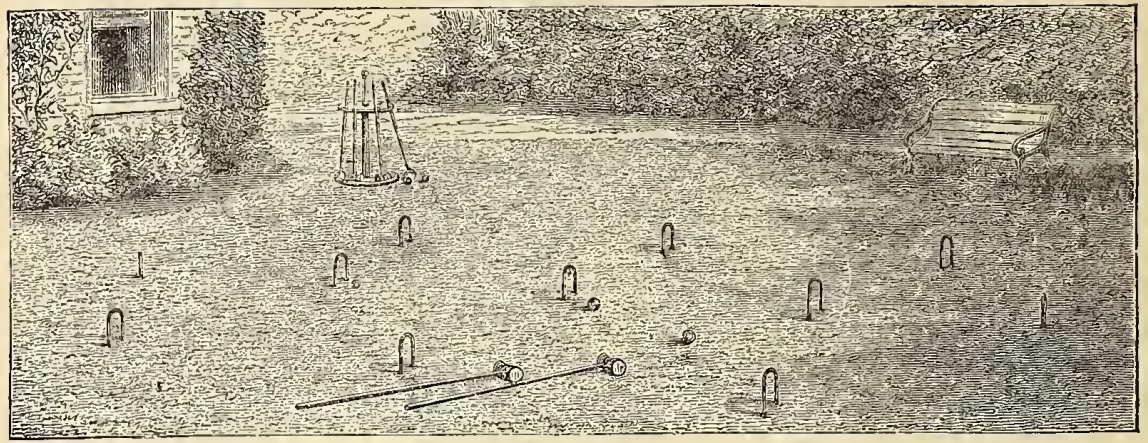

THE PREPARATION OF LAWNS AND THEIR IMANAGEMENT.

In the formation of lawns the ground should be thoroughly cleansed of root weeds before sowing. It shonld be dug or trencher to an equal depth to prevent unequal settlements; and to secure this, it shonld be repeatedly trodden, rolled and leveled, until at last a firm and uniform surface is obtained. The selection of proper grass seeds is the next important matter, and this requires more than ordinary attention, that the kinds of grass be suited both to the purpose and soil, and that the mixture of these graszes be proportioned to suit the end in view. Our mixtures are prepared to suit all soils and situations, and whether used in pasture or lawns have invariably borno the best results. It is of great importance that we should be acquainted with the nature of the land, which enables us to furnish mixtures composed of grasses best adapted for the purpose. It must be remembered, however, that much of the fine appearance of our Lawns depends upon regularity in mowing; if they are left too long in Spring before the operation is commenced, or if allowed to grow strong in Summer; and, more especially, if not closely mown at the latest period in Autumn, they become coarse, the stronger grasses overgrowing the weaker and the best, the smoothness of the surface is destroyed, and ultimately the whole becomes patchy and unsightly. For this purpose we cannot recommend too strongly the Excelsior Lawu Iower. The improvement in many of the lawns in this country where this mower has been used, since its introduction a few years since, is truly wonderful, and no one who wishes for a fine smooth lawn can afford to dispense with it. All lawns should also be regularly rolled, and, unless the subsoil be a porous alluvial gravel, should be thoroughly drained at their formation, and a drain should be carried along at the bottom of each terrace slope, so that they may at all times be comfortable to walk upon. The seed may be sown in Spring or Fall; but if sown in hot weather, a slight sowing of oats among the grass, which vegetates quickly, will serve to protect the springing grass. For forming new lawns three bushels are required per acre, or about four quarts to six rods of land, which should be regularly and evenly distributed,-the Philadelphia Seed-Sower, noticed on another page, will be found a most useful implement for this purpose, -15 pounds to the bushel.

If by mail, postage must be added at the rate of $8 c$. per quart.

Lawn Grass. - Central Park mixt ure; composed | the above; recommended for large areas. Per qt., of dwarf, and close growing grasses, which, properly managed, produce a fine velvety lawn and permanent sod. Per qt., 25 cents; bush., \$5.00.

Lawn Grass, French.-For Croquet grounds and small plots. Per qt., 20 cents ; bush., $\$ 4.00$.

Lawn Grass.-Fine mixture; a second quality of 15 cents; bush., $\$ 3.50$.

Lawn Grass.- Mixture of best grasses especially adapted for shady situations, such as orchards, shrubberies, \&c. Per qt., 25 cents; bush., \$5.00.

Flint's IMixture.-For permanent grass land; adapted for various kinds of soils. Per bush. $\$ 5.00$.

\section{BIRD SEEDS, Etc.}

By mait 25 cents per quart, 16 ccnts per pound additional for postage. Prices variable.

Canary (Phalaris canariensis) - Per qt., 20 cents. Hemp (Cannabis sativa),-Per qt., 20 cents.

IIaw (Papaver rhceas).-Per lb., 25 cents.

villett (Panicum miliaceum),-Per qt., 15 cents.
Rape (Brassica napes), - Per qt., 25 cents.

Rice, unhulled (Oryza sativa).-Per qt., 25 cents.

Lettuce (Lactuca sativa).-Per oz, 10 cents; $1 \mathrm{~b} ., 50$.

Mocking-Bird Food (prepared),-Per bottle, 50c.

\section{FRUIT SEEDS.}

By mail 25 cents per quart, 16 cents per pound additional for postage. Prices variable.

Pear Seed (Pyrus communis).-Per oz., 25 cents; lb., $\$ 2.00$.

Quince Seed (Cydonia vulgaris),-Per oz., 35 cents; $1 \mathrm{~b} ., \$ 3.50$.

Apple Seed (Pyrus malus).-Per qt., 40 cents; bush., $\$ 6.00$.

Plum Pits (Prunus communis).-Per qt., 50 cents; bush., $\$ 8.00$.
Apricot Pits (Armenica vulgaris).-Per oz., 10 cents; 1b., 75.

Cherry Mahaleb (Cerasus Mahaleb).-Per lb., 75c Cherry IMazzard (Cerasus communis).-Per qt., 25 cents.

Currant Seed, red and white(Ribes).-Per oz., 50 cents.

Peach Pits.-Per qt., 10 cents; bush., $\$ 1.50$. 


\section{GRAINS.}

In order to givo theso varicties a thorough trial, we offer se 210 in premiums to thoso who produce the largest quantity of seed from one packet of tho sech, and for the twenty best and heaviest heads of both the varieties of Wheat and Oats. Please state, with the order, if vou lesiro tocompete for premiums. See color supplement for particulars of premiuns; or circulars, with full particulars, nubled free on application.

\section{PRINGLE'S NEW CEREALS.}

Wo take mueh pleasuro in offering tho following newly liybritized varieties of Spring Wheats and Oats, origrinatel by Mr, C. G. Pringle of Northeru Vermont, this woll-known aud successful hydridizer of Potatocs and Grain, aml the originatur of the celebrated (ilamplain and Dofiance Spring Wheats, Snowflake Potatoes, etc., whiel liavo given universal satisfaction wherever they hava been introluced, not only in this conntry, but in Europo and Australii. Tho following virieties aro belioved to possess qualities superior to any hitherto introduced, and wo offer them fully confirlent that they will givo satisfaction to those wlin mily wish to givo tlen st trial.

Our stock of tho bits and Whost being limited, and wisling them to be tested as exteusively as pos. siblo in all parts of the country, we shall ofter them only in one-onuco packets.

\section{PRINGLE'S AMERICAN TRIUMPH OATS.}

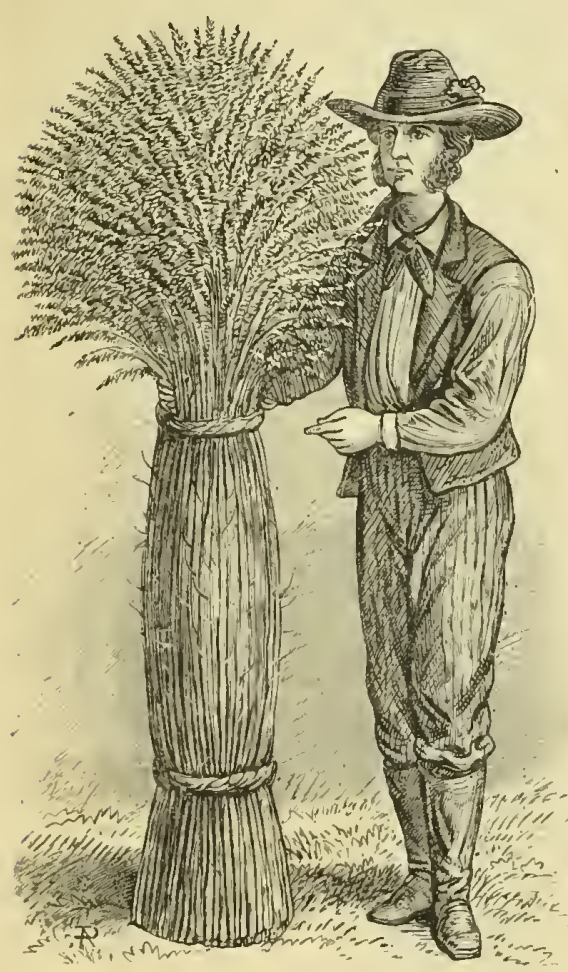

It is with great plensuro that we introduce to public notice, and ofler for sale, this now valety of Onts, beins fully couvinced of its raru excellence and great superiority over tho ulder varieties now cultivated. The valuablo services which Mr. C. G. Pringle, of Veruont, has rendered to the farming world are too well known to every progressive agri. culturist to require mention lere, yet it will be proper to stute that tho "American Triumph Oats" aro justly cousiderel tho "Crowning Trinuplı" of Mr. Pringle's persevering and labo. rious oxperiments in liybridizing cereats.

This variety, now offered for tho dirst time, is a cross between tho kixcelsior and tho Waterloo Oats, combining, in a romarkable degree, the excel. lent dualities of both. To presont a clearer illea of the claricter of its growtls than words could give, we liad a photograph taken from a sluaf closen at random in tho fick. Tho man lolding tho sleaf was 5 feet 10 inchey ligh, so thit, by comparison, tho proportionate sizes are leadily scun in the annexed illustration.

The averago lieight, as the grain stands in the fick, is six feet, yet the straw is so strong and firm that it lohls up well, without lolging, the tall, luxuriant heals filled with blump, heavy grains. Tho quality and prouluctiveness of tho grain aro unexcclled, yielling from 50 to 100 busleels w y acre, ac cording to the condition and state of fertility of the land.

The crop from which our seed was obtained has while stauling ou tho field, heen exumined by many experiencerl Ont growers, all of which ileclared that they never saw anything to equil tho "American Trinmple Oats" in health and vigor of straw or in yield and weight of grain.

25 cents per packet of 1 ounco; 5 packets, $\$ 1.00$

\section{PRINGLE'S ADAMANT WHEAT.}

In this variety wo lave one of the luardiest and most flinty varieties in cultivation, very productive, hardy, and vigorous. It is a bearlless white chaff variety, with lont narrow heads closely set with medium sized amber colored kernels which prounce flonr of very superior quality. Straw, yellowish white, very stiff and erect, averaging about 4 fect in height. For cultivation in tho North.west, colorado, and the Pacific coast, where lard wheat is the favorite sort, we are contirlent that this will be partienlarly desirable. Price 25 cents per packet of 1 onnce, 5 packets, 81,00 .

\section{PRINGLE'S GREEN MOUNTAIN WHEAT.}

This is another bealless variety of great promise. It lias been grown for tho past two years loy ono of the most experiencel wheat cultivators in Nolthorn Vermont, in close proxinity to the Green aronintains, whiv pronounces it tho best he has ever grown. The straw are riges about 4 fect, light yellow, very strong, aud free from rust. Ifeads averago 4 to 5 inches in length, somowhat tapering, kernels wlitte, large, amil plump, very harly and productive, and well worthy the attention of every wheat grower. Price 25 c'nts per packet of 1 ounce, 5 packets, $\$ 1.00$ 


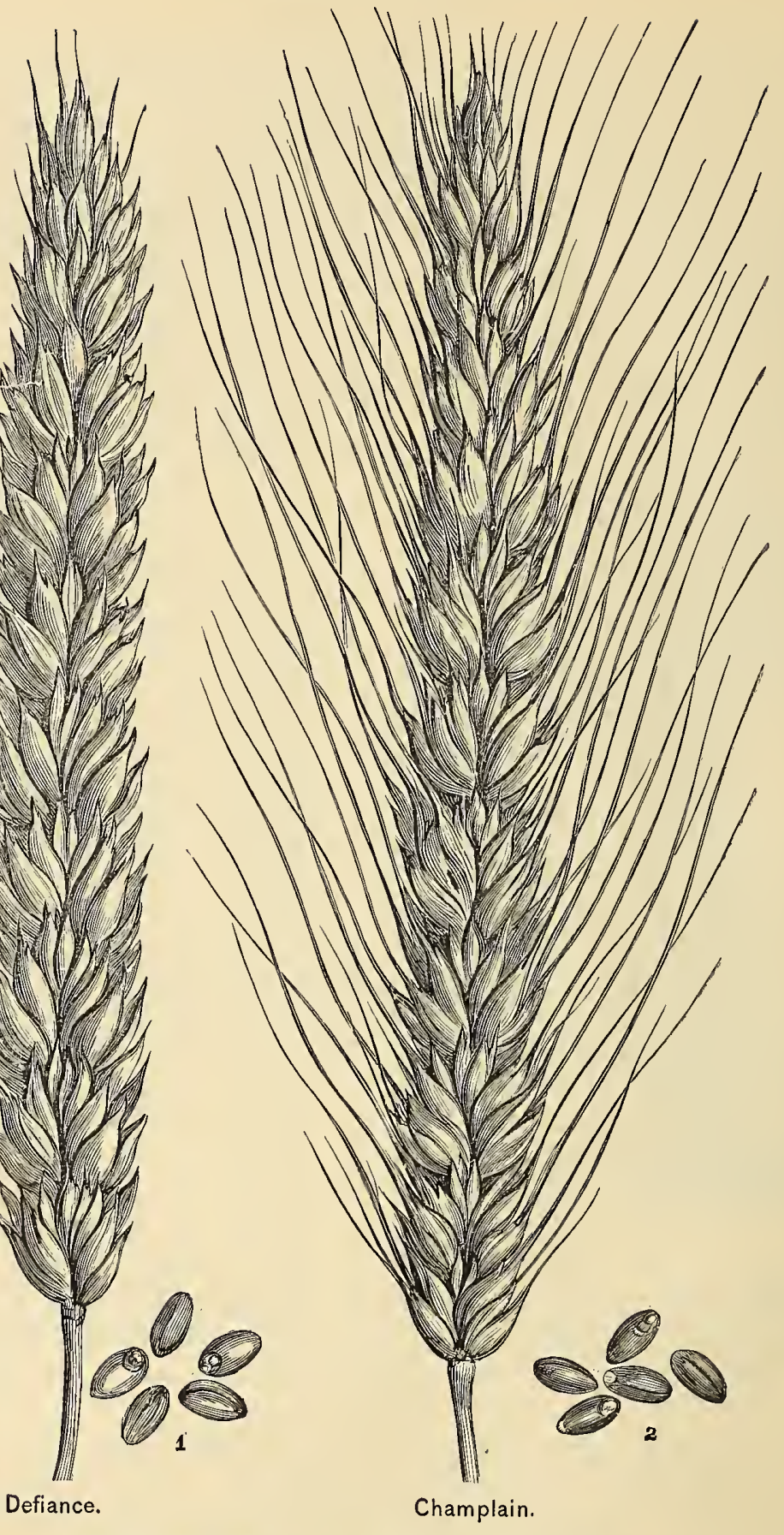

PRINGLE'S NEW HYBRID SPRING WHEATS.

The above are actual representations of some of the heads selected from wheat grown in a field with ordinary farm culture. 
Grain in quantities of $1 / 2$ bushel and upward should bc shipped in canvas bags, which. we can supply at following rates: $1 \frac{1}{3}$ bushel, 15 eents; 1 bushel, 20 cents ; 2 bushels, 25 ecnts. Customers will please acld cost of bags to remittance when ordering.

\section{SPRING WHEAT. PRINGLE'S NEW IIYBRID RPIRING WHEATS.}

The two following varieties were tirst ufferell loy $11 \mathrm{~g}$ in 1878 , and the most satisfactory reports of their vieli and quality luve been jeceived from growers in all scctions of the conntry. Some of the reports recened concerning these varieties were truly wenlerful, and sliewed what good culture and good seril will do. One pourd of Cliamplain produced 761 pounds, and one pouml of Defiance prothced 528 ponnds, and many of the best heals uncasured from six to seven incles in lengtl, and produced from ei rlity to winety kernels per heasl. They were awardol a diploma by the American Institute in 1879 , anl were also awarded tho first and sccond prizes at the Intereolonial Exhibition it s"yiney, N. S. W., Australia, in April, 1874, as the best new varietiesexhiluitell.

Chauplain (791 pounds of this variety were grown from one pound of 8 eed). - Was prodıced by $\mathrm{Mr}$. Prugle, in lis endeavors to unito the remarkablo latuliness of the blick sica with the fine aud superior quality of the Golden Drop. A continued careful selection fully estublished its cliaracter, and wo have a Wheat learded like the Blick Sia, with the wlite cliafi of the Golden Drop, free from rust and smut, yielding a ligliter colored grain than the former, and producing a flenr of superior quality. Its strong and vigorous straw stands erect, and frequently bcars, witl very ordinary 'ulture, lieads from five to six inches in lengtl, containing froul sixty to seventy. five keruels each. By muil, 40 conts por ponnt. Threo ponnds for $\$ 1.00$. Per peck, $\$ 1.50$; per buslicl, $\$ 4.50$.

Definnce (528 pound of this variety were groun from one pound of seed). - This is the result ot cxperi. ments by Mr. Plingle to incorporate superior qualities upon tho liarily stock of our common club Wheat, by hybrilizing it with ene of the best serts of the Pacific evast.

It is of great prodnctirencss, vigor, and liarliness; is a beardless white claff wheat, witl heads fre quently fire to six inches long, closely set with lirge wlite kerucls, frefuently numbering seventy-five to eiglity to the single liead. Its white, stiff, erect straw, exempt from the attack of rust, its carliness, corm bined with great vigor and snperior qualities, render it invaluable. By mail, one ponmo, 40 cents; three ponnds for $\$ 1.00$. Per leck, \$1.25; busli., \$1.00.

Thite Rusian.-This variety lias proved rery raluable in th geod length, strong, does notlodge, is not inclined to rnst; lieads large an! well filled.......... \$2.50 China Spring.-A whito cliafi, bearled variety; prodnces lengheals well filled wiv plump kernels. 3.00 Yeditermnean spring.-This variety is bearied, yields well, and tho kernels are very large..... 3.00 Thee penuds of eitlier of above, by mail, $\$ 1.00$.

\section{WINTER WHEAT.}

Fultz.-A beardless amber variety, very liardy and productive; straw of medium lencth aul stroug: makcs excelleut flour. Three pounds, by mail, $\$ 1.00$; buslsel, $\$ 2.25$.

Seneca or Clawaon.- Is a smooth white Wheat, witl rul chaff, a superior variety. Threo ponnds, by mail, s1.00; bushel, 82.25

Red Meditemanean.-Fhis is the imported variety, fully acclimated. Heads beardod, well filled ; suc. ceeds well in nearly all localities; ripens early. Three jomuls, by mail, $\$ 1.00$; busliel, $\$ 2.25$.

\section{RYE.}

Thousnnd-Fold.-A desirable European novelty, producing enormons heuls from six to eight inches in leugtl, grains very large and full; ancl, as its name inplies, an nnusully prolific variety. By mal, 75 cents per pound; theo pomds for $\$ 2.00$. Per express, at purchascr's expense, $\$ 5.00$ per peck.

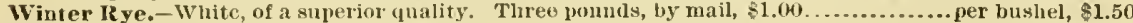

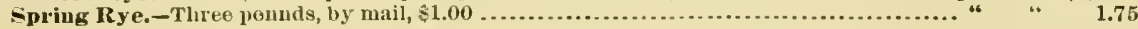

\section{BARLEY.}

Kinver Chevalier. - An English variety, surpassing all ordinary kinds in its "normons yield from thin sceding, and in excetlence of grail, the lattel being thin-skinued, bright, plimp, and rery lieavy; the straw is of good lengtl and quality. It auswers well ill all soils, having been grown with great success in many different localities. By uail, $40 \mathrm{cts}$. per $1 \mathrm{~b}$; ; 3 lbs., $\$ 1.00$.

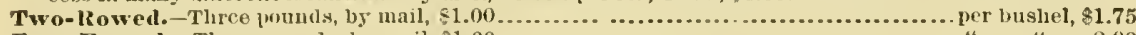

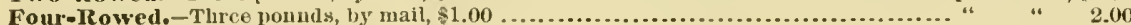

\section{SILVER-HULL BUCKWHEAT.}

This varlety is a great improviment upon the ordinary Buckwlieat. Sown at the same time as the common Buekwhent, it centinues in blom longer, matures earlier, and yiells nearly donble nnder the same conditions. The grain is of a beautiful light gray color, varying slightly in sluale, and the corncrs are mich less promineut than in the orlinary varicty, while tho lusk is thinner, therelyy saving from fifteen to twenty per cent. waste in the process of manufacturing into fiour. Price, per peck, 75 cents; bushel, 82.00. By mail, one pound, 40 ecnts; three pounds, \$1.00.

Buckwheat, common.-Per busliel, $\$ 1.25$; thee pounds, by nuil, 81.00 . 


\section{OATS. \\ PRINGLE'S HYBRIDIZED EXCELSIOIR HULLESS OATS.}

With a view to impart to the hulless species the size of plant, vigorous habit, and productiveness of one or other of the favorite lulled solts, Mr. Pringle, among other experiments, hybridized the wellknown Excelsior Oats with the Chinese Hulless, and the experiment proved, beyond questiou, highly successful, the result being the variety now offered.

It is quite distinct from the Chinese, with splentid straw, tall and stiff as that of the Excelsior, and with a panicle as broad and numerously seeded as in that variety. It is exceedingly prolific, being equal in yield to the best huhed varieties, and double tliat of the Chinese hulless oats. As a variety for milling purposes, the Excelsior Hulless is destined to become rapidly popular, not alone on account of absence of liusk and frcelom from bran, but also on account of the enormous size of the grain, and the excellent and nutritions quality of the meal produced from it

Price per peck, $\$ 2.50$; bushel of $32 \mathrm{lbs}, \$ 7.00$; trial packages, by mail, 60 cents per $1 \mathrm{~b} ., 31 \mathrm{bs} ., \$ 1.50$.

Challeuge.-This splendid White oat is rapidly superseding the older varieties, being univaled for pro. ductiveness and fne quality. It produces long, s tout straw, with neat panicle completely covered with close-set, plump, heary grains; of excelleut quality. Three pouuds, by mail, 1.00 ; by express, at purcliaser's expense, per bushel, $\$ 1.50$.

Mold's Selected Black Tartarian.-Ono of the most prolific of all Black Oats, and las attained an extraortinary reputation wherever grown. Three pounds, by mail, $\$ 1.00$; by express, at purchaser's expense, per bushel, $\$ 2.00$.

White Probst eier,-Three pounds, by mail, $\$ 1.00$; per bushel of $321 \mathrm{bs}, \$ 1.25$.

White Russian.-An extremely handsome, hardy, aud wonderfully prolific variety, with strong, bright straw, which, so far, has been entirely flec from rust. The liearls are of enormous length, well filler with plump, heary grain of great untritive qualities, which renters it very valuable for feeding pur. poses. Three pounds, by mail, $\$ 1.00$; per bushel of $32 \mathrm{lbs}$, $\$ 1.50$.

Washington.-A distinet variety, yielding at least one-thir'd moro than the common sorts; straw stiff and heavy, and staudiug well until fully ripe. Three pounds, by mail, $\$ 1.00$; per bushel of 321 bs., $\$ 1.50$.

\section{FORAGE PLANTS.}

Pearl, or Egyptian Millet.-This is quite distinct from all other species, and is without doubt destined to take a place in the front rank of valuable forage plants. Sown in light sandy soil, the plants at first appear feeble, resembling broom corn; but when a few inclies above ground they begin to tiller, ant new shoots appear very rapidly from the original loot. The stems at first are nearly prostrate, but when about two feet long they begin to assume an npright position, reaching a lieiglit of ciglit to ten feet, not differing in color or substance from our common Indian corn. When cultivated for foditer, the seed should be dropped in drills and given plenty of room, on account of the peculiar liabit of tillering; the fodder is in the best condition for cutting and curing when the stalks are five or six feet ligh; but, if used for soiling, it might be cut earlier or later, at the conveniencs of the cultivator; the stumps, sprouting and throwing up a new growth, continue to grow until killed by frosts. Per oz., 10 cents; 1 1b., 20 ; 1b., 50, by mail, post-paid; by express ox freiglt, at expense of purchaser, 30 ceuts per lb. 10 libs., $\$ 2.50$.

German, or Golden Millet.-Golden Millet is of extraordinary value, and coming iuto great favor as an anul hay and fodder crop. 1 t is medium early; lieight 3 to 5 fcet; heads closely condensed, spikes very numerous; seeds round, golden ycllow, in rough, bristly sheaths. Per brsh., \$2.50.

Hungarian (Crass) Millet (Panicum Germanicum).-Early; height 2 to 3 feet; abundant foliage and slenter lieaıl; withstands drought and yields well on light soils. Per bush., $\$ 2.00$.

Cowmon Millet (Panicum Miliaceum).-Very early; heiglit 2 to 3 feet; foliage broad and very abundant; heads very open, branching panicles; seeds glossy oval, soluewhat flattened. Per bush., \$2.00.

Three pounds of cither of above, by mail, \$1.00.

The above varieties sliould be cut wheu in blossom. Prices quoted are subject to fluctuation.

Rural Branching Durm.-This is a wonderfully protuctive fodder plant, is superior to drill corn for soiling silos, or dry fodder, and possesses the following alvantages: It yields fire hundred per cent. more feed. It is more highly relislied by stock. It imparts a better color to butter. It withstands drought better, producing heavy erops where arill corn burns up. It is essentially different from all otlier Durras, from the fact that tliey ploduce but one stalk, whereas this rariety throws lip from six to six teen stalks from each seed. It staits a new growth readly after being cut for fodder, and will, in this was, produce two or three crops a season. It is usually planted in four-fect rows, and three feet apart in the drills, and when well up thinned out to two stalks in the hill, and cultivated like con. Fivo pounds is sufficient for an acre. Prico by xuail, post-paid, per pkt., 10 cents; $\frac{1}{4} 1 \mathrm{~b} ., 15 ; 1 \mathrm{lb}$., 50.

Durra (Sorghum Irulgarc).-This is a valuable forage plant, growiug from 8 to 10 feet in height, and yielding an abundance of grayish-green foliage, greatly relished by stock.

For fodder, sow in divils from 2 to 3 feet apart, dropping the seeds 3 to 4 inches apart iu the drill; when 6 or 8 inches high, thin to about 8 or 9 inclies apart; and when it has attained a lieight of 4 or 5 feet, it may be cut for forage, whel can be continued every thirt or fomth week until frost. Prices by mail: per oz., 10 cents ; 11 ., 45 cents. By express, at lurchaser's expense, 25 cents per $1 \mathrm{~b}$.

Prickly Comfrey - This plant is specially adapted for the feeding of stock and for increasing the milk of cows. It produces on a given space a far greater quantity of forage than any other green soiling plant. Being deep rooted, it withstands protracted drought in a remarkable degree, and affords abundance of forage until cut down by severe frost. 1 t is propagated by subdivision of the roots, about 4,000 sets being lequired for an acre. Descriptive curcular's, giving directions for culturc, mailed to all applicants.

We will supply roots of the above at the following prices, post-paid by mail : $4 \mathrm{oz} ., 20 \mathrm{ceuts} ; 8 \mathrm{oz}$., 30 cents ; 1 lb., 50 ccnts. By express, freiglit paid by purchaser, per $1 b ., 40$ cents ; 51 bs., $\$ 1.50$.

one pound of the roots will make abont oue lundred cuttings; they can be cut smaller if desired. 


\section{AGRICULTURAL IMPLEMENTS.}

\section{PLOWS.}

\section{EAGLE PLOIVS.}

Kinds. Light Horse Medium Horse. Wilh Wheel $R$. Wheel Nos, Plain, Wheel. Cueter. Cutter. $18 \$ 3.90 \$ 5.20$

. $18 \frac{1}{2} \quad 4.25 \quad 5.60 \$ 7.10$ $\begin{array}{llllll}\text { Hebt Two Horso... } & 193 / 2 & 6.00 & 7.50 & 9.00 & 10.75\end{array}$ Two Horse ......... 20 $207.00 \quad 8.50 \quad 10.00 \quad 12.00$ $\begin{array}{lllllll}\text { Two Horse } & 21 & 7.75 & 9.25 & 10.75 & 12.50\end{array}$

\section{Cambatie platís.}

No. $2, \mathrm{M}$ $\$ 4.00$ No. 19

No. 1

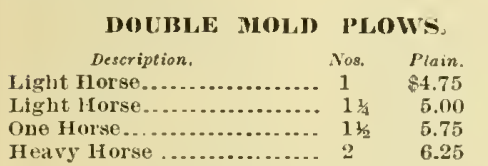

With

si.25

6.50

7.25

7.75
TIIE SILVER EATIAE PLOWNA.

With Wheal R. Whieet Description. Nos. Plain. Wheel. Cutter: Cutter. One 1 rorse ......... $104 \$ 6.00 \$ 7.50 \quad \$ 9.00 \$ 10.75$

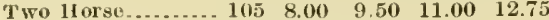
$\begin{array}{llllll}\text { Two or Three Ilorse } & 106 & 9.00 & 10.50 & 12.00 & 13.75\end{array}$

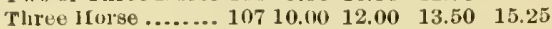

\section{SIDE-HIJI, OR SIVIVEL PIOWS.}

Wheel R.IIheel Description. Not. Pinin. Wheel, Cucter. Cutter. Light llorso....... $0 \quad \$ 5.00 \$ 6.50 \$ 8.00 \$ 9.75$

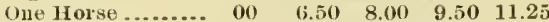
Two 110rse...... B $1 \quad 8.00 \quad 9.50 \quad 11.00 \quad 12.75$ Sod ............... A 1 1/ $9.50 \quad 11.0012 .50 \quad 14.25$ sot................ A $2 \quad 11.00 \quad 12.50 \quad 14.00 \quad 15.75$ Large sod.......... A $3 \quad 12.00 \quad 13.50 \quad 15.00 \quad 16.75$ Heavy Road....... \& $4 \quad 14.00 \quad 15.50 \quad 17.00 \quad 18.75$ Lal'ge Sod. ....... $83 \quad 13.50 \quad 15.00 \quad 16.50 \quad 18.25$

AILEN'S POTATO PLOWS.

1 ron ................................ \$12.00

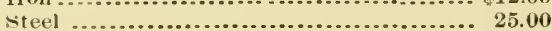

\section{CIJAR'TER OAK SIVIVEL PLOW'S.}

One Horse, 5 to 6 incles deep, 8 to 10 incles wide

TINER'A PATENT "(IOLI) MEUAL" SIBAOIL PLOIVS

\begin{tabular}{|c|c|c|c|c|}
\hline 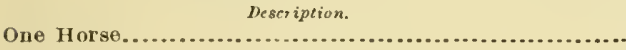 & $\begin{array}{c}\text { Nos. } \\
16\end{array}$ & $\begin{array}{l}\text { Jlain. } \\
\$ 8.00\end{array}$ & $\begin{array}{c}\text { Wilk Wrheel. } \\
\$ 9.50\end{array}$ & $\begin{array}{l}\text { Wheel and D. Rod. } \\
\quad \$ 11.00\end{array}$ \\
\hline Two Horse.................... & 17 & 10.00 & 11.50 & 13.00 \\
\hline 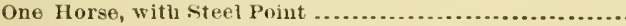 & 16 & 10.00 & 11.50 & 13.00 \\
\hline Two Horse, with Steel Point........................ & 17 & 12.00 & 13.50 & 15.00 \\
\hline
\end{tabular}

STEEL PJOWY, CAST FIIARES.

\begin{tabular}{|c|c|c|c|c|}
\hline 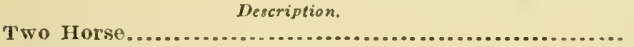 & $\begin{array}{l}\text { Nios. } \\
\mathbf{X} 0\end{array}$ & $\begin{array}{l}\text { Plain. } \\
89.00\end{array}$ & $\begin{array}{l}\text { With Wheel. } \\
\$ 10.50\end{array}$ & $\begin{array}{l}\text { Wheel and Cutter. } \\
\quad \$ 12.00\end{array}$ \\
\hline 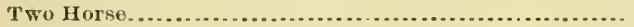 & $\mathrm{X} N$ & 11.00 & 12.50 & 14.00 \\
\hline ................. & $\mathrm{X} \mathbf{M}$ & 12.50 & 14.00 & 15.53 \\
\hline
\end{tabular}

NEW PATTERN STEEL PLOWS.

\begin{tabular}{|c|c|c|c|c|}
\hline Description. & Plain. & Wilh Wheel. & $\begin{array}{l}\text { Wheel and } \\
\text { Cutter. }\end{array}$ & $\begin{array}{l}\text { Wheeland Cir. } \\
\text { cular Cutter }\end{array}$ \\
\hline Light One Horse, 7 inclu cut...... & 88.10 & $\$ 10.00$ & $\$ 11.50$ & $\$ 13.50$ \\
\hline Light Two llorse, $7 \frac{1}{1 / 2}$ inch cut...................... 2 L & 9.50 & 11.00 & 12.50 & 14.50 \\
\hline Medium Two Horse, 8 inch cut .................... $3 \mathrm{~L}$ & 12.00 & 13.50 & 15.00 & 18.50 \\
\hline Light Two Horse, $83_{2}$ inch cut ..................... 4 L & 13.00 & 14.50 & 16.00 & 19.50 \\
\hline Light Two Horse, 9 inch cut ..................... 5 M & 10.00 & 11.50 & 13.00 & 16.50 \\
\hline Two 1 forse, 10 inch cut........................... $6 \mathrm{M}$ & 13.50 & 15.00 & 16.50 & 18.00 \\
\hline Light Two 1Iorse. . . . . . . . . . . . . . . & 10.50 & 12.00 & 13.50 & 15.50 \\
\hline Medium Two Horse................................ & 12.00 & 13.50 & 15.00 & 17.00 \\
\hline 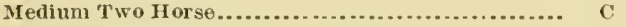 & 13.50 & 15.00 & 16.50 & 19.50 \\
\hline 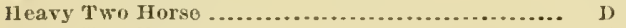 & 12.00 & 13.50 & 15.00 & 17.00 \\
\hline 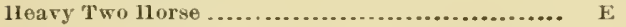 & 14.00 & 15.50 & 17.00 & 19.00 \\
\hline Heavy Two Horse, 10 inch cut . . . . . . . . . . . . . . . & 13.00 & 14.50 & 16.00 & 18.00 \\
\hline Two or Three 11 orse $\ldots . . . \ldots \ldots \ldots . . . . . . . . . . . .$. & 18.00 & 19.50 & 21.00 & 23.00 \\
\hline
\end{tabular}

\section{BALDIVIN'S AVEIRICAN FODDEIR CUTTEIRS.}

WITH ONE KXIFH.

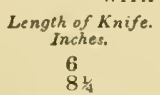

Length: of Ciut-
Inches.

$\begin{array}{ll}1 / 2 & 1,13 \frac{1}{2} \text { \& } 2 \\ 1 / 2 & 1,13 \frac{1}{2} \text { \& } 2\end{array}$
Price.
818.00
22.00

WITH TWO KNIVES.

\begin{tabular}{|c|c|c|c|}
\hline No. & $\begin{array}{c}\text { Length of Knife. } \\
\text { lnches. }\end{array}$ & $\begin{array}{c}\text { Lengthe of Cut. } \\
\text { Inches. }\end{array}$ & \\
\hline 9 & $\begin{array}{l}71 / 4 \\
81 / 4\end{array}$ & $\begin{array}{l}\frac{1}{4}, 3 / 2,3 / 4, \text { \& } 1 \\
\frac{1}{4}, 1 / 2,3 / 4, \text { \& } 1\end{array}$ & $\begin{array}{r}\$ 28.50 \\
31.00\end{array}$ \\
\hline
\end{tabular}




\section{HAIRROWS.}

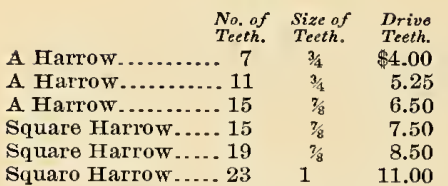

\section{CORN AND SEED PLANTER.}

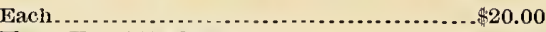
Horse Hoe Attachment...................... $\quad 3.00$ Fertilizer ................................. 3.00

\section{CORN SHELLERS.}

All with Wrought-Iron Shafts.

Clinton, 1 wheel, ........................... 7.50 1 Wheel, Improved.................. 7.50

2 Wheel, Improved. . . ............... 8.50

2 wheel, Regular................... 8.50

2 Wineel, Double Hopper............. 12.50

2 Whecl, Iron Hopper ............... 8.50

Eagle, Single Hopper...................... 12.50

" Double Hopper......................... 18.00

Silver Eagle, Single Hopper.................. 12.50

" " " Double Hopper.............. 18.00

\section{HAND CORN IMLLS.}

No". 3 ................................. 4.50

No. 4 .................................... 6.00

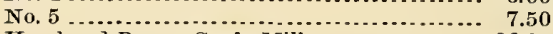

Hand aud Power Grain Mill................. 26.00

\section{BLANCHARD CHURNS.}

Family sizes.

No. 3, for up to about 2 gallons of cream....\$6.00 " 4 , " " " 404 " 4 "

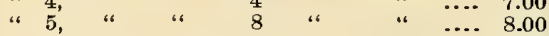

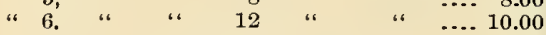
"7, " " 716 " $16 \quad$ " $1 . . .12 .00$

\section{CHDER MILLS.}

Farmers* Favorite, Family ......... " " 1 bbl. Press.............. 30.00 " " 3 bbl. Press, for two men or power.............6 65.00

WINE PRESSES.

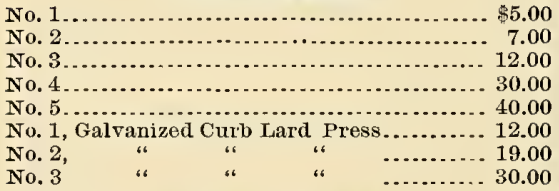
Broad Tire, Each $\ldots \ldots \ldots \ldots \ldots \ldots \ldots \ldots \ldots \ldots \ldots$
Narrow Tire . VEGETABLE CUTTERS.

No. 1, Clark's Patent . . . . . . . . .............. \$12.00 No. 2, " " No. 3, “ " "

STUMIP PULLEIR.

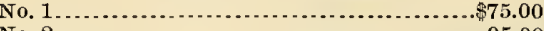

No. 2 ........

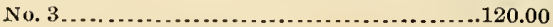

\section{HAY CUTTERS.}

No. 1, Lever...... $\$ 5.50$

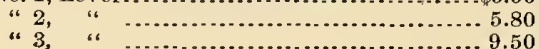

\section{CULTIVATORS.}

Five-Tootl, Steel Teeth, to screw. Plain. Wheel. to wedge...... $7.00 \quad 7.50$ “ultivator Harrow, 9-tooth, ${ }_{4}^{3}$ in. tceti...... " " 9-tooth, 7/8 in. teeth.... 7.50 " " 11-tooth, $3 / 4$ iu. teeth. ... 7.00 Commou Cast-iron tooth, 5 teetl ......... 7.00 " " " new pattern.. ... 7.50 Set of Cast CultivatorTecth (5)........... 2.00

\section{HORSE HOES.}

Higganum Horse Hoe Price. djustable Horse Hoe, No. 1 ................ 8.00

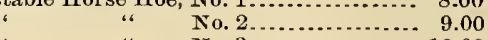

$$
\begin{aligned}
& \text { No. } 3 \ldots \ldots . . .10 .00
\end{aligned}
$$

HIDE ROLLER HAY CUTTEIR.

New Yorle Pattern.

\begin{tabular}{|c|c|c|c|c|c|c|}
\hline $\begin{array}{l}\text { No. of } \\
\text { Cutter. }\end{array}$ & & $\begin{array}{l}\text { No, of } \\
\text { Knives. }\end{array}$ & & $\begin{array}{l}\text { Length of } \\
\text { Knives. }\end{array}$ & & Price. \\
\hline 00 & ... & 4 & $\ldots$ & 6 inch & $\ldots$ & $\$ 6.50$ \\
\hline 0 & $\ldots$ & 5 & $\ldots$ & 64 & ... & 7.00 \\
\hline 1 & $\ldots$ & 6 & $\ldots$ & $6 \div$ & $\ldots$. & 8.00 \\
\hline$\overline{2}$ & .... & 6 & $\ldots$. & $61 / 2 " 6$ & $\ldots$. & 9.00 \\
\hline 3 & .... & 6 & $\ldots$ & 7 “ & .... & 11.00 \\
\hline 4 & .... & 6 & .... & 8 " & ... & 12.00 \\
\hline 5 & . & 6 & ... & 9 ، & $\ldots$ & 14.00 \\
\hline 6 & ... & 6 & $\ldots$ & $10 "$ & .... & 20.00 \\
\hline 1 & .... & 8 & $\ldots$ & 6 " & ... & 8.50 \\
\hline 2 & ... & 8 & $\ldots$ & $6 \frac{1}{2} / 6$ & ... & 9.50 \\
\hline 3 & $\ldots$ & 8 & .... & 7 “ & .... & 11.50 \\
\hline 4 & .... & 8 & .... & 8 “ & .... & 13.00 \\
\hline 5 & .... & 8 & .... & 9 “" & .... & 15.00 \\
\hline 6 & $\ldots$ & 8 & ... & $10 "$ & ... & 21.00 \\
\hline 1 & . & 10 & $\ldots$ & $6 " 6$ & $\ldots$ & 9.00 \\
\hline 2 & $\ldots$ & 10 & .... & $6 \frac{1}{2} "$ " & $\ldots$ & 10.00 \\
\hline 3 & .... & 10 & .... & 7 ، & .... & 12.00 \\
\hline 4 & .... & 10 & $\ldots$ & $8 ،$ & $\ldots$. & 14.00 \\
\hline 5 & .... & 10 & $\ldots$ & $9 \quad 4$ & .... & 16.00 \\
\hline 6 & $\ldots$ & 10 & $\ldots$ & $10 "$ & $\ldots$ & 22.00 \\
\hline
\end{tabular}

Mounted, 15 inch, each ................ 6.00

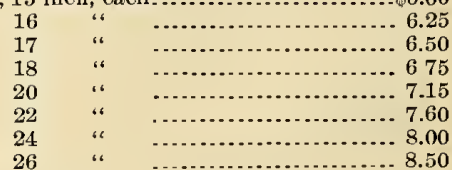

CANAL BARROWS.

Gach. GARDEN BARROWS.

\section{New-York Wood Hubs.}

Garden Wheelbarrows, No. 1 ...............\$4.50

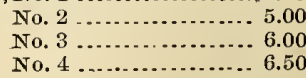

\section{DIRT-SCRAPER OR OX-SHOVEL.}

No. 1, with Iron Back................... \$7.00 No. 2, "4 " No. 21/2, " " No. 3, " " " No. 4, " " " No. 5, " " No. 2, with Wood Back................... 8.00 No. 3 , " "

STEEL BLADE ROAD SURAPERS.

No. 1, 30 inch Chain Bail ..................\$10.00 No. 2,34 " 34 " 


\section{HORTICULTURAL AND OTHER IMPLEMENTS.}

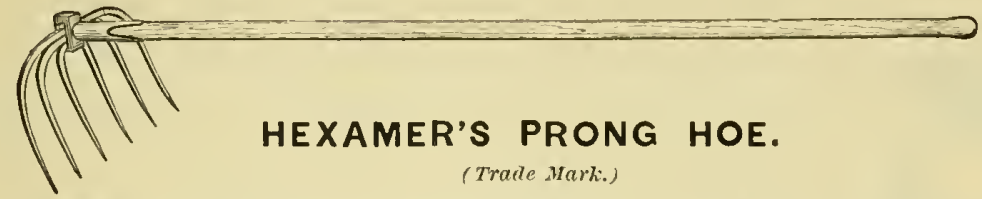

This implement subserves the pmpose of a hoe and rake. It is an excellent tool for pulverizing the soil between rows of all kinds of growing plants and for rooting up suall wecds; and it is a wonderful improvement on Hand Potato Diggers. As the tines are long, suill, and strong, they pass through the soil with the application of less force than is required to work the old style of aggers. Jrice $\$ 1.50$ ench; $\$ 15.00$ per dozen. Without handles, \$1.40 each. By mail, post-paid, $\$ 2.00$ cacli.

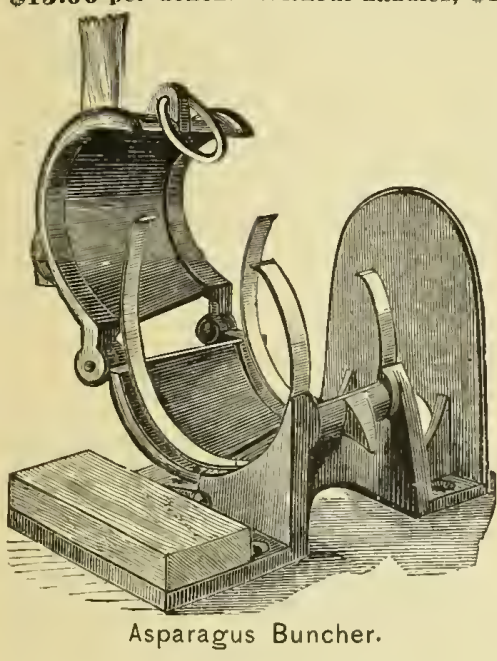

\section{ASPARAGUS BUNCHER.}

In offcring this Machine to the public, we feel no hesi. tation in claiming that it is the most simple, compact, durable, and at the same time the most powerful Bunching Machine crer made, and that a child ten or twelve years old can bumch, tic, and prepare for market more A sparagus than a mau conld by the old process; the bunches being of uniform size and sliape, and put up tight enough to prevent falling to pieces in handling; thereby proventing loss, and makiug for it a more ready sale, as rery much depends ou condition of its arrival in market as to the prices oftained for it. P'rice $\$ 3.50$.

TYING MATERIALS.

Roffea, per lb................................. $\$ 0.75$

Cuba Bast, best..................................... $\quad .75$

American, (10 ................................... .40

\section{BATEMAN'S HAND-PLOW.}

This is a first-class and rery neat all-steol nold-boari Hand-plow. The side landle aud set for regulating deptli make it the most managcable tool of the kind yet introduccd. Price $\$ 2.00$.

\section{THE IMPROVED NEW-YORK SEED DRILL.}

\section{Invented and Patented by E. G. Matthew.}

With Patent Combination Metal Dial that will not Corrode or Rust. Read its New Points.

Patent Bars in the Drop, to scatter seed, which no other drill las; ncw plan for opening furrow, which is adjustable to any depth; plow opens a wider furrow than any other drill; markers uuder the drill; easy shifting of marker by simply loosening two thmmb nuts; dial is set on fulcrun aud holds close up, hence no chance for seed to spill; I'atent Counbination Metal Dlal which will not corrodc or rust; the agitator is the simplest, strongest, ant most positive working ever jut into a irill; for simplicity, strengtli, compact ness, and dnrability it camnot be excellci. Ask for Improved New-York Drill. Price, \$12.00, boxed.

\section{PATENT EXCELSIOR WEEDING HOOK.}

The only instruncnt that can be used to ad vantage among small and tender plants. This instrument is

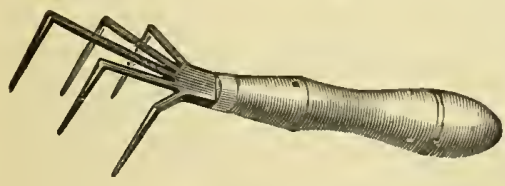
warranted to grive satisfaction when used among rows of seedlings, among ormanental plants, or in any placo where absolnte freedion from weeds is the result desired to be obtained. It removes the weeds with far greater rapidity than in the nsual manner, without injuring the plants or soiling the lands, and is in all respects the lest, if not the only instrument ever offered to the public for this julpose. Price, 25 cents; by mail, 30 cents.

\section{THERMOMETERS}

Of varions styles aud finish, from 50 cents to $\$ 5.00$ cach. Self.registering Thermometers, $\$ 2.00$ each. Dairy Thermometers, 75 cents to $\$ 1.50$ each, according to size. Storm-glass and Thermometer combincd, a useful and ormamental weather indicator, 75 ceuts each; by mail, $\$ 1.00$ 


\section{RANDOLPH'S HAND SEED SOWER.}

For Sowing all kinds of small Garden Seeds with Accuracy and Dispatch.

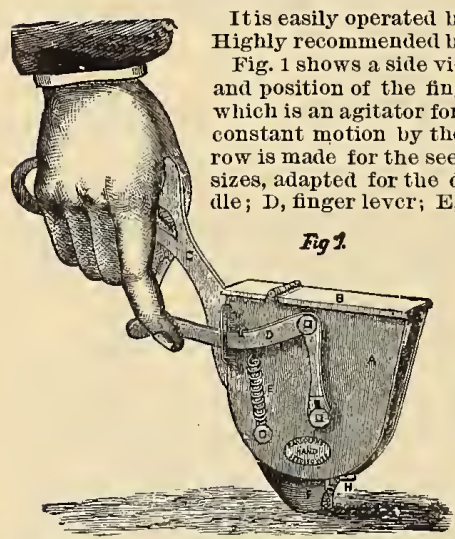

It is easily operated by a lady or a child of ordinary intelligence with a little practice. ended by some of our most experienced gardeners and farmers.

a side view of the implement, with the manner of holding it in the hand, and position of the finger; $A$, hopper for containing the seeds to be sowed, inside of is an agitator for discharging the seeds, connected with the lever $\mathrm{D}$, to be kept in finger while in use; $k$, earth opener, by means of which a fur. or the seed; the removable sides $I$ are perforated with holes of various sizes, adapted for the different varieties of seeds to be sown; B, cover or lid; C, han.

Fig 2 to

This fruitful source of waste in the ordinary method of planting is entirely lemedien by the use of this implement. It is rapid in its action, so that a great saving of time results from its use. Its construction is such that it is impossible to clog it under any proper circumstances.

Being made of metal, it cannot easily be broken, and its con. struction is so simple that it cannot readily get out of order.

For a more complete description send for Circular.

This Seed sower can also be furnished with an extended handle, to allow the operator to stand while using it. Price, $\$ 1.50$. On account of its length, this pattern cannot be sont by mail.

A liberal discount to the trade or traveling agents.

Its cost is trifling compared with the advantages resnlting from its use. The saving in time and seeds will undoubtedly repay the outlay in the planting of a single day. $\$ 1.25$ each. Sent by mail, post-paid, to any address in the United States upon receipt of $\$ 1.50$.

\section{RANDOLPH'S FERTILIZER DISTRIBUTOR.}

An implement for depositing Fertilizers of all kinds used in hill crops, such as Corn, Potatoes, Tobacco, Cotton, $d c$.

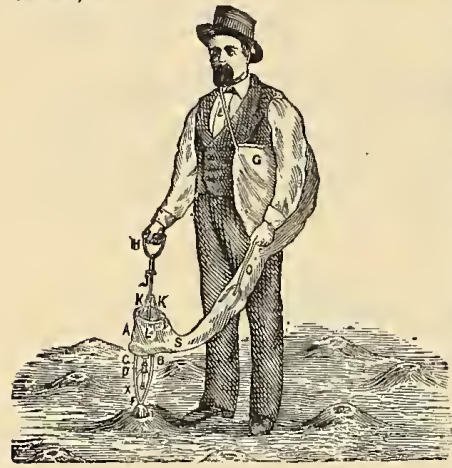

By its use, all kinds of Phosphates, Bone Dust, Fish and Peruvian Guano, Poudrette, Ashes, Plaster, and all kinds of concentrated Fertilizers and Chemical Manures can be distributed, without the material used coming in contact with the liands.

The manner of using the dropper will be readily understood from an inspection of the cut.

The sack, $G$, having been filled with the fertilizer, is attached to the person by passing the adjustable strap, E, over the shonl. der as slown. The liandle, $\mathrm{O}$, of the connecting shoot, $\mathrm{S}$, is then held by the left hand, and the handle, $H$, of the plunger, $J$, by the right, mless the person is left-handed, in which case the arrangement is just the leverse, the dropper being adapted for use in either way.

The implement is used after the manner of a cane, it being operated by simply swinging it from hill to hill, no exereise of care or judgment being required other than to select the spots upon which to rest its step, $F$.

For recommendations, and a more complete description, send for circular, Price, \$5.00 each.

\section{NOYES' HAND WEEDER.}

This is a convenient, cheap and uscful littio imple. ment for clearing away weeds, working between plants, dressing pots, and for other small work, where a large hoe could not casily ve used. Price, 40 cents each; by mail, 50 cents.

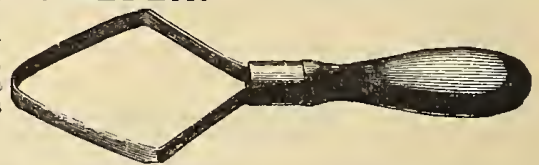

\section{THE EUREKA FUMIGATOR.}

In this article we offer an effectual apparatus for the fumigating of greenhouses, etc., doing away with the necessity of being smoked almost to death by the old mode, as it required constant attention to preessity of being smoked almost to death by the old mode, as it required constant attention to pre-

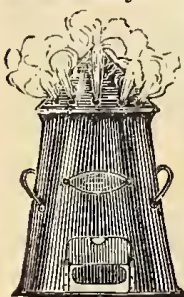
of the towacco-stems rom

This Apparatus is of simple construction, and not liable to get out of order. When once lit, it is self-acting, and may be left in the louse with yerfect safety, as flaring or once lit, setting anything on fire is an impossibility, while all the matelial is completely con. sumed without waste, and given of in a flesse smok

thus insuring the cntire destruction of insect ife. It can be used for fumigating Greenhouses, Conservatories, Pits, Frames, Hospitals,
Ships, Poultry-houses, cte.; for destroying Vcrmin or Purifying Rooms. Directions for'

No. 1. Height 12 in., diameter at top, 5 in.; suitablo for a small greonhousc.

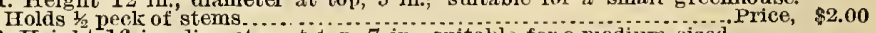

No. 2. Hei ght 16 in, diameter at top, 7 in.; suitable for a neduum sized

greenhouse. Holds 1 peck of stems ....

No. 3. Height 20 in., diameter at top, 9 in.; suitable for a largo green- 


\section{THE PHILADELPHIA BROADCAST SEED SOWER.}

(Patented April 5tlı, 1875, ant .1 inury 23แ1, 1877.)

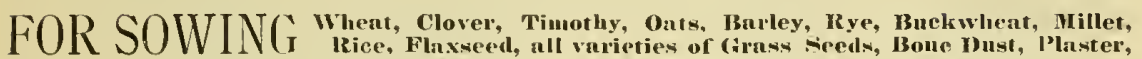
I'oultry Manure, Plomphates and Fertilizer's and Lime.

\section{N P O P U L A R U S E}

not ouly in this Country, but also in Europe, South Afriea, Australia, ete., and by all rousidered one of the greatest labor-sat ving maelines invented for agricultural pur poses.

Brond Casting.-We have the arintage in presentiug the claims of this over newer broad-custing medines, becansethe " Plila." lias been ThIED AN1 pliovkn, not in our section only, but in nearly eycry stale in the Unom, having as well an envable leputation abroat. We will not speak disparagingly of onr competitors, but in a few plain wolds mention some points of snperiority this sower has over others.

1st. The ease with which both the No. 1 aud No. 2 Maehines are adjusteil and operated.-

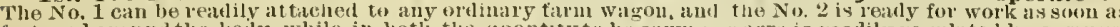
fastened aronnd the boils, while in botli the fuantity to be sown per acre is readily regulated by a gauge The gronnd need not be prepilled firther than plowing, the latrowing cill tollow the sowing.

21. The Uniforuity and IR apidity of Sowing. O Owing to the construction of the se sowers, the seed is evenly distributed if elirections are properly followed. We also claim that we liave a greater breadth of east than that of any other sower, consequently, we can do moje werk in a given lime. At the walking gait of a liorse the No. 1 machine will sow from twelve to titteen acres per lour; No, 2, or liant. machine, sowing from fonr to six acres. You can judge from this liew uncli more taconomical of time (nuking no uention of cost) it is than a drill, the best of wheh will not average more than ten acres per (lav.

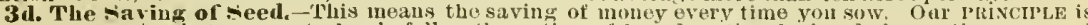
the correct oute in that we most closely follow the action of broad-castiur by land. by casting our sted

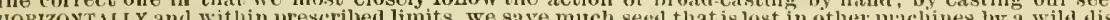
tributioul or by being blowon away by the wind.

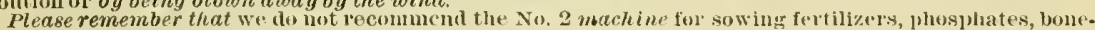
lust, ete. as it is too sullill for this puripose.

\section{FEW (HOOD WORDS FIROM RECENT ('TSTOMERS.}

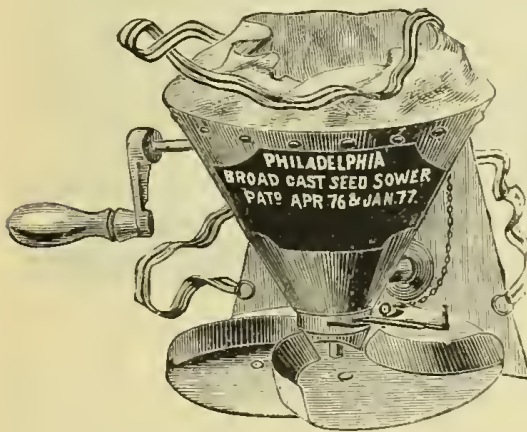

No. 2, or Hand Machine, Price $\$ 6.00$.

R. W. Fisk, Scio, Allegany Co., N. Y., writes: "It is the best sower that $I$ erer used. I pit in my spring erop and I think that I got one-third mores grain than when sowed by himd. I cleamed my seed well befor sowing and it ran tlurongh as if it hat been greased. womlit not he witheut it tor three times the cost."

H. Mion, Clay centre, Clay Co., kas, writes: " llke your sower very well. For a min like myself, who does not know much about land-sowing, it is the begt acquisition that lie call make"

S. K, Shmmaker, Dediville, Armstron $\mathrm{Co}, \mathrm{Pa}$, writes: "I like sect-sower very much for sowin thuothy and clover, I tlink it 'can't be beat." Mine loeks so even over the gronmd that I wenld not be without it test all it cost

IVith the No. 1 Machine we can sow the following with unifurmity: Wheat, 50 teet ; Oats, 40 foet ; Bar ley, 50 feet; clover, 40 fect; l3u+kwheat, 50 leet; Tim otliv, 35 tcil: Hye, 50 feet: Orchard (irass. 25 feet. No. 2 or liunc, more thin one-half the aboredistance.

There is no farmer who can afforld to bes without these sowers for anothire season. One party, after te'st. ing a yo. O Machine for hims.lf last spring, sold eight to his neighbors with satisfaction to all concerned. ("annot. we nake the same repert of you next year?

Price, No. 1, or Power Iachine, complete with all couplings (weight 101 lbs.), etc......\$30.00

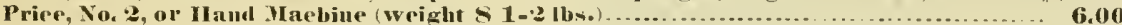

For further information, see Descriptive sord sown ("ireular, whield will be mailed free on application.

\section{RUHLMAN'S HAND CULTIVATOR.}

The Latest and best (Anden Weeder in Ises, and is the cheapest IIoc ever oflered to the l’ublie. One. Hau cau do as mucl, Wiork as Five. Yen withou it. It ean beset from 7 to 16 inclues in width, and is warranted to work to perfectiou.

This superior implement embrates the tour essential point s requisite for al successtul lant 'n tivator, vis: durability, simplieity of construction. thoroughness in work, anul perfection as a pliut pro. tector. It is especially alapted to the culture of all sarden crops (particularly onions), and nursely stock that leconize cale'nl liand enltivation in the *arly stages of their growth.

It is easily reculatel by set serews, as to the

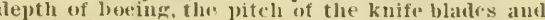
lieiglit of landles. It is casily workecl, aud cloes its work with it thoroughness that will satisfy all who try it.

The Frane and Whecl are mate of the fuest cast iron. The kuives are the best cast steed. They cut the weeds only on the inside of the knile. 80 that any pcrson can walk aloug within one-half an iuch witlont injurlng the smallest or tenderest jilut, which no otler Cultivalor (in tho. It will dlo the work of sis men witl is coumou lioe.

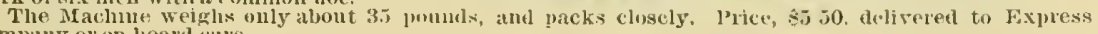
Company or on board cars.

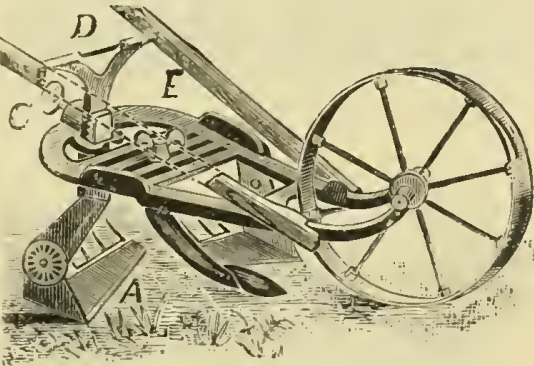




\section{THE PLANET JR. FARM AND GARDEN IMPLEMENTS.}

This is the most complete and popular line of goods we have ever sold, and althougli light and easy running. they are practical all-day tools, admirable in design, workmanship, material, aud finish, and iniversally acknowleilged to be the most perfect and reliable male, and every purchaser uust be delighted with the ease and rapidity with which they perform all that is promised, a really marvelous variety of work.

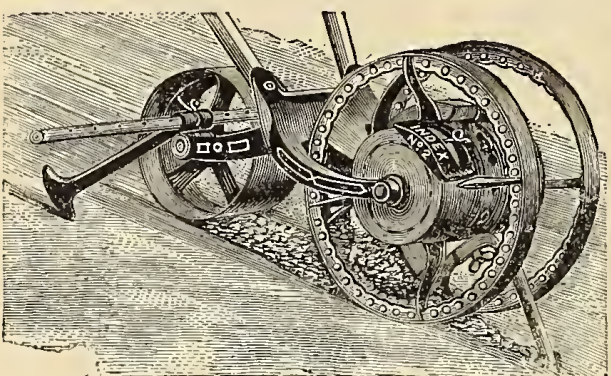

Fig. 1. As a Seed Drill. A complete descriptive Catalogue of these goods, illustrated with over 40 engravings showing the tools at work, and containing prac tical iustruction in the cultivation of gardeu and field crops, invaluable to beginner's and useful to every tiller of the soil, will be mailet free on application to us.

The Planet Jr. No. 2 Drill.

Holds 21/2 qts. It will sow witli equal ease and accuracy a single paper of seed or a ful hopper, covering evenly at any exact cepth, and will roll down and mark the next row perfectly, all at a single passage. It has no cams. levers, brushes, cooss springs, or shakers. It is noiscless automatic, self-cleaning and al is voays reliable. It is renarkable for simplicity strength, and beauty and fion of work in the thell. and eone having use for such a tool can afford to buy any without such adrantages : it is
latest improved and best

The Planet Jy'. Combined Drill, Wheel Hoe, Wheel Cultirator, and Wheel Plow.

This is the most popular machine we liave ever sold, and it is unrivaled in beauty of design, perfectiou of finislr, conveuience, aud capacity for work. It is suitable either for the Farm or Garden, anil, except the Planet $J i$, separate tools, has no cqual, either as a drill, or as a wheel hoe, eultivator, and plow.

As a Drill, it is exactly similar anc equal to the No. 2, except in size. It loolds one quar't. As a Plow, it opeus furrows, covers theu, liills, plows to and from, etc., etc. As a Hoe, it works safely and closely to and from both sides of the row at once, at tho eritical time wheu plants are smal and weeds abndiaut, or betwecn rows as plants become larger, working all rows from 8 to 16 iu. wide at one passage as a Cultivator it is ad mirably adapted to dcep mellowing of the soil. The blades are temperch and polished steel.

The Planet Jr. Double-wheel Hoe, Wheel Cultivator, and Wheel Plow.

Will do the work of from six to ten men with the common hand-hoe among market rardeu and

root crops, nursery stock, etc, and is especially adapted to onion culture. It is light, firm, strong. quickly set, and casily managed; cach one is sent ont with all the tools shown in the cut. All the blades are tempered and polished steel. The tool is light and graceful, made of the bcst material aud

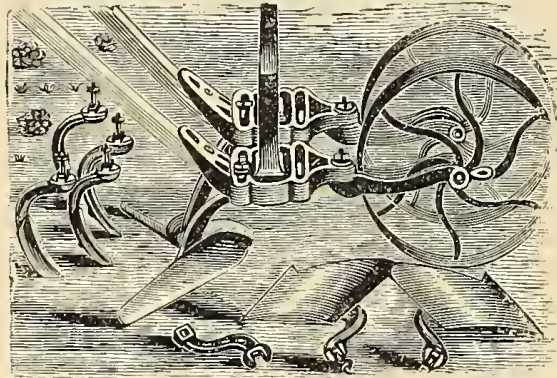

Fig. 3. As a Double Wheel Hoe.

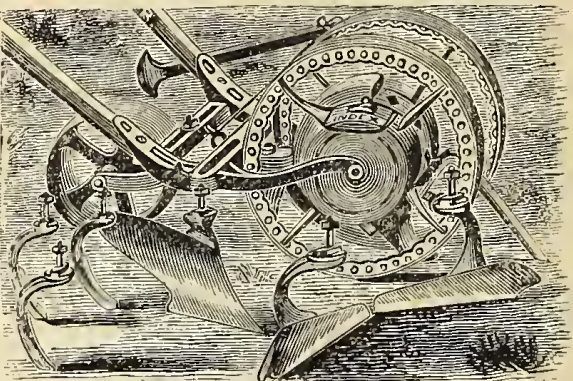

Fig. 2. As a Combined Machine. highly fiusher, and nothing can exced the per fectiou and variety of work it performs, nor equal the cun variety of work it perform

The Planet Jr. Single-wheel Hoe, Wheel Cultivator, and Wheel Plow Combined.

In improving this tool care has been taken to com bine extrcue lightuess, strength, varicty of tools, and great adjustability. It lias one pair of long, and one pair of short exchangeable hoes, a sct of three reversible cultivator teeth, and a steel garden plow. All the blades are temperer and polished steel This tool is pronounced by practical men as without an equal in beauty of lesign and finisly, case o operation quality of work and variety of adjustunent and in this improved form it is unquestion ably the lolitest runing the most convenient, and practical single-wheel Hoe known.

The Firefly Wheel Garden Plow

Makes the care of a vegetable garden a pleasure, and ten thousand families who conld not find time to keep a gardeu, if attempting its cultivation with the ordinary hand-hoe, can raise their own vegetable successfully with the Firefly.

Prices of Planct Jr. Goods, paelced ready for shipmcnt and delivered at express office or acpot.

No. 2 Drill. $\$ 12.00$

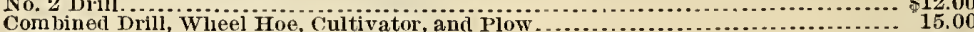

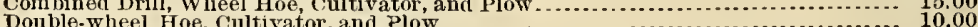

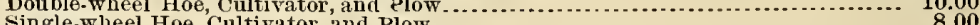

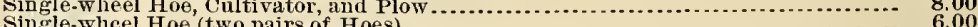

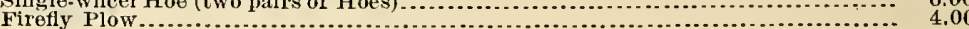




\section{COMSTOCK'S GARDENING IMPLEMENTS.}

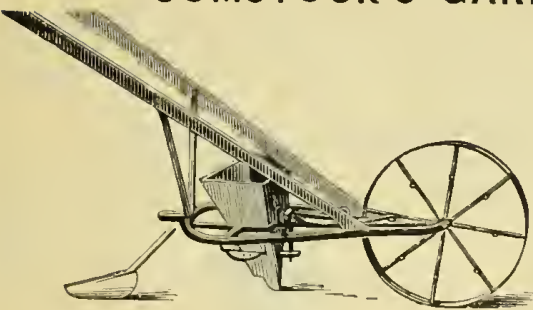

Seed Sower.

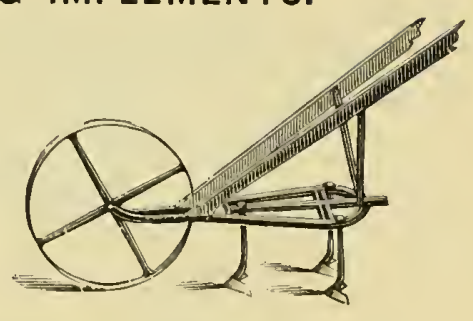

Cultivator

Comstock's Hand Cultivator and Onion Wecler Combined.-In the enltivation of onions,

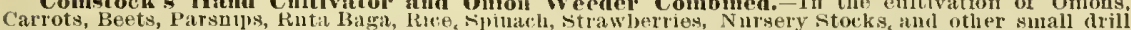
crops, this mplement will do the work of sisw witl hoes. It pulls the vechs and thorouglily pulverizes the soil: rnus close to tlie rows, anl takes out all the the eath up to or away from the rows. It is raslily adjusted to cloan the splice between rows from six to the en inches a part at one passagn. Price, $\$ 7.00$.

Comstock's jeel sower. $\$ 3.00$.

Comstoek's Feed fiower, IIund Cultivator, and IVeeder Combined. -Tlis is a new and perfect small seed Sower, combined with the cultivator ind Wverter, and cau bo separated or attached in five mintes. It sows Beet, Parsnip, and other difficnlt sceds which ean bo sown with any Seeder, with the groatest regnlarity, and is esperially anlapted to sowing Onion at the rate of four, tive, or six ponuls to the acre. By revolving the disk, which is lobll in place by a spring, it can be changed instantly to sow thick or thin, withont removing the seen from the hopper. Price, \$12.00.

Hopper and Cover to make a sied Sower of a Cnitivator, s5.00. Set of two rakes and three teeth to make a Cultivator and Weeder of a Seed Sower, 83.75 . Wherel and Knife to be fixed to the Cintivator to make a strawberry Rumner Cutter, $\$ 2.00$. Estra teetn aud rakes less than a set, cach $\$ 1.00$. Verge 01 Turf Cutter, $\$ 1.25$. Mole I'low, 75 cents.

\section{COMSTOCK'S TURF CUTTER, EDG- ING KNIFE, AND SCUFFLE HOE.}

(All in one.)

By thrusting into the sol with slıol, (1uick, and strong strokes, it will cut ont ribbous of turf of nniform width and thickness truer and taster than aty implement uvented. It is used for enting the elges of walks a th borters, and scraping and cleaming alleys in lawus and garbens, and as a Hand Cultivator in weeding. It will lo the work of lialf a dozen men. A nseful accoupaninent to a lawn Mower. Price, \$5.00.

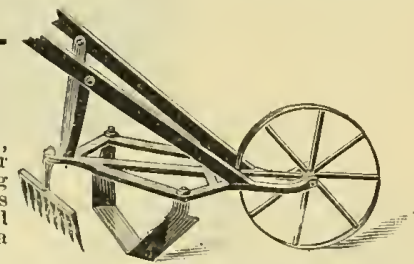

Circnlars giving a crops, will be malled to all applicants.

\section{THE "GEM" OF THE GARDEN,}

Inand Wheel IIoe and Cultivator.

As lately improved, this implement is the most etfective and eonvenient tool of the kind yet invented. The working parts are

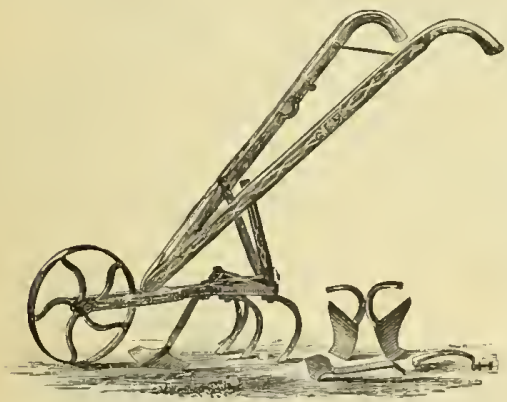
2 scufle or Cntting Blades, one $4 \frac{1}{2}$, and one 9 inclies wille. 2 Plows, ri $y$ ht and left hand.
5 stirring Teeth. $\left\{\begin{array}{l}\text { steel. } \\ \text { stester }\end{array}\right.$

The wheels and lindles are adjustable in lieight. while the frame is so slotted that the loces, teeth, and plows ean be set in almost any position or angle.

The scufle hoe makes a clean cut and is followed by the teetl - five or less - which thoronglily pulverize the the teethe lioe. soil, amt diag ont roots of the whot tlirow ilit enongi Being of sllch slender shape loes are of thin stecl, and to cover small plants. The hoes are of thin sted, and present nearly it straight line to the work, and the avold tle "lod ging" so cormmon to thols of this kint.

Uver five linulled of these machines have been solit ruring the past three years, to the greatest satisfaction of buyers. Many lave said tlat they would not he with. out it for double the cost, and all acree that it is by tar the cheapest and best artirlo of tho kiul mate.

are It is always golil with the privilege ot let urning if not (antircly satisfactory, Price, boxed, \$5.00.

\section{BRYANT'S IMPROVED PLANT PROTECTOR.}

The nues of the Plant Protectors are three-fold:-First, against insects; secoml, against early frosts; third, against the colld winds so fatal to tender

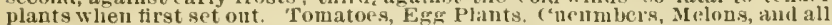
veretables of a tender nature, can bo forwarded au? unre safely grown by the vegetables of a tender nature, can bo forwarien and ninre safely grown by the of annnal thower seeds, cau be raised by being covered with them. Price, of annual tlowe

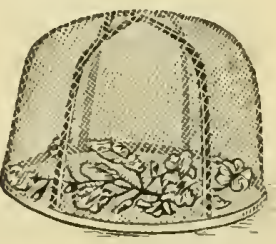




\section{PLANT STAKES.}

For neatness and durability these are the best Plant stakes marle, for supporting such plants as the Tuberose, Fuchsia, Gladiolus, Carnation, etc. The roumd ones are neatly turued, painted green, and taper. ing to the top, and have an airy and ornamental appearance. The square ones are of a lieavier make, painted green, and though less elegant, are very useful for staking strong plants.

\begin{tabular}{|c|c|c|c|c|c|c|c|}
\hline \multicolumn{4}{|c|}{ ROUND PLANT STAKES. } & \multicolumn{4}{|c|}{ SQUARE PLANT STAKES. } \\
\hline 2 feet long & $\begin{array}{r}\text { Each. } \\
\ldots \$ 0.03\end{array}$ & $\begin{array}{l}\text { Doz. } \\
\$ 0.30\end{array}$ & $\begin{array}{l}\text { Hund. } \\
\$ 2.00\end{array}$ & 2 feet long & $\begin{array}{r}\text { Each, } \\
\$ 0.04\end{array}$ & $\begin{array}{c}D o z . \\
80.40\end{array}$ & $\begin{array}{l}\text { Hund. } \\
\$ 2.50\end{array}$ \\
\hline 160 & $\ldots .05$ & .50 & 4.00 & 3 " & .06 & .60 & 4.00 \\
\hline “ & $\ldots \quad .08$ & .70 & 6.00 & 4 & .07 & .70 & 5.00 \\
\hline ." & .......... 10 & 1.00 & 7.00 & $\overline{5}$ & .... .08 & .80 & 6.00 \\
\hline “ & …....... 15 & 1.50 & 10.00 & 6 & 10.............. & 1.10 & 8.00 \\
\hline
\end{tabular}

\section{PLANT AND TREE LABELS (Wood).}

列

Pot or Plant, $51 /$ incles

Pot or Plant, 6 inches long......................................................... $\quad .30 \quad 2.00$

Garden or Nursery, 12 inches long............................................... $\quad .75 \quad 6.00$

Tree, notched or pierced, 4 inches long ......................................... $\quad .20 \quad 1.25$

WOLFF'S MARKING INK PENCILS.-Black, Blue, or Red.--The cheapest made for producing an indelible mark upon wood labels for garden purposes. Price 20 cents each.

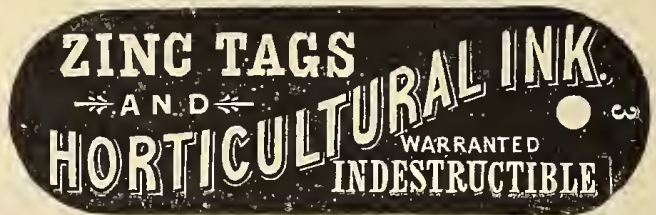

FOR GARDEN, GREENHOUSE, AND OTHER PURPOSES.

These tags will be found far more economical than the common wooden ones, and are a useful and neat appendage to Plants, Trees, \&c. The ink, when used with a clean quill or other pen, marks a jet black, and weather or time has no effect on the writing. The marking may be erased by Emery paper, and the name on the tag ehanged as may be desired. Tags (in four sizes), 10, 15, 20, and 30 cents per dozen. Ink, 50 cents per bottle. Boxes containing 4 dozen Tags, 1 dozen each size, a pen, 1 bottle of ink, 5 dozen plated wires, and emery paper. Price $\$ 1.00$.

Either size Tag may be had separate, by the gross, hundred, or thousand.

Galvanized Wire Verbena Pins.-Largely used for pegging down Verbenas, \&c.; also for layering C'arnations, Picotees, \&c. Per box'(1 gross), $\$ 1.00$.

\section{PATENT INSOLUBLE METALLIC CARD LABELS, FOR ROSE TREES, FRUIT TREES, SHRUBS, \&.}

These Labels are insoluble in water of any temperature. They can be written upon with any good ordinary black ink (do not use copying ink, as it spreads when exposed to rain), such writing, eveu after long exposure to the weather, being clear and distinct. They may be used either as a tree or suspending label, or for insertion in the soil. When ordering, state for which purpose intended. Price $\$ 1.25$ per hundred.

Waterproof Twine, for using with the above or other labels, in packets of 100 ties. Thin, per pkt., 35 cents; thick, per pkt., 40 cents.

\section{SULPHUR BELLOWS.}

Or Floral and Vintage Flour of Sulphur Duster.

For the Extermination of Bugs, Worms, and all IXsECTs; likewise MILDEW UPON GRAPE VINES. By the use of this implement the Flontr of Sulphur can be evenly distributed over every part of the affected plant. Price, \$2.50.
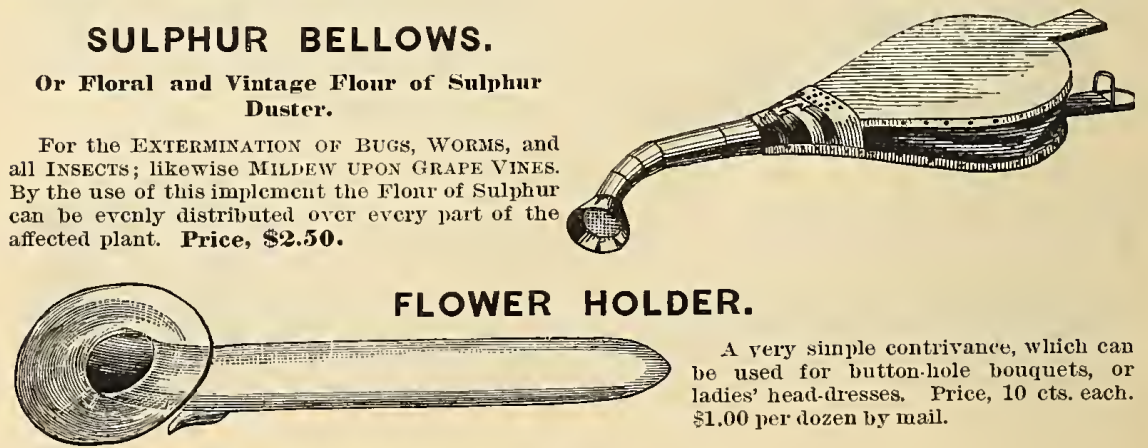

A very sinple contrivance, wlich can e used for button-liole bouquets, or ladies' head-dresses. Price, $10 \mathrm{cts}$. each. $\$ 1.00$ per dozen by mail. 



\section{THE DAVIS LAWN RAKE.}

Made in the most thorough manner, of the best material, best quality of Spring Steel Teeth.

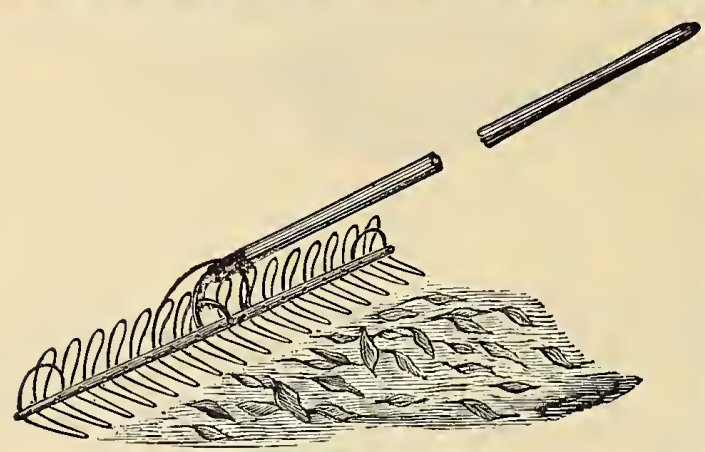

A Perfect I MPlement for Cleantng LaWNG FROM LEAVES, GRASS, AND ALL KINDS OF RUBBISH, AND THE ONLY ONE THAT WILL

DO IT WITHOUT INJURING THE GRASS AND ROOTS.

Will level and prepare a garden bed for the seed better and quicker than any other tool. Will clean a race track per. fectly. Just the thing for ladies wishing open air exercise. A man with one will do tho work of six or eight men in a superior manner. The work is light and casy, as the rake is drawn over the ground instead of being carried. Landscape gardeners will use no other after trying this. Grass will grow faster and look mnch better after being combed a fow times with the Rake.

It requires many years of great care to prodnco a fine Lawn, which may be injured and perhaps ruined in a short time by using common rakes. Price, $\$ 1.00$.

\section{BATES'S FOLDING PLANT PROTECTOR.}

This simple arrangemeut not only protects from bugs, borers, and fowl, but subdues all violence of wind, rain, and cold; keepiug off light frosts, and facilitating the growth of young plants in a wonderful degree. Adting to all this their durability, portability, and cleapness, the purchaser will find he lhas made a good investment. They fold liko an umbrella, and one dozen will make a package four inches square and twenty-two inches long. When open they cover nineteen inches square. With fair usago they will last ten years, for they are made of durable uetting, firmly fastened between two closely fitting pieces of wood, with tinned tacks securely clenched. Price, 15 cents each ; $\$ 1.50$ per dozen.

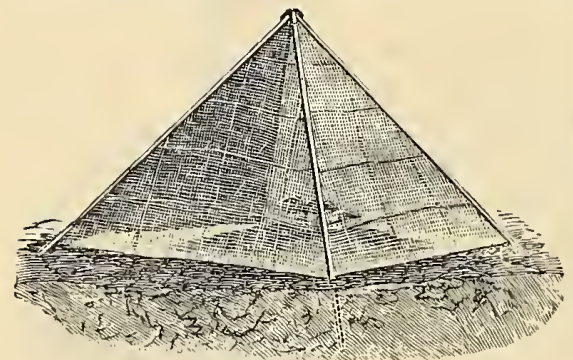

Plant Protector.

\section{REVOLVING LAWN AND GARDEN SPRINKLER.}

The "Perfection" is warranted by the inventors to accomplish as much as any sprinkler in the market, at the same pressure. Its superiority is shown by its simplicity, ease with which it can be cleared of any obstructions, and effectiveness while working in a strong wind. The circle watered can be reduced to any desired size by turning the supply partly off. By its simple construction, it can be used witl equal facility on lill-side or terrace. In connection with a force-pump, it can be used with good cffect in greenhouses, hot-beds, etc. The bearings and working parts are made of brass, and it is complete in itself; has only to be screwed to the hose, aud the pin stuck in the ground to be used.

Price, \$1.25. By mail, $\$ 1.40$.

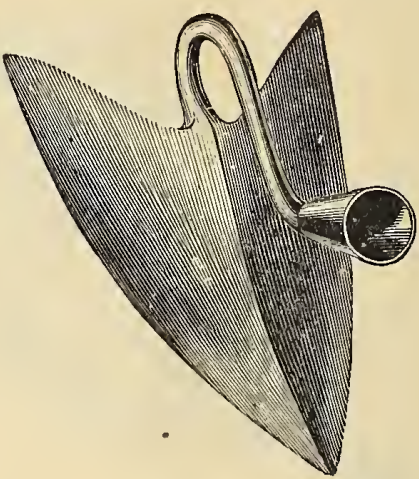

Warren Hoe.

THE WARREN HOE.

It is perfectly adapted for Field, Nursery, or It is pard is superior to any other Hoe at all work cast-steel, and warranted not to break with the old Hoe.

Prices.-No. 1, Ladies' and Garden Hoe, $\$ 1.00$ each; No. 2, Garden and Field Hoe, \$1.25 each, No. 3, Field Hoe, $\$ 1.25$ each.

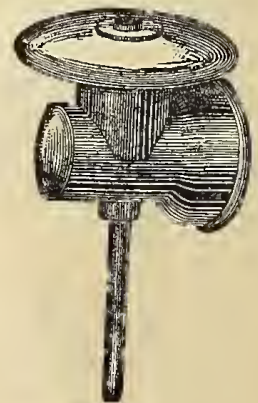

Perfection Sprinkler. 


\section{WATERS'S IMPROVED TREE-PRUNER.}

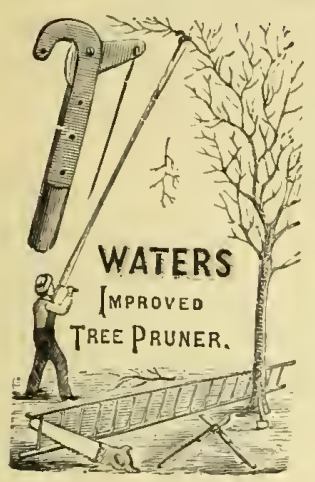

The Waters Improved Tree-Pruner is by far the best instrument for the purpose in view that has yet becu invented.

The following are some of its alvantages:

First.-The peenliar construetion of the hook that encireles the limb, the support of the blade being upon botls sides, whieh is very important, allow. ing the blate to be made very thin, thereliy relueing the resistanee of the wook, and making an easier and smoother cut than any other alevice.

Seconit.-Tho knifo being eomeeted by a rod, the pole may be of any desired length, thus requiring no ladder or climbing.

Third.-The small space required for working the knife allows it to be useil among elose, dense branelies, where great difficnlty is fonnt in using the old-fashioned shcars.

For pruning Raspbery, Bluckberry, and Rose Busbes it has proved peculiarly serviceable.

For removing worms' nests, and thinning ont fruits, it is rery desirable, and cau bo used as a fruit-pieker.

Length of pole, 4 feet; weight, $2 \frac{1}{4}$ lbs............................ $\$ 2.00$

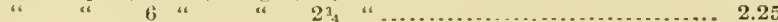

".

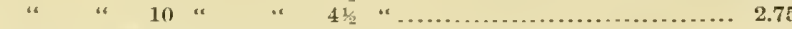

Extra Knives, each _..................... 0.30

Extra Knives, per dozen....................................... 3.50

\section{AMERICAN PRUNING SHEARS.}

Wiss Ameriean Pruning Shear will be foun the most desirable as well as most durable made. In fonr sizes: $7 \frac{1}{3}$ in., $\$ 1.75 ; 8$ in., $82.00 ; 8 \frac{1}{i l l}$. $\$ 2.25 ; 9$ in., $\$ 2.50$.

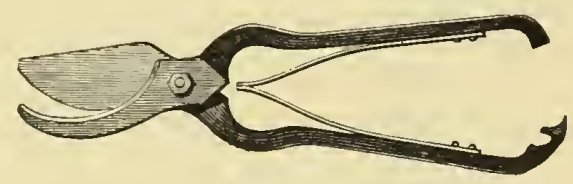

\section{WISS TREE-PRUNING SHEARS.}

These shears are attached to a pole, and operated ly means of a lever, moved by a eord and pulley. It enables a person standing on the gromnel to prune trees, somes of the branches of which eonld not, perltaps, be as well firmed by any other instrmment. Branches of ono ineh and a half in tianeter maty be easily fut oft with this instrument. l'rice, without handle, 82.50 , hy mail, 83.00

\section{THE O. G. PRUNER.}

This is an improved hand-pruner of the Freneh pattern, but English make. They are strong and lurable, and make a elean ent. We have three sizes, 6,7 , ant 8 in., whicli we offer at $\$ 1.75,82.25,82.50$ by mail, 25 cents each extra.

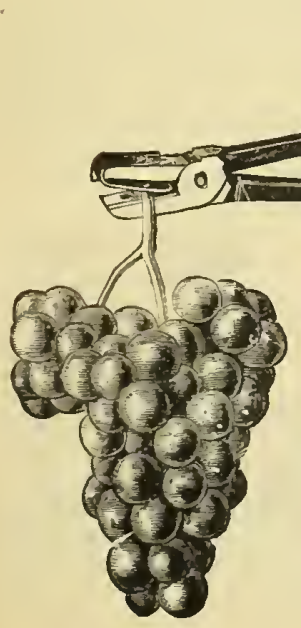

\section{WEEK'S ( RRAPE, FRUIT, AND FLOWER} PICKEIR.

VALENTINE'S PAT., AUG, 1, 1865

This eut represents one of the most nsefn artieles of its kint yet invented, which supplies a want that has long becn felt. Every one engaged in picking fruit knows the diffieul ty of detaehing the fruit from the braneh and depositing it in the basket or other reecptacle for receiving it withont brnising the fruit, and partieularly witl Grapes, for unless tery great care is exereised, eael bunel will be more or less injuret. The tool is a pair of shears so inrauged with a strel spring holdfast that the stem is ent and held so that the fruit ean be deposited in the receptaele for receiving it without toucbing it with the hants.

It will take the smallest ehery, or hold a bunch of grapes weighing five pounts.

Fur pieking oranges, where the branches are full of thorns, it will save many a hart work.

For large pears and ehoice frnit of any kint, it is an invaluable assistant. Priee 75 eents; loy mail, 85 eents.

The No. 2, or smallest size, is partieularly adapted fol-Flowers, and will be fonnd an invaluable assistant in the (iarden or Hot-honse. Price 50 cents ; by inail, 60 eents. 


\section{LAWN MOWERS.}

\section{IMPROVED EXCELSIOR LAWN MOWERS.}

The side-Wheel Mower possesses many important advantages over other mowers of this pattern. Its self-cleaning gear cannot clog. It is noiseless in its operations. Its improved ratchet has no spring to get out of ordor. It is the lightest and best side-wheel mower.

The Roller Mower is well known to the pnblic. It is lighter in draft. It cuts the borders better. It leaves the lawn smoother, and does better work than any other roller mower:

\begin{tabular}{|c|c|c|c|}
\hline \multicolumn{2}{|r|}{ SIDE-WHEEL MOWERS. } & \multicolumn{2}{|r|}{ ROLLLR MOWEISS. } \\
\hline 12 " & - 15.00 & $\begin{array}{l}10 \text { inch } \\
12\end{array}$ & 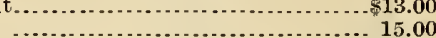 \\
\hline 14 & 17.00 & 14 & .. 17.00 \\
\hline & ... 19.00 & 16 & 19.00 \\
\hline & .. 21.00 & 18 & 21.00 \\
\hline & .23 .00 & 20 & 23.00 \\
\hline
\end{tabular}

Our Horse Mower is the best one mannfactnred. Its sectional caster wlieels do not roll down the standing grass nor leave marks on the lawn. Its side-draft attachment (which is furmished with the three larger sized mowers) allows the horse to walk only on the cnt grass. Every mower fully gnaranteed A trial is solicited.

25 inch cut, withont seat or shafts......... $\$ 65.00 \mid 35$ inch cnt, witl seat and silafts ...........\$135.00 30 " with scat and shafts............. 110.00 40 " $1100 . .170 .00$

The 25 inch Mower is furnished with shafts when desired. Price $\$ 10.00$. Horse Boots, per set, $\$ 12.00$. Full directions for setting-up, adjusting, and using accompany each mower.

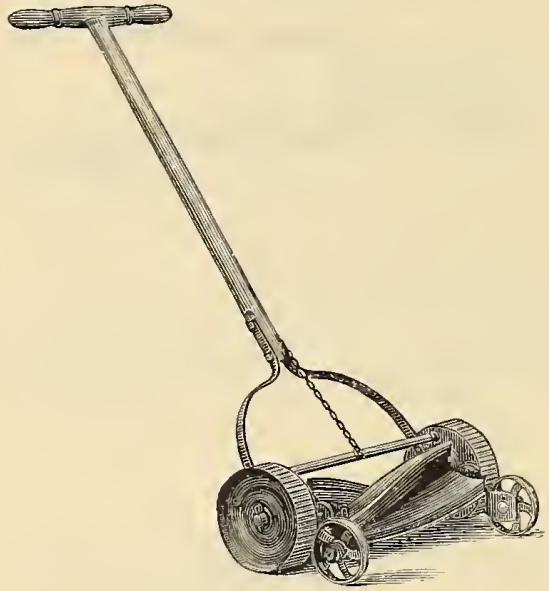

\section{THE DAISY LAWN MOWER. \\ EVERY MACHINE UNCONDITIONATHY WARRANTED.}

'The best, the simplest in construction, finest finish, the cheapest, handsomest, and most durable side. wheel mower in the market. Interchangeable in all its parts. Every Machine unconditionally warranted. It has an adjustablo vibrating handle, and is perfectly adapted for cntting Terraces, Slopes, and every variety of Lawn.

\section{AT REDUCEn PRICEs.}

Everybody can now afford to buy a Lawn Mower. Manufactured in four sizes for hand use, as follows :

12 inch . . . . . . . . . . . . . . . . . . . . . . . . . $\$ 11.00$

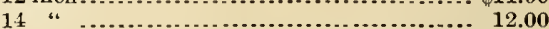

16 "

18

\section{PHILADELPHIA LAWN MOWERS.}

The Pliladelphia is not a new Lawn Mower, bnt several recent improvements, together with its simplicity of construction and lightness, have deservedly made it a general favorite.

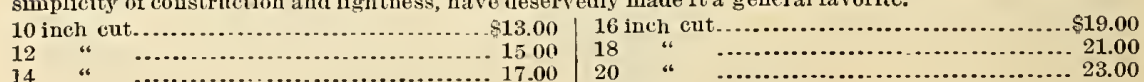

\section{CHARTER OAK LAWN MOWER.}

Emphatically oue of the best and most beantiful Lawn Mowers in the World.

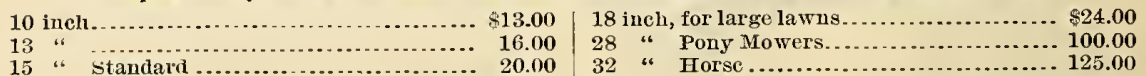

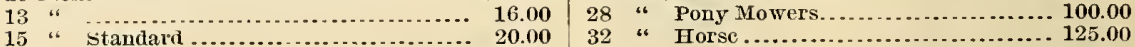

\section{GARDEN ROLLERS. \\ WEIGITS KEEP HANDLE ERECT.}

\begin{tabular}{|c|c|c|c|c|c|c|c|c|}
\hline 1. & 12 & " & 20 & “. & " & " & $140^{\prime \prime}$ & -10.00 \\
\hline 1 “ & 20 & *. & 20 & " & “ & “. & 220 “ & $\ldots .14 .00$ \\
\hline 2 “ & 12 & “ & 20 & $\bullet$ & " & " & $300 "$ & -18.00 \\
\hline $3 *$ & 12 & “ & 20 & " & “ & “ & $450^{\prime \prime}$ & -25.00 \\
\hline 1 “ & 12 & " & 24 & “ & “ & “ & $200 "$ & .13 .00 \\
\hline 2 “ & 12 & “ & 24 & “ & “ & “ & $400^{\prime \prime}$ & 22.00 \\
\hline 1 “ & 12 & “ & 28 & “ & “ & " & $250 " *$ & 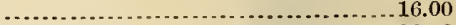 \\
\hline $2 \cdots$ & 12 & " & 28 & 4 & “ & “ & $500 *$ & (2, \\
\hline “ & 12 & " & 28 & “ & “ & “ & $700 ،$ & $6 n^{2}$ \\
\hline
\end{tabular}

We decluct for weights, when not wanted, from $\$ 2.00$ to $\$ 5.00$. 


\section{WOODWARD'S MEDICATED NEST EGGS.}

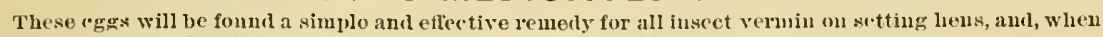

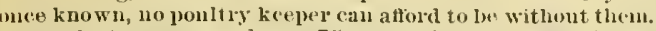

Each, 8 cents; per dozen, 75 cents. By mail, each, 15 couts : per (tozc'11, \$1.25.
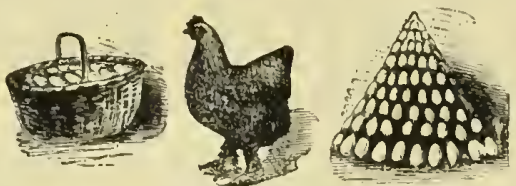

[Trade Mark.]

\section{IMPERIAL EGG FOOD.}

For all Vurietien of Poultry: Taying IIens, Voung Chicks, Mucks, and Turkeys.

WILI, MAKE YOUIR II ENS IA Y.

From all parts of the country, evilenco of tho remarkablo properties of Iminua, EgG Foov las been reeeived. The condition of the fow $1 \mathrm{~g}$ is so improver, and egg prouluction so increased, in winter as well as summer, that prultry breome tho most pofitablo stock on the farm. It is estinated that one-half tho chicks and turkeys annually hatehed dis beforo reaching maturity. When tho IMPERIA, EGG FOOD is fed according to direetions, slck and dropling chieks will nerer bo seen. It supplies all tho nected material for forming bone, muscle, and feuthcrs, and, by its gentle tonic eftect, strengthens tho digestivo organs and lays the foundation for vigorous, healthy, and thereforo profitable, fowls. Tbey will also bo fitterl for mar. ket a month earlier thau by common treatment. Plices, per mail, 50 couts and $\$ 1.00$ per package. Por express, 50 cents per lb.; 2 lbs. for $\$ 1.00 ; 6$ llus. for $\$ 2.00 ; 2511$ ). kegs for $\$ 6.25$.

\section{FOR THE DESTRUCTION OF INSECTS, Etc.}

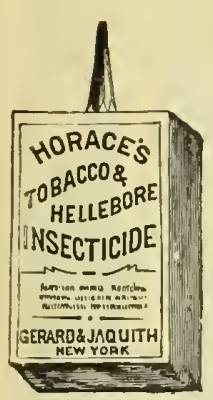

HORACE'S TOBACCO AND IIELLEBORE INSECTICHDE.

In I'atent Bellows Box, for Rose Bugs, Aphis, and Plant-Infecting Insects.

IIORACE'S PERSIAN INSECT POWDEIR.

In Patcnt Bellows Box, for Ants, Croton Bugs, Bed-Bugs, F'leas, and Lice on Animals and House?loli P'csts.

Theso Powders liave both a well.established reputation as being very effective and as non-poisonous to animal lite. Their cffieiency depouding largely on being applied in fine dust, the very clurable Bellows will be found a mosi useful and effective addition. It may bo refilled.

Irice, complete, 25 ccnts cach ; $\$ 2.25$ per azen.

Jacques' Sapo Tabacnm, or Tobacco Sonp.-A nniversal remedy for the pests of tho gardens and nurseries, ete. Tho most couvenicut, elseap, aud potent specific for the destruetion of insects, jarasites, and their eggs, infesting plants. Also, an efficient specitic for the destruction of ticks and other parasitic vermin on sheep and domestleated animals. Price, 40 cents per lb; five pounds for \$1.75. 13y mail, 16 cents per pound exirn.

Gishnrst Compound.-An English preparation, higlily recommended for preventing and testroying RED SPIDERS, SCALE, MEALY BUg, THRLP, GREEN AND BRown Fly, ete.; also, for wiuter diressing and washing walls, frames and sashes of grcenbouses. Price, per box, $\$ 1.00$; by mail, $\$ 1.20$.

Whale Oil Soap.-For preserving Plants, Flowering Shrubs, Vines, and particularly Rose Bushes from the destructive effects of Slugs, Grub Worms, etc, 2 lbs., 35 cents; 5 lbs., 80 cents; 10 lbw., 81.50. By mail, 16 cents per lb. extra. Tin syringes, for apulying the above, $\$ 1.00 ; 13 r i s 8$ Syringeg, \$2.00 to \$9.00.

\section{SELF-HEATING SOLDERING IRON.}

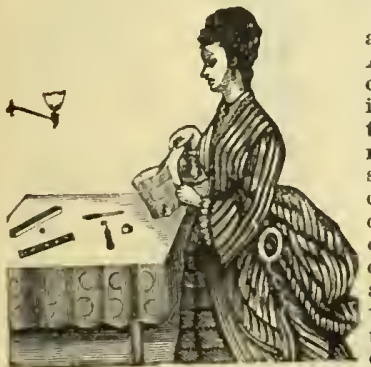

EFery lionsekceper shonld lav'o a Gem Soldering Casket, as it contains all the implemcuts necessary to mako overy person their owu tiusmith. An economical person can seo at a glanco tbat from ten to twenty-five cents can be saved, and tio annoyauce of learing tbeir bouso (just when in want of using a vessel they lhavo diseovered that it leaks) to find a tinsmith, perliaps on a roof, or too busy just then to attend to jobbing; it may bo that his firo is out, and it wouli causo him timo and troublo for so small a fob; leneo tho Gem comes in jlay, and its valuo is unprecodented in every louselıold. This littlo Gem pays for itself in soldering ono dozen fruit cans, and doos away with tbo inconvenienco of carrying cans full of lot fruit or vogetables to tho tinsmith's to havo them soldered, of tho annoyanco of waiting for tho tiusmith to como to tho honso and solder up tho cans. It is also very uscful in opening fruit cans, as it will open them instantly, by simply leatiug tho iron and rubbing it over tho soldered top, and thereforo preserving tho can for fnture uso. The Casket contalng a Self-Heating Soldering Iron, Seraper for cleaning place to be soldered, a Bar of Solder, and a Bottlo of Soldering Salts. Whero tbere is no gas tbo irou can be heated in the stovo. Price, \$1.00. Isy mail, \$1.16. 


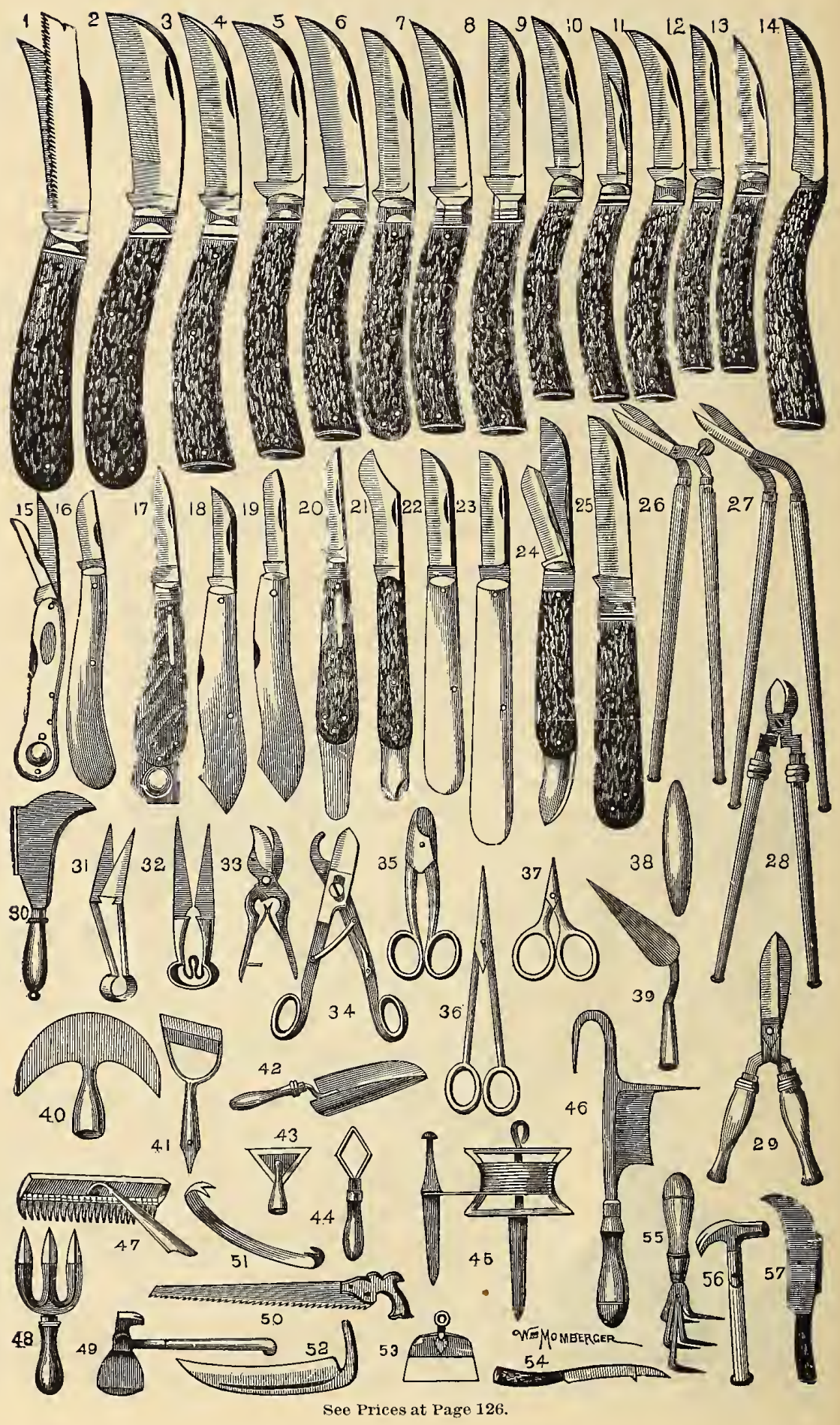




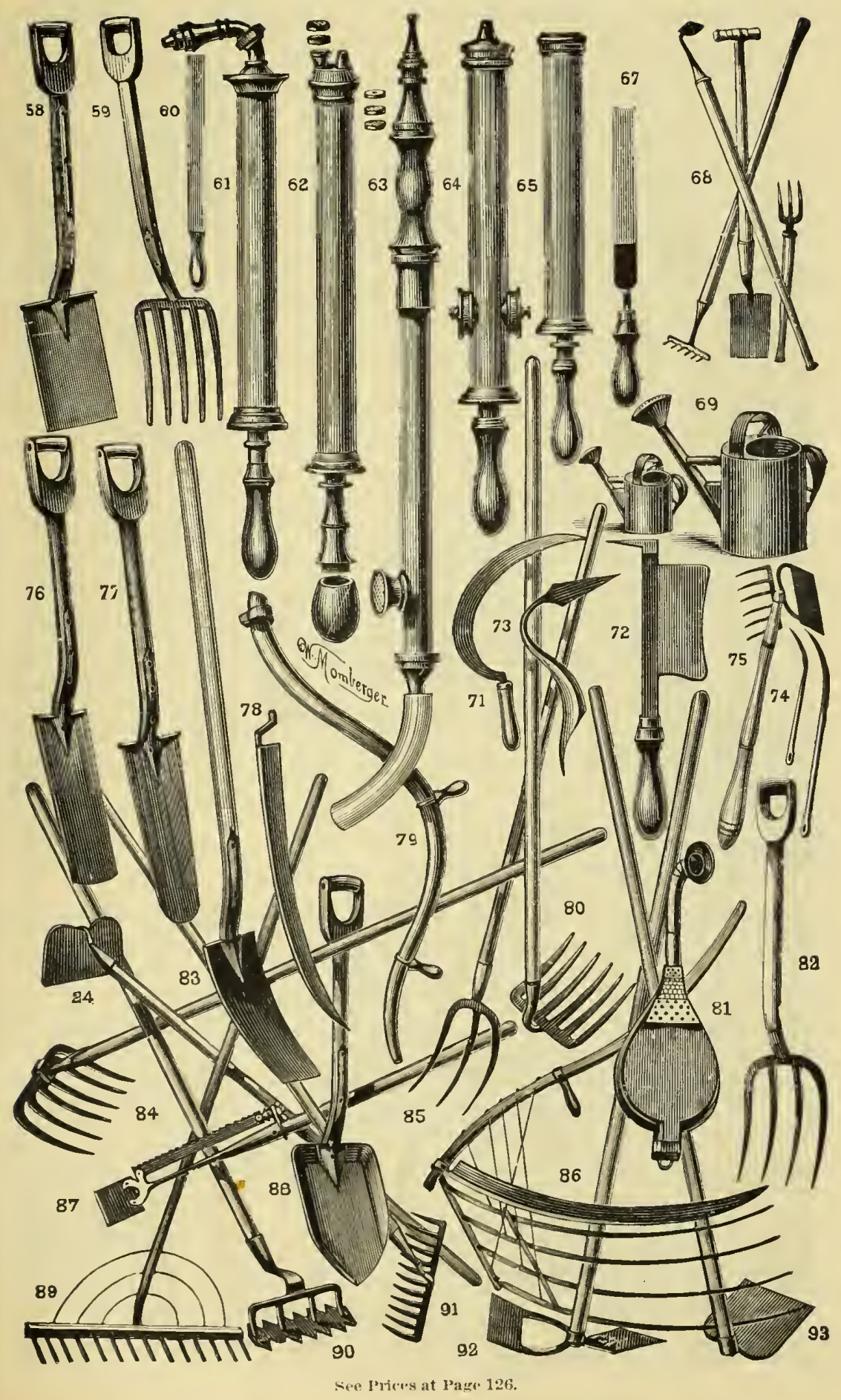




\section{GARDEN AND HORTICULTURAL IMPLEMENTS.}

From the Best English and American Manufacturers. See Illustrations on pages $126 \& 12 \%$. No.

1-Pruning Knife, with saw (Saynor's)

2-Pruning Knives.-(Saynor's) \$1.25; No. 3, \$1.25; No. 4, \$1.25; No. 5, \$1.00; No. 6, 75 cents; No. 7 , 1.25 ; No. $8, \$ 1.25$; No. $9, \$ 1.25$; No. $10, \$ 1.75$; No. $11, \$ 1.00 ;$ No. 12 , $\$ 1.00$; No. $13, \$ 1.00 ;$ No. $14, \$ 1.00 ;$ No. 25,75 cents.

15-Budding Knives.-(Saynor's) No. $15 . \$ 2.00$; No. $16, \$ 1.25 ;$ No. $17, \$ 1.25 ;$ No. 18 , $\$ 1.00$; No. 19, $\$ 1.00 ;$ No. $20, \$ 1.75$; No. 21 , $\$ 1.75 ;$ No. $22, \$ 1.25$; No. $23, \$ 1.25 ;$ No. 24 , $\$ 2.00$.

Pruning and Rudding Knives of similar patterns, from other manufacturers...

26-Border or Grass Shears, with wheel, 8-inch, $\$ 2.50 ; 9$-inch, $\$ 3.00 ; 10$-inch, $\$ 3.50$.

27-Border Shears, 8-inch, $\$ 2.00$; 9-inch, $\$ 2.50 ; 10$-inch, $\$ 3.00$.

28-Branch or Topping Pruning Shears, tliree sizcs, $\$ 2.00$, $\$ 3.00$ and $\$ 4.00$.

29-Hedge and Garden Shears, 53/2-incl (ladies), $\$ 1.50 ; 8$-inch, $\$ 1.25 ; 9$-inch, $\$ 1.50$; 10 -inch, $\$ 2.00$; 12-inch; $\$ 3.00$; notched, 25 cents extra.

30-Garden Bilh Hooks, for pruning with one hand.....................................

31-Spring Grass Shears, for edging

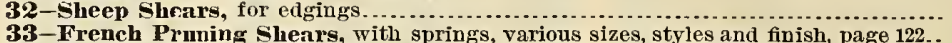

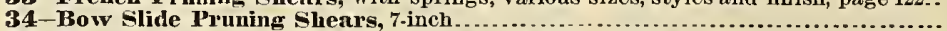

35-Pruning Seissors, with bows, three sizes, $\$ 1.00, \$ 1.25$ and $\$ 1.50$.

36-Grape Scissors, 6 .inch, $\$ 1.00 ; 7$-inch, $\$ 1.25$.

37-Propagating Scissors.

38 -Scotch Scytle Stones, 25 cents each; $\$ 2.50$ per dozen.

40-Grass Plot Elging Knives, cast steel (Saynor's), 8-inch, $\$ 1.25 ; 9$-inch, $\$ 1.50$; 10-inch, $\$ 2.00$.

41-Dutch or Scufle Hoes (Saynor's), 4-incl, 35 cents ; 5 -inch, 45 ; 6 -inch, 85 ; 7 -inch, 60 ; 8-inch, 70 ; 9-inch, 80 ; 10-inch, 90 .

42-English Transplauting Trowels, blued steel, 6-inch, 75 cents; 7-inch, $\$ 1.00$; 8-inch, 1.25 .

Similar pattern of American manufacture, 6-inch, 25 cents; 7-inch, 35; 8-inch, 50.

43-Triangular Hoes, used also for Tree Scrapers, 5-inch, 50 cents; 6-inch, 60; 7 -inch, 75 .

44-Noyes' Garden Weeder.

45-Gaiden Reels, with stakes ; English, 8-inch, \$1.00; 10-inch, $\$ 1.25$. Similar patterns of American manufacture.

47-English Lawn Rakes, 16 -inch, $\$ 2.50$; 20-inch, $\$ 3.00 ; 24$-inch, $\$ 3.50$.

48-Ladies' Blue Weeding Forks, English .

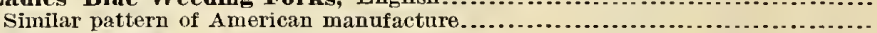

49-Claw Hatchets.

50-Pruming Saws, 14-inch, 75 cents; 16 -inch, $\$ 1.00 ; 18$-inch, $\$ 1.25 ; 20$-inch, $\$ 1.50$.

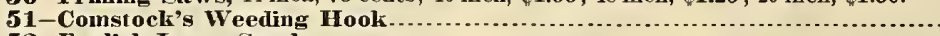

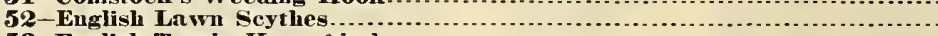

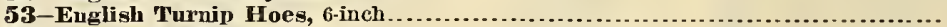

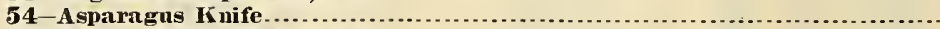

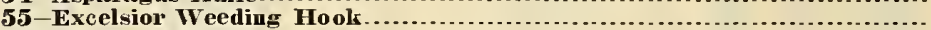

56-Garden Hammers. . . . . .

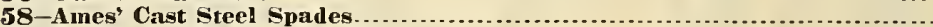

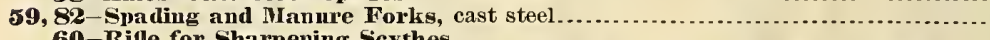

60-Rille for Sharpening Scythes-

61-Brass Syringe, $\$ 7.50$; No. $62, \$ 7.00$; No. $04, \$ 7.00$ and $\$ 4.25$; No. $65, \$ 2.75$; unpolished, $\$ 2.50$ and $\$ 2.00$.

63-Fonntain Pump, brass, with three feet of hose..................................

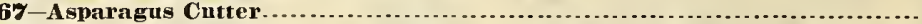

68-Ladics' and Children's Gardeu Sets (4 pieces), according to size and finish, $\$ 1.25, \$ 2.00$, and $\$ 3.50$.

69-Tin Water Pots, painted green, from 2 to 16 quarts

71-Grass Hoolss or Sickles, English, three sizes, 50 cents, 75, and $\$ 1.00$.

72-Grafting Chisel

74-Sacking Needles

75-Ladies' Floral Rake and Hoe

76-Post Hole Spade, Ames' Cast Steel

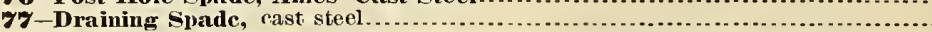

78 -Scythes of various patterns and mannfactures

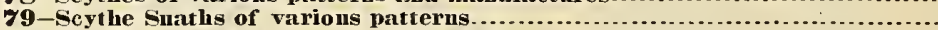

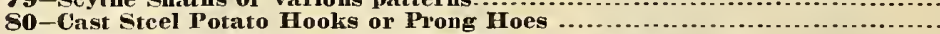

81-Sulphur Bellows, for preventing mildew, see page 124 .

83 -Spades and Shovels, long handles, Ames' and others........................

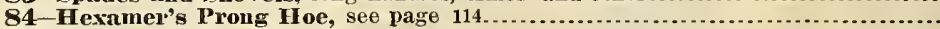

85-Hay or Mauure Forks.

86-Grain Cradles

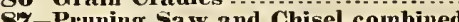

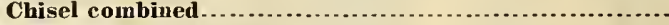

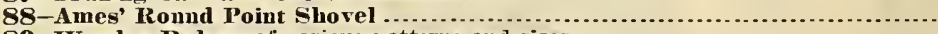

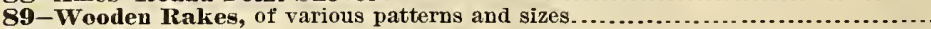

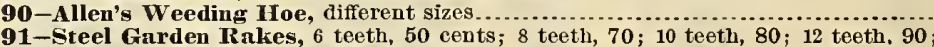

91-Steel Garden Rakes, 6 teeth, 50 cents; 8 teeth,
14 teeth, $\$ 1.00 ; 16$ teeth, $\$ 1.25 ; 20$ teeth, $\$ 1.50$.

92-Weeding Hoe, old pattern

1.50 to 2.00

1.25

1.25

2.50 to 4.25

3.00

1.25

.75 to 1.25

.40 to $\begin{array}{r}.75 \\ .50\end{array}$

1.25

.50

1.25 to 2.00

.50

.75

.30

1.00

1.50

1.00 to 2.25

.25 to 3.00

1.00

.20 to .25

.25

1.75

1.75

1.00 to 2.00

75 to 1.50

1.00

1.50 to 2.50

1.25 to 2.00

1.50

.50 to 1.50

3.50 to 5.50

2.00

1.50

.50 to .75

1.00 to 1.75

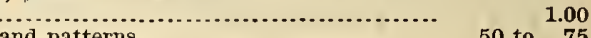

various sizes and patterns........................... .50 to $\quad \mathbf{7 5}$ 


\section{CROPS AND THE COMPLETE MANURES ADAPTED FOR THE SAME.}

The following well-known mannres have been in successfnl practical nse among many of the most noted trnck, frnit, and special erop growers, and are now cmployed, particularly among farmers in Long Island, Connecticnt, and New Jerse 5 , by many exclusively in place of purchased stable manure. Among the advantages the Mapes Complete Manurcs posscss over pnrchased stable mannre are: saving in cost and labor in hauling and applicaiion to the crop; greater certainty of cffects, espccially dnring seasons of dronght; promoting healthier growth, earlicr maturity, and producing vegetables of bictter quality. They

\section{RESTORE WORN-OUT LANDS AND ADD TO THE PERMANENT FERTILITY}

of the soil, as is abundantly shown by the testimony of practical growers who have usca them for six successive seasons on the same land.

The analyses and reports on the "valuatious" of these manures-published during the past year by the New Jerscy Agricultural Station, the Connccticut A gricultural Station, and others-show these mannres to be fully maintained in staudard, and to $b c$ the chcapest of all fertilizers known in the market.

If the fertilizcrs be used in connection with stable manure, then reduce quantitics one-lralf.

Irish Potatoes, Sweet Potatoes.-Use The Mapes Potato Manure; 3 bag's per acre; price per bag (200 lbs.), \$5.10; per ton, \$51.00.

Asparagus.-Use The Mapes Asparagus Manure, for now beds, 5 to 6 bags per acre; renovating ola beds, 3 to 5 bags per acre. Price per bag, $\$ 5.20$; per ton, $\$ 52.00$.

Cabbages (early and late), Canliflowers.-Use The Mapes Cabbage and Cauliflowcr Manure; 3 to 5 bags per acre. Price per bag (200 lbs.), $\$ 4.90$; per ton, $\$ 49.00$.

Tomatoes. Radishes, Cucumbers, Bects, Carots, Melons, Spinach, Early Spinach, Onions, Early Cabbages, Kale, Celery, Eag Plants, Lima Beans, Use The Mapcs Completé Vanure, for light soils; 4 to 8 bags per acre. Price per bag, $\$ 5.40$; per ton, $\$ 54.00$.

Peas (green), Turuips (late), Beaus (green), Pcanuts,-Use Thc Mapes "A " Brand; 3 to 5 bags per acre. Price per bag, $\$ 4.20$; per ton, $\$ 42.00$.

Corlu (carly, sweet, and field), Fodder Corn.-Use The Hapes Coru Manure; 3 bags per acre. Price per bag, $\$ 5.00$; per ton, $\$ 50.00$. For" use in bills take the "A " Brand.

Fruit Trees (bearing), Grape Vines (bcaring).-Use The Mapes Fruit aud Vine Mannre; 1 bag to about 4,000 square feet. Price per bag, $\$ 3.70$ : per ton, $\$ 37.00$.

Young Fruit Trees, Nurscry Stock, Peach Trces.-Use The Mapcs Orange-Tree Manure; 1 bag to about 4,000 square fect. Price per bag, $\$ 4.20$; per ton, $\$ 42.00$.

Tobnceo.-Use The Mapes Tohacco Manure ("Connceticut Brand"); 3 to 10 bags per acre. Price per bag, $\$ 5.40$; per ton, $\$ 54.00$.

Grass (top dressing), Grain Crops (top dressing in Spring).-In early Spring use The Mapes Grass and Grain Spring Tor Dressing; 1 to 3 bags per acre. Price per bag, \$5.20; per ton, $\$ 52.00$.

Lawns, Croquet Grounds, etc.-In early Spring nse The Mapes Lawn Top Dressing (half strength); 2 to 4 bags per acre. Price per bag, $\$ 3.50$; per ton, $\$ 35.00$.

See pamphlet for Manures for Ficld Beets, Mangolds, IIops, Sugar Cane, Orange-Trces (for sctting out young trees and bearing orchards), Fodder Corn, Strawberries (setting out beds and dressing old beds), Tobacco (fertilizer for nse in connection with tobacco stems), also for fertilizers and chemicals adapted for preparing home-made mannres and composts.

These Manurcs are sold by the ton or bag, delivered firee on board cars or boat at New York at the above prices. Cash with order.

Fach bag is plainly branded, and also has a tag attached, giving aunlysis, directions for use, etc. Send postal for descriptive pamphlet.

\section{PRICES OF PURE GROUND BONE, PREPARED GROUND FISI,} peruVian GUano, Chemicals, etc.

Mapes's Pure Gronnd Bone (1nedium) . _. 438.00

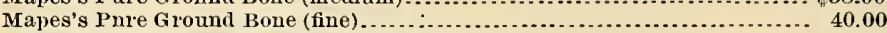

Mapes's Pnre Ground Bone, meal and oxtra fine .......................... 43.00

Mapes's Pure Fine (raw) Bone (dissolved) ............................. 42.00

Mapes's Dried Ground Fish (with plosphoric acid and potash added)........ 42.00

No. 1 Peruvian Guano-Lobos (supply and price too nncertain to qnote).....

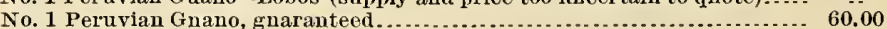

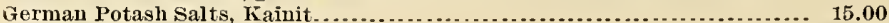

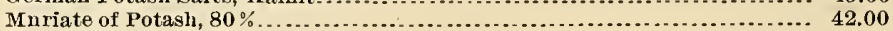

Land Plaster, per barrel

..

Per bag of 200 lbe

$\$ 3.80$

4.00

4.30

40

4.20

$\because$ 


\section{POWELL'S PREPARED CHEMICALS.}

For Composting -520 1bs. mixed at home makus a ton of good fertlizer (pamplilet describing sent on application). Per barrel, enough to make half ton of phosphate, $\$ 6.00$.

\section{SPECIAL MANURES for HOUSE or GARDEN PLANTS.}

By mail, 16c. per pounl, cxtra.

Lawson's Plospho- (Rnano.--This article has been thoroughly tested in varions localitics in this conntry for several yours past, and has viven grcat satisfaction. It is particularly valuable for the Flower. Border, and for city lots, and all other places where there is difficulty in obtaining stable manure. One lb., 30 cents ; 2 lbs., 50 cents; $411 \mathrm{~s} ., \$ 1.00 ; 7 \mathrm{lbs} ., \$ 1.50$.

Franden's Gardener's and Amatenr's Friend.-One of the riehest fertilizing agents known; the volatile principles being chenically fixed, the componnd is thercby renderod perfectly inodorous, and may, in consequence, be freely used in conservatory and parlor. Has betn highly extolled as being the most valuable fertilizer for all kinds of greenhouse plants, having none of the injurions effects of guano when nsed in too larges quantitics. Canisters of $1 \frac{16}{1 b s}, 60 \mathrm{cents} ; 3 \frac{16}{1 b s}, \$ 1.00$.

Carter's Fertilizer. - This is spccially prepared for trardeners and anateurs; it possesses remarkably stimulating properties in superind ncing a quick, healthy, and vigorons growth in whatever it is applied to in the way of greenlionse or garien plants. Per canister of $31 \mathrm{lbs}, 75$ cents.

Prepared l3one Flour. - This is one of the most useful of all fertilizers for Pot Plauts, such as Roses, Gerraniums, Heliotropes, Falvias, ctc., ctc, also may be nsedl as top-dressing for all kinds of I Iouse Plants when planted ont into the flower border during the summer. In boxes of $21 \mathrm{ls}$. each, 35 cents.

Pernvisu Guano, in boxes, 25 nud 50 cents.

Cocon Fiber Refuse.-One of the most valuable materials for mixing with soil, for plants, either in bels or in pots, and a most excellent substitute for leaf moll or peat. Plants of all kinds thrive in it with the greatest luxuriance. 50 cents per peck; $\$ 1.50$ per bushel, in bags or bbls.

\section{MOLE TRAPS.}

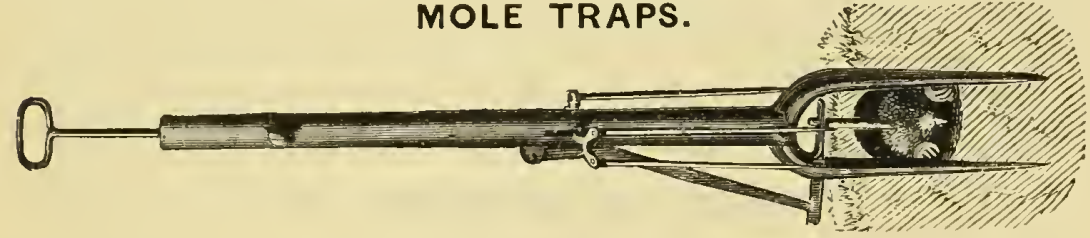

The Isabel Mole Trap.--(See cut above.)-This is acknowledgerl by all who have given it a trial to be one of the best traps ever invented. When properly set it never allows the mole to escape, and no skill is required in setting it.

Nothing but a small wooden piu is visible in the track, which the mole is sme to run against, the slightest touch springing the trap, which never fails to catch and kill the mole. Price, \$2.00 each. If by mail, 60 cents extra.

Hale's Patent Mole Trap.-This is a lisht, neat, and durable trap, casier and safer to set than any otleer, in which a strong spring forms part of the mechanism. It also has the ad rantage of being free fron any pin orobstruction, projecting into the run when set, aut the construction of the tran is such that it will catch moles when quite deep in the ground. Price, $\$ 2.50$ cach.

Edge's Mole Trap. - This is the neatest in construction, the sinplest in operation, and the most durable of any mole traperer offerell to the public, and will catch fifty per cent. more noles than any other contrivance yct invented. Price, $\$ 2.00$ each.

Olmsted's Mole Trap. - In this we have a cheap, uxeful trap, operated either with or withont sprin.s. It is so simplo in construction, and so safe to handle, that a child may set it with the same facility as a grown-np person. It tombines all the good points of traps of similar make, and on account of price caunot fail to bccome populat. Price, \$\$1.50 each.

\section{TROWBRIDGE'S GRAFTING WAX.}

Put up in convenieut rolls for nse, of 1,16 , and $\frac{2}{2}$ pounds. This has been in use for a number of years, and is highly recommended. Price, 40 cents per $1 \mathrm{~b}$; ; $1 \mathrm{lb}$. packages, 15 conts. By mail, 16 cents pur $1 \mathrm{lb}$ extra.

\section{THERMOMETERS}

Of various styles aul finish, from 50 cents to $\$ 5.00$ rach. Self-registering Thermometers, $\$ 2.00$ each, Dairy Thermometers, 75 cents to $\$ 1.50$ cacl, according to size. Storm-ylass and Thermometer combined, a useful and ornamental weather indicator, 75 cents each; by mail, \$1.00).

\section{AMERICAN FAMILY FRUIT-DRIER.}

With lle Americau Frnit-Drier, surplns fruit of every kind, and also that which fiom wer.ripencss or inferiol size or quality is unfit for ntarketing in the nupleparcel state, can all be converted into a mar ketable commodity, which, from its excelfence, will command the highest price. Such fruit as is prepared by this means is now selling in this city at an avcrawe of fifty per cent. more than orlinary drict fruit.

Price, including stove, \$50.00. Descriptive Circulars sent to all applicants. 


\section{SMALL FRUITS.}

\section{STRAWBERRIES.}

Culfivation.-Strawberries may be grown on any soil that will produce corn or potatoes. A light clay loam, well euriched with rotten barn-yard manure, is the most favorable soil for most varieties. Spring is the best season for planting. As soon as the plants are received from the nursery, open the package or box at once, and if possible plant the same day. If the ground is not ready, or for other causesthe planting must be delayed, undo each bundle and head in the plants in a sliady place, or cover with damp moss, and keep in a cool cellar until ready for planting. In the garden, plant in rows eighteen inches apart, and twelve inclies in the rows; after every third row leave a space of two feet, instead of eighteen inches, for a path. In the field, for cultivation by horses, the rows should be three feet apart. After the beds are marked out dio a hole for each plant, laroe enough to admit all the roots of the plant without crowding or bending them over. Then spread the roots in the hole and carefully sprinkle pulverized soil upon them, until the hole is half filled, and press tle soil firmly around the roots; then fill up the hole to the crown of the plant, but no more, without pressing the soil again. If the ground is very dry, it is best to plant towari evening, and to water the plants well. To secure liealthy plants, and a bountiful crop' of fruit the year after planting, the plants should not be allowed to fruit the first season; the runners should be cut off before the tips take root, and the ground kept loose and free from weeds. Whcn permanentcold weather sets in (in this latitude about the last week in November) the plants should be covered with straw, leaves, salt liay, or any other light material, to a depth of about two inches. This mulch is not removed until after the bearing of the plant. In the Spring, when the strawberry-leaves start, open with a pointed stick or the liand, the mulch over the crown of eacli plant. No other care is required before bearing. After the last picking the mulch is to be taken away altogether, and the beds cultivated as during the previous season. A strawberry bed managed in this way will last three or four years; therefore, in orter to secure a full supply of fruit every season a new bed should be laid out every second year.

The varieties marked (P) are pistillate, and require to be fertilized by setting every fifth or sixth row with some strong growing and perfect flowering variety, such as Charles Downing, Sharpless, Bidwell, etc., ete.

N. B.-Strawberry Plants, at the dozen rate, will be mailed to any Post-offce in the United States without extra charge. At the fifty or hundred rate if to be sent by mail, 50 cents additional must be remitted for each hundred plants.

\section{NEW STRAWBERRIES.}

The Manchester (P).--It is safe to assert that no strawberry introduced within several years luas received so many favorable comments from prominent fruit-growers and dealers, and that no other kind combines so many desirable qualities. For family use, as well as for market, it stands preëminent. It is a strong growcr, does not rust, and is wonderfully productive, bearing uniformly large fruit, of a bright, glossy scarlet; in quality richer than any other productive variety, while for shipping it is unsurpassed.

Price, per clozen, 75 cents; per hundred, $\$ 3.00$.

Jerscy Qucen (P). - This is one of the best late Strawberries wo know of, and is claimed by many to be the nearest approach to the ideal strawberry yet seen, at all events it is one of the very best berries in cultivation. It is very productive; the fruit being large, broadly conical, and of a fine shade of scarlet. The flesh is firm and melting, and is full of a rich, vinous juice, with a delicious aroma.

Per dozen, $\$ 1.00$; per hundred, $\$ 4.00$

James Vick.-This introduction of last Fall is deseribed as an unusually vigorous grower, with an abundance of heavy, dark green folinge. The fruit is of a bright scarlet color, uniformly large, and unequaled in productiveness. Not the least important feature is the fact that it stands on the vines a week after ripcning, without becoming soft or rotting, or in any marked degree affecting its qnality or luster, firm and of good form.

Per dozen, $\$ 2.00$; per hundred, $\$ 10.00$.

Primo.-This new and highly praised variety has been well tested for a number of years, and seems destined to take high rank in the list of strawberries. It is of large size, very prolific, hardy, and of the best quality. Season, medium to lato. A Hudson River fruit-grower has grown it two years, and finds it hardy, prolific, a sure cropper, and of exquisite flavor.

Per dozen, $\$ 1.00$; per hundrea, $\$ 4.00$.

Queens County.-In size the fruit of this variety may be classed as from medium to large; color, a bright crimson; flesh, firm and melting, and of extra fine flavor. It is very prolific, a robust grower, and quite hardy; and is, in fact, a most delicious variety for family or any other use.

Perdozen, 50 cents; per liundred, $\$ 2.00$.

Seneca Queen.-This promises to be one of the most prolific strawberries grown; and we have no hesitation in sayiug that it is unsurpassed by any of theolder or newer sorts as an early market 5 ariety, or for home use. The plant is remarkably strong, a vigorous grower, and very productive; fruit of large size and very fine quality, remaining so to the last picking; very uniform, color dark red. A little soft for loug shipment by rail, but firm enough for near-by market, or transportation by boat.

Per dozen, 50 conts; per hundred, $\$ 2.00$.

Warrcn.-This berry lias proved, under ordinary culture, a strong grower, and very productive. The fruit is large, remarkably firm, and exceedingly sweet and rich. It is carly, and cannot fail to rank among the best for lome and market use.

Per dozen, 50 cents ; per hundred, 1.50 


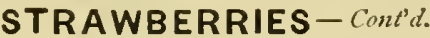 \\ STANDARD VARIETIES.}

FARLY VARIETIES.

Inchess.-The best early varicty for general cultivation

Doz. Fifty. Hund. Thous.

Crescent (1). -Very prolitic; suctects on all soils.

Duncan.-Very cally ; larg(: ; prolific; valuable for home use

Cinderella. - Very early; good uedium size; briglt glossy red.............. .50

Crystal City. - The earliest of all ......................

Pioueer.-Early; large ; irregularly round ; bright red ; of excellent yuality.. . .

MEDILI VARIETIE:

Chas. Downing. - Very prolific ; best for general cultivation.................

Wilson.-The old standar, but is generally smperseied by better varieties...

Black Defiance.--Very large and delicious ; requiring good cultivation....... Seth Boyden.--Very large, anul of ixcellent flavor ; desirable

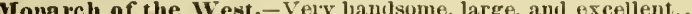

Chnmpion (P).-Large and very prolific .

Cumberland Triumph. - Largest size; exceedingly liandsome and luxuriant.

Bidwel1.-Berries very large, bright glossy crimson, of very gool quality ; a strong grower, liealthy, and bears imnuense crops when fair eultivation is given; of enormous size and faix quality .............................

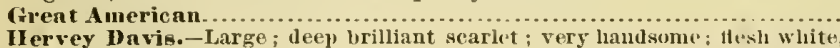
firm, aud of the best qualit

1.ATE VAIULTIEB.

Sharpless.-A grand variety in every respect; monstrous in size : most herries of good sliape, thongli some are compressed or coxcomb-sliaped ; 1les] solid, sweet, rieh, and juicy, and of a luscions flavol; plant hardy, very large, and vigorous.

Hiner's Prolific-Berries large, glubular irregulur, firm deep crimson, glossy, of a rich aromatic flavor; ripens late, and holds out nutil very late.

(t)endale-Very late; large, conical, of bright scarlet color, very firm, and of good, sprightly flavor; the plant is entirely lardy, is a strong rampaut grower, and very prolific.

(Folden Defiance (P). - A very strong growing, prolitic, late variety; a most desirablesort for home use.

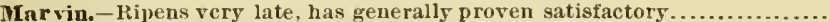

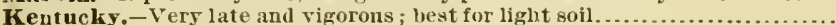

Triomphe de Gnnd.-Fine tlavor, does not do so well in many localities....... Jucunda. - Good tlavor, sncceeds only on rich clay soil ......................

Capt. Jack.-A great vearer.-

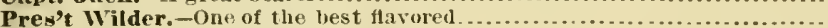

Longfellow,-An excellent new va

Fob.

It. Vernon.-A n excellent late market variety . .

Lening's White.-The best white ; Havor gool ; but very unprodnctive.... ...

$\begin{array}{llll}.50 & .75 & 1.00 & 5.00 \\ .50 & .75 & 1.00 & 5.00 \\ 50 & .75 & 1.00 & 6.00 \\ .50 & .75 & 1.00 & 6.00 \\ .50 & .75 & 1.00 & 5.00 \\ .50 & .75 & 1.00 & 5.00 \\ .50 & .75 & 1.00 & 5.00 \\ & & & \\ .50 & .75 & 1.00 & 6.00 \\ .50 & .75 & 1.00 & 5.00 \\ & & & \\ .50 & .75 & 1.00 & 6.00\end{array}$

\section{POTTED STRAWBERRY PLANTS.}

After the first of August we can furnish pot-grown plants of most of the abore rarieties, the mew kinds excepted, at $\$ 1.50$ per fifty; $\$ 2.50$ per hundred. A special Price List of Potted Plants will be issued in seasou. Pot-growu plauts cannot be sent by mail.

\section{NEW BLACKBERRIES.}

MeCrackin.-This new berry is of medium size, and of the best flavor. It has no core like the Law. ton or Kittatinn, ripens alont oue week before the Kittatinny ; saicl to be more harly aud productive than the suyder, and bears a erop every year. Price, 20 cents each; $\$ 2.00$ per doz.

Stayman's Enrly. - Claimed to be the earliest Blackberry known. Alsu that it is the liardiest and most productive. It does not sucker profusely, but is propagated from the tips. Price, \$1.00 each.

stone"s Hardy. - A new Blackberry from Wiseonsin, elaimed to be hardier than the snyder: plants vigorous and productive; beries of good size and excelleut umality. Price, 25 ceuts each; $\$ 2.00$ per doz.

\begin{tabular}{|c|c|c|}
\hline Cittatinny - The best for gencral rultivation $\ldots \ldots \ldots \ldots \ldots \ldots \ldots \ldots \ldots \ldots \ldots \ldots \ldots \ldots$. & $\begin{array}{l}\text { Iund. } \\
\$ 3.06\end{array}$ & $\begin{array}{l}\text { Thous. } \\
\$ 20.00\end{array}$ \\
\hline ew Rochelle, or Lawton. - When well ripented, are very sweet and delicious... 1.00 & 3.00 & 20.00 \\
\hline Ison's Enrly. - One of tlie most profitable for the uarket.............. & 3.00 & 20.00 \\
\hline st ern Triumph.-Perfectly hardy; berries small, but of excellen & 3.00 & 20.00 \\
\hline der.-The laruliest ; very sweet and juicy.......... & 3.00 & 20.00 \\
\hline ly Harvest. - Very early; will be very protitable for market. & 3.00 & 20.00 \\
\hline issouri Mammoth.-Very large....... & 3.00 & 20.00 \\
\hline
\end{tabular}




\section{NEW RED RASPBERRIES.}

Crimson Beanty.-A new red Raspberry from Kansas, claimed to be the hardiest, most productive, and earliest Raspberry yet offered. Price, 50 cents each ; \$5.00 per dozen.

Reder.-A new red from Michigan; very early, productive, ant perfectly liealthy ; berries of good size and flavor and remarkably firm; on account of its good shipping qualities it will be very iesirable for market. Price, $\$ 2.00$ per dozen; $\$ 10.00$ per hundred.

Hansell. - A new red; probably the earliest of all, and therefore will bo very profitable for market. Price, 35 cents eacl ; $\$ 3.00$ per dozen ; twent $v$-five for $\$ 5.00 ; \$ 18.00$ per hundred.

Superb.-A new, early, vigorous-growing varlety; fruit bright erimson, large, of rich and spicy flavor; very productive. Price, 50 cents each; $\$ 5.00$ per dozen.

\section{STANDARD VARIETIES.}

\section{RED FRUITED.}

Belle de Fontenay, bost Fall-bearing variety, large and sweet

.

Reliance, a seedling of Philadelphia, very similar, but more vigorous and fruit is

larger....................................................................... 1.00

Cuthbert, large, good quality, hardy; best for family use........................... 1.00

Brandywine, vory fine, firm and hardy ............................................. 1.00

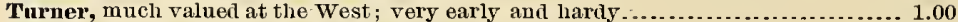

Herstine. $-A$ very large and prolific variety ...................................... 1.00

Shaffer's Colossal. - Truly colossal in size of canes and fruit. The verries are of

the largest size and excellent in quality. Color rather dark .................... 1.00

$4.00 \quad 30.00$

$4.00 \quad 30.00$

$4.00 \quad 30.00$

$4.00 \quad 30.00$

$4.00 \quad 30.00$

BLACK FRUITED.

Sou hegau, new, the earliest large Black Cap, 25c. each ........................ $2.00 \quad 10.00$

Doolittle, large, sweet, and juicy............................................................. 1.00

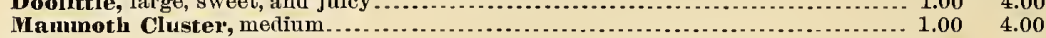

Gregg, very valuable, late .................................................... $1.00 \quad 5.00$

30.00

30.00

40.00

YELLOW FRUTTED.

Brinkle's Orange, large; the richest-flavored Raspberry ........................ $2.00 \quad 10.00$

Carolime, new, large, sweet, and hardy....................................... $2.00 \quad 10.00$

\section{NEW CURRANTS.}

Black Champion.-This new Currant has been awarded a first-class certificate by the Royal Horticultural Society. Described as being of a luscious and delicate flavor; bunches long and berries of greal size. Price, $\$ 2.00$ each.

FAY'S PROLIFIC, new red. Price, for 1 year, $\$ 1.00$ each; 2 years, $\$ 1.50$ each.

White Versailles.-As large as the Cherry; white, translucent; very sugary; said to be the best white, 50 cents each.

STANDARD VARIETIES.

Cherry, largo, best for market

Each. Doz. Hrund. Thous.

$\$ 0.20 \$ 1.00 \$ 6.00 \$ 50.00$

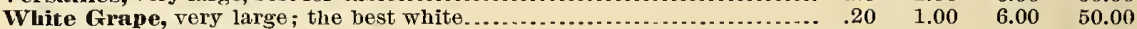

Victoria, best late red.

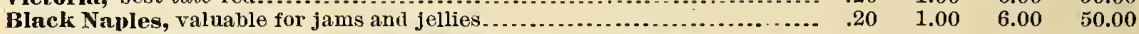

LEE'S PROLIFIC, new black, an improvement on Black Naples. 30 cents each ; $\$ 1.50$ per dozen.

Two-ycar old bushes, of any variety.

$\begin{array}{lll}30 & 1.50 \quad 9.00\end{array}$

Three-year old bushes, of any variety.

$2.00 \quad 12.00$

\section{GOOSEBERRIES.}

Houghton Seedling, very prolific, free from mildew

'I'wo-year old bushes.

Downing pale green, very large,

Two-year old buslies. . . . . .

Simith's Improved

Each. Doz. Hund, Thous.

$\$ 0.25 \$ 1.00 \$ \$ 6.00 \$ \$ 50.00$

$2.00 \quad 12.00$

$2.00 \quad 15.00$

$.50 \quad 3.00$

$\begin{array}{lll}30 & 2.00 \quad 15.00\end{array}$

\section{CRANBERRY PLANTS.}

Mansfield Creeper.-A new upland variety, takes root freely; and the most desirable. Price, per 100, 60e. Eaton Black Bell.-The earliest Cranberry. The berry is not large, but nniform in size, and prolific; desirable on account of earliness. Price, per $100,75 \mathrm{c}$.

1,000 plants, by mail, post-paid.......................................... \$4.00

5,000 "

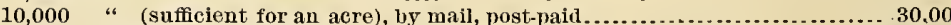

By express, at purchaser's expense.................................. 25.00

Full directions for cultivation sent with each lot ordored; no plants sent C. $O$. D.

Raspberries, Blackberries, Currants, Gooseberries, and Grape-vines can be mailed for 25 cents per dozen, in addition to the price. When this amount is not remitted, a number of plants suffleient to cover the amount of postage is acducted from the order. 


\section{HARDY WHITE GRAPES.}

\section{NEIV VARIETIES.}

The Duchess.

It is our unqualified opiniou that the Dncliess is to-day the Best Hardy White Grape in existence. It is of a delicious tityor, and fre frou that sour, hard pulp so frequently unet with. For size and showiness it does not equal the pocklington, while iu other points it doubtless surpasses it. 1 year old, 75 cents each; $\$ 7.00$ per dozen. 2 years old, \$1.00 each; $\$ 10.00$ per dozeu.

\section{Pocklington.}

New and higlily commended; a seedling of Coucord; strong grower; healthy and hardy, ncver liaving been known to mildew or winter-kill. Bunel very large, compact; berrieg lonud, viry large, liglit yellow, covered witl a fine bloom, of as good or better yuality than concord, and ripens about tlie sane time. Altogether a very showy anl valnable sort. 1 year, $\$ 1.00$ each; 2 years, \$1.50 eacli.

\section{Tie Prentiss.}

Another popular white grape. Bunch large, compact; berry medium to large, yellowish green; skin thin, but firm; flesl tender, sweet, melting, and juley; vine a good grower, harly, and vory prodictive; ripens with Coucord. 1 year, 75 ceuts uach; 2 years, $\$ 1.00$ each.

\section{Ann Arbor.}

A white seedliug of the Coneord, from Michigan, elained to be perfectly hardy ; vigorous and prodnc. tive. Two weeks earlier than Coucord. Berries very large and of good thavor, Priee, 1 year, 75 cents each; 2 jears, $\$ 1.00$.

\section{Eldorndo.}

New white. A full sister of Laly Wasliugton, and by some considered superior, belng probably the ligher thavored of the two, and more boantiful. Very early. Price, 1 year, $\$ 1.00$ each; 2 years, $\$ 1.25$ each.

\section{Iady Washington.}

New wlite. Bunches and berrics very larke, single bunches haviug been grown weighing two pounds: quality good. Priee, 1 year, $\$ 1.00$ eaeli; 2 years, $\$ 1.25$ eatel.

\section{STANUAIR VARIETIE:}

Elvira, greonish-white; skin rery thin; pnlp teuder. Lady, light yellowish-green, early; herries large, sweet, and rich. Irartha, greenish.wlite; vely sweet .

\begin{tabular}{|c|c|c|c|}
\hline \multicolumn{2}{|c|}{1 year. } & \multicolumn{2}{|c|}{2 years. } \\
\hline Each. & Doz. & Each. & Doz. \\
\hline$\$ 0.35$ & $\$ 3.00$ & $\ldots \$ 0.50$ & $\$ 4.00$ \\
\hline .50 & 4.00 & .75 & 6.00 \\
\hline .35 & 3.00 & .50 & 4.00 \\
\hline
\end{tabular}

\section{HARDY GRAPES.-GENERAL LIST.}

Agnwan (Rogers's No, 15), maroon, bunclies large, berries rery large, aromatic

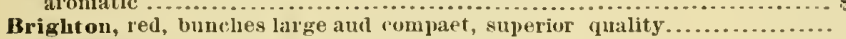

Catawbn, red, old staudard variety, excelleut kceper.........................

Concord, blaek, the hardiest and best grape for general enltivatiou.........

Delaware, red, coupact bunch, berries small, very sweet and delicious.....

Diana, pale red, tender, sweet, witl luusky flavor. .....................

Early Dawn, black, very early

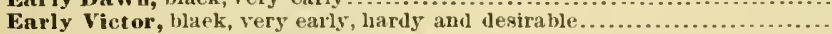

Gothe (Rogers's No. 1), yellowish greeu, berries very large, of deliecous aroma

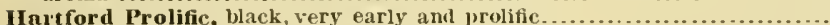

Highland, New Blaek; very large aud slowy ..........................

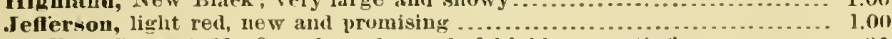

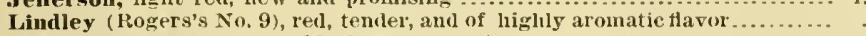

Ierrimack (Rogers's No. 19), black, very vigorons, sweet.................

Doore's Early, black, vERY early.

Salem (Rogers's No. 53), chestnut color, berry very large, quality best .......

Talman (Early Champiou). black, me of the earliest......................

Teleqraph, black, early, large, juiey aul sweet

Vergennes, early red, very hanly, vigorous and healthy .................... 1.00

IVilder (Rogers's No. 4), dark punle, juicy, ricl aud sweet . . . . . . . . . . . . . .

Worden, black, similar to Concord, one week warlier . . . . . . . . . . . . . ......

Wy oming Red, berties l'esemble Deluware lu color and Havor, but are clonble

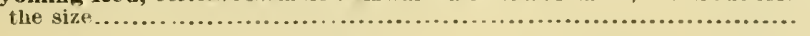

\begin{tabular}{|c|c|c|c|}
\hline$E a c$ & Doz. & Each. & Wors. \\
\hline & $\$ 3.00$ & $\ldots 0.50$ & $\$ 4.00$ \\
\hline .50 & 4.00 & .. .75 & 6.00 \\
\hline .35 & 3.00 & . .50 & 4.00 \\
\hline .25 & 2.00 & .. . 35 & 3.00 \\
\hline .35 & 3.00 & .. .50 & 4.00 \\
\hline .35 & 3.00 & .. .50 & 4.00 \\
\hline .60 & 6.00 & . & \\
\hline .00 & 10.00 & . & \\
\hline .0 & 3.0 & .50 & 4.00 \\
\hline .25 & 2.00 & .. .35 & 3 \\
\hline 00 & & & \\
\hline 001 & 10.00 & 1.50 & 12 \\
\hline .33 & & .. .50 & 90 \\
\hline . Bin & 3.00 & .. .50 & 4.00 \\
\hline .50 & 5.00 & .. .60 & 6.00 \\
\hline .35 & 3.00 & - . .50 & 4.00 \\
\hline & 3.0 & .. . .50 & 4.00 \\
\hline .35 & 3.00 & .. . .50) & 4.00 \\
\hline 1.00 & & .2 .00 & \\
\hline .35 & 3.0 & $\ldots . \overline{0} 0$ & 4.00 \\
\hline .35 & 3.00 & $\ldots \quad .50$ & 4.00 \\
\hline & & -1.00 & \\
\hline
\end{tabular}

\section{FOREIGN GRAPE VINES.}

\section{For Growing Under dilass.}

From a very large list of tender Grapes we lave seleeted ouly the very beat varleties suitable for yeneral $11 \mathrm{se}$, as woll as for forcing; the vines are of the best quality, with fine and strong canes, which are certain of giving satisfaction.

Twelve distinct varieties, suitable for a cold grapery.

Twelve distinct varieties, sutitable for a lot grapery:

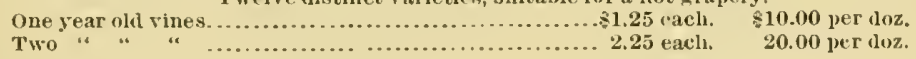




\section{FRUIT AND ORNAMENTAL TREES.}

Our customers may rely on being supplied with well-grown, strong, and healthy stock of all the leading sorts. Special care has been exercised to insure correctness of name, a fact of no small importance to fruitgrower's. Our stock embraces manj other varieties not enumerated on this page, but wlich we can sup. ply. The actual cost of packing will be added to prices quoted below.

\section{FRUIT TREES.}

\section{APPLES.}

Price-Standards, 35c.; Dwarfs, 50c. each. Baldwin,

Bough,

Early Harvest,

Fall Pippin,

Golden Russet,

King of Tompkins

Maiden's Bluslı,

Newtown Pippin (green),

Northern Spy,

R. I. Greening,

Seek-No-Further,

Spitzenberg,

Yellow Bellflower.

\section{APRICOTS.}

Price -50 c. each

Early Golden, Peach.

Large Red,

Royal.

\section{CHEIRTIES.}

Price-Standard or Dwarf, 50c. each.

American Amber, Bello d'Orleans, Early Whiteleart, Gor. Wood,

Bigarreau(Yel Spanisl1), Maydnke,

Black Tartarian, Morello,

Coe's Transparent, Ohio Beauty,

Early Richmond, Reine Horte use.

\section{CIRAB APPLES. \\ Price $-50 \mathrm{c}$, each.}

Large Red, Large Yellow,

Hyslop, Trauscendent.

\section{MULBERRIES.}

Price-50c. eacli.

Downing's Everbearing, White.

\section{NECTARINES.}

Price - ou Peach, 35c.; on Plum, 50c. each. Boston, Red Roman.

\section{PEACHES.}

Price - on Peach, 30c.; on Plum, 50c. each. Crawford's Early, old Mixon, Free,

Early York Late,

Fox's Seedling,

Large Farly York, Late Red Rareripe,

\section{President,}

Red Cheek Melocoton,

stump the Work,

Troth's Early Red,

Yellow Alberge.

\section{PEARS.}

Price-staudards, 75c.; Dwarfs, 50c. each.

Bartlett

Belle Lucrative,

Buerre d'Anjou,

Rose,

Clapp's Favorite,

Doyenne d'Et'́,

Duchess d'Angouleme,

Kingsessing,

Lawrence,

Onondago,

Rostiezer,

Seckel.

Kieffer's Hybrid - One year old, \$1.50; per dozeu, $\$ 15.00$. Two years old, $\$ 2.50$ each; jer dozen, $\$ 25.00$

\section{PLUMS.}

Price $-75 \mathrm{c}$, eacli.

$\begin{array}{ll}\text { Coe's Goldeu Drop, } & \text { Imperial Gage, } \\ \text { Damson, } & \text { Purple Favorite, } \\ \text { Greeu Gage, } & \text { Waslington. }\end{array}$

QUINCES.

Price-50c, each.

Orange,
ORNAMENTAL TREES.

Ash, white.......... .50 Maple, Norway ....\$ .75 " variegated.... 1.50 " 1.50 "Scarlet...... Beech, Purple Lcav- _ " $\quad$ Sugar....... cd ............. 1.00 " Weir's Cut Beech, Americau... . .50 Leaved.......... 1.00 “ European.... .50 Oak, Chestnut...... .75 " Cut Leared.. 1.00 " White......... .75 Elm, A merican.... $\quad .75 \quad$ “ $\quad$ Pin ........... “ English ...... .75 Poplar, Lombarly. .50 Gingko Tree........ 1.00 Horse Chestmut.... $\quad .75$ Liuden, Americau.. $\quad .75$ Tulip Tree........... European.. .75 Yellow Locust ..... .50

\section{WEEPING TREES (Deciduous).}

Weeping Ash...... \$1.00 Weeping Larch ....\$2.00 “ Beech..... 1.50 " Poplar.... 1.00

“ Cherry ... 2.00 “ Willow ... 1.00 Cypress,

Americau....... 2.00 American......... 1.50 Weeping Elm, Slip- Weepiug Willow,

pery............ 1.50 Kilmarnock ...... 1.50

\section{EVERGREENS.}

Arbor Vitæ (Speci. Piue, Austriau.....\$0.75 mens) ...........\$\$ 0.75 “ White ....... .75 Balm of Gilead..... .75 " Scoteh...... 75 $\begin{array}{llll}\text { Hemlocks (Speci- ". “ Clnster...... } & .75\end{array}$ mens) ............ .75 Juniper, Irish...... $\quad .50$ Spruce, Norway... .75 “ J Japanese .75 Fir-Balsam ........ $\quad .75$ Retilisporas........ $\quad .75$ "Silver ......... .75 spruce, White...... Box Trees .......... $\quad .50 \quad$ Yew, Japan......... 1.00

\section{WEEPING EVERGREENS.}

Weep'g Arbor Vita $\$ 1.00$ Weeping Hemlock. $\$ 1.50$

“ Fir, Silver.. 1.50 " Spruce... 1.50

“ Juniper.... 1.00 Lawson's Cyress ... 1.00

\section{MAGNOLIAS.}

Too much cannot be said of the bcautiful flowers, elegant form, and effective foliage of the Magnolias. From a large list we name a few of the most desirable varieties :

Magnolia atro-purpure (Japan M.). Dark purple flowers; blooms in May ....\$3.00 conspicua (Yulan or Chinese M.). Beautiful white flowers; May..... 1.50 cordata (Yellow cucumber tree).

Bright yellow flowers; blooms twice, Mav and August............ 1.00 glauca (our native M.). Of low growtll ; flowers white; very fragraut; early............. 75 maciopliylla (great. leaved M.). With immense leaves, and white Howers a foot in diameter.......... 1.00

\section{HEDGE PLANTS.}

Per 100 . $\$ 10.00$ " " " " 11 to 2 ft.......... 12.00 " " " $\quad 2$ to $2 \frac{1}{3} \mathrm{ft} \ldots \ldots \ldots \ldots . . .15 .00$ “. “ Siberian, $1 \frac{1}{4}$ to $11 \mathrm{ft} \ldots \ldots \ldots \ldots . . .15 .00$ " " " " 2 to $2 \frac{1}{2} \mathrm{ft} \ldots \ldots \ldots . .30 .00$ Norway, Spruce, $\quad 112$ to $2 \mathrm{ft} . . . . . . . .35 .00$ Privet, Califoruian. ............................. 12.00 “ Europeal.......................... 15.00 Japan Quiuce .......................... 15.00 


\section{THE AMERICAN GARDEN.}

\section{A Monthly Illustrated Journal, Devoted to the Gardening Interests of America}

\section{ONE DOLIAR I YHAR.}

This elegant and richly illustrated Journal contains sixteen large pages of elosely printed matter, relating to the Vegetable, Fruit, and Flower (Aarden, the Lawn, (Arenhouse, and ivindow (An rden, aud all other branches of IIorticulture in its varions Departments.

\section{Dr. F. I. IEXXMEIR, Eulitor,}

\section{B. K. BLISt o sions. Publishers,}

34 Barclay sitret, New-York.

All orders should be addressed to the Publis7ers.

Volume IV commences with the January number, 1883, and as a carefully prepared iuclex of the voluu. is issued at the end of the year, it is desirable that snibscriptions should comnence with the Jinuary num ber, althougli they may be entered at any time for a year from the date of entry.

is speciuen copy will be mailed free ou applicatiou.

\section{THE AMERICAN GARDEN}

aims to serve as a friend aud guide to every one who cultirates a gardeu, and any one wlo secks practical and reliable information about any or all brauches of garlening, may teel assuled to find the same in its wares. It has beem onr aiu, from the tirst issue, to make each succeeling number better tban the previous one, and alveady do we liave the satisfaction to see mie Auerican Carden recognizent every where as the best popular Iforticultural publication in Anerica.

But it is not our intention to rest liert, anl arrangenents have bcen perfccted to make the next volume still more complete, practical, and useful to its yeaders, A number of superb colored plates, alveady iu course of preparation, will be presented to every subscriber. These plates, the first one of which, a beauti. ful gromp of Perpetual Carnations, is to every subscriber. These plates, the first one of which, abeautiful gromp of Perpetual Carnati

send for a sample copy, it will speak for itself, aul cost you nothiug. (September numbur, with large colored plate of Clematis coccinen, or January number, witli colored group of Carnations, will bes uailed for 10 cent $\rightarrow$.)

\section{VALUABLE PREMIUMS FOR 1883.}

The success of our Premium seeds offered in former years lias been so satisfactory that we liave decided to enlarge aud increase the lint. It fomprises several valuable novelties, never before offered for sale; a sclection of the choicest thower and vegetable seeds in enltivation. rarc and beantiful bulbs and plauts; the choice of the best horticultural books publislied, and nany saluable implements for the plauts; the choice of the

Every subseriber - new or old - is cutitled to one Premium, either a plant of clematis coccinea (for description of which, secpase 58 in this Catalogue), or others as selected from our Premium List; and with but little exertion to obtain new subscribers, any one inay secure vegetable and flower seeds enough to stock a garleu, aud books to furnish a library.

Sent for The American (tarden Preminu List, which will be mailed freo on application.

\section{NOTICES OF THE PREAS.}

THE AMFRICAN G.ARlix, we are sure, will be very ustul to the class for whom it is iutended.-Gar iener's ifonthly.

THE AMERICAN GARDEX is well fixed, botl in its publishers and in its elliturial features, and we predict a wide success for it.-Pacinc Rural Press.

THE AMERICAN GARDEN, mublished by B. F. Bliss c. Sons, New.York, comes each month liandsomer than before, and ranks with the best of its class. Farm and Garden.

THF AMEICAX GAIDEN, - In point of ability in editiug,oxcellence of matt"r, and mechanical beauty, heads the list of American horticultural publicatious. - Farmers' Review.

THE AMERICAN GARDEN being edited by Dr. F. M. Hexamer, the readers will be sure that its teachings will be sound and praetical, and that it will not be a mero advertising sheet.-American Agri. culturist.

THE AMERICAX GARDEX (of which, when our readers reniember that it is editel by Dr. F. M. Hexamer, it woulu be but a redundance to say that it is eminently practical. trust worthy, and eujoyable as well). - Yew York Tribune.

We lave no doubt that this haudsome journal wil meet with all the success it deserves, and from all neet with all the success it deserves, and from al lishers, its deserts will prove of no mean order.Rural New Yorker.

Tile A uERICAN GARDry is, as usual, full of in TnE. AMERICAN GARDre is, as usual, full of fustructive and interesting natter relating to the planting aud cultivation of regetables, flower's, and
fruits. Tlis periodical is now in its third year, and fruits. This periodical is now in its third year, and start is well maintained, if not surpassed, at the present time. No jomrnal devoted to the interest. of the garden is more haudsome in general appearance, better plinted, or supplied with more practi cal and timely fufolmation than is TIn AMERICAN G.Aluks-Berkshire Courier.

TIE AMERICA.Y GARDEN, - This illustrated jonrnal of horticulture, which has bisetofore appeared as quarterly, comes ou the first of Jaunary ay quanthly. It is edited by the veteran hor ticulturist, Dr. F. if. Hexamer, who las no superior in this country as a practical and scientific lorticulturist The of will wive inforuatiol to ful

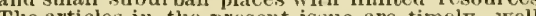
The articles in the present issue aro timely, well chosen, carefully witten by persons familiar wit the subjects treated. The low subscription price of 1 a year will nake this neatly dressed jonrnal a welcone visitor to huitreds who whil be instructer and interested in realing its pages - Vewark Daily Advertiser.

\section{SPECIAL OFFER.}

\section{THE AYERICAN GAIREEN FOR 1883 FREE.}

Purchasers of seeds in packers to the amount of Four Dollars (in one order), at Catalogue prices, may select as premiuns, either TIE AMERICAN GAkIEN for 1883 or the offer of seeds on page 3. Purchasers to the amount of Eight Dollars (in ono orcler), whether in packets or otherwise, will rocive, ou application, TIE A HERCAN GARUEN for 1883 free. 


\section{TABLE OF CONTENTS.}

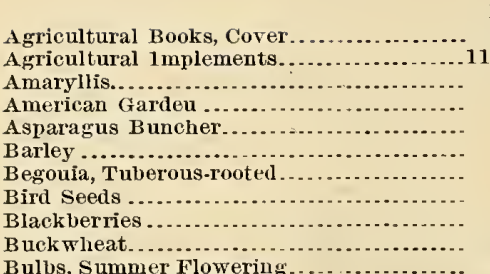

Caladium Esculentum......................

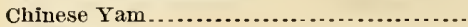

Clover Seed.

Cocoa Fiber Refuse.

Collections of Flower Seets by Mail.

Collectious of Kitchen Garden Seeds.

Collections of Plants by Mail

Collections of Veretable Seeds by Mail

Cranberry Plants...............................

and Horse Hoes $112,113,115,116,117$

Currants. 132

Cutlery, Saynor's................... 124, 125, 126

Dahlias ......... 56,58

Dioscorca Batatas.............. 103

Dixertions for Sowing Seeds............. 4

Dried Flowers (Immortelles, etc.) ........

DnITa..................................... 110

Egg Food, 1mperial....................... 123

Eucalyptus Globulus, or Australian Ferer Gum Tree

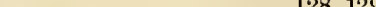

Fertilizer Distributor..................... 114

Fertilizing Moss................................. 127

Flower Holders, Button-hole............. 118

Flower and Grape Gatherer............... 121

Flower Seeds, Miscellaneous. ............. 7-46

Flower Seeds by Weight.................... 46

Forage Plants, New...................... 110

Fruit Seeds............................. 106

Fruit Dryer, American.................. 129

Fruit aud ormamental Trees............... 134

Fumigator, Eureka . ...................... 114

Garden and Horticultural Inplemeuts.....113-127

Gladiolus................................. 48-51

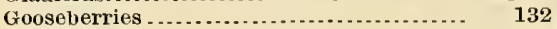

Grafting Wax

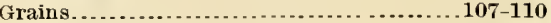

Grapes, Native.......................... 133

Grapes, Exotic ........................ 133

Grass Sceds.............................. 105, 106

Hauging Baskets....................... 127

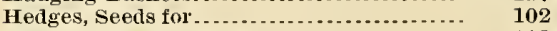

Hoe, Hexamer's Prong................... 113

Hoe, The Warren........................ 120

Hot-bed, Preparation of....................

Inducemeuts for forming Clubs.

1 nsect Destroyers

Ink, Horticultural

Kitchen Garden Roots an

Labels, Garden, Metallic and IVood.........

Lawn Grass.

Lawn Mowing Machines..................

Lilies, Japan, aud others

Madeira Vine

Irail Facilities for For'warding Seeds, ete

Manures, Mapes's Complete and Special.
Manures, Special, for Plants............... PAGE.

Medicated Nest Eggs. .................. 123

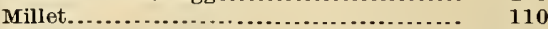

Miscellaneous Secds..................... 103

Mole Traps

Mushroom Spawn ........................ $\quad 85$

Novelties and Seeds of Spceial Merit-Sup-

plement.............. 1-8

Oats...............................................

Oats, Chin ese Hulless................... 110

Ornamental Grasses, Dried ............... 47

Ornamental Grasses, Seeds............... 45

Philadelphia Broadcast Seed Sower...... 115

Plant and Tree Labels (wood).............. 118

Plant Stakes.............. 118

Plants, in Special Collections.............. 6

Plants, Miscellaneous ani Bedding....... 57-66

Plant Protector's.......................... 117, 120

Plow, Bateman's Hand Garden ........... 113

Pot, Sweet aud Medicinal Herbs........... 101

Potato Seed, Hybridized................... 94

Potatoes for seed . ................... 91, 92

Potatoes, Sweet ............................... 101

Prickly Comfrey......................... 110

Pruners, Tree............................. 121

Pruning Knives........................... 126

Pruning Shears . . . . . . . . . . . . . . . . . . . . 121

Pump, Garden ............................ 119

Rake, Lawn, Davis's...................... 120

Raspberries ................................. 132

Remarks to Purcliasers..................

Rollers, Garden.......................... 122

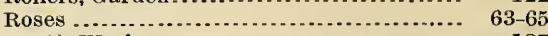

Rustic Work ............................... 127

Rye................................. 109

Seed Sowers, Broadcast, Philadelphia...... 115

" " Comstock's ................. 117

" " " New York Improved.....

" " $\quad$ Planet..................... 116

" " Randolph's Hand............. 114

Shrubs ............................... 65,66

Small Fruits............................ 130-134

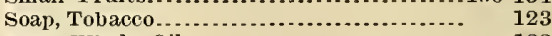

Soap, Whale Oil........................ 123

Soldering Iron ......................... 123

Sprinklers................................... 119, 120

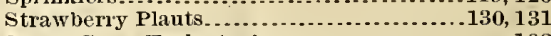

Sugar Cane, Early Amber................ 103

Sulphux Bellows for Mildew.............. 118

Syringe, New Bellows.................... 119

Syriuges, Garden, Brass...................119-126

Tags, Ziuc, for Trees .................. 118

Thermometers ........................... 129

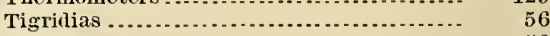

Tuberoses . . . .

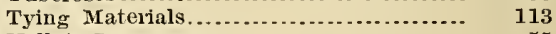

Vallota Purpurea.......................

Vegetable Plants.................... 101

Vegetable Secds, General List, with Cultu-

ral Directions......................... 67-102

Watering Pot, Improved French.......... 127

Weeder, Excelsior Hand.................. 113

Weeder, Hand (Noyes) ..................... 114

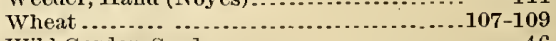

Wild Garden Seeri...................... 46

Wreaths, Immortelle.................... 47

Entercal according to Act of Congress, in the year 1883 , by B. K. BLIss \& Soxs, iu the Office of the Librarian of Congress at Washingtou. 


\section{Valuable Agricultural Books for Sale by B. K. Bliss \& Sons.}

MAILED, POAT-PAHD, AT TIE FOILOWIN( PRICES

Farus aud (tarulen.

Allen's New Americau Farm Book..........\$2.50

Barry's Fruit (iarl' ') ....................... 2.50

Brill's Faru Gardemm anil seed (imowing..... 1.00

Bromm-Corn and 13rooms, paper, bo cts, ; cloth .75

Curtis's Wheat (iulture... ...

Flax Conture. By seven jactical growers.... 5

Flax Cilture, By seren plactical growers... . .80

Fitz's Sweet Potato Culture.................

Hartis on Garleniug for Yommer ani oli........ 1.25

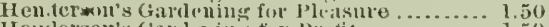

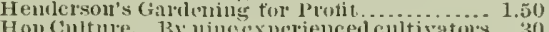

Hop Colture. 13y nincexperienced cultivaton's .30)

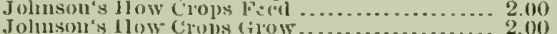

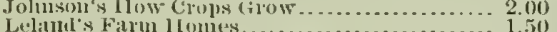

Vicliol's Cluemistry ot tho Farm and Sea..... 1.25

Ocmler's 'rinck farming at the south ......... 1,jo

Onions-How to Raise the'm l'rotitably

Onr l'arm of Fom Acres, loper, $30 \mathrm{cts}$; clotli

Pibor"s Colociulo is an A grieultural state..... 1.50

Potito C'nltule. (P'rizo Essay.) .............. .25

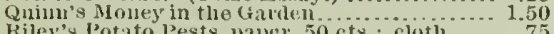

Riley's ['otato l'ests, piep'r, 50 cts.; clotl ..... . .

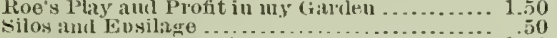

Stewart's 1rrigation for the Farm .......... 1.50

Thomas's Fand Implements and M achinety... 1.50

Tobacto Culture. By 14 oxperiencel cultivatus .2J

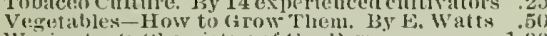

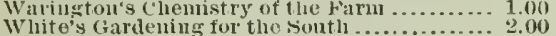

\section{Fruits and Flower's.}

A Ecru Book for Ererybody. Colowed plites.. .50 American Roso Cultulist .................... American Weeds and Useful Plaits.............. 1.75 Breck's Now bouk of Flowerts .............. 1.7 Buist's lelower Gullen Direetory............. 1.50 Cliorlton's Gribo Grower's Gnirlia ............... . . Flowers aul Flowel Ganden. By E. Watts... Fuller's Grape Culturist......... Cuiturist ...... 1.5? Fnller's simall Frut ('nlturist. (New relition.) 1.50 Fulton's Peasli culture......

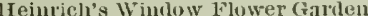
Henclersou's Practical Floriculture Husmann's American Grape Growing anil

Wine Makille........................... 1.

Johnson's Winter Greeneries at Iuno........... $1.1,0$

Molir on tho Grapo Viue.................... 1.00

My Viueyan at Lakeriew .................... 1.2

Pindeo on Strawberry Cinltire.................

Parsons on tho koso ........................ 1.50

Quiun's Pear Culture fur Profit

hivers's Miniatnro Fruit (intell ............... 1.00

Tho Orchard aml Frut Gintlit. its culturo

anil

Whito's Crauberiy cuiture........................

\section{Hor'ses.}

Dadl's Motlern 1Ior'so Doctor, $12 \mathrm{mo}$

Darli's Americat It Reformed 110rse Book...... 2.50

Herbert's Hints to Hor'sekeeler's ............. 1.75

Howien's The Horse-How to Buy aut sell .. 1.00
Hriles on the Horse's Foot....................

Whe Horse. Valleties am Mamagement in Health and Jisease

Tho salde $\mathrm{Hol}$ se. A Grible for Kidiug and

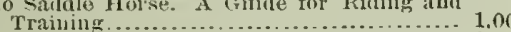

Youat and spooke on the iforse............ 1.50

\section{Cattle, Sheep, and swiue.}

Allen's (L. F.) American Cattli ............ 2.50 Cattle. Varicties and if anigeme-13t in Healti and Diseaso. By Georgr: Alu titge....... 75 Coburu's strine Hnsbaudi'y

Dadl's Anterican ('attle Doetor, 12 mo......... 1.5

Dalld's Anrerican ('attlo Doctor, 8vo., clotli... 2.50

Guenon on . Mileli Cows...................... 1.00 lisepines () Cow

$\$ 1.00$

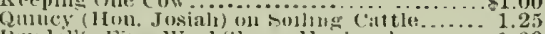

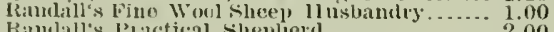

Ramlatl's l'tactiral sheplieril............... 2.00

linudull's sluep Ifusbandry................ 1.50

Stewalt's Sllcpherl's Maumal............... 1.50

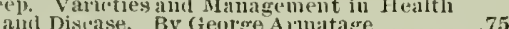

Yonatt and Maitin on Cattle.................. 1.50

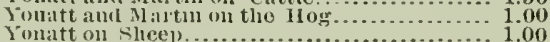

\section{Poult ry.}

(ieyelin's Fonltry-Breenling .............. 1.25

Gra.y's Tlio (iame Fowl....................... 1.50

low is's l'actical l'oultiry book ........

ponltrs, 'Ihen Brecding, Rearing, Fecdins, aud Exlribitiun

Samnlers's Domestic Poultry, pap., $40 \mathrm{c.}$; cloth

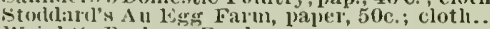

Vriglit's Bialuun row

Arehitecture and Tandscape (iardeniust.

Alleu's (L. F.) Rumal Aichitecture

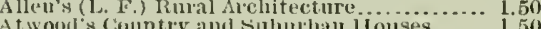

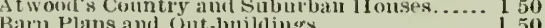

Barn Plans and ont-buildings -............ 1.50

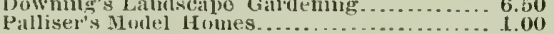

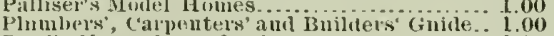

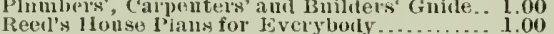

Reel's liouse Plank for Fveryboily ........... l.00

Woodward's Cottaces and Farın Houses..... 1.00
Woodward's Coututry Homes................ 1.00

Woodward's Graperies and Horticultural Buileliugs

Woodward's Subnrban ani (country Howses.. 1.00

Field Sports anel Aunsements.

Batty's How to Humt aud Trap............. 1.50

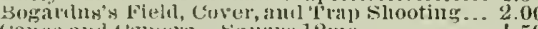

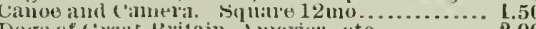

Dogrs of Greate 13ritain, Anrerica, etc........... 2.00

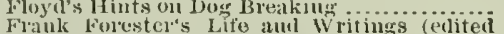

by Datid W. Judi). Two Volmues. Each 1.50

Hallock's sportsuan's (iazct teel-........... 3.00

1Iouper"s Dom anu (inu, pajer, 30 cents; clotl .60

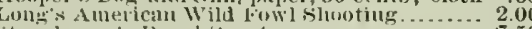

Stouteluenge's Rural sionts.................. 7.50

The Dog. Varietics anl Management in Health

ant Distase.................

\section{Hiscellaneous.}

American Bird Fancier, (Eularged Edition).. $\quad .50$ 13ement's Rabbit bintejer................... Bird-kecping. A l'ractical Guicle. By Miss Dysoll

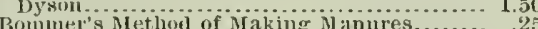
l3ook of Honseliold Pets, priper, $50 \mathrm{c}$; cloth...... 13onssinganlt' \& Rnral Economy .............. 1.60

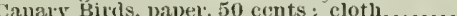

Cooking School Toxt Book and Housekeejej's'

Guicle (Miss Juliet Corsori) .............. 1.25

Do Voe's Malket A ssistant . . . . . . . . . . . . . . . . 2.50

Do Voe's Malket Assistant $\ldots \ldots \ldots \ldots \ldots \ldots \ldots \ldots \ldots .2 .50$

Garcluer"s luow to Paiut .

llatris's Inseets Injurioms to jegrtition.

Plaiu, 4: Coloren Engru incs..........6.50

lavis's l'alks on unmres

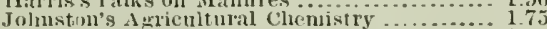

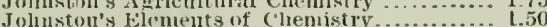

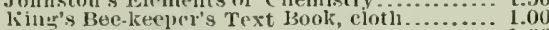

Quimby'y New Bee-kerpina .............. 1.5

loot'y A 13 Co of IBre-Culture.....

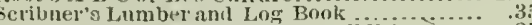

Twenty-five Cont Dinnel's, New Fiditinn...... .2

Warler's Hedres aud Evergreens........

Waring's Draning for 1'rotit and Healti...... 1.50

Wariug's Flements of A criculture........... 1.00

iVillard's 1'ractical Dain'y Insbandry............... 3.00

IONDON GARDENER'S CHRONICLE.

Subscriptions receivel for this popnlar weekly publication. Price to subscribers in the United ftates, including postage, $\$ 7.50$ per year.

\section{LONDON GARDEN.}

A weckly magazine deroted to gardening in all its branclies. A colored engraring and other illustra. tions in cacli number. 87.50 ver rear. 


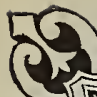

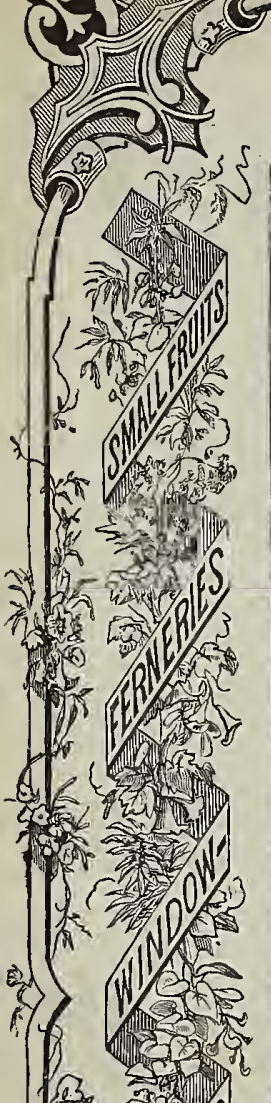

$\sqrt{3 x}$

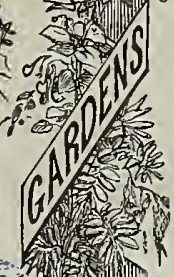

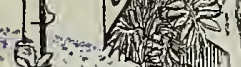

6.) $\sqrt{ } \cdot(x)$

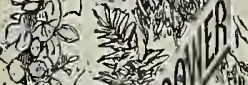
on 0 .

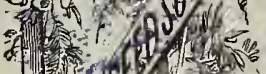
1 ,

特

sen

6

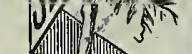

$\rightarrow$

13
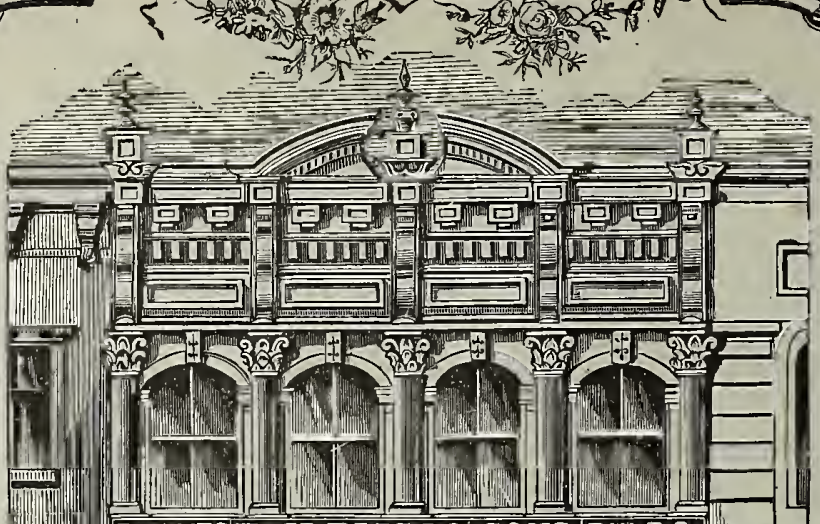

(4)(10) PLANTSIB.K. BLISS E SONS.BUULB.

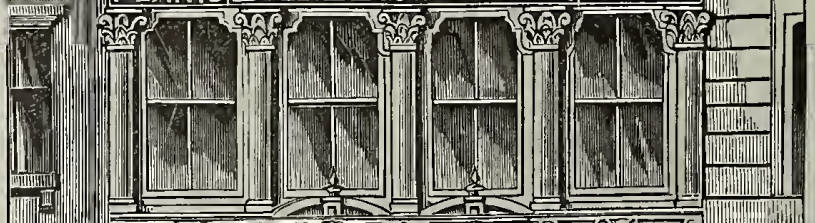

(II) (I)
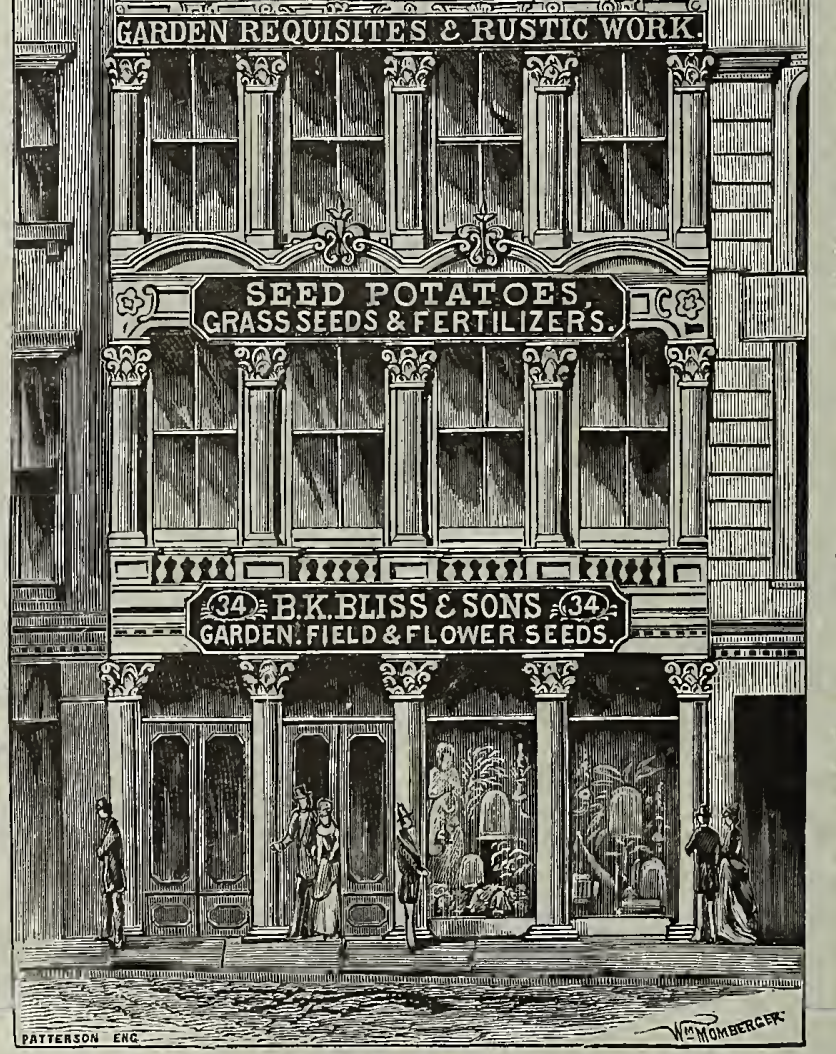

B. K. BLISS \&ONS" SEED WAREHOUSE,

34 BARCLAY STREET, NEW $=Y O B K$.
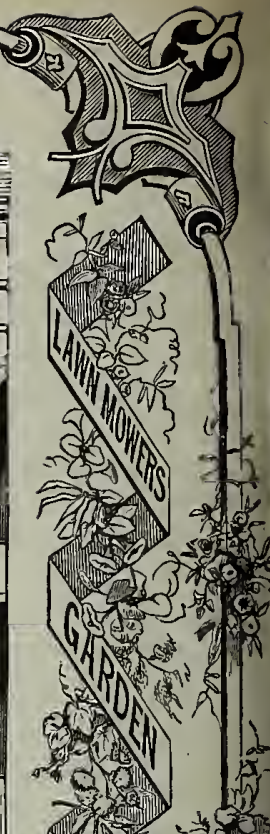

Niv

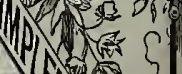

sin

2)

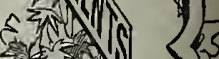

and

Ans os

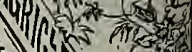

$z^{2}=$ on

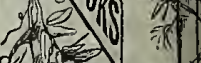

(t)

5017

C.

$8 \rightarrow 00$ D

10.
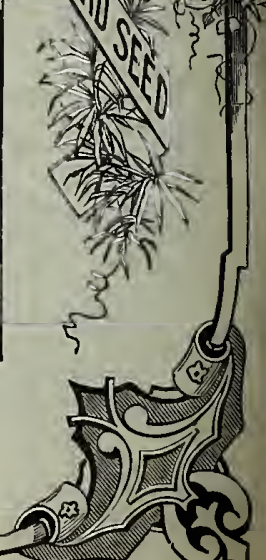